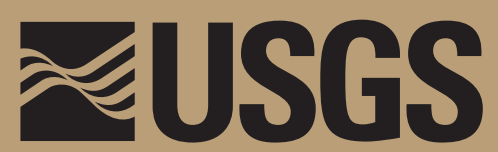

science for a changing world

\title{
Geological Studies of the Salmon River Suture Zone and Adjoining Areas, West-Central Idaho and Eastern Oregon
}

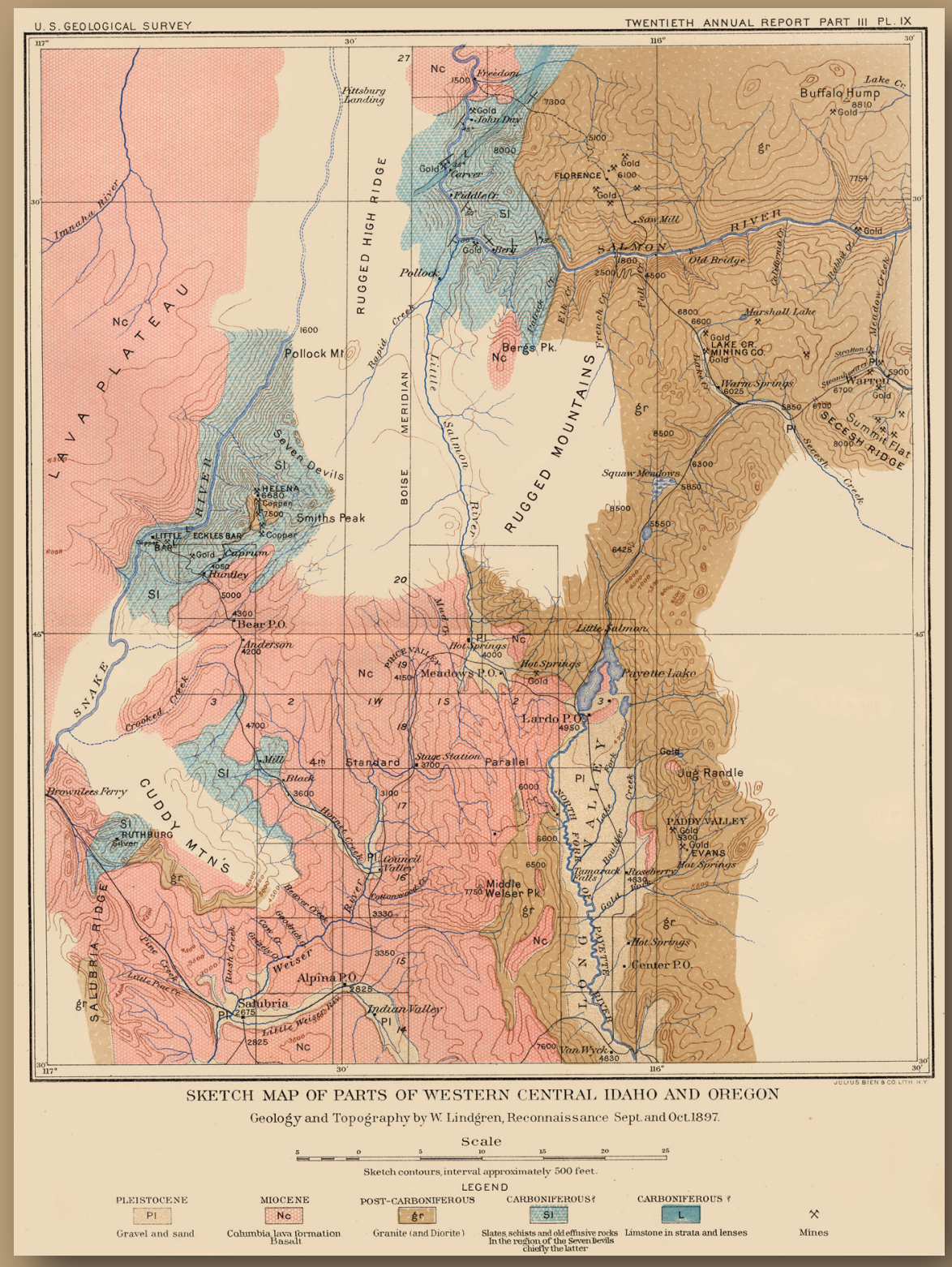

Professional Paper 1738

U.S. Department of the Interior U.S. Geological Survey 
Other than this note, this page intentionally left blank. 


\section{Geological Studies of the Salmon River Suture Zone and Adjoining Areas, West-Central Idaho and Eastern Oregon}

Edited by Mel A. Kuntz and Lawrence W. Snee

Professional Paper 1738 


\section{U.S. Department of the Interior DIRK KEMPTHORNE, Secretary}

\section{U.S. Geological Survey Mark D. Myers, Director}

\section{U.S. Geological Survey, Reston, Virginia: 2007}

This report and any updates to it are available online at:

http://pubs.usgs.gov/pp/2007/1738/

For product and ordering information:

World Wide Web: http//www.usgs.gov/pubprod

Telephone: 1-888-ASK-USGS

For more information on the USGS - the Federal source for science about the Earth,

its natural and living resources, natural hazards, and the environment:

World Wide Web: http://www.usgs.gov

Telephone: 1-888-ASK-USGS (1-888-275-8747)

Any use of trade, product, or firm names in this publication is for descriptive purposes only and does not imply endorsement of the U.S. Government.

Although this report is in the public domain, permission must be secured from the individual copyright owners to reproduce any copyrighted materials contained within this report.

Suggested citation:

Kuntz, M.A., and Snee, L.W., eds., 2007, Geological studies of the Salmon River suture zone and adjoining areas, westcentral Idaho and eastern Oregon: U.S. Geological Survey Professional Paper 1738, 202 p.

Cataloging-in-publication data are on file with the Library of Congress (http://www.loc.gov/).

Produced in the Western Region, Menlo Park, California

Manuscript approved for publication, January 17, 2007

Text edited by Peter Stauffer

Layout and design by Judy Weathers

FRONT COVER

Sketch map of parts of west-central Idaho and eastern Oregon. This is one of the classic early geological maps of this region by Waldemar Lindgren and was published in the U.S. Geological Survey's Twentieth Annual Report in 1900 See chapter 1 for more information. 


\section{Contents}

1. Introduction to geological studies of the Salmon River suture zone and adjoining areas, west-central Idaho and eastern Oregon.

By Mel A. Kuntz and Lawrence W. Snee

2. Location, age, and tectonic significance of the western Idaho suture zone 15

By Robert J. Fleck and Robert E. Criss

3. Geologic, geochemical, and ${ }^{40} \mathrm{Ar} /{ }^{39} \mathrm{Ar}$ and U-Pb thermochronologic constraints for the tectonic development of the Salmon River suture zone near Orofino, Idaho

By Lawrence W. Snee, Gary F. Davidson, and Daniel M. Unruh

4. Ultramafic rocks of the western Idaho cratonic suture zone-composition, origin, and emplacement..

By Martha M. Godchaux and Bill Bonnichsen

5. The Idaho Batholith near McCall, Idaho-field relations, petrology, major-element chemistry, emplacement history, and magma genesis

By Mel A. Kuntz

6. Mesozoic telescoping of island arc terranes and geologic evolution of the Cuddy Mountains region, western Idaho.

By Gary M. Mann and Tracy L. Vallier

7. Structure and tectonic evolution of plutonic units of the Idaho Batholith near

McCall, Idaho. 181

By Mel A. Kuntz 


\section{Contributors}

Bill Bonnichsen

Idaho Geological Survey

University of Idaho

Moscow, ID 83844

Robert E. Criss

Department of Earth and Planetary Sciences

Washington University

St. Louis, M0 63130

Gary F. Davidson

Geology Department

University of Washington

Seattle, WA 98195

Robert J. Fleck

U.S. Geological Survey

Menlo Park, CA 94025

Martha M. Godchaux

Department of Geology

Mount Holyoke College

South Hadley, MA 01075

Mel A. Kuntz

U.S. Geological Survey

Denver, CO 80225

Gary M. Mann

U.S. Geological Survey

Flagstaff, AZ 86004

Lawrence W. Snee

U.S. Geological Survey

Denver, CO 80225

Daniel M. Unruh

U.S. Geological Survey

Denver, CO 80225

Tracy L. Vallier

U.S. Geological Survey

Menlo Park, CA 94025 


\title{
1. Introduction to Geological Studies of the Salmon River Suture Zone and Adjoining Areas, West-Central Idaho and Eastern Oregon
}

\author{
By Mel A. Kuntz and Lawrence W. Snee
}

\section{Definition and Description of the Salmon River Suture Zone}

The papers in this volume describe petrologic, structural, and geochemical studies related to geographic areas adjacent to and including the Salmon River suture zone. We therefore start this volume by defining and giving a general description of that suture zone.

The western margin of the North American continent was the setting for complex terrane accretion and large-scale terrane translation during Late Cretaceous and Eocene time. In western Idaho, the boundary that separates the PaleozoicMesozoic accreted oceanic, island-arc rocks on the west from Precambrian continental metamorphic and sedimentary rocks on the east is called the Salmon River suture zone (SRSZ). Readers will note that the term "Salmon River suture zone" is used in the title of this volume and in the text of several of the papers and the term "western Idaho suture zone" is used in several other papers in this volume. Both terms refer to the same geologic feature and reflect historical usage and custom; thus no attempt has been made by the editors to impose or demand a single term by the various authors of this volume.

The suture zone is marked by strong lithologic and chemical differences. Rocks adjacent to the suture zone are characterized by high-grade metamorphism and much structural deformation. In addition, the zone was the locus of emplacement of plutons ranging in composition from tonalite to monzogranite during and after the final stages of accretion of the oceanic terrane to the North American continent.

In the McCall, Idaho, area (fig. 1), the suture zone can be located fairly accurately by the abrupt contrast in the character of inclusions and screens of metamorphosed wall rocks in plutonic units of the Idaho Batholith. Inclusions east of the suture zone are typically biotite-garnet-sillimanite schist, metaquartzite, and calc-silicate rocks that are correlative with the Belt Supergroup and pre-Belt rocks of Proterozoic age. Inclusions west of the suture zone are andesitic gneiss, amphibolite, and marble (Manduca and others, 1993).

The western edge of continental crust that marks the pre-Cretaceous margin of the North American Plate (Coney and others, 1980) in Nevada, western Idaho, and Washington was first defined by strontium-isotope studies (Kistler and Peterman, 1978; Armstrong and others, 1977). These and later studies determined that all continental rocks east of the suture zone, and plutonic rocks that intrude them, have initial ${ }^{87} \mathrm{Sr} /{ }^{86} \mathrm{Sr}$ ratios greater than 0.706 and that initial strontium ratios of oceanic rocks west of the suture zone are $<0.7045$. The sharp break in the strontium ratios occurs within a zone that is less than $5 \mathrm{~km}$ wide (Armstrong and others, 1977; Fleck and Criss, 1985; Fleck and Criss, this volume, chapter 2).

Lund (1984) and Lund and Snee (1988) proposed that the Salmon River suture zone was a right-lateral transpressive fault along which oceanic, island-arc terranes were accreted to the North American continent during the interval 118 to 93 Ma. Lund and Snee (1988) portrayed the suture zone as a flower structure in their description of the metamorphism and structure of rocks in the Riggins, Idaho, area. East of the suture zone, they documented east-vergent folds and eastdirected thrust faults; steepening of the thrust faults closer to the suture zone; and stacking of higher grade metamorphic rocks over lower grade rocks due to thrust faulting. West of the suture zone, they described east-over-west vergent folds; west-directed thrust faults; steepening of the thrust faults eastward toward the suture zone; and stacking of higher grade metamorphic rocks over lower grade metamorphic rocks, also due to thrust faulting. In addition, Lund and Snee (1988) described (1) vertical transport of rock material at and adjacent to the suture, (2) formation of a "secondary schistosity" parallel to and within a few kilometers of the suture zone that was superimposed on both plutons and screens within them, and (3) rapid uplift, cooling, and erosion of plutons and host rocks near the suture zone beginning about $88 \mathrm{Ma}$.

In their tectonic interpretation of the Salmon River suture zone, Selverstone and others (1992) suggested that most of the deformation in and adjacent to the suture followed strike-slip emplacement of the arc against the continent and resulted from "head- on" collision of the arc with the continent. They describe three major events in the kinematic evolution of the upper (their "supracrustal") part of the suture zone: (1) intracontinental subduction, (2) rapid unroofing, perhaps initiated by separation of negatively buoyant mantle lithosphere from a 


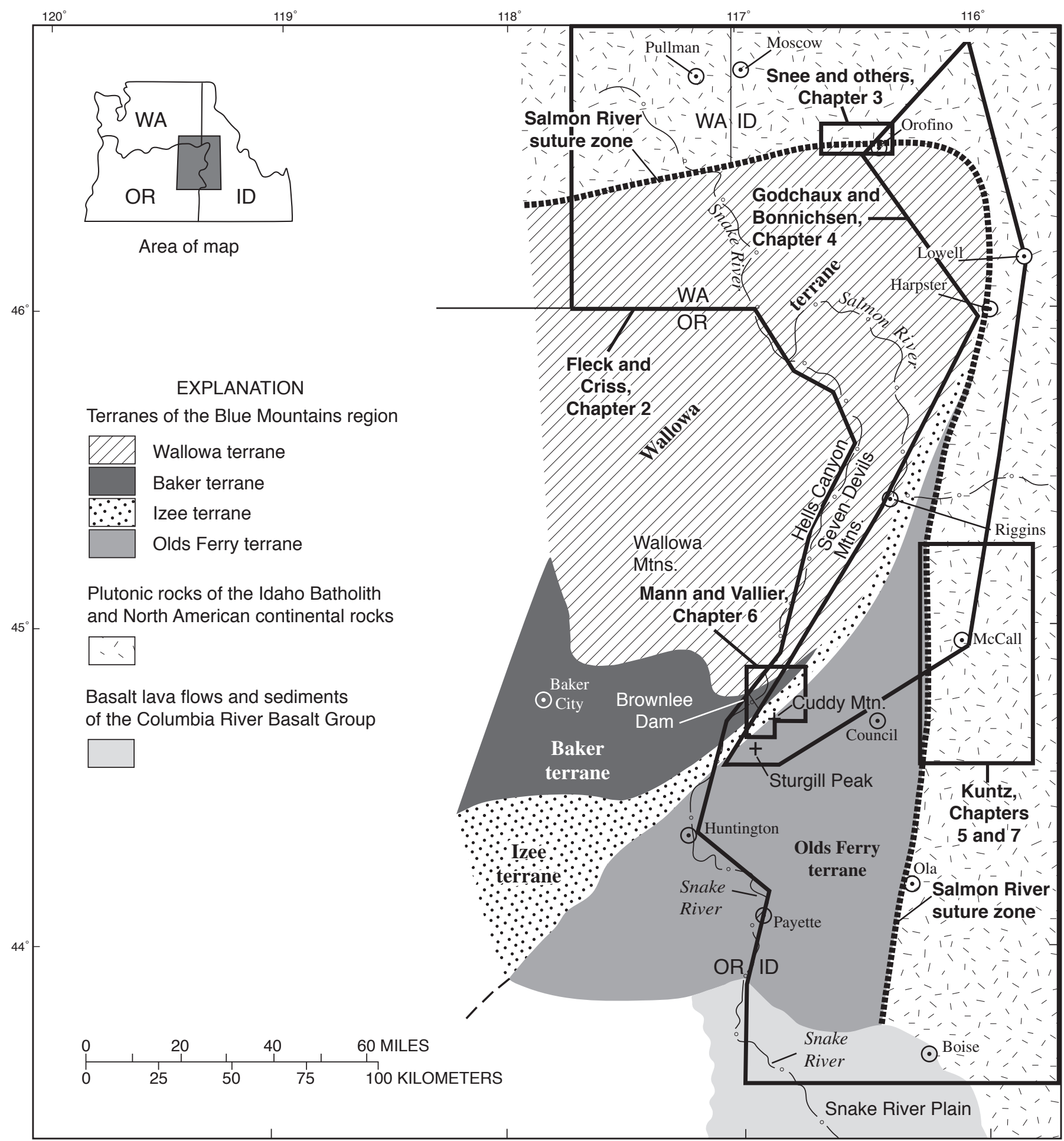

Figure 1. Index map of eastern Oregon and western Idaho showing location of the Salmon River suture zone, boundaries of study areas for papers in this volume, major cities and towns, and other geographic areas cited in the text. Based in part on figure 3.8 in Vallier (1995). 
buoyant crustal root during subduction, and (3) slow, "hinged" unroofing, as topography and erosion rates diminished.

McClelland and others (2000) integrated the studies of earlier workers and provided a detailed analysis of the Salmon River suture zone. They described an accretion-related thrust belt west of the Salmon River suture zone and noted that a post-accretion shear zone coincides with the suture zone. In addition, they described syndeformational tabular tonalitic plutons that are concordant with shear-zone fabrics, show dextral strike-slip indicators, and display pervasive down-dip mineral elongations and lineations. They concluded that the plutons and fabrics were both formed in an intra-arc transpressional setting. They proposed a two-stage history for the formation of the Salmon River suture zone involving (1) initial underthrusting of accreted oceanic fragments followed by (2) modification of the suture zone by intra-arc transpressional shearing, exhumation of high pressure-moderate temperature rocks within the thrust belt to the west and moderate pressure-high temperature batholitic rocks east of the suture zone.

\section{Early Studies of the Region of the Salmon River Suture Zone}

The papers in this volume have drawn upon the studies and wisdom of previous geologists working in the SRSZ area. Notable among these are Waldemar Lindgren, Clyde Ross, Alfred Anderson, Anna Hietanen, Warren Hamilton, Tracy Vallier, and Howard Brooks. Here, we briefly describe the contributions made by these and several other investigators who made pioneering contributions in the region of the SRSZ.

Waldemar Lindgren, one of the premier early American geologists, completed reconnaissance studies in Idaho and Oregon from 1896 to 1900 (Lindgren, 1900, 1901, 1904). Even though Becker (1880) and Eldridge (1895) conducted earlier field excursions in adjoining areas of Idaho and described the great expanse of granite and the character of gold and silver deposits that had been worked since 1860, it was Lindgren's observations that defined the unique and salient geologic features of this region. The maps that resulted from three of those studies are reproduced as figures 2, 3, and 4 .

In the autumn of 1897, after completing his mapping of the Boise gold-mining district, an area covering more than $15,000 \mathrm{~km}^{2}$ (Lindgren, 1897, 1898), Lindgren reconnoitered northward. He was particularly interested in describing the geology of other important gold-mining districts in this part of west-central Idaho. During this reconnaissance, he recognized that the granitic rocks that make up what is now called the Idaho Batholith form one of the largest granitic areas in the United States. He described these granites and noted the nearly ubiquitous presence of orthoclase and biotite; he also recognized that hornblende was rarely present but muscovite was common in many places. His chemical analyses showed that the rock is not true granite as commonly defined, but is more closely related to quartz monzonite. He noted that the batholith was generally uniform in composition but that local variations occurred, including gabbroic and dioritic plutons west of Hailey and a variety of dikes that cut the granites. He also recognized that the granites intruded and metamorphosed sedimentary rocks of probable Carboniferous age on the east. In contrast, on the west near the Seven Devils Mountains and the Lower Salmon River, the granites also were shown to be intrusive into sedimentary and volcanic rocks of probable Paleozoic age, but Lindgren noted that these country rocks had a different character from those on the east. He concluded that the Idaho Batholith was entirely of post-Paleozoic age, in contrast to Becker's (1880) assignment of an Archean age.

In his 1897 field reconnaissance, which encompassed an area of about $92,000 \mathrm{~km}^{2}$, Lindgren examined the rock units that bound the Idaho Batholith along its western margin in the Salmon River Canyon, the Seven Devils Mountains, Cuddy Mountain, and near Huntington (figs. 1, 4). He described the rocks as "strongly compressed slates and crystalline limestones accompanied by large masses of Mesozoic or Paleozoic effusive rocks and schists derived from these" [italics added], all having a northeasterly strike. These units are now known as the Martin Bridge Formation, the Seven Devils Group, and the Riggins Group. Although the limestone generally lacks fossils, Lindgren found crinoid stems and assigned a Carboniferous age. He also recognized the superposition of the younger "Columbia lavas" (Columbia River Basalt Group), the great thickness of the undeformed lavas, and that the lava province extended far to the northwest.

In his exploration to the east and north of present-day Riggins, downstream and within the Salmon River Canyon, Lindgren (1900, p. 87) described in some detail the geology of what is now recognized as the suture zone. Along the trail from Florence, east of Riggins and north of the Salmon River, to Freedom (see figure 3 for location) to the northwest, Lindgren passed out of typical granites of the Idaho Batholith into schists, marbles, and slates crosscut by dikes of hornblende granite and amphibolite. South of Freedom, heading toward Riggins, he noticed that the metamorphic character of these rocks changed from finer grained schists to coarser grained micaceous schists near Fiddle Creek and ultimately to gneissic rock containing garnet east of Salmon Point (Riggins), near Berg. In the Salmon River Canyon just east of Berg (approximately 8-16 km south-southwest of Florence), the gneissic rock is described as being injected by hornblende granite that shows a rough schistosity or jointing dipping very steeply eastward. Lindgren's description of the geology here captures some of the most important observations about the suture zone- that metamorphic grade increases from the west toward the suture zone; that granites within the zone are strongly deformed; and that metamorphic rocks of the Riggins Group are structurally intercalated with Martin Bridge and Seven Devils rocks.

From late July to late October 1899, Lindgren traversed the area of the Clearwater Mountains and Bitterroot Range extending from the Bitterroot Valley in western Montana across Idaho to its border region with Oregon and Washington, an area of $31,000 \mathrm{~km}^{2}$. He produced another remarkable map (fig. 3), which also straddles the area of the Salmon River 


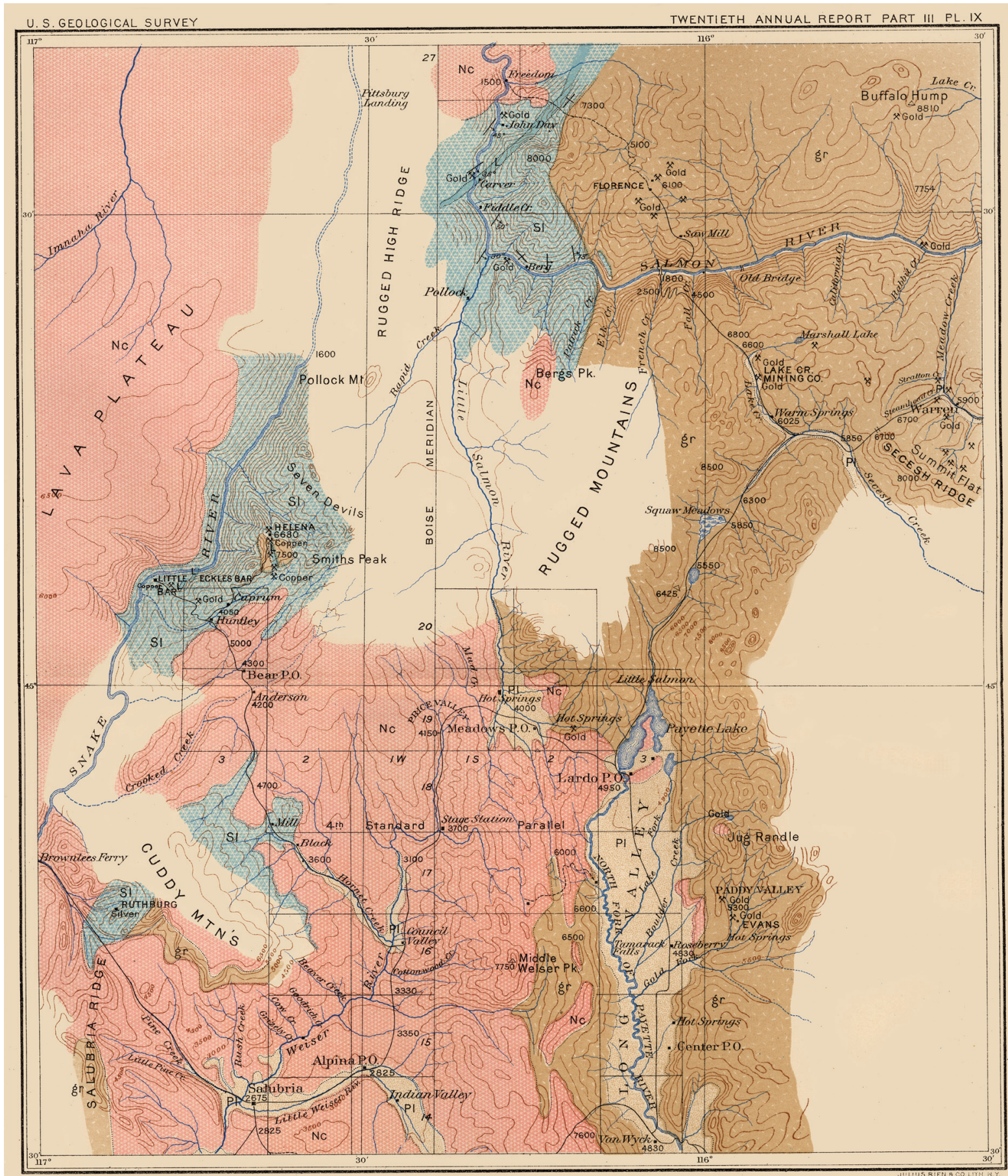

SKETCH MAP OF PARTS OF WESTERN CENTRAL IDAHO AND OREGON Geolog̉y and Topog̉raphy by W. Lindġren, Reconnaissance Sept.and Oct.1897.

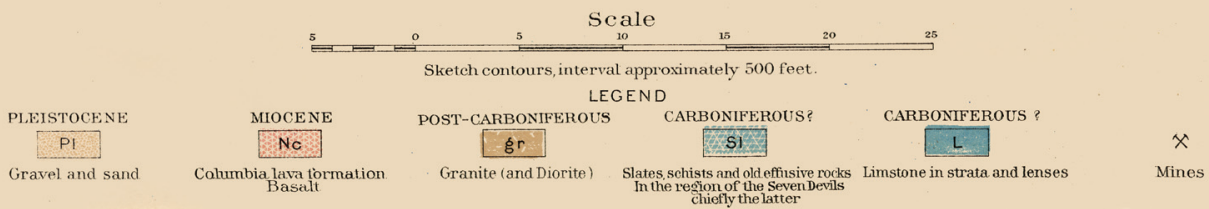

Figure 2. Scanned reproduction of part of Waldemar Lindgren's "Sketch Map of Parts of Western Central Idaho and Oregon" based on his 1897 reconnaissance geologic mapping and published in Lindgren (1900). The map straddles the exposed southern part of the Salmon River suture zone covering the area of the Riggins Group, Seven Devils Group, Martin Bridge Limestone, plutons of the Idaho Batholith, and Columbia River Basalt Group. 


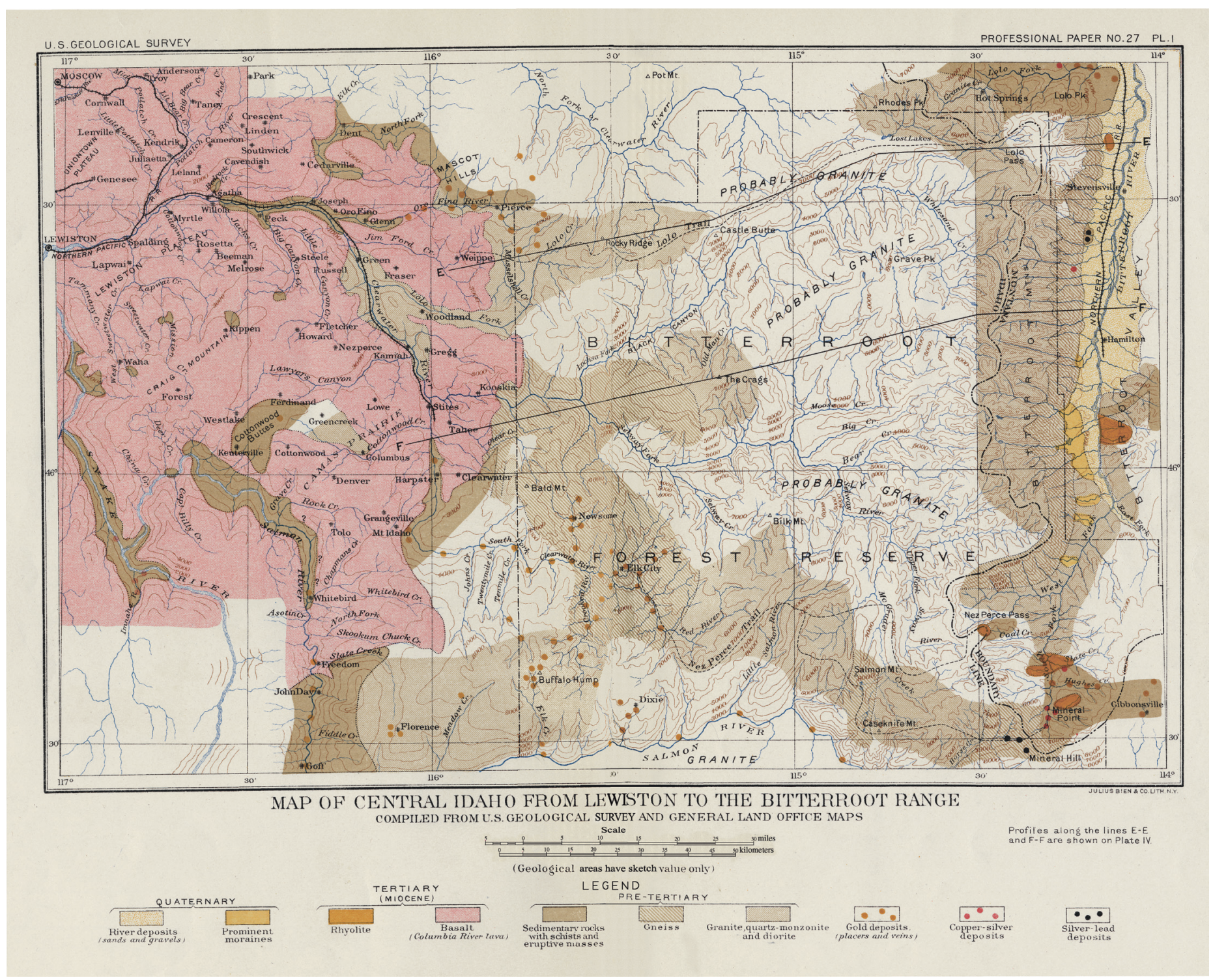

Figure 3. Scanned reproduction of part of Waldemar Lindgren's "Map of Central Idaho from Lewiston to the Bitterroot Range" based on his 1899 reconnaissance of central Idaho and published in his 1904 Professional Paper (Lindgren, 1904). This map adjoins along the northern edge of his 1897 map and also straddles the Salmon River suture zone. On it he shows the extensive belt of mylonites along the eastern side of the Idaho Batholith, the northern extension of plutons of the Idaho Batholith, Precambrian sedimentary rocks, Precambrian gneisses, the metamorphic rocks of the Orofino area, and Columbia River basalts. 


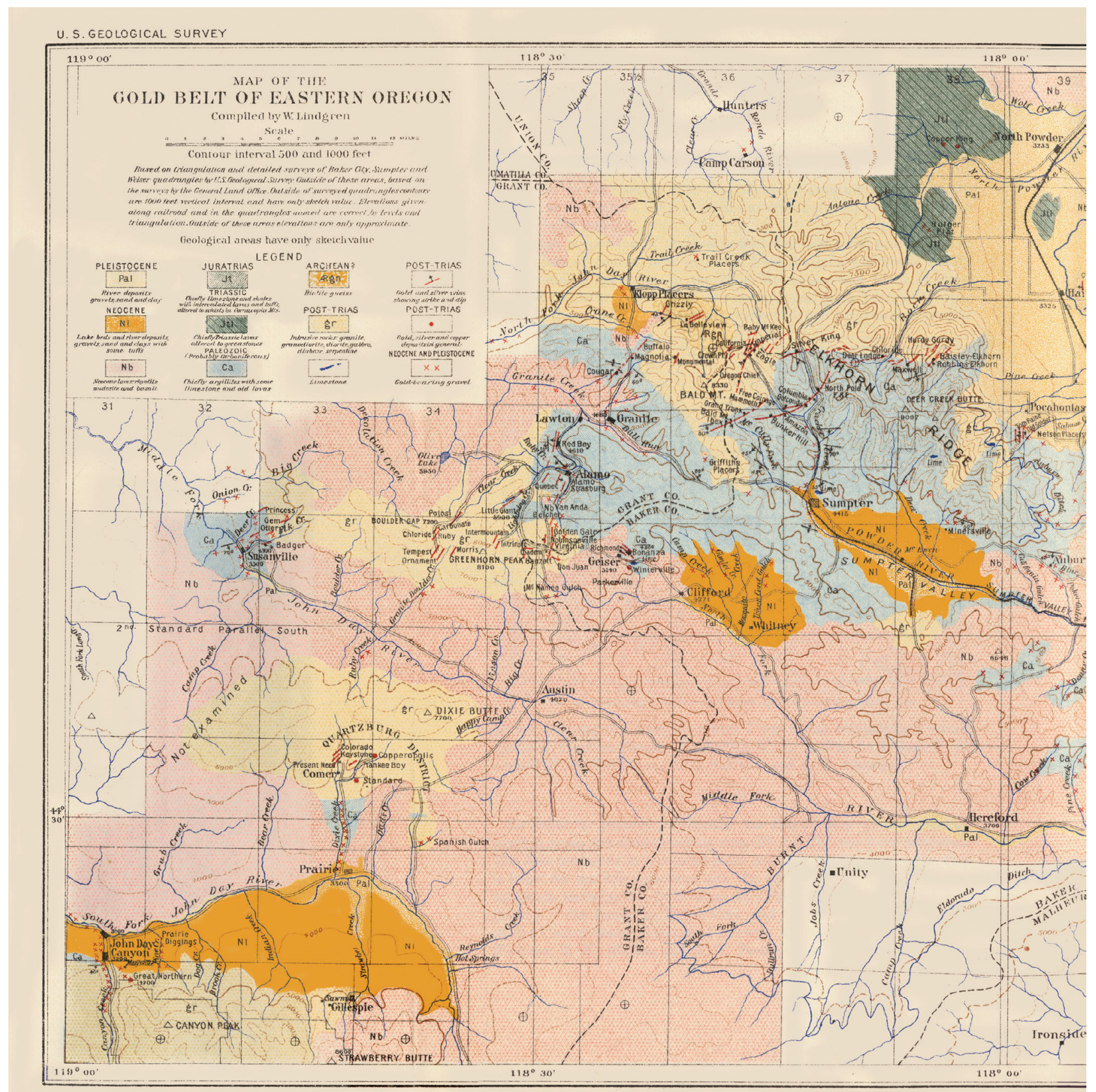

Figure 4. Scanned reproduction of part of Waldemar Lindgren's “Gold Belt of Eastern Oregon" map published in Lindgren (1901). This map shows Paleozoic and Mesozoic sedimentary and volcanic rocks, plutonic rocks distinct from those of the Idaho Batholith, and Columbia River basalts. The area includes what are now believed to be parts of accreted Wallowa, Baker, Izee, and Olds Ferry islandarc terranes. 


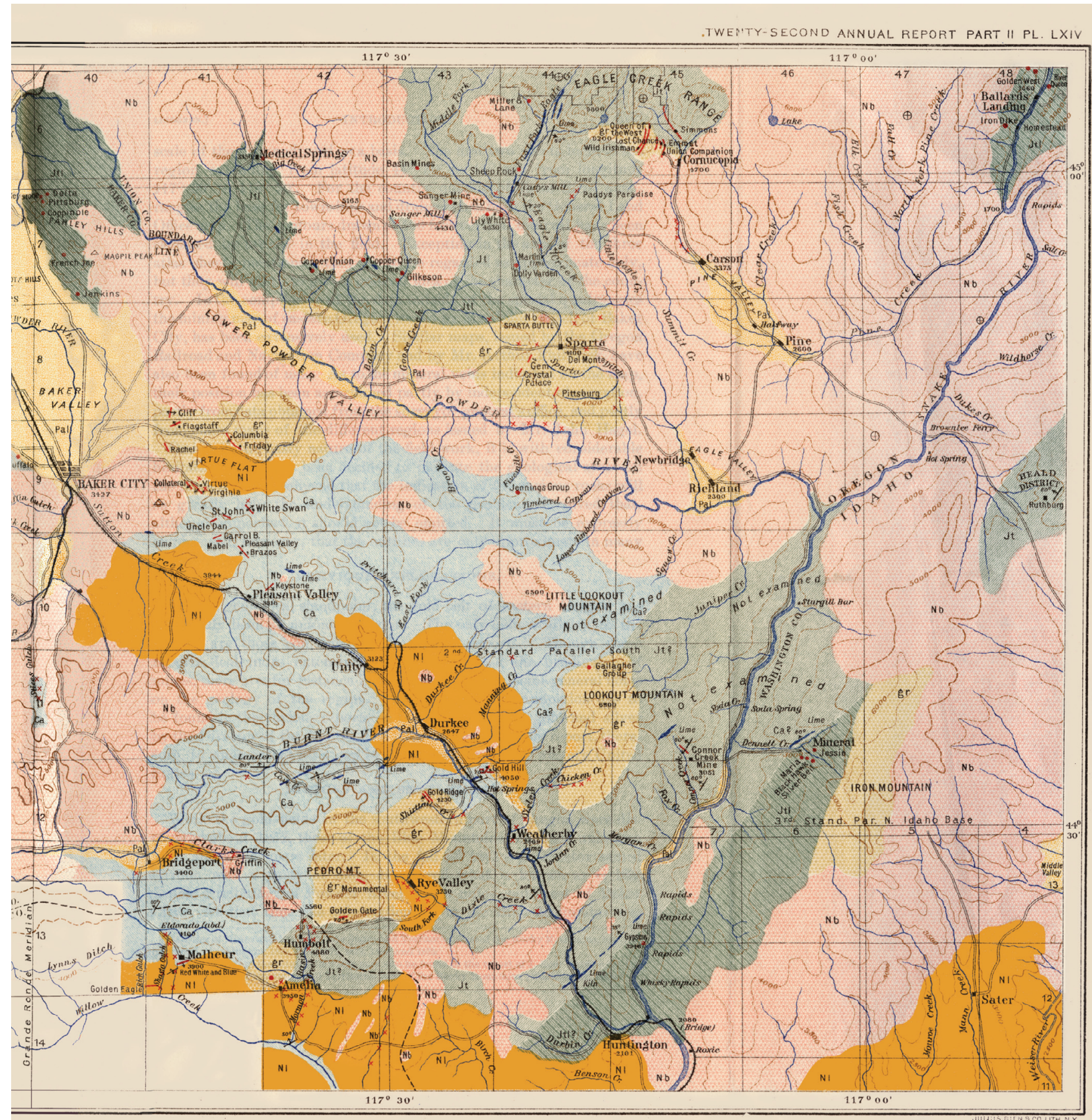

Figure 4.-Continued. 
suture zone, but lies farther north and adjoins the previously discussed map (fig. 2). Lindgren described the geology of the eastern and central part of this large region as comparatively simple. The main Bitterroot Range and much of the Clearwater Mountains consist of granitoid rocks, more precisely quartz monzonite, of the Idaho Batholith, and this mass is continuous with and equivalent in age to the granitic mass to the south in the Salmon River country. However, despite this simple lithology, he recognized and defined in detail a schistose zone in the granite that extends more than $150 \mathrm{~km}$ north to south and dips about $20^{\circ}$ east along the entire eastern slope of the Bitterroot Mountains. This zone is now known to be a mylonite formed during unroofing of the Bitterroot lobe of the batholith. Lindgren correctly surmised that the schistose zone was formed during faulting after the emplacement of the Idaho Batholith.

Lindgren's 1899 reconnaissance also continued westward into the areas around Harpster, Mount Idaho, and Orofino. In the Harpster and Mount Idaho areas, he described slates, limestones, and greenstones, noting that they were northward extensions of similar rocks exposed in the Seven Devils region; we now know these as the Martin Bridge Formation and the Seven Devils Group. Lindgren described other metamorphic rocks in contact with the granites of the Idaho Batholith near Orofino. These rocks include garnetiferous mica schists and marbles, and he correctly attributed the metamorphism to regional causes, not contact effects caused by granite emplacement. The Orofino area is where the suture zone makes a curious abrupt swing to the west and the metamorphic rocks along the suture zone include both the Orofino metamorphic series and Middle Proterozoic Belt Supergroup.

The third Lindgren report that helped to set the foundation for understanding the geology of the region straddling the Salmon River suture zone is "The Gold Belt of the Blue Mountains of Oregon" (Lindgren, 1901; fig. 4). The Blue Mountains lie within the accreted island-arc terrane west of the Salmon River suture zone and contain oceanic sedimentary and volcanic rocks and plutons having a different chemical character and age from those of the Idaho Batholith. Lindgren recognized that the rocks in the northeastern part of this area, around the Eagle Creek Range, are similar to those in the southeastern part of the area near Huntington and include marble, slate, and volcanic rocks of Triassic age. He then correlated these with the Triassic rocks in the Seven Devils Mountains to the northeast. More remarkably, he discussed the entire Triassic System of the western United States and noted two distinct facies; the western facies rocks were distinctly marine and extended from California and Nevada through Oregon, Idaho, Washington, and into Canada. Lindgren, in essence, was making the "Wrangellian" connection.

In his report on the Blue Mountains, Lindgren also described older argillites of presumed Carboniferous age and greatly altered greenstones that form a syncline in the middle of the area. In his paper "The Igneous Geology of the Cordilleras and its Problems," Lindgren (1915) later correlated these older volcanic rocks with similar volcanic rocks along the west coast of North America from California to Alaska. (He made an analogous correlation of the Triassic and Jurassic volcanic rocks of western North America in this same paper.) One important final observation was in his discussion of the igneous rocks of the Blue Mountains area. He remarked that true orthoclase granites appear to be absent; thus granites similar to those of the Idaho Batholith are lacking. Instead, he described granodiorite, diorite, gabbro, serpentinite, and a curious "soda granite" containing albite in place of orthoclase, much quartz, and few ferromagnesian minerals. This latter rock is probably what we now call trondhjemite.

Following on the fundamental works of Lindgren, Clyde Ross and Alfred Anderson conducted studies that better defined the nature of the Cretaceous Idaho Batholith, younger plutonic rocks, and ore deposits associated with each. Ross (1928) showed that the Idaho Batholith was not a single monolithic mass of quartz monzonite but instead exhibited significant compositional variation. He also showed that younger, batholith-scale granitic masses of distinctive composition intruded older plutons of the batholith. Ross more comprehensively analyzed the question of age of the batholith by applying the revolutionary ideas of geologic time set forth by Holmes (1913) and Barrell (1917). Ross also concluded that ore deposits throughout the area underlain by the Idaho Batholith were likely derived from the magmatic activity associated with both the Idaho Batholith and younger plutons. Overlapping Ross' work in part, but generally later, Anderson (1930, 1951, 1952) further described the plutons of the Idaho Batholith and younger granitic bodies. Instead of two periods of ore deposition, however, Anderson (1951) recognized five different metallogenic epochs. He stated that Ross' contention that most mineralization was associated with magmatic activity of the Idaho Batholith was incorrect. Arguments about the age of ore deposits in central Idaho continue to the present day.

Although Lindgren discussed the nature of metamorphism in rocks of central Idaho and eastern Oregon, Warren Hamilton $(1963,1969)$ and Anna Hietanen (1963a,b,c, d,e, 1984) provided comprehensive descriptions of critical metamorphic rocks along the northern, northwestern, and western margins of the Idaho Batholith in areas that lie adjacent to the SRSZ. Hietanen mapped more than $6,000 \mathrm{~km}^{2}$ comprising primarily metamorphic rocks and plutons of the Idaho Batholith. She described evidence for several periods of metamorphism, both synkinematic and postkinematic, and later metasomatism. She assigned the metasedimentary rocks to various formations within the Belt Series (now Supergroup), but noted the difference between metamorphic rocks in the Orofino area (the Orofino series of Anderson, 1930) and those to the east and northeast of Orofino.

Hamilton mapped metamorphic and igneous rocks primarily in the Riggins quadrangle of western Idaho. This area lies along the western border zone of the Idaho Batholith and straddles the Salmon River suture zone. Hamilton described two tectonic packages of rocks, a lower plate consisting of his Seven Devils Volcanics, Martin Bridge Limestone and the Lucille Slate and an upper plate of metamorphosed volcanic and sedimentary 
rocks of higher grade that he named the Riggins Group. He noted the likelihood of several periods of metamorphism in the Riggins Group, with all being older than the Idaho Batholith. Although he recognized that the metamorphism was dynamothermal and clearly noted evidence for several deformational events, Hamilton assigned the metamorphism to a single episode and ascribed it to contact metamorphism on a regional scale. Hamilton also noted, as did Lindgren (1915), that the metavolcanic rocks of this area were similar to volcanic rocks in Alaska. Taken together, the studies of Hamilton and Hietanen provided an important foundation for subsequent work along the SRSZ.

For the recognition and interpretation of the Salmon River suture zone, Richard Armstrong, William Taubeneck, and Peter Hales (1977) published one of the most significant contributions. Besides determining the ages of many plutonic rocks of the Pacific Northwest, they used initial strontium ratios of these plutonic rocks to define a narrow boundary in western Idaho that separated two groups of plutonic rocks having different initial $\mathrm{Sr}$ isotopic ratios. This boundary, which is now referred to informally as the "704-706 line," coincides with the change from oceanic rocks on the west side of the line to continental rocks on the east. Armstrong and coauthors clearly showed that this boundary takes a very sharp westerly bend in the Orofino, Idaho, area. They interpreted this sharp boundary to mark the western "edge of older Precambrian crust, abruptly juxtaposed against late Paleozoicearly Mesozoic material accreted onto North America during Phanerozoic time" (Armstrong and others, 1977, p. 408).

It is important that we acknowledge the significant contributions that Tracy Vallier and Howard Brooks have made to our knowledge of the geology of the Pacific Northwest and, specifically, to the study of the Blue Mountains island-arc terrane and early studies of the SRSZ. Together, they have inspired many to continue studies of the geology of the region and they have, through sheer tenacity, ensured that these studies were appropriately published.

Tracy Vallier began his geological career with studies of the geology of the rugged Hells Canyon region of the Snake River (Vallier, 1967) and continued in the equally rugged Seven Devils region (Vallier and others, 1977). These investigations led to his conclusion that the rocks in these two areas were sedimentary and volcanic rocks formed in oceanic environments. Vallier subsequently began studies of sedimentation, volcanism, and plutonism in modern island arcs in the 1980's and 1990's. With the modern arcs as analogues that formed a framework for plate-tectonic interpretations, Vallier has reinterpreted his earlier work in western Idaho and eastern Oregon and formulated, in a remarkable, classic paper, the definitive plate-tectonic interpretation for the formation and assemblage of the various terranes that form the Blue Mountains island-arc complex and the accretion of that complex to the western edge of the Late Cretaceous North American craton (Vallier, 1995). Vallier's leadership in fostering and mentoring various geologic studies, assembling papers, and editing several volumes related to the Blue Mountains region is recognized by all geologists who have conducted geologic studies in eastern Oregon and western Idaho.
Howard Brooks began his geologic career with the Oregon Department of Geology and Mineral Resources in 1956. He completed comprehensive reports on such mineral resources of Oregon as mercury (Brooks, 1963) and gold and silver (Brooks and Ramp, 1968) and began prolific production of geologic maps for areas of eastern Oregon. In the later 1960's, he teamed with Tracy Vallier to focus on their common interest in the nature of the basement rocks exposed along the Snake River Canyon, including the nearly inaccessible stretch within Hells Canyon (Brooks and Vallier, 1967). Their work, and that of studies that were inspired by them, has provided the basis for our geologic understanding of the many packages of amalgamated island-arc rocks that were accreted to the North American continent along the SRSZ (for example, Brooks and Vallier, 1978; Vallier and others, 1977). Like Vallier, Brooks fostered many geologic investigations of this area and co-edited several U.S. Geological Survey Professional Papers dedicated to presentation of studies of the Blue Mountains/Hells Canyon region.

This volume is presented in the spirit of a quote from Lindgren (1915):

As geologic science developed, we have become aware that the volcanoes, impressive as they are, form but one aspect of igneous action and that far below the surface processes go on in comparison to which the surface phenomena assume less importance. We have ascertained that immense quantities of fluid magma are forced up into the crust from abyssal depths without reaching the surface, and that these magmas, congealed, have been exposed by erosion. We want to ascertain the relations of these magmas - if any such relations exist-as to chemical and mineralogical composition. We also want to ascertain their place of origin, their differentiation, their mode of ascent, injection, and intrusion; and finally the relation of the mise en place of the magmas to the great stresses to which the crust has been subjected, and which have resulted in the building of continents and mountain chains.

\section{Papers in This Volume}

The papers in this volume are arranged in the following order: First are those that deal with the geochemistry and petrology of plutonic units along the SRSZ. These include studies of the isotopic character of plutonic rocks on both sides of the SRSZ (chapter 2); the petrology, geochemistry, age, and tectonic development of rocks in the Orofino, Idaho, area (chapter 3); the origin and character of ultramafic rocks along the SRSZ (chapter 4); and the petrology and origin of plutonic rocks just east of the SRSZ (Chapter 5). These papers are followed by studies of the stratigraphy, structure, and tectonic history of units along the SRSZ. These describe the stratigraphy and structure of telescoped rocks in the Cuddy Mountain 
area (chapter 6); and studies of the structure of plutonic units of the Idaho Batholith immediately east of the Salmon River suture zone near McCall, Idaho (chapter 7). Brief introductory notes on each of these chapters follow.

\section{Chapter 2-Robert J. Fleck and Robert E. Criss, Location, Age, and Tectonic Significance of the Western Idaho Suture Zone (WISZ)}

In discussing the Idaho Batholith, Wallace Pitcher, in his book "The Nature and Origin of Granite," said the following (Pitcher, 1997, p. 324-5):

Miller and Barton reviewed the evidence for both magma generation and its motivation, but before commenting on these general matters I turn to Fleck's [and Criss's] geochemical studies of part of the Idaho Batholith as an in-depth example of the type of analysis now available using a combination of neodymium and strontium isotope and trace element data. It is of the greatest interest that Fleck's traverse crosses what is now recognized as a terrane boundary separating the late Palaeozoic-Mesozoic accreted terranes from the Precambrian 'sialic' crust, which is also the location of the 'magic' $0.706 \mathrm{Sr}_{\mathrm{i}}$ isopleth. Fleck recorded a dramatic increase in $\mathrm{Sr}_{\mathrm{i}}$ from 0.704 to 0.712 in less than $10 \mathrm{~km}$, and this is paralleled by a leap in $\delta^{18} \mathrm{O}$ from between 6 and $8 \%$ 。 to between 9 and $12 \%$. There is also a clear inverse correlation between $\varepsilon \mathrm{Nd}$ and Sri, the former falling from +5 to -16 .

Although Armstrong and others (1977) developed the idea that the boundary (that is, the suture zone) between Paleozoic and Mesozoic volcanic and sedimentary rocks of accreted terranes to the west and Precambrian sialic crust to the east could be defined and located precisely by the strontium isotopic composition of plutonic rocks, it is the detailed isotopic studies of Bob Fleck and Bob Criss referred to by Pitcher (Fleck and Criss, 1985; Fleck, 1990), that defined the scale of isotopic variation across the suture zone. Those two papers, the chapter by Fleck and Criss (chapter 2) in this volume, and other papers referenced in that chapter, have now located the "magic" 0.706 Sri isopleth for the suture zone over a wide area of western Idaho (fig. 1).

Fleck and Criss have used isotopic and trace-element data to further refine the location of the 0.706 Sri isopleth. They describe the suture zone as the boundary between crust overlying Proterozoic North American lithosphere on the east and upper Paleozoic and Mesozoic intraoceanic crust accreted during Cretaceous time on the west. They detail the pronounced variations in $\mathrm{Sr}, \mathrm{Nd}, \mathrm{Sm}$, and $\mathrm{Rb}$ isotope ratios, in major- and trace- element compositions, and in ages of plutons that occur across the suture zone. They also define the suture zone location by an abrupt increase in initial ${ }^{87} \mathrm{Sr} /{ }^{86} \mathrm{Sr}$ ratios in Mesozoic plutons from eastern Washington east along the Clearwater River through a clockwise bend of about $110^{\circ}$ from Orofino to Harpster, and finally south-southwest to south of Ola, Idaho, where it is concealed by flows of the Columbia River Basalt Group (fig. 1). They conclude that the suture zone remained the locus of continued thermal and tectonic activity long after accretion. They also conclude that deformation and emplacement of plutons migrated from north to south along the suture zone. Interpretations by others of the tectonic origin of rocks on either side of the SRSZ, some of which are described in this volume, are based in large part on the studies of Fleck and Criss.

\section{Chapter 3-Lawrence W. Snee, Gary F. Davidson, and Daniel M. Unruh, Geologic, Geochemical, and ${ }^{40} \mathrm{Ar} /{ }^{39} \mathrm{Ar}$ Thermochronologic Constraints for the Tectonic Development of the Salmon River Suture Zone near Orofino, Idaho}

The late Mesozoic suture zone along the western margin of North America is mostly straight and oriented northsouth, except for an enigmatic, near- $90^{\circ}$ bend to the west near Orofino, Idaho. This bend (fig. 1) has been a subject of much speculation. In a multifaceted approach, Larry Snee, Gary Davidson, and Dan Unruh have studied the Orofino area in great detail by employing regional mapping, structural studies, geochemical analyses, and ${ }^{40} \mathrm{Ar} /{ }^{39} \mathrm{Ar}$ and U-Pb dating.

Where the Salmon River suture zone trends east-west, lower amphibolite-facies igneous and metasedimentary rocks of the Wallowa terrane of the Blue Mountains island- arc complex (to the south) are separated from high-grade, metasedimentary Middle Proterozoic, Belt Supergroup metasedimentary rocks of the pre-Late Cretaceous North American craton by a zone, 8 to $10 \mathrm{~km}$ wide, of strongly deformed, high-grade orthogneiss and metasedimentary rocks of the "Orofino series." Most rocks of the Orofino series have volcanic-arc characteristics as determined by trace-element geochemical studies; thus Snee and others correlate them with the Wallowa terrane. However, rocks having continental affinities are also present in the Orofino series, suggesting that tectonic processes mixed the arc- and continental-affinity rocks with one another. Strongly deformed quartz diorite plutons that were emplaced within the 8- to $10-\mathrm{km}$-wide, west-trending zone provide evidence for the timing of deformation and accretion.

Snee and others suggest that the Orofino segment of the suture zone experienced at least four periods of deformation. During the second, predominant period, high-grade cratonic rocks were thrust to the southwest over lower grade metasedimentary rocks of the Wallowa terrane. This deformation also 
caused southwest-directed telescoping of the margin of the Wallowa terrane that was adjacent to the suture zone. Snee and his coauthors document fold geometry in the Orofino area that suggests deformation having a left-lateral shear component. This deformation was concurrent with the southwest-directed thrusting of continental rocks over island-arc rocks.

Through ${ }^{40} \mathrm{Ar} /{ }^{39} \mathrm{Ar}$ studies, Snee and his coauthors document important plutonic and metamorphic events in the Orofino area. They dated a plutonic event in the Wallowa terrane at 145 Ma, lower-amphibolite metamorphism probably associated with the accretion event at $130 \mathrm{Ma}$, emplacement of quartz diorite plutons in the island-arc terrane about 122 to $115 \mathrm{Ma}$, and postaccretion, west-directed thrust faulting between 93 and 80 $\mathrm{Ma}$. The thrusting event translated this part of the suture zone to the southwest, creating the bend in the suture zone. A zone of left-lateral, ductile, strike-slip translation created a shear zone now exposed within the east-west-trending boundary. Snee and coauthors speculate that the cause of the southwest-directed thrusting was the buoyant rise of plutons in the Idaho Batholith that were emplaced about $90 \mathrm{Ma}$ and/or isostatic rebound of the underthrust northern margin of the Wallowa terrane.

\section{Chapter 4-Martha M. Godchaux and Bill Bonnichsen, Ultramafic Rocks of the Western Idaho Cratonic Suture Zone: Composition, Origin, and Emplacement}

The association of ultramafic rocks with strongly deformed orogenic areas has been known since the early 1900's, when studies in the Swiss and Italian Alps gave birth to the concepts of Alpine-type peridotites and "Steinmann's Trinity" (the association of serpentinized ultramafic rocks, spilite, and chert). Since that time, the combined aspects of field studies, petrologic characterization, experimental petrology, fabric analysis, geophysical studies, and plate tectonics have led to the concepts of ophiolites as representing oceanic crust and underlying upper mantle, obduction of ophiolites into the upper continental crust, and their relationship to suture zones. The relationship can be summarized concisely as "Ophiolites on a large scale mark suture zones of converging plate margins. In most cases, they are parallel to the suture and form pronounced linear belts" (Hyndman, 1985, p. 184).

Marty Godchaux and Bill Bonnichsen provide a systematic inventory and discuss the petrologic character, field details, and geochemistry of ultramafic bodies and their metamorphic equivalents on both sides of the Salmon River suture zone, from Sturgill Peak northward to the bend of the suture zone near Orofino, Idaho (fig. 1). They define a "western Idaho ultramafic belt," which consists of discontinuous small bodies of dunite, serpentinite, metaharzburgite, and clinopyroxenite in a narrow band that is 16 to $24 \mathrm{~km}$ wide and more than $275 \mathrm{~km}$ in length. Two types of original, predeformation and prealteration ultramafic-rock associations have been identified: a dunite-harzburgite suite and a suite composed primarily of Ca-rich pyroxenites. Primary minerals in these rocks were $\mathrm{Mg}$-rich olivine, bronzite, augite, and high-Cr chromite. At present, however, the rocks are mostly altered to mineral assemblages that indicate metamorphism in the greenschist or amphibolite facies; most of them now consist of varying amounts of anthophyllite, tremolite, talc, chlorite, antigorite, magnesite and magnetite, the typical minerals of serpentinites.

Godchaux and Bonnichsen note that all of the ultramafic bodies are probably of the same Mesozoic age, yet some of them are enclosed within rocks designated as Proterozoic. They account for this dilemma by suggesting that the ultramafic bodies were emplaced into the older rocks by faulting, but they discuss the implications of an alternative interpretation that the ultramafic bodies are "stratabound" and thus of the same age as their host rocks. Like other students of ultramafic bodies in orogenic areas, Godchaux and Bonnichsen infer that (1) the ultramafic bodies were originally part of ophiolitic sequences, but the rocks have been thoroughly changed by later tectonic events, and (2) the ultramafic bodies were probably emplaced by obduction processes (into various components of the Blue Mountains island arc terrane(s)) during convergent plate motions. They note that subsequent docking of the Blue Mountains island-arc terrane against the western edge of Late Cretaceous North America and the emplacement of various plutonic units of the Idaho Batholith have obscured the early history of the ultramafic bodies in the western Idaho ultramafic belt and led to their complex metamorphism and alteration.

\section{Chapter 5-Mel A. Kuntz, The Idaho Batholith Near McCall, Idaho: Field Relations, Petrology, Major-Element Chemistry, Emplacement History, and Magma Genesis}

Just as the mafic and ultramafic rocks described by Godchaux and Bonnichsen are characteristic of the suture zones of convergent plate margins, so too are granitoid plutons. This chapter by Mel A. Kuntz describes plutonic units of the Idaho Batholith, straddling and lying to the east of the SRSZ, in an area containing twelve 71/2-minute quadrangles near McCall, Idaho (fig. 1). He and colleagues mapped plutonic units both east and west of the Salmon River suture zone, but his paper focuses on those units that lie east of the zone. He found that the plutonic units have unique three-dimensional shapes. The oldest unit, the tonalite of Payette River, occurs as a narrow, dikelike pluton, and farther east the granodiorite of Box Lake also forms a narrow pluton. In contrast, monzogranite plutons east of the tonalite and granodiorite plutons are more equant in outcrop pattern. The age range for emplacement of these 
plutons is from about $90 \mathrm{Ma}$ for the tonalite of Payette River to about $83 \mathrm{Ma}$ for monzogranite plutons.

Kuntz examines the major-element geochemistry and uses these data to discriminate and identify various tectonic and melt-source environments for the plutonic units. With the chemically constrained tectonic discriminations identified, Kuntz then relates the nature and timing of the formation of the various magmas that produced the contrasting plutonic units to the subduction and suturing of the Blue Mountains island-arc to the western margin of North America in the Late Cretaceous. Briefly, he states that the transition from older tonalite of Payette River to the younger monzogranite of Lick Creek represents a transition from dominantly I-type igneous source rocks to crustal source rocks that may have a significant metasedimentary component. The tectonic compression resulting from the plate interaction was the driving mechanism for horizontal shortening, vertical thickening of the crust, metamorphism, and magmatism. He suggests that tonalite magma could have formed by dehydration melting of subducted tonalitic and amphibolitic source rocks in a crust 45 to $60 \mathrm{~km}$ thick under a normal geothermal gradient. The partial melting of fertile pre-Belt gneisses that contained considerable amounts of muscovite and biotite was an extremely efficient process, yielding large volumes of relatively homogeneous monzogranite magma that probably formed plutons "in place." The efficient melting process produced rather homogenous plutons with a lack of sharp contacts with one another, little contrast in textures and chemical composition, and little if any content of restite.

\section{Chapter 6-Gary M. Mann and Tracy Vallier, Mesozoic Telescoping of Island Arc Terranes and Geologic Evolution of the Cuddy Mountains Region, Western Idaho}

Geologic maps of western Idaho and eastern Oregon (for example, Vallier, 1995, p. 137) show that the terranes of the Blue Mountains island-arc complex are telescoped as they approach the Salmon River suture zone in the area between Brownlee Dam and Harpster, Idaho (fig. 1). The Baker, Izee, and Olds Ferry terranes of the Blue Mountains island-arc complex narrow markedly in outcrop pattern as they trend northeastward toward Riggins, and these three terranes are sequentially cut out in a northeasterly direction by the Wallowa terrane. The tectonic processes that caused the constriction and obliteration (at least at the present level of exposure) of these terranes adjacent to the SRSZ are both extremely complex and mostly abstruse.

In order to set the stage for the discussion of their study of the attenuated terranes in the Cuddy Mountain area (fig. 1), Gary Mann and Tracy Vallier first review critical petrologic, structural, and plate-tectonic characteristics for each of the four upper Paleozoic-Mesozoic tectonostratigraphic terranes that were amalgamated to form the Blue Mountains island-arc complex. In the Cuddy Mountain area, they recognize two terranes (termed "belts") that are similar in petrologic character to the Baker and Olds Ferry terranes to the southwest, and a third terrane, the Wildhorse belt, which they correlate with the Wallowa terrane. They also mapped two separate units within the Olds Ferry belt, the Weatherby and Huntington Formations. Each of these three, narrow tectonic belts - the Baker, Olds Ferry, and Wildhorse - is bounded by faults; the evaluation of these faults is a major contribution of their paper.

On the basis of field mapping, Mann and Vallier describe one of these faults, the Wildhorse shear zone, in much detail. They interpret the Wildhorse shear zone as a thrust-fault duplex that separates the Wildhorse and Baker belts, and they suggest the duplex was a major structure involved in the telescoping of the terranes and the accretion of the Blue Mountains island-arc complex to the North American continent. All rocks within the Wildhorse zone are highly sheared, either cataclastic or mylonitic. Several rock types are unique to the shear zone. Silicic tuff; volcaniclastic sandstone, tuffs and ribbon chert; and conglomerate composed of recrystallized chert pebbles appear to be of Baker belt affinity and they were likely emplaced in the Wildhorse shear zone as fault-bounded horses stripped from the Baker belt during collapse of footwall ramps during obliquethrust duplexing. Another unique rock type in the Wildhorse shear zone is dismembered, recrystallized quartz diorite, which is probably a hanging-wall fragment, plucked from the Wallowa-terrane basement during thrusting.

Mann and Vallier state that during collision, the Blue Mountains terranes were telescoped against North America along major oblique, overthrust faults that created the distinct elongated tectonic belts in the Cuddy Mountain region (fig. 1). The Wallowa terrane was thrust eastward over the Baker terrane along the Wildhorse shear zone. Specifically, they state that the telescoping and thinning processes are the result of extensive, left-oblique transpression and that the east-directed thrusting produced overriding and the characteristic thinning of the various belts in the Cuddy Mountain area.

\section{Chapter 7-Mel A. Kuntz, Structure and Tectonic Evolution of the Border Zone of the Idaho Batholith Near McCall, Idaho}

In his study of the plutonic units of the western margin of the Idaho Batholith, Kuntz measured foliations, lineations, dikes, veins, and joints to statistically evaluate the orientation and strength of these structures. Generally, he found that the structures were better ordered and systematic in the older plutonic units closer to the Salmon River suture zone and more diffuse and dispersed in younger plutonic units farther away, suggesting that there is a genetic link between the timing and intensity of the structures and the sequential tectonic develop- 
ment of the suture zone. To investigate this relationship, he analyzed and characterized the general strain regimes that existed during formation of the various plutonic units and then made inferences regarding the orientation of stresses and their tectonic significance. This approach follows that of Oldow and others (1984), who related structures in Mesozoic rocks of the Sierran arc to the kinematics of plate motions relative to North America. In order to examine the relationship between the orientation of stresses and their tectonic significance, Kuntz made the following assumptions: (1) Foliation and lineation formed in compressional shear, and poles to foliation are parallel to axes of shortening, (2) lineations result from stretching and are nearly parallel to axes of extension, and (3) poles to dikes and joints are nearly parallel to axes of extension. From these structural assumptions, in conjunction with ages of the plutons from ${ }^{40} \mathrm{Ar} /{ }^{39} \mathrm{Ar}$ studies, he inferred that the orientation of axes of compression and extension during the period of emplacement of the various plutons changed from $90 \mathrm{Ma}$ to $70 \mathrm{Ma}$. He suggests that the region of the western border of the Idaho Batholith was one of severe compression at about 90, Ma with the axis of shortening oriented northwest-southeast, and that the degree of compression weakened in the next 20 m.y. and was reoriented to an axis of southwest-northeast. He also suggests that the region progressed from severe compression through weak compression and finally to extension during this period. The change in the absolute motion trajectory of the North American Plate, from a northwest direction in the period 120-90 Ma to east-west at about $70 \mathrm{Ma}$, may explain the shifting orientation of the paleostrain system during this same period. He states that a component of sinistral translational movement of the block west of the SRSZ, the changing motions of the North American Plate, and a component of vertical movement of the eastern block appear to account for the timing of emplacement of the plutonic units and for the orientation of the structures within them.

Generation and emplacement mechanisms for the huge volumes of granitoid magmas that form batholiths in magmatic arcs have been the subject of great debate and are still largely unresolved. One of the main questions concerns the generation and emplacement of magmas in zones undergoing severe shortening and translation; that is, how can room be created for magmas emplaced in zones of shortening? Using studies by other researchers, Kuntz discusses this problem and offers suggestions for the emplacement mechanisms for the various plutonic units in the western margin of the Idaho Batholith.

\section{Editors' Comment}

Plans for the publication of this volume began with discussions among the various authors of the papers about a decade ago. Since that time, several adverse and untimely events conspired to delay publication of this volume. The patience of the authors and their faith that this volume would one day come to life is greatly appreciated. We hope the pub- lication and significance of the volume will help to alleviate their long-held concerns.

\section{Acknowledgments}

The authors appreciate the careful and thorough reviews of this paper provided by Paul K. Sims and Karl V. Evans of the U. S. Geological Survey. Peter Stauffer of the U.S. Geological Survey is to be commended for his thoughtful and thorough review of all papers in this volume.

\section{References Cited}

Anderson, A.L., 1930, The geology and mineral resources of the region about Orofino, Idaho: Idaho Bureau of Mines and Geology, Pamphlet 34, 63 p.

Anderson, A.L., 1951, Metallogenic epochs in Idaho: Economic Geology, v. 46, p. 592-607.

Anderson, A.L., 1952, Multiple emplacement of the Idaho batholith: Journal of Geology, v. 60, p. 255-265.

Armstrong, R.L., Taubeneck, W.H., and Hales, P.O., 1977, Rb/ $\mathrm{Sr}$ and $\mathrm{K} / \mathrm{Ar}$ geochronometry of the Mesozoic granitic rocks and their $\mathrm{Sr}$ isotopic composition, Oregon, Washington, and Idaho: Geological Society of America Bulletin, v. 88, p. 397-411.

Barrell, J., 1917, Rhythms and the measurement of geologic time: Geological Society of America Bulletin, v. 28, p. 745904.

Becker, G.F., 1880, Geologic sketch of the Pacific Division of the U.S. Geological Survey: Publications of the Tenth Census; Volume 12, p. 5-59.

Brooks, H.C., 1963, Quicksilver in Oregon: Oregon Department of Geology and Mineral Industries Bulletin 55, 223 p.

Brooks, H.C., and Ramp, L., 1968, Gold and silver in Oregon: Oregon Department of Geology and Mineral Industries Bulletin $61,337 \mathrm{p}$.

Brooks, H.C., and Vallier, T.L., 1967, Progress report on the geology of part of the Snake River Canyon, Oregon and Idaho: The Ore Bin, v. 29, p. 233-266.

Brooks, H.C., and Vallier, T.L., 1978, Mesozoic rocks and tectonic evolution of eastern Oregon and western Idaho, in Howell, D.G., and McDougall, K.A., eds., Mesozoic paleogeography of the western United States: Los Angeles, California, Society of Economic Paleontologists and Mineralogists, p. 133-145.

Coney, P.J., Jones, D.L., and Monger, J.W.H., 1980, Cordilleran suspect terranes: Nature, v. 288, p. 329-333.

Eldridge, G.H., 1895, A geological reconnaissance across Idaho: U.S. Geological Survey Sixteenth Annual Report, Part 2, p. 211-276. 
Fleck, R.J., 1990, Neodymium, strontium, and trace-element evidence of crustal anatexis and magma mixing in the Idaho batholith, in Anderson, J.L., ed., The nature and origin of Cordilleran magmatism: Geological Society of America Memoir 174, pp. 359-374.

Fleck, R.J., and Criss, R.E., 1985, Strontium and oxygen isotopic variations in Mesozoic and Tertiary plutons of central Idaho: Contributions to Mineralogy and Petrology, v. 90, p. 291-308.

Hamilton, W., 1963, Metamorphism in the Riggins region, western Idaho: U. S. Geological Survey Professional Paper 436, $95 \mathrm{p}$.

Hamilton, W., 1969, Reconnaissance geologic map of the Riggins quadrangle, west-central Idaho: U. S. Geological Survey Miscellaneous Geologic Investigations Map I-579, scale 1:125,000.

Hietanen, A., 1963a, Metasomatic metamorphism in western Clearwater County, Idaho: U. S. Geological Survey Professional Paper 344-A, 116 p.

Hietanen, A., 1963b, Anorthosite and associated rocks in the Boehls Butte quadrangle and vicinity, Idaho: U. S. Geological Survey Professional Paper 344-B, 78 p.

Hietanen, A., 1963c, Metasomatism of the Belt Series in the Elk River-Clarkia area, Idaho: U. S. Geological Survey Professional Paper 344-C, 116 p.

Hietanen, A., 1963d, Idaho batholith near Pierce and Bungalow, Clearwater County, Idaho: U. S. Geological Survey Professional Paper 344-D, 42 p.

Hietanen, A., 1963e, Belt Series in the region around Snow Peak and Mallard Peak, Idaho: U. S. Geological Survey Professional Paper 344-E, 34 p.

Hietanen, A., 1984, Geology along the northwest border zone of the Idaho batholith, Idaho: U. S. Geological Survey Bulletin $1608,17 \mathrm{p}$.

Holmes, A., 1913, The age of the Earth: New York, Harper Brothers, $195 \mathrm{p}$.

Hyndman, D.W., 1985, Petrology of igneous and metamorphic rocks ( $2^{\text {nd }}$ ed.): New York, McGraw-Hill, 785 p.

Kistler, R.W., and Peterman, Z.E., 1978, Reconstruction of crustal blocks of California on the basis of initial strontium isotopic compositions of Mesozoic granitic rocks: U.S. Geological Survey Professional Paper 1071, 17 p.

Lindgren, W. 1897, The mining districts of the Idaho Basin and Boise Ridge, Idaho: U.S. Geological Survey Eighteenth Annual Report, Part 3, p. 617-719.

Lindgren, W., 1898, Boise Folio, Idaho: U.S. Geological Survey, Geologic Atlas of the United States, Folio 45.

Lindgren, W., 1900, The gold and silver veins of the Silver City, De Lamar and other mining districts in Idaho: U.S. Geological Survey Twentieth Annual Report, Part 3, p. 65-256.

Lindgren, W., 1901, The gold belt of the Blue Mountains of Oregon: U.S. Geological Survey Twenty-Second Annual Report, Part 2, p. 551-776.
Lindgren, W., 1904, A geological reconnaissance across the Bitterroot Range and Clearwater Mountains in Montana and Idaho: U.S. Geological Survey Professional Paper 27, 123

p.

Lindgren, W., 1915, The igneous geology of the Cordilleras and its problems: in Rice, W. N. and others, Problems in American Geology: New Haven, Connecticut, Yale University Press, p. 234-376.

Lund, K., 1984, Tectonic history of a continent-island arc boundary, west-central Idaho: State College, Pennsylvania State University, Ph.D. dissertation, 210 p.

Lund, K., and Snee, L.W., 1988, Metamorphism, structural development, and age of the continent-island arc juncture in west-central Idaho, in Ernst, W.G., ed., Metamorphism and crustal evolution in the western conterminous U.S.: Englewood Cliffs, New Jersey, Prentiss Hall, p. 296-331.

Manduca, C.A., Kuntz, M.A., and Silver, L.T., 1993, Emplacement and deformation history of the western margin of the Idaho Batholith near McCall, Idaho; influence of a major terrane boundary: Geological Society of America Bulletin, v. 105 , p. 749-765.

McClelland, W.C., Tikoff, B., and Manduca, C.A., 2000, Twophase evolution of accretionary margins; examples from the North American Cordillera: Tectonophysics, v. 326, p. 37-55.

Oldow, J.S., Ave' Lallement, H.G., and Schmidt, W.J., 1984, Kinematics of plate convergence deduced from Mesozoic structures in the western Cordillera: Tectonics, v. 3, p. 201227.

Pitcher, W.S., 1997, The nature and origin of granite ( $2^{\text {nd }}$ ed.): London, England, Chapman and Hall, 387 p.

Ross, C.P., 1928, Mesozoic and Tertiary granitic rocks in Idaho: Journal of Geology, v. 36, p. 673-693.

Selverstone, J., Wernicke, B.P., and Aliberti, E.A., 1992, Intracontinental subduction and hinged unroofing along the Salmon River suture zone, west central Idaho; Tectonics, v. 11, p. 124-144.

Vallier, T. L., 1967, Geology of part of the Snake River canyon, Oregon and western Idaho: Corvallis, Oregon State University, Ph.D. dissertation, 267 p.

Vallier, T.L., 1995, Petrology of pre-Tertiary igneous rocks in the Blue Mountains region of Oregon, Idaho, and Washington; implications for the geologic evolution of a complex island-arc, in Vallier, T.L., and Brooks, H.C., eds., Geology of the Blue Mountains region of Oregon, Idaho, and Washington: U.S. Geological Survey Professional Paper 1438, p. 125-210.

Vallier, T.L., Brooks, H.C., and Thayer, T.P., 1977, Paleozoic rocks of eastern Oregon and western Idaho, in Stewart, J.H., Stevens, C.H., and Gritsche, A.E., eds., Paleozoic paleogeography of the western United States: Los Angeles, California, Society of Economic Paleontologists and Mineralogists, p. 455-466. 


\title{
2. Location, Age, and Tectonic Significance of the Western Idaho Suture Zone
}

\author{
By Robert J. Fleck and Robert E. Criss
}

\section{Abstract}

The western Idaho suture zone (WISZ) represents the boundary between crust overlying Proterozoic North American lithosphere and Late Paleozoic and Mesozoic intraoceanic crust accreted during Cretaceous time. Highly deformed plutons constituted of both arc and sialic components intrude the WISZ and in places are thrust over the accreted terranes. Pronounced variations in $\mathrm{Sr}, \mathrm{Nd}$, and $\mathrm{O}$ isotope ratios and in major- and trace-element composition occur across the suture zone in Mesozoic plutons. The WISZ is located by an abrupt west to east increase in initial ${ }^{87} \mathrm{Sr} /{ }^{86} \mathrm{Sr}$ ratios, traceable for more than $300 \mathrm{~km}$ from eastern Washington near Clarkston, east along the Clearwater River thorough a bend to the south of about $110^{\circ}$ from Orofino Creek to Harpster, and extending southsouthwest to near Ola, Idaho, where Columbia River basalts conceal its extension to the south. K- $\mathrm{Ar}$ and ${ }^{40} \mathrm{Ar} /{ }^{39} \mathrm{Ar}$ apparent ages of hornblende and biotite from Jurassic and Early Cretaceous plutons in the accreted terranes are highly discordant within about $10 \mathrm{~km}$ of the WISZ, exhibiting patterns of thermal loss caused by deformation, subsequent batholith intrusion, and rapid rise of the continental margin. Major crustal movements within the WISZ commenced after about $135 \mathrm{Ma}$, but much of the displacement may have been largely vertical, during and following emplacement of batholith-scale silicic magmas. Deformation continued until at least $85 \mathrm{Ma}$ and probably until $74 \mathrm{Ma}$, progressing from south to north.

\section{Introduction}

Geologic investigations of western Idaho and eastern Oregon and Washington have disclosed the presence of several tectonostratigraphic terranes, referred to here collectively as the Wallowa-Seven Devils (WSD) terranes, representing Late Paleozoic to Mesozoic island-arc complexes accreted to North America in Cretaceous time (Hamilton, 1976; Jones and others, 1977; Vallier, 1977; Fleck and Criss, 1985; Lund and Snee, 1988; Snee and others, 1995). The classic Sr-isotope and geochronologic study by Armstrong and others (1977) demonstrated that plutons intruding these arc terranes are distinct from those intruding the Precambrian crust of North America. Subsequent studies by Fleck and Criss (1985), Criss and Fleck (1987), Fleck (1990), and Manduca and others (1992, 1993) generally confirm these relationships and provide abundant data on the isotope geochemistry and age of plutonic rocks of the region, as well as on the character of their sources and the terranes through which they were emplaced.

This study focuses on the location, age, and character of the tectonic boundary between the North American craton and the WSD terranes. Although inferred to extend from southeastern Washington to the Snake River Plain, exposures of this boundary are recognized in western Idaho from near Ahsahka in the north to near Ola in the south (fig.1). Because the suture boundary is confined to western Idaho over its recognized length, but is not well located by any other geographic feature, the structure is referred to here as the "western Idaho suture zone" or WISZ (Strayer and others, 1987; Strayer and others, 1988; Fleck and Criss, 1988; Strayer and others, 1989; Fleck, 1990). The name "Salmon River suture zone" has also been used for the zone (Lund and Snee, 1988) in west-central Idaho, but because the Salmon River is one of several geographic features that cross the suture at almost $90^{\circ}$, we do not consider the name adequately representative. McCelland and others (2000) have used "western Idaho shear zone" for the late-stage, mylonitic part of the terrane boundary, essentially consistent with the use of WISZ here, but use "Salmon River suture zone" to incorporate the belt of Cretaceous(?) thrust faults within the WSD terranes into their definition of the suture. We confine our usage of Western Idaho suture zone to the highly strained and metamorphosed rocks of the terrane boundary zone, recognized by their degree of deformation and an abrupt transition of geochemical and isotopic characteristics from intraoceanic island-arc to North American craton. We accept that many of the plutons now representing the zone were emplaced subsequent to the initial suturing events, which may not have been synchronous along the $>280-\mathrm{km}$ length of the suture.

\section{Acknowledgments}

We thank Ron Kistler and Andy Calvert for helpful discussions and reviews of the manuscript. Susan Gunn, Elliot Kollman, and Betsy Rosenberg assisted with Rb-Sr and Sm-Nd analyses. Jarel Von Essen, James Saburomaru, and Elliot Kollman performed argon analyses and sample preparation. Paul Klock, David Vivit, and Terry Fries performed potassium analyses. James Saburomaru prepared samples for irradiation and performed ${ }^{40} \mathrm{Ar} /{ }^{39} \mathrm{Ar}$ analyses. Don Shamp assisted with data compilation. 


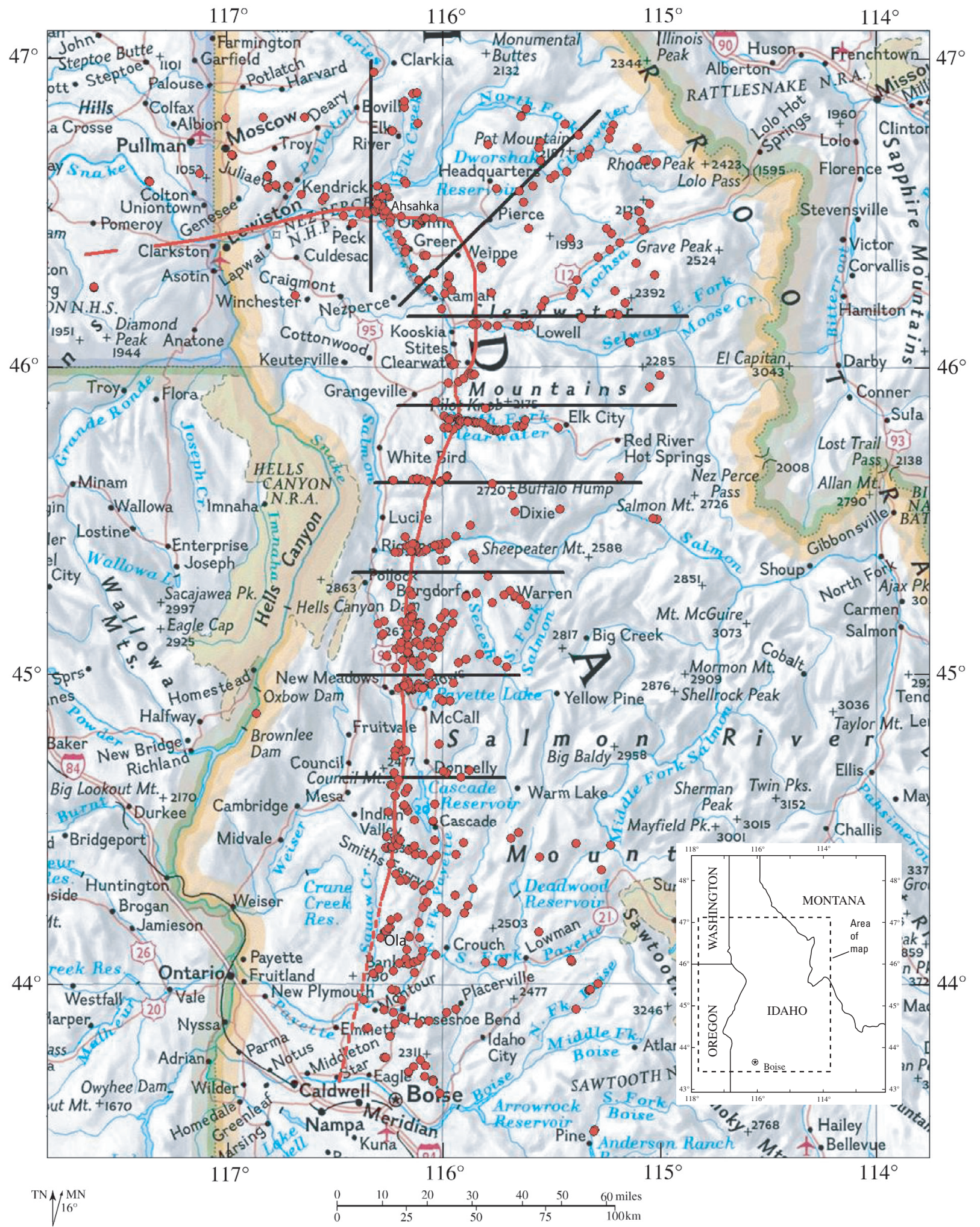

Figure 1. Location of the western Idaho suture zone (WISZ). The suture zone is shown as a heavy red line, traceable from southeastern Washington to southwestern Idaho. The zone is identified primarily on the basis of isotopic analyses of samples located here as red dots. Locations of age traverses discussed in the text are shown as heavy black lines crossing the suture zone from the Late Paleozoic and Mesozoic accreted terranes on the south or west to the cratonal terranes of Mesozoic North America on the north and east. The location of the figure is shown in the index map. The WISZ occurs near the western margin of the Idaho Batholith over much of its length. (Shaded relief map created with TOPO! 2002 National Geographic). 


\section{Regional Relations}

\section{Geologic Setting}

The western limit of Precambrian rocks of North American cratonal terranes in Idaho south of the Clearwater River occurs at about long $116^{\circ} \mathrm{W}$, but bends abruptly westward north of the river, cropping out discontinuously from beneath Columbia River basalt flows into eastern Washington (fig. 1). West and south of this limit, the oldest rocks are Devonian to Permian suites of sedimentary shelf deposits, dismembered oceanic crust, and volcanic/plutonic arc rocks (Vallier and others, 1977; Beaulieu, 1972; Walker, 1977; Mullen, 1985), representing an intraoceanic assemblage of depositionally and tectonically juxtaposed igneous and sedimentary units. The boundary between these distinct crustal types is a highly deformed, often mylonitic zone with anastomosing fractures, cataclasis, and recrystallization (Myers, 1982; Strayer and others, 1989), representing the "suture" between North American cratonal terranes and the WSD terranes (Fleck and Criss, 1985; Criss and Fleck, 1987; Fleck, 1990, Manduca and others (1992, 1993), McCelland and others, 2000). The character of rocks proximal to the suture zone is key to understanding the WISZ. Rocks of both terrane groups were variably metamorphosed, reaching upper amphibolite grade with P-T conditions up to $600^{\circ} \mathrm{C}$ and 8 to 9 kbar near the suture (Myers, 1982;

Lund and Snee, 1988; Selverstone and others, 1992; Getty and others, 1993). WDS terranes only reached these highest grades in proximity to the suture, whereas contact metamorphic effects of plutons of the Idaho Batholith extend high-temperature isograds well into the Precambrian terrane (for example, Hietanen (1962, 1963a, 1963b; Myers, 1982). Studies of the Idaho Batholith and cratonal terrane in the region of the WISZ include Hietanen (1962, 1963a, 1963b, 1967), Myers (1982), Wiswall and Hyndman (1987), Lund and Snee (1988), Manduca and others (1992, 1993), and Lund (1995). The WSD terranes are discussed by Hamilton (1963a,b), Taubeneck (1971), Beaulieu (1972), Vallier and others (1977), Brooks and Vallier (1978), Ave Lallemant and others (1980, 1985), Mullen (1985), Onasch (1987), Manduca and others (1992, 1993), and Lund (1995).

Volumes edited by Vallier and Brooks (1987b, 1995) include important studies of both the WSD and cratonal terranes, as well as specific studies of the suture zone (WISZ). In the first of these volumes, Criss and Fleck (1987) provide K-Ar and ${ }^{40} \mathrm{Ar} /{ }^{39} \mathrm{Ar}$ results for rocks of north-central Idaho, including samples from the suture zone. These ages constrain the age of suturing to the period between 135 and $75 \mathrm{Ma}$ and suggest a most probable range of 95 to $80 \mathrm{Ma}$. Lund and Snee (1988) concluded that suturing occurred between 118 and $93 \mathrm{Ma}$, based on ${ }^{40} \mathrm{Ar} /{ }^{39} \mathrm{Ar}$ ages of metamorphic rocks of the WSD terranes and undeformed plutons in and adjacent to the WISZ. Getty and others (1993) report Sm-Nd ages from 144 to $128 \mathrm{Ma}$ for garnet amphibolites formed during metamorphism of the accreted ter- ranes. They interpret the age of $128 \pm 3 \mathrm{Ma}$ to represent the time of peak metamorphism, with the ${ }^{40} \mathrm{Ar} /{ }^{39} \mathrm{Ar}$ age of $118 \mathrm{Ma}$ for coexisting hornblende representing cooling subsequent to suturing. Manduca and others (1993) report the presence of supracrustal units from both the WSD and cratonal terranes in $110 \pm 5$ Ma orthogneiss, supporting an earlier joining of these terranes. They also support a timing of arc-continent collision prior to $125 \mathrm{Ma}$. Snee and others (1995) report ${ }^{40} \mathrm{Ar} /{ }^{39} \mathrm{Ar}$ results for a suite of samples along the suture zone from south of its intersection with the Salmon River to where it crosses the South Fork of the Clearwater River. They argue that suturing was complete by $93 \mathrm{Ma}$, followed by rapid uplift of cratonal terranes. Contrary to results reported by Criss and Fleck (1987) farther north, they conclude that no plutonism occurred in the area between 88 and 78 Ma during the major period of uplift.

The results from all of these studies suggest that suturing of the WSD terranes to the North American craton was a prolonged event, with continuation of contractional deformation long after peak metamorphism. Late Cretaceous plutons with isotopic signatures of continental crust reflect tectonic emplacement and uplift of 10 to $20 \mathrm{~km}$, indicating that major crustal movements occurred within the suture zone until at least 85 Ma (Myers, 1982; Criss and Fleck, 1987; Lund and Snee, 1988; Selverstone and others, 1992; Manduca and others, 1992, 1993). Snee and others (1995) report four periods of metamorphism between 130 and $101 \mathrm{Ma}$ with plutonism peaking at about $115 \mathrm{Ma}$ and 93 to $88 \mathrm{Ma}$ in the Slate CreekSalmon River section of the WISZ. Most authors accept an age of $130 \mathrm{Ma}$ to $115 \mathrm{Ma}$ for collision and accretion (suturing) of the WSD terrane to North America, but there is widespread evidence of continued deformation and intrusion along the WISZ after $95 \mathrm{Ma}$.

Plutonism within the WSD terranes occurred in three primary episodes: 270 to $215 \mathrm{Ma}, 145$ to $115 \mathrm{Ma}$, and 95 to $85 \mathrm{Ma}$, although a few Middle to Late Jurassic ages have been reported (Armstrong and others, 1977; Brooks and Vallier, 1978; Ave Lallemant and others, 1980; Criss and Fleck, 1987; Walker, 1995; Snee and others, 1995). Although most plutons reveal some evidence of subsequent deformation, mylonitization is only common in major shear zones such as the Oxbow shear zone (Vallier, 1974; Ave Lallemant and others, 1985), the Rapid River thrust (Hamilton, 1963a,b), and the WISZ. Only the last involves rocks of the cratonal terrane, however. Although deformation and metamorphism of the rocks involved may have begun earlier, significant movement along these shear zones clearly postdated emplacement of the mylonitized plutons and peak metamorphism of the host terranes. Hamilton (1963a,b) and Ave Lallemant and others (1980, 1985) present strong evidence for at least two periods of metamorphism and mylonitization within the WSD terranes. A Late Triassic-Early Jurassic age is favored for the older of these events (Brooks and Vallier, 1978; Ave Lallemant and others, 1985). Deformation along the WISZ is not confined to the accreted terranes and represents an even younger period, continuing until at least $78 \mathrm{Ma}$ (Criss and Fleck, 1987; Lund and Snee, 1988). 


\section{The Western Idaho Suture Zone}

The western Idaho suture zone (WISZ) is a highly deformed zone of near-vertical foliation, anastomosing fractures, cataclasis or mylonitization, recrystallization, and interleaved tectonic slivers (Myers, 1982; Hoover, 1986; Strayer and others, 1989; Manduca and others, 1992, 1993; Lund, 1995). Within this zone of extreme deformation, Late Paleozoic and Mesozoic volcanic and sedimentary rocks are complexly sheared and tectonically juxtaposed with Proterozoic gneisses and schists and Cretaceous granitoids emplaced during or prior to deformation (Myers, 1982). The WISZ is recognizable not only by its juxtaposition of distinct rock types and its degree of deformation, but also by geochemical and isotopic variations in plutons emplaced within and through the two different crustal types. Armstrong and others (1977) first documented the large change in initial ${ }^{87} \mathrm{Sr} /{ }^{86} \mathrm{Sr}$ ratio $\left(\mathrm{Sr}_{\mathrm{i}}\right)$ of plutons in this part of Idaho. Further investigation by Fleck and Criss (1985) revealed that, although abrupt, the west to east increase in initial ratios was not discontinuous, but that the low $(<0.704)$ ratios characteristic of plutons intruding the WSD terranes give way almost continuously to the high $(>0.708)$ values characteristic of magmas emplaced through Precambrian sialic crust. Fleck (1990) demonstrated that $\boldsymbol{\varepsilon}_{\mathrm{Nd}}$ decreases across this narrow zone, almost antithetic to the $\mathrm{Sr}_{\mathrm{i}}$ increase, from values of about +6 to below -8 . This change in $\mathrm{Sr}$ and $\mathrm{Nd}$ initial ratios occurs across a 5 - to 15 -km-wide zone that coincides with the WISZ. Plutons intruding this narrow transition zone have inherited their geochemical characteristics from both of the crustal types (Fleck and Criss, 1985; Fleck, 1990).

Data presented by Fleck and Criss (1985), Criss and Fleck (1987), Fleck (1990), and Manduca and others (1992, 1993) demonstrate both chemical and isotopic variations across the WISZ. In addition to the variations in $\mathrm{Sr}_{\mathrm{i}}$ and $\varepsilon_{\mathrm{Nd}}$, whole-rock $\delta^{18} \mathrm{O}$ values of plutons increase systematically from a range of +5.5 to +8.0 in the WSD terranes to +9.0 to +12.5 in the Precambrian-hosted Idaho Batholith, changing continuously across the WISZ. Systematic west to east changes also occur in $\delta \mathrm{D}$ values, $\mathrm{Rb} / \mathrm{Sr}$ ratios, and in $\mathrm{SiO}_{2}, \mathrm{Al}_{2} \mathrm{O}_{3}$, and $\mathrm{K}_{2} \mathrm{O}$ contents of plutons within the WISZ (Criss and Fleck, 1987). Fleck (1990) demonstrated west to east increases in $\mathrm{Nd}, \mathrm{Sm}, \mathrm{Y}$, and $\mathrm{Nb}$ and concomitant decreases in $\boldsymbol{\varepsilon}_{\mathrm{Nd}}$ and $\mathrm{Sr} / \mathrm{Sm}$.

\section{Isotopic Results}

$\mathrm{Sr}$ and $\mathrm{Nd}$ isotopic results obtained in this study for plutonic rocks of western Idaho are compatible with our earlier results (Fleck and Criss, 1985; Criss and Fleck, 1987; Fleck, 1990), demonstrating the similarity of the crustal signatures of the cratonal and accreted terranes along the length of the suture zone. The similarities must also extend in at least a general way to the sources of the magmas from which the plutons of each terrane were derived and to the processes of crystallization and assimilation affecting the final products. The broad similarity over the nearly $300-\mathrm{km}$ length of the suture zone reinforces the usefulness of isotopic tracers as a means of locating and identifying the suture zone throughout western Idaho. Isotopic data from previous studies have been incorporated in this study, but are not tabulated here. Discussions of the chemical and isotopic variations and their significance to magma sources are covered in greater detail in Fleck (1990) for rocks of the South Fork of the Clearwater River (SFCR).

Analytical techniques used in this study were essentially the same as reported by Fleck and Criss (1985) and Fleck (1990). All Sm and Nd concentrations and some Rb and Sr concentrations were determined by isotope dilution. $\mathrm{Sr}$ and $\mathrm{Nd}$ isotopic ratios were measured by double collection on a Finnigan-MAT 261 thermal-ionization mass spectrometer. Uncertainties in measured ${ }^{87} \mathrm{Sr} /{ }^{86} \mathrm{Sr}$ were commonly \pm 25 $\operatorname{ppm}\left(2 \sigma\right.$ mean). For Sr calculations, $\lambda_{\mathrm{Rb}}=1.42 \times 10^{-11} \mathrm{yr}^{-1}$, $\left({ }^{87} \mathrm{Sr} /{ }^{86} \mathrm{Sr}\right)_{\mathrm{CHUR}}=0.7045$, and $\left({ }^{87} \mathrm{Rb} /{ }^{86} \mathrm{Sr}\right)_{\mathrm{CHUR}}=0.0839$. Uncertainties in ${ }^{143} \mathrm{Nd} /{ }^{144} \mathrm{Nd}$ ratios averaged $\pm 35 \mathrm{ppm}(2 \sigma$ mean $)$, equivalent to $\pm 0.35 \varepsilon_{\mathrm{Nd}}$ units. Constants used in Nd calculations were: $\lambda_{\mathrm{Sm}}=6.54 \times 10^{-12} \mathrm{yr}^{-1},\left({ }^{143} \mathrm{Nd} /{ }^{144} \mathrm{Nd}\right)_{\mathrm{CHUR}}=0.51264$, and $\left({ }^{147} \mathrm{Sm} /{ }^{144} \mathrm{Nd}\right)_{\mathrm{CHUR}}=0.1967$. Where used here, $\varepsilon_{\mathrm{Sr}}$ and $\varepsilon_{\mathrm{Nd}}$ are calculated in the usual manner relative to a model undisturbed chondritic reservoir CHUR (DePaolo and Wasserburg, 1976, 1979). $\varepsilon_{\mathrm{Nd}}(\mathrm{t})$ designates $\boldsymbol{\varepsilon}_{\mathrm{Nd}}$ at the age of the rock, analogous to an initial ratio. Sr isotopic results and location information are shown in table 1 and $\mathrm{Nd}$ results appear in table 2. New K-Ar and ${ }^{40} \mathrm{Ar} /{ }^{39} \mathrm{Ar}$ age determinations are reported in tables 3 and 4 , respectively.

\section{Chemical and Isotopic Characteristics}

Studies of both plutonic rocks and their wall rock hosts exposed along the South Fork of the Clearwater River (SFCR) by Myers (1982), Fleck and Criss (1985), Hoover (1986), Criss and Fleck (1987), and Fleck (1990) have provided a detailed characterization of chemical and isotopic variations across the terrane boundary between Precambrian crust and Late Paleozoic-Mesozoic island-arc rocks. Similar studies by Lund and Snee (1988) and Manduca and others (1992, 1993) characterize this suture zone farther south in the area of McCall, Idaho. This boundary, the western Idaho suture zone or WISZ, was formed when arc-derived terranes were accreted to the North American craton in Cretaceous time. Combined with the earlier studies, the isotopic results permit identification of the WISZ throughout western Idaho, even where the boundary zone itself is completely obscured by younger plutons, young basalt flows, or alluviated valleys. Clearly, these studies cannot replace careful geologic mapping of the suture, but provide both a guide and confirmation for those studies.

\section{Unique Character of Suture-Zone Magmas}

Fleck and Criss (1985) and Fleck (1990) have presented evidence of multiple components in plutons of the SFCR, whose proportions vary geographically across the WISZ. Hart 
(1985) reported similar results for basaltic rocks that cross the presumed southwestward projection of the Mesozoic suture zone into southern Idaho and Oregon. Interpretation of chemical and isotopic variations to be genetically related to tectonically juxtaposed lithospheric types depends critically on documenting a systematic geographic control of these variations. Examples of unsystematic, source-related variations with no interpretable geographic control have been reported by Carlson and others (1981) and Carlson (1984), where variable proportions of multiple components in Columbia River basalt magmas cannot be related to any current model of terrane boundaries.

$\mathrm{Nd}$ and $\mathrm{Sr}$ isotopic variations across the WISZ were reported for Mesozoic plutons in a study along the South Fork of the Clearwater River by Fleck (1990). Additional analyses (table 3) and the SFCR data are plotted in figure 2 against their distance from the WISZ. As expected from increased contributions from cratonal crust, $\mathrm{Sr}$ initial ${ }^{87} \mathrm{Sr} /{ }^{86} \mathrm{Sr}$ ratios $\left(\mathrm{Sr}_{\mathrm{i}}\right)$ become strikingly more radiogenic from west to east and $\varepsilon_{\mathrm{Nd}}(\mathrm{t})$ decreases abruptly. Isotopic results for plutons within $5 \mathrm{~km}$ of the suture exhibit the effects of components characteristic not only of the WSD terranes, but also of older, subcontinental source terranes (fig. 2). Although the variations are clearly centered on the WISZ, isotopic ratios begin to show respective increases or decreases on either side of the zone well before the zone is reached. This influence on magmas by both terranes suggests that at least some of the plutons postdate actual accretion and that magmatism and tectonism continued after initial suturing. Samples most distant from the WISZ in either of the terranes have $\varepsilon_{\mathrm{Nd}}(\mathrm{t})$ and initial ${ }^{87} \mathrm{Sr} /{ }^{86} \mathrm{Sr}$ ratios, also calculated as $\varepsilon_{\mathrm{Sr}}(\mathrm{t})$, that are representative of the extremes of the two terranes. The covariation of the two radiogenic isotopes across the suture zone defines the inverse relation expected of a mixing process of oceanic-crustal or arc sources with Proterozoic lithospheric sources (fig. 3). As discussed by Fleck (1990), multiple end-members are required to provide the observed chemical and isotopic variations, but the primary

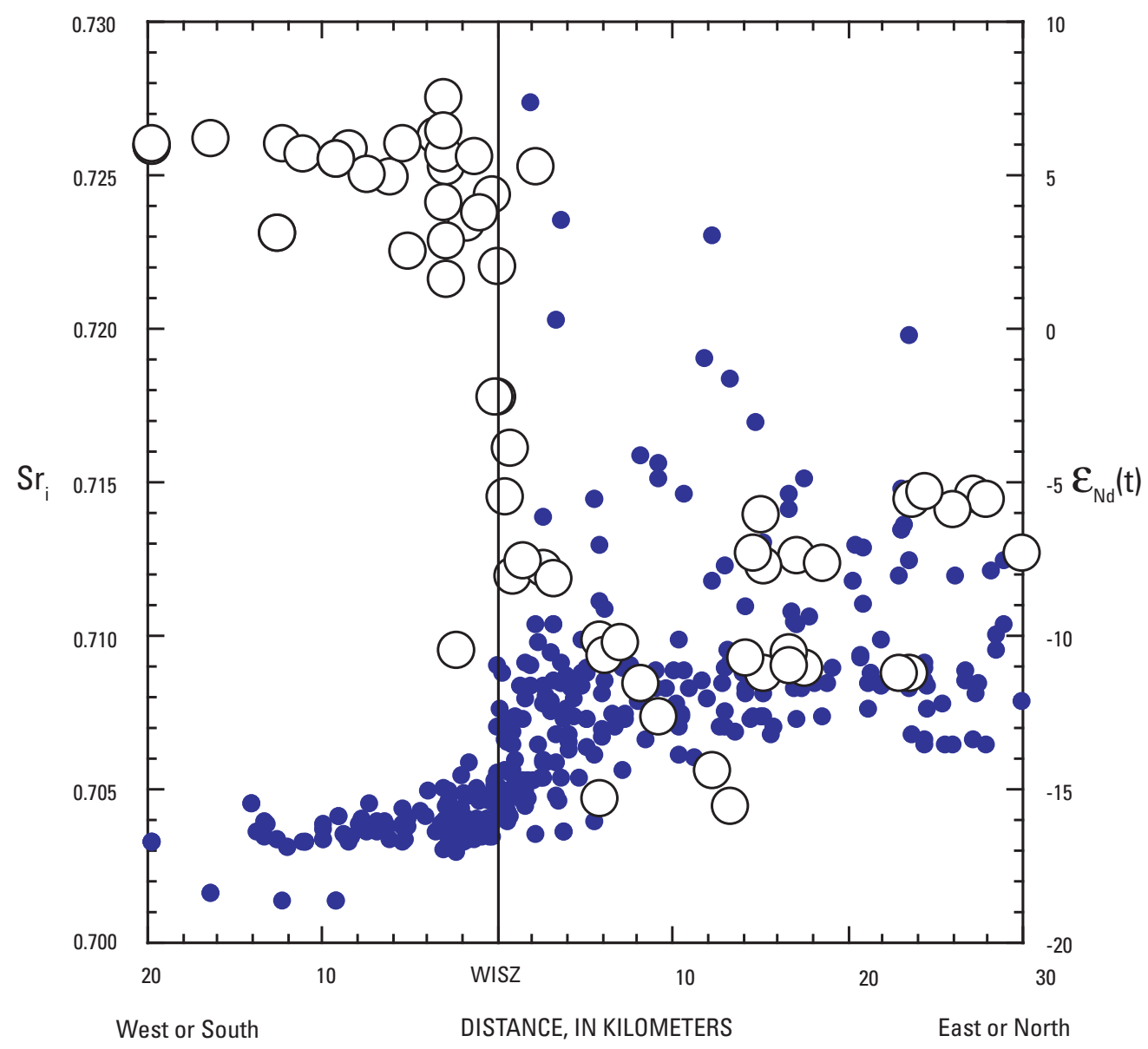

Figure 2. Variation diagrams of $\varepsilon_{\mathrm{Nd}}$ (circles) and Sri (dots) calculated at $80 \mathrm{Ma}$ with distance from the western Idaho suture zone (WISZ; vertical line). Plutons west of the WISZ intrude the accreted terranes; to the east, wall rocks are referred to "cratonal" or Precambrian Belt/Yellowjacket terranes and may range in age from 1,900 to $1,300 \mathrm{Ma}$. 
components represent the two crustal types sutured at the WISZ. Low $\varepsilon_{\mathrm{Nd}}(\mathrm{t})$ samples indicate Proterozoic crustal sources with both upper- and lower-crustal affinities. Volcanic arc magma also represents a substantial component in suture-zone plutons of Cretaceous age (Fleck, 1990).

Trace-element variations in plutons across the WISZ reveal patterns consistent with mixing within suture-zone magmas of components from substantially different sources. In addition to data reported here, results of Fleck (1990) and Manduca and others (1993) are used to illustrate the differences in magma chemistry of plutons emplaced within the different terranes and within the suture zone itself. Grouping data based on $\mathrm{Sm} / \mathrm{Nd}$ and $\varepsilon_{\mathrm{Nd}}(\mathrm{t})$, Fleck (1990) noted that plutons within $1 \mathrm{~km}$ west of the suture and $4 \mathrm{~km}$ to the east of it (Group 1) were isotopically and chemically distinct from those more distant from the zone. For the current study, samples of Manduca and others $(1992,1993)$ were grouped on the basis of their map units. Their Little Goose Creek complex includes the most highly deformed rocks of the WISZ, with $\mathrm{Sr}_{\mathrm{i}}>0.704$. Most were included in Group 1, but their samples of Eastern porphyritic orthogneiss, with $\mathrm{Rb}$ contents greater than most
Group 1 values, were located between 3.9 and $6 \mathrm{~km}$ east of the WISZ and were included with Group 2 rocks here. Rocks mapped as Hazard Creek complex (Manduca and others, 1992, 1993) have $\mathrm{Sr}_{\mathrm{i}}$ less than about 0.7045 , but many of the samples occur less than $3 \mathrm{~km}$ west of the suture and were included with Group 1. Nb versus Rb variations along the South Fork of the Clearwater River clearly distinguish suture-zone magmas from magmas of both the WSD and cratonal terranes (Fleck, 1990). $\mathrm{Rb} / \mathrm{Nb}$ values west and east of the immediate area of the WISZ are characteristic of granites of volcanic-arc and continentalcollision origin, respectively (Pearce and others, 1984; Leeman and Hawksworth, 1986). Those east of the zone are more elevated, as expected from emplacement through Proterozoic crust. Plutons within the WISZ, however, have Nb contents 3 to 8 times those of plutons within the accreted terranes (fig. 4). Results reported by Manduca and others (1993) show a similar pattern, with rocks of both the Hazard Creek and Little Goose Creek complexes north of McCall (fig.1) being significantly higher in $\mathrm{Nb}$ than WSD plutons. Rb concentrations in plutonic rocks increase from west to east across western Idaho, but make an abrupt increase within $5 \mathrm{~km}$ east and west of the

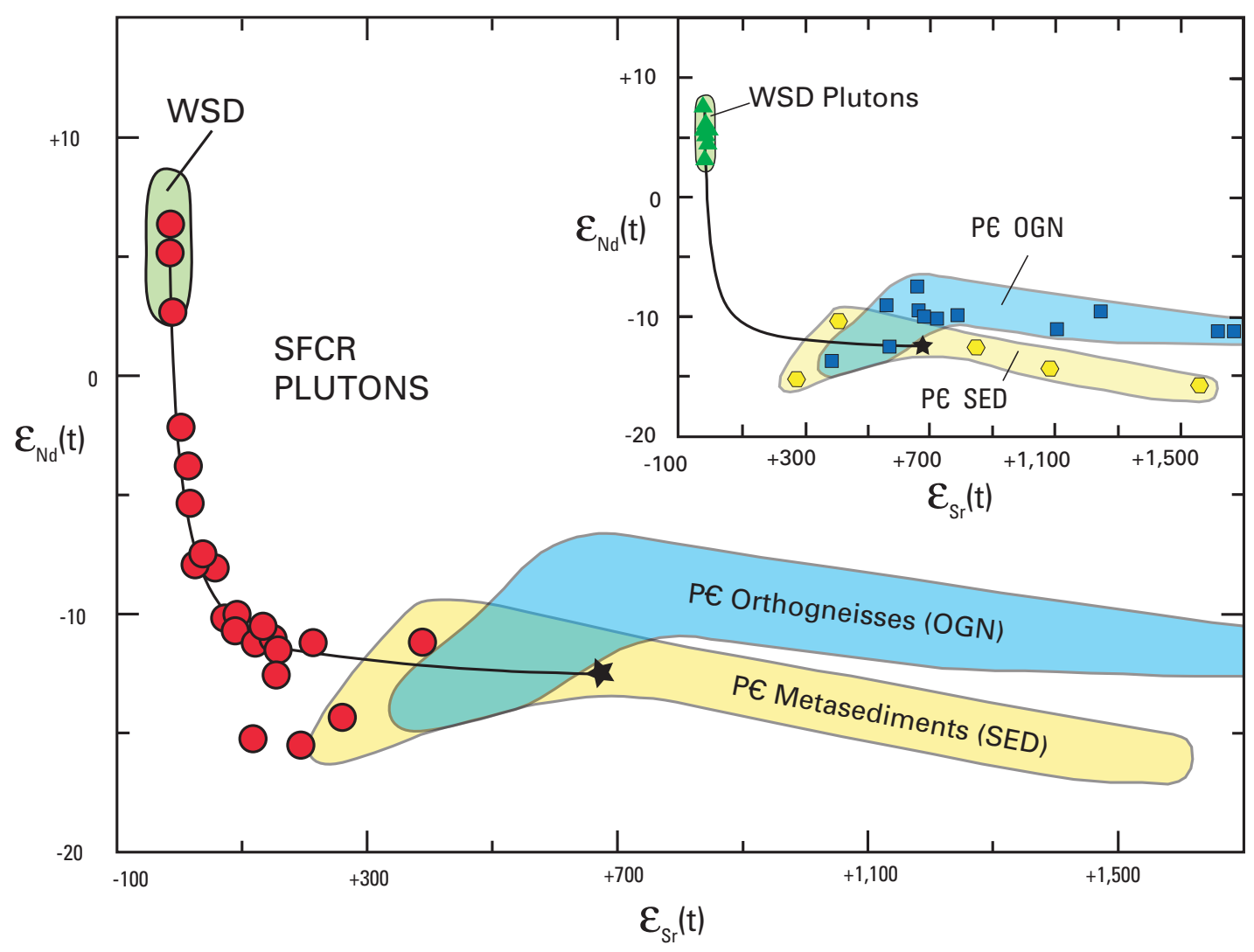

Figure 3. Variation of $\varepsilon_{\mathrm{Nd}}(\mathrm{t})$ with $\varepsilon_{\mathrm{Sr}}(\mathrm{t})$ in South Fork Clearwater River (SFCR) plutons (circles), WallowaSeven Devils (WSD) plutons (triangles), and samples of Precambrian orthogneisses (squares) and metasedimentary rocks (hexagons), calculated at $t=80 \mathrm{Ma}$. A simple mixing model shown for mixtures of an arc magma $\left(\varepsilon_{\mathrm{Nd}}=5.5, \varepsilon_{\mathrm{Sr}}=-11\right)$ and a cratonal component $\left(\varepsilon_{\mathrm{Nd}}=-12, \varepsilon_{\mathrm{Sr}}=675\right)$ fits suture zone magmas with $\varepsilon_{\mathrm{Nd}}$ $>-10$ very well, but is not necessarily representative of available cratonal lithosphere. (From Fleck, 1990) 
terrane boundary (fig. 5). Like Nb concentrations, however, $\mathrm{Sr}$ values peak in plutons emplaced within the suture zone and decrease in both directions away from the boundary (fig. 5). Interestingly, some of the lowest $\mathrm{Sr}$ values also occur in this area, near the eastern edge of WSD terranes. These low values, however, appear to relate to high-silica, trondhjemitic plutons in the western margin of the WISZ. Sr concentrations also peak in plutons of the Hazard Creek and Little Goose Creek complexes (Manduca and others, 1993). High contents of sphene, epidote, and plagioclase in suture-zone plutons are consistent with elevated levels of these trace elements, but the distinctive enrichment of $\mathrm{Nb}$ and $\mathrm{Sr}$ in suture-zone magmas is unique.

Uniqueness of suture-zone magmas is defined further by variations in $\mathrm{Y}, \mathrm{Nd}$, and $\mathrm{Sm}$ when compared to each other and to elements discussed above. Normalized to Y concentrations, $\mathrm{Nb}$ concentrations define a clear maximum in Group 1 (suture-zone) plutons (fig. 6). $\mathrm{Nb} / \mathrm{Y}$ values for the WSD suite form a generally constant band between about 0.1 and 0.5 (fig. $6)$. Suture-zone plutons, however, range from a low of 0.6 to greater than 2.4. (Some samples of Manduca and others, 1993, with exceptionally low yttrium were omitted from figure 6). $\mathrm{Nb} / \mathrm{Y}$ in plutons east of the WISZ decreases back toward values averaging about $0.7 . \mathrm{Nd} / \mathrm{Y}$ values also reflect significant increases in suture-zone magmas due not only to increases in total REE, but also to greater light REE and yttrium fractionation within and east of the WISZ (fig. 7). An Nd peak is observed, but is only defined by a few samples. These and other distance versus isotopic or trace-element variations such as $\mathrm{Sm} / \mathrm{Y}, \mathrm{Sr} / \mathrm{Sm}$, and $\mathrm{Sr} / \mathrm{Nd}$ not only aid in locating the true crustal boundary between the WSD and cratonal terranes, but also constrain the nature of source materials and petrogenetic processes in plutons emplaced within the WISZ (Fleck, 1990). Increases in $\mathrm{Nb}, \mathrm{Rb}, \mathrm{Sr}$, and ${ }^{87} \mathrm{Sr} /{ }^{86} \mathrm{Sr}$ in plutons emplaced near

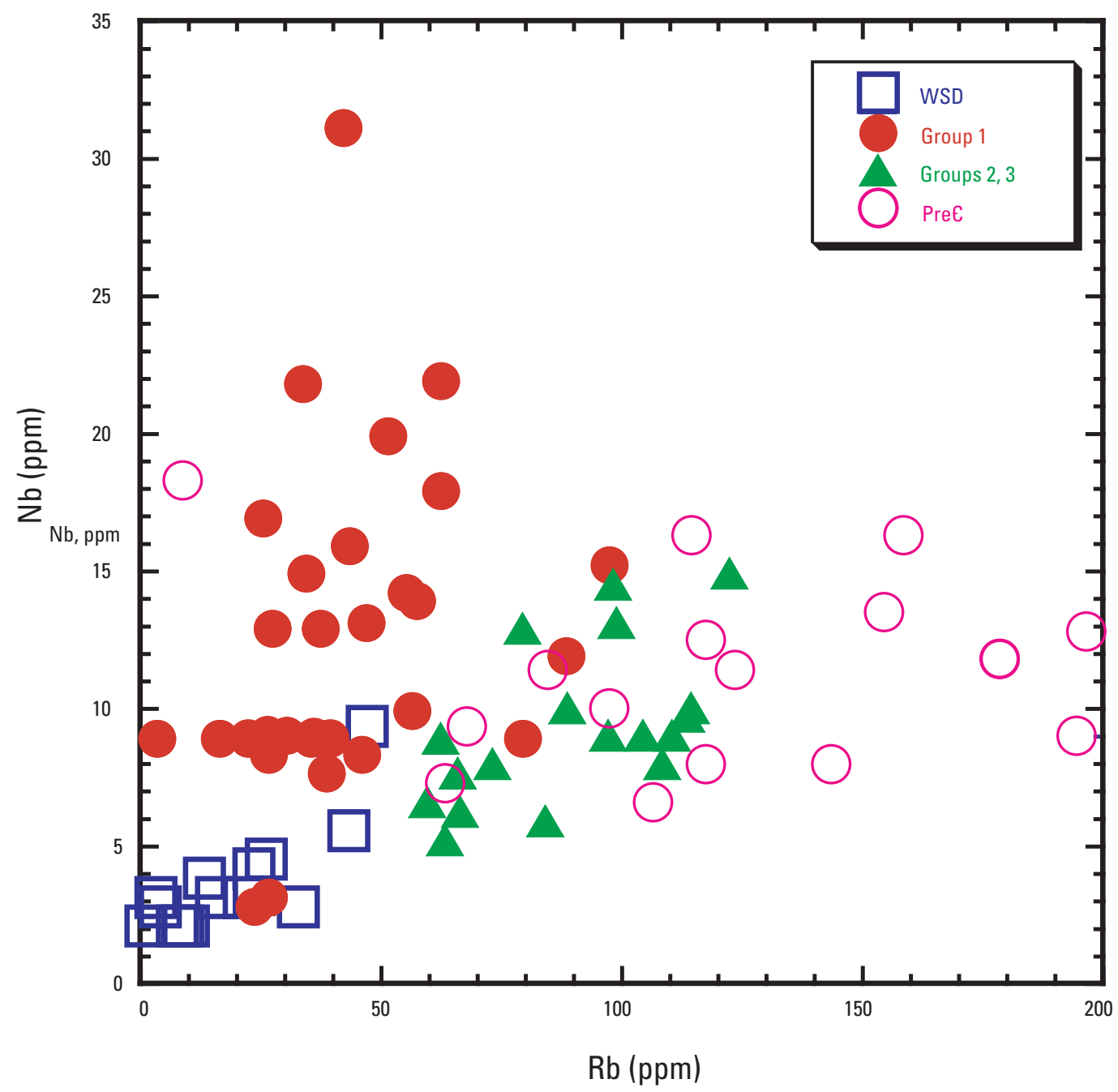

Figure 4. Variation diagram of $\mathrm{Nb}$ versus $\mathrm{Rb}$ in plutons of western Idaho. Symbols include: squares, Wallowa-Seven Devils (WSD) plutons; dots, suture-zone plutons assigned to Group 1 by Fleck (1990); triangles, plutons east of the suture zone within cratonal or Precambrian terranes and corresponding to Groups 2 and 3 of Fleck (1990); circles, Precambrian orthogneisses and schist. 
the suture within the WSD terranes supports other evidence that accretion of this crust occurred prior to the $110 \pm 5 \mathrm{Ma}$ age obtained by Manduca and others (1993) for a pluton of the Little Goose Creek complex.

\section{Location of the Western Idaho Suture Zone}

The geochemical indicators mentioned above provide excellent tools for delineating the western Idaho suture zone (WISZ). Most importantly, extensive measurements (more than 625 samples) of initial ${ }^{87} \mathrm{Sr} /{ }^{66} \mathrm{Sr}$ ratios $\left(\mathrm{Sr}_{\mathrm{i}}\right)$ reported by Armstrong and others (1977), Fleck and Criss (1985), Criss and Fleck (1987), Manduca and others (1992), and the present study define this boundary (fig. 1) in a way that is consistent with geologic mapping of segments of the zone (Myers, 1982; Hoover, 1986; Onash, 1987; Bonnichsen, 1987; Lund and Snee, 1988; Manduca and others, 1992; Lund, 1995). Much additional mapping is needed to establish the boundary between supracrustal rocks from the different terranes. As available mapping reveals, however, postcollisional plutonic rocks have replaced much of the suture, and the isotopic variation may well represent the best approximation of its original position. In all figures and discussions in this paper, distances to or from the WISZ are measured to the best estimate line shown in figures 1 and 8, which is based on available topographic, structural, petrologic, isotopic, and chemical data. We accept that the location can only be approximate, partially because the suture is a zone of substantial width rather than a line, but also because even the hundreds of isotopic results pale in the face of a $300-\mathrm{km}$ structure.

Location of the WISZ at its northwesternmost extent is controlled by samples in eastern Washington at Granite Point $\left(46^{\circ} 36.2^{\prime} \mathrm{N}, 117^{\circ} 21.4^{\prime} \mathrm{W}\right)$ northwest of Clarkston and along Cummings Creek ( $\left.46^{\circ} 15.7^{\prime} \mathrm{N}, 117^{\circ} 36.8^{\prime} \mathrm{W}\right)$ west-southwest of Clarkston (fig. 8). Eastward in Idaho, the suture must pass north of Lewiston, Spaulding, and Peck, and south of Genesee, Juliaetta, and Teakean, trending approximately eastwest. Exposures of the highly sheared zone several hundred meters north of Dworshak Dam and fault slivers of high $\mathrm{Sr}_{\mathrm{i}}$ $(>0.706)$ granitic gneiss pinpoint the suture at the southeast end of Dworshak Reservoir and crossing Orofino Creek near its confluence with Cedar Creek $\left(46^{\circ} 29.1^{\prime} \mathrm{N}, 116^{\circ} 05.2^{\prime} \mathrm{W}\right)$. In the area of Weippe, Idaho, the WISZ makes a clockwise

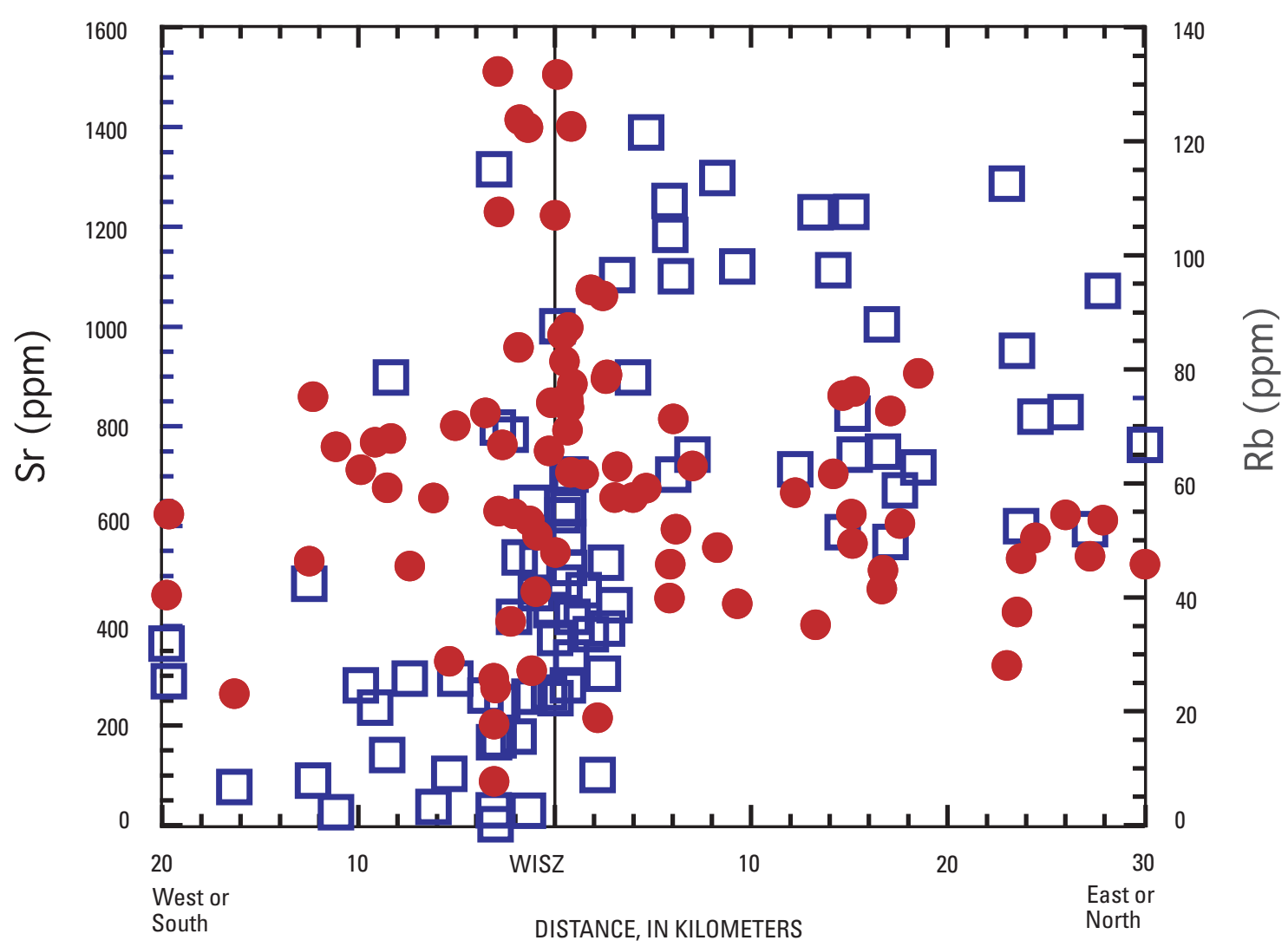

Figure 5. Variation diagram of $\mathrm{Rb}$ and $\mathrm{Sr}$ in plutons of western Idaho. $\mathrm{Rb}$ (squares, right ordinate axis) and $\mathrm{Sr}$ (dots, left ordinate axis) are plotted against distance $(\mathrm{km})$ from the western Idaho suture zone (WISZ; vertical line). $\mathrm{Rb}$ concentrations increase abruptly crossing the WISZ from accreted terranes eastward into cratonal terranes, whereas the highest and lowest Sr contents occur within $5 \mathrm{~km}$ on either side of this suture. 
bend of about $110^{\circ}$ probably passing 2 to 3 miles northeast of that town, but is concealed by flows of Columbia River basalt. The suture then trends slightly west of south, crossing the main Clearwater River near the confluence with Suttler Creek $\left(46^{\circ} 08.5^{\prime} \mathrm{N}, 115^{\circ} 50.7^{\prime} \mathrm{W}\right)$, but it appears to be complicated in this area by tectonic slivers or a thrust duplex of WSD rocks east of Suttler Creek. Continuing southward, the WISZ passes about 1.5 miles east of Clearwater. Data along the South Fork of the Clearwater River (SFCR) were discussed above, placing the axis of the zone along Browns

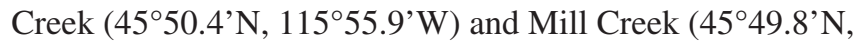
$\left.115^{\circ} 56.0^{\prime} \mathrm{W}\right)$ and trending south-southwest along Little Slate Creek from near its confluence with Slate Creek $\left(45^{\circ} 37.2^{\prime} \mathrm{N}\right.$ $\left.116^{\circ} 04.0^{\prime} \mathrm{W}\right)$. The WISZ crosses the Salmon River near Partridge Creek $\left(45^{\circ} 25.2^{\prime} \mathrm{N}, 116^{\circ} 07.8^{\prime} \mathrm{W}\right)$ and trends almost due south from there along the east flanks of Patrick Butte $\left(45^{\circ} 19.1^{\prime} \mathrm{N}, 116^{\circ} 12.2^{\prime} \mathrm{W}\right)$ and Granite Mountain $\left(45^{\circ} 05.6^{\prime} \mathrm{N}\right.$, $\left.116^{\circ} 12.3^{\prime} \mathrm{W}\right)$. As shown in figure 8 , the zone continues south along the east flank of No Business Mountain $\left(44^{\circ} 46.0^{\prime} \mathrm{N}\right.$, $116^{\circ} 12.3^{\prime} \mathrm{W}$ ), where it follows the plagioclase-quartz-biotite gneiss unit of Bonnichsen (1987), and south along the west side of the West Mountains $\left(44^{\circ} 30^{\prime} \mathrm{N}, 116^{\circ} 09^{\prime} \mathrm{W}\right)$. In this area the suture zone apparently was reactivated by post-

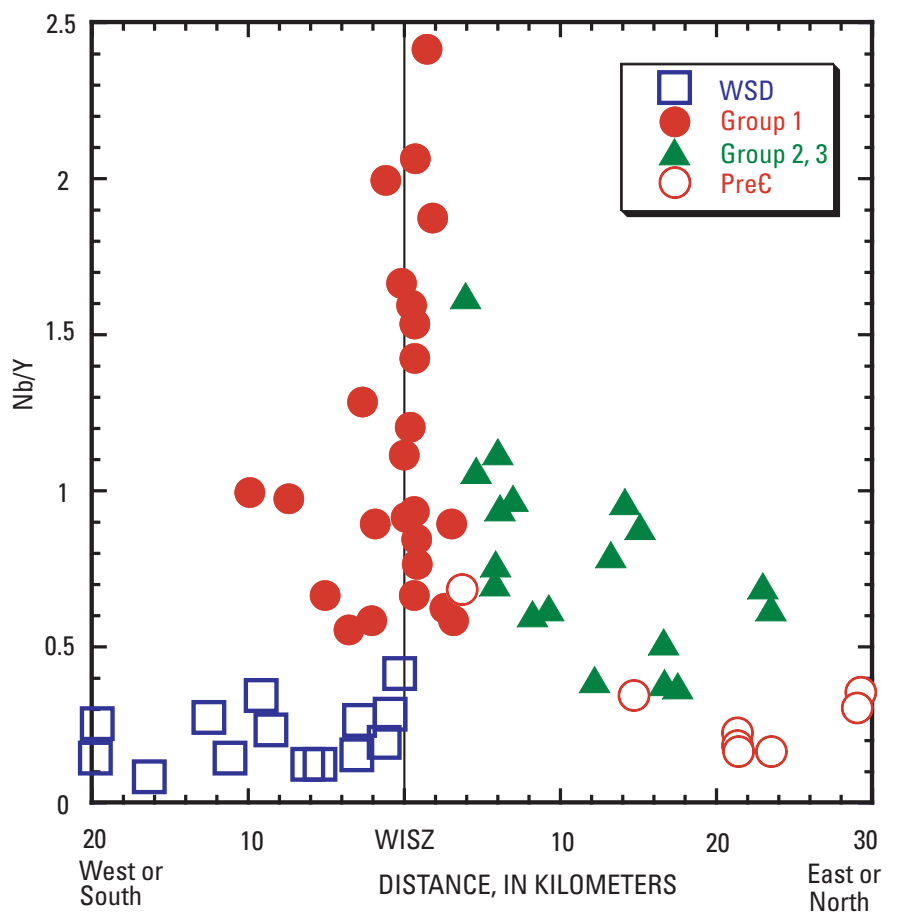

Figure 6. Variation diagram of $\mathrm{Nb} / \mathrm{Y}$ ratio in plutons of western Idaho, showing different chemical signatures in magmatic sources as the terrane boundary is approached and crossed. The highest $\mathrm{Nb} / \mathrm{Y}$ ratios occur within about $5 \mathrm{~km}$ east and west of the western Idaho suture zone (WISZ; vertical line) in Group 1 plutons (Fleck, 1990). Symbols are as in figure 4. Comparison with fig. 2 demonstrates that plutons most affected by mixing of components from isotopically distinct sources are also the ones with the highest $\mathrm{Nb} / \mathrm{Y}$ ratios.

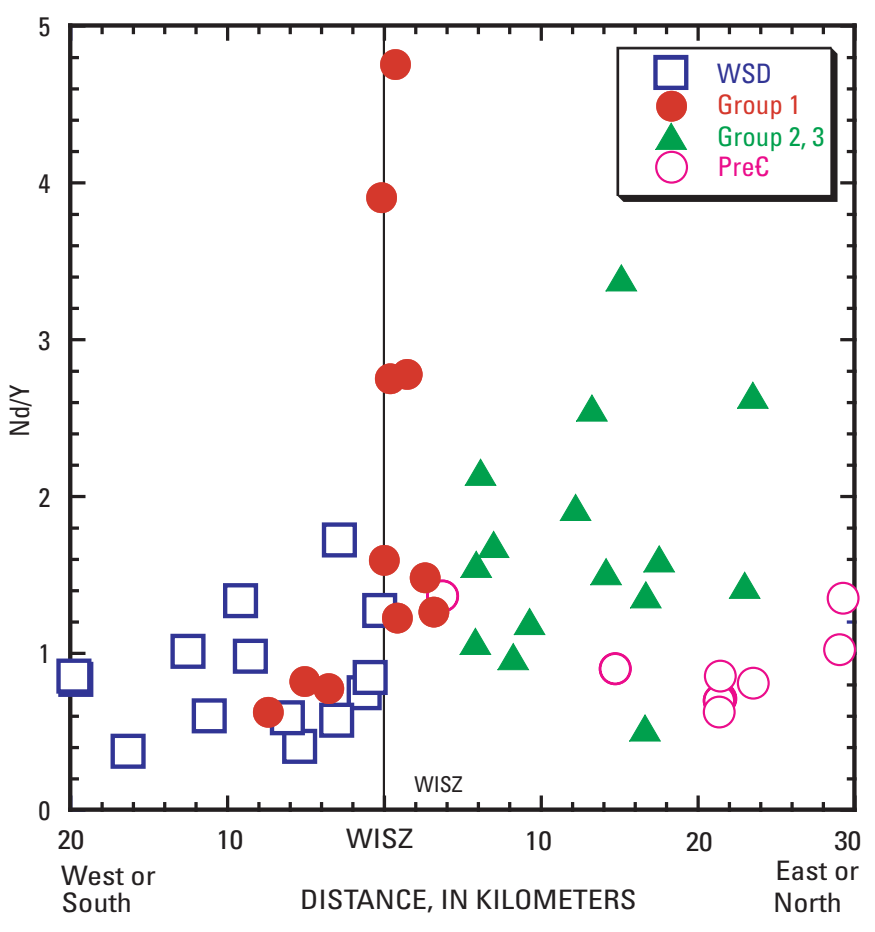

Figure 7. Variation in $\mathrm{Nd} / \mathrm{Y}$ in plutons of western Idaho is shown with distance from the western Idaho suture zone (WISZ). As with $\mathrm{Nb} / \mathrm{Y}$, the highest Nd/Y ratios occur near the WISZ (vertical line). Symbols are as in figure 4.

Columbia River basalt normal faults, which mimic its trend southward along the east side of Indian Mountain. South of Indian Mountain (443․ $\left.{ }^{\circ} \mathrm{N}, 116^{\circ} 15.0^{\prime} \mathrm{W}\right)$, rocks of the WSD terranes are not well exposed and the WISZ is at least partially covered by flows of Columbia River basalt. Long, linear, north-trending valleys, such as that of Squaw Creek $\left(44^{\circ} 13.7^{\prime} \mathrm{N}, 116^{\circ} 17.6^{\prime} \mathrm{W}\right)$, follow the well-developed foliation in medium- to high-grade schist that parallels the WISZ, but these topographic features may also be a result of normal fault reactivation in Tertiary time. The WISZ is located west of the alignment of Squaw Creek in the area of Ola, Idaho (fig. 8), where it is hidden beneath Tertiary and Quaternary cover after being traceable for more than $300 \mathrm{~km}$.

\section{Age Patterns and Chronology of the WISZ}

With a few exceptions, most age determinations in western Idaho have used the K-Ar or ${ }^{40} \mathrm{Ar} /{ }^{39} \mathrm{Ar}$ techniques. The current study is no exception, adding to the already large data set produced by McDowell and Kulp (1969), Armstrong (1974, 1975, 1976), Armstrong and others (1977), Criss and others (1982), Fleck and Criss (1985), Criss and Fleck (1987), Lewis and others (1987), Lund and Snee (1988), and Snee and others (1995). Previously, we suggested limiting ages for 


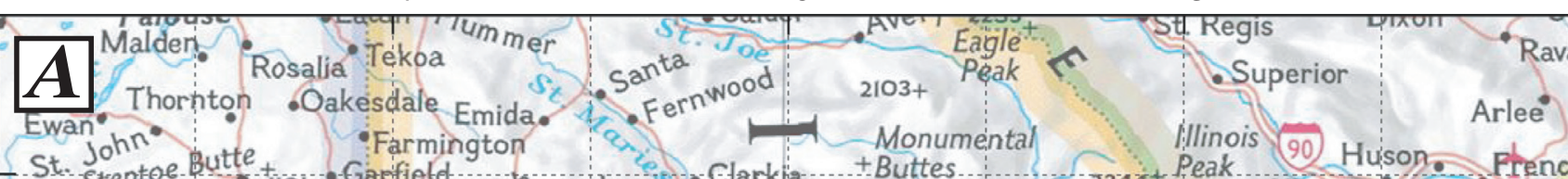
RATTLESNAKE N

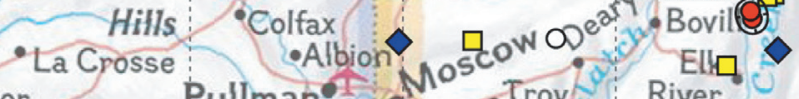
per Pullman Nos Troy River - Hay snate? Colton
buck - Clarkston 0.704 N.H.P. Peck DayWISZ - Clarkston wat. Culdesac

tsburg $\Delta \quad$ Asotin La Craigmont Winchester. Netperce

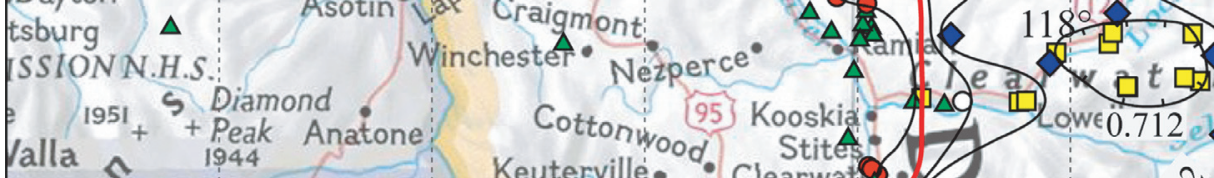

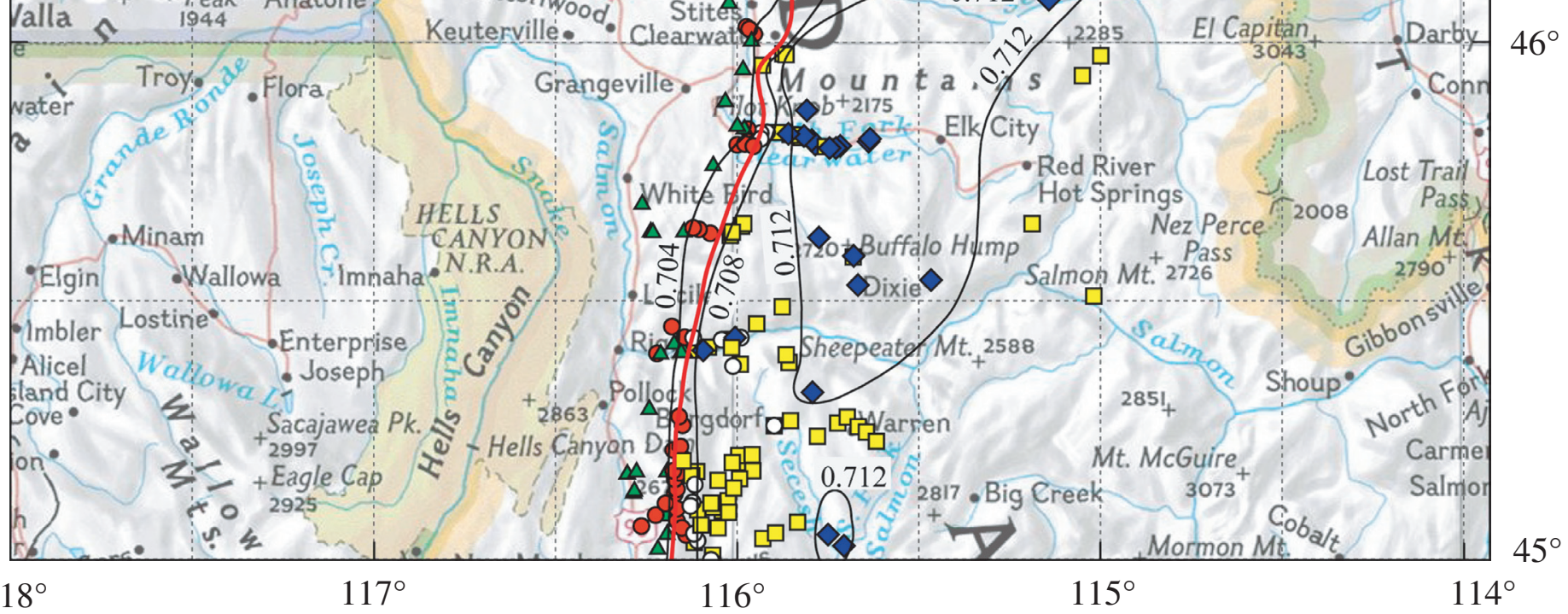

Oregon ( $A$, north half of study area. $B$, south half). Sr isopleths are shown in black for initial ratios of $0.704,0.708$, and 0.712 . Symbols for samples indicate ${ }^{87} \mathrm{Sr} /{ }^{86} \mathrm{Sr}$ ratios calculated for ages shown in table 1 , as follows: $<0.704$, dark green triangles; 0.704 to 0.706 , red dots; 0.706 to 0.708 , white dots; 0.708 to 0.712 , yellow squares; $>0.712$, blue diamonds. The heavy red line shows the approximate location of the western Idaho suture zone (WISZ) that forms the boundary between the oceanic Wallowa-Seven Devils (WSD) terranes and Precambrian cratonal terranes of North America. (Shaded relief map created with TOPO!® @2002 National Geographic.) 


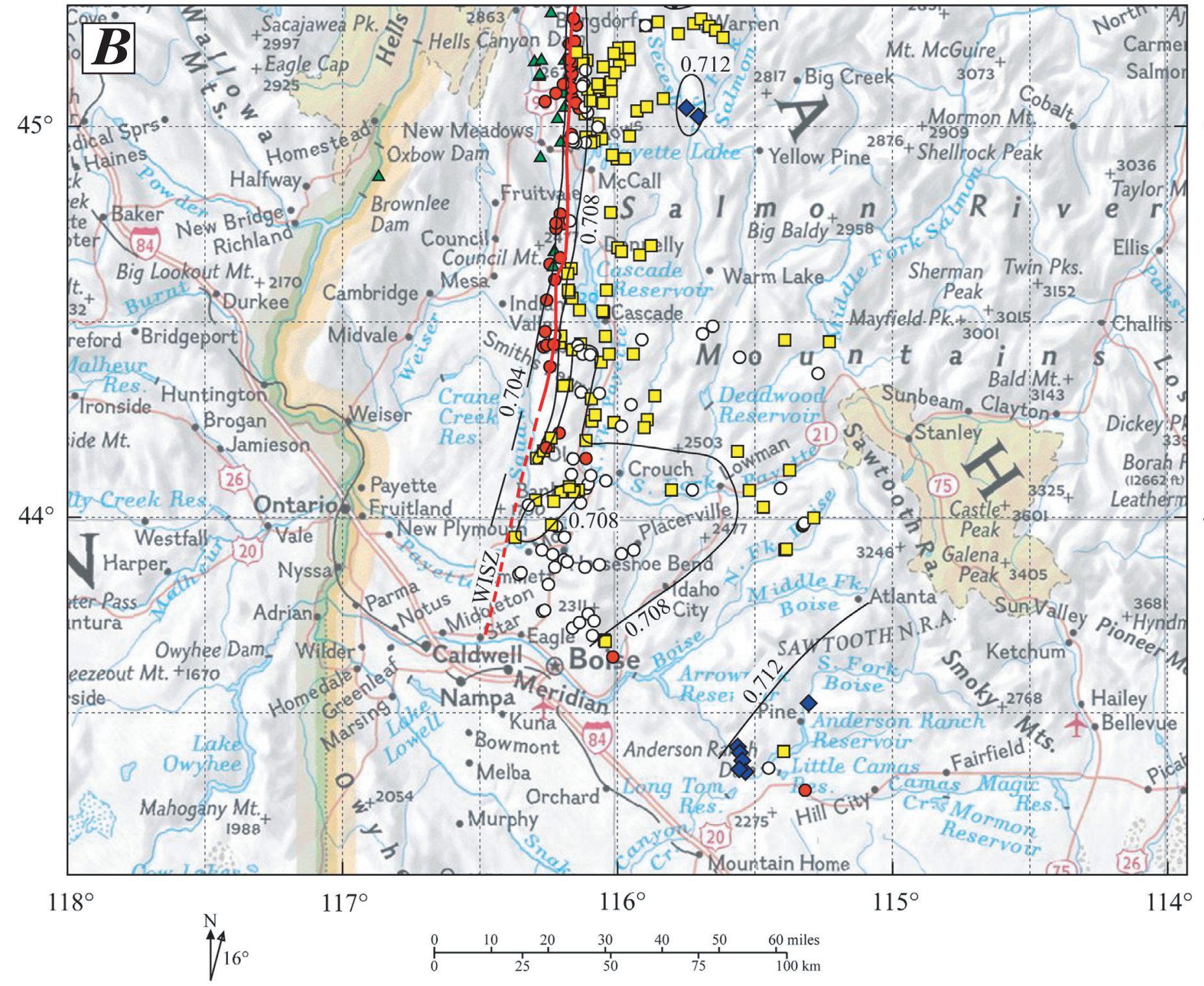

Figure 8.-Continued 
Table 1. Results of Rb-Sr analyses of rocks of western Idaho.

[For analytical procedures, see text.]

\begin{tabular}{|c|c|c|c|c|c|c|c|c|c|c|}
\hline Sample No. & N. Latitude & W. Longitude & $\mathrm{Rb}(\mathrm{ppm})$ & $\operatorname{Sr}(p p m)$ & $\mathbf{R b} / \mathbf{S r}$ & ${ }^{87} \mathrm{Rb} /{ }^{66} \mathrm{Sr}$ & ${ }^{87} \mathrm{Sr} /{ }^{86} \mathrm{Sr}$ & $\left({ }^{87} \mathrm{Sr} /{ }^{86} \mathrm{Sr}\right) \mathrm{i}$ & $\begin{array}{c}\text { Age } \\
\text { (Ma) }\end{array}$ & $\mathrm{Sr}_{\mathrm{i}}$ \\
\hline 00RL503 & $46^{\circ} 32.657^{\prime}$ & $116^{\circ} 33.645^{\prime}$ & 86 & 308 & 0.27922 & 0.808395 & 0.714516 & 0.713482 & 90 & 0.7135 \\
\hline 00RL508 & $46^{\circ} 33.234^{\prime}$ & $116^{\circ} 33.002^{\prime}$ & 41 & 742 & 0.05526 & 0.159872 & 0.707874 & 0.707670 & 90 & 0.7077 \\
\hline 00RL589 & $46^{\circ} 31.98^{\prime}$ & $116^{\circ} 18.435^{\prime}$ & 21 & 569 & 0.03691 & 0.106735 & 0.703299 & 0.703163 & 90 & 0.7032 \\
\hline $797-15 \mathrm{~A}$ & $44^{\circ} 05.041^{\prime}$ & $116^{\circ} 06.245^{\prime}$ & 72.35 & 769.2 & 0.09406 & 0.272123 & 0.70723 & 0.706963 & 70 & 0.7070 \\
\hline 797-15B & $44^{\circ} 05.566^{\prime}$ & $116^{\circ} 02.294^{\prime}$ & 58.6 & 836.3 & 0.07006 & 0.202687 & 0.70720 & 0.706998 & 70 & 0.7070 \\
\hline $797-15 \mathrm{C}$ & $44^{\circ} 04.119^{\prime}$ & $115^{\circ} 43.662^{\prime}$ & 82.6 & 1102.0 & 0.07492 & 0.216737 & 0.70672 & 0.706578 & 45 & 0.7066 \\
\hline $797-16 \mathrm{~A}$ & $43^{\circ} 58.621^{\prime}$ & $115^{\circ} 19.798^{\prime}$ & 167.7 & 83.9 & 1.99998 & 5.787693 & 0.70992 & 0.706220 & 45 & 0.7062 \\
\hline 797-16B & $43^{\circ} 58.806^{\prime}$ & $115^{\circ} 19.539^{\prime}$ & 138.5 & 404.1 & 0.34279 & 0.991774 & 0.707535 & 0.706901 & 45 & 0.7069 \\
\hline $797-16 \mathrm{C}$ & $43^{\circ} 58.832^{\prime}$ & $115^{\circ} 19.271^{\prime}$ & 143.2 & 345.4 & 0.41453 & 1.199279 & 0.70708 & 0.706314 & 45 & 0.7063 \\
\hline 797-16D & $43^{\circ} 59.893^{\prime}$ & $115^{\circ} 17.155^{\prime}$ & 71.5 & 546.6 & 0.13074 & 0.378378 & 0.71113 & 0.710755 & 70 & 0.7108 \\
\hline $797-16 \mathrm{~F}$ & $43^{\circ} 55.017^{\prime}$ & $115^{\circ} 23.376^{\prime}$ & 36.6 & 745.8 & 0.04909 & 0.142050 & 0.70950 & 0.709362 & 70 & 0.7094 \\
\hline $807-24 \mathrm{~B}$ & $44^{\circ} 07.161^{\prime}$ & $115^{\circ} 22.573^{\prime}$ & 50.6 & 756 & 0.06693 & 0.193686 & 0.70966 & 0.709467 & 70 & 0.7095 \\
\hline $807-24 \mathrm{D}$ & $44^{\circ} 04.075^{\prime}$ & $115^{\circ} 31.306^{\prime}$ & 74.7 & 588 & 0.12704 & 0.367633 & 0.70971 & 0.709340 & 70 & 0.7093 \\
\hline $807-24 \mathrm{E}$ & $44^{\circ} 04.275^{\prime}$ & $115^{\circ} 24.402^{\prime}$ & 92.2 & 546 & 0.16886 & 0.488571 & 0.70776 & 0.707451 & 45 & 0.7075 \\
\hline $807-24 \mathrm{~F}$ & $44^{\circ} 01.623^{\prime}$ & $115^{\circ} 28.11^{\prime}$ & 81.5 & 633 & 0.12875 & 0.372539 & 0.70843 & 0.708062 & 70 & 0.7081 \\
\hline $807-25 \mathrm{~A}$ & $44^{\circ} 18.383^{\prime}$ & $115^{\circ} 17.417^{\prime}$ & 160.0 & 129 & 1.24031 & 3.589707 & 0.71105 & 0.708756 & 45 & 0.7088 \\
\hline $807-25 B$ & $44^{\circ} 13.333^{\prime}$ & $115^{\circ} 05.833^{\prime}$ & 154.0 & 133 & & 3.351192 & 0.71109 & 0.708946 & 45 & 0.7089 \\
\hline $818-17 \mathrm{~A}$ & $44^{\circ} 22.001^{\prime}$ & $115^{\circ} 16.236^{\prime}$ & 76.2 & 1517.0 & 0.05023 & 0.145314 & 0.70655 & 0.706405 & 70 & 0.7064 \\
\hline 818-17B & $44^{\circ} 27.214^{\prime}$ & $115^{\circ} 23.415^{\prime}$ & 154.0 & 610.0 & 0.25246 & 0.730508 & 0.70883 & 0.708104 & 70 & 0.7081 \\
\hline $818-17 \mathrm{C}$ & $44^{\circ} 28.150^{\prime}$ & $115^{\circ} 41.388^{\prime}$ & 69.7 & 1056.0 & 0.06600 & 0.190941 & 0.706380 & 0.706190 & 70 & 0.7062 \\
\hline 818-17D & $44^{\circ} 29.296^{\prime}$ & $115^{\circ} 39.209^{\prime}$ & 138.0 & 684.0 & 0.20175 & 0.583689 & 0.70705 & 0.706470 & 70 & 0.7065 \\
\hline 818-17E & $44^{\circ} 26.883^{\prime}$ & $115^{\circ} 13.832^{\prime}$ & 40.7 & 608.0 & 0.06694 & 0.193686 & 0.70818 & 0.707987 & 70 & 0.7080 \\
\hline $818-17 \mathrm{~F}$ & $44^{\circ} 24.472$ & $115^{\circ} 33.406^{\prime}$ & 80.2 & 785.0 & 0.10217 & 0.295593 & 0.70776 & 0.707466 & 70 & 0.7075 \\
\hline $818-18 \mathrm{~A}$ & $44^{\circ} 10.047^{\prime}$ & $115^{\circ} 33.668^{\prime}$ & 112.0 & 308.0 & 0.36364 & 1.052412 & 0.71081 & 0.709763 & 70 & 0.7098 \\
\hline 818-18B & $43^{\circ} 55.065^{\prime}$ & $115^{\circ} 23.282^{\prime}$ & 48.0 & 737.0 & 0.06513 & 0.188467 & 0.70946 & 0.709273 & 70 & 0.7093 \\
\hline $818-18 \mathrm{C}$ & $43^{\circ} 55.043^{\prime}$ & $115^{\circ} 23.339^{\prime}$ & 47.7 & 790.0 & 0.06038 & 0.174724 & 0.70944 & 0.709266 & 70 & 0.7093 \\
\hline $827-25 \mathrm{~F}$ & $46^{\circ} 36.393^{\prime}$ & $117^{\circ} 21.676^{\prime}$ & 76.98 & 577.6 & 0.13328 & 0.385632 & 0.708550 & 0.708112 & 80 & 0.7081 \\
\hline $827-25 \mathrm{G}$ & $46^{\circ} 36.222^{\prime}$ & $117^{\circ} 21.440^{\prime}$ & 83.58 & 375.1 & 0.22282 & 0.644775 & 0.709270 & 0.708537 & 80 & 0.7085 \\
\hline $827-25 \mathrm{H}$ & $46^{\circ} 36.222^{\prime}$ & $117^{\circ} 21.440^{\prime}$ & 96.15 & 291.5 & 0.32985 & 0.954517 & 0.709740 & 0.708655 & 80 & 0.7087 \\
\hline $827-25 \mathrm{I}$ & $46^{\circ} 36.222^{\prime}$ & $117^{\circ} 21.440^{\prime}$ & 86.26 & 347.4 & 0.24830 & 0.718501 & 0.709150 & 0.708333 & 80 & 0.7083 \\
\hline $837-22 \mathrm{~A}$ & $46^{\circ} 39.507^{\prime}$ & $116^{\circ} 47.642^{\prime}$ & 96.31 & 785.5 & 0.12261 & 0.354938 & 0.713370 & 0.712967 & 80 & 0.7130 \\
\hline $837-22 B$ & $46^{\circ} 39.354^{\prime}$ & $116^{\circ} 47.601$ & 63.76 & 805.4 & 0.07917 & 0.229145 & 0.712100 & 0.711840 & 80 & 0.7118 \\
\hline $837-22 \mathrm{C}$ & $46^{\circ} 37.365^{\prime}$ & $116^{\circ} 48.981^{\prime}$ & 54.08 & 820.5 & 0.06591 & 0.190752 & 0.710610 & 0.710393 & 80 & 0.7104 \\
\hline $837-22 \mathrm{D}$ & $46^{\circ} 37.227^{\prime}$ & $116^{\circ} 48.849^{\prime}$ & 63.33 & 717.5 & 0.08826 & 0.255457 & 0.711100 & 0.710810 & 80 & 0.7108 \\
\hline $837-30 \mathrm{~A}$ & $45^{\circ} 10.454^{\prime}$ & $116^{\circ} 16.556^{\prime}$ & 1.80 & 884.8 & 0.00203 & 0.005884 & 0.703866 & 0.703859 & 80 & 0.7039 \\
\hline $837-30 \mathrm{~B}$ & $45^{\circ} 5.017$ & $116^{\circ} 13.373^{\prime}$ & 22.74 & 628.2 & 0.03620 & 0.104705 & 0.705110 & 0.704991 & 80 & 0.7050 \\
\hline $837-30 \mathrm{C}$ & $45^{\circ} 3.772$ & $116^{\circ} 15.724^{\prime}$ & 31.24 & 520.6 & 0.06001 & 0.173558 & 0.704220 & 0.704023 & 80 & 0.7040 \\
\hline 837-30D & $45^{\circ} 1.402^{\prime}$ & $116^{\circ} 13.232^{\prime}$ & 12.02 & 819.8 & 0.01466 & 0.042406 & 0.703919 & 0.703871 & 80 & 0.7039 \\
\hline $837-30 \mathrm{E}$ & $44^{\circ} 58.780^{\prime}$ & $116^{\circ} 10.03^{\prime}$ & 24.07 & 926.4 & 0.02598 & 0.075156 & 0.705360 & 0.705275 & 80 & 0.7053 \\
\hline $837-30 \mathrm{~F}$ & $44^{\circ} 57.230^{\prime}$ & $116^{\circ} 08.559^{\prime}$ & 24.42 & 851.4 & 0.02868 & 0.082976 & 0.706655 & 0.706561 & 80 & 0.7066 \\
\hline $837-31 \mathrm{~A}$ & $45^{\circ} 16.465^{\prime}$ & $116^{\circ} 09.596^{\prime}$ & 31.08 & 947.5 & 0.03280 & 0.094880 & 0.705035 & 0.704927 & 80 & 0.7049 \\
\hline $837-31 \mathrm{~B}$ & $45^{\circ} 15.563^{\prime}$ & $116^{\circ} 08.923^{\prime}$ & 29.41 & 1212.0 & 0.02427 & 0.070189 & 0.705090 & 0.705010 & 80 & 0.7050 \\
\hline $837-31 \mathrm{C}$ & $45^{\circ} 12.999^{\prime}$ & $116^{\circ} 09.005^{\prime}$ & 52.64 & 837.8 & 0.06283 & 0.181748 & 0.705543 & 0.705336 & 80 & 0.7053 \\
\hline
\end{tabular}


Table 1. Results of Rb-Sr analyses of rocks of western Idaho.-Continued

[For analytical procedures, see text.]

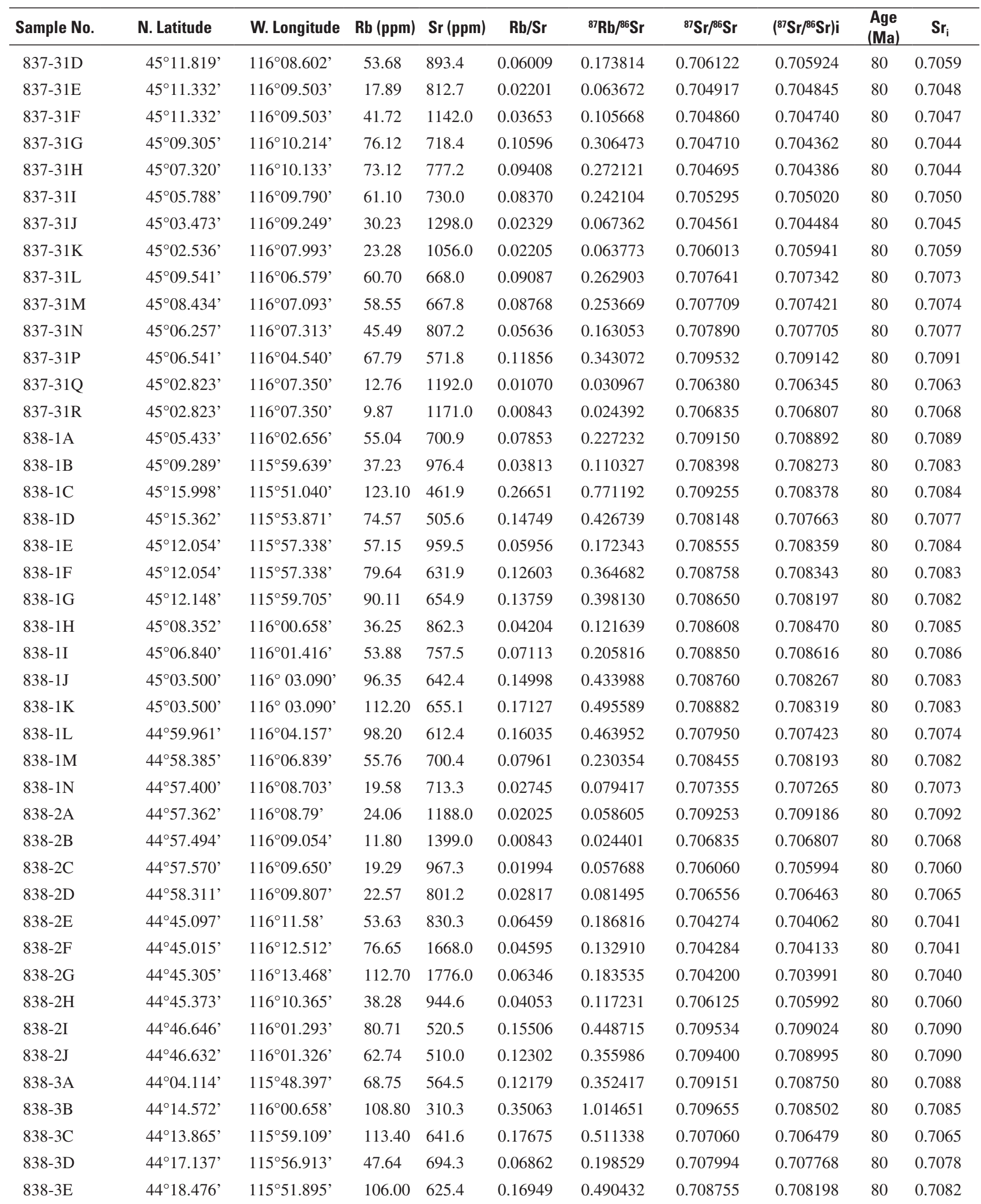


Table 1. Results of Rb-Sr analyses of rocks of western Idaho.-Continued

[For analytical procedures, see text.]

\begin{tabular}{|c|c|c|c|c|c|c|c|c|c|c|}
\hline Sample No. & N. Latitude & W. Longitude & $\mathbf{R b}(\mathbf{p p m})$ & $\operatorname{Sr}(p p m)$ & $\mathrm{Rb} / \mathrm{Sr}$ & ${ }^{87} \mathrm{Rb} /{ }^{86} \mathrm{Sr}$ & ${ }^{87} \mathrm{Sr} /{ }^{86} \mathrm{Sr}$ & $\left({ }^{87} \mathrm{Sr} /{ }^{86} \mathrm{Sr}\right) \mathrm{i}$ & $\begin{array}{l}\text { Age } \\
\text { (Ma) }\end{array}$ & $\mathrm{Sr}_{\mathrm{i}}$ \\
\hline $838-3 \mathrm{~F}$ & $44^{\circ} 15.137^{\prime}$ & $115^{\circ} 53.427^{\prime}$ & 104.00 & 544.2 & 0.19111 & 0.552993 & 0.709075 & 0.708446 & 80 & 0.7084 \\
\hline $838-3 \mathrm{G}$ & $44^{\circ} 13.672^{\prime}$ & $115^{\circ} 54.229^{\prime}$ & 129.70 & 127.7 & 1.01566 & 2.939709 & 0.711678 & 0.708337 & 80 & 0.7083 \\
\hline $858-12 \mathrm{~A}$ & $45^{\circ} 15.414^{\prime}$ & $115^{\circ} 40.144^{\prime}$ & 75.30 & 727.2 & 0.10355 & 0.299608 & 0.708971 & 0.708630 & 80 & 0.7087 \\
\hline $858-12 B$ & $45^{\circ} 13.644^{\prime}$ & $115^{\circ} 37.086^{\prime}$ & 85.88 & 576.9 & 0.14886 & 0.430765 & 0.709383 & 0.708893 & 80 & 0.7089 \\
\hline $858-12 \mathrm{C}$ & $45^{\circ} 14.764$ & $115^{\circ} 38.806^{\prime}$ & 101.77 & 618.1 & 0.16464 & 0.476408 & 0.709118 & 0.708576 & 80 & 0.7087 \\
\hline $858-12 \mathrm{D}$ & $45^{\circ} 22.626^{\prime}$ & $115^{\circ} 59.42^{\prime}$ & 106.95 & 547.5 & 0.19535 & 0.565261 & 0.708603 & 0.707960 & 80 & 0.7080 \\
\hline $858-12 \mathrm{E}$ & $45^{\circ} 22.395^{\prime}$ & $116^{\circ} 00.667^{\prime}$ & 82.76 & 579.0 & 0.14293 & 0.413543 & 0.708013 & 0.707543 & 80 & 0.7075 \\
\hline $858-12 \mathrm{~F}$ & $45^{\circ} 24.487^{\prime}$ & $116^{\circ} 00.974^{\prime}$ & 121.00 & 562.4 & 0.21514 & 0.622534 & 0.709001 & 0.708293 & 80 & 0.7083 \\
\hline $858-13 \mathrm{~A}$ & $45^{\circ} 19.329^{\prime}$ & $115^{\circ} 47.648^{\prime}$ & 115.92 & 323.9 & 0.35785 & 1.035937 & 0.713446 & 0.712269 & 80 & 0.7122 \\
\hline $858-13 \mathrm{C}$ & $45^{\circ} 16.525^{\prime}$ & $115^{\circ} 41.698^{\prime}$ & 95.39 & 453.3 & 0.21044 & 0.609118 & 0.712081 & 0.711389 & 80 & 0.7114 \\
\hline 858-13D & $45^{\circ} 15.652^{\prime}$ & $115^{\circ} 43.273^{\prime}$ & 87.05 & 628.9 & 0.13843 & 0.400598 & 0.709034 & 0.708579 & 80 & 0.7085 \\
\hline $858-13 \mathrm{E}$ & $45^{\circ} 14.198^{\prime}$ & $115^{\circ} 46.572^{\prime}$ & 129.66 & 429.5 & 0.30186 & 0.875260 & 0.709289 & 0.708294 & 80 & 0.7083 \\
\hline $858-13 \mathrm{~F}$ & $45^{\circ} 15.471$ & $115^{\circ} 53.838^{\prime}$ & 97.76 & 451.1 & 0.21673 & 0.627139 & 0.709166 & 0.708453 & 80 & 0.7085 \\
\hline $858-13 \mathrm{G}$ & $45^{\circ} 23.653^{\prime}$ & $115^{\circ} 51.844^{\prime}$ & 70.93 & 120.1 & 0.59043 & 1.709149 & 0.713073 & 0.711130 & 80 & 0.7111 \\
\hline $858-13 \mathrm{H}$ & $45^{\circ} 22.728^{\prime}$ & $115^{\circ} 51.371^{\prime}$ & 99.45 & 541.5 & 0.18365 & 0.531500 & 0.710537 & 0.709933 & 80 & 0.7099 \\
\hline $877-12 \mathrm{~A}$ & $43^{\circ} 42.700^{\prime}$ & $116^{\circ} 09.757^{\prime}$ & 109.08 & 509.5 & 0.21411 & 0.619515 & 0.708419 & 0.707715 & 80 & 0.7077 \\
\hline $877-12 B$ & $43^{\circ} 42.887^{\prime}$ & $116^{\circ} 09.761^{\prime}$ & 72.17 & 581.4 & 0.12413 & 0.359121 & 0.707066 & 0.706658 & 80 & 0.7067 \\
\hline $877-12 \mathrm{C}$ & $43^{\circ} 43.813^{\prime}$ & $116^{\circ} 08.277^{\prime}$ & 72.92 & 627.5 & 0.11621 & 0.336199 & 0.706851 & 0.706469 & 80 & 0.7065 \\
\hline $877-12 \mathrm{D}$ & $43^{\circ} 45.102^{\prime}$ & $116^{\circ} 06.376^{\prime}$ & 94.22 & 617.3 & 0.15264 & 0.441603 & 0.707000 & 0.706498 & 80 & 0.7065 \\
\hline $877-12 \mathrm{E}$ & $43^{\circ} 44.009^{\prime}$ & $116^{\circ} 05.107^{\prime}$ & 67.22 & 528.2 & 0.12726 & 0.368205 & 0.708348 & 0.707929 & 80 & 0.7079 \\
\hline $877-12 \mathrm{~F}$ & $43^{\circ} 41.844^{\prime}$ & $116^{\circ} 05.358^{\prime}$ & 71.92 & 600.4 & 0.11979 & 0.346611 & 0.708305 & 0.707911 & 80 & 0.7079 \\
\hline $877-12 \mathrm{G}$ & $43^{\circ} 41.197^{\prime}$ & $116^{\circ} 02.830^{\prime}$ & 64.99 & 621.2 & 0.10462 & 0.302731 & 0.709332 & 0.708988 & 80 & 0.7090 \\
\hline $877-12 \mathrm{H}$ & $43^{\circ} 40.898^{\prime}$ & $116^{\circ} 02.932^{\prime}$ & 62.51 & 594.7 & 0.10510 & 0.304198 & 0.711170 & 0.710824 & 80 & 0.7108 \\
\hline $877-12$ I & $43^{\circ} 38.475^{\prime}$ & $116^{\circ} 01.011^{\prime}$ & 100.41 & 325.5 & 0.30850 & 0.892440 & 0.706291 & 0.705277 & 80 & 0.7053 \\
\hline $877-13 \mathrm{~A}$ & $43^{\circ} 21.302^{\prime}$ & $115^{\circ} 27.011^{\prime}$ & 155.15 & 814.7 & 0.19043 & 0.550953 & 0.707475 & 0.706849 & 80 & 0.7068 \\
\hline 877-13B & $43^{\circ} 21.431$ & $115^{\circ} 27.083^{\prime}$ & 66.72 & 972.6 & 0.06860 & 0.198479 & 0.707558 & 0.707332 & 80 & 0.7073 \\
\hline $877-13 \mathrm{E}$ & $43^{\circ} 24.703^{\prime}$ & $115^{\circ} 33.749^{\prime}$ & 67.71 & 113.7 & 0.59562 & 1.725377 & 0.720160 & 0.718199 & 80 & 0.7182 \\
\hline $877-13 F$ & $43^{\circ} 22.675^{\prime}$ & $115^{\circ} 32.845^{\prime}$ & 104.13 & 366.0 & 0.28451 & 0.824188 & 0.720545 & 0.719608 & 80 & 0.7196 \\
\hline 877-17E & $44^{\circ} 52.488^{\prime}$ & $116^{\circ} 51.955$ & 5.79 & 46.8 & 0.12380 & 0.358084 & 0.705047 & 0.703671 & 270 & 0.7037 \\
\hline $877-18 \mathrm{~A}$ & $44^{\circ} 28.498^{\prime}$ & $116^{\circ} 15.936^{\prime}$ & 30.83 & 953.6 & 0.03233 & 0.093515 & 0.704762 & 0.704656 & 80 & 0.7047 \\
\hline 877-18B & $44^{\circ} 26.336^{\prime}$ & $116^{\circ} 16.156^{\prime}$ & 31.63 & 924.3 & 0.03422 & 0.098975 & 0.704603 & 0.704491 & 80 & 0.7045 \\
\hline $877-18 \mathrm{C}$ & $44^{\circ} 26.462^{\prime}$ & $116^{\circ} 15.482^{\prime}$ & 17.68 & 1093.2 & 0.01617 & 0.046780 & 0.704961 & 0.704908 & 80 & 0.7049 \\
\hline 877-18D & $44^{\circ} 26.421^{\prime}$ & $116^{\circ} 14.389^{\prime}$ & 39.77 & 669.7 & 0.05938 & 0.171767 & 0.704853 & 0.704658 & 80 & 0.7047 \\
\hline $877-18 \mathrm{E}$ & $44^{\circ} 26.474^{\prime}$ & $116^{\circ} 14.111^{\prime}$ & 24.92 & 978.6 & 0.02547 & 0.073662 & 0.705409 & 0.705325 & 80 & 0.7053 \\
\hline $877-18 \mathrm{~F}$ & $44^{\circ} 27.845^{\prime}$ & $116^{\circ} 13.56^{\prime}$ & 50.45 & 541.5 & 0.09316 & 0.269527 & 0.707150 & 0.706844 & 80 & 0.7067 \\
\hline $877-18 \mathrm{G}$ & $44^{\circ} 28.071^{\prime}$ & $116^{\circ} 12.444^{\prime}$ & 5.33 & 7.45 & 0.71544 & 2.074406 & 0.729766 & 0.727408 & 80 & 0.7274 \\
\hline $877-18 \mathrm{H}$ & $44^{\circ} 27.74^{\prime}$ & $116^{\circ} 12.19^{\prime}$ & 96.36 & 892.6 & 0.10796 & 0.312446 & 0.710731 & 0.710376 & 80 & 0.7104 \\
\hline $877-18 \mathrm{I}$ & $44^{\circ} 27.74^{\prime}$ & $116^{\circ} 12.19^{\prime}$ & 46.44 & 536.2 & 0.08660 & 0.250626 & 0.710012 & 0.709727 & 80 & 0.7097 \\
\hline 877-18J & $44^{\circ} 26.749^{\prime}$ & $116^{\circ} 12.693^{\prime}$ & 32.97 & 900.2 & 0.03663 & 0.105985 & 0.709349 & 0.709229 & 80 & 0.7092 \\
\hline $877-18 \mathrm{~K}$ & $44^{\circ} 23.128^{\prime}$ & $116^{\circ} 14.745^{\prime}$ & 12.58 & 787.1 & 0.01598 & 0.046233 & 0.705254 & 0.705201 & 80 & 0.7052 \\
\hline $877-19 A$ & $43^{\circ} 54.803^{\prime}$ & $116^{\circ} 16.486^{\prime}$ & 99.92 & 546.6 & 0.18281 & 0.528948 & 0.708363 & 0.707762 & 80 & 0.7078 \\
\hline 877-19B & $43^{\circ} 54.776^{\prime}$ & $116^{\circ} 16.445^{\prime}$ & 105.61 & 621.2 & 0.17000 & 0.491863 & 0.707656 & 0.707097 & 80 & 0.7071 \\
\hline
\end{tabular}


Table 1. Results of Rb-Sr analyses of rocks of western Idaho.-Continued

[For analytical procedures, see text.]

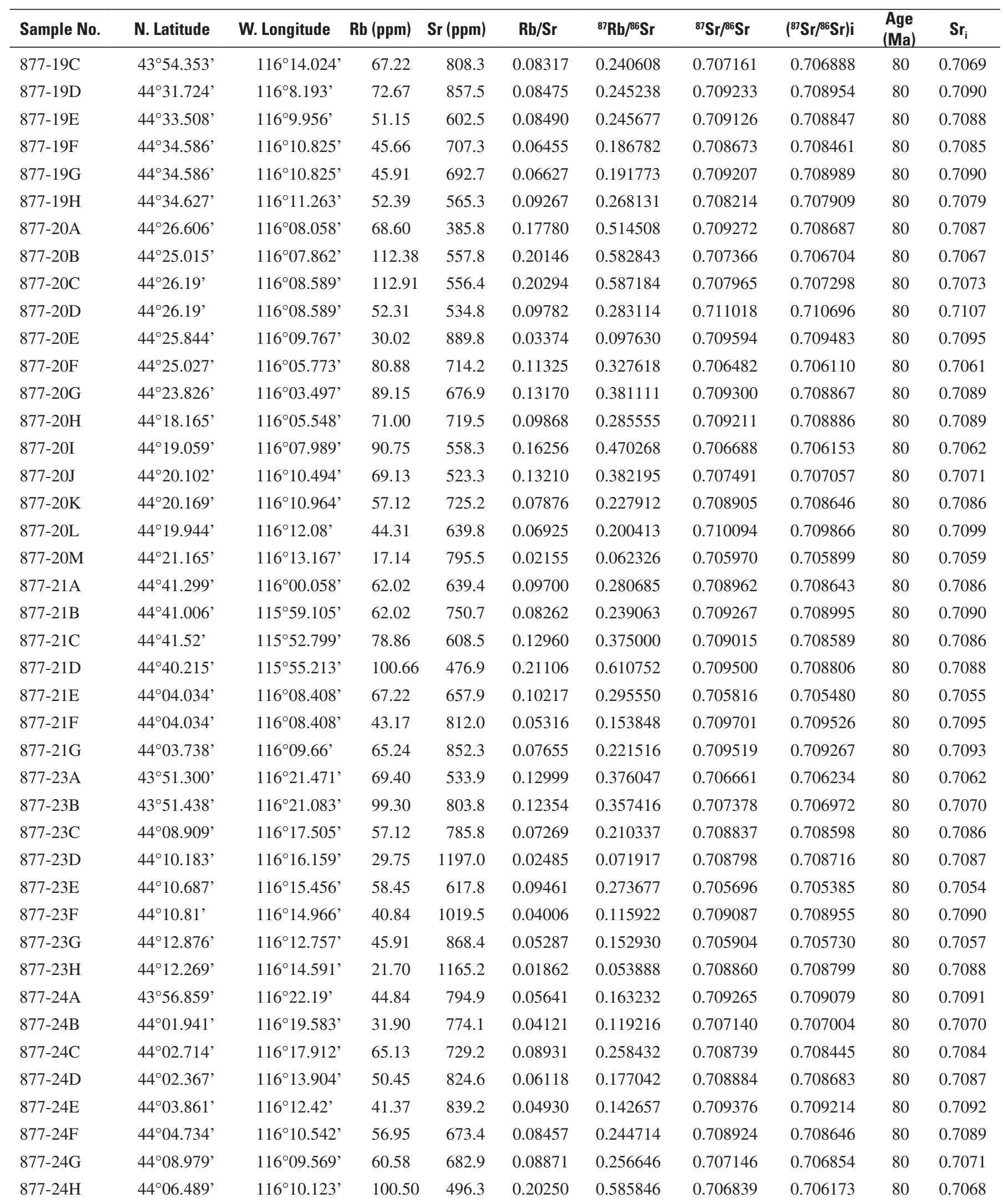


Table 1. Results of Rb-Sr analyses of rocks of western Idaho.-Continued

[For analytical procedures, see text.]

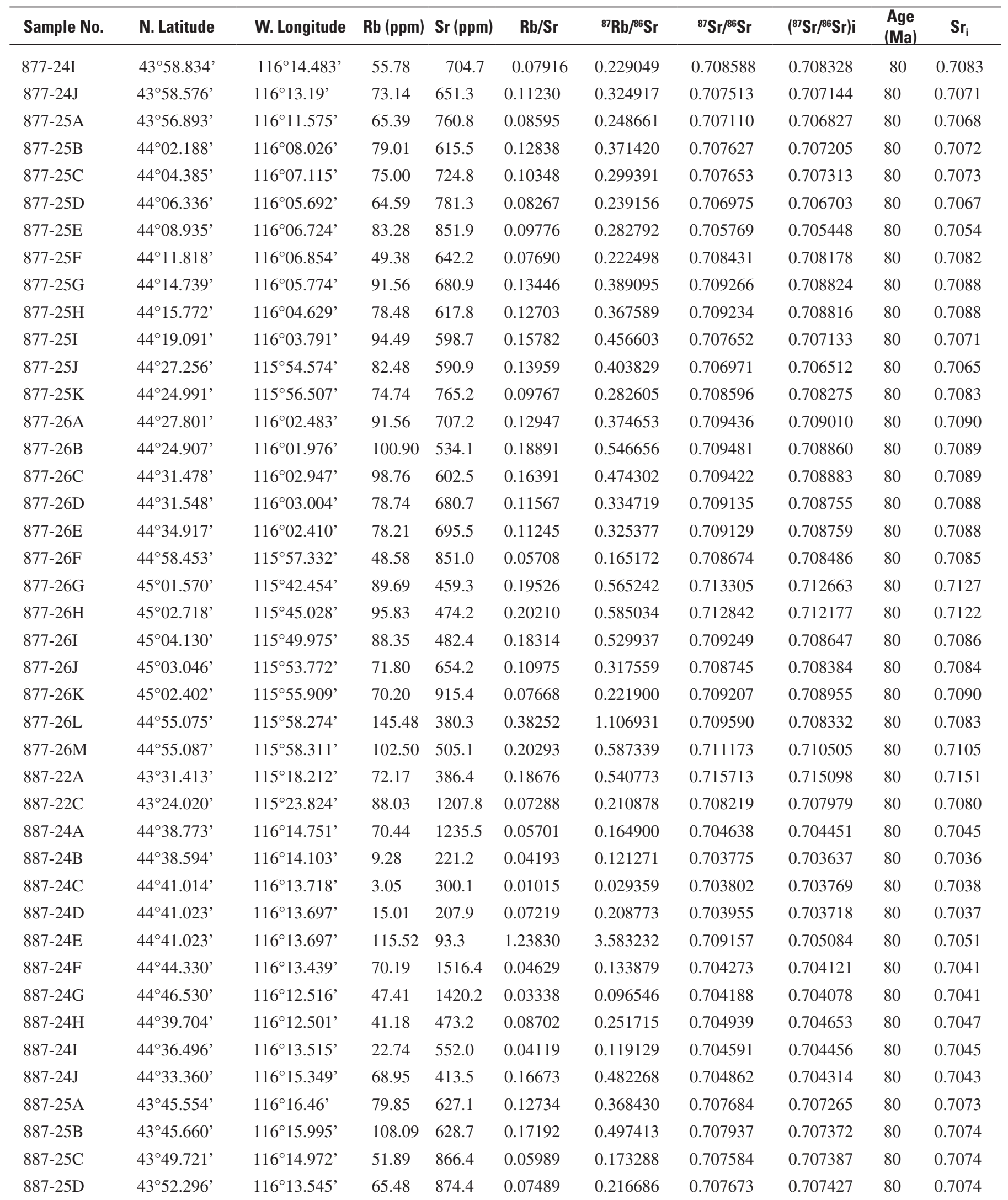


Table 1. Results of Rb-Sr analyses of rocks of western Idaho.-Continued

[For analytical procedures, see text.]

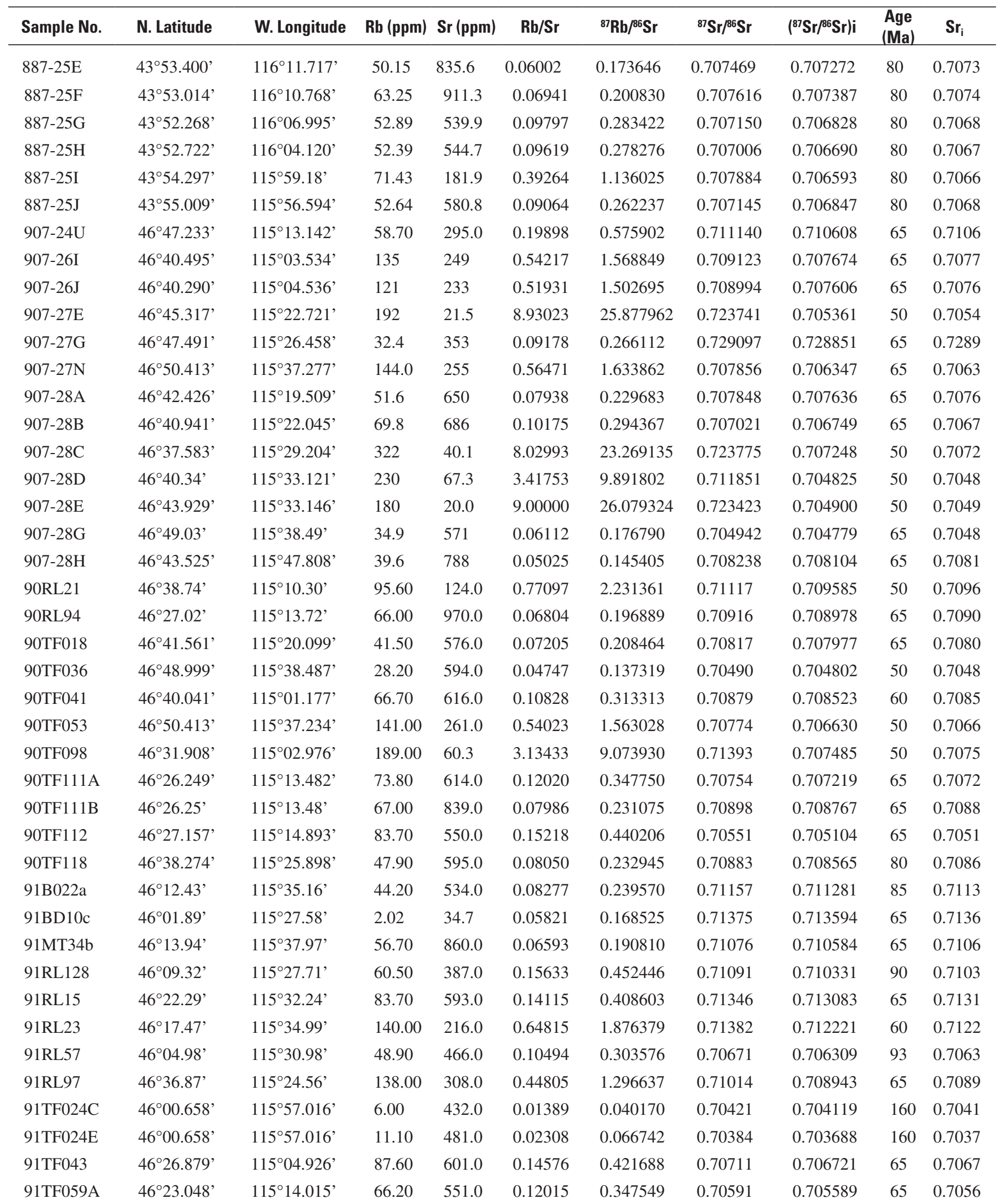


Table 1. Results of Rb-Sr analyses of rocks of western Idaho.-Continued

[For analytical procedures, see text.]

\begin{tabular}{|c|c|c|c|c|c|c|c|c|c|c|}
\hline Sample No. & N. Latitude & W. Longitude & $\mathbf{R b}(\mathrm{ppm})$ & $\operatorname{Sr}(p p m)$ & $\mathrm{Rb} / \mathrm{Sr}$ & ${ }^{87} \mathrm{Rb} /{ }^{86} \mathrm{Sr}$ & ${ }^{87} \mathrm{Sr} /{ }^{86} \mathrm{Sr}$ & $\left({ }^{87} \mathrm{Sr} /{ }^{86} \mathrm{Sr}\right) \mathrm{i}$ & $\begin{array}{l}\text { Age } \\
\text { (Ma) }\end{array}$ & $\mathrm{Sr}_{\mathrm{i}}$ \\
\hline 91TF059F & $46^{\circ} 23.05^{\prime}$ & $115^{\circ} 14.02^{\prime}$ & 26.20 & 220.0 & 0.11909 & 0.344509 & 0.70620 & 0.705882 & 65 & 0.7059 \\
\hline ВСР-20 & $46^{\circ} 48.833^{\prime}$ & $116^{\circ} 38.517^{\prime}$ & 154.5 & 155.5 & 0.99357 & 2.875443 & 0.710534 & 0.706857 & 90 & 0.7105 \\
\hline BCР-258 & $46^{\circ} 47.367^{\prime}$ & $115^{\circ} 35.850^{\prime}$ & 171.0 & 144.5 & 1.18339 & 3.424772 & 0.710455 & 0.706075 & 90 & 0.7105 \\
\hline DG-PC-2 & $46^{\circ} 33.738^{\prime}$ & $116^{\circ} 39.444^{\prime}$ & 31 & 874 & 0.03547 & 0.102626 & 0.708215 & 0.708084 & 90 & 0.7081 \\
\hline PEM-82126 & $45^{\circ} 48.207^{\prime}$ & $115^{\circ} 58.666^{\prime}$ & 21.95 & 229.2 & 0.09577 & 0.277000 & 0.704719 & 0.704404 & 80 & 0.7044 \\
\hline PEM-82134 & $45^{\circ} 48.190^{\prime}$ & $115^{\circ} 59.974^{\prime}$ & 23.00 & 783.8 & 0.02934 & 0.084871 & 0.704150 & 0.704054 & 80 & 0.7041 \\
\hline PEM-82147 & $45^{\circ} 45.926^{\prime}$ & $116^{\circ} 04.093^{\prime}$ & 47.33 & 672.2 & 0.07041 & 0.203641 & 0.703942 & 0.703711 & 80 & 0.7037 \\
\hline PEM-83054 & $45^{\circ} 48.747^{\prime}$ & $115^{\circ} 56.014^{\prime}$ & 41.03 & 888.6 & 0.04617 & 0.133573 & 0.706248 & 0.706096 & 80 & 0.7061 \\
\hline WMC-00-86 & $46^{\circ} 33.37^{\prime}$ & $116^{\circ} 17.037^{\prime}$ & 54.0 & 666.0 & 0.08108 & 0.234582 & 0.707439 & 0.707139 & 90 & 0.7071 \\
\hline
\end{tabular}

Table 2. Results of Sm-Nd analyses of rocks of western Idaho.

[Epsilon values and initial ratios are based on an age of $80 \mathrm{Ma}$. For locations of samples, see table 1.]

\begin{tabular}{|c|c|c|c|c|c|c|c|}
\hline Sample & $\mathrm{Nd}$ (ppm) & Sm (ppm) & $\mathrm{Sm} / \mathrm{Nd}$ & ${ }^{147} \mathrm{Sm} /{ }^{144} \mathrm{Nd}$ & ${ }^{143} \mathrm{Nd} /{ }^{144} \mathrm{Nd}$ & $\varepsilon_{\mathrm{Nd}}(t)$ & $\varepsilon_{\mathrm{sr}}(t)$ \\
\hline $877-12 B$ & 29.88 & 4.69 & 0.1569 & 0.09488 & 0.512322 & -5.23 & 31.99 \\
\hline $877-12 \mathrm{C}$ & 30.01 & 4.81 & 0.1602 & 0.09685 & 0.512293 & -5.81 & 29.30 \\
\hline $877-12 \mathrm{D}$ & 50.64 & 7.99 & 0.1578 & 0.09542 & 0.512310 & -5.47 & 29.72 \\
\hline $877-12 \mathrm{E}$ & 22.17 & 2.05 & 0.0923 & 0.05577 & 0.512198 & -7.27 & 50.04 \\
\hline $877-12 \mathrm{G}$ & 20.62 & 3.31 & 0.1605 & 0.09699 & 0.512085 & -9.87 & 65.07 \\
\hline $877-12 \mathrm{I}$ & 14.68 & 2.44 & 0.1659 & 0.10032 & 0.512312 & -5.48 & 12.38 \\
\hline 877-13B & 29.44 & 4.11 & 0.1397 & 0.08447 & 0.512162 & -8.18 & 41.56 \\
\hline $877-13 \mathrm{C}$ & 87.53 & 21.47 & 0.2453 & 0.14826 & 0.511857 & -14.78 & 1022.8 \\
\hline 877-13D & 57.41 & 11.64 & 0.2027 & 0.12254 & 0.511516 & -21.17 & 448.6 \\
\hline $877-13 \mathrm{E}$ & 167.81 & 16.82 & 0.1002 & 0.06058 & 0.512098 & -9.18 & 195.8 \\
\hline $877-13 \mathrm{G}$ & 22.20 & 3.68 & 0.1658 & 0.10020 & 0.510824 & -34.45 & 798.3 \\
\hline $887-22 \mathrm{~A}$ & 132.62 & 21.89 & 0.1650 & 0.09975 & 0.512115 & -9.25 & 151.8 \\
\hline $887-22 B$ & 22.13 & 5.94 & 0.2687 & 0.16240 & 0.511944 & -13.23 & \\
\hline $887-22 \mathrm{C}$ & 51.15 & 6.19 & 0.1210 & 0.07314 & 0.512071 & -9.84 & 50.75 \\
\hline $887-22 \mathrm{D}$ & 113.77 & 15.11 & 0.1328 & 0.08030 & 0.512125 & -8.86 & 1323.8 \\
\hline $887-24 \mathrm{~A}$ & 33.94 & 7.16 & 0.2108 & 0.12744 & 0.512664 & 1.71 & 0.65 \\
\hline $887-24 B$ & 16.32 & 2.74 & 0.1680 & 0.10154 & 0.512825 & 5.31 & -10.90 \\
\hline $887-24 C$ & 7.47 & 1.78 & 0.2377 & 0.14373 & 0.512926 & 6.53 & -9.03 \\
\hline 887-24D & 6.83 & 1.40 & 0.2048 & 0.12382 & 0.512870 & 5.79 & -9.75 \\
\hline $887-24 \mathrm{E}$ & 10.74 & 3.53 & 0.3289 & 0.19884 & 0.512857 & 4.20 & 9.65 \\
\hline $887-24 \mathrm{~F}$ & 34.89 & 7.41 & 0.2124 & 0.12839 & 0.512729 & 2.96 & -4.03 \\
\hline $887-24 G$ & 44.00 & 9.12 & 0.2072 & 0.12530 & 0.512755 & 3.52 & -4.63 \\
\hline $887-24 \mathrm{H}$ & 10.66 & 2.23 & 0.2096 & 0.12672 & 0.512773 & 3.85 & 3.52 \\
\hline $887-24 \mathrm{I}$ & 14.52 & 2.76 & 0.1899 & 0.11482 & 0.512670 & 2.05 & 0.72 \\
\hline $887-24 \mathrm{~J}$ & 12.86 & 2.42 & 0.1884 & 0.11391 & 0.512503 & -1.19 & -1.29 \\
\hline $887-25 B$ & 20.39 & 3.04 & 0.1490 & 0.09009 & 0.512276 & -6.01 & 42.12 \\
\hline $887-25 C$ & 45.13 & 7.88 & 0.1745 & 0.10549 & 0.512222 & -7.22 & 42.34 \\
\hline $887-25 \mathrm{D}$ & 51.98 & 8.96 & 0.1723 & 0.10418 & 0.512200 & -7.64 & 42.90 \\
\hline $887-25 \mathrm{E}$ & 34.92 & 5.56 & 0.1592 & 0.09621 & 0.512211 & -7.34 & 40.70 \\
\hline
\end{tabular}


Table 2. Results of Sm-Nd analyses of rocks of western Idaho.-Continued

[Epsilon values and initial ratios are based on an age of $80 \mathrm{Ma}$. For locations of samples, see table 1.]

\begin{tabular}{cccccccc}
\hline Sample & $\mathbf{N d}(\mathbf{p p m})$ & $\mathbf{S m}(\mathbf{p p m})$ & $\mathbf{S m} / \mathbf{N d}$ & ${ }^{147} \mathbf{S} \mathbf{m} /{ }^{144} \mathbf{N d}$ & ${ }^{143} \mathbf{N d} /{ }^{144} \mathbf{N d}$ & $\boldsymbol{\varepsilon}_{\mathbf{N d}}(\mathbf{t})$ & $\varepsilon_{\mathbf{s r}}(\mathbf{t})$ \\
\hline $887-25 \mathrm{~F}$ & 51.25 & 9.55 & 0.1864 & 0.11269 & 0.512206 & -7.61 & 42.34 \\
$887-25 \mathrm{G}$ & 33.21 & 4.80 & 0.1445 & 0.08734 & 0.512301 & -5.50 & 34.40 \\
$887-25 \mathrm{H}$ & 21.10 & 3.19 & 0.1513 & 0.09143 & 0.512314 & -5.29 & 32.44 \\
$887-25 \mathrm{I}$ & 3.73 & 1.05 & 0.2816 & 0.17025 & 0.512433 & -3.77 & 31.06 \\
$887-25 \mathrm{~J}$ & 13.45 & 2.23 & 0.1659 & 0.10027 & 0.512297 & -5.71 & 34.67 \\
\hline
\end{tabular}

Table 3. K-Ar apparent ages of rocks of western Idaho

[Material abbreviations: $\mathrm{Bi}=$ biotite, $\mathrm{Hb}=$ Hornblende, $\mathrm{Mu}=$ muscovite, $\mathrm{Pl}=$ plagioclase .

40Ar* indicates radiogenic 40Ar. Age calculated using decay constants of Steiger and Jäger, 1977.]

\begin{tabular}{|c|c|c|c|c|c|}
\hline Sample \# & Material & $\mathrm{K}_{2} \mathrm{O}(\%)$ & $\mathrm{mol}{ }^{40} \mathrm{Ar} * \mathrm{~g}$ & ${ }^{40} \mathrm{Ar}^{*}(\%)$ & $\begin{array}{c}\text { Mean Age } \\
(\mathrm{Ma})\end{array}$ \\
\hline \multirow[t]{4}{*}{$807-27 \mathrm{~A}$} & $\mathrm{Pl}$ & $0.180,0.174$ & $2.01 \mathrm{E}-11$ & 41.0 & $76.56 \pm 0.75$ \\
\hline & & & $1.97 \mathrm{E}-11$ & 40.6 & \\
\hline & $\mathrm{Bi}$ & $9.28,9.28$ & $1.06 \mathrm{E}-09$ & 88.2 & $77.65 \pm 0.30$ \\
\hline & & & $1.06 \mathrm{E}-09$ & 79.3 & \\
\hline \multirow[t]{4}{*}{$807-30 \mathrm{I}$} & $\mathrm{Bi}$ & $9.64,9.65$ & $9.80 \mathrm{E}-10$ & 85.4 & $69.04 \pm 0.19$ \\
\hline & & & $9.75 \mathrm{E}-10$ & 68.0 & \\
\hline & $\mathrm{Mu}$ & $10.71,10.65$ & $1.13 \mathrm{E}-09$ & 85.1 & $71.78 \pm 0.34$ \\
\hline & & & $1.12 \mathrm{E}-09$ & 65.6 & \\
\hline \multirow[t]{2}{*}{$807-31 \mathrm{~A}$} & $\mathrm{Hb}$ & $1.194,1.181$ & $1.44 \mathrm{E}-10$ & 77.3 & $84.86 \pm 2.73$ \\
\hline & & & $1.53 \mathrm{E}-10$ & 82.3 & \\
\hline \multirow[t]{2}{*}{ 808-1I } & $\mathrm{Hb}$ & $1.521,1.550$ & $1.76 \mathrm{E}-10$ & 74.2 & $79.61 \pm 1.49$ \\
\hline & & & $1.83 \mathrm{E}-10$ & 84.8 & \\
\hline \multirow[t]{4}{*}{$818-11 G$} & $\mathrm{Bi}$ & $9.49,9.39$ & $8.72 \mathrm{E}-10$ & 78.2 & $63.75 \pm 0.69$ \\
\hline & & & $8.91 \mathrm{E}-10$ & 78.0 & \\
\hline & $\mathrm{Hb}$ & $0.701,0.701$ & $8.10 \mathrm{E}-11$ & 66.4 & $80.16 \pm 1.60$ \\
\hline & & & $8.44 \mathrm{E}-11$ & 59.8 & \\
\hline \multirow[t]{2}{*}{$818-12 \mathrm{E}$} & $\mathrm{Hb}$ & $0.281,0.276$ & $2.64 \mathrm{E}-11$ & 36.2 & $67.21 \pm 2.58$ \\
\hline & & & $2.85 \mathrm{E}-11$ & 23.1 & \\
\hline \multirow[t]{3}{*}{ 818-13A } & $\mathrm{Bi}$ & $9.82,9.86$ & $1.08 \mathrm{E}-09$ & 82.2 & $74.04 \pm 0.86$ \\
\hline & & & $1.06 \mathrm{E}-09$ & 86.4 & \\
\hline & $\mathrm{Hb}$ & $1.539,1.552$ & $1.71 \mathrm{E}-10$ & 79.7 & $75.22 \pm 0.60$ \\
\hline \multirow[t]{4}{*}{$818-13 \mathrm{C}$} & $\mathrm{Bi}$ & $8.74,8.68$ & $8.71 \mathrm{E}-10$ & 79.2 & $67.99 \pm 0.18$ \\
\hline & & & $8.67 \mathrm{E}-10$ & 68.0 & \\
\hline & $\mathrm{Mu}$ & $10.68,10.65$ & $1.04 \mathrm{E}-09$ & 91.5 & $66.95 \pm 0.34$ \\
\hline & & & $1.05 \mathrm{E}-09$ & 87.6 & \\
\hline \multirow[t]{4}{*}{ 818-13D } & $\mathrm{Bi}$ & $9.13,9.18$ & $9.35 \mathrm{E}-10$ & 74.1 & $70.43 \pm 0.85$ \\
\hline & & & $9.58 \mathrm{E}-10$ & 85.8 & \\
\hline & $\mathrm{Mu}$ & $10.96,10.94$ & $1.21 \mathrm{E}-09$ & 96.0 & $75.27 \pm 0.12$ \\
\hline & & & $1.21 \mathrm{E}-09$ & 86.1 & \\
\hline \multirow[t]{3}{*}{$818-13 \mathrm{E}$} & $\mathrm{Bi}$ & $9.62,9.66$ & $1.06 \mathrm{E}-09$ & 76.2 & $74.27 \pm 0.53$ \\
\hline & & & $1.04 \mathrm{E}-09$ & 79.0 & \\
\hline & $\mathrm{Mu}$ & $10.48,10.51$ & $1.14 \mathrm{E}-09$ & 87.9 & $72.91 \pm 1.05$ \\
\hline
\end{tabular}


Table 3. K-Ar apparent ages of rocks of western Idaho-Continued

[Material abbreviations: $\mathrm{Bi}=$ biotite, $\mathrm{Hb}=$ Hornblende, $\mathrm{Mu}=$ muscovite, $\mathrm{Pl}=$ plagioclase.

40Ar* indicates radiogenic 40Ar. Age calculated using decay constants of Steiger and Jäger, 1977.]

\begin{tabular}{|c|c|c|c|c|c|}
\hline Sample \# & Material & $\mathrm{K}_{2} \mathrm{O}(\%)$ & $\mathrm{mol}{ }^{40} \mathrm{Ar} * \mathrm{~g}$ & ${ }^{40} \mathrm{Ar}^{*}(\%)$ & Mean Age (Ma) \\
\hline & & & $1.11 \mathrm{E}-09$ & 91.7 & \\
\hline \multirow[t]{4}{*}{$827-27 \mathrm{~F}$} & $\mathrm{Hb}$ & $0.848,0.858$ & $8.89 \mathrm{E}-11$ & 40.4 & $72.82 \pm 1.93$ \\
\hline & & & $9.52 \mathrm{E}-11$ & 66.4 & \\
\hline & & & $9.15 \mathrm{E}-11$ & 68.2 & \\
\hline & & & $8.94 \mathrm{E}-11$ & 63.0 & \\
\hline \multirow[t]{3}{*}{$827-30 \mathrm{C}$} & $\mathrm{Hb}$ & $1.004,1.004$ & $1.45 \mathrm{E}-10$ & 58.3 & $97.69 \pm 1.33$ \\
\hline & & & $1.48 \mathrm{E}-10$ & 71.9 & \\
\hline & & & $1.43 \mathrm{E}-10$ & 44.7 & \\
\hline \multirow[t]{4}{*}{$827-30 \mathrm{~K}$} & $\mathrm{Bi}$ & $9.53,9.54$ & $1.08 \mathrm{E}-09$ & 69.4 & $77.37 \pm 0.08$ \\
\hline & & & 1.09E-09 & 84.6 & \\
\hline & $\mathrm{Hb}$ & $1.428,1.433$ & $1.51 \mathrm{E}-10$ & 58.7 & $71.10 \pm 0.71$ \\
\hline & & & $1.48 \mathrm{E}-10$ & 62.1 & \\
\hline \multirow[t]{5}{*}{$837-23 B$} & $\mathrm{Bi}$ & $8.10,8.38$ & $8.38 \mathrm{E}-10$ & 82.8 & $73.17 \pm 3.48$ \\
\hline & & & $9.43 \mathrm{E}-10$ & 65.8 & \\
\hline & & & $8.77 \mathrm{E}-10$ & 82.0 & \\
\hline & $\mathrm{Hb}$ & $0.927,0.911$ & $1.04 \mathrm{E}-10$ & 68.6 & $77.62 \pm 0.81$ \\
\hline & & & $1.06 \mathrm{E}-10$ & 81.2 & \\
\hline \multirow[t]{5}{*}{$837-24 \mathrm{~A}$} & $\mathrm{Bi}$ & $9.49,9.44$ & $9.93 \mathrm{E}-10$ & 79.6 & $71.55 \pm 0.10$ \\
\hline & & & $9.96 \mathrm{E}-10$ & 82.6 & \\
\hline & $\mathrm{Hb}$ & $1.347,1.353$ & $1.50 \mathrm{E}-10$ & 60.3 & $76.38 \pm 1.62$ \\
\hline & & & $1.56 \mathrm{E}-10$ & 84.2 & \\
\hline & & & $1.48 \mathrm{E}-10$ & 79.9 & \\
\hline \multirow[t]{3}{*}{$837-24 \mathrm{D}$} & $\mathrm{Hb}$ & $0.376,0.377$ & $3.94 \mathrm{E}-11$ & 34.5 & $70.20 \pm 0.84$ \\
\hline & & & $3.82 \mathrm{E}-11$ & 49.5 & \\
\hline & & & $3.89 \mathrm{E}-11$ & 37.8 & \\
\hline \multirow[t]{4}{*}{$837-25 \mathrm{C}$} & $\mathrm{Bi}$ & $9.41,9.34$ & $8.01 \mathrm{E}-10$ & 63.3 & $58.59 \pm 0.20$ \\
\hline & & & $8.06 \mathrm{E}-10$ & 70.5 & \\
\hline & $\mathrm{Mu}$ & $10.48,10.51$ & $9.68 \mathrm{E}-10$ & 75.1 & $62.66 \pm 0.28$ \\
\hline & & & $9.59 \mathrm{E}-10$ & 72.5 & \\
\hline \multirow[t]{4}{*}{$837-25 E$} & $\mathrm{Bi}$ & $9.50,9.45$ & $9.83 \mathrm{E}-10$ & 88.2 & $70.81 \pm 0.17$ \\
\hline & & & $9.87 \mathrm{E}-10$ & 88.0 & \\
\hline & $\mathrm{Hb}$ & $0.499,0.492$ & $6.73 \mathrm{E}-11$ & 32.6 & $91.24 \pm 0.74$ \\
\hline & & & $6.62 \mathrm{E}-11$ & 47.2 & \\
\hline \multirow[t]{7}{*}{$837-26 \mathrm{D}$} & $\mathrm{Bi}$ & $9.29,9.54$ & $9.90 \mathrm{E}-10$ & 76.6 & $71.97 \pm 1.22$ \\
\hline & & $9.34,9.37$ & $9.73 \mathrm{E}-10$ & 66.4 & \\
\hline & & & $9.91 \mathrm{E}-10$ & 75.5 & \\
\hline & & & $1.01 \mathrm{E}-09$ & 84.8 & \\
\hline & $\mathrm{Hb}$ & $1.538,1.549$ & $1.80 \mathrm{E}-10$ & 60.0 & $76.46 \pm 2.07$ \\
\hline & & & $1.71 \mathrm{E}-10$ & 74.3 & \\
\hline & & & $1.69 \mathrm{E}-10$ & 75.1 & \\
\hline
\end{tabular}


Table 3. K-Ar apparent ages of rocks of western Idaho-Continued

[Material abbreviations: $\mathrm{Bi}=$ biotite, $\mathrm{Hb}=$ Hornblende, $\mathrm{Mu}=$ muscovite, $\mathrm{Pl}=$ plagioclase.

40Ar* indicates radiogenic 40Ar. Age calculated using decay constants of Steiger and Jäger, 1977.]

\begin{tabular}{|c|c|c|c|c|c|}
\hline Sample \# & Material & $\mathrm{K}_{2} \mathrm{O}(\%)$ & $\mathrm{mol}{ }^{40} \mathrm{Ar} / \mathrm{g}$ & ${ }^{40} \mathrm{Ar}^{*}(\%)$ & Mean Age (Ma) \\
\hline \multirow[t]{2}{*}{$837-27 I$} & $\mathrm{Bi}$ & $8.33,8.32$ & $6.14 \mathrm{E}-10$ & 72.8 & $50.46 \pm 0.08$ \\
\hline & & & $6.12 \mathrm{E}-10$ & 72.3 & \\
\hline \multirow[t]{3}{*}{$837-28 B$} & $\mathrm{Bi}$ & $9.71,9.72$ & $1.05 \mathrm{E}-09$ & 81.0 & $74.16 \pm 0.30$ \\
\hline & & & $1.06 \mathrm{E}-09$ & 78.8 & \\
\hline & $\mathrm{Hb}$ & $1.968,1.846$ & $2.32 \mathrm{E}-10$ & 83.1 & \\
\hline \multirow[t]{2}{*}{$837-28 \mathrm{C}$} & $\mathrm{Bi}$ & $9.65,9.67$ & $1.08 \mathrm{E}-09$ & 75.2 & $76.02 \pm 0.30$ \\
\hline & & & $1.08 \mathrm{E}-09$ & 88.8 & \\
\hline \multirow[t]{4}{*}{$837-28 \mathrm{~F}$} & $\mathrm{Bi}$ & $9.86,9.83$ & 1.19E-09 & 72.5 & $78.36 \pm 2.16$ \\
\hline & & & $1.13 \mathrm{E}-09$ & 90.3 & \\
\hline & & & $1.11 \mathrm{E}-09$ & 91.0 & \\
\hline & & & $1.11 \mathrm{E}-09$ & 87.6 & \\
\hline \multirow[t]{4}{*}{$837-29 G$} & $\mathrm{Bi}$ & $8.84,8.92$ & 1.13E-09 & 51.8 & $87.67 \pm 1.63$ \\
\hline & & & $1.17 \mathrm{E}-09$ & 91.7 & \\
\hline & $\mathrm{Hb}$ & $1.21,1.189$ & $1.72 \mathrm{E}-10$ & 50.5 & $100.91 \pm 4.04$ \\
\hline & & & $1.87 \mathrm{E}-10$ & 84.7 & \\
\hline \multirow[t]{2}{*}{$837-30 \mathrm{~A}$} & $\mathrm{Hb}$ & $0.611,0.609$ & $9.33 \mathrm{E}-11$ & 72.4 & $101.89 \pm 2.35$ \\
\hline & & & $9.78 \mathrm{E}-11$ & 74.9 & \\
\hline \multirow[t]{2}{*}{$837-30 \mathrm{C}$} & $\mathrm{Bi}$ & $8.46,8.42$ & $1.02 \mathrm{E}-09$ & 70.4 & $82.43 \pm 0.43$ \\
\hline & & & $1.03 \mathrm{E}-09$ & 83.2 & \\
\hline \multirow[t]{4}{*}{$837-31 E$} & $\mathrm{Bi}$ & $9.10,9.13$ & $1.08 \mathrm{E}-09$ & 89.3 & $80.72 \pm 0.15$ \\
\hline & & & 1.09E-09 & 87.4 & \\
\hline & $\mathrm{Hb}$ & $1.461,1.453$ & $1.89 \mathrm{E}-10$ & 69.6 & $85.74 \pm 2.36$ \\
\hline & & & 1.79E-09 & 30.2 & \\
\hline \multirow[t]{6}{*}{$837-31 I$} & $\mathrm{Bi}$ & $9.51,9.46$ & 1.09E-09 & 86.8 & $78.97 \pm 0.75$ \\
\hline & & & $1.11 \mathrm{E}-09$ & 89.8 & \\
\hline & $\mathrm{Hb}$ & $1.653,1.655$ & $1.92 \mathrm{E}-10$ & 82.2 & $81.80 \pm 3.04$ \\
\hline & & & $2.09 \mathrm{E}-10$ & 78.2 & \\
\hline & & & $2.04 \mathrm{E}-10$ & 87.6 & \\
\hline & & & $1.92 \mathrm{E}-10$ & 57.0 & \\
\hline \multirow[t]{4}{*}{$837-31 L$} & $\mathrm{Bi}$ & $9.42,9.42$ & $1.08 \mathrm{E}-09$ & 80.6 & $78.70 \pm 0.69$ \\
\hline & & & $1.10 \mathrm{E}-09$ & 78.2 & \\
\hline & $\mathrm{Hb}$ & $0.996,1.001$ & $1.19 \mathrm{E}-10$ & 52.5 & $79.56 \pm 1.38$ \\
\hline & & & $1.15 \mathrm{E}-10$ & 42.9 & \\
\hline \multirow[t]{5}{*}{$838-2 I$} & $\mathrm{Bi}$ & $9.59,9.61$ & $1.06 \mathrm{E}-09$ & 83.5 & $76.04 \pm 0.61$ \\
\hline & & & $1.08 \mathrm{E}-09$ & 85.6 & \\
\hline & $\mathrm{Hb}$ & $1.512,1.521$ & $1.70 \mathrm{E}-10$ & 81.4 & $78.49 \pm 2.24$ \\
\hline & & & $1.82 \mathrm{E}-10$ & 78.9 & \\
\hline & & & $1.73 \mathrm{E}-10$ & 82.2 & \\
\hline \multirow[t]{4}{*}{$838-3 C$} & $\mathrm{Bi}$ & $9.79,9.75$ & $1.02 \mathrm{E}-09$ & 68.0 & $71.34 \pm 0.20$ \\
\hline & & & $1.03 \mathrm{E}-09$ & 88.6 & \\
\hline & $\mathrm{Hb}$ & $1.419,1.424$ & $1.57 \mathrm{E}-10$ & 69.3 & $74.74 \pm 0.32$ \\
\hline & & & $1.55 \mathrm{E}-10$ & 75.9 & \\
\hline
\end{tabular}


[The ${ }^{39} \mathrm{Ar}(\%)$ column indicates the percentage of total ${ }^{39} \mathrm{Ar}$ released in each step of the experiment. $\%{ }^{40} \mathrm{Ar} *$ is the percentage radiogenic ${ }^{40} \mathrm{Ar}$ in each

step. The $\%{ }^{36} \mathrm{ArCa}$ column reports the percentage of ${ }^{36} \mathrm{Ar}$ in each step derived from neutron reactions with calcium. LF in Temp column is complete fusion by laser.]

\begin{tabular}{|c|c|c|c|c|c|c|c|c|c|c|}
\hline Sample & Temp $\left({ }^{\circ} \mathrm{C}\right)$ & ${ }^{39} \mathrm{Ar}(\%)$ & $\%{ }^{40} \mathrm{Ar}^{*}$ & $\%{ }^{36} \mathrm{Ar}_{\mathrm{Ca}}$ & ${ }^{40} \mathrm{Ar} /{ }^{39} \mathrm{Ar}$ & ${ }^{37} \mathrm{Ar} /{ }^{39} \mathrm{Ar}$ & ${ }^{36} \mathrm{Ar} /{ }^{39} \mathrm{Ar}$ & J-Value & Age (Ma) & $+/-(\mathrm{Ma})$ \\
\hline \multirow[t]{10}{*}{$827-27 \mathrm{~F}$} & $700^{+}$ & 0.42 & 9.4 & 0.09 & 190.33 & 1.917 & 0.5842 & 0.0051775 & 159.66 & 14.36 \\
\hline & $800^{+}$ & 0.33 & 6.4 & 0.13 & 200.69 & 3.019 & 0.6365 & do. & 116.30 & 19.08 \\
\hline & $875^{+}$ & 0.90 & 5.7 & 0.31 & 134.84 & 4.877 & 0.4315 & do. & 70.90 & 6.68 \\
\hline & $930^{+}$ & 1.49 & 11.5 & 0.81 & 62.21 & 5.622 & 0.1879 & do. & 65.78 & 3.72 \\
\hline & 955 & 7.40 & 50.5 & 5.83 & 15.56 & 5.928 & 0.0277 & do. & 72.19 & 0.84 \\
\hline & 980 & 5.86 & 50.0 & 5.70 & 15.79 & 5.928 & 0.0283 & do. & 72.59 & 0.98 \\
\hline & 1005 & 7.37 & 50.7 & 5.82 & 15.60 & 5.906 & 0.0276 & do. & 72.75 & 0.85 \\
\hline & 1155 & 75.85 & 92.3 & 41.59 & 8.73 & 5.867 & 0.0038 & do. & 74.08 & 0.43 \\
\hline & Fuse & 0.38 & 27.8 & 2.30 & 27.37 & 5.779 & 0.0684 & do. & 69.91 & 12.67 \\
\hline & & & & & & & \multicolumn{3}{|c|}{$\begin{array}{lc}\text { Total-gas age }(\mathrm{Ma})- & 74.1 \\
\text { Plateau age }(\mathrm{Ma})--------73.4 \pm 0.4\end{array}$} & \\
\hline \multirow[t]{10}{*}{$837-23 B$} & $700^{+}$ & 0.58 & 9.4 & 0.56 & 153.30 & 9.785 & 0.4727 & 0.0051775 & 130.61 & 9.58 \\
\hline & $830^{+}$ & 0.92 & 6.0 & 0.15 & 116.92 & 2.096 & 0.3726 & do. & 64.16 & 6.14 \\
\hline & $895^{+}$ & 1.67 & 10.9 & 0.48 & 67.00 & 3.608 & 0.2030 & do. & 67.11 & 3.42 \\
\hline & 940 & 8.71 & 65.7 & 8.86 & 12.62 & 5.234 & 0.0161 & do. & 76.04 & 0.72 \\
\hline & 955 & 13.98 & 77.6 & 15.50 & 10.62 & 5.418 & 0.0095 & do. & 75.59 & 0.56 \\
\hline & 995 & 28.13 & 87.4 & 26.83 & 9.49 & 5.435 & 0.0055 & do. & 76.12 & 0.47 \\
\hline & 1060 & 43.79 & 91.3 & 36.25 & 9.15 & 5.555 & 0.0042 & do. & 76.66 & 0.45 \\
\hline & 1095 & 2.33 & 63.7 & 8.63 & 13.02 & 5.546 & 0.0175 & do. & 76.16 & 2.33 \\
\hline & Fuse & 0.21 & 12.3 & 0.81 & 57.83 & 5.163 & 0.1729 & do. & 65.63 & 23.10 \\
\hline & & & & & & & \multicolumn{3}{|c|}{ Total-gas age (Ma)-76.3 } & \\
\hline \multirow[t]{7}{*}{$837-28 B$} & $\mathrm{LF}$ & 100.00 & 90.2 & 28.64 & 9.40 & 4.765 & 0.0042 & 0.005414 & 81.29 & 0.54 \\
\hline & LF & 100.00 & 90.9 & 28.74 & 9.25 & 4.347 & 0.0038 & do. & 80.55 & 0.60 \\
\hline & $\mathrm{LF}$ & 100.00 & 89.9 & 28.87 & 9.48 & 5.024 & 0.0044 & do. & 81.67 & 0.56 \\
\hline & $\mathrm{LF}$ & 100.00 & 92.7 & 33.59 & 9.37 & 4.377 & 0.0033 & do. & 83.14 & 0.54 \\
\hline & $\mathrm{LF}$ & 100.00 & 93.0 & 32.63 & 9.39 & 4.059 & 0.0031 & do. & 83.53 & 0.61 \\
\hline & $\mathrm{LF}$ & 100.00 & 92.1 & 31.01 & 9.60 & 4.337 & 0.0035 & do. & 84.64 & 0.58 \\
\hline & & & & & & & \multicolumn{3}{|c|}{$\begin{array}{l}\text { Weighted mean (Ma)----82.5 } \pm 0.5 \\
\text { MSWD }\end{array}$} & \\
\hline
\end{tabular}


Table 4. Results of ${ }^{40} \mathrm{Ar} /{ }^{39} \mathrm{Ar}$ incremental-heating analyses of hornblende from rocks of western Idaho.-Continued

[The ${ }^{39} \mathrm{Ar}(\%)$ column indicates the percentage of total ${ }^{39} \mathrm{Ar}$ released in each step of the experiment. $\%{ }^{40} \mathrm{Ar} *$ is the percentage radiogenic ${ }^{40} \mathrm{Ar}$ in each step. The $\%{ }^{36} \mathrm{ArCa}$ column reports the percentage of ${ }^{36} \mathrm{Ar}$ in each step derived from neutron reactions with calcium. LF in Temp column is complete fusion by laser.]

\begin{tabular}{|c|c|c|c|c|c|c|c|c|c|c|}
\hline Sample & Temp $\left({ }^{\circ} \mathrm{C}\right)$ & ${ }^{39} \operatorname{Ar}(\%)$ & $\%{ }^{40} \mathrm{Ar}^{*}$ & $\%{ }^{36} \mathrm{Ar}_{\mathrm{Ca}}$ & ${ }^{40} \mathrm{Ar} /{ }^{39} \mathrm{Ar}$ & ${ }^{37} \mathrm{Ar} /{ }^{39} \mathrm{Ar}$ & ${ }^{36} \mathrm{Ar} /{ }^{39} \mathrm{Ar}$ & J-Value & Age (Ma) & $+/-(\mathrm{Ma})$ \\
\hline $837-30 \mathrm{~A}$ & LF & 100.00 & 78.7 & 15.41 & 15.88 & 7.873 & 0.0135 & 0.004749 & 104.61 & 0.89 \\
\hline \multirow[t]{9}{*}{$837-30 \mathrm{~A}(\mathrm{IH})$} & 750 & 0.28 & 0.01 & 0.09 & 303.59 & 3.343 & 1.0281 & 0.004749 & 0.28 & 140.29 \\
\hline & 875 & 3.57 & 15.5 & 0.96 & 70.42 & 7.419 & 0.2034 & do. & 91.51 & 3.28 \\
\hline & 940 & 77.98 & 87.3 & 25.67 & 13.89 & 7.794 & 0.0080 & do. & 101.54 & 0.61 \\
\hline & 975 & 17.64 & 80.8 & 18.33 & 14.70 & 8.111 & 0.0117 & do. & 99.50 & 0.74 \\
\hline & 1000 & 0.08 & -13.7 & 0.17 & 215.09 & 5.185 & 0.8292 & do. & -273.62 & 168.43 \\
\hline & 1030 & 0.08 & -12.0 & 0.14 & 236.68 & 4.853 & 0.8980 & do. & -261.25 & 177.29 \\
\hline & 1100 & 0.09 & -8.4 & 0.13 & 280.51 & 5.207 & 1.0306 & do. & -215.50 & 178.05 \\
\hline & Fuse & 0.28 & -5.6 & 0.29 & 170.15 & 6.735 & 0.6096 & do. & -83.40 & 38.60 \\
\hline & & & & & & \multicolumn{5}{|c|}{$\begin{array}{l}\text { Total-gas age }(\mathrm{Ma})-99.3 \\
\text { Plateau age (Ma)------100.7 } \pm 0.5\end{array}$} \\
\hline
\end{tabular}


terrane juxtaposition and consolidation of 130 to $75 \mathrm{Ma}$, with a preferred period between 95 and $80 \mathrm{Ma}$ (Fleck and Criss, 1985; Criss and Fleck, 1987). Lund and Snee (1988) suggested late Early Cretaceous and early Late Cretaceous accretion confined to a 25-m.y. period between 118 and 93 Ma, but suggest that movement took place along other parts of the WISZ until $79 \mathrm{Ma}$. Results of zircon U-Pb and garnet $\mathrm{Sm}-\mathrm{Nd}$ geochronology (Manduca and others, 1993; Getty and others, 1993) are consistent with our broader range, but show that initial suturing occurred at about $130 \mathrm{Ma}$. Evidence that movements took place along the WISZ until at least $80 \mathrm{Ma}$, however, remains unaffected by these results.

$\mathrm{U}-\mathrm{Pb}$ zircon, $\mathrm{Rb}-\mathrm{Sr}, \mathrm{K}-\mathrm{Ar}$, and ${ }^{40} \mathrm{Ar} /{ }^{\beta 9} \mathrm{Ar}$ ages of intrusive rocks of the WSD terranes document a history of Permian to Early Cretaceous plutonism (Armstrong, 1975, 1976; Armstrong and others, 1977; Ave Lallemant and others, 1980; Criss and Fleck, 1987; Walker, 1995). Although the apparent ages of some rocks were reduced somewhat by regional metamorphic events, $\mathrm{K}-\mathrm{Ar}$ and ${ }^{40} \mathrm{Ar} /{ }^{39} \mathrm{Ar}$ ages decrease abruptly to Late Cretaceous ages over a distance of $10 \mathrm{~km}$ or less near and within the WISZ (fig. 9; tables 3, 4). North and east of the WISZ, apparent ages continue a gradual eastward decrease within the cratonal or Precambrian terrane toward the central parts of the Idaho Batholith (Armstrong, 1974, 1975, 1976; Criss and others, 1982; Fleck and Criss, 1985; Criss and Fleck, 1987; Lund and Snee, 1988; Snee and others, 1995). Ages for hornblende range from about 82 to $74 \mathrm{Ma}$ in plutons within 25 to $30 \mathrm{~km}$ east of the WISZ in the Atlanta lobe of the Idaho
Batholith (Criss and Fleck, 1987). Similar plutons within the western part of the Bitterroot lobe are farther east, and their ages are lower, ranging from 65 to $55 \mathrm{Ma}$ (Criss and Fleck, 1987). Despite this evidence of an eastward migration of magmatism and or cooling, Ar apparent-age patterns in western Idaho are characterized by a "step function," nearly coincident with the WISZ (fig. 9).

To evaluate the relation between the WISZ and the general age pattern documented in figure 9, a series of age-versusdistance plots were constructed approximately normal to the trend of the suture (fig. 1). Eight age profiles across the WISZ are shown in figures 10 through 18, extending from west of Orofino, Idaho, on the north to the area of Cascade, Idaho, near the southern extent of exposures. Profiles were constructed by measuring the perpendicular distance of each sample from the WISZ and grouping them by location along the suture. This procedure is equivalent to projecting the data to the centerline of each group. Where data are available, profile lengths are from $20 \mathrm{~km}$ west to $30 \mathrm{~km}$ east of the suture and incorporate data over a width of 25 to $38 \mathrm{~km}$ along the suture. Each profile is named for a major location within the area represented.

\section{Orofino}

Compiled K-Ar and ${ }^{40} \mathrm{Ar} /{ }^{39} \mathrm{Ar}$ ages from the east-westtrending portion of the WISZ are centered on Orofino, Idaho. An age versus distance profile (fig. 10) reveals a steep

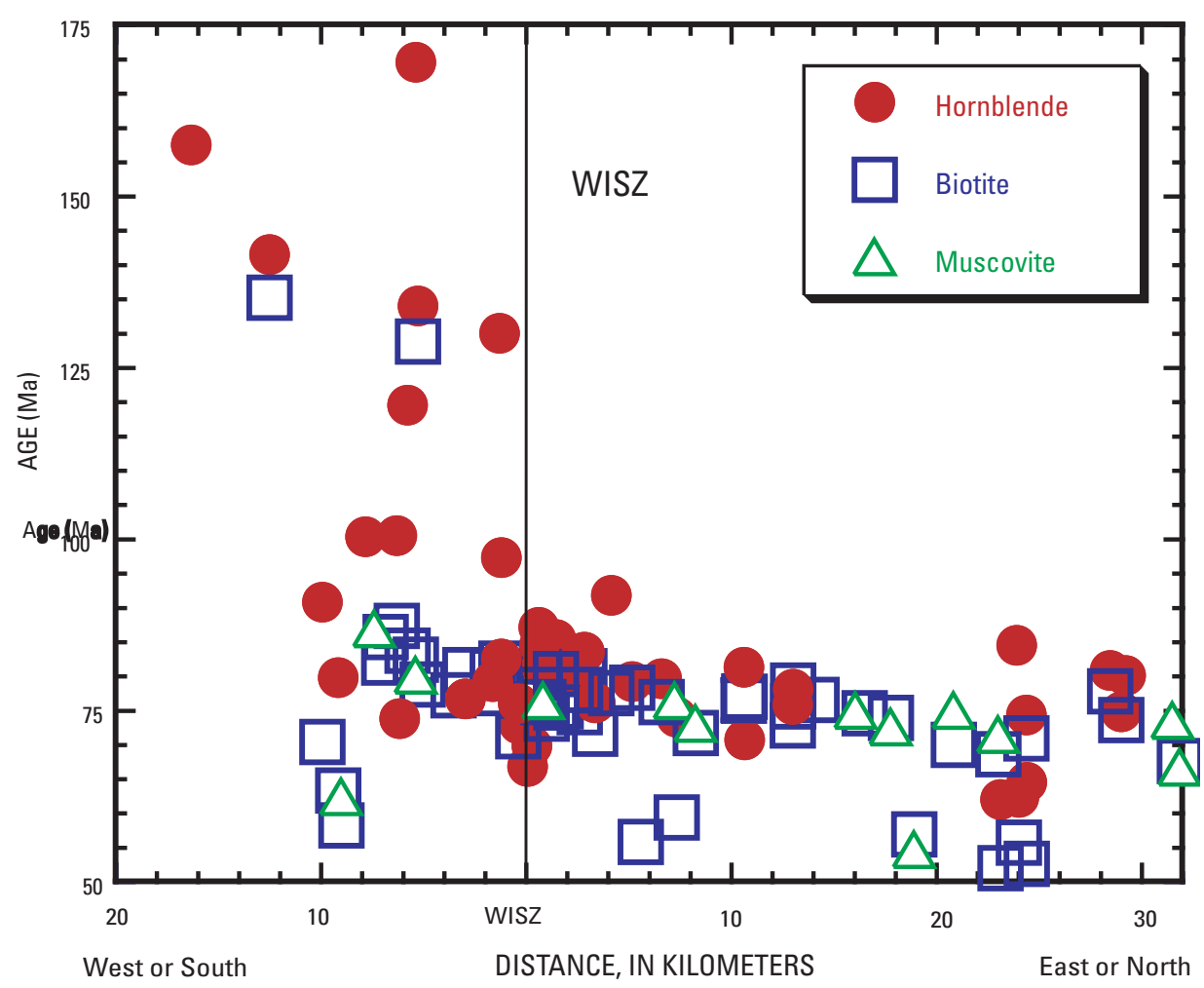

Figure 9. Variation diagram of $\mathrm{K}-\mathrm{Ar}$ and ${ }^{40} \mathrm{Ar} /{ }^{39} \mathrm{Ar}$ ages on hornblende, biotite, and muscovite from plutonic rocks in western Idaho. Note that biotite ages decrease abruptly between 6 and $10 \mathrm{~km}$ west (or south) of the western Idaho suture zone (WISZ), whereas hornblende ages generally exhibit this decrease much closer to the zone. We suggest that this effect is related to greater thermally induced Ar loss from biotite in plutons near the eastern margin of the accreted terranes, caused by the precipitous rise of cratonal terranes along the WISZ and syntectonic emplacement of suture-zone plutons. We interpret the presence of biotite and muscovite ages less than about $65 \mathrm{Ma}$ on both sides of the suture zone as indicating effects of young, probably postdeformational, Bitterroot-age plutonism, especially in the Kamiah-Weippe-Pierce area. Hornblende ages appear to be less affected by these younger events. 
decrease in both biotite and hornblende ages between 1 and $5 \mathrm{~km}$ west of the suture. The profile defines an age minimum coinciding with the strongly foliated zone of the WISZ. Ages within the WSD terranes (negative distances) are variable and probably reflect real age differences in the plutons, as discussed by Criss and Fleck (1987). Ages of 75 to $70 \mathrm{Ma}$ for hornblende in the WSD terrane and within the suture zone east of Orofino are consistent with emplacement of Late Cretaceous or Early Tertiary intrusions across the suture zone and into WSD terranes. Isotopic data demonstrate, however, that these plutons, such as those along the main canyon of the Clearwater River southeast of Orofino, are derived primarily from sources within the accreted lithosphere. Early Tertiary plutons are documented near Elk River to the north and to the east of Lowell along the Lochsa River (Criss and Fleck, 1987). The latest Jurassic to Early Cretaceous pluton at Peck, Idaho, with a $\mathrm{Sr}_{\mathrm{i}}$ of 0.7034 yields biotite and hornblende ages of 129 and $135 \mathrm{Ma}$, respectively (fig. 10), indicating only minimal discordance at a distance of $6 \mathrm{~km}$ south of the WISZ. North of the suture, Armstrong and others (1977) report K-Ar ages of 83 and $73 \mathrm{Ma}$ from hornblende and biotite, respectively, in a quartz diorite, whereas ages within the zone are as low as 74 and $71 \mathrm{Ma}$, respectively. Both age and age discordance of hornblende and biotite decrease toward the suture zone, suggesting that either the youngest intrusive rocks were emplaced along it or that recrystallization or shear heating due to deformation and uplift produced argon loss in the affected rocks. Defined on the basis of the ages observed, thermal and tectonic events within the WISZ in the Orofino area ceased in the period 75 to $70 \mathrm{Ma}$.

\section{Weippe}

The axis of an approximately $110^{\circ}$ bend in the WISZ is located inexactly in the area of Weippe, Idaho (fig. 8), where the zone is concealed by flows of Columbia River basalt. As at Orofino, ages near the WISZ show the effects of Late Cretaceous and Early Tertiary plutons characterized by muscovite ages as young as $63 \mathrm{Ma}$ for sample $837-25 \mathrm{C}$ (table 3). Minimum ages of biotite in both terranes near the WISZ, however, are less than $60 \mathrm{Ma}$, whereas hornblende ages decrease abruptly from more than 140 Ma down to 65 to $62 \mathrm{Ma}$ about $12 \mathrm{~km}$ west of the projected location of the zone (fig. 11). Because the WISZ is only approximately located in this area, an interpretation placing its position 5 to $10 \mathrm{~km}$ farther southwest would be consistent with the age pattern, but isotopic constraints indicate that plutons in that area represent WSD-type magmas. In either case, however, the decrease in age across the zone follows the general pattern discussed by Criss and Fleck (1987), with Early Cretaceous and older rocks becoming highly discordant immediately adjacent to the WISZ and reflecting thermal disturbance. Plutons intruding the Precambrian terrane north and east of Weippe reflect

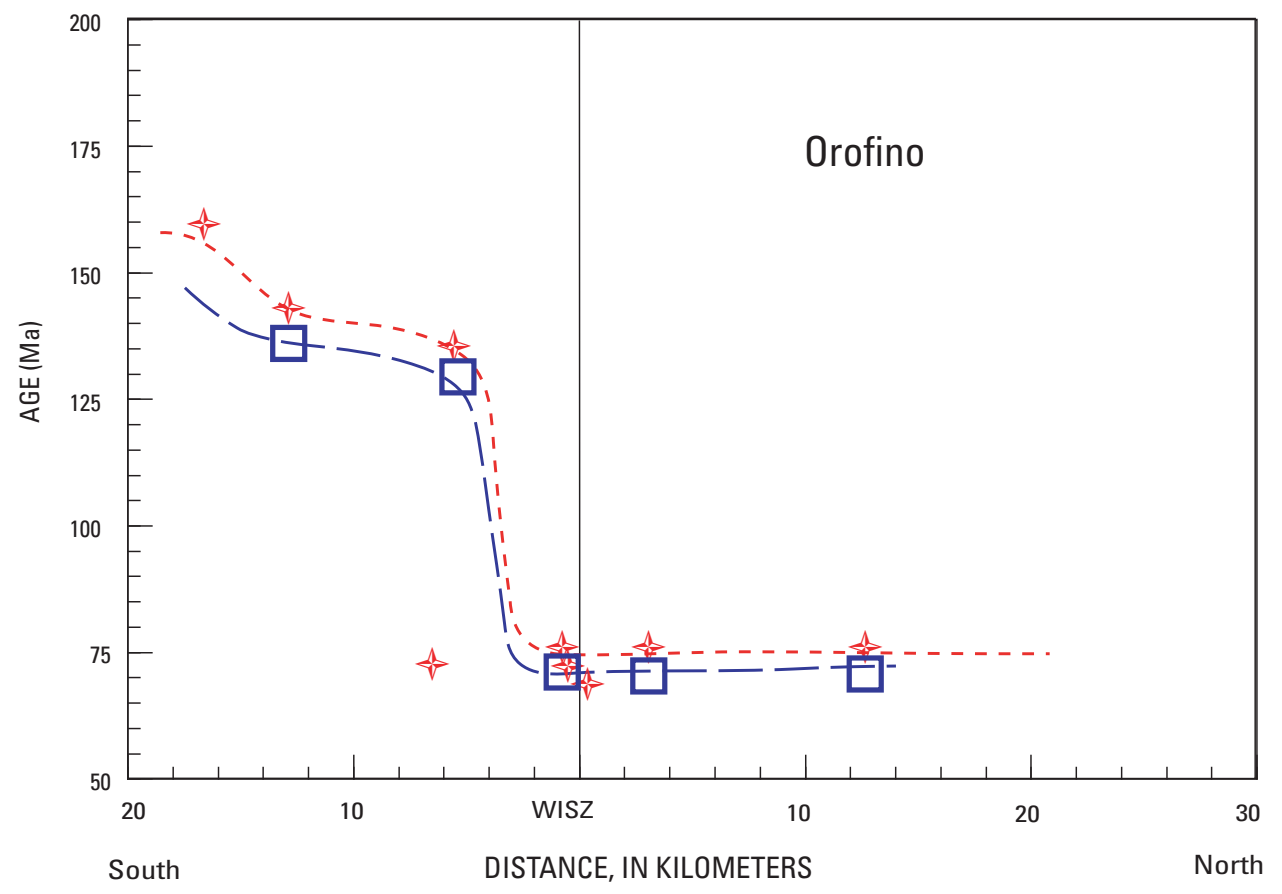

Figure 10. Profile of $\mathrm{K}-\mathrm{Ar}$ and ${ }^{40} \mathrm{Ar} /{ }^{39} \mathrm{Ar}$ ages of hornblende (dots) and biotite (squares) from plutonic rocks centered approximately on Orofino, Idaho (see fig 1). The profile trends northsouth across the western Idaho suture zone (WISZ) from the accreted terranes on the south to the Precambrian terranes on the north. 
the age pattern of the western part of the Bitterroot lobe of the Idaho Batholith, with hornblende ages of 66 to $62 \mathrm{Ma}$. Criss and Fleck (1987) considered these values representative of one of the early Tertiary plutonic episodes in the Bitterroot lobe, where they also reported abrupt steps in hornblende age/ distance profiles. Age data in the Weippe area indicate thermal and/or tectonic disturbance of argon systems in WSD rocks between 80 and $62 \mathrm{Ma}$, with plutons of the episode from 66 to $62 \mathrm{Ma}$ emplaced near or across the zone subsequent to the major deformation.

\section{Kooskia}

The geographic distribution of argon ages across the WISZ where it crosses the Clearwater River just east of Kooskia, Idaho (fig. 12), reveals a classic pattern of thermal loss, such as that described by Hart (1964) (fig. 13). The greatest age discordance occurs 2 to $3 \mathrm{~km}$ west of the suture, where biotite ages are more than $50 \mathrm{~m}$.y. younger than coexisting hornblende, but slightly older than ages on hornblende $7 \mathrm{~km}$ east of the zone. The steep decrease in biotite ages occurs about $12 \mathrm{~km}$ west of the suture, but some hornblende analyses still yield Early Cretaceous ages only $2 \mathrm{~km}$ from the suture.
Farther west in the WSD terrane the two minerals are nearly concordant at about $140 \mathrm{Ma}$, reflecting slow cooling or only minor thermal disturbance. Because of the abrupt bend in the WISZ near Weippe, overlap of the Kooskia profile with the northeast-trending Weippe profile in the area west of the suture results in complexity related to the plutonism of 66 to $62 \mathrm{Ma}$. East of the WISZ, younger plutonism of the Bitterroot lobe of the Idaho Batholith (Criss and Fleck, 1987) strongly affects biotite ages, but coexisting hornblende yields ages as high as $74 \mathrm{Ma}$, similar to ages for highly deformed rocks within the suture zone near Orofino. These results suggest that plutons immediately east of the suture, many of which are also highly deformed, were emplaced during or cooled shortly after the last major tectonism in the zone. Suture zone deformation may be as young as 78 to $74 \mathrm{Ma}$ in the Kooskia area.

\section{South Fork Clearwater River (SFCR)}

As noted above, studies along the South Fork of the Clearwater River have been the basis for characterizing geochemical trends across the WISZ (Fleck and Criss, 1985; Fleck, 1990). Age patterns are also well documented along the SFCR, but the age/distance trends of the WSD terranes are less

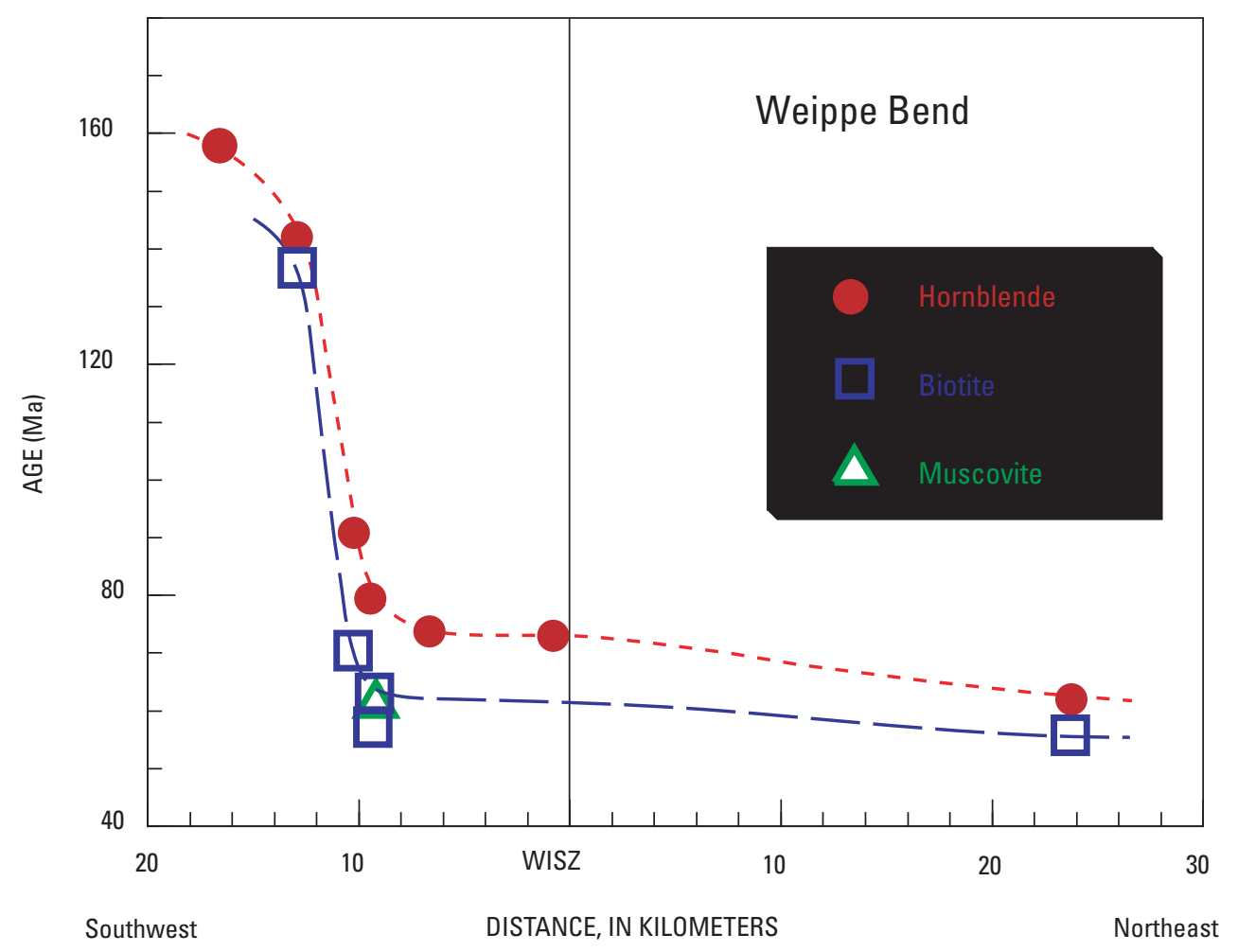

Figure 11. Profile of $\mathrm{K}-\mathrm{Ar}$ and ${ }^{40} \mathrm{Ar} /{ }^{39} \mathrm{Ar}$ ages of hornblende, biotite, and muscovite from plutonic rocks trending southwest to northeast approximately through Weippe, Idaho (see fig 1). This profile crosses the western Idaho suture zone (WISZ) in the area of its $110^{\circ}$ bend, concordant with similar changes in trends of compressional structures in the adjacent rocks. 


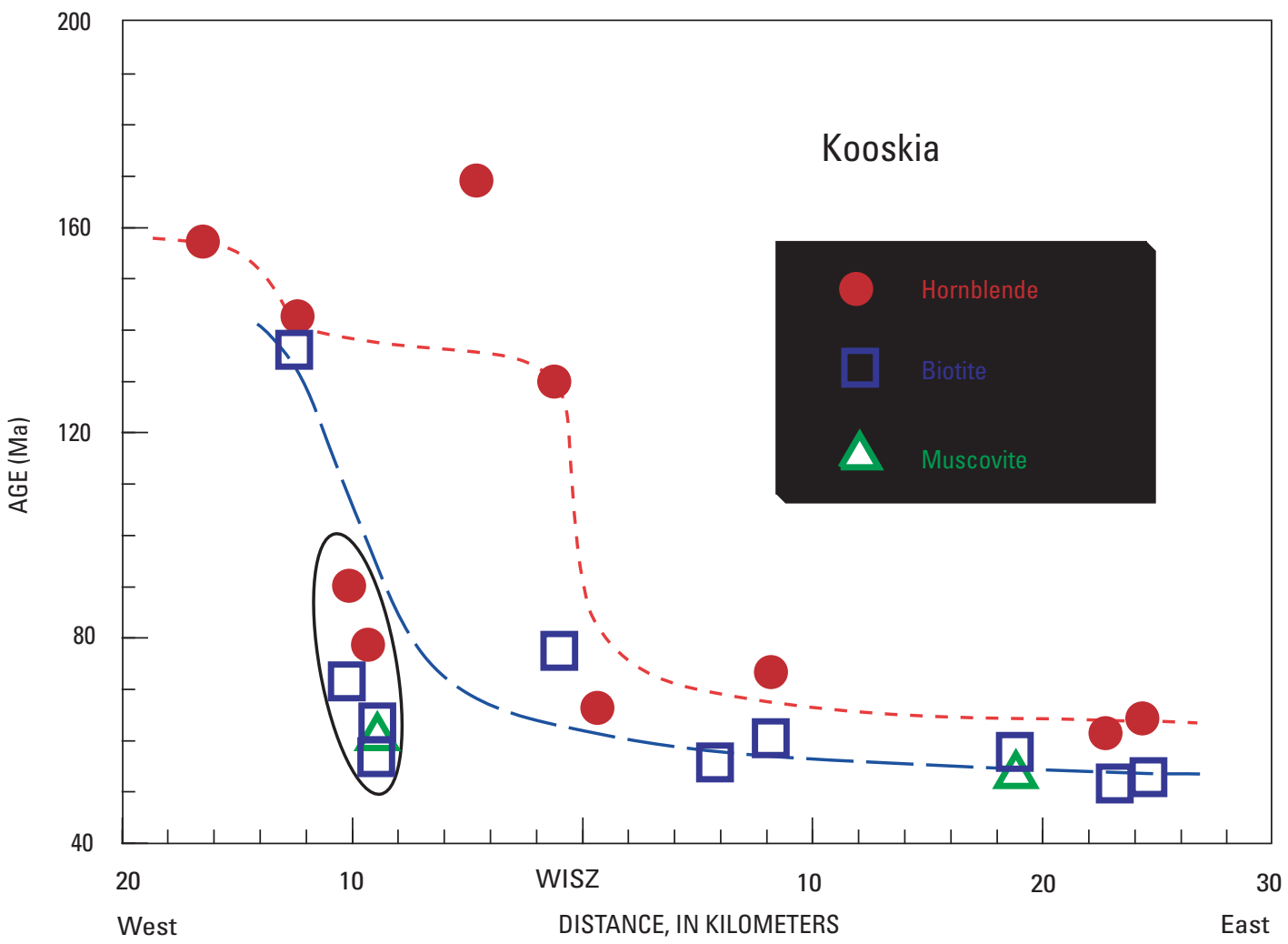

Figure 12. Profile of K-Ar and ${ }^{40} \mathrm{Ar} /{ }^{39} \mathrm{Ar}$ ages of plutonic rocks centered approximately on Kooskia, Idaho (see fig.1). Because of the bend in the suture zone, this profile significantly overlaps the Weippe age profile (fig. 11) south and west of the zone. This results in a duplication of a group of young ages, probably related to Early Tertiary plutons north of Weippe. That group of ages (enclosed by a solid line) was omitted from the trendlines of the Kooskia profile.

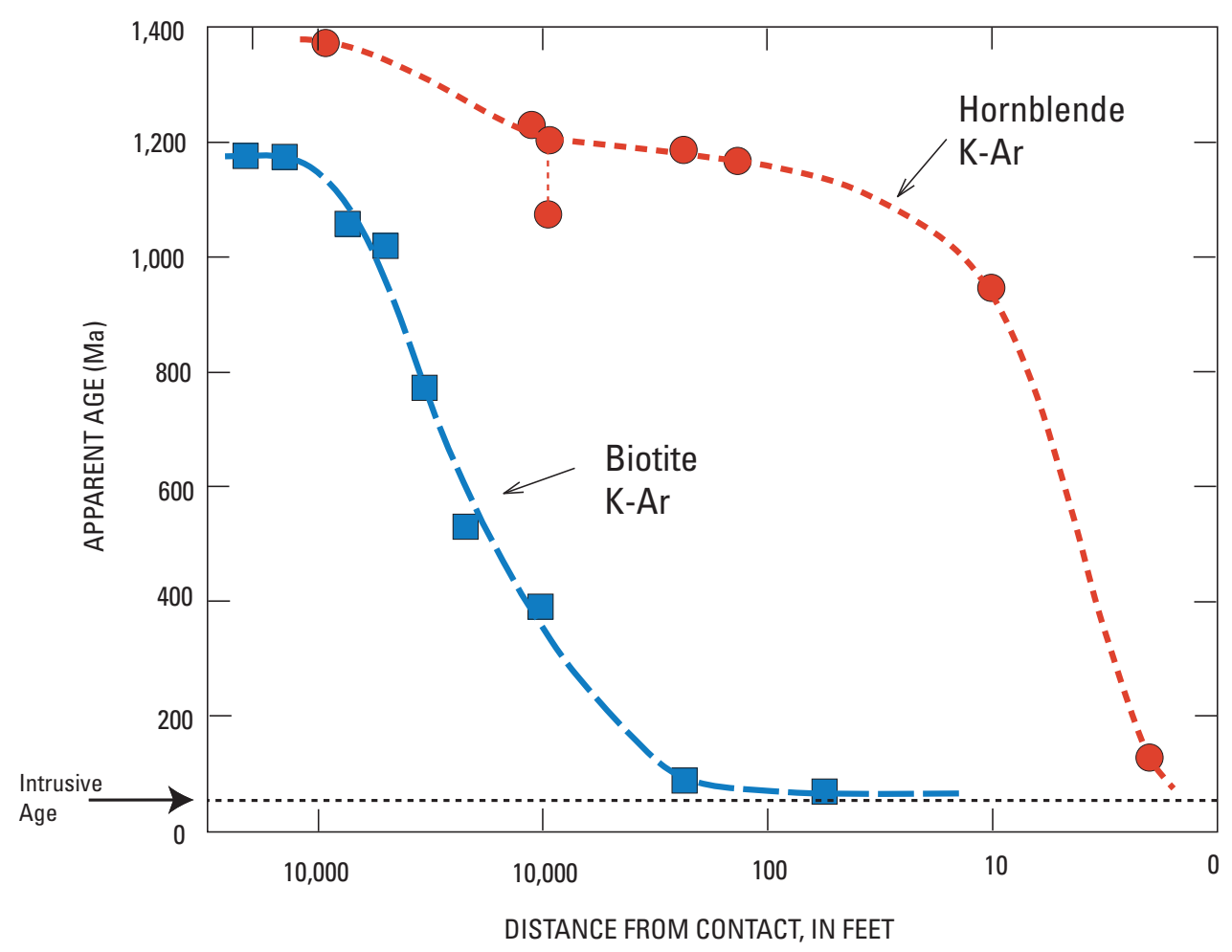

Figure 13. Variation diagram of apparent age versus distance from a plutonic contact (after Hart, 1964). Note that the greatest age discordance occurs at distances where the rate of increase in hornblende ages toward their true age decreases sharply, yet biotite ages are still near the age of the disturbing event (about 100 feet in this example). As shown in figure 9 , this point would be between about 2 and 8 kilometers west (or south) of the western Idaho suture zone (WISZ), where hornblende ages of 170- to 140-Ma plutons of the accreted terranes approach their true ages, but biotite ages of these bodies reflect the Late Cretaceous thermal and tectonic events associated with the WISZ. 
well defined because flows of Columbia River basalt cover the Jurassic and Early Cretaceous plutons west of the suture. Late Cretaceous plutons dominate both terranes, and concordant or nearly concordant ages on biotite and muscovite decrease smoothly from about $87 \mathrm{Ma}$ west of the WISZ to about $70 \mathrm{Ma}$ $22 \mathrm{~km}$ east of it (fig. 14). Highly deformed granodiorite in the suture zone at Mill Creek (807-28H, Criss and Fleck, 1987) yields a Rb-Sr muscovite and whole-rock age of $85.7 \mathrm{Ma}$, indicating cooling below about $500^{\circ} \pm 50^{\circ} \mathrm{C}$ (Jäger and others, 1967 ; Hunziker and others, 1992). The K-Ar age of this muscovite, however, is concordant with coexisting biotite at $76.7 \mathrm{Ma}$ (fig. 14), indicating a cooling rate of about $20^{\circ}$ to $25^{\circ}$ per m.y. Only $700 \mathrm{~m}$ away, tonalite yields a K-Ar age on biotite of $75.8 \mathrm{Ma}$, whereas coexisting hornblende, with a closure temperature of about $530^{\circ} \pm 40^{\circ} \mathrm{C}$ (Harrison, 1981), yields a ${ }^{40} \mathrm{Ar} /{ }^{39} \mathrm{Ar}$ plateau age of $80.8 \pm 0.4 \mathrm{Ma}$ (Criss and Fleck, 1987). The indicated cooling rate for this pluton would be $45^{\circ}$ to $50^{\circ}$ per m.y. or twice that calculated for the granodiorite. The indicated difference in cooling rates for adjacent plutons and the concordance of the micas suggests substantial differential movements within the suture zone, with completion and cooling at about 77 to 76 Ma. Biotite-muscovite age differences increase with distance to the east of these suture zone rocks, indicating slower uplift rates away from the WISZ, similar to those observed in the central part of the Idaho batholith (Criss and Fleck, 1987).

\section{Slate Creek}

The Ar age profile for the Slate Creek area (fig. 15) suffers from the scarcity of plutonic rocks to delineate age patterns within the WSD terranes. Lund and Snee (1988) and Snee and others (1995) report apparent ages for hornblende from metamorphosed supracrustal rocks of the Riggins Group 12 to 15 $\mathrm{km}$ west of the suture of about $109 \mathrm{Ma}$, decreasing to 95 to 90 Ma near the zone. These data have not been included in the age profile, which has been restricted to plutonic rocks. A small, highly deformed pluton $2 \mathrm{~km}$ west of the suture, however, yields reversely discordant biotite and hornblende ages at about $80 \mathrm{Ma}$, significantly less than reported for the supracrustal metamorphic rocks. Without better control of depth relations between the plutonic and supracrustal samples, their ages may not be compared reliably in the same age profile. We conclude that plutonic rocks in and near the WISZ in the Slate Creek area reached temperatures of $500^{\circ}$ to $300^{\circ} \mathrm{C}$ at about 84 to $80 \mathrm{Ma}$ and ages were not significantly affected subsequently. Suturing clearly occurred

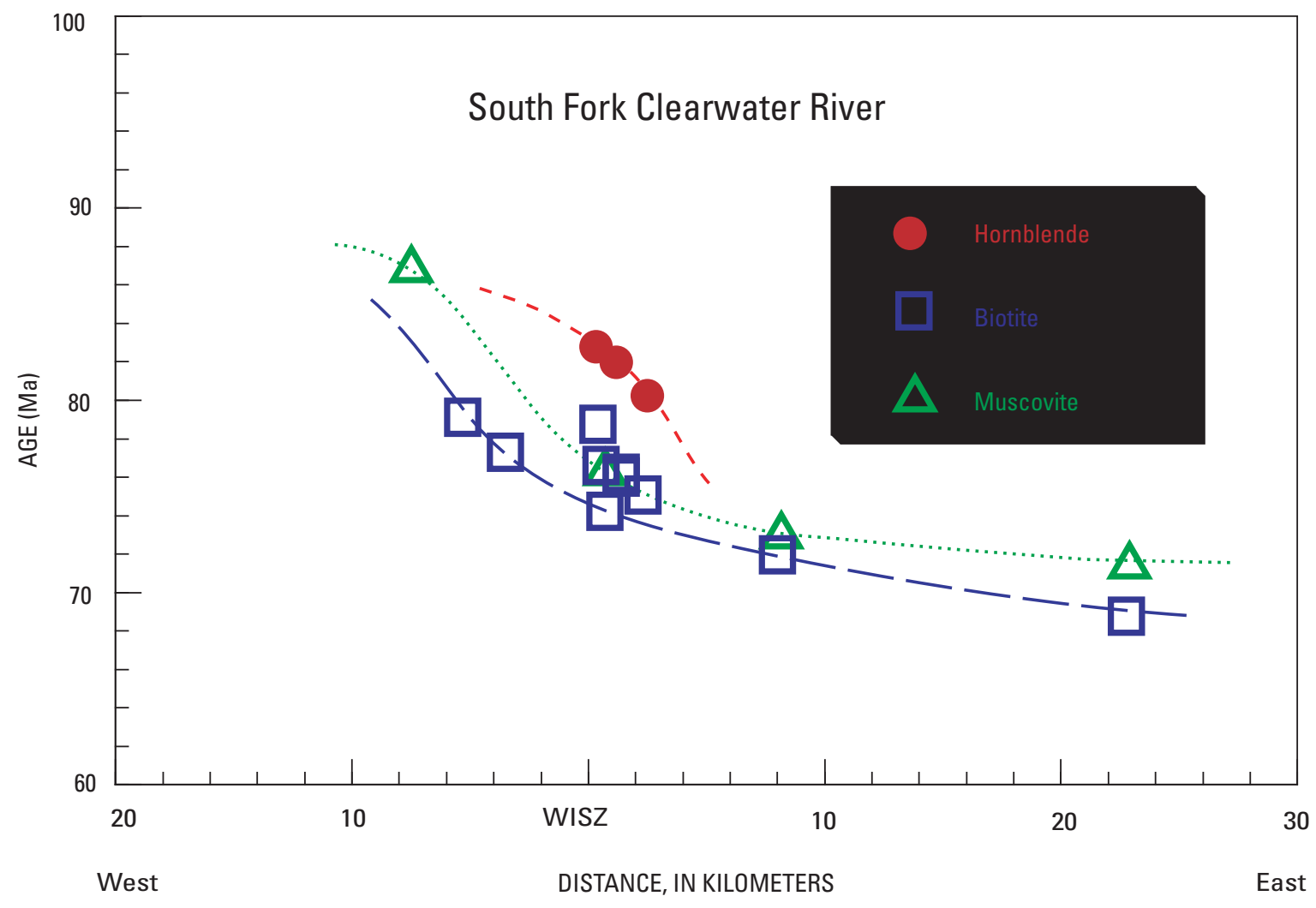

Figure 14. Profile of $\mathrm{K}-\mathrm{Ar}$ and ${ }^{40} \mathrm{Ar} /{ }^{39} \mathrm{Ar}$ ages of plutonic rocks centered approximately on the South Fork of the Clearwater River (SFCR), Idaho (see fig 1). WISZ, western Idaho suture zone. 
well before that time, and deep-seated, mildly deformed, epidote-bearing tonalite was emplaced $2 \mathrm{~km}$ east of the suture at about $84 \mathrm{Ma}$ (Lund and Snee, 1988). The epidote-bearing pluton also yields a biotite age of $82 \mathrm{Ma}$ (Criss and Fleck,1987), documenting the rapid cooling of the body. These ages support a model of rapid vertical uplift of the cratonal terranes such as discussed by Lund and Snee (1988).

\section{Salmon River}

As in the Slate Creek profile, no early plutons of the WSD terranes were revealed by Ar geochronology of rocks along the Salmon River. Results of $\mathrm{K}-\mathrm{Ar}$ and ${ }^{40} \mathrm{Ar}{ }^{39} \mathrm{Ar}$ studies along the Salmon River east of Riggins, Idaho, reveal subparallel biotite and hornblende age/distance variations within the Precambrian terrane that extend westward into the WSD terranes (fig. 16). Apparent ages of hornblende average 4 to 5 m.y. older than those of coexisting biotite, with muscovite ages equal to or slightly less than those on biotite. The approximately linear west-to-east decrease in mica ages suggests up-on-the-east tilting, although this could occur as small, sequential vertical uplifts as suggested by Lund and Snee (1988, fig. 11). Suture zone plutons, generally strongly foliated and planar bodies, were probably emplaced prior to about $85 \mathrm{Ma}$, as indicated by ages of hornblende from deformed tonalites within the suture zone. Discordant ${ }^{40} \mathrm{Ar} /{ }^{39} \mathrm{Ar}$ incremental-heating spectra, however, indicate disturbance of Ar isotopes, possibly including modest amounts of extraneous ${ }^{40} \mathrm{Ar}$. Accepting an age of $85 \mathrm{Ma}$ for the deformed plutons cooling below about $500^{\circ} \mathrm{C}$, major deformation probably ceased between 85 and $80 \mathrm{Ma}$.

\section{Granite Mountain}

Older plutons in the Granite Mountain area, located about $25 \mathrm{~km}$ northwest of Mc Call, Idaho, define a typical pattern of argon loss. Studied by Manduca and others (1992, 1993), the Hazard Creek complex represents early postsuturing emplacement of magmas along the WISZ. Manduca and others (1993) report a U-Pb zircon age of $118 \mathrm{Ma}$ for this unit, which yields Ar ages of about 100 Ma on hornblende, but only 88 to $82 \mathrm{Ma}$ on coexisting biotite. The age profile (fig. 17) has the characteristic sigmoidal pattern expected from Ar loss from phases with

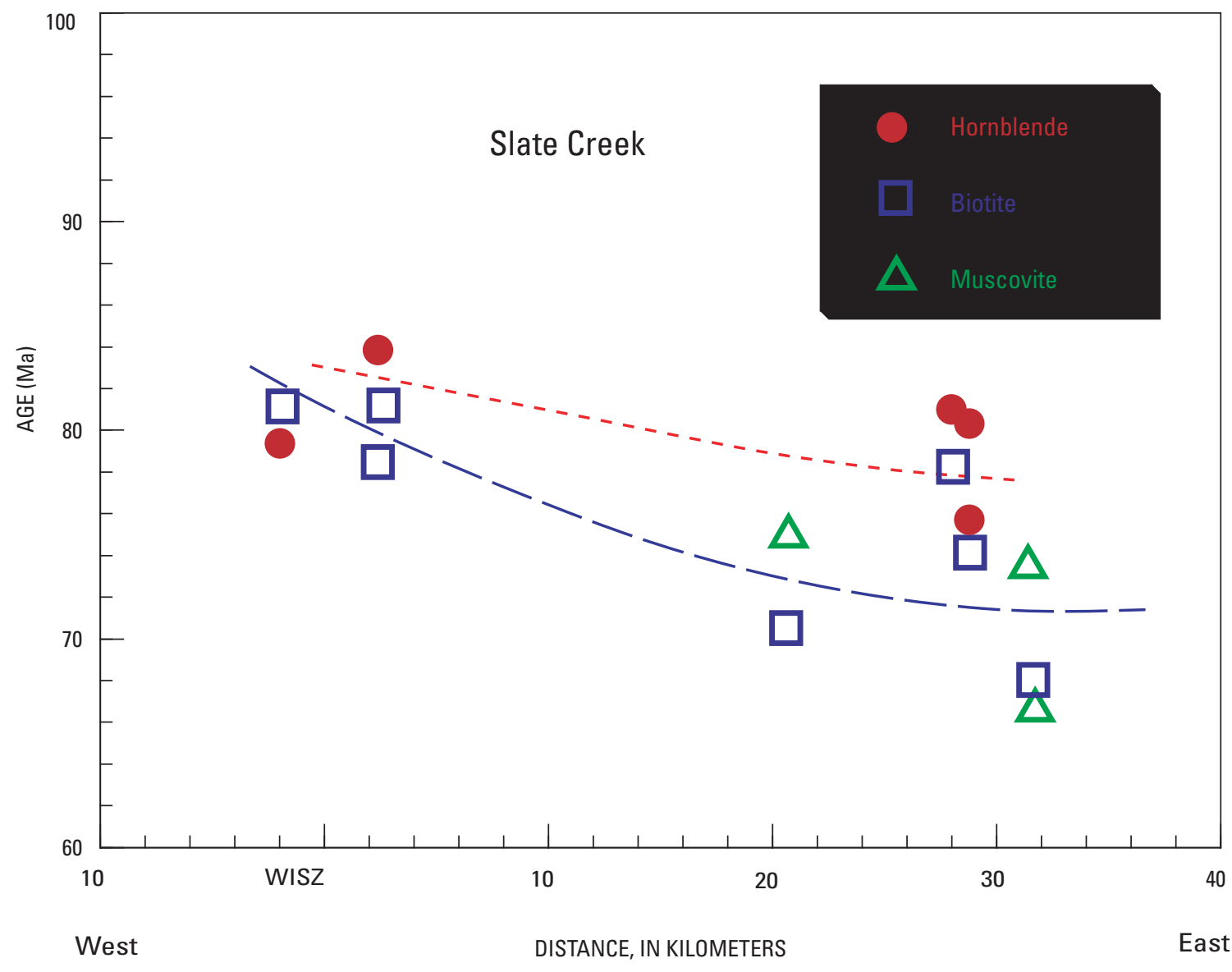

Figure 15. Profile of $\mathrm{K}-\mathrm{Ar}$ and ${ }^{40} \mathrm{Ar} /{ }^{39} \mathrm{Ar}$ ages of plutonic rocks centered approximately on Slate Creek (see fig 1). WISZ, western Idaho suture zone. 


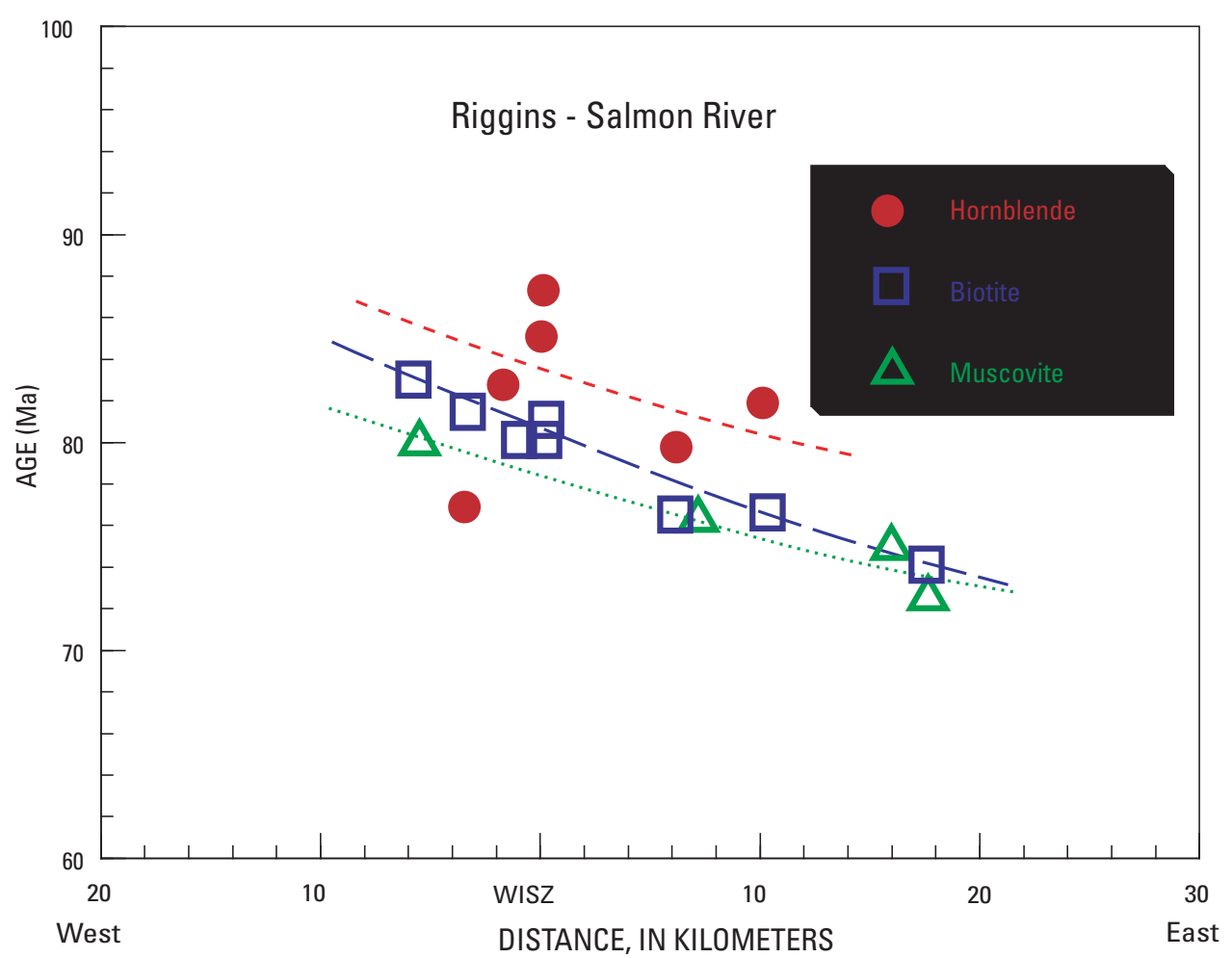

Figure 16. Profile of $\mathrm{K}-\mathrm{Ar}$ and ${ }^{40} \mathrm{Ar} /{ }^{39} \mathrm{Ar}$ ages of plutonic rocks centered approximately on the Salmon River at Riggins, Idaho (see fig 1). WISZ, western Idaho suture zone.

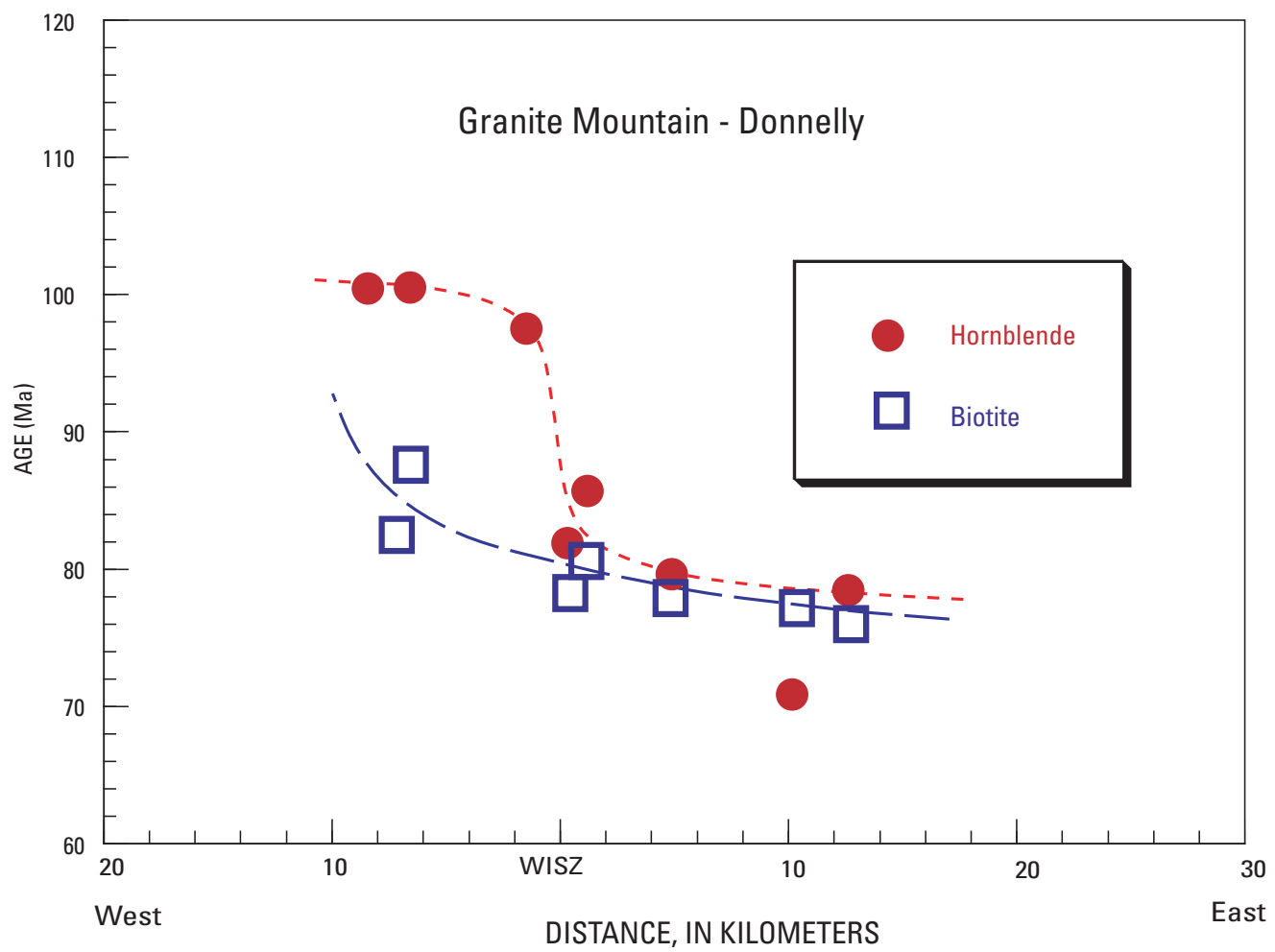

Figure 17. Profile of $\mathrm{K}-\mathrm{Ar}$ and ${ }^{40} \mathrm{Ar} /{ }^{39} \mathrm{Ar}$ ages of plutonic rocks centered approximately on Granite Mountain north of McCall, Idaho (see fig 1). WISZ, western Idaho suture zone. 
different closure temperatures (fig. 13; Hart, 1964). The steep decrease in the hornblende ages occurs between 1 and $2 \mathrm{~km}$ west of the suture, whereas that for biotite is not well defined, but must occur more than $8 \mathrm{~km}$ west of the zone. This defines a discordance of approximately 18 to $20 \mathrm{~m}$.y. immediately west of the suture zone. Ages east of the suture continue to decline, as might be expected from tilting or closely spaced block uplift. However, concordant or nearly concordant mineral pairs raise the possibility of eastward migrating intrusion, with progressively younger plutons and rapid uplift. A U-Pb age of about 90 Ma is reported by Manduca and others (1993) for these rocks, indicating a discordance of about $10 \mathrm{~m}$.y. with hornblende. A discordance of this magnitude compared to the near concordance for Ar ages favors a progressive uplift over any model of multiple intrusion. Apparent ages within the suture zone are consistent with cessation of deformation in the period 85 to 80 Ma, similar to results to the north along the Salmon River.

\section{Cascade}

The age profile across the WISZ in the area of Cascade, Idaho, is the southernmost for which sufficient data are available (fig. 18). Results from Armstrong (1975) and from tables 3 and 4 reflect significant argon loss from biotite $6 \mathrm{~km}$ west of the suture. Hornblende ages may also be affected, but no other age control is available. Compared to the U-Pb zircon age of 118 Ma reported by Manduca and others (1993) for the Hazard Creek complex, however, the 120-Ma K-Ar age for hornblende is quite consistent. Plutons east of the WISZ also have discordant biotite and hornblende ages, but in contrast to the pattern observed near Orofino, the discordance continues across the zone, approaching zero about $13 \mathrm{~km}$ to the east. This pattern suggests that 92-Ma plutons, similar to the Payette River tonalite of Manduca and others (1992, 1993), occupy the suture zone, which shows little effect on hornblende K-Ar ages. Results are more consistent with thermal disturbance of the argon systems by younger plutons of the Idaho Batholith to the east and may be unrelated to movement on the WISZ. The hornblende ages suggest that deformation along the WISZ probably has not been significant after about $92 \mathrm{Ma}$. Considering primary movement on the WISZ to have been complete by $92 \mathrm{Ma}$, biotite ages in this area must relate to the pattern of regional cooling following emplacement of the western margin of the Atlanta lobe of the Idaho Batholith. This same, smooth pattern is reflected by biotite along the western edges of the Bitterroot lobe (Criss and Fleck, 1987) and the Sierra Nevada Batholith (Evernden and Kistler, 1970), whereas hornblende values define a series of plutonic episodes in each of these areas. Although additional hornblende ages within the actual suture zone near Cascade could clarify the timing of deformation, a minimum age of about $92 \mathrm{Ma}$ is indicated for hornblende recrystallization and/or cooling in this area.

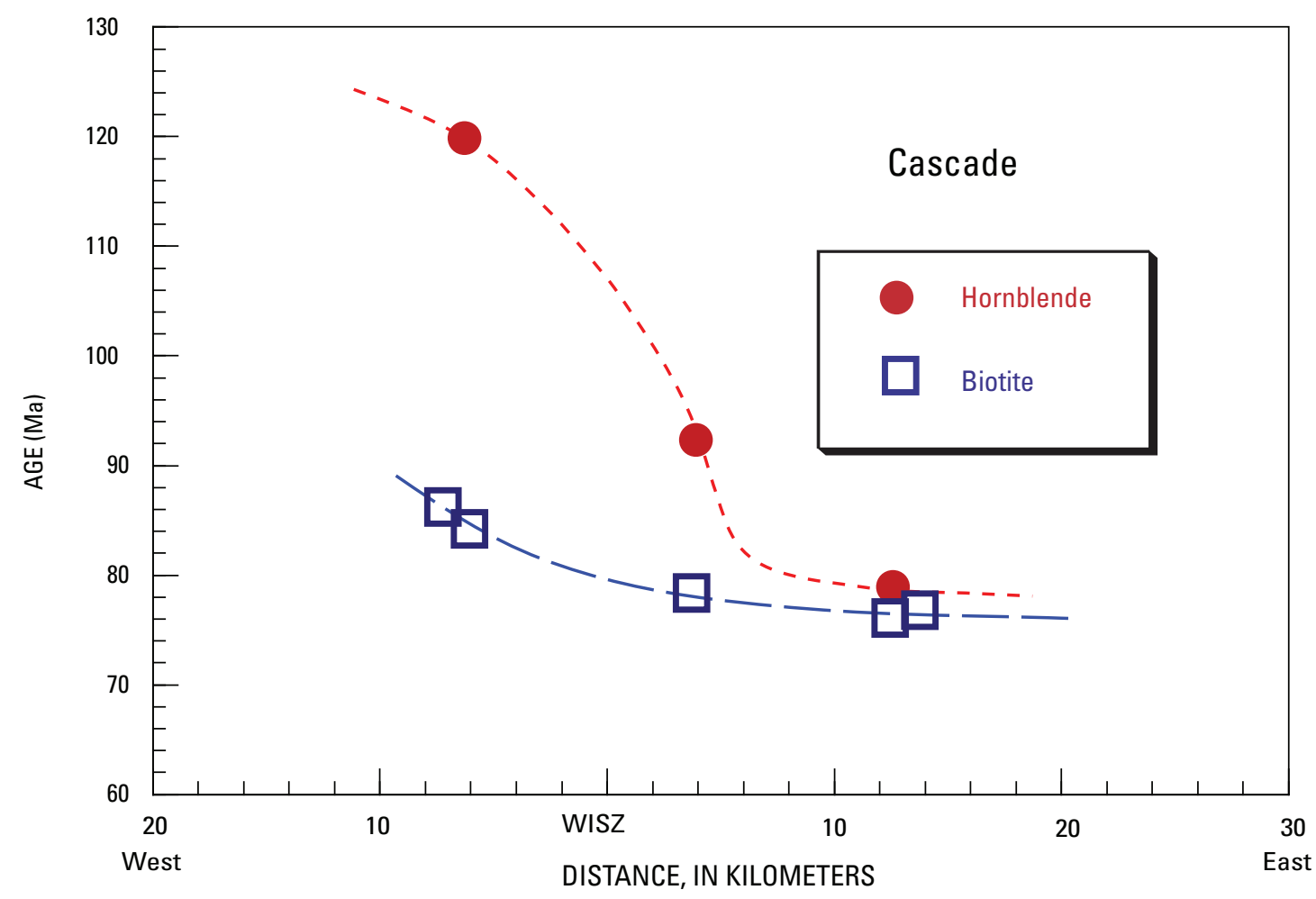

Figure 18. Profile of $\mathrm{K}-\mathrm{Ar}$ and ${ }^{40} \mathrm{Ar} /{ }^{39} \mathrm{Ar}$ ages of plutonic rocks centered approximately on Cascade, Idaho (see fig 1). WISZ, western Idaho suture zone. 


\section{Discussion and Conclusions}

Chemical and isotopic results from plutons of the Wallowa, Seven Devils, and related accreted terranes, of the Belt, Yellowjacket, and related Proterozoic (cratonal) terranes, and of plutons within the western Idaho suture zone that forms the boundary between them confirm the significance of the WISZ as a major crustal-scale feature, marking the location of the Mesozoic continental margin of North America. As demonstrated by Fleck and Criss (1985) and Fleck (1990), plutons emplaced into and deformed by the suture zone represent mixtures of components derived from sources in both the accreted and cratonal lithospheres. Location with respect to the WISZ strongly controls magma chemistry and isotopic composition, in effect proportioning the broad range of lithospheric mantle, lower crustal, and upper crustal components incorporated into the melt from each of the two lithospheres. These characteristics may be used in turn to locate the accretionary boundary, even where it has been engulfed completely by younger plutons. Suture-zone magmas are chemically unique, characterized by high $\mathrm{Sr}, \mathrm{Nb}, \mathrm{Nb} / \mathrm{Y}$, and $\mathrm{Nd} / \mathrm{Y}$, low $\mathrm{Rb} / \mathrm{Nb}$ ratios, and $\mathrm{Sr}$ and $\mathrm{Nd}$ isotopic compositions near "bulk Earth" values. The latter translate into initial ${ }^{87} \mathrm{Sr} /{ }^{86} \mathrm{Sr}$ ratios averaging about 0.7045 and $\varepsilon_{\mathrm{Nd}}(\mathrm{t})$ values between about -5 and +2 for the lithospheres involved in western Idaho.

Although argon geochronology restricted the timing of accretion of the WSD terranes to North America to the interval 135 to $75 \mathrm{Ma}$ in Idaho (Fleck and Criss, 1985; Criss and Fleck, 1987), detailed understanding of the timing of suturing requires use of techniques such as $\mathrm{U}-\mathrm{Pb}$ zircon studies to establish events such as emplacement age. Further progress will require careful geologic mapping of the suture zone and additional U-Pb, Sm-Nd, or Rb-Sr geochronology. U-Pb zircon ages reported by Manduca and others (1993) and Lund and Snee (1988) provide critical emplacement ages of units within and adjacent to the suture zone, but these represent only a few plutons. Sm-Nd ages on garnet reported by Getty and others (1993) suggest a 128-Ma age for peak metamorphism of the WSD terranes following initial accretion. Because K-Ar and ${ }^{40} \mathrm{Ar} /{ }^{39} \mathrm{Ar}$ apparent ages are affected by plutonic and tectonic events, however, these ages may provide useful information through patterns of age discordance revealed. Minerals with different "closure temperatures" (Dodson, 1973, 1979), yield different apparent ages when subjected to prolonged cooling or subsequent thermal events. Strain and recrystallization may disturb or "reset" argon geochronometers independent of closure temperatures, yielding concordant or nearly concordant ages that approach the time of disturbance, not the age of the rock. Generally accepted closure temperatures for biotite and hornblende at geologically average cooling rates are $280 \pm 40^{\circ} \mathrm{C}$ (Harrison and McDougall, 1980) and $530 \pm 40^{\circ} \mathrm{C}$ (Harrison, 1981), respectively. In the current study, age profiles across the suture zone have demonstrated that the suture remained the locus of continued thermal and tectonic activity long after initial accretion. Emplacement ages of preaccretion- ary plutons in the accreted terranes, which extend into and are deformed by the suture zone, represent a maximum age for accretion. This places a limiting age for accretion at about 135 Ma (Criss and Fleck, 1987).

Patterns of biotite and hornblende ages from rocks of the accreted terranes (WSD) exhibit the greatest discordance at distances of 2 to $10 \mathrm{~km}$ west of the suture zone (figs. 9, 10, $12,17,18)$. Near Orofino, hornblende ages decrease abruptly from about $135 \mathrm{Ma}$ within the accreted terranes to a minimum of about $74 \mathrm{Ma}$ within the WISZ. Discordance between hornblende and biotite ages is greatest within the 5- to $10-\mathrm{km}$ zone of the accreted terranes adjacent to the WISZ (see, for example, fig. 19 of Criss and Fleck, 1987). The amount of discordance is variable, however, probably because of a combination of differing levels of exposure, uplift rates, thermal effects from younger plutons, and deformation. The highly strained rocks of the suture zone yield the least discordant mineral pairs, but discordance remains at about 2 to $8 \mathrm{~m}$.y. This is consistent with immediate retention of Ar by hornblende following recrystallization at temperatures below its closure temperature, but with more prolonged cooling for biotite closure. Hornblende ages within the WISZ probably establish a reliable age for cessation of deformation, especially of rapid vertical translation within the zone (fig. 10). Hornblende ages within the zone from Orofino to Kooskia indicate a minimum age for closure of about 74 Ma (figs. 10-12). At the SFCR profile (fig. 14) biotite and muscovite yield nearly concordant $\mathrm{K}$-Ar and ${ }^{40} \mathrm{Ar} /{ }^{39} \mathrm{Ar}$ ages at about $76 \mathrm{Ma}$, whereas hornblende ages average about $82 \mathrm{Ma}$. Results for rocks at Slate Creek yield a similar age for hornblende closure (fig. 15), although older ages obtained from hornblende in plutonic xenoliths have been used by Lund and Snee (1988) and Snee and others (1995) to establish an age of about $90 \mathrm{Ma}$. Uncertainty about complete resetting and loss of protolith Ar from these xenoliths, however, suggests that these ages represent maximums for recrystallization within the WISZ. Hornblende ages from deformed tonalite within the WISZ along the Salmon River indicate deformation continued there until about $85 \mathrm{Ma}$ (fig. 16). Manduca and others (1993) report a zircon U-Pb age of about $90 \mathrm{Ma}$ for a sample of tonalite roughly $12 \mathrm{~km}$ east of the WISZ in the Granite Mountain area. Although a 90-Ma age may reflect cessation of deformation, this tonalite is well outside the zone of highest strain. Evidence from hornblende within the deformed rocks suggests deformation may have continued until 85-82 Ma in this area (fig. 17). None of the samples around Cascade occurs within the WISZ, but tonalite less than $4 \mathrm{~km}$ east of the suture yields a hornblende $\mathrm{K}-\mathrm{Ar}$ age of $92 \mathrm{Ma}$, representing cooling of that body below about $530^{\circ} \mathrm{C}$ and consistent with a maximum age for significant deformation of the pluton. A biotite age for this sample is highly discordant (fig. 18), consistent with thermal effects from younger intrusions east of that location.

Ages for hornblende from deformed rocks within the western Idaho suture zone appear to decrease from south to north, ranging from as early as $92 \mathrm{Ma}$ in the area of Cascade 
to $74 \mathrm{Ma}$ or less at Orofino and the Weippe bend (fig. 19). We suggest that these ages represent the approximate end of deformation within a given section of the WISZ and the time when recrystallization ceased and temperatures were below about $530^{\circ} \mathrm{C}$. The suture zone was clearly the locus of greatest differential movement within the region deformed during collision and subsequent structural adjustment. This is documented by the occurrence of flaser gneisses, syntectonic plutons, and magmatic epidote- and garnet-bearing tonalites and trondhjemites (see, for example, Zen and Hammarstrom, 1984; Strayer and others, 1989; Selverstone and others, 1992), as well as by isotopic evidence that the zone coincides with the terrane boundary. The progression of hornblende ages along the suture suggests that this deformation did not occur simultaneously along the length of the WISZ, but migrated from south to north. We suggest that the differences observed in apparent ages of suture-zone rocks from Cascade to near Weippe and Orofino (fig. 19) are related to the timing of rapid uplift of cratonal terranes and emplacement of younger plutons subsequent to accretion. Whether it is the cause or the effect, the ages of the Idaho Batholith decrease from the Atlanta lobe in the south to the Bitterroot lobe in the north, in a manner similar to ages of suture-zone hornblendes. Magmatism in the southern (Atlanta) lobe ranges from 120 to about $70 \mathrm{Ma}$, whereas most of the northern (Bitterroot) lobe was emplaced from about 80 to $55 \mathrm{Ma}$ (Armstrong and others, 1977; Criss and others, 1982; Criss and Fleck, 1987; Lewis and others, 1987; Snee and others, 1995). If deformation along the WISZ was related to extreme vertical movements such as necessary to bring magmatic-epidote-bearing tonalites to their present positions and this rapid rise of cratonal terranes was related to emplacement of batholithic-scale silicic magmas, much of

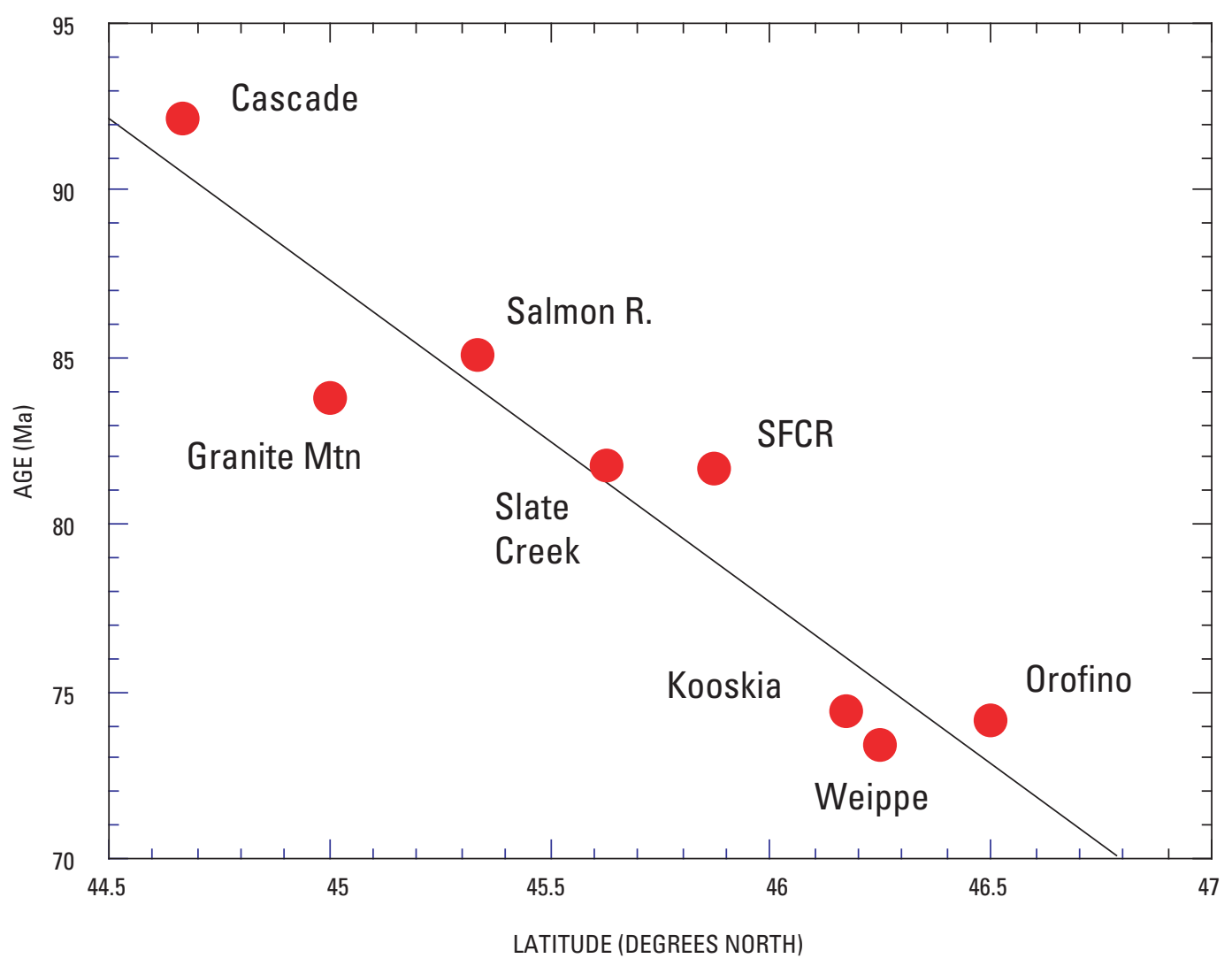

Figure 19. Summary of Ar closure ages for hornblende, calculated as the average age of hornblende at the western Idaho suture zone (WISZ) for each of the profiles shown in figures 10-18. Generally, this is the average of available hornblende ages for samples within $2 \mathrm{~km}$ of the suture zone. Geologic variability is difficult to determine for small numbers of samples, although reproducibility of the ages is commonly between 1 and 2 m.y. at one standard deviation (table 3). These data indicate that the time of cooling or recrystallization of hornblende in the suture zone varied along the zone, favoring a progression of precipitous vertical movements over synchronous lateral displacement along the WISZ. The regression line shown is for reference only and not intended as an estimate of the timing at a given latitude. Practically, there are 3, or perhaps 4, groups of closure ages along the suture zone, but the age difference between the northern and southern groups is easily significant at any reasonable level of confidence, confirming the validity of the general trend in age. 
the deformation along the WISZ may be a consequence of the south to north migration of Idaho batholith emplacement. The decrease in apparent ages of hornblende within the WISZ from more than $90 \mathrm{Ma}$ in the south to less than $75 \mathrm{Ma}$ near Weippe and Orofino supports this model. If deformation were not synchronous along the WISZ but progressed from south to north analogous to batholith emplacement, then models of synchronous, transcurrent shearing along the WISZ may be precluded. Additionally, the coincidence of the WISZ and the terrane boundary may be the result of reactivation of the initial suture zone, as emplacement of batholithic-scale silicic magmas within the western margin of the cratonal terranes resulted in the precipitous rise of these terranes.

\section{References Cited}

Armstrong, R.L., 1974, Geochronometry of the Eocene volcanic-plutonic episode in Idaho: Northwest Geology, v. 3, p. 1-15.

Armstrong, R.L., 1975, The geochronometry of Idaho: Isochron/West, no.14, 50 p.

Armstrong, R.L., 1976, The geochronometry of Idaho (part 2): Isochron/West, no.15, p. 1-33.

Armstrong, R.L., Taubeneck, W.H., and Hales, P.O., 1977, $\mathrm{Rb}-\mathrm{Sr}$ and $\mathrm{K}-\mathrm{Ar}$ geochronometry of Mesozoic granitic rocks and their Sr isotopic composition, Oregon, Washington, and Idaho: Geological Society of America Bulletin, v. 88, p. 397-411.

Ave Lallemant, H.G., Phelps, D.W., and Sutter, J.F., 1980, ${ }^{40} \mathrm{Ar} /{ }^{39} \mathrm{Ar}$ ages of some pre-Tertiary plutonic and metamorphic rocks of eastern Oregon and their tectonic relationships: Geology, v. 8, p. 371-374.

Ave Lallemant, H.G., Schmidt, W.J., and Kraft, J.L., 1985, Major Late Triassic strike-slip displacement in the Seven Devils terrane, Oregon and Idaho; a result of left-oblique plate convergence?: Tectonophysics, v. 19, p. 299-328.

Beaulieu, J.D., 1972, Geologic formations of eastern Oregon (east of longitude $121^{\circ} 30^{\prime}$ ): Oregon Dept. of Geology and Mineral Industries, v. 73, 80 p.

Bonnichsen, Bill, 1987, Pre-Cenozoic geology of the West Mountain-Council Mountain-New Meadows area, westcentral Idaho, in Vallier, T.L., and Brooks, H.C., eds., The Idaho batholith and its border zone: U. S. Geological Survey Professional Paper 1436, p. 151-170.

Brooks, H.C., and Vallier, T.L., 1978, Mesozoic rocks and tectonic evolution of eastern Oregon and western Idaho, in Howell, D.G., and MacDougall, K.A., eds., Mesozoic Paleogeography of the Western United States: Society of Economic Paleontologists and Mineralogists, Pacific Coast
Paleogeography Symposium, 2d, p. 133-146.

Carlson, R.W., 1984, Isotopic constraints on Columbia River flood basalt genesis and the nature of the subcontinental mantle: Geochimica et Cosmochimica Acta, v. 48, p. 23572372 .

Carlson, R.W., Lugmair, G.W., and Macdougall, J.D., 1981, Columbia River volcanism; the question of mantle heterogeneity or crustal contamination: Geochimica et Cosmochimica Acta, v. 45, p. 2483-2499.

Criss, R.E., and Fleck, R.J., 1987, Petrogenesis, geochronology, and hydrothermal systems of the northern Idaho batholith and adjacent areas based on ${ }^{18} \mathrm{O} /{ }^{16} \mathrm{O}, \mathrm{D} / \mathrm{H},{ }^{87} \mathrm{Sr} /{ }^{86} \mathrm{Sr}$, $\mathrm{K}-\mathrm{Ar}$, and ${ }^{40} \mathrm{Ar} /{ }^{39} \mathrm{Ar}$ studies, in Vallier, T.L., and Brooks, H.C., eds., The Idaho batholith and its border zone: U. S. Geological Survey Professional Paper 1436, p. 95-137.

Criss, R.E., Lanphere, M.A., and Taylor, H.P., Jr., 1982, Effects of regional uplift, deformation, and meteoric-hydrothermal metamorphism on K-Ar ages of biotites in the southern half of the Idaho batholith: Journal Geophysical Research, v. 87, no.B8, p. 7029-7046.

DePaolo, D.J., and Wasserburg, G.J., 1976, Nd isotopic variations and petrogenetic models: Geophysical Research Letters, v. 3, no.5, p. 249-252.

DePaolo, D.J., and Wasserburg, G.J., 1979, Petrogenetic mixing models and Nd-Sr isotopic patterns: Geochimica et Cosmochimica Acta, v. 43, p. 615-627.

Dodson, M.H., 1973, Closure temperature in cooling geochronological and petrological systems: Contributions to Mineralogy and Petrology, v. 40, p. 259-274.

Dodson, M.H., 1979, Theory of cooling ages, in Jäger, E., and Hunziger, J.C., eds., Lectures in isotope geology: Berlin, Springer-Verlag, 329 p.

Evernden, J. F., and Kistler, R.W., 1970, Chronology of emplacement of Mesozoic batholithic complexes in California and western Nevada: U.S. Geological Survey Professional Paper 623, 42 p.

Fleck, R.J., 1990, Neodymium, strontium, and trace element evidence of crustal anatexis and magma mixing in the Idaho batholith, in Anderson, J.L., ed., The nature and origin of Cordilleran magmatism: Boulder, Colorado, Geological Society of America Memoir 174, p. 359-373.

Fleck, R.J., and Criss, R.E., 1985, Strontium and oxygen isotopic variations in Mesozoic and Tertiary plutons of central Idaho: Contributions to Mineralogy and Petrology, v. 90, p. 291-308.

Fleck, R.J., and Criss, R.E., 1988, Location, age, and tectonic significance of the western Idaho suture zone (WISZ) and its relation to the Idaho batholith [abs.]: Geological Society 
of America Abstracts with Programs, v. 20, no. 6, p. 414.

Getty, S.R., Selverstone, J, Wernicke, B.P., Jacobsen, S.B., Aliberti, E., and Lux, D.R., 1993, Sm-Nd dating of multiple garnet growth events in an arc-continent collision zone, northwestern U.S. Cordillera: Contributions to Mineralogy and Petrology, v. 115 , p. 45-57.

Hamilton, W.B., 1963a, Metamorphism in the Riggins region western Idaho: U.S. Geological Survey Professional Paper 436, $95 \mathrm{p}$.

Hamilton, W.B., 1963b, Overlapping of late Mesozoic orogens in western Idaho: Geological Society of America Bulletin, v. 74 , p. $779-788$.

Hamilton, W.B., 1976, Tectonic history of west-central Idaho [abs.]: Geological Society of America Abstracts with Programs, v. 8, p. 378.

Harrison, T.M., 1981, Diffusion of ${ }^{40} \mathrm{Ar}$ in hornblende: Contributions to Mineralogy and Petrology, v. 78, p. 324-331.

Harrison, T.M., and McDougall, I., 1980, Investigations of an intrusive contact, northwest Nelson, New Zealand-I. Thermal, chronological and isotopic constraints: Geochimica et Cosmochimica Acta, v. 44, p. 1985-2003.

Hart, S.R., 1964, The petrology and isotopic mineral age relations of a contact zone in the Front Range, Colorado: Journal of Geology, v. 72, p. 493-525.

Hart, W.K., 1985, Chemical and isotopic evidence for the mixing between depleted and enriched mantle, northwestern U.S.A.: Geochimica et Cosmochimica Acta, v. 49, p. 131-144.

Hietanen, A., 1962, Metasomatic metamorphism in western Clearwater County, Idaho: U.S. Geological Survey Professional Paper 344A, 116 p.

Hietanen, A., 1963a, Metamorphism of the Belt series in the Elk River-Clarkia area, Idaho: U.S. Geological Survey Professional Paper 344-C, 78 p.

Hietanen, A., 1963b, Idaho batholith near Pierce and Bungalow, Clearwater County, Idaho: U.S. Geological Survey Professional Paper 344-D, 42 p.

Hietanen, A., 1967, Scapolite in the Belt Series in the St. JoeClearwater region, Idaho: Geological Society of America Special Paper 86, 56 p.

Hoover, A.L., 1986, Transect across the Salmon River suture, South Fork of the Clearwater River, western Idaho; rare earth element, geochemical, structural and metamorphic study: Corvallis, Oregon State University, Masters thesis, 138 p.

Hunziker, J.C., Desmons, J., and Hurford, A.J., 1992, Thirtytwo years of geochronological work in the central and western Alps; a review on seven maps: Memoires de Geologie (Lausanne), no. 13, 59 p.
Jäger, E., Niggli, E, and Wenk, E., 1967, Rb-Sr Alterbestimmungen an Glimmern der Zentralalpen: Bern, Lieferungen, Kummerly and Frey, Beitrag zur geologischen Karte der Schweiz, NF 134, 67 p.

Jones, D.L., Silberling, N.J., and Hillhouse, J, 1977, Wrangellia - A displaced continental block in northwestern North America: Canadian Journal of Earth Science, v. 14, p. $2565-$ 2577.

Leeman, W.P., and Hawksworth, C.J., 1986, Open magma systems; trace element and isotopic constraints: Journal of Geophysical Research, v. 91, p. 5901-5912.

Lewis, R.S., Kiilsgaard, T.H., Bennett, E.H., and Hall, W.E., 1987, Lithological and chemical characteristics of the central and southeastern part of the southern lobe of the Idaho batholith, in Vallier, T.L., and Brooks, H.C., eds., The Idaho batholith and its border zone: U. S. Geological Survey Professional Paper 1436, p. 171-196.

Lund, K., 1995, Metamorphic and structural development of island-arc rock in the Slate Creek-John Day Creek area, west-central Idaho, in Vallier, T.L., and Brooks, H.C., eds., Geology of the Blue Mountains Region of Oregon, Idaho, and Washington; petrology and tectonic evolution of preTertiary rocks of the Blue Mountains Region: U.S. Geological Survey Professional Paper 1438, p. 517-540.

Lund, K., and Snee, L.W., 1988, Metamorphism, structural development, and age of the continent-island arc juncture in west-central Idaho, in Ernst, W.G., ed., Metamorphism and crustal evolution of the western United States: Englewood Cliffs, New Jersey, Prentice-Hall, p. 296-331.

Manduca, C.A., Silver, L.T., and Taylor, H.P., $1992,{ }^{87} \mathrm{Sr} /{ }^{86} \mathrm{Sr}$ and ${ }^{18} \mathrm{O} /{ }^{16} \mathrm{O}$ isotopic systematics and geochemistry of granitoids plutons across a steeply-dipping boundary between contrasting lithospheric blocks in western Idaho: Contributions to Mineralogy and Petrology, v. 109, p. 355-372.

Manduca, C.A., Kuntz, M.A., and Silver, L.T., 1993, Emplacement and deformational history of the western margin of the Idaho batholith near McCall, Idaho; influence of a major terrane boundary: Geological Society of America Bulletin, v. 105, p. $749-765$.

McCelland, W.C., Tikoff, B., and, Manduca, C.A., 2000, Twophase evolution of accretionary margins; examples from the North American Cordillera: Tectonophysics, v. 326, p. 37-55.

McDowell, F.W., and Kulp, J.L., 1969, Potassium-argon dating of the Idaho batholith: Geological Society of America Bulletin, v. 80, p. 2379-2382.

Mullen, E.D., 1985, Petrologic character of Permian and Triassic greenstones from the mélange terrane of eastern Oregon and their implications for terrane origin: Geology, v. 13, p. 131-134. 
Myers, P.E., 1982, Geology of the Harpster area, Idaho County, Idaho: Idaho Bureau of Mines and Geology Bulletin $25,46 \mathrm{p}$.

Onasch, C M., 1987, Temporal and spatial relations between folding, intrusion, metamorphism, and thrust faulting in the Riggins area, west-central Idaho, in Vallier, T.L., and Brooks, H.C., eds., The Idaho batholith and its border zone, U. S. Geological Survey Professional Paper 1436, p. 139-149.

Pearce, J.A., Harris, N.B.W., and Tindle, A.G., 1984, Trace element discrimination diagrams for the tectonic interpretation of granitic rocks: Journal of Petrology, v. 25, p. 956-983.

Selverstone, J., Wernicke, B.P., and Aliberti, E.A., 1992, Intracontinental subduction and hinged unroofing along the Salmon River suture zone, west central Idaho: Tectonics, v. 11, no. 1, p. 124-144.

Snee, L.W., Lund, K., Sutter, J.F., Balcer, D.E., and Evans, K.V., 1995, An ${ }^{40} \mathrm{Ar} /{ }^{39} \mathrm{Ar}$ chronicle of the tectonic development of the Salmon River suture zone, western Idaho, in Vallier, T.L., and Brooks, H.C., eds., Geology of the Blue Mountains Region of Oregon, Idaho, and Washington: Petrology and Tectonic Evolution of Pre-Tertiary Rocks of the Blue Mountains Region, U.S. Geol. Survey Professional Paper 1438, p. 359-414.

Steiger, R.H., and Jäger, E., 1977, Subcommission on geochronology; convention on the use of decay constants in geo- and cosmochronology: Earth and Planetary Science Letters, v. 36 p. 359-362.

Strayer, L.M., IV, Hyndman, D.W., and Sears, J.W., 1987, Movement direction and displacement estimate in the western Idaho suture zone mylonite; Dworshak Dam/ Orofino area, west central Idaho [abs.]: Geological Society of America Abstracts with Programs, v. 19, no. 7, p. 857.

Strayer, L.M., Sears, J.W., and Hyndman, D.W., 1988, Western Idaho suture zone (I); Evidence for a structural and metamorphic culmination [abs.]: Geological Society of America Abstracts with Programs, v. 20, p. 471.

Strayer, L.M., Hyndman, D.W., Sears, J.W., and Myers, P.E., 1989, Direction and shear sense during suturing of the Seven Devils-Wallowa terrane against North America in western Idaho: Geology, v. 17, p. 1025-1028.

Taubeneck, W.H., 1971, Idaho batholith and its southern extension: Geological Society of America Bulletin, v. 82, p. 1899-1928.
Vallier, T.L., 1974, Preliminary report on the geology of part of the Snake River Canyon: Oregon Dept. Geology and Mineral Industries, Map GMS-6, 28 p.

Vallier, T.L., 1977, The Permian and Triassic Seven Devils Group: U.S. Geological Survey Bulletin 1437, 58 p.

Vallier, T.L., and Brooks, H.C., 1987a, The Idaho batholith and its border zone; a regional perspective, in Vallier, T.L., and Brooks, H.C., eds., The Idaho batholith and its border zone: U.S. Geological Survey Professional Paper 1436, p. 1-7.

Vallier, T.L., and Brooks, H.C., eds., 1987b, The Idaho batholith and its border zone, U.S. Geological Survey Prof. Paper $1436,196 \mathrm{p}$.

Vallier, T.L., and Brooks, H.C., eds., 1995, Geology of the Blue Mountains region of Oregon, Idaho, and Washington; petrology and tectonic evolution of pre-Tertiary rocks of the Blue Mountains region: U.S. Geol. Survey Professional Paper 1438, 540 p.

Vallier, T.L., Brooks, H.C., and Thayer, T.P., 1977, Paleozoic rocks of eastern Oregon and western Idaho, in Stewart, J., Stevens, C.H., and Fritsche, A.E., eds., Paleozoic paleogeography of the western United States: Society of Economic Paleontologists and Mineralogists, Pacific Coast Paleogeography Symposium, 1st, p. 455-466.

Walker, G.W., 1977, Geologic map of Oregon east of the $121^{\text {st }}$ meridian: U.S. Geological Survey Miscellaneous Investigations Series Map I-902, scale 1:500,000.

Walker, N.W., 1995, Tectonic implications of U-Pb zircon ages of the Canyon Mountain complex, Sparta Complex, and related rocks of the Baker terrane, northeastern Oregon, in Vallier, T.L., and Brooks, H.C., eds., Geology of the Blue Mountains region of Oregon, Idaho, and Washington; petrology and tectonic evolution of pre-Tertiary rocks of the Blue Mountains region: U.S. Geological Survey Professional Paper 1438, p. 247-269.

Wiswall, C.G., and Hyndman, D.W., 1987, Emplacement of the main plutons of the Bitterroot lobe of the Idaho batholith, in Vallier, T. L., and Brooks, H. C., eds., The Idaho batholith and its border zone: U. S. Geological Survey Professional Paper 1436, p. 59-72.

Zen, E., and Hammarstrom, J.M., 1984, Magmatic epidote and its petrologic significance: Geology, v. 12, p. 515-518. 


\title{
3. Geologic, Geochemical, and ${ }^{40} \mathrm{Ar} /{ }^{39} \mathrm{Ar}$ and $\mathrm{U}-\mathrm{Pb}$ Thermochronologic Constraints for the Tectonic Development of the Salmon River Suture Zone Near Orofino, Idaho
}

\author{
By Lawrence W. Snee, Gary F. Davidson, and Daniel M. Unruh
}

\section{Abstract}

Through most of western Idaho, the Salmon River suture zone is a north- to northeast-trending terrane boundary between island-arc rocks of the Wallowa terrane and continental rocks of pre-Late Cretaceous North America. Near Orofino, Idaho, the terrane boundary turns abruptly west. The west-trending segment near Orofino is marked by an 8 - to 10 -km-wide zone of strongly deformed high-grade orthogneiss and metasedimentary screens of the "Orofino series," which separates high-grade Middle Proterozoic metasedimentary rocks of the Belt Supergroup on the north from lower-amphibolite-facies igneous and metasedimentary rocks of the Wallowa terrane of the Blue Mountains island arc on the south. Rocks along the Orofino segment of the terrane boundary were multiply deformed during at least four structural episodes. Of these, F2 and related structures are dominant and were formed during southwest-vergent thrust faulting that juxtaposed highgrade rocks of the boundary zone over lower grade island-arc rocks and telescoped the northern margin of the Wallowa terrane toward the southwest. Left-lateral translation, which formed F3 folds and related structures, of continental rocks along a west-trending zone characterized by ductile deformation accompanied the southwestward thrusting of continent over island arc. The intensity of deformation associated with these two events overprinted to varying degree the structures and isotopic ages of accretion-related activity.

Trace element characteristics of metasedimentary rocks of probable clastic origin within the boundary zone near Orofino and Ahsahka indicate that most of the rocks mapped as "Orofino series" were derived from a volcanic arc provenance and are broadly correlative with Permian to Jurassic rocks of the Wallowa terrane. Local occurrence of "Orofino series" rocks with probable continental affinity suggests that continental and island-arc rocks were tectonically intercalated within the boundary zone.

Detailed ${ }^{40} \mathrm{Ar} /{ }^{39} \mathrm{Ar}$ thermochronology along the Orofino segment of the Salmon River suture zone records a tectonic history that began in the island-arc terrane with preaccretion plutonism at about $145 \mathrm{Ma}$, a common age for many of the large plutons within the Wallowa terrane. Lower-amphibolite- facies dynamothermal metamorphism, which was probably associated with arc accretion to North America along the Salmon River suture zone, occurred about $130 \mathrm{Ma}$. On the basis of ${ }^{40} \mathrm{Ar} /{ }^{39} \mathrm{Ar}$ hornblende dates, plutons were emplaced into the island-arc terrane between 122 and $115 \mathrm{Ma}$; this general age of pluton emplacement is confirmed by a precise $\mathrm{U}-\mathrm{Pb}$ zircon date of $116.8 \pm 0.6(2 \sigma)$ Ma on highly deformed quartz diorite within the boundary zone. Postaccretion southwest-directed thrusting occurred between about 93 and $80 \mathrm{Ma}$ and emplaced rocks from deeper crustal levels along the terrane boundary over rocks from progressively shallower levels toward the southwest within the northern margin of the Wallowa terrane. This thrusting event effectively translated the surface exposure of the Salmon River suture zone to the southwest and loaded the beheaded suture zone with thickened crust. This thrust plate was terminated along its northern extreme by a zone of ductile left-lateral, west-trending, strikeslip translation, which produced a ductile shear zone now exposed as the west-trending terrane boundary. Uplift resulting from the thrusting caused cooling of the overthrust high-grade rocks. Uplift progressed toward the northeast, resulting in a northeasterly decrease in mineral cooling ages to as young as $54 \mathrm{Ma}$ for biotite in both continental metamorphic rocks and Idaho Batholith plutons. This uplift may have been driven by bouyancy of Idaho Batholith plutons emplaced after about 90 Ma east of the suture zone and (or) isostatic rebound of the underthrust northern margin of the Wallowa terrane.

\section{Introduction}

In western Idaho, along the western margin of the Idaho Batholith, distinct differences in lithology, geochemical affinity, and structure define a terrane boundary that juxtaposes oceanic and island-arc rocks against continental rocks of North America (fig. 1). This boundary, named the Salmon River suture zone (SRSZ) by Lund and Snee (1988), turns approximately north to north-northeast through much of western Idaho; near Orofino, the boundary trends abruptly to the west. Rocks west and south of the Salmon River suture zone include mainly metamorphosed volcanic and volcaniclastic rocks 
(Hamilton, 1963; Myers, 1982; Lund, 1984) of the islandarc-related Wallowa terrane (Silberling and others, 1984). Metasedimentary rocks to the north and east are correlative with Belt Supergroup and pre-Belt rocks of Proterozoic age (Hietanen, 1962; Hamilton, 1963; Myers, 1982) and possibly Late Proterozoic or Paleozoic rocks of the Cordilleran miogeocline (Lund, 1984).

Although there is generally a distinct lithologic contrast across it, this terrane boundary's exact location and structural character have been obscured by high-grade metamorphism and late plutons, some of which were strongly deformed subsequent to their emplacement. Because of the abundance of plutons within the SRSZ, its location is most clearly defined by an abrupt change in initial ${ }^{87} \mathrm{Sr} /{ }^{86} \mathrm{Sr}$ ratios from $<0.704$ in granitic rocks that intrude oceanic and island-arc rocks west of the boundary to $>0.706$ in granitic rocks that intrude Precambrian rocks to the east (Armstrong and others, 1977; Fleck and Criss, 1985; Manduca, 1988). This change in the isotopic composition of granitoids corresponds closely with structural trends and the change from oceanic and island-arc to continental lithologies observed in the country rocks (Hamilton, 1963; Myers, 1982; Lund, 1984; Lund and Snee, 1988; Manduca, 1988).

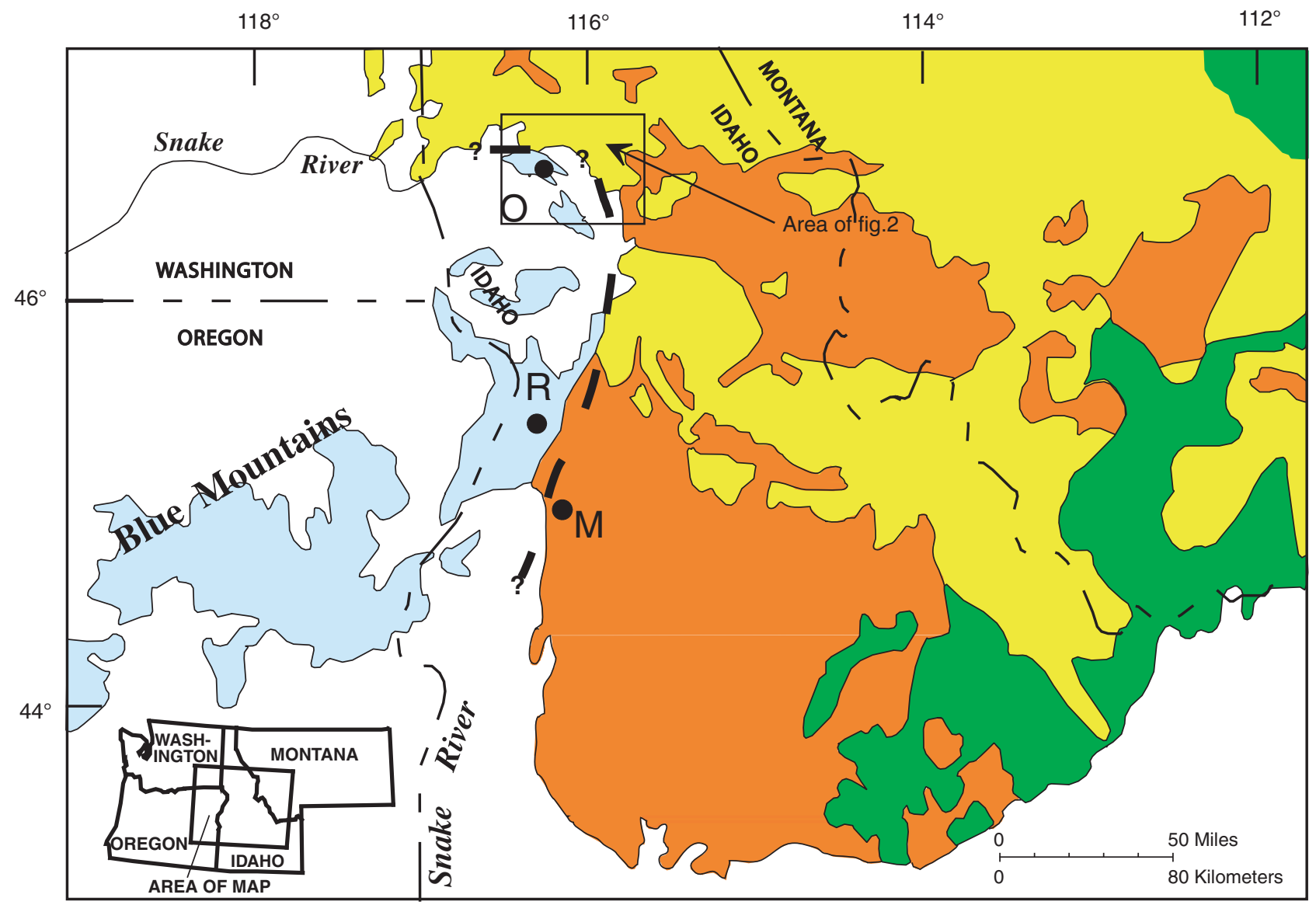

EXPLANATION

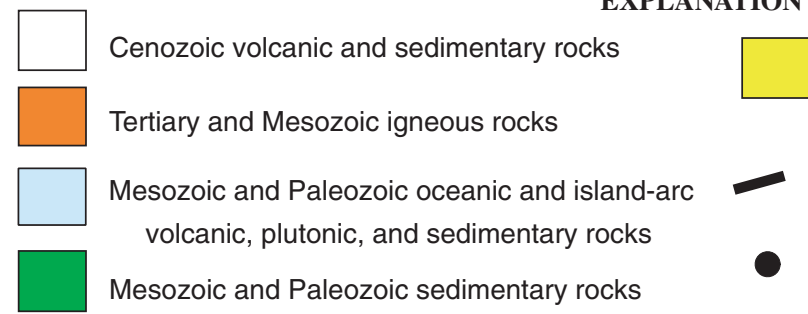

Precambrian sedimentary, plutonic, and sedimentary rocks

0.704-0.706 strontium "line" in Mesozoic and older rocks, queried where covered by younger rocks

Towns: O,Orofino; R, Riggins; M, McCall

Figure 1. Generalized tectonic map of northeastern Oregon, southwestern Washington, western Montana, and part of Idaho showing the distribution of major tectonostratigraphic packages of rock. The approximate location of the Salmon River suture zone is marked by the north-trending segment of the $\left.{ }^{87} \mathrm{Sr} /{ }^{86} \mathrm{Sr}\right)_{i}=0.704-0.706$ "line" (heavy dashed line after Armstrong and others, 1977, and Fleck and Criss, 1985). Nature of "line" at apparent bend in the Orofino area is unclear because of extensive Tertiary basalt cover. Present study indicates that west-trending segment of "line" is a left-lateral ductile shear zone. Inset marks area of figure 2 . 
Both the mechanism and timing of accretion of the Wallowa terrane to North America have been much debated. Many workers have suggested a subduction-related mechanism (Hamilton, 1976; Hyndman and Talbot, 1976; Onasch, 1977; Brooks and Vallier, 1978; Hillhouse and others, 1982). More recently, Lund (1984) and Lund and Snee (1988) proposed that the Salmon River suture zone represents a transpressive strike-slip boundary along which the oceanic rocks were accreted. Proposed times of accretion include Late Permian or Triassic (Hamilton, 1976), Late Triassic to Jurassic (Brooks and Vallier, 1978), Late Jurassic (Jones and others, 1977), Early Cretaceous (Davis and others, 1978; Selverston and others, 1992; Vallier, 1995), Early to Late Cretaceous (Sutter and others, 1984; Criss and Fleck, 1987; Lund and Snee, 1988; Manduca and others, 1993; Snee and others, 1995), and Late Cretaceous (Strayer and others, 1989). Interpretations of pre-Cretaceous accretion are based in large part on imprecise $\mathrm{Rb}-\mathrm{Sr}$ dates of about 160-130 Ma for the oldest apparently post-tectonic plutons within the Blue Mountains province of northeastern Oregon (Armstrong and others, 1977) and a lack of Cretaceous-age penetrative deformation in that region (Avé Lallemant and others, 1980). Recently Snee and others (1995) have shown that many of those plutons (for example, those in the Blue and Wallowa Mountains) have argon-cooling ages of about $145 \mathrm{Ma}$. In addition, several recent studies have shown that rocks along the SRSZ experienced Early to Late Cretaceous deformation and metamorphism (Sutter and others, 1984; Lund and Snee, 1985; Criss and Fleck, 1987; Lund and Snee, 1988; Manduca, 1988; Selverstone and others, 1992; Manduca and others, 1993; Snee and others, 1995). At present, the best constraints on the timing of accretion along the Salmon River suture zone are based on ${ }^{40} \mathrm{Ar} /{ }^{39} \mathrm{Ar}$ studies near Riggins in west-central Idaho (figure 1; Lund and Snee, 1988; Snee and others, 1995). The ${ }^{40} \mathrm{Ar}{ }^{\beta 9} \mathrm{Ar}$ studies show that the oldest metamorphism and deformation in rocks spatially related to the terrane boundary began by about $130 \mathrm{Ma}$. Final stitching of the boundary occurred at about $93 \mathrm{Ma}$, when tonalitic plutons intruded both oceanic and continental rocks. The results of the ${ }^{40} \mathrm{Ar} /{ }^{\beta 9} \mathrm{Ar}$ studies suggest that pre-Cretaceous deformation in the Blue Mountains of Oregon was related to earlier tectonic events such as pre-accretion amalgamation of the oceanic and island-arc terranes (Lund and Snee, 1988; Snee and others, 1995).

An important problem in developing a model for terrane accretion, including kinematics and timing, is the requirement that it be possible to recognize structures formed during a given tectonic event. This can be particularly difficult in rocks that have experienced multiple deformational and (or) metamorphic events. In western Idaho, the problem is exacerbated because original tectonic relationships along the terrane boundary are obscured by later plutons. Several studies have described near-vertical to moderately east-dipping foliation and shear zones and approximately down-dip mineral lineation in rocks along the north-trending segment of the Salmon River suture zone (Myers, 1982; Lund, 1984; Lund and Snee, 1985, 1988; Hoover and others, 1985; Manduca, 1988). Near
Orofino, where the boundary trends more westward, structures are similar; gneissic foliation and shear zones generally dip to the northeast with near-down-dip lineation (Hietanen, 1962; Strayer and others, 1989, Davidson, 1989). Where kinematic indicators have been described, they indicate east-northeast over west-southwest shear sense (that is, continent-side-up; Myers, 1982; Strayer and others, 1989; Davidson, 1989). Strayer and others (1989) interpreted these structures near Orofino to have formed during northeast-directed underthrusting of the Wallowa terrane beneath North America during Late Cretaceous accretion. However, other workers have shown that elsewhere along the Salmon River suture zone much of this deformation occurred after terrane accretion in western Idaho and during a period of uplift of the continental terrane (Lund and Snee, 1988; Manduca, 1988; Lund and others, 1990; Snee and others, 1995).

In this paper we describe the structural and metamorphic setting along the Orofino segment of the Salmon River suture zone, present trace-element chemical data for Orofino series metasedimentary rocks, summarize the results of $70{ }^{40} \mathrm{Ar} /{ }^{\beta 9} \mathrm{Ar}$ mineral analyses from this area, and present $\mathrm{U}-\mathrm{Pb}, \mathrm{Rb}-\mathrm{Sr}$, and Sm-Nd geochronology and geochemistry for one pluton within the high-strain boundary zone of the suture. These data provide new constraints on the timing of plutonism, deformation, and metamorphism near Orofino that bear on the timing of terrane accretion and subsequent tectonic events in western Idaho. The data provide evidence for: (1) the origin of Orofino series sedimentary rocks; (2) the emplacement of a preaccretion pluton and associated thermal metamorphism of the adjacent country rocks at about $145 \mathrm{Ma}$, along the present-day northern edge of the Wallowa terrane; (3) the effects of probable accretion-related deformation, lower amphibolite-facies metamorphism of island-arc rocks, and pluton emplacement that began by about $130 \mathrm{Ma}$ and ended by about $100 \mathrm{Ma}$; (4) the extent of post-accretion southwest-directed ductile thrusting of continental rocks over island-arc terrane and associated left-lateral west-trending strike-slip translation from about 93 to $80 \mathrm{Ma}$ that resulted in tectonic intercalation, inverted metamorphic facies, and structural telescoping; and (5) the regional nature and effect of late-stage uplift and cooling, following cessation of thrusting, that progressed from along the terrane boundary towards the northeast.

As along other parts of the Salmon River suture zone, the structural and metamorphic patterns in the Orofino area resulted from processes related to accretion as well as later postaccretion structural activity along the terrane boundary. However, in contrast to the north-south segment of the Salmon River suture zone south of Orofino, in the Orofino area evidence for Early Cretaceous accretion-related deformation and metamorphism is only locally preserved. Importantly, however, the similarity in style and age between demonstrably late-formed structures present near Orofino and structures described elsewhere along the Salmon River suture zone suggests a dynamic connection between them. Likewise, the early accretion history along the Salmon River suture zone is shared along its length. Thus, the details of the late structural devel- 
opment along the Salmon River suture zone in the Orofino area, the evidence of earlier activity on the suture zone that took place during accretion from Orofino and other areas (Snee and others, 1995), and the dynamic links along the entire length of the suture zone provide a unique opportunity to develop a model for the tectonic evolution of the Salmon River suture zone and the origin of the abrupt change in trend in the terrane boundary, which we discuss in the last part of this report.

\section{Geologic Setting}

The Orofino segment of the Salmon River suture zone is marked by a generally northwest- to west-northwest-trending belt of strongly deformed orthogneiss and high-grade metasedimentary screens which separate high-grade continental metasedimentary rocks of the Middle Proterozoic Belt Supergroup (Anderson, 1930; Hietanen, 1962) from metaigneous and metasedimentary rocks of the Wallowa island-arc terrane (fig. 2). Within the orthogneiss components of this belt, the initial ${ }^{87} \mathrm{Sr} /{ }^{86} \mathrm{Sr}$ ratios change from $<0.704$ along the Clearwater River to $>0.706$ (Armstrong and others, 1977; Fleck and Criss, 1985) about $8 \mathrm{~km}$ north of Ahsahka and east of Orofino. This change in isotopic composition in granitoids corresponds in a general way to the change from metamorphosed volcanic and volcaniclastic rocks to quartz-rich aluminous continental metasedimentary rocks across the terrane boundary. However, uncertainty as to the correlation of metasedimentary rocks and the abundance of granitic rocks within the boundary zone, as well as extensive younger basalt cover, have made precise location of the lithologic boundary difficult. Structurally, the boundary zone is characterized by southwest-directed thrust faults and shear zones (Strayer and others, 1989; Davidson, 1989) that juxtapose high-grade rocks along the boundary with lower grade island-arc rocks and have telescoped the northern margin of the Wallowa terrane towards the southwest.

\section{Areas North and East of Orofino: Metamorphosed Belt Rocks}

Areas to the north and east of Orofino (fig. 2), along Dworshak Reservoir and near Pierce, respectively, are underlain by sillimanite-grade metasedimentary rocks (mica schists, quartzofeldspathic gneisses, quartzites, and calcsilicate rocks) that have been correlated with rocks of the Middle Proterozoic Belt Supergroup (Anderson, 1930; Kopp, 1959, Hietanen, 1962, 1963a,b,c). Sedimentary and metasedimentary rocks of the Belt Supergroup underlie large areas in northern Idaho and western Montana and are thought to represent sediments that were deposited along the western edge of the North American Precambrian craton between about 1,450 and 850 Ma (Harrison, 1972). Hietanen (1962) reported the presence of two generations of folds in these rocks, with fold axes trending both east to southeast and north to northeast. Small, generally undeformed, discordant quartz diorite to granodiorite plutons crosscut folds and foliations (Hietanen, 1962). The southernmost exposures of clearly continental rocks that appear to be continuous with rocks to the north are outcrops of quartzite exposed along the southern base of Teakean Buttes, at Huckleberry Buttes, and along Dworshak Reservoir about $11 \mathrm{~km}$ north of Ahsahka (fig. 2).

\section{Ahsahka-Orofino Area: High-Grade Rocks of the Boundary Zone}

Within a strongly deformed zone, approximately 8 to 10 $\mathrm{km}$ wide, that lies southwest of and adjacent to the terrane boundary north and east of Ahsahka and Orofino are highgrade metamorphic rocks of the "Orofino series" (Anderson, 1930; Hietanen, 1962) and abundant plutonic gneisses that intrude them (figs. 2, 3). (According to the 1983 North American Stratigraphic Code, the term "series" is improperly

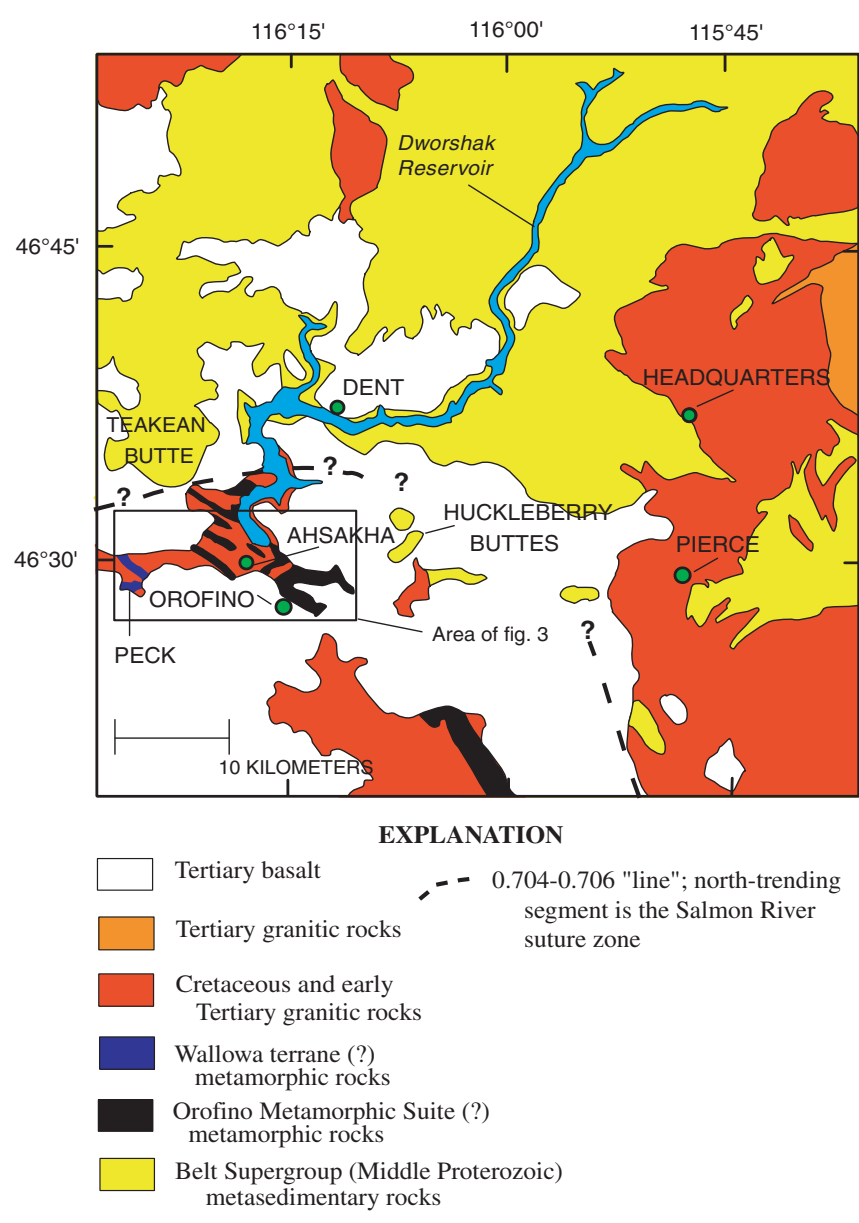

Figure 2. Generalized regional geologic map of the Orofino area and adjacent areas (modified after Rember and Bennett, 1978, and Heitanen, 1962, 1963a,b,c) Inset shows area of figure 3 . The terrane boundary between island-arc rocks and continental rocks in the Orofino area exhibits an apparent abrupt change in trend indicated by change in trend of the $\left({ }^{87} \mathrm{Sr} /{ }^{86} \mathrm{Sr}\right)_{i}=0.704-0.706$ "line" (heavy dashed line after Armstrong and others, 1977, and Fleck and Criss, 1985). The geologic nature of the two segments is discussed in text. 


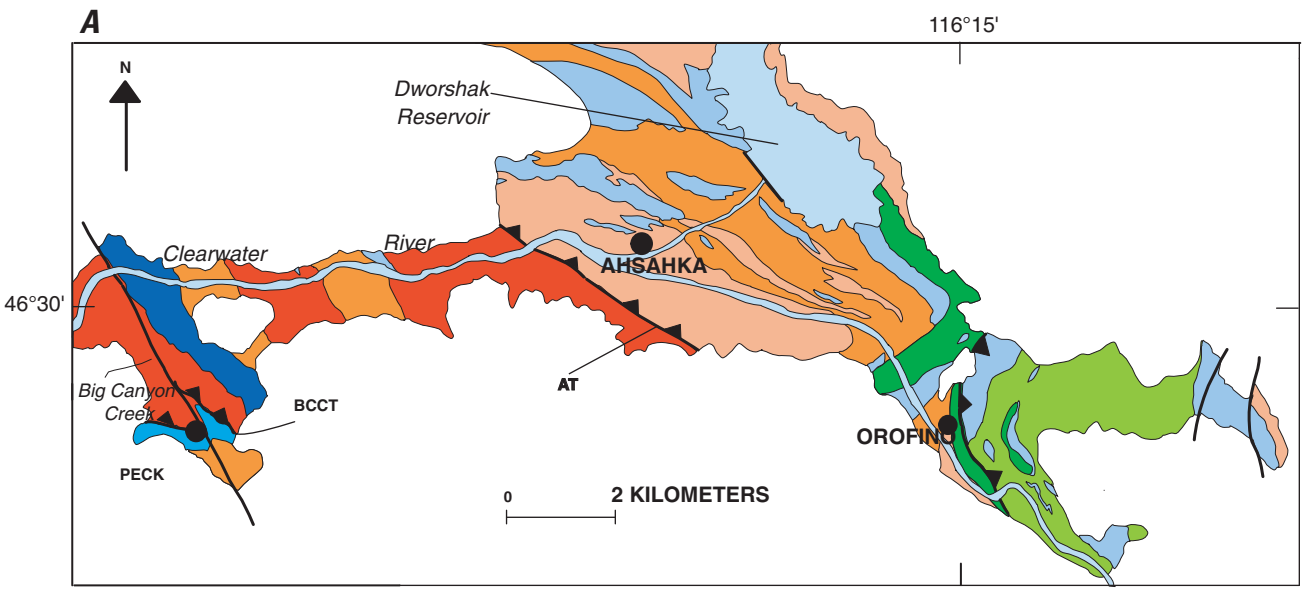

EXPLANATION

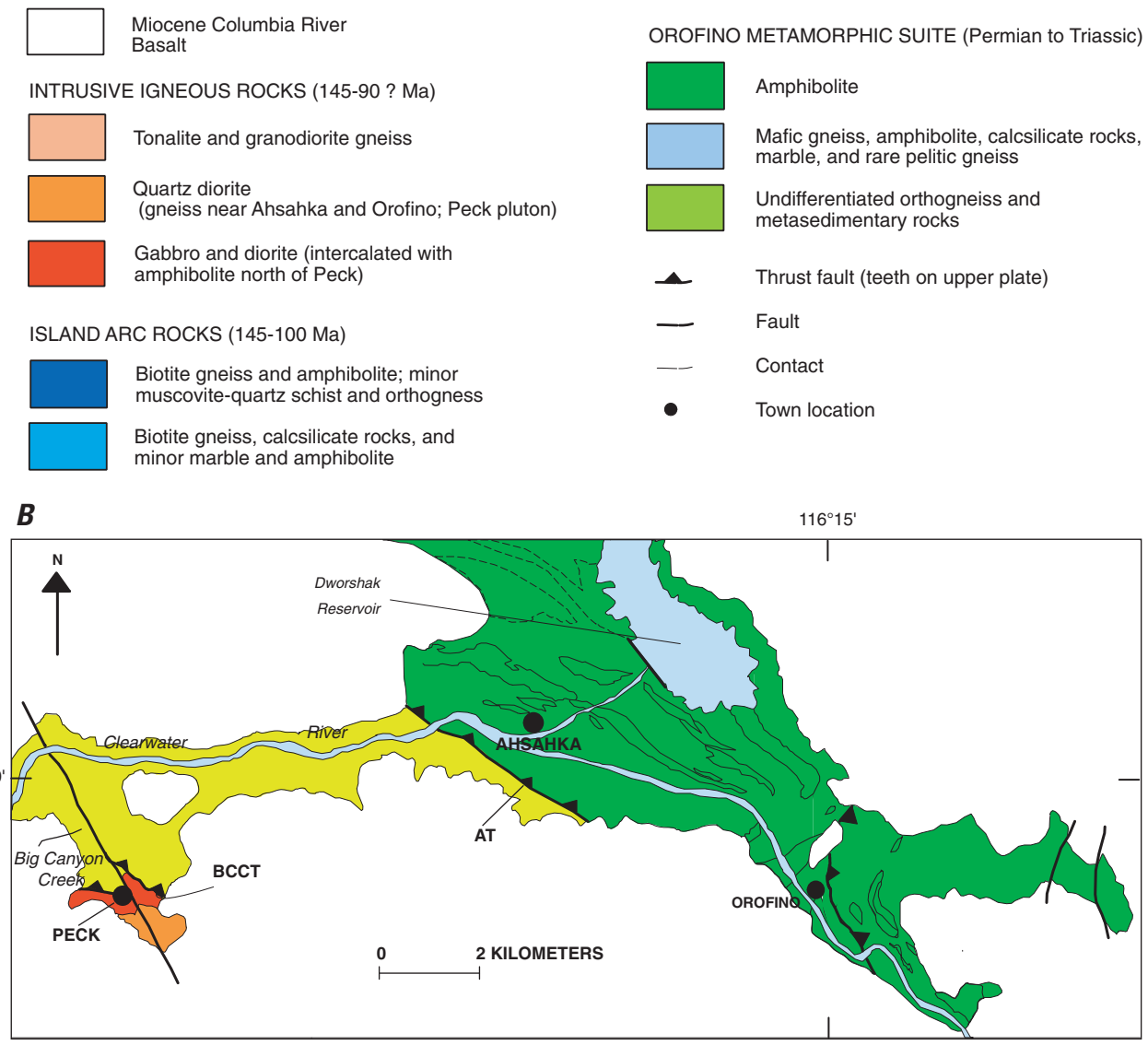

EXPLANATION

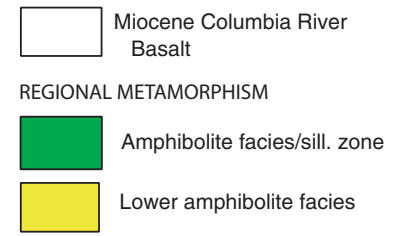

CONTACT METAMORPHISM

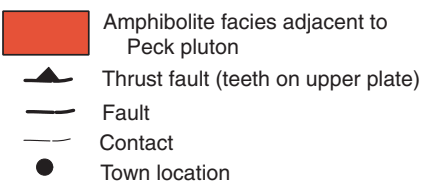

Figure 3. Geology of the Peck-Ahsahka-Orofino area. A, Generalized geologic map showing lithologic units, major structures, and metamorphic grade discussed in text (based on unpublished mapping by G.F. Davidson 1987-1988, and Heitanen, 1962). Abbreviations: AT, Ahsahka thrust; BCCT, Big Canyon Creek Thrust. $B$, Distribution of metamorphic packages and the corresponding metamorphic grade of each. Abbreviations: AT, Ahsahka thrust; BCCT, Big Canyon Creek Thrust. 
used in this case. Although this misuse is of long standing, herein we rename the "Orofino series" the Orofino Metamorphic Suite.) The lithologically varied Orofino Metamorphic Suite includes biotite and biotite-hornblende schist and gneiss, amphibolite, calcsilicate rocks, marble, as well as minor micaceous sandstone, pelitic schist and gneiss, and talc-anthophyllite schist. These rocks are found primarily as concordant screens within the enclosing orthogneiss. Rocks of the Orofino Metamorphic Suite differ from the metamorphosed Belt rocks to the north and east primarily by the abundance of mafic biotite-hornblende gneiss, relatively pure marble layers, and the relative lack of aluminosilicate- and quartz-rich rocks (Anderson, 1930; Hietanen, 1962). On the basis of these differences, Anderson (1930) suggested that the Orofino Metamorphic Suite is the lowest part of the Prichard Formation of the Belt Supergroup, which is not exposed elsewhere. However, he later suggested that the unit may be much younger, probably Paleozoic or Mesozoic in age (see Johnson, 1947, p. 491). Hietanen (1962) tentatively correlated the Orofino Metamorphic Suite with the lower part of the carbonate-bearing Wallace Formation of the Belt Supergroup, on the basis of similarities with exposures about $12 \mathrm{~km}$ east of Orofino. Myers (1982) proposed that the Orofino Metamorphic Suite may be correlative with rocks east of Harpster which are thought to be pre-Beltian in age (Armstrong, 1975), but more recently expressed the view that parts of the Orofino Metamorphic Suite may correlate with metamorphosed islandarc rocks of unknown age in the Riggins and Harpster areas (P.E. Myers, oral commun., 1987). Thus, it has been suggested that the Orofino Metamorphic Suite may be of any age from Precambrian to Mesozoic and of either continental or islandarc origin. Geochemistry that we present below indicates that the Orofino Metamorphic Suite is of island-arc origin and the best correlation to nearby units suggests that the age of this metamorphic suite is Permian to Jurassic.

The rocks of the Orofino Metamorphic Suite are intruded by abundant quartz diorite to tonalite and minor granodiorite orthogneiss that forms roughly 60-70\% of the outcrop area near Orofino and Ahsahka (fig. 3). Although foliation and lithologic contacts are, for the most part, strongly concordant as a result of deformation, locally preserved cross-cutting intrusive contacts allow delineation of individual intrusive units (fig. 3) and relative age relationships. The earliest intrusive phase is epidote-bearing, biotite-hornblende quartz diorite that is spectacularly exposed in the North Fork of the Clearwater River canyon near Dworshak Dam, north of Ahsahka. The boundary zone next was intruded by biotite tonalite containing variable amounts of hornblende, epidote, and locally garnet. The last main phase of plutonic activity is represented by minor garnetbearing biotite granodiorite, which locally contains xenoliths of both the quartz diorite and tonalite. Mafic dikes (now concordant amphibolite bands), as well as several generations of pegmatite dikes and veins, intruded all three orthogneiss units.

The high-grade metasedimentary rocks and orthogneiss within the boundary zone near Ahsahka and Orofino are structurally dominated by a strong gneissic foliation (fig. 4) that in most places parallels compositional layering. Metasedimentary rocks in this zone appear to contain at least three (Kopp, 1959), and probably four, generations of variably expressed folds. Tight to isoclinal folding of compositional layering is common; fold axes commonly plunge to the northeast, nearly down-dip in the foliation. The dominant foliation is parallel to the axial planes of these folds (Strayer and others, 1989). In a few outcrops, two sets of isoclinal folds, having strongly discordant fold axes, are present. Also, a relict foliation, folded in the hinge zones of isoclinal folds, is preserved locally. Thus, there are likely two generations of isoclinal folds (F1 and F2) in the metasedimentary rocks, and the dominant foliation in the area is an S2, second generation fabric. It is possible that the observed discordant isoclinal folds indicate the presence of sheath folds, as interpreted by Strayer and others (1989).

$\mathrm{F}_{3}$ folds are manifest as small-scale, close to tight or isoclinal asymmetric folds that fold S2 and that generally have steeply northeast-plunging fold axes. No new axial-plane foliation is associated with F3. Locally, these folds are directly superposed on isoclinal F2 folds, the limbs of which were boudinaged prior to F3, indicating that F3 indeed postdates F2. An apparent dominance of down-plunge S-fold over Z-fold asymmetric geometry suggests that the deformation which produced F3 had a left-lateral shear component.

The final phase of folding, F4, is small-scale, symmetric, northeast-plunging open folds that fold all earlier structural elements. F4 likely is related to the large-scale folding of foliation and lineation trends and lithologic contacts that is exhibited in the vicinity of Orofino (figs. 3, 4).

The orthogneisses, mafic dikes, and some pegmatite dikes were emplaced before much of the deformation described above. Within the orthogneisses, isoclinally folded amphibolite dikes, which have axial planes parallel to S2 and northeastplunging fold axes, are common. However, nowhere do two sets of isoclinal folds or dikes cut preexisting folds in the orthogneiss, suggesting that emplacement of intrusive rocks followed F1 and preceded F2. The relationship of pegmatite dikes to structures indicates several phases of pegmatite emplacement, from pre-F2 (and F1?) dikes that subsequently were isoclinally folded to dikes that were variably deformed during later shearing; some pegmatite dikes are completely transposed parallel to the gneissic foliation and form trails of feldspar augen, whereas others are nearly undeformed tabular dikes (Strayer and others, 1989).

Qualitative observations of the tectonite fabric within the high-grade package in the vicinity of Ahsahka and Orofino indicate that the rocks are dominantly S-tectonites (Flinn, 1965). A linear fabric is only locally well developed. Lineations are generally defined by aligned hornblende and biotite, fold axes, and aligned sillimanite in pelitic lithologies. Parts of the orthogneiss bodies lack clear mineral lineations but exhibit an overall linear fabric as defined by the strong alignment of planar features (mainly pegmatite dikes) when viewed along strike of the foliation and the poor alignment of planar structural elements when viewed down-dip (Strayer and others, 1989). This type of linear fabric parallels mineral lineations, 
suggesting that both linear fabric elements define the stretching direction in the rocks. Within the Orofino Metamorphic Suite, prograde metamorphic mineral assemblages in amphibolites (brownish-green hornblende + plagioclase + garnet + quartz + reddish-brown biotite + minor epidote), calcsilicate rocks (various combinations of diopside, hornblende, garnet, quartz, plagioclase, epidote, calcite, scapolite, and K-feldspar), and rare pelitic schists (sillimanite + kyanite + biotite + muscovite + garnet + quartz + plagioclase) indicate that metamorphism of these rocks took place within the sillimanite zone of the amphibolite facies (Turner, 1981). Both sillimanite and kyanite occur in some pelitic samples of the Orofino Metamorphic Suite (Hietanen, 1962). In such samples, sillimanite typically occurs as small well-developed prisms while kyanite appears embayed, suggesting that peak metamorphic conditions were within the stability field of sillimanite. This relationship provides evidence for either (1) an early, relatively high-pressure metamorphic event followed by a subsequent higher temperature metamorphic event, as seen by Lang and Rice (1985; their M2 and M3 events?) in the Snow Peak area,
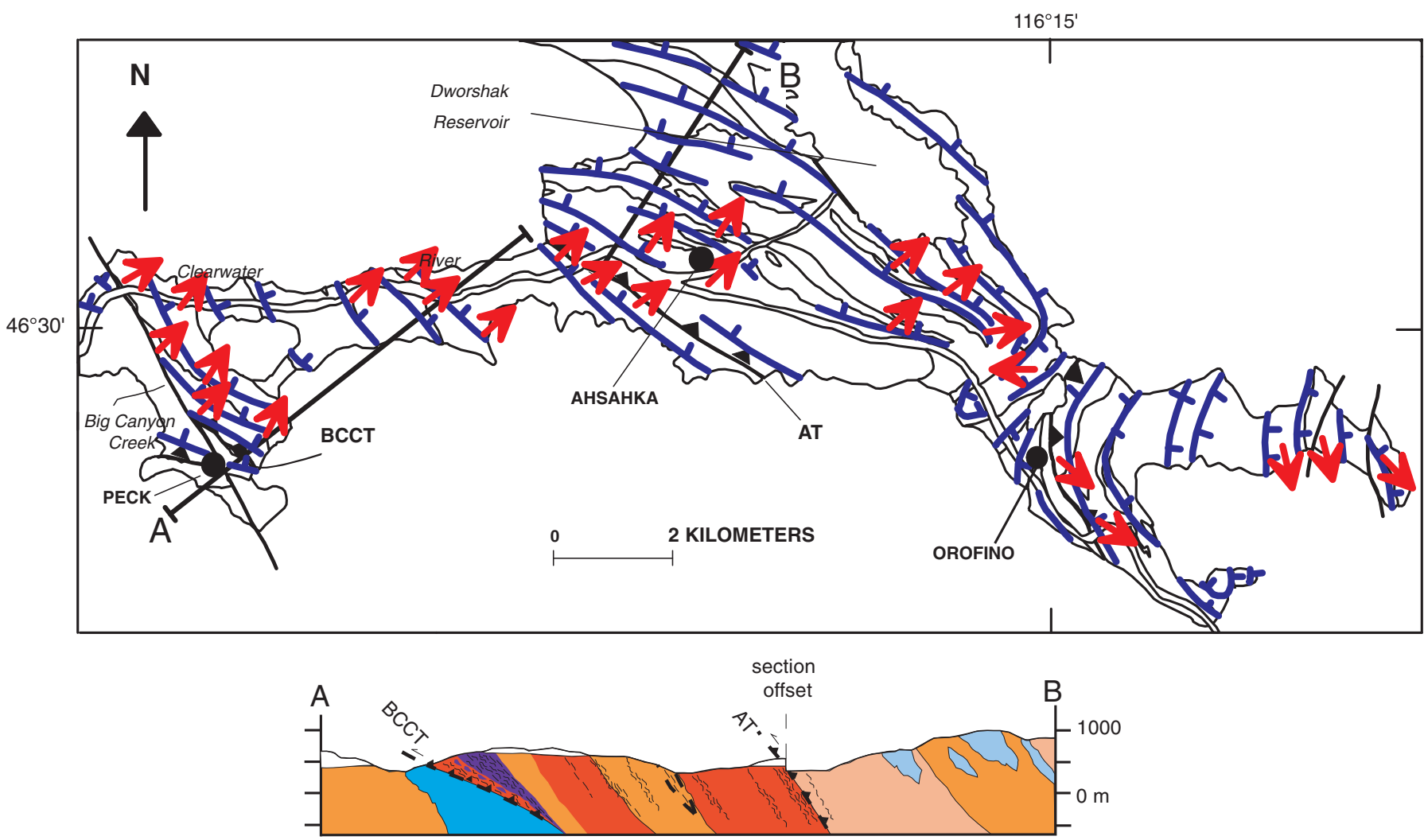

EXPLANATION
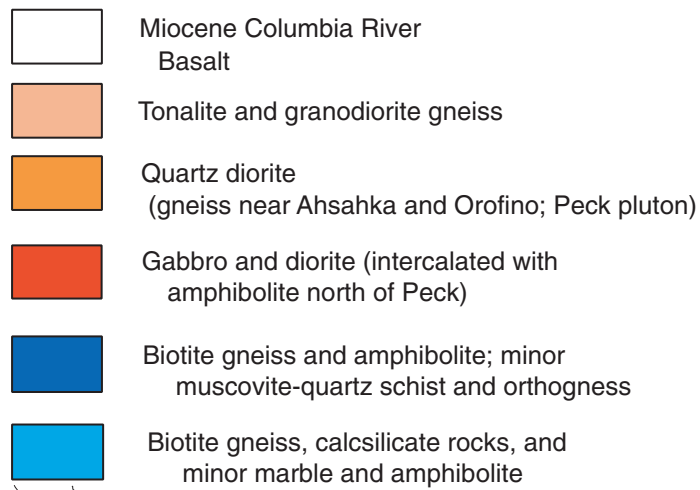

Mafic gneiss, amphibolite, calcsilicate rocks, marble, and rare pelitic gneiss

Shear zones

Thrust fault (teeth on upper plate)
Fault
Contact
Town location
Foliation trend and dip direction

Figure 4. Foliation and lineation trend map of the Peck-Ahsahka-Orofino area and generalized structure cross section along line A-B. For general geology, see figure 3; coloring of units is deleted on the map of figure 4 for clarity. Color of units on figure 4 cross section are consistent with colors on figure 3 . The cross section follows the two-part line extending from $A$ to $B$. No vertical exaggeration. Abbreviations: AT, Ahsahka thrust; BCCT, Big Canyon Creek Thrust. 
about $50 \mathrm{~km}$ northeast of Orofino, or (2) a single progressive metamorphic event involving an early stage of moderately high pressure and temperature metamorphism followed by decompression or an increase in temperature. The occurrence of rare lineated sillimanite suggests that at least the late, lower pressure and temperature stage of metamorphism that produced sillimanite was synkinematic. Except for the presence of very minor retrograde chlorite, calcite, and sericite, these high-grade rocks show no significant retrograde effects.

Texturally, both the metasedimentary and metaigneous rocks within this zone are medium grained to coarsely crystalline, with variable preservation of ductile strain features. In places, the rocks possess annealed fabrics in which preferred orientations of crystal shapes are preserved, but intracrystalline strain features are weak to absent and 120o triple junctions are common. These annealed fabrics indicate that the rocks underwent continued heating after deformation ended. Elsewhere, the rocks variably preserve undulose extinction, subgrain development, and bent micas. Locally, the orthogneisses display protomylonitic fabrics with quartz and plagioclase subgrains surrounding larger porphyroclastic feldspars. Combined, these features suggest that (1) much of the deformation within the boundary zone occurred at relatively high temperatures (Strayer and others, 1989), (2) the rocks remained hot well after much of the deformation had ended, and (3) late-stage deformation occurred at lower temperatures and tended to be localized.

The main deformation event in the high-grade boundary zone is interpreted to coincide with F2. Strayer and others (1989) interpreted northeast-plunging lineations, transposition of amphibolite dikes into the gneissic foliation, and consistent northeast-over-southwest offset of late-stage crosscutting pegmatite dikes as indicating a large amount of northeastover-southwest simple shear along the terrane boundary near Ahsahka. Progressive deformation and shearing during this event may have been responsible for rotation of some F1 and F2 fold axes into parallelism with other observed linear elements as suggested by Strayer and others (1989). Assuming simple shear, Strayer and others (1989) estimated that 27 to $84 \mathrm{~km}$ of top-to-the-southeast movement was localized along this zone. However, the apparent dominance of S-tectonite fabric and only local development of L or LS fabrics suggest that deformation was heterogeneous and included zones of bulk flattening as well as zones of simple shear (Lund and others, 1990). Consistent offsets of late-stage pegmatite dikes across amphibolite bands provide the only clear evidence for northeast-over-southwest sense of shear during this event-kinematic information for earlier stages of deformation is rare. Concordance between foliation and lineation orientations in the high-grade rocks containing shear zones and shear-zone mineral lineations in structurally underlying lower grade rocks (see below) suggests that the main fabric-producing deformation in the high-grade rocks and shearzone deformation in the lower grade rocks were part of the same event. The significance of prior deformation (F1) is unclear, but F1 probably records deformation during early stages of accretion of island-arc terranes to the North American continent along the Salmon River suture zone.

\section{Areas South and West of Ahsahka/ Orofino: Metamorphosed and Unmeta- morphosed Island-Arc Rocks}

The contact between the high-grade boundary-zone rocks and underlying island-arc rocks (figs. 3,4 ), herein referred to as the Ahsahka thrust (AT), is marked by an approximately 250-m-wide zone of northeast-dipping banded gneiss consisting of both mafic hornblende-rich bands and more felsic tonalitic bands. Although not sharply defined in outcrop, the Ahsahka thrust marks a major change in deformation style, metamorphic grade, and ${ }^{40} \mathrm{Ar} /{ }^{39} \mathrm{Ar}$ hornblende dates (discussed in detail in a subsequent section), which indicates that it is a regionally important structure. The interpretation that the Ahsahka thrust is a thrust fault is based on the relationship of high-grade rocks over lower-grade rocks (inverted metamorphism) and ${ }^{40} \mathrm{Ar} /{ }^{39} \mathrm{Ar}$ data, which indicate that juxtaposition of rocks along the fault occurred during northeast-over-southwest shearing in the underlying mafic plutonic rocks (see below).

Rocks exposed below the Ahsahka thrust (fig. 3) include mainly lower amphibolite-facies biotite schist, amphibolite, and gneiss, and minor muscovite-quartz schist. Near Peck, minor calcsilicate rocks and marble are also present below the Ahsahka thrust. Mafic plutonic rocks of gabbroic to quartz dioritic composition, which are heterogeneously deformed and variably metamorphosed, intruded these rocks. The nonplutonic rocks below the Ahsahka thrust are metamorphosed volcanic, volcaniclastic (Hietanen, 1962), and minor calcareous rocks that are probably of the Martin Bridge (Upper Triassic) and Hurwal (Upper Triassic and Lower Jurassic) Formations (T.L. Vallier, written commun., 1993) of the Wallowa islandarc terrane. The mafic plutons have initial ${ }^{87} \mathrm{Sr} /{ }^{86} \mathrm{Sr}$ ratios $<0.704$ (Armstrong and others, 1977; Fleck and Criss, 1985) and chemical signatures (L.W. Snee, unpublished data) that indicate no involvement of Precambrian continental crust, consistent with an oceanic island-arc affinity.

The island-arc rocks below the Ahsahka thrust occur in two main structural packages that are separated by a northnortheast-dipping, brittle thrust fault, the Big Canyon Creek thrust fault (BCCT, fig. 3). Directly below the Big Canyon Creek thrust fault, poorly exposed biotite gneiss, calcsilicate rocks, and minor marble and amphibolite are intruded by biotite-hornblende quartz diorite. The quartz diorite is massive to weakly foliated and, with the exception of trace amounts of chlorite and minor undulose extinction in quartz, plagioclase, and biotite, displays no effects of later metamorphism or deformation. The metamorphic country rocks generally have a hornfelsic texture consistent with thermal metamorphism as a result of intrusion of the quartz diorite.

Rocks between the Big Canyon Creek thrust fault and the Ahsahka thrust (fig. 3) are mainly variably deformed mafic plutonic rocks, lesser amounts of amphibolite, and minor mica schist and gneiss. These rocks are cut by numerous shallowly 
to moderately northeast-dipping ductile shear zones (see fig. 4, cross-section). Small-scale folds, some of which are isoclinal, are present locally, but not abundant. Between the Big Canyon Creek thrust fault and the mouth of Big Canyon Creek (fig. 3), deformed gabbroic rocks (now hornblende gneiss) appear to be tectonically interleaved with finer grained amphibolite; both display a well-developed northeast-plunging lineation defined by aligned hornblende grains.

Amphibolite, biotite schist, and minor muscovite-quartz schist and deformed mafic plutonic rocks tectonically overlie the sheared gabbro and amphibolite (fig. 3). In places, amphibolite and biotite schist appear to be conformable and are interpreted to be interlayered metamorphosed mafic volcanic and volcaniclastic rocks, respectively. Hornblende lineations in the amphibolite parallel the linear fabric in the underlying gabbro/amphibolite unit, and the two packages appear to have undergone similar deformation. Where gabbro occurs with biotite gneiss and amphibolite, the contacts are sheared.

Along the Clearwater River between the mouth of Big Canyon Creek and the Ahsahka thrust (fig. 3), massive to weakly foliated and (or) lineated gabbroic and quartz dioritic plutonic rocks are cut by discrete northeast-dipping ductile shear zones ranging from $1 \mathrm{~mm}$ up to approximately 200 meters in thickness (fig. 4). Contacts between the plutonic units are poorly exposed, but most appear to be marked by shear zones. Within the shear zones, locally well developed S-C mylonite fabrics, sigmoidal amphibole grains, asymmetric folds, and northeast-plunging hornblende and chlorite lineations indicate northeast-over-southwest sense of shear (Davidson, 1988).

The amphibolite between the Big Canyon Creek thrust fault and the Ahsahka thrust has a prograde mineral assemblage of hornblende + plagioclase + epidote + chlorite \pm biotite \pm quartz, consistent with metamorphism under lower amphibolite-facies conditions. Small subhedral garnets, found in a single sample of plagioclase-quartz-biotite-epidote-garnet gneiss, indicate that metamorphic conditions were at least within the garnet zone. Hornblende commonly defines a strong lineation and prograde chlorite and biotite, where present, help define the foliation. In biotite schist and gneiss, locally developed elongate epidote prisms parallel the biotite foliation. These relations indicate that mineral growth during the lower amphibolite-facies event was broadly synkinematic. The preservation of igneous textures in undeformed parts of the mafic plutonic rocks suggests that they intruded the metamorphic rocks after amphibolite-facies metamorphism. However, locally developed retrograde actinolite (after hornblende) and chlorite in rocks within and adjacent to the shear zones that cut the mafic plutonic rocks along the Clearwater River indicate that greenschist-facies metamorphic conditions occurred during shear-zone deformation.

In summary, the metavolcanic and metasedimentary rocks between the Big Canyon Creek thrust fault and the Ahsahka thrust experienced lower amphibolite-facies metamorphism. Subsequent to metamorphism, the rocks were intruded by mafic plutons, and then the entire package was heterogeneously deformed; that is, deformation was localized along shear zones in the upper part of the section and more pervasive lower in the section. Local, greenschist-facies metamorphism affected some shear zones.

\section{Geochemistry}

Trace-element compositions of eleven samples of metasedimentary rocks with probable clastic protoliths were determined as part of a comprehensive geochemical study of rocks of the Orofino, Idaho, area (L.W. Snee, unpublished data); seven of the samples were collected from the Orofino Metamorphic Suite or presumed Orofino Metamorphic Suite and four were collected from probable Belt Supergroup units. Instrumental neutron-activation analysis was used following standard procedures described in Laul (1979) and Snee and others (1989). Selected data that have particular importance for the origin of the Orofino Metamorphic Suite are given in table 1; sample localities are shown in figure 5.

The trace-element compositions of six of the seven Orofino Metamorphic Suite samples (samples 88-19, 88-06, $88-29,88-23,88-05$, and 87-57) are similar to the compositions of metavolcanic and metasedimentary rocks within the Wallowa island-arc terrane (Vallier and Batiza, 1978; Sarewitz, 1983; Hoover, 1986; Goldstrand, 1994; Vallier, 1995). Chondrite-normalized, rare-earth-element (REE) patterns (fig. 6A) are relatively flat to slightly light-REE-enriched, with small positive or negative Eu anomalies. Chondrite-normalized REE abundances are low, ranging from about 10 to 40 times chondritic values. Abundances of $\mathrm{Rb}, \mathrm{Zr}$, $\mathrm{Th}, \mathrm{Ba}$, and $\mathrm{Cr}$ also are relatively low (fig. $6 \mathrm{C}$ ), consistent with existing data for samples from the Wallowa terrane. In contrast, samples collected from probable Belt metasedimentary rocks, three near Dent (samples 88-07, 88-08, and 88-09) and one near Pierce (sample 88-16), show marked light-REE enrichment to about 60-to-120 -times chondritic values and lower heavy-REE abundances (fig. $6 B$ ), similar to patterns observed by Bittner (1987) for continental metasedimentary rocks within the Bitterroot lobe of the Idaho Batholith, east of the Salmon River suture zone. Abundances of $\mathrm{Rb}, \mathrm{Zr}$, Th, $\mathrm{Ba}$, and $\mathrm{Cr}$ generally are distinctly higher than for rocks of the Orofino Metamorphic Suite (fig. 6C). One sample (sample 88-30) of garnet-biotite-plagioclase-quartz gneiss from rocks mapped as Orofino Metamorphic Suite about $3 \mathrm{~km}$ north-northeast of Ahsahka, along the western side of Dworshak Reservoir, is distinct in trace-element composition from the other Orofino Metamorphic Suite samples but is similar to samples near Dent and Pierce (fig. 6A, $B, C$ ).

These trace-element data strongly support the interpretation that most of the metamorphosed clastic rocks in the Orofino Metamorphic Suite in the Ahsahka-Orofino area are derived from an island-arc provenance and are not Middle Proterozoic Belt Supergroup rocks. The similarity of the apparently interlayered mafic schist and gneiss, calcsilicate rocks and marble, and rare pelites in the Orofino Metamorphic Suite with very low to low-grade metavolcanic, clastic, and 
[Analyses done at the Radiation Center, Oregon State University, by instrumental neutron activation analysis by Robert Walker. Concentrations are in parts per million (ppm). Analytical details are discussed in Laul, 1979, Snee and others, 1989, and G.F. Davidson and L.W. Snee, unpublished data. Errors shown in percent after each element are one standard deviation from the mean of repeated analyses of standards; errors shown after each concentration are counting errors calculated at one standard deviation. Superscripts after sample numbers are ${ }^{\circ}$ Orofino Metamorphic Suite; ${ }^{\mathrm{C}}$ presumed Orofino Metamorphic Suite rocks but with continental chemical affinity; and ${ }^{\mathrm{B}}$ Belt Supergroup.]

\begin{tabular}{|c|c|c|c|c|c|c|c|c|c|c|c|}
\hline \multicolumn{12}{|c|}{ Samples $^{1}$} \\
\hline (error) & $88-30^{C}$ & $88-19^{0}$ & $88-09^{B}$ & $88-06^{0}$ & $88-07^{B}$ & $88-29^{0}$ & $88-16^{B}$ & $88-23^{0}$ & $88-05^{0}$ & $88-08^{B}$ & $87-57^{0}$ \\
\hline $\mathrm{La}(3 \%)$ & $31.7 \pm 0.2$ & $4.6 \pm 0.1$ & $27.7 \pm 0.2$ & $8.5 \pm 0.1$ & $18.4 \pm 0.2$ & $9.8 \pm 0.1$ & $74.9 \pm 0.4$ & $7.1 \pm 0.1$ & $12.8 \pm 0.2$ & $20.7 \pm 0.2$ & $8.0 \pm 0.1$ \\
\hline $\mathrm{Ce}(7 \%)$ & $55.1 \pm 0.3$ & $12.0 \pm 0.3$ & $52.6 \pm 0.5$ & $22.6 \pm 0.4$ & $36.9 \pm 0.3$ & $22.8 \pm 0.3$ & $167.7 \pm 0.5$ & $19.6 \pm 0.3$ & $31.3 \pm 0.3$ & $40.8 \pm 0.3$ & $21.1 \pm 0.4$ \\
\hline $\mathrm{Nd}(12 \%)$ & $20.9 \pm 1.9$ & $8.8 \pm 1.3$ & $21.6 \pm 3.1$ & $16.2 \pm 3.0$ & $13.4 \pm 1.5$ & $15.2 \pm 2.1$ & $63.1 \pm 3.4$ & $15.2 \pm 1.9$ & $17.0 \pm 2.0$ & $22.0 \pm 2.4$ & $14.2 \pm 3.1$ \\
\hline $\operatorname{Sm}(5 \%)$ & $3.56 \pm 0.02$ & $2.95 \pm 0.02$ & $5.79 \pm 0.03$ & $4.27 \pm 0.02$ & $2.32 \pm 0.02$ & $3.39 \pm 0.02$ & $10.74 \pm 0.04$ & $4.53 \pm 0.02$ & $4.67 \pm 0.02$ & $4.51 \pm 0.03$ & $3.71 \pm 0.03$ \\
\hline $\mathrm{Eu}(5 \%)$ & $0.85 \pm 0.01$ & $1.24 \pm 0.01$ & $1.64 \pm 0.02$ & $1.31 \pm 0.01$ & $1.37 \pm 0.01$ & $1.11 \pm 0.01$ & $1.50 \pm 0.02$ & $1.24 \pm 0.01$ & $1.25 \pm 0.01$ & $1.56 \pm 0.01$ & $1.01 \pm 0.01$ \\
\hline $\mathrm{Tb}(5 \%)$ & $0.26 \pm 0.02$ & $0.67 \pm 0.02$ & $3.72 \pm 0.04$ & $0.84 \pm 0.02$ & $0.25 \pm 0.02$ & $0.56 \pm 0.02$ & $0.90 \pm 0.03$ & $0.94 \pm 0.02$ & $0.97 \pm 0.02$ & $0.78 \pm 0.02$ & $0.77 \pm 0.02$ \\
\hline $\mathrm{Yb}(5 \%)$ & $0.78 \pm 0.06$ & $2.62 \pm 0.11$ & $23.56 \pm 0.13$ & $2.98 \pm 0.11$ & $0.78 \pm 0.08$ & $1.88 \pm 0.08$ & $2.13 \pm 0.10$ & $3.60 \pm 0.10$ & $4.36 \pm 0.07$ & $1.72 \pm 0.08$ & $2.87 \pm 0.02$ \\
\hline $\mathrm{Lu}(5 \%)$ & $0.12 \pm 0.02$ & $0.41 \pm 0.02$ & $3.80 \pm 0.03$ & $0.46 \pm 0.02$ & $0.11 \pm 0.01$ & $0.27 \pm 0.02$ & $0.28 \pm 0.02$ & $0.58 \pm 0.02$ & $0.69 \pm 0.01$ & $0.22 \pm 0.01$ & $0.44 \pm 0.02$ \\
\hline $\mathrm{Rb}(10 \%)$ & $81 . \pm 2$ & $25 . \pm 2$ & $47 . \pm 4$ & $40 . \pm 3$ & $89 . \pm 2$ & $33 . \pm 3$ & $135 . \pm 3$ & $49 . \pm 2$ & $30 . \pm 2$ & $110 . \pm 2$ & $50 . \pm 3$ \\
\hline $\mathrm{Zr}(15 \%)$ & $142 . \pm 10$ & $64 . \pm 11$ & $484 . \pm 29$ & $112 . \pm 16$ & $133 . \pm 9$ & $102 . \pm 17$ & $498 . \pm 21$ & $94 . \pm 15$ & $149 . \pm 13$ & $210 . \pm 14$ & $127 . \pm 19$ \\
\hline Th $(5 \%)$ & $13.0 \pm 0.1$ & $0.4 \pm 0.1$ & $7.6 \pm 0.1$ & $0.8 \pm 0.1$ & $12.3 \pm 0.05$ & $1.4 \pm 0.1$ & $28.7 \pm 0.1$ & $0.8 \pm 0.1$ & $1.6 \pm 0.05$ & $4.4 \pm 0.1$ & $0.9 \pm 0.1$ \\
\hline $\mathrm{Ba}(10 \%)$ & $876 . \pm 25$ & $523 . \pm 33$ & $672 . \pm 45$ & $260 . \pm 34$ & $381 . \pm 23$ & $476 . \pm 35$ & $1140 . \pm 44$ & $494 . \pm 32$ & $235 . \pm 25$ & $656 . \pm 35$ & $361 . \pm 38$ \\
\hline $\mathrm{Cr}(10 \%)$ & $15 . \pm 0.4$ & $9 . \pm 1$ & $191 . \pm 1$ & $28 . \pm 1$ & $60 . \pm 0.5$ & $25 . \pm 1$ & $140 . \pm 1$ & $6 . \pm 1$ & $4 . \pm 1$ & $82 . \pm 1$ & $16 . \pm 1$ \\
\hline
\end{tabular}

${ }^{1}$ Description of samples:

88-30. Coarse-grained garnet-biotite gneiss also containing plagioclase, quartz, sphene, epidote, muscovite, allanite, K-feldspar, and zircon.

88-19. Medium- to coarse-grained hornblende-garnet-biotite gneiss also containing plagioclase, quartz, rutile, opaque minerals, and minor retrograde chlorite.

88-09. Coarse-grained sillimanite-garnet-biotite gneiss with abundant large garnet porphyroblasts and also containing plagioclase, and quartz.

88-06. Medium-grained hornblende-biotite gneiss with alternating biotite- and hornblende-rich laminae on a centimeter scale also containing quartz, plagioclase, sphene, epidote, opaque minerals, and apatite.

88-07. Fine- to medium-grained muscovite-sillimanite-biotite schist also containing quartz, plagioclase, rutile, and zircon.

88-29. Medium-grained biotite-hornblende gneiss also containing plagioclase, quartz, sphene, muscovite, apatite, epidote, allanite, and pyrite.

88-16. Medium- to coarse-grained biotite gneiss also containing plagioclase, quartz, hornblende, zircon, allanite, opaque minerals, and minor amounts of retrograde chlorite

88-23. Medium-grained sillimanite-kyanite-garnet-biotite-K-feldspar gneiss also containing quartz, plagioclase, and muscovite.

88-05. Fine- to medium-grained muscovite-biotite schist also containing plagioclase and quartz.

88-08. Medium- to coarse-grained biotite schist with large rounded plagioclase and also containing quartz, muscovite, and trace phases.

87-57. Fine- to medium-grained hornblende-biotite schist also containing plagioclase, quartz, sphene, apatite, and K-feldspar. 


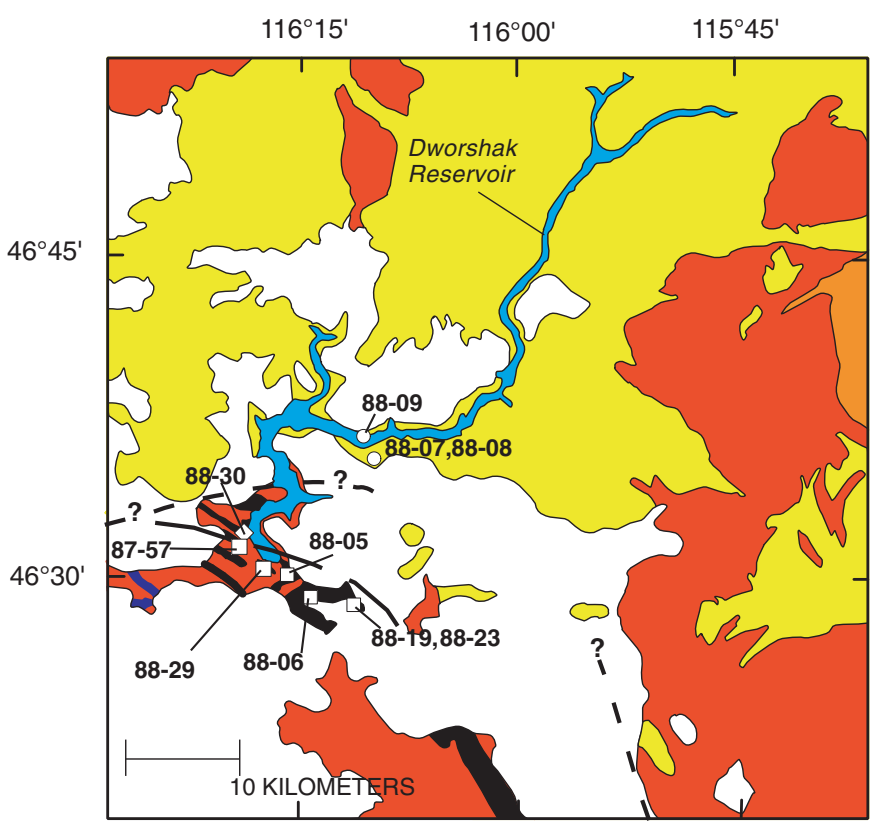

EXPLANATION

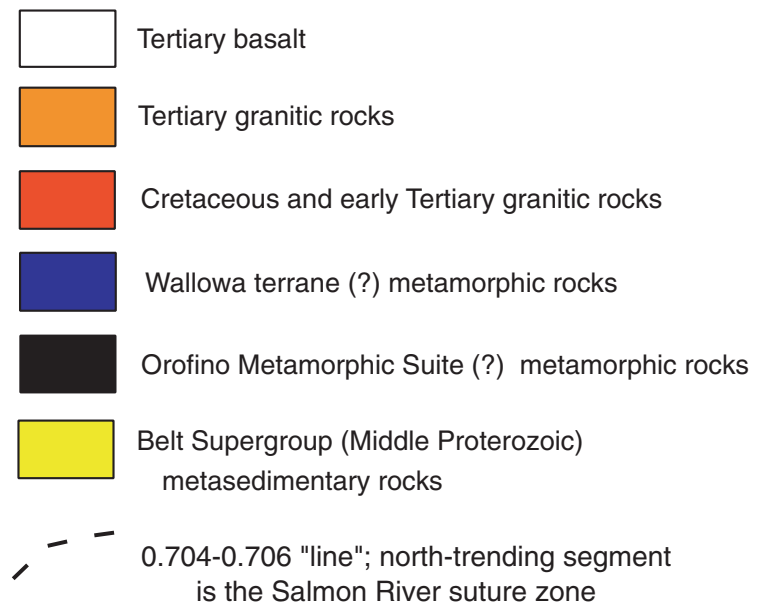

\section{Sample localities \\ $\square \quad$ Orofino Metamorphic Suite (?) rocks with island-arc affinity \\ $\diamond$ Orofino Metamorphic Suite (?) rocks with probable continental affinity \\ - Metamorphosed continental rocks of the Belt Supergroup}

Figure 5. Generalized regional geologic map (same as figure 2) showing geochemical sample localities. Short-dash line shows approximate location of the terrane boundary defined by $\left({ }^{87} \mathrm{Sr} /{ }^{86} \mathrm{Sr}\right)$ i =0.704-0.706 "line" (after Armstrong and others, 1977, and Fleck and Criss, 1985); north-trending segment is the Salmon River suture zone (SRSZ). Long-dash line shows the southernmost extent in the Ahsahka area of Orofino Metamorphic Suite rocks with probable continental affinities based on available trace-element data. South of this line, samples have island-arc affinity. carbonate-bearing sequences in the Baker, Olds Ferry, and Wallowa terranes (Brooks and Vallier, 1978; Silberling and others, 1984) suggests that the Orofino Metamorphic Suite may be broadly correlative with rocks in one of these terranes. Because very low-grade metamorphosed limestone and shale, mapped as Martin Bridge Limestone (Rember and Bennett, 1978), are only $25 \mathrm{~km}$ southwest of Orofino, the island-arc rocks near Ahsahka-Orofino most likely correlate with these rocks of the Wallowa terrane. Thus, we conclude that much of the Orofino Metamorphic Suite correlates with Permian to Jurassic rocks (Vallier, 1977; Brooks and Vallier, 1978) of the Wallowa island-arc sequence.

The similarity of the trace-element compositions of the gneiss sample from along Dworshak Reservoir to continental metasediments near Dent and Pierce suggests the possibility that the gneiss also may be a Precambrian continental rock. Even if the gneiss originated from a granitic protolith, it is chemically more similar to granitic rocks of continental derivation than to granitic rocks in the island-arc terrane (Hoover and others, 1985; Hoover, 1986; Vallier, 1995). Thus, the actual lithologic boundary between island-arc rocks and Precambrian continental rocks in the Ahsahka area is at least as far north as shown by the long-dash line in figure 5. However, initial ${ }^{87} \mathrm{Sr} /{ }^{86} \mathrm{Sr}$ ratios (Fleck and Criss, 1985) indicate that the terrane boundary is as far north and east as the short-dash line. On the basis of the tectonic setting of these rocks and the complexities in initial ${ }^{87} \mathrm{Sr} /{ }^{86} \mathrm{Sr}$ ratios of nearby plutons (see below), there likely is structural intercalation of rocks from opposite sides of the terrane boundary within the zone bounded by the two dashed lines.

\section{${ }^{40} \mathrm{Ar} /{ }^{39} \mathrm{Ar}$ Geochronology}

The ${ }^{40} \mathrm{Ar} /{ }^{39} \mathrm{Ar}$ isotopic dating technique is one of the best methods for determining the timing of metamorphism and thermal history in complex metamorphic terranes. Combined with structural studies, it can also provide valuable constraints on the timing of deformation events. The usefulness of the method for metamorphic and structural studies results from the fact that an ${ }^{40} \mathrm{Ar} /{ }^{39} \mathrm{Ar}$ mineral date records the time when an analyzed mineral closed to diffusion of argon. Closure of a mineral to argon diffusion is controlled mainly by temperature, to a lesser extent by cooling rate (Dodson, 1973) and possibly by chemical composition or strain. Thus, an ${ }^{40} \mathrm{Ar} /{ }^{39} \mathrm{Ar}$ mineral date is a measure of time and temperature. Commonly accepted closure-temperature ranges for rapid cooling $\left(1,000^{\circ} \mathrm{C} / \mathrm{m}\right.$.y. $)$ to slow cooling $\left(5^{\circ} \mathrm{C} / \mathrm{m} . \mathrm{y}\right.$. $)$ are $580^{\circ} \mathrm{C}$ to $480^{\circ} \mathrm{C}$ for hornblende (Harrison, 1981 ), $325^{\circ} \mathrm{C}$ to $270^{\circ} \mathrm{C}$ (Snee and others, 1988) but up to $410^{\circ} \mathrm{C}$ (Hames and Bowring, 1994; Kirschner and others, 1996) for muscovite, and $345^{\circ} \mathrm{C}$ to $280^{\circ} \mathrm{C}$ for biotite (Harrison and others, 1985 ; Snee, 1982). The closure temperature for K-feldspar depends on the nature of argon-diffusion domains within the mineral and may range from less than $150^{\circ} \mathrm{C}$ to greater than the argon-closure temperature of biotite (Harrison and McDougall, 1980). For 
$\boldsymbol{A}$

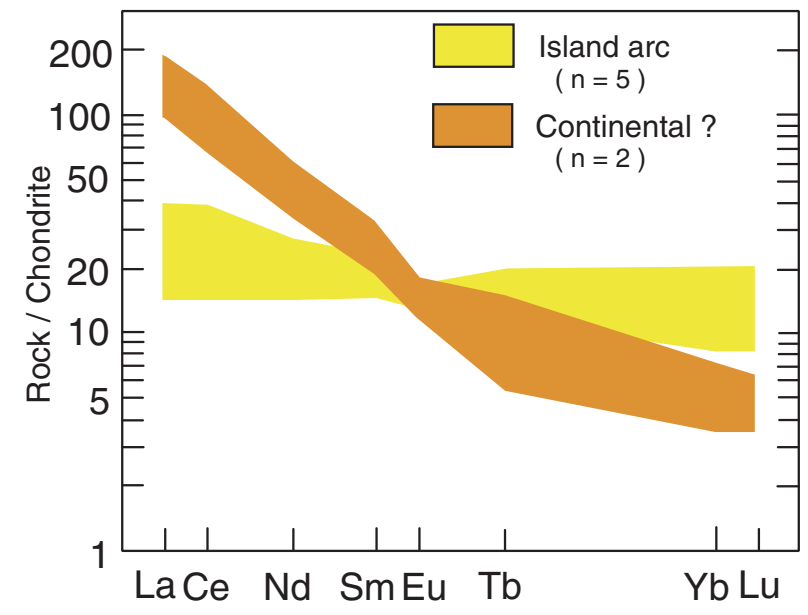

Figure 6. Summary of selected trace-element data for metasedimentary rocks in the area shown in figure 5. $A$, Summary chondrite-normalized rare-earth-element (REE) diagram of Orofino Metamorphic Suite metasedimentary rock samples from the Ahsakha-Orofino area. Yellow pattern (n $=5$ samples) outlines REE of samples with probable islandarc affinity. Orange pattern ( $\mathrm{n}=2$ samples) outlines REE of samples with probable affinity to Proterozoic continental rocks. $B$, Summary chondrite-normalized REE diagram of metasedimentary rock samples from the Belt Supergroup in the Dent and Pierce areas (blue pattern; $\mathrm{n}=3$ samples). Possibly correlative samples of the Orofino Metamorphic Suite (same as figure $6 A$ ) are shown in the green pattern. $C, \mathrm{Rb}, \mathrm{Zr}$, $\mathrm{Th}, \mathrm{Ba}$, and $\mathrm{Cr}$ data for all metasedimentary samples from the area of figure 5 . Key to symbols: squares, Orofino series rock samples with probable island-arc affinity; diamonds, Orofino Metamorphic Suite rock samples with probable continental affinity; circles, Belt Supergroup samples from the Dent and Pierce areas.

this study, a hornblende-closure temperature of $520^{\circ} \mathrm{C}$ is assumed, based on comparison of estimated cooling rates in the study area with experimentally determined hornblendeclosure temperature and cooling-rate relationships of Harrison (1981). Intermediate closure temperatures of $350^{\circ} \mathrm{C}$ and $300^{\circ} \mathrm{C}$ are assumed for muscovite and biotite, respectively. For the single K-feldspar analyzed in this study, we estimate a closure temperature from calculated regional cooling rates.

In order to constrain the timing of deformation, metamorphism, plutonism, and cooling along the Orofino segment of the Salmon River suture zone, Snee and others (1987) and Davidson (1991) conducted detailed ${ }^{40} \mathrm{Ar} /{ }^{39} \mathrm{Ar}$ analyses of hornblende, muscovite, biotite, and K-feldspar mineral separates from metamorphic and plutonic rocks from an area extending from Peck to approximately $5 \mathrm{~km}$ north of Ahsahka and $8 \mathrm{~km}$ east of Orofino (figure 3). In addition, Snee and
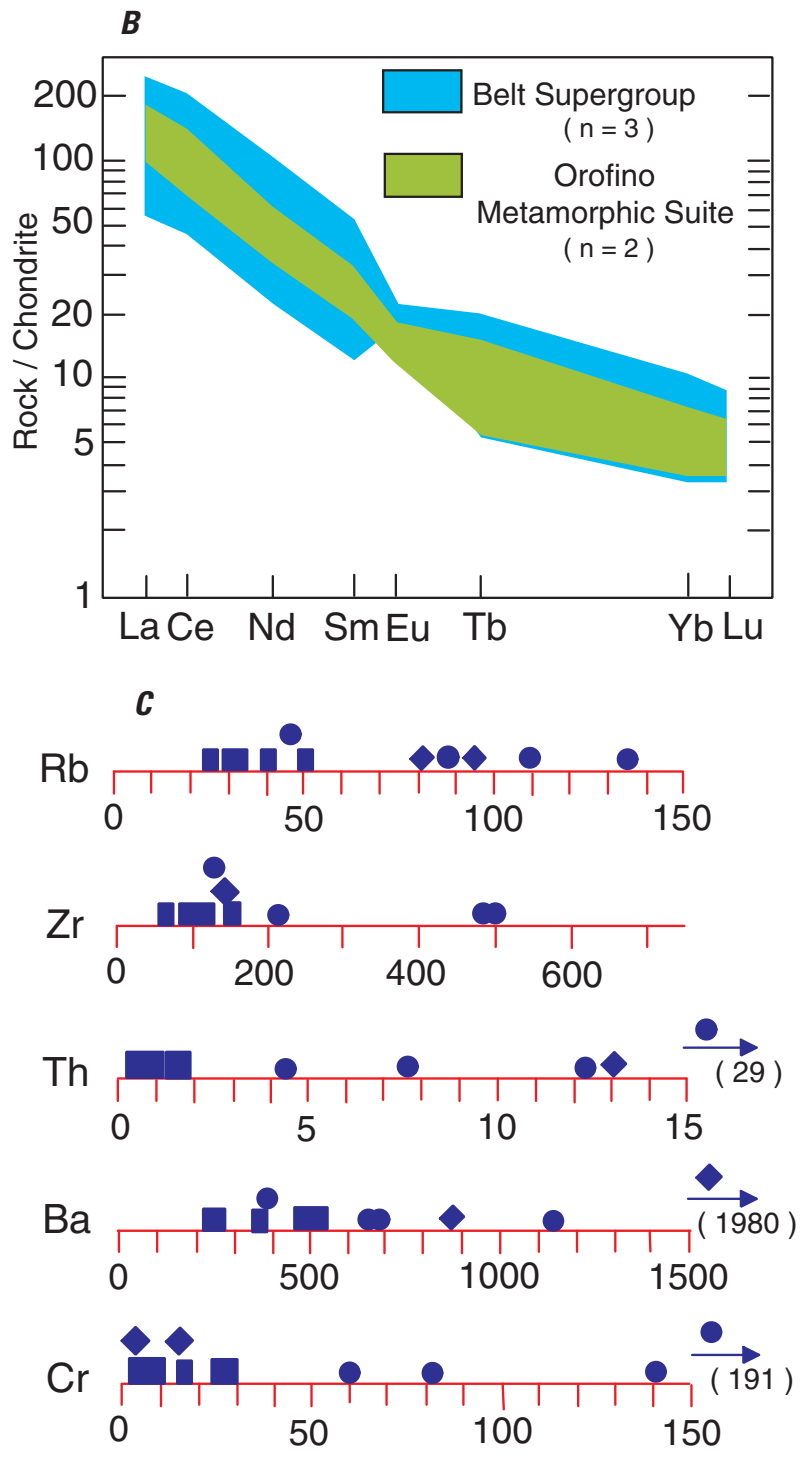

ppm

others (1987) completed reconnaissance-scale ${ }^{40} \mathrm{Ar} /{ }^{\beta 9} \mathrm{Ar}$ analyses on samples from the Dent, Headquarters, and Pierce areas, located north and east of Orofino (fig. 2), that place constraints on the regional cooling and uplift history. Samples in this study show a range from simple plateau age spectra to strongly discordant age spectra. Age spectra are interpreted to define a plateau (abbreviated $\mathrm{T}_{\mathrm{p}}$ ) if apparent ages from adjacent heating steps comprising 50 percent or more of the total released ${ }^{39} \mathrm{Ar}_{\mathrm{K}}$ are analytically indistinguishable at the two sigma level (95-percent confidence interval). For samples that yield plateau age spectra, the plateau date is interpreted to represent the best estimate of the time when the mineral closed to argon diffusion. In some cases where age spectra are more complex and apparent ages do not define a plateau, argon-isochron analysis was employed and an isochron date is the preferred date. 
Strongly discordant age spectra are interpreted individually in combination with other information. Where average apparent ages are reported as preferred dates (abbreviated $\mathrm{T}_{\mathrm{pf}}$ ), apparent ages for selected steps that statistically overlap at the threesigma level (99-percent confidence interval) are weighted according to the released ${ }^{39} \mathrm{Ar}_{\mathrm{K}}$ for each step included in the calculation. The reported uncertainty for a preferred date represents one standard deviation from the mean apparent age. For age spectra that show apparent argon loss, that is, the apparent age of temperature steps in the age spectrum increases from younger to older dates with increasing cumulative percent of released ${ }^{39} \mathrm{Ar}_{\mathrm{K}}$, maximum and minimum apparent ages (abbreviated $\mathrm{T}_{\mathrm{mx}}$ and $\mathrm{T}_{\mathrm{mn}}$, respectively) are reported. Comprehensive discussions on the interpretation of ${ }^{40} \mathrm{Ar} /{ }^{39} \mathrm{Ar}$ age spectra can be found in Snee (2002) and McDougall and Harrison (1999).

Because, in this data set, there is a clear spatial pattern in which rocks preserving evidence for the oldest events occur farthest outboard of the terrane boundary, discussion of the ${ }^{40} \mathrm{Ar} /{ }^{39} \mathrm{Ar}$ data begins with the oldest samples, collected from rocks below the Big Canyon Creek thrust fault at Peck. Discussion then proceeds to the data for rocks between the Big Canyon Creek thrust fault and the Ahsahka thrust, which record the oldest dynamothermal event and subsequent resetting of the K-Ar isotopic systems. Next, data are presented for the high-grade rocks within the boundary zone (above the Ahsahka thrust) and areas north and east of Orofino. Sample localities and interpreted dates are shown in figures 7 and 9; interpreted ${ }^{40} \mathrm{Ar} /{ }^{39} \mathrm{Ar}$ data are presented in table 2. Detailed interpretations of the data of this paper with all data, age spectra, $\mathrm{K} / \mathrm{Ca}$ diagrams, isochron diagrams, and analytical procedures are given in Davidson (1991), and some analytical details are summarized at the beginning of table 2. Typical methods of ${ }^{40} \mathrm{Ar} /{ }^{39} \mathrm{Ar}$ dating are described in Dalyrmple and others (1981), Snee and others (1988), and Snee (2002).

\section{Peck Area: Oldest Plutonism}

The oldest thermal event preserved in the study area is recorded in the Wallowa terrane by hornblende samples from a biotite-hornblende quartz diorite pluton (sample 1H) and amphibolite hornfels (sample $2 \mathrm{H}$ ) from its country rocks at Peck, below the Big Canyon Creek thrust fault (fig. 7A).

Although age spectra for both samples show minor Ar loss in the low temperature steps, hornblende sample $1 \mathrm{H}$ gives a plateau date of $138.0 \pm 0.4 \mathrm{Ma}$. Biotite from the same sample (sample 1B) yields a plateau date of $135.1 \pm 0.4 \mathrm{Ma}$ (fig. 7B). Because of the undeformed and unmetamorphosed character of the pluton and the simple age spectra, these dates are interpreted to represent postemplacement cooling ages; the sample cooled below $520^{\circ} \mathrm{C}$ at $138 \mathrm{Ma}$ and below $280^{\circ} \mathrm{C}$ at $135 \mathrm{Ma}$. The argon data for hornblende sample $2 \mathrm{H}$ from the amphibolite hornfels, collected about $170 \mathrm{~m}$ from the mapped pluton contact, give an isochron date of $144.3 \pm 2.0$
Ma (Davidson, 1991), which includes steps with a large portion of the released ${ }^{39} \mathrm{Ar}_{\mathrm{K}}$ and provides a close approximation of the time when the amphibolite hornfels cooled to below hornblende-closure temperature. From these data, we conclude that rocks below the Big Canyon Creek thrust fault were $\operatorname{cool}\left(<280^{\circ} \mathrm{C}\right)$ before the ca. 130-Ma metamorphic event that affected the rocks above the fault and were unaffected, within the resolution of the thermochronologic data, by the 130-Ma and subsequent dynamothermal events that occurred along the terrane boundary.

\section{Peck to the Clearwater River: Oldest Dynamothermal Event and Younger Plutonism}

Lower amphibolite-facies island-arc rocks between the Big Canyon Creek thrust fault and the Ahsahka thrust record the oldest clearly dynamothermal event in the area as well as a complicated pattern of subsequent structural and thermal overprinting. Age spectra for eight hornblende samples from amphibolite and mafic plutonic rocks along Big Canyon Creek, north of the Big Canyon Creek thrust fault, and along the Clearwater River near the mouth of Big Canyon Creek, show varying degrees of discordance and argon loss, with maximum or plateau dates in the range 129 to $116 \mathrm{Ma}$ (fig. 7). These data are interpreted to reflect a period of metamorphism at about $129 \mathrm{Ma}$ and a later period of emplacement of mafic magmas derived from melting island-arc crust and upper mantle between about 122 and $115 \mathrm{Ma}$. Most samples have experienced variable degrees of argon loss due to the effects of later thermal and (or) structural activity.

The observed pattern of hornblende dates for samples of amphibolite between the Big Canyon Creek thrust fault and the Clearwater River (samples $3 \mathrm{H}, 4 \mathrm{H}, 5 \mathrm{H}$, and $6 \mathrm{H}$ ) is strong evidence that amphibolite-facies metamorphism occurred at about $129 \mathrm{Ma}$. Within the hornblende argon data for the metamorphic rocks, there appears to be a relationship between greater percent ${ }^{40} \mathrm{Ar}$ loss and lower maximum apparent ages or plateau dates for the higher temperature gas fractions; the most strongly disturbed spectra show the youngest apparent ages, consistent with theoretical predictions by Turner (1968). Therefore, the oldest date of about $129 \mathrm{Ma}$ for sample $4 \mathrm{H}$, which experienced only very minor Ar loss, should most closely approximate the time of metamorphism in this rock package. The common prograde mineral assemblage of hornblende + plagioclase + epidote + chlorite is consistent with metamorphic conditions in the lower amphibolite facies, which indicates that the maximum temperature was probably not much above $500^{\circ} \mathrm{C}$, at or below the closure temperature of hornblende. Therefore, it is likely that hornblende in these rocks closed to Ar diffusion either immediately upon formation or soon after, and that 129 Ma closely approximates the time of hornblende 
Table 2. Summary of ${ }^{40} \mathrm{Ar} /{ }^{39} \mathrm{Ar}$ age-spectrum data for the Orofino, Idaho, area

[Mineral abbreviations as letter suffixes after sample numbers are H, hornblende, M, muscovite, B, biotite, and K, K-feldspar. Structure abbreviations are BCCT, Big Canyon Creek thrust, and AT, Ahsakha thrust. Other abbreviations: do, ditto; $\mathrm{T}_{\mathrm{p}}$, plateau date; $\mathrm{T}_{\mathrm{p}}$, preferred date; $\mathrm{T}_{\mathrm{i}}$, isochron date; $\mathrm{T}_{\mathrm{mx}}$, maximum date; $\mathrm{T}_{\mathrm{mn}}$, minimum date; $\mathrm{s}$, shear zone sample, cr, coarse-grained, fn, fine-grained. Samples with superscript ${ }^{\mathrm{r}}$ were analyzed in the Argon Laboratory, U.S. Geological Survey, Reston, Virginia; all others were analyzed in the Argon Geochronology Laboratory, U.S. Geological Survey, Denver, Colorado. Analytical details are available in Davidson (1991) and Snee and others (1995). All errors are one standard deviation from the mean. Decay constants are those of Steiger and Jäger (1977). Irradiation standard for all analyses was MMhb-1 hornblende with K-Ar age=520.4 Ma.]

\begin{tabular}{|c|c|c|c|}
\hline Sample No. & Rock type & $\begin{array}{l}\text { Date } \\
\text { (Ma) }\end{array}$ & Characteristic \\
\hline \multicolumn{4}{|c|}{ Units below the BCCT } \\
\hline $1 \mathrm{H}$ & Quartz diorite & $\mathrm{T}_{\mathrm{p}}=138.0 \pm 0.4$ & Plateau \\
\hline 1B & do & $\mathrm{T}_{\mathrm{p}}=135.1 \pm 0.4$ & Plateau \\
\hline $2 \mathrm{H}$ & Amphibolite hornfels & $\mathrm{T}_{\mathrm{i}}=144.3 \pm 2.0$ & Slightly disturbed \\
\hline \multicolumn{4}{|c|}{ Units between BCCT and AT } \\
\hline \multirow[t]{2}{*}{$3 \mathrm{H}^{\mathrm{r}}$} & Amphibolite & $\mathrm{T}_{\mathrm{mx}}=120.8 \pm 0.7$ & Argon loss \\
\hline & & $\mathrm{T}_{\mathrm{mn}}=107.1 \pm 1.0$ & \\
\hline $4 \mathrm{H}^{\mathrm{r}}$ & Amphibolite & $\mathrm{T}_{\mathrm{pf}}=129.1 \pm 1.0$ & Slightly disturbed \\
\hline $5 \mathrm{H}$ & Hornblende gneiss & $\mathrm{T}_{\mathrm{pf}}=123.9 \pm 0.7$ & Slightly disturbed \\
\hline $6 \mathrm{H}$ & Amphibolite & $\mathrm{T}_{\mathrm{pf}}=124.1 \pm 1.2$ & do \\
\hline $7 \mathrm{H}^{\mathrm{r}}$ & Gabbro & $\mathrm{T}_{\mathrm{pf}}=117.2 \pm 0.9$ & Argon loss \\
\hline $8 \mathrm{H}$ & Quartz diorite & $\mathrm{T}_{\mathrm{pf}}=119.4 \pm 1.2$ & do \\
\hline $9 \mathrm{H}$ & do & $\mathrm{T}_{\mathrm{pf}}=115.0 \pm 0.8$ & do \\
\hline $10 \mathrm{H}$ & Quartz diorite & $\mathrm{T}_{\mathrm{p}}=121.1 \pm 0.5$ & Plateau \\
\hline $11 \mathrm{H}$ & Diorite & $\mathrm{T}_{\mathrm{p}}=82.0 \pm 0.5$ & Plateau \\
\hline $12 \mathrm{H}$ & do & $\mathrm{T}_{\mathrm{pf}}=106.5 \pm 0.5$ & Slightly disturbed \\
\hline $13 \mathrm{H}$ & do & $\mathrm{T}_{\mathrm{pf}}=94.0 \pm 1.0$ & Disturbed \\
\hline $14 \mathrm{H}$ & Quartz diorite & $\mathrm{T}_{\mathrm{pf}}=99.5 \pm 1.0$ & do \\
\hline 14B & do & $\mathrm{T}_{\mathrm{i}}=77.1 \pm 1.0$ & Slightly disturbed \\
\hline $21 \mathrm{~B}$ & Biotite schist & $\mathrm{T}_{\mathrm{p}}=78.6 \pm 0.2$ & Plateau \\
\hline $22 \mathrm{M}$ & Late felsic dike & $\mathrm{T}_{\mathrm{p}}=77.3 \pm 0.2$ & Plateau \\
\hline \multicolumn{4}{|c|}{ Sheared Units between BCCT and AT } \\
\hline $15 \mathrm{H}$ & Sheared pluton & $\mathrm{T}_{\mathrm{i}}=88.3 \pm 1.5$ & Disturbed \\
\hline $16 \mathrm{H}$ & do & $\mathrm{T}_{\mathrm{pf}}=87.0 \pm 0.7$ & do \\
\hline $17 \mathrm{H}$ & do & $\mathrm{T}_{\mathrm{i}}=85.6 \pm 1.5$ & Slightly disturbed \\
\hline $17 \mathrm{~B}$ & do & $\mathrm{T}_{\mathrm{i}}=78.2 \pm 1.2$ & do \\
\hline $18 \mathrm{M}-\mathrm{cr}$ & $\begin{array}{l}\text { Sheared pegmatite } \\
\text { (coarse-grained muscovite) }\end{array}$ & $\mathrm{T}_{\mathrm{i}}=97.5 \pm 0.8$ & do \\
\hline $18 \mathrm{M}-\mathrm{fn}$ & do & $\mathrm{T}_{\mathrm{i}}=81.5 \pm 1.0$ & do \\
\hline $19 \mathrm{H}$ & $\begin{array}{l}\text { (fine-grained muscovite) } \\
\text { Sheared amphibolite }\end{array}$ & $\mathrm{T}_{\mathrm{i}}=92.5 \pm 3.0$ & do \\
\hline 19B & do & $\mathrm{T}_{\mathrm{i}}=80.2 \pm 1.3$ & do \\
\hline \multirow[t]{2}{*}{$20 \mathrm{M}$} & Sheared schist & $\mathrm{T}_{\mathrm{mx}}=89.0 \pm 0.2$ & Argon loss \\
\hline & & $\mathrm{T}_{\mathrm{mn}}=82.0 \pm 0.2$ & \\
\hline \multicolumn{4}{|c|}{ Units above AT } \\
\hline $23 \mathrm{H}$ & Tonalite gneiss & $\mathrm{T}_{\mathrm{p}}=83.5 \pm 0.4$ & Plateau \\
\hline $23 \mathrm{~B}$ & do & $\mathrm{T}_{\mathrm{p}}=76.4 \pm 0.2$ & do \\
\hline $24 \mathrm{H}$ & Diorite gneiss & $\mathrm{T}_{\mathrm{pf}}=81.5 \pm 1.2$ & Slightly disturbed \\
\hline $25 \mathrm{H}^{\mathrm{r}}$ & Quartz diorite gneiss & $\mathrm{T}_{\mathrm{p}}=81.9 \pm 0.4$ & Plateau \\
\hline $25 \mathrm{~B}^{\mathrm{r}}$ & do & $\mathrm{T}_{\mathrm{p}}=76.4 \pm 0.4$ & do \\
\hline $26 \mathrm{H}^{\mathrm{r}}$ & do & $\mathrm{T}_{\mathrm{p}}=81.9 \pm 0.3$ & do \\
\hline
\end{tabular}


Table 2. Summary of ${ }^{40} \mathrm{Ar} /{ }^{39} \mathrm{Ar}$ age-spectrum data for the Orofino, Idaho, area.-Continued

[Mineral abbreviations as letter suffixes after sample numbers are H, hornblende, M, muscovite, B, biotite, and K, K-feldspar. Structure abbreviations are BCCT, Big Canyon Creek thrust, and AT, Ahsakha thrust. Other abbreviations: do, ditto; $\mathrm{T}_{\mathrm{p}}$, plateau date; $\mathrm{T}_{\mathrm{pf}}$, preferred date; $\mathrm{T}_{\mathrm{i}}$, isochron date; $\mathrm{T}_{\mathrm{mx}}$, maximum date; $\mathrm{T}_{\mathrm{mn}}$, minimum date; $\mathrm{s}$, shear zone sample, cr, coarse-grained, fn, fine-grained. Samples with superscript ${ }^{\mathrm{r}}$ were analyzed in the Argon Laboratory, U.S. Geological Survey, Reston, Virginia; all others were analyzed in the Argon Geochronology Laboratory, U.S. Geological Survey, Denver, Colorado. Analytical details are available in Davidson (1991) and Snee and others (1995). All errors are one standard deviation from the mean. Decay constants are those of Steiger and Jäger (1977). Irradiation standard for all analyses was MMhb-1 hornblende with K-Ar age=520.4 Ma.]

\begin{tabular}{|c|c|c|c|}
\hline Sample No. & Rock type & $\begin{array}{l}\text { Date } \\
\text { (Ma) }\end{array}$ & Characteristic \\
\hline \multicolumn{4}{|c|}{ Units above AT } \\
\hline $26 \mathrm{~B}^{\mathrm{r}}$ & do & $\mathrm{T}_{\mathrm{p}}=$ & do \\
\hline $27 \mathrm{H}$ & Garnet amphibolite & $\mathrm{T}_{\mathrm{p}}=80.6 \pm 0.3$ & do \\
\hline $28 \mathrm{H}$ & do & $\mathrm{T}_{\mathrm{p}}=79.4 \pm 0.5$ & do \\
\hline $29 \mathrm{H}$ & Biotite-hornblende schist & $\mathrm{T}_{\mathrm{p}}=80.4 \pm 0.2$ & do \\
\hline 29B & do & $\mathrm{T}_{\mathrm{p}}=73.9 \pm 0.2$ & do \\
\hline $30 \mathrm{H}^{\mathrm{r}}$ & Amphibolite & $\mathrm{T}_{\mathrm{p}}=81.9 \pm 0.4$ & do \\
\hline $31 \mathrm{H}$ & Biotite-hornblende gneiss & $\mathrm{T}_{\mathrm{p}}=80.6 \pm 0.3$ & do \\
\hline $31 \mathrm{~B}$ & do & $\mathrm{T}_{\mathrm{p}}=75.1 \pm 0.3$ & do \\
\hline $32 \mathrm{H}$ & Amphibolite & $\mathrm{T}_{\mathrm{p}}=79.4 \pm 0.5$ & do \\
\hline $32 \mathrm{~B}$ & do & $\mathrm{T}_{\mathrm{p}}=73.5 \pm 0.4$ & do \\
\hline $33 \mathrm{H}$ & do & $\mathrm{T}_{\mathrm{p}}=78.8 \pm 0.2$ & do \\
\hline $34 \mathrm{H}$ & do & $\mathrm{T}_{\mathrm{p}}=78.2 \pm 0.9$ & do \\
\hline $35 \mathrm{H}$ & Quartz diorite & $\mathrm{T}_{\mathrm{p}}=81.2 \pm 0.2$ & do \\
\hline $35 \mathrm{~B}$ & do & $\mathrm{T}_{\mathrm{p}}=75.3 \pm 0.2$ & do \\
\hline $36 \mathrm{M}$ & Tonalite gneiss & $\mathrm{T}_{\mathrm{p}}=75.3 \pm 0.2$ & do \\
\hline $36 \mathrm{~B}$ & do & $\mathrm{T}_{\mathrm{p}}=74.1 \pm 0.2$ & do \\
\hline 37B & Quartz diorite gneiss & $\mathrm{T}_{\mathrm{p}}=73.5 \pm 0.2$ & do \\
\hline \multirow[t]{2}{*}{$37 \mathrm{~K}$} & do & $\mathrm{T}_{\mathrm{mx}}=70.9 \pm 0.2$ & Apparent \\
\hline & & $\mathrm{T}_{\mathrm{mn}}=60.6 \pm 0.2$ & argon loss \\
\hline $38 \mathrm{M}$ & Schist & $\mathrm{T}_{\mathrm{p}}=74.6 \pm 0.3$ & Plateau \\
\hline $38 \mathrm{~B}$ & do & $\mathrm{T}_{\mathrm{p}}=74.6 \pm 0.3$ & do \\
\hline $39 \mathrm{M}$ & Granite & $\mathrm{T}_{\mathrm{p}}=72.1 \pm 0.3$ & do \\
\hline 40B & do & $\mathrm{T}_{\mathrm{p}}=72.4 \pm 0.2$ & do \\
\hline \multicolumn{4}{|c|}{ Units above AT--Regional Coverage } \\
\hline $41 \mathrm{H}$ & Amphibolite & $\mathrm{T}_{\mathrm{pf}}=81.2 \pm 0.3$ & Slightly disturbed \\
\hline $42 \mathrm{H}$ & Gneissic tonalite & $\mathrm{T}_{\mathrm{p}}=76.3 \pm 0.2$ & Plateau \\
\hline $42 \mathrm{~B}$ & Granodiorite gneiss & $\mathrm{T}_{\mathrm{p}}=73.5 \pm 0.2$ & do \\
\hline $43 \mathrm{H}^{\mathrm{r}}$ & Amphibolite & $\mathrm{T}_{\mathrm{p}}=69.9 \pm 0.5$ & do \\
\hline $44 \mathrm{H}^{\mathrm{r}}$ & do & $\mathrm{T}_{\mathrm{p}}=75.1 \pm 0.3$ & do \\
\hline $45 \mathrm{H}^{\mathrm{r}}$ & Tonalite & ------ & Excess argon \\
\hline $45 \mathrm{~B}^{\mathrm{r}}$ & do & $\mathrm{T}_{\mathrm{p}}=55.2 \pm 0.4$ & Plateau \\
\hline $46 \mathrm{H}$ & Garnet amphibolite & ------ & Excess argon \\
\hline $47 \mathrm{H}^{\mathrm{r}}$ & Quartz diorite & $\mathrm{T}_{\mathrm{p}}=63.8 \pm 0.4$ & Plateau \\
\hline $47 \mathrm{~B}^{\mathrm{r}}$ & do & $\mathrm{T}_{\mathrm{p}}=57.3 \pm 0.5$ & do \\
\hline $48 \mathrm{H}^{\mathrm{r}}$ & do & $\mathrm{T}_{\mathrm{p}}=62.6 \pm 0.5$ & do \\
\hline $48 \mathrm{~B}^{\mathrm{r}}$ & do & $\mathrm{T}_{\mathrm{p}}=54.1 \pm 0.4$ & do \\
\hline $49 \mathrm{M}^{\mathrm{r}}$ & Schist & $\mathrm{T}_{\mathrm{p}}=63.8 \pm 0.2$ & do \\
\hline $49 \mathrm{~B}^{\mathrm{r}}$ & do & $\mathrm{T}_{\mathrm{p}}=64.2 \pm 0.5$ & do \\
\hline $50 \mathrm{M}^{\mathrm{r}}$ & Granite & $\mathrm{T}_{\mathrm{p}}=63.7 \pm 0.2$ & do \\
\hline $50 \mathrm{~B}^{\mathrm{r}}$ & do & $\mathrm{T}_{\mathrm{p}}=62.0 \pm 0.5$ & do \\
\hline
\end{tabular}




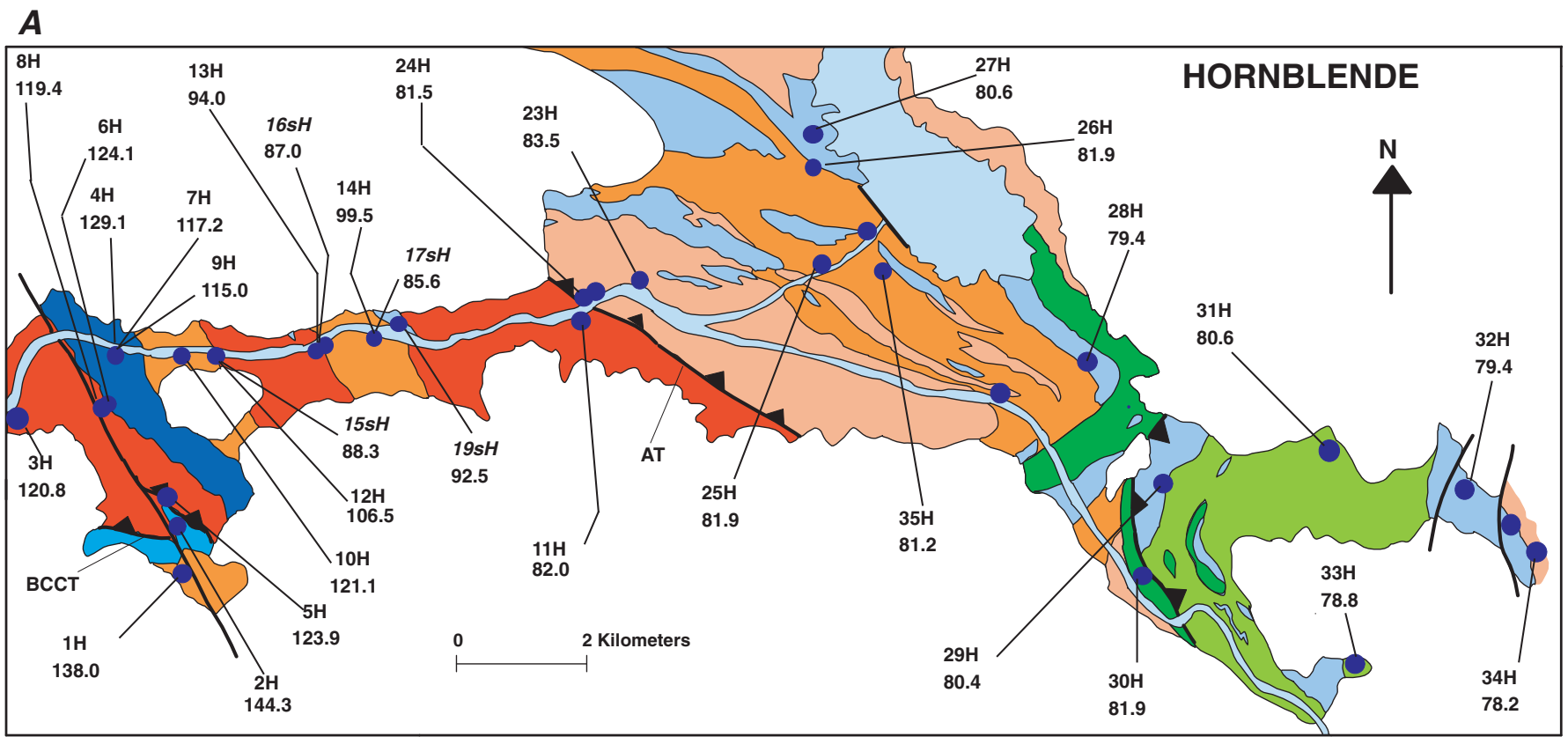

\section{B}

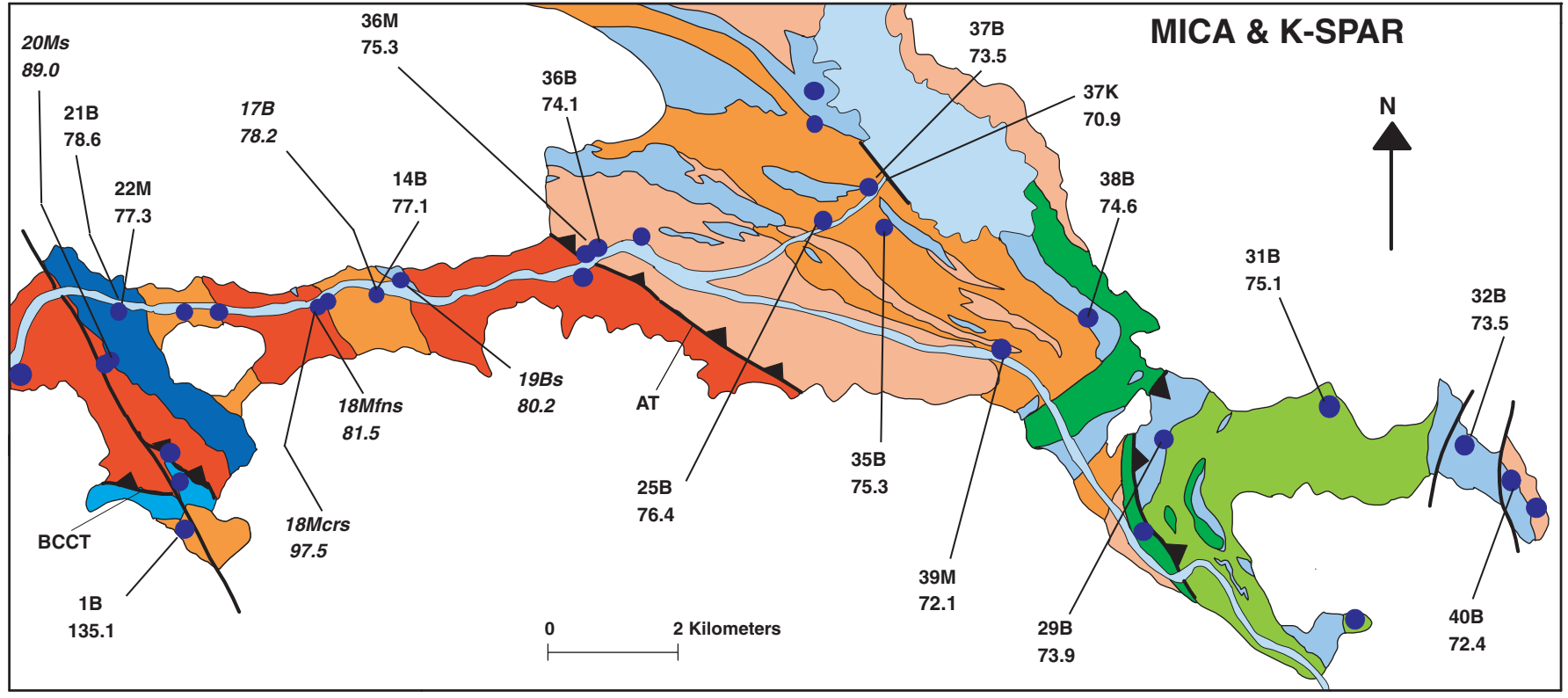

Figure 7. Geologic map of the Peck-Ahsahka-Orofino area showing ${ }^{40} \mathrm{Ar} /{ }^{39} \mathrm{Ar}$ sample localities and interpreted age-spectrum data (in Ma). Data shown in italic print and with "s" after mineral abbreviation are from shear zones. For explanation of general geology, see figure 3. Abbreviations: AT, Ahsahka thrust; BCCT, Big Canyon Creek Thrust. $A$, Data for hornblende (H). B, Data for biotite (B), muscovite (M; cr-coarse grained, fn-fine grained), and K-feldspar (K). 
formation during the lower amphibolite facies metamorphic event. The fact that the hornblende in these samples commonly defines a strong lineation indicates that metamorphism was accompanied by deformation. The disturbed character of most of the age spectra suggests that the K-Ar isotopic systems in hornblende from these rocks were variably affected by subsequent deformation and (or) thermal activity as exhibited texturally in some samples (fig. $8 A, B, F$ ).

Similarly, the hornblende argon data for plutonic rocks of this area (samples $7 \mathrm{H}, 8 \mathrm{H}, 9 \mathrm{H}$, and $10 \mathrm{H}$ ) indicate that emplacement of mafic magmas probably took place between 122 and $115 \mathrm{Ma}$. At the time of emplacement of these plutons, the metamorphic host rocks had cooled below the hornblende argon-closure temperature of about $520^{\circ} \mathrm{C}$ based on ${ }^{40} \mathrm{Ar} /{ }^{39} \mathrm{Ar}$ cooling ages for the metamorphic hornblendes. The disturbed character of most of the plutonic hornblende age spectra, as with the spectra for the metamorphic hornblendes, suggests that the K-Ar isotopic systems in hornblende from these rocks were variably affected by later deformation and thermal activity. That these dates are reasonable approximations for emplacement ages is supported by $\mathrm{U}-\mathrm{Pb}$ zircon data, presented below, that confirm emplacement of quartz diorite within the islandarc terrane at about $116 \mathrm{Ma}$.

Also of geologic interest for this study, the close proximity of sample $5 \mathrm{H}\left(\mathrm{T}_{\mathrm{p}}=123.9 \pm 0.7 \mathrm{Ma}\right)$ from immediately above the Big Canyon Creek thrust fault to sample $2 \mathrm{H}$ (approximately $144 \mathrm{Ma}$ ) from below the fault (fig. 7A), provides evidence that the rock packages were juxtaposed along the Big Canyon Creek thrust fault after about $124 \mathrm{Ma}$. Below, we constrain the age of the Big Canyon Creek thrust fault to younger than $80 \mathrm{Ma}$. Lack of resetting of the mineral K-Ar isotopic systems in rocks below the Big Canyon Creek thrust fault suggests that the rocks in the hanging wall were relatively cool at the time of juxtaposition. This is consistent with the observed brittle character of the Big Canyon Creek thrust fault.

\section{Overprinting Events in Rocks along the Clearwater River}

In order to define a possible gradient in mineral dates from oldest to youngest samples in the high-grade rocks along the terrane boundary, detailed sampling of the mafic plutons and nonplutonic metamorphic rocks along the Clearwater River from north of Peck to the Ahsahka thrust was carried out. Samples were collected both from massive plutonic rocks and from northeast-dipping mylonitic shear zones that cut the plutons in an attempt to constrain the time of southwest-directed thrusting in the area. With the exception of sample $11 \mathrm{H}$ (collected just west of the Ahsahka thrust), which yielded a plateau date of $82.0 \pm 0.5 \mathrm{Ma}$ that is consistent with dates in the high-grade terrane (discussed in a subsequent section), all age spectra for hornblende from the massive plutonic rocks are strongly disturbed and have discordant apparent ages younger than about $107 \mathrm{Ma}$ (fig. 7A). In contrast, hornblendes from the mylonitic shear zones yield significantly younger apparent ages between 93 and $85 \mathrm{Ma}$.

Four hornblende samples from relatively undeformed mafic plutonic rocks along the Clearwater River were analyzed. From west to east, samples in this group include $12 \mathrm{H}$ and $13 \mathrm{H}$ from gabbro, $14 \mathrm{H}$ from quartz diorite, and $11 \mathrm{H}$ from diorite located just west of the Ahsahka thrust (fig. 7A). The samples typically are medium grained and massive; relict igneous textures are commonly preserved and foliation and lineation, where present, are weak. Minor deformation features include undulose extinction in quartz and plagioclase and bent biotite. In view of the lithologic and chemical similarities between these plutons and the 122- to 115-Ma plutons structurally lower in the section, the plutons are likely comagmatic. Except for sample $11 \mathrm{H}$, age spectra for these samples (Davidson, 1991) are complex and do not define plateau dates. The age spectra show apparent ages that span most of the range between apparent ages for the most disturbed samples from structurally lower rocks to the west and southwest and apparent ages for hornblende from shear zones that cut the plutons (see below). This observation suggests that the complex hornblende age spectra do not directly record geologically meaningful ages, but result from disturbance of the K-Ar isotopic systematics in the hornblende subsequent to earlier closure to argon diffusion. Although it is possible that the disturbed age spectra resulted from a post-115-Ma metamorphic event, it is more likely that these spectra were disturbed during later shear-zone activity.

In order to constrain the timing of movement on the numerous northeast-dipping mylonitic shear zones that cut the mafic plutons below the Ahsahka thrust, three hornblende samples from mylonitic plutonic rocks within three different shear zones were analyzed. Shear-zone hornblende samples are $15 s H, 16 s H$, and $17 s H$ (figs. $7,8 C-F$ ). These samples were collected from within a few meters of samples $12 \mathrm{H}, 13 \mathrm{H}$, and $14 \mathrm{H}$, respectively (discussed above), which are protoliths to the shear-zone rocks. Dates recorded by the shear-zone hornblende samples range from 93 to 85 Ma. These dates are not strictly cooling ages as clearly demonstrated by the preservation of distinctly older apparent ages recorded by hornblende from adjacent massive plutonic rocks (protoliths to the mylonitic rocks). Two lines of evidence suggest that the ambient temperature in this rock package as a whole was probably below hornblende-closure temperature $\left(\mathrm{ca} .520^{\circ} \mathrm{C}\right.$ ) during the shear-zone deformation. First, if an ambient temperature at or above hornblende closure was maintained for an extended time interval, hornblende from rocks outside the shear zones should show cooling ages similar to apparent ages seen for the shear-zone samples; this is not observed. Second, although retrograde actinolite is not visible in thin sections of the analyzed samples, similar shear zones within mafic plutons along the Clearwater River contain locally developed retrograde actinolite and chlorite within the foliation, suggesting that shearing took place under greenschist-facies conditions, at least during the late stages of deformation. 

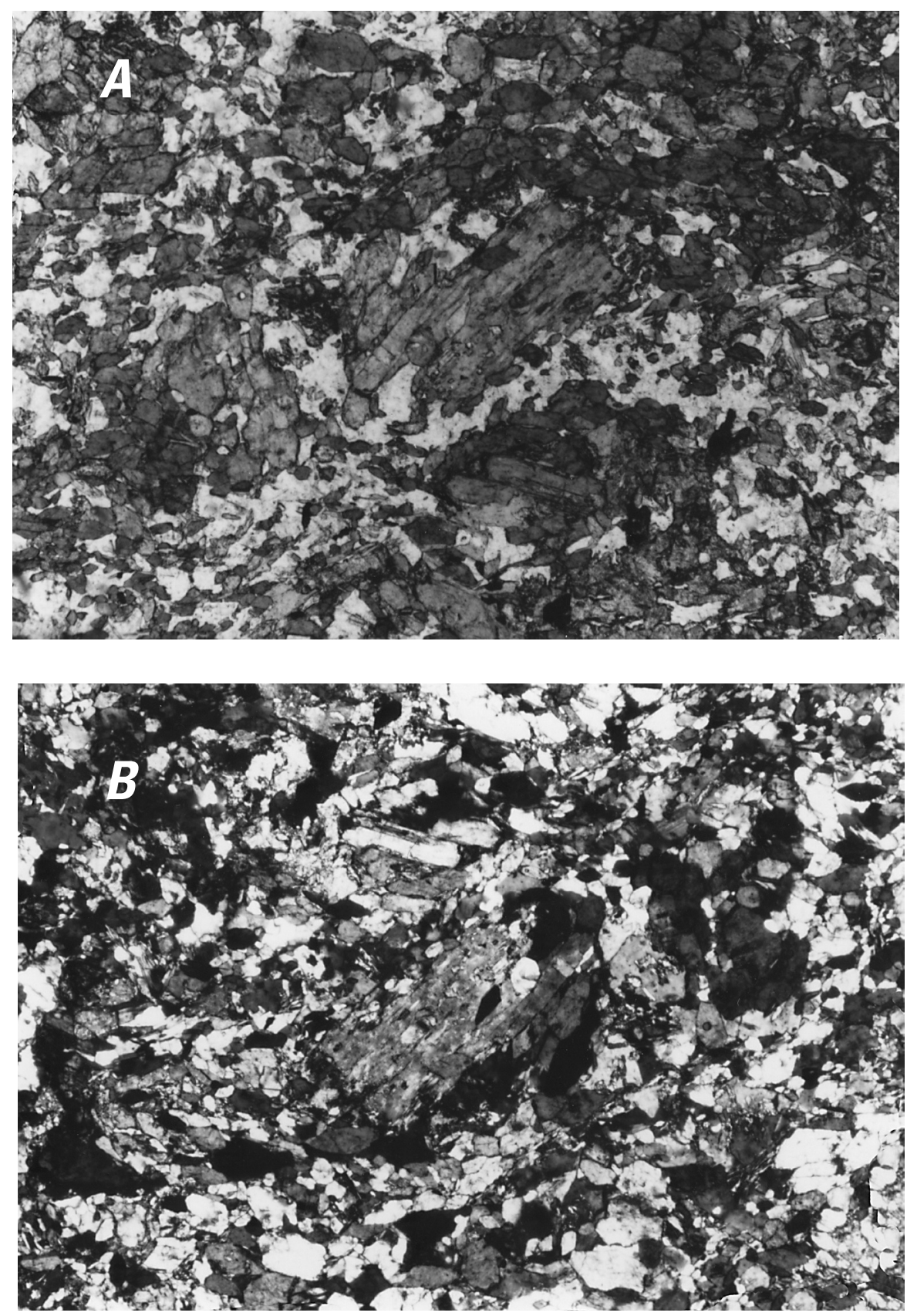

Figure 8. Photographs of rocks along the Clearwater River: $A$, Photomicrograph of amphibolite (sample 6) with bimodal hornblende; view parallel to strong hornblende lineation defined by alignment of small euhedral hornblende prisms (plane polarized light; field of view $2.25 \mathrm{~mm}$ in long direction). $B$, Same as $A$ except in cross-polarized light. $C$, Weakly deformed massive quartz diorite (sample 14) with igneous texture crosscut by nonpenetrative cleavage planes. $D$, Photomicrograph of a sample from $C$ (cross-polarized light; field of view is $5.2 \mathrm{~mm}$ across); minerals include hornblende, biotite, plagioclase, quartz, epidote, and chlorite; weakly developed cleavage exhibited by biotite and chlorite aligned in layers crossing photograph from bottom left to top right. $E$, Mylonitic diorite from a shear zone that cuts massive diorite (short dimension of photograph is $30 \mathrm{~cm})$. F, Photomicrograph of a sample from $E$ (cross-polarized light; field of view is $5.2 \mathrm{~mm}$ across); sense of shear is northeast-over-southwest (sinustral in this figure); minerals are hornblende, plagioclase, epidote, and chlorite. $G$, Photomicrograph of sheared pegmatite (sample 18; plane-polarized light; field of view is $5.2 \mathrm{~mm}$ in long dimension) with two generations of muscovite-coarsegrained relict grains (sample 18-cr) and fine-grained muscovite (sample 18-fn) that grew parallel to foliation. $H$, Same as $G$ except in cross-polarized light.
The conclusions about the nature and age of shearing derived from these hornblende data are supported by ${ }^{40} \mathrm{Ar} /{ }^{39} \mathrm{Ar}$ data for muscovite samples $18 \mathrm{~m}$-cr and $18 \mathrm{~m}$-fn from a pegmatite dike that intrudes massive diorite exposed along the Clearwater River (figs. $7 B, 8 G, H$ ). At the sample locality, both the diorite and the pegmatite are cut by the western margin of a northeast-dipping mylonitic shear zone that separates the diorite from a more felsic quartz diorite unit to the east. Although the diorite outside the shear zone is dominantly massive, anatomizing shear zones approximately 1 to $3 \mathrm{~mm}$ thick occur throughout the diorite near the shear-zone margin. These thin shear zones are approximately concordant with, and appear to be related to, the larger shear zone. The pegmatite is strongly discordant with the shear zone, but possesses a moderately well developed shear fabric parallel to the shear zone, indicating that it behaved more ductilely during shearing than did the diorite. The pegmatite contains two generations of muscovite, including strongly strained relict (igneous?) coarse-grained muscovite, commonly sigmoidal in shape ("mica fish"), and fine-grained muscovite that occurs along foliation planes and that appears to have formed during shearing. These two generations of muscovite were carefully separated; $18 \mathrm{~m}$-cr and $18 \mathrm{~m}$-fn are the coarse- and fine-grained muscovite, respectively. Both samples show very similar age-spectrum patterns (Davidson, 1991) — generally flat, but with minor discordance among apparent ages of about 1.5-2 m.y.; neither sample yielded a well-defined plateau. However, the different size fractions yield distinctly different dates. The coarse-grained 

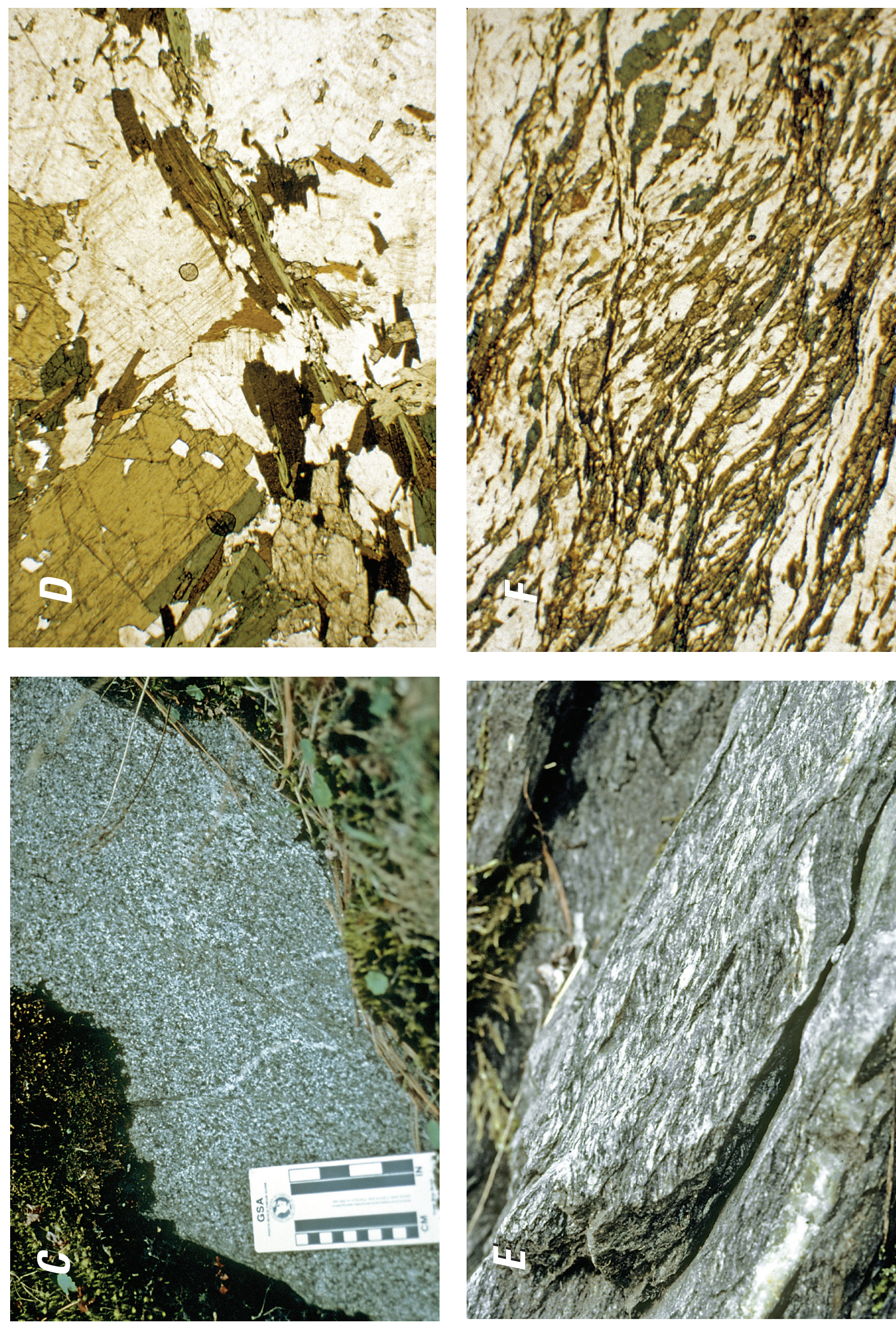

o. 

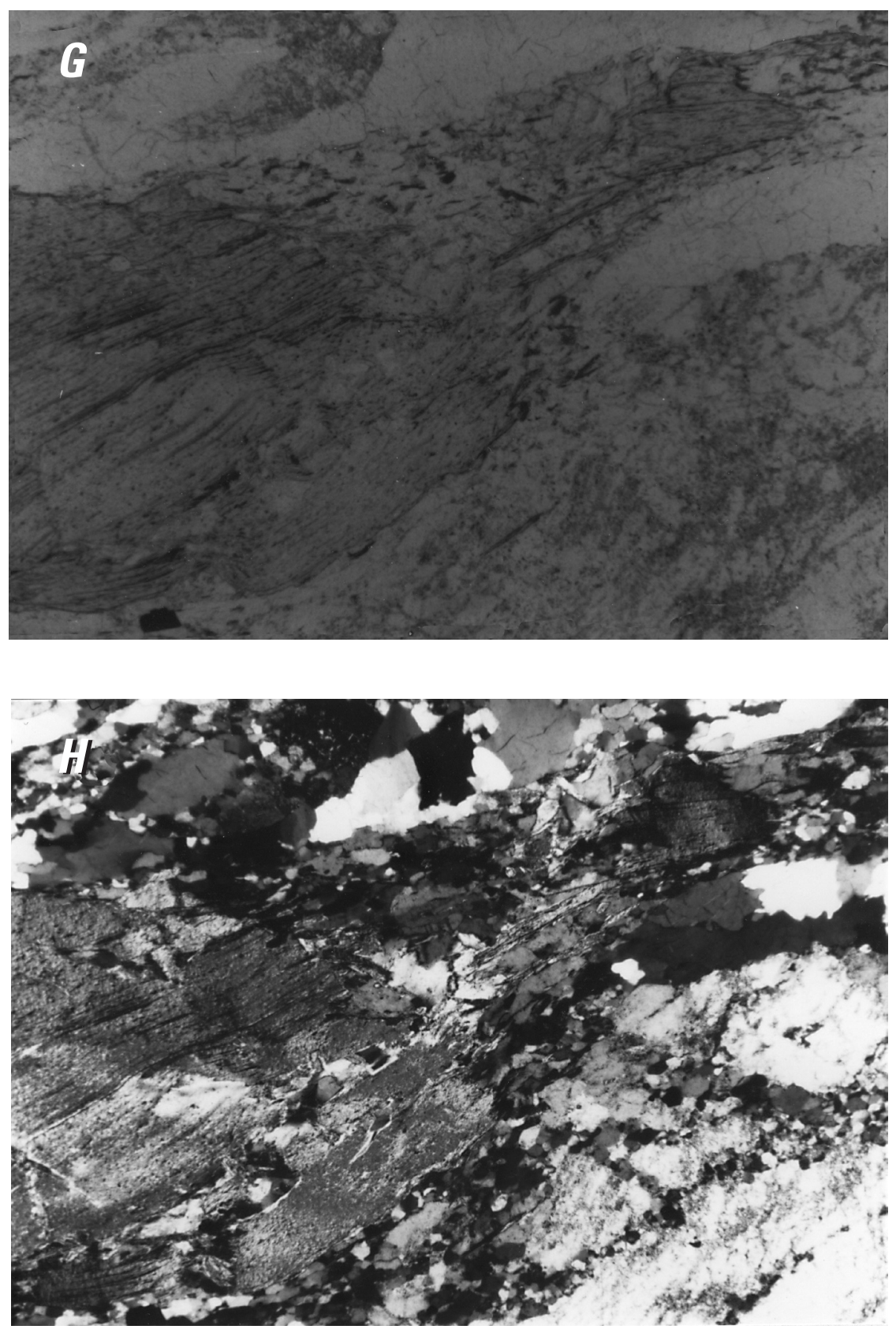

Figure 8.-Continued.

muscovite fraction yields an isochron date of $97.5 \pm 0.8 \mathrm{Ma}$, with a sample-defined ${ }^{40} \mathrm{Ar} /{ }^{36} \mathrm{Ar}$ initial ratio of $296 \pm 3$ indicating the presence of no excess ${ }^{40} \mathrm{Ar}$ (Davidson, 1991). The age spectrum for the fine-grained muscovite fraction shows significantly younger apparent ages, and the sample yields an isochron date of $81.5 \pm 1.0 \mathrm{Ma}$, with an initial ${ }^{40} \mathrm{Ar} /{ }^{36} \mathrm{Ar}$ ratio of $304 \pm 4$, indicating the presence of minimal excess ${ }^{40} \mathrm{Ar}$. The discordance between the two muscovite samples supports the petrographic interpretation that there are indeed two distinct generations of muscovite.

These two muscovite samples from a single pegmatite provide important constraints on the thermal history and time of shearing within this part of the area. Although the coarsegrained muscovite is clearly strained, it seems likely that 98 Ma represents the time at which the pegmatite cooled to below about $350^{\circ} \mathrm{C}$ (closure temperature of muscovite) following its emplacement. This provides strong support for the interpretation that the 93-80-Ma hornblende apparent ages for rocks in this area are related to shearing and are not merely regional cooling ages. The muscovite clearly suggests that, at least in places, the rocks had cooled significantly below muscoviteclosure temperature (ca. $350^{\circ} \mathrm{C}$ ) by $98 \mathrm{Ma}$. Thus, the $98-\mathrm{Ma}$ muscovite date places a lower limit on the age of lower amphibolite-facies metamorphism in these rocks. 
Because the fine-grained muscovite fraction (18m-fn) occurs along and helps define the foliation in the pegmatite, the muscovite is interpreted to have grown synkinematically with shearing. Based on the lack of evidence for thermal resetting of the argon isotopic system in coarse muscovite from the same sample, it is likely the temperature during formation of the fine-grained muscovite was below the closure temperature of muscovite. In this case, the 82.5 -Ma date for sample $18 \mathrm{~m}-\mathrm{fn}$ is interpreted to directly record the time of shearing and growth of fine-grained muscovite in the pegmatite.

Additional constraints on the timing of shear-zone activity are derived from data for hornblende sample $19 \mathrm{sH}$, from garnet-biotite amphibolite in a fault-bounded high-grade block exposed on the north side of the Clearwater River (fig. 7A), and muscovite sample 20M, from strongly sheared muscovite-quartz schist near Big Canyon Creek (fig. 7B). The hornblende age spectrum yields an isochron date of $92.5 \pm 3.0$ $\mathrm{Ma}$; the muscovite age spectrum displays apparent argon loss from about 89 Ma to about $82 \mathrm{Ma}$ (Davidson, 1991). Because the hornblende sample is from a structurally bound block of rocks with higher metamorphic grade than plutonic rocks around it and because the enclosing gabbroic rocks were below hornblende closure-temperature (perhaps significantly cooler-see arguments below) at about $93 \mathrm{Ma}$, the fault block would have cooled rapidly upon structural emplacement; 92.5 Ma should represent essentially a tectonic "quenching" age. Similarly, the muscovite probably originally closed to diffusion of argon at or before $89 \mathrm{Ma}$ and was partially reset at or after $82 \mathrm{Ma}$; the occurrence of this muscovite within the shear fabric suggests that its partially reset age spectrum responded to shearing. Because all hornblende dates from nearby rocks are greater than about $120 \mathrm{Ma}$, the temperature of these rocks during shearing was less than $520^{\circ} \mathrm{C}$. In fact, the temperature of the rocks before shearing was probably less than $350^{\circ} \mathrm{C}$, because the muscovite had closed prior to being partially reset by the shear event.

\section{Cooling History and Later Brittle Defor- mation of Rocks along the Clearwater River}

${ }^{40} \mathrm{Ar} /{ }^{39} \mathrm{Ar}$ dates for four biotite samples from metamorphic and plutonic rocks along the Clearwater River, between the mouth of Big Canyon Creek and the Ahsahka thrust, (fig. $7 B$ ) provide valuable constraints on the post $-300^{\circ} \mathrm{C}$ cooling history of this part of the study area. Samples within this group include 21B, from biotite schist at the mouth of Big Canyon Creek, 14B and 17B, from unsheared and mylonitic quartz diorite, respectively, on the south side of the Clearwater River, and 19B, from garnet-biotite amphibolite in the high-grade tectonic block on the north side of the Clearwater River. The plateau and isochron dates of these samples fall within a narrow range between 80 and $77 \mathrm{Ma}$. Because the discordance between these biotite dates and hornblende and muscovite dates from this part of the study area is large, the biotite dates are cooling ages and mark the time when the rocks cooled below $300^{\circ} \mathrm{C}$. Because biotite samples from unsheared and mylonitic quartz diorite give the same biotite-cooling ages, shearing occurred before $80 \mathrm{Ma}$ and the ambient temperature of the host rocks and shear zones was greater than $300^{\circ} \mathrm{C}$. We also conclude that because the biotite dates for the rocks structurally above the Big Canyon Creek thrust fault are much younger than the 135-Ma biotite date for the pluton near Peck, which is in the lower plate of the Big Canyon Creek thrust fault, these two structural plates underwent completely different cooling histories; in addition, at least some, and possibly all, of the movement on the Big Canyon Creek thrust fault must have occurred after $80 \mathrm{Ma}$. In contrast, the post $-300^{\circ} \mathrm{C}$ cooling history of the rocks along the Clearwater River is identical to that of rocks in the boundary zone (see below), indicating that these two blocks cooled below $300^{\circ} \mathrm{C}$ together.

The age of a period of brittle shearing after the rocks along the Clearwater River cooled below $300^{\circ} \mathrm{C}$ is recorded in the ${ }^{40} \mathrm{Ar} /{ }^{39} \mathrm{Ar}$ data for muscovite sample $22 \mathrm{M}$, from a steeplydipping felsic dike that crosscuts amphibolite and gabbro at the mouth of Big Canyon Creek. The dike is strongly discordant with the more shallowly northeast-dipping foliation and low-angle faults in the outcrop and thus clearly postdates these structures. A strong L-S tectonite fabric within the dike parallels the dike margin. Foliation in the dike is defined by muscovite that probably formed during shearing. The dike may have intruded along a pre-existing fault or fracture, with subsequent movement resulting in shearing of the dike. The ${ }^{40} \mathrm{Ar} /{ }^{39} \mathrm{Ar}$ age spectrum for the muscovite $(22 \mathrm{M})$ shows a well-defined plateau date of $77.3 \pm 0.2 \mathrm{Ma}$ for 73 percent of the ${ }^{39} \mathrm{Ar}$ released. This muscovite date is slightly younger than a 78.6 \pm 0.2 Ma plateau date for biotite sample 21B from schist at the same outcrop. Statistically these dates are different and indicate that the schist had cooled to below $300^{\circ} \mathrm{C}$ (biotiteclosure temperature) before either intrusion or shearing of the dike and that 77.3 Ma is a minimum estimate for the age of the dike and development of high-angle brittle structures in this part of the area.

\section{Rocks Within and East of the Boundary Zone}

To evaluate the thermochronologic history of rocks above the Ahsahka thrust, 21 hornblende, 5 muscovite, 17 biotite, and $1 \mathrm{~K}$-feldspar samples were analyzed from an area extending from the high-strain zone directly above the Ahsahka thrust (AT) to about $45 \mathrm{~km}$ to the east and northeast into undeformed plutonic and regional metamorphic rocks. More than half of the samples were collected within $10 \mathrm{~km}$ of the AT in an attempt to detect local thermochronologic variations. The remaining samples were collected in a reconnaissance fashion 
to evaluate the regional cooling history east of the highly deformed Ahsahka thrust zone.

Thirteen hornblende samples (samples $23 \mathrm{H}$ through $35 \mathrm{H}$ ) from high-grade metamorphic and plutonic rocks along the terrane boundary in the Ahsahka-Orofino area were analyzed. In contrast to the complexity of the ${ }^{40} \mathrm{Ar} /{ }^{39} \mathrm{Ar}$ data for hornblende samples discussed above, age spectra for hornblende from the high-grade rocks above the Ahsahka thrust are simple and in most cases display well-defined plateaus. Hornblende plateau dates for both metasedimentary and metaigneous rocks above the Ahsahka thrust range from $83.5 \pm 0.4$ to $78.2 \pm 0.3 \mathrm{Ma}$ (fig. 7A). These dates are distinctly younger than all hornblende dates for the lower amphibolite-facies rocks below the Ahsahka thrust, with the exception of sample $11 \mathrm{H}$ (plateau date of $82.0 \pm 0.5 \mathrm{Ma}$; fig. $7 A$ ), from diorite just below the Ahsahka thrust. Notably, the oldest hornblende dates from the highgrade rocks closely coincide with the youngest muscovite dates directly related to shear-zone activity to the west and are slightly younger than the youngest hornblendes from the shear zones. Hornblende dates for rocks near Orofino $(80.6 \pm 0.2$ to $78.2 \pm 0.3$ $\mathrm{Ma})$ are slightly younger than those near Ahsahka (83.5 \pm 0.4 to $80.6 \pm 0.2 \mathrm{Ma}$ ); in the Orofino area, hornblende dates generally decrease towards the east. On a more regional scale (discussed below), as seen in figure 9, this pattern of decreasing hornblende dates continues northward towards Dent and eastward towards Pierce, where the hornblende date is $62.6 \pm 0.5 \mathrm{Ma}$.

The high metamorphic grade of the rocks, the simple plateau age spectra, and the observed spatial gradients in mineral dates suggest that the hornblende dates are cooling ages. A well-constrained estimate of the pressure and temperature during metamorphism in these rocks is not available, but general estimates can be made. Zen and Hammarstrom (1984) estimated the depth of emplacement of deformed quartz diorite within the highest-strain part of the boundary zone (dated by us at $116.8 \mathrm{Ma}$; see below) to be greater than $25 \mathrm{~km}$. The presence of well-developed sillimanite, relict kyanite, muscovite, and quartz in rare pelitic lithologies, lack of evidence for partial melting, and the simple hornblende plateau age spectra suggest that the temperature during metamorphism was greater than about $520^{\circ} \mathrm{C}$ (hornblende closure) and less than about $650^{\circ} \mathrm{C}$ (minimum granite melting and muscovite-out reaction); the pressure was greater than about $4 \mathrm{~kb}\left(\mathrm{Al}_{2} \mathrm{SiO}_{5}\right.$ triple point; Holdaway, 1971) and less than about $7 \mathrm{~kb}$ (intersection of granite melting and kyanite = sillimanite curves; Hyndman,

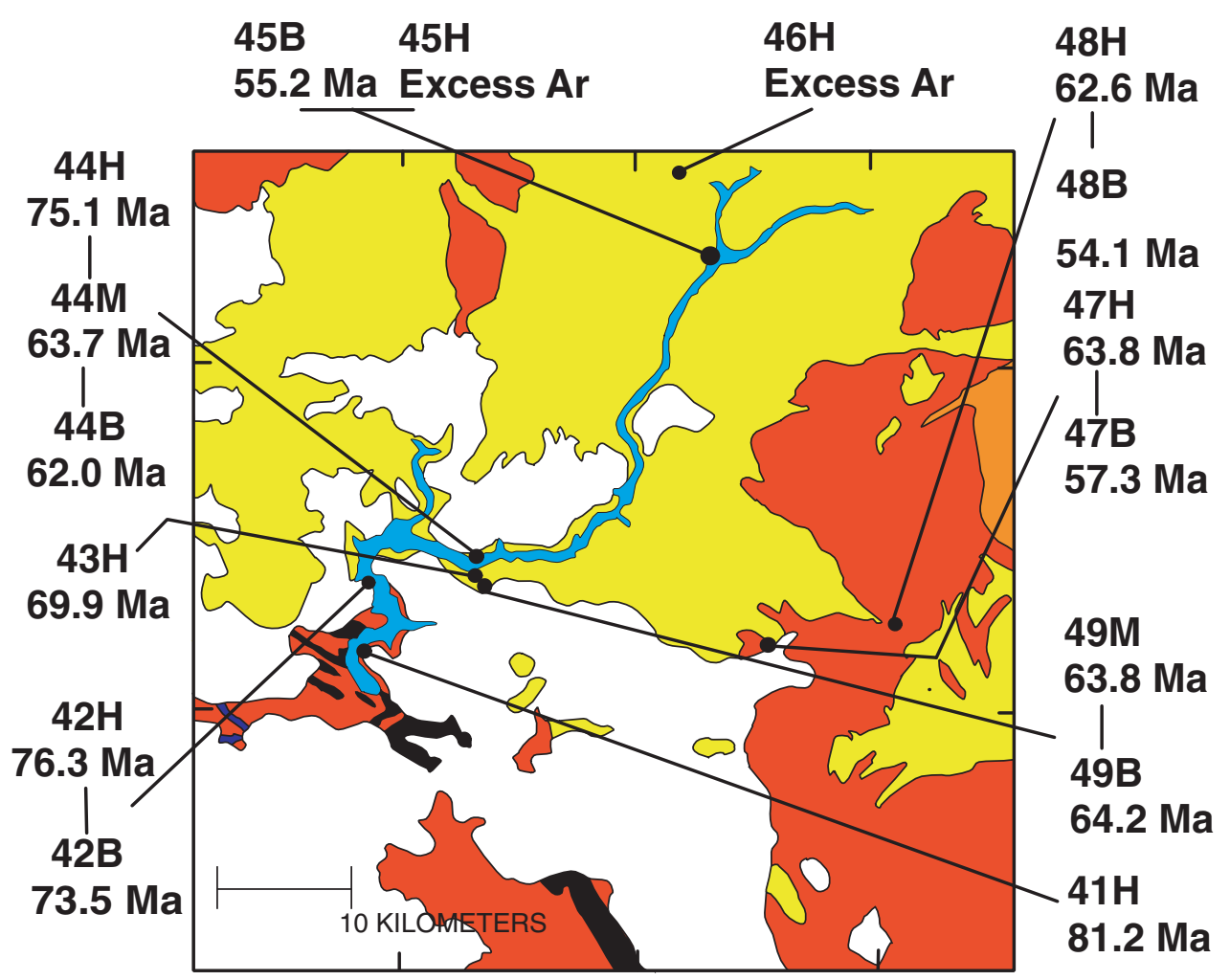

Figure 9. Generalized regional geologic map showing ${ }^{40} \mathrm{Ar} /{ }^{39} \mathrm{Ar}$ sample localities and interpreted ages (in Ma) for areas north and east of Orofino; abbreviations as for figure 7. For explanation of general geology, location names, and longitude and latitude identifiers, see figure 2. Abbreviations: M, Muscovite; B, Biotite; H, Hornblende. 
1985). An additional line of evidence which suggests that the temperature was above hornblende closure-temperature is based on the ${ }^{40} \mathrm{Ar} /{ }^{39} \mathrm{Ar}$ data for sample $11 \mathrm{H}$, from relatively undeformed diorite collected approximately $100 \mathrm{~m}$ west of the Ahsahka thrust. Although the diorite is identical to other massive mafic plutonic rocks along the Clearwater River to the west which give discordant hornblende age spectra with apparent ages $>100 \mathrm{Ma}$, hornblende sample $11 \mathrm{H}$ yields a plateau date of $82.0 \pm 0.5 \mathrm{Ma}$. This suggests that upon juxtaposition of the high-grade rocks over the lower-grade rocks to the southwest, enough heat conducted from the hot hanging-wall rocks to the cooler foot-wall rocks to raise the temperature in the foot-wall sufficiently to reset the hornblende ages near the Ahsahka thrust. The close coincidence of hornblende cooling ages in the still hot $\left(>520^{\circ} \mathrm{C}\right)$ high-grade rocks above the Ahasahka thrust and the timing of shear-zone deformation in rocks below the Ahsahka thrust suggest that northeastover-southwest thrust faulting in the area was responsible for bringing the high-grade rocks up to crustal levels at which the temperature was below hornblende closure.

Eight ${ }^{40} \mathrm{Ar} /{ }^{39} \mathrm{Ar}$ hornblende dates (samples $41 \mathrm{H}$ through $48 \mathrm{H}$ ) for rocks farther east within a $2,200-\mathrm{km}^{2}$ area previously mapped by Hietanen (1962, 1963a,b,c) extend the constraints on cooling and uplift history to a regional scale. These hornblende dates are cooling ages that progressively decrease toward the east. Eastward from the Ahsakha and Orofino area, where hornblende cooling ages are between 84 and $78 \mathrm{Ma}$, cooling ages decrease to about 75 Ma near Dent, then to about $64 \mathrm{Ma} 25 \mathrm{~km}$ farther east, and ultimately to $62.6 \pm 0.5 \mathrm{Ma}$ near Pierce, $10 \mathrm{~km}$ even farther east. (To the northeast, near Headquarters, the hornblendes contain excess argon and yield no meaningful cooling ages.) These samples extend well into the area where plutons exhibit initial ${ }^{87} \mathrm{Sr} /{ }^{86} \mathrm{Sr}$ ratios greater than 0.7065 (Criss and Fleck, 1987) indicating derivation of the magma from continental crust.

The regional cooling pattern established by the 21 hornblende dates is reinforced by ${ }^{40} \mathrm{Ar} /{ }^{\beta 9} \mathrm{Ar}$ age-spectrum data for 4 muscovite samples $(36 \mathrm{M}, 38 \mathrm{M}, 39 \mathrm{M}$, and $50 \mathrm{M}), 17$ biotite samples (23B, 25B, 26B, 29B, 31B, 32B, 35-38B, 40B, 42B, 47-51B), and $1 \mathrm{~K}$-feldspar sample (37K) from this area. Except for a fifth muscovite sample (39M), discussed below, these dates are also cooling ages that progressively decrease eastward. All mica samples from the high-grade rocks above the Ahsahka thrust are several million years younger than hornblendes from the same rocks and younger than all minerals from lower-grade rocks below the Ahsahka thrust. As observed with hornblende, mica dates also decrease towards the east and northeast. The muscovites, samples $36 \mathrm{M}$ from a granitic dike and $38 \mathrm{M}$ from biotite schist, yielded cooling ages of $75.4 \pm 0.2$ and $74.6 \pm 0.2 \mathrm{Ma}$, respectively; coexisting biotites are the same age or younger. The biotite cooling ages, in general, range from $76.4 \pm 0.2$ to $72.4 \pm 0.2 \mathrm{Ma}$. A single $\mathrm{K}$-feldspar sample (37K), from a thin concordant body of biotite granodiorite at the base of Dworshak Dam, north of Ahsahka (fig. 7B), shows apparent argon loss from about 70.9 Ma down to about 60.6 Ma.
Although biotite dates within the immediate Ahsakha and Orofino area show no simple age progression, biotite dates do generally decrease toward the east. Regionally there is a clear progressive decrease in biotite cooling age toward the east, from the 76- to 72-Ma range in the Ahsakha-Orofino area to 64- to 62-Ma for both biotite and muscovite near Dent to about $55 \mathrm{Ma}$ in areas $40 \mathrm{~km}$ to the northeast near Headquarters and $35 \mathrm{~km}$ east of Dent near Pierce.

One muscovite sample (39M) from the AhsakhaOrofino area seems to record igneous emplacement of an unusual greisenlike, muscovite-bearing, but biotite-free granitic rock that is apparently intrusive into biotite tonalite gneiss approximately $2 \mathrm{~km}$ northwest of Orofino. The muscovite appears to be primary, and although it defines a moderately developed foliation, in thin section the rock appears only weakly strained. The muscovite has a plateau date of $72.1 \pm 0.3 \mathrm{Ma}$, only slightly older than a K-feldspar cooling age and younger than all other mica dates in the area. Because this muscovite date is younger than all biotite dates in adjacent rocks, the country rocks were relatively cool $\left(<300^{\circ} \mathrm{C}\right)$ when the granite was emplaced; emplacement was at shallow crustal levels; and cooling was rapid following final crystallization of the small granitic body. Thus, 74 to $72.5 \mathrm{Ma}$ is considered to be a close approximation for the emplacement age of this small granitic body.

\section{U-Pb Geochronology}

Sample $35(35 \mathrm{H}$ and $35 \mathrm{~B}$ on fig. $7 A$ and $7 B)$ represents a highly deformed quartz diorite collected from a large quarry $1 \mathrm{~km}$ south of Dworshak Dam near Ahsahka, Idaho. Based on geologic relationships (Heitanen, 1962; Davidson, 1991), this is the oldest plutonic body within the high-strain boundary zone west of the Salmon River suture zone and is about 2.5 $\mathrm{km}$ from the 0.706 initial ${ }^{87} \mathrm{Sr} /{ }^{86} \mathrm{Sr}$ boundary of Armstrong and others (1977) and Fleck and Criss (1985). The sample was chosen to provide crystallization-age constraints for the oldest, highly deformed, deeply emplaced plutons within the boundary zone and to anchor cooling curves derived from ${ }^{40} \mathrm{Ar} /{ }^{39} \mathrm{Ar}$ hornblende, muscovite, biotite, and $\mathrm{K}$-feldspar dates.

Zircons from sample 35 exhibit a fairly wide range in crystal form from elongate prismatic, euhedral to rounded (typical plutonic morphology) to nearly equant, euhedral to rounded having complex crystal forms (typical metamorphic morphology). The zircons are generally nonmetamict and free from mineral inclusions. However, in thin section many grains exhibit three distinct stages of optically discontinuous growth. Individual populations of crystals and fragments were handpicked for analyses (table 3), and a population of large, equant grains (approx. 250- $\mu \mathrm{m}$ size) was subjected to a series of air-abrasion steps (table 3; Krogh, 1982) in an attempt to resolve potential age differences among the three zones. Owing to the low $\mathrm{Pb}$ contents in the zircons, analysis of single crystals was not feasible and populations of similar- 
Table 3. Uranium-lead data for zircon separates from sample 35, Ahsahka, Idaho.

\begin{tabular}{|c|c|c|c|c|c|c|c|c|c|}
\hline \multirow{2}{*}{$\begin{array}{l}\begin{array}{l}\text { Fraction }{ }^{1} \\
{ }^{207} \mathrm{~Pb} /{ }^{206} \mathrm{~Pb}\end{array} \\
\mathrm{~A}\end{array}$} & \multirow{2}{*}{$\begin{array}{l}\begin{array}{l}\mathrm{Wt}^{2} \\
\text { (mg) }\end{array} \\
2.83\end{array}$} & \multirow{2}{*}{$\begin{array}{r}\mathbf{U}(\mathbf{p p m}) \\
101.5\end{array}$} & \multirow{2}{*}{$\begin{array}{r}\mathbf{P b}(\mathbf{p p m}) \\
1.809\end{array}$} & \multirow{2}{*}{$\begin{array}{r}{ }^{204} \mathbf{P b} /{ }^{206} \mathbf{P b}^{(3)} \\
0.00020\end{array}$} & \multirow{2}{*}{$\frac{{ }^{206} \mathrm{~Pb} /{ }^{238} \mathbf{U}^{(4)}}{0.01813 \pm 0.00010}$} & \multirow{2}{*}{$\begin{array}{l}{ }^{207} \mathbf{P b} /{ }^{235} \mathbf{U}^{(4)} \\
0.1210 \pm 0.0007\end{array}$} & \multirow{2}{*}{$\frac{{ }^{207} \mathbf{P b} /{ }^{206} \mathbf{P b}^{(4)}}{0.04841 \pm 0.00009}$} & \multicolumn{2}{|c|}{$\begin{array}{c}\text { Model ages (Ma) } \\
{ }^{206} \mathrm{~Pb} /{ }^{238} \mathrm{U}\end{array}$} \\
\hline & & & & & & & & $115.9 \pm 0.6$ & $119.4 \pm 4.3$ \\
\hline B1 & 2.86 & 137.4 & 2.394 & $\leq 0.00005$ & $0.01800 \pm 0.00009$ & $0.1197 \pm 0.0008$ & $0.04825 \pm 0.00019$ & $115.0 \pm 0.5$ & $111.3 \pm 9.4$ \\
\hline B2 & $(1.36)$ & 134.2 & 2.542 & 0.00065 & $0.01864 \pm 0.00012$ & $0.1240 \pm 0.0008$ & $0.04830 \pm 0.00011$ & $119.0 \pm 0.8$ & $114.3 \pm 5.4$ \\
\hline $\mathrm{C}$ & 0.70 & 84.5 & 1.611 & 0.00123 & $0.01797 \pm 0.00010$ & $0.1196 \pm 0.0007$ & $0.04834 \pm 0.00015$ & $114.8 \pm 0.6$ & $116.1 \pm 7.3$ \\
\hline $\mathrm{E}$ & 0.12 & 99.5 & 1.792 & $\leq 0.00005$ & $0.01814 \pm 0.00009$ & $0.1211 \pm 0.0007$ & $0.04844 \pm 0.00073$ & $115.9 \pm 0.6$ & $121 \pm 35$ \\
\hline $\mathrm{F}$ & 0.26 & 200.3 & 3.546 & 0.00048 & $0.01790 \pm 0.00013$ & $0.1191 \pm 0.0010$ & $0.04826 \pm 0.00018$ & $114.4 \pm 0.8$ & $112.3 \pm 8.5$ \\
\hline AA1a & 0.14 & 119.5 & 2.218 & 0.00066 & $0.01815 \pm 0.00011$ & $0.1211 \pm 0.0012$ & $0.04839 \pm 0.00039$ & $116.0 \pm 0.7$ & $118 \pm 19$ \\
\hline AA1b & $(0.07)$ & 82.3 & 1.513 & $\leq 0.00005$ & $0.01853 \pm 0.00012$ & $0.1227 \pm 0.0030$ & $0.04803 \pm 0.00108$ & $118.4 \pm 0.8$ & $101 \pm 53$ \\
\hline AA1c & $(0.051)$ & 63.5 & 1.161 & $\leq 0.00005$ & $0.01834 \pm 0.00016$ & $0.1223 \pm 0.0012$ & $0.04837 \pm 0.00016$ & $117.1 \pm 1.1$ & $117.3 \pm 7.9$ \\
\hline $\mathrm{AA} 2 \mathrm{a}$ & 1.78 & 120.5 & 2.169 & 0.00029 & $0.01816 \pm 0.00008$ & $0.1212 \pm 0.0006$ & $0.04842 \pm 0.00005$ & $116.0 \pm 0.5$ & $119.9 \pm 2.5$ \\
\hline $\mathrm{AA} 2 \mathrm{~b}$ & 1.23 & 106.6 & 1.953 & 0.00039 & $0.01832 \pm 0.00012$ & $0.1221 \pm 0.0008$ & $0.04836 \pm 0.00005$ & $117.0 \pm 0.7$ & $117.1 \pm 2.2$ \\
\hline AA3a & 0.75 & 93.7 & 1.813 & 0.00098 & $0.01830 \pm 0.00009$ & $0.1219 \pm 0.0007$ & $0.04832 \pm 0.00012$ & $116.9 \pm 0.6$ & $114.8 \pm 5.8$ \\
\hline $\mathrm{AA} 3 \mathrm{~b}$ & 0.73 & 83.0 & 1.558 & 0.00033 & $0.01840 \pm 0.00011$ & $0.1227 \pm 0.0008$ & $0.04834 \pm 0.00013$ & $117.6 \pm 0.7$ & $116.1 \pm 6.1$ \\
\hline Apatite & 36.46 & 14.0 & 1.199 & 0.04064 & $0.00731 \pm 0.00004$ & $0.0482 \pm 0.0028$ & $0.04785 \pm 0.00261$ & $47.0 \pm 0.3$ & $92 \pm 130$ \\
\hline
\end{tabular}

'Fractions:

A, Equant, euhedral to rounded, clear crystals with complex crystal faces

B, Prismatic, clear, euhedral to somewhat rounded

C, Apparent exterior fragments with no obvious zoning

E, Angular shards with no apparent zoning or exterior faces

F, Equant, euhedral to rounded, smallest crystals

AA1, Fraction A, abraded to about 45 percent of the origin mass (estimated on an average weight-per-crystal basis).

AA2, Fraction A, abraded to about 35 percent of the original mass.

AA3, Fraction A, abraded to about 10 percent of the original mass.

${ }^{2}$ Sample weights in parentheses are estimated.

${ }^{3}$ Corrected for blank and mass fractionation durning mass specrometry of $0.12 \pm 0.03$ percent per mass unit.

${ }^{4}$ Corrected for initial $\mathrm{Pb}$ with ${ }^{206} \mathrm{~Pb} / 204 \mathrm{~Pb}=18.698$, and ${ }^{207} \mathrm{~Pb} / 204 \mathrm{~Pb}=15.583$, based on analyses of plagioclase. 
appearing crystals were analyzed. In addition to the zircons, an apatite separate was also analyzed.

Results of the U-Pb analyses of zircon and apatite are summarized in table 3 and figure 10 . U contents in the zircon separates range from 64 to $200 \mathrm{ppm}$, and $\mathrm{Pb}$ contents range from 1.2 to $3.5 \mathrm{ppm}$ (table 3 ). In spite of the obvious zonation within the crystals and the highly deformed nature of the pluton, the ${ }^{206} \mathrm{~Pb} /{ }^{238} \mathrm{U}$ and ${ }^{207} \mathrm{~Pb} /{ }^{206} \mathrm{~Pb}$ model dates are surprisingly uniform. The ${ }^{206} \mathrm{~Pb} /{ }^{238} \mathrm{U}$ model dates range from $119.0 \pm 0.8$ to $114.4 \pm 0.8 \mathrm{Ma}$, and the ${ }^{207} \mathrm{~Pb} /{ }^{206} \mathrm{~Pb}$ model dates range from $119.9 \pm 2.5$ to $111.3 \pm 9.4 \mathrm{Ma}$ (table 3 , excluding the two highly imprecise analyses). The low ${ }^{206} \mathrm{~Pb} /{ }^{238} \mathrm{U}$ model date for the apatite separate $(47.0 \pm 0.3 \mathrm{Ma})$ indicates significant recent $\mathrm{Pb}$ loss relative to $\mathrm{U}$ from the apatite.

When the $\mathrm{U}-\mathrm{Pb}$ data for the zircon and apatite separates are plotted on a U-Pb evolution diagram (concordia diagram, fig. 10), the linear array defined by the data intersects the concordia curve at $116.7 \pm 0.6 \mathrm{Ma}$ (95-percent confidence interval). Because all data plot, within uncertainty, on the concordia curve, the mean ${ }^{206} \mathrm{~Pb} /{ }^{238} \mathrm{U}$ model date of 116.7 $\pm 0.6 \mathrm{Ma}$ (95-percent confidence interval) for the zircon separates is essentially identical to the upper intercept date. The discordia line results from the open system behavior of apatite and may have no geologic meaning or may indicate that the apatite was open to $\mathrm{Pb}$ diffusion until about $40 \mathrm{Ma}$. In addition, all zircon dates, despite the crystallographic complexity of the zircons, are identical within analytical error, providing evidence that no older components are contained in any of the zircon fractions. However, we do observe a small, but at best marginally distinct, difference in mean ${ }^{206} \mathrm{~Pb} /{ }^{238} \mathrm{U}$ model dates between the abraded $(116.8 \pm 0.6 \mathrm{Ma})$ and unabraded $(115.6 \pm 1.2 \mathrm{Ma})$ fractions. This difference may have resulted from zircon growth over a 1-to-3-m.y. period, or perhaps longer considering that pure innermost and outermost zones of the zircons are not represented by the data. Alternatively, these small differences in apparent age may reflect 1-to-2-percent recent $\mathrm{Pb}$ loss from some fractions, similar to that suggested by the apatite data. Because there is no evidence for either xenocrystic zircon or significant recent $\mathrm{Pb}$ loss from zircon, the $116.8 \pm 0.6 \mathrm{Ma}$ average ${ }^{206} \mathrm{~Pb} /{ }^{238} \mathrm{U}$ model date for the abraded fractions represents our best estimate for the emplacement age of the pluton.

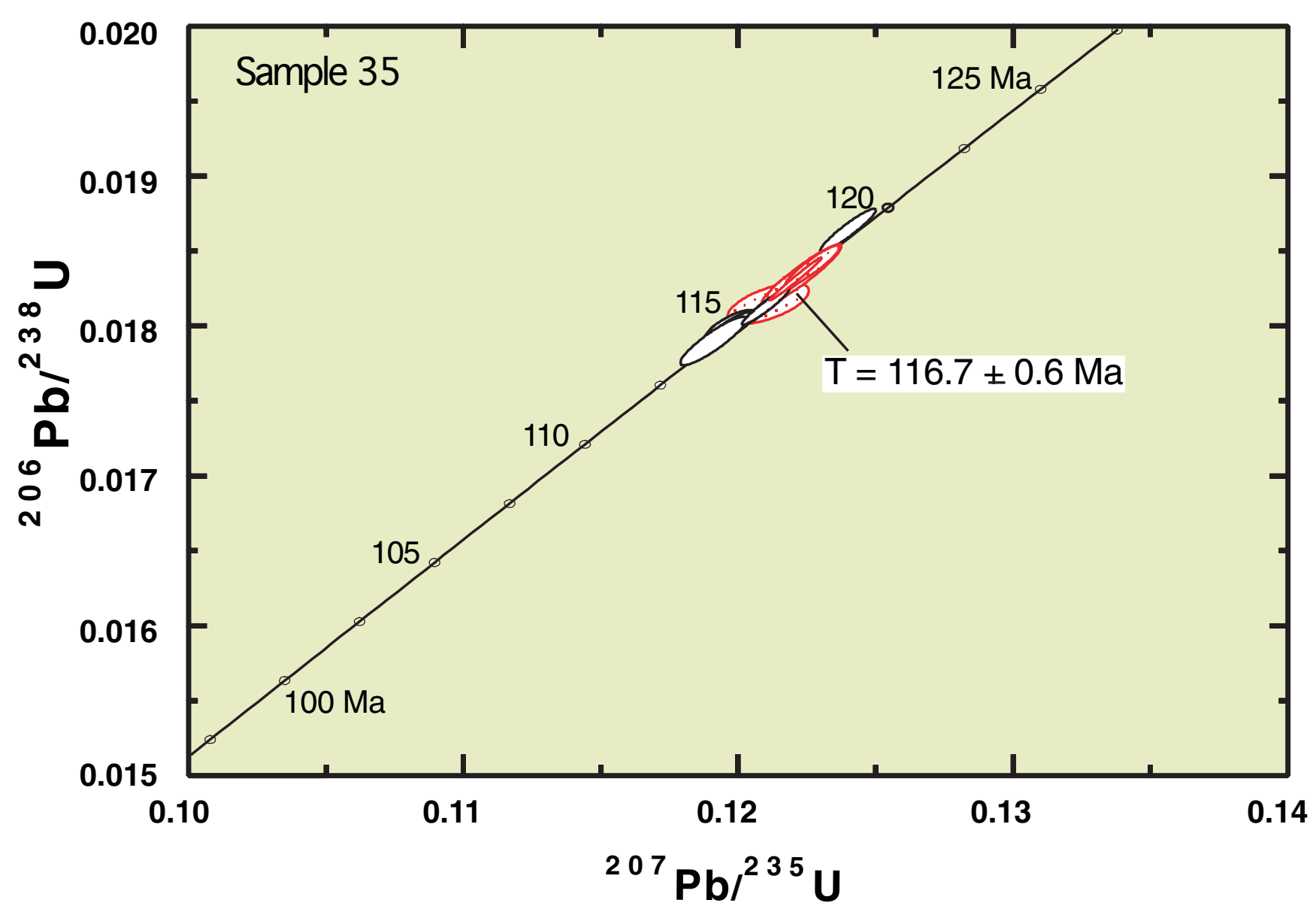

Figure 10. Concordia diagram $\left({ }^{206} \mathrm{~Pb} /{ }^{238} \mathrm{U}\right.$ versus $\left.{ }^{207} \mathrm{~Pb} /{ }^{235} \mathrm{U} \mathrm{U}-\mathrm{Pb}\right)$ for sample 35 , quartz diorite gneiss, Ahsahka, Idaho. Data for air-abraded samples (stippled, seven fractions) yield an average ${ }^{206} \mathrm{~Pb} /{ }^{238} \mathrm{U}$ age of $116.7+0.6 \mathrm{Ma}$. The average ${ }^{206} \mathrm{~Pb} /{ }^{238} \mathrm{U}$ age for all data is $116.3+0.9 \mathrm{Ma}$. Average ${ }^{207} \mathrm{~Pb} /{ }^{206} \mathrm{~Pb}$ ages are $117.8+1.9 \mathrm{Ma}$ for the abraded samples and $117.8+1.6 \mathrm{Ma}$ for all data. 
Table 4. Rb-Sr and Sm-Nd data for mineral separates from sample 35, Ahsahka, Idaho

\begin{tabular}{|c|c|c|c|c|c|c|c|c|c|c|c|}
\hline Separate & $\begin{array}{c}\mathbf{R b} \\
(\mathrm{ppm})\end{array}$ & $\begin{array}{c}\mathrm{Sr} \\
(\mathrm{ppm})\end{array}$ & $\begin{array}{c}\text { Sm } \\
(\mathrm{ppm})\end{array}$ & $\begin{array}{c}\text { Nd } \\
\text { (ppm) }\end{array}$ & ${ }^{87} \mathrm{Rb} /{ }^{86} \mathrm{Sr}$ & ${ }^{87} \mathrm{Sr} /{ }^{86} \mathrm{Sr}$ & ${ }^{87} \mathrm{Sr} /{ }^{86} \mathrm{Sr}_{\mathrm{i}}$ & ${ }^{147} \mathrm{Sm} /{ }^{144} \mathrm{Nd}$ & ${ }^{143} \mathrm{Nd} /{ }^{44} \mathrm{Nd}$ & ${ }^{143} \mathrm{Nd} /{ }^{144} \mathrm{Nd}{ }^{1}$ & $\varepsilon \mathbf{N d}_{i}{ }^{1}$ \\
\hline Plagioclase-1 & 0.992 & 1425 & 0.184 & 1.132 & $0.00201 \pm 0.00002$ & $0.703566 \pm 0.000026$ & $0.703566 \pm 0.000026$ & $0.0967 \pm 0.0001$ & $0.512826 \pm 0.000015$ & $0.512769 \pm 0.000024$ & +4.9 \\
\hline Plagioclase-2 & 0.938 & 1305 & 0.115 & 0.631 & $0.00208 \pm 0.00002$ & $0.703576 \pm 0.000021$ & $0.703573 \pm 0.000021$ & $0.1068 \pm 0.0005$ & $0.512824 \pm 0.000016$ & $0.512761 \pm 0.000026$ & +4.7 \\
\hline Hornblende-1 & 3.067 & 54.07 & 3.674 & 7.452 & $0.1640 \pm 0.0016$ & $0.703751 \pm 0.000026$ & $0.703541 \pm 0.000075$ & $0.2977 \pm 0.0003$ & $0.512939 \pm 0.000017$ & $0.512764 \pm 0.000061$ & +4.8 \\
\hline Hornblende-2 & 3.176 & 52.95 & 3.809 & 8.199 & $0.1735 \pm 0.0019$ & $0.703794 \pm 0.000041$ & $0.703572 \pm 0.000085$ & $0.2806 \pm 0.0001$ & $0.512930 \pm 0.000014$ & $0.512765 \pm 0.000057$ & +4.8 \\
\hline Biotite-1 & 256.1 & 26.12 & 0.060 & 0.260 & $28.44 \pm 0.32$ & $0.733513 \pm 0.000025$ & $0.697 \pm 0.012$ & --- & --- & --- & --- \\
\hline Biotite-2 & 247.5 & 25.36 & --- & --- & $28.30 \pm 0.36$ & $0.733449 \pm 0.000022$ & $0.697 \pm 0.012---$ & --- & --- & --- & \\
\hline Apatite-1 & 0.092 & 441.4 & 10.434 & 17.216 & $0.00060 \pm 0.00001$ & $0.703596 \pm 0.000026$ & $0.703595 \pm 0.000026$ & $0.3660 \pm 0.0004$ & $0.512941 \pm 0.000029$ & $0.512726 \pm 0.000077$ & +4.0 \\
\hline Apatite-2 & 0.127 & 563.2 & 9.331 & 15.168 & $0.00065 \pm 0.00001$ & $0.703601 \pm 0.000020$ & $0.703600 \pm 0.000020$ & $0.3715 \pm 0.0004$ & $0.512942 \pm 0.000014$ & $0.512723 \pm 0.000074$ & +4.0 \\
\hline Epidote & 1.728 & 1184 & 94.45 & 603 & $0.00422 \pm 0.00005$ & $0.703601 \pm 0.000028$ & $0.703596 \pm 0.000028$ & $0.095 \pm 0.005$ & $0.512837 \pm 0.000013$ & $0.512777 \pm 0.000030$ & +5.0 \\
\hline Zircon-1 & --- & --- & 1.381 & 1.161 & --- & --- & --- & $0.7182 \pm 0.0007$ & $0.513284 \pm 0.000023$ & $0.512861 \pm 0.000143$ & +6.7 \\
\hline Zircon-2 & --- & --- & 1.608 & 1.324 & --- & --- & --- & $0.7340 \pm 0.0008$ & $0.513300 \pm 0.000020$ & $0.512868 \pm 0.000145$ & +6.8 \\
\hline Whole-rock-1 & 18.96 & 862.2 & 2.981 & 16.076 & $0.0636 \pm 0.0014$ & $0.703607 \pm 0.000016$ & $0.703526 \pm 0.000031$ & $0.1120 \pm 0.0001$ & $0.512849 \pm 0.000010$ & $0.512783 \pm 0.000024$ & +5.1 \\
\hline Whole-rock-2 & 18.30 & 675.1 & 2.472 & 12.402 & $0.0784 \pm 0.0017$ & $0.703658 \pm 0.000020$ & $0.703558 \pm 0.000039$ & $0.1204 \pm 0.0001$ & $0.512854 \pm 0.000018$ & $0.512783 \pm 0.000028$ & +5.1 \\
\hline
\end{tabular}

${ }^{1}$ Apparent initial ratios calculated assuming an age of $90 \pm 30 \mathrm{Ma}$ based on the range of $\mathrm{Ar} / \mathrm{Ar}$ and U-Pb ages.

Table 5. U-Th- $\mathrm{Pb}$ data for mineral separates from sample 35, Ahsahka, Idaho

$[\mathrm{Pb}$ isotopic data are corrected for Pb blank (where concentrations were measured) and mass fractionation of $0.12 \pm 0.03$ percent per mass unit on the basis of analyses of $\mathrm{Pb}$ isotopic standard SRM-983. For Plagioclase-2 and Apatite-2 only Pb isotopic ratios were determined.]

\begin{tabular}{|c|c|c|c|c|c|c|c|c|c|}
\hline Fraction & $\begin{array}{c}U \\
\text { (ppm) }\end{array}$ & $\begin{array}{c}\text { Th } \\
\text { (ppm) }\end{array}$ & $\begin{array}{c}\mathrm{Pb} \\
(\mathrm{ppm})\end{array}$ & ${ }^{238} \mathrm{U} /{ }^{204} \mathrm{~Pb}$ & ${ }^{206} \mathrm{~Pb} /{ }^{204} \mathrm{~PB}$ & ${ }^{207} \mathrm{~PB} /{ }^{204} \mathrm{~Pb}$ & ${ }^{208} \mathrm{~Pb} /{ }^{204} \mathrm{~Pb}$ & ${ }^{207} \mathrm{~Pb} /{ }^{206} \mathrm{~Pb}$ & ${ }^{208} \mathrm{pb} /{ }^{206} \mathrm{~Pb}$ \\
\hline Plagioclase-1 & 0.0287 & 0.0208 & 8.458 & $0.216 \pm 0.002$ & $18.702 \pm 0.011$ & $15.583 \pm 0.014$ & $38.283 \pm 0.046$ & $0.83321 \pm 0.00026$ & $2.0470 \pm 0.0012$ \\
\hline Plagioclase-2 & -- & -- & -- & --- & $18.702 \pm 0.011$ & $15.583 \pm 0.014$ & $38.283 \pm 0.047$ & $0.83322 \pm 0.00026$ & $2.0470 \pm 0.0012$ \\
\hline Apatite-1 & 13.976 & 4.26 & 1.199 & $807.9 \pm 3.9$ & $24.604 \pm 0.027$ & $15.866 \pm 0.019$ & $38.769 \pm 0.056$ & $0.64482 \pm 0.00035$ & $1.5757 \pm 0.0012$ \\
\hline Apatite-1 & -- & -- & -- & --- & $25.287 \pm 0.015$ & $15.888 \pm 0.014$ & $38.802 \pm 0.048$ & $0.62829 \pm 0.00019$ & $1.5345 \pm 0.0010$ \\
\hline Hornblende & 0.0317 & n.d. & 1.230 & $1.640 \pm 0.095$ & $18.730 \pm 0.013$ & $15.595 \pm 0.015$ & $38.325 \pm 0.048$ & $0.83264 \pm 0.00026$ & $2.0462 \pm 0.0012$ \\
\hline
\end{tabular}




\section{$\mathrm{Rb}-\mathrm{Sr}, \mathrm{Sm}-\mathrm{Nd}$, and $\mathrm{Pb}-\mathrm{Pb}$ Isotope Geo- chemistry}

In order to evaluate the petrogenesis of the oldest plutonic rock within the high-strain boundary zone near Orofino, quartz diorite sample 35 was analyzed for concentrations of $\mathrm{Rb}$, $\mathrm{Sr}, \mathrm{Sm}, \mathrm{Nd}, \mathrm{U}, \mathrm{Th}$, and $\mathrm{Pb} ; \mathrm{Sr}, \mathrm{Nd}$, and $\mathrm{Pb}$ isotopic ratios of selected mineral separates and a whole-rock split also were determined. Data are shown in tables 4 and 5. Also shown are calculated initial ${ }^{87} \mathrm{Sr} /{ }^{86} \mathrm{Sr}$ and ${ }^{143} \mathrm{Nd} /{ }^{144} \mathrm{Nd}$ ratios using an assumed age of $90 \pm 30 \mathrm{Ma}$. This age was chosen to cover the range of possible ages including emplacement at about 116.8 $\mathrm{Ma}$, cooling below $520^{\circ} \mathrm{C}$ at $82 \mathrm{Ma}$, cooling below $320^{\circ} \mathrm{C}$ at $76 \mathrm{Ma}$, and lower temperature effects as young as $60 \mathrm{Ma}$.

The $\mathrm{Rb}-\mathrm{Sr}$ data are displayed on a ${ }^{87} \mathrm{Rb} /{ }^{86} \mathrm{Sr}$ versus ${ }^{87} \mathrm{Sr} /{ }^{86} \mathrm{Sr}$ evolution diagram in figure 11 . The data define an apparent age of 74.2 $\pm 1.3 \mathrm{Ma}$ (95-percent confidence interval) and an initial ${ }^{87} \mathrm{Sr} /{ }^{86} \mathrm{Sr}$ of $0.70358 \pm 0.00002$. However, the data in figure 11 consist of essentially only two points, biotite and the rest of the analyses pooled (see inset in fig. 11). Therefore the 74.2-Ma isochron date should probably best be thought of as a biotite $\mathrm{Rb}-\mathrm{Sr}$ closure age. This date is identical to the 74-Ma ${ }^{40} \mathrm{Ar} /{ }^{39} \mathrm{Ar}$ cooling age for biotite from this sample and significantly younger than the $82-\mathrm{Ma}{ }^{40} \mathrm{Ar} /{ }^{39} \mathrm{Ar}$ cooling age obtained for hornblende from this sample (see above). These results suggest that the closure temperature for the Rb-Sr system in biotite in this rock is certainly less than $520^{\circ} \mathrm{C}$, the argon closure temperature for hornblende, and is probably close to $300^{\circ} \mathrm{C}$, the approximate argon-closure temperature for biotite.

The data in figure 11 exhibit a considerable amount of scatter as indicated by the MSWD (mean square of the weighted deviants) of 3.3 for all points. Excluding one wholerock and one hornblende split of the sample, a best-fit line

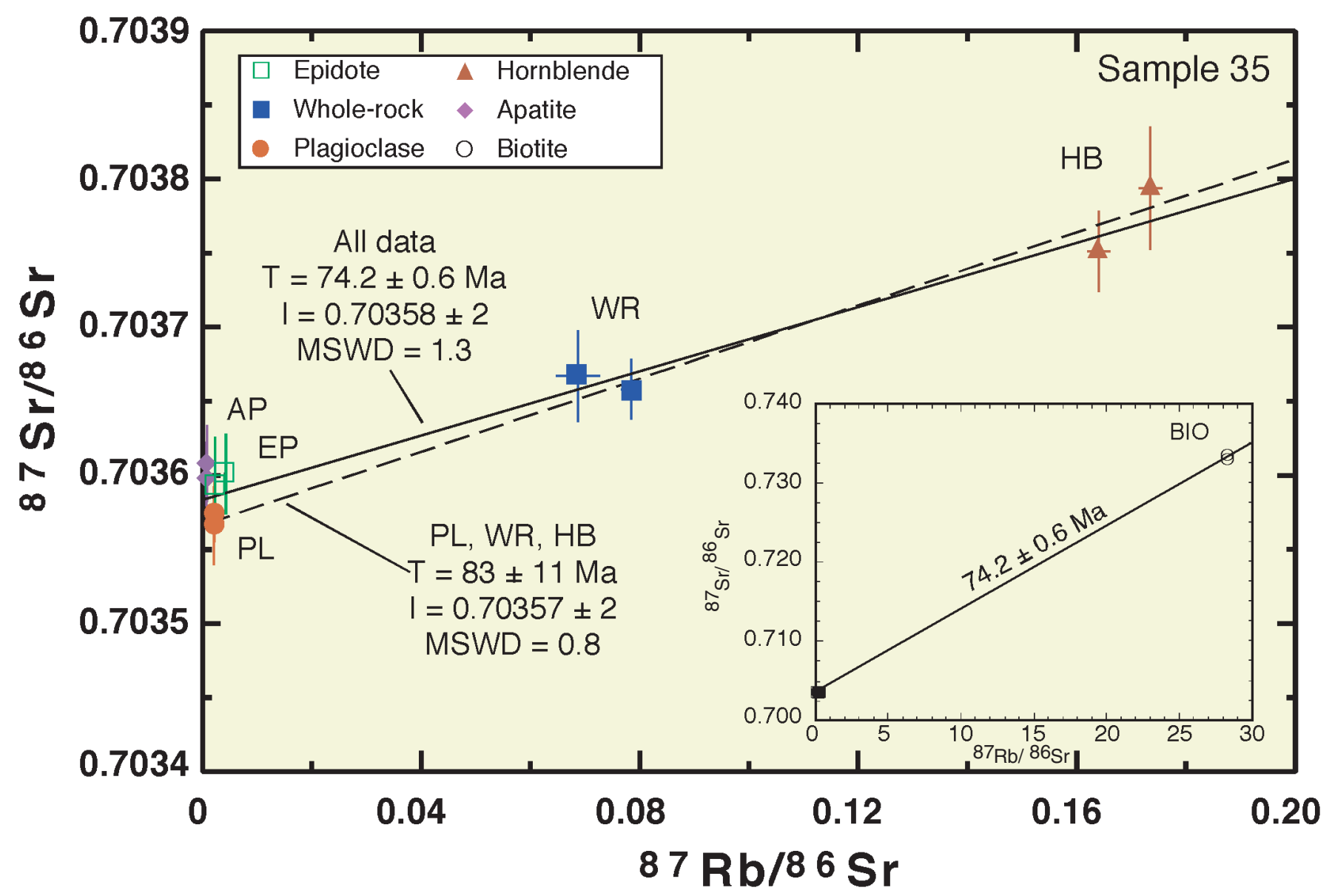

Figure 11. $\mathrm{Rb}-\mathrm{Sr}$ evolution diagram $\left({ }^{87} \mathrm{Rb} /{ }^{86} \mathrm{Sr}\right.$ versus $\left.{ }^{87} \mathrm{Sr} /{ }^{86} \mathrm{Sr}\right)$ for mineral separates and whole rock from sample 35 . Vertical error bars indicate uncertainties in ${ }^{87} \mathrm{Sr} /{ }^{86} \mathrm{Sr}$. The best-fit line defined by the data corresponds to a date of $74.2+0.6 \mathrm{Ma}$, controlled by biotite (BIO), and an initial ${ }^{87} \mathrm{Sr} /{ }^{86} \mathrm{Sr}=0.70358 \pm 0.00002$ (inset graph). Plagioclase (PL), whole-rock (WR), and hornblende (HB) data yield an apparent age of $83 \pm 11 \mathrm{Ma}$. Apatite (AP) and epidote (EP) have clearly higher initial ${ }^{87} \mathrm{Sr} /{ }^{86} \mathrm{Sr}$ ratios than plagioclase, which indicate younger ages of (re)crystallization. If we assume that plagioclase formed at 116-112 Ma, and that the whole-rock system remained closed, then the initial ${ }^{87} \mathrm{Sr} /{ }^{86} \mathrm{Sr}$ of apatite would have been reached at 80-75 Ma. If the metamorphism involved some open-system behavior (Rb-enrichment), then a somewhat younger age for apatite would be indicated. Hornblende appears to have reequilibrated with respect to $\mathrm{Rb}-\mathrm{Sr}$ at $83-74$ Ma depending on the assumptions used. 
with age of $74.2 \pm 0.6 \mathrm{Ma}$ and MSWD of 1.3 is defined. In addition, plagioclase has a lower ${ }^{87} \mathrm{Sr} /{ }^{86} \mathrm{Sr}$ value than apatite and epidote, despite similar ${ }^{87} \mathrm{Rb} /{ }^{86} \mathrm{Sr}$ ratios. If we assume that crystallization began at $116.5 \mathrm{Ma}$, as indicated by the U-Pb zircon age; that plagioclase was one of the first phases to crystallize and to equilibrate with the magma with respect to $\mathrm{Rb}$ and $\mathrm{Sr}$; that epidote was one of the last phases to crystallize and to equilibrate with the magma with respect to $\mathrm{Rb}$ and $\mathrm{Sr}$ (this crystallization sequence is consistent with the texture of the sample and with predictions resulting from the experimental work of Naney, 1983); and that apatite exhibited open-system behavior as predicted by the U-Pb data; then the apparent difference in initial ratios between plagioclase and epidote may reflect radiogenic growth of ${ }^{87} \mathrm{Sr}$ within the parent magma. That is, for the evolution of ${ }^{87} \mathrm{Sr} /{ }^{86} \mathrm{Sr}$ from the plagioclase value of 0.7056 at $117 \mathrm{Ma}$ to the epidote value of 0.7060 at $75 \mathrm{Ma}, \mathrm{a}{ }^{87} \mathrm{Rb} /{ }^{86} \mathrm{Sr}$ value of 0.070 is required; this ${ }^{87} \mathrm{Rb} /{ }^{86} \mathrm{Sr}$ value is similar to that observed in the whole-rock splits. This observation suggests that the initial ${ }^{87} \mathrm{Sr} /{ }^{86} \mathrm{Sr}$ of each mineral phase is slightly different but lies between the values for plagioclase and epidote, reflecting the crystallization sequence of the magma. Therefore, it is not surprising that some scatter in the data is observed, particularly when the difference in mineral initial ${ }^{87} \mathrm{Sr} /{ }^{86} \mathrm{Sr}$ ratios is combined with the fact that each mineral has a characteristic Rb-Sr closure temperature.

Because biotite appears to be one of the last phases to close with respect to the K-Ar and Rb-Sr systems, its initial ratio should be closer to that of epidote than that of plagioclase. However, biotite is so radiogenic that the small differences in initial ${ }^{87} \mathrm{Sr} /{ }^{86} \mathrm{Sr}$ ratios do not affect its apparent age $(74.2 \pm 0.6 \mathrm{Ma}$ relative to plagioclase or $74.1 \pm 0.6$ Ma relative to epidote). Therefore our best estimate of the closure age of the $\mathrm{Rb}-\mathrm{Sr}$ system in biotite is $74.2 \pm 0.6 \mathrm{Ma}$ $\left({ }^{87} \mathrm{Sr} /{ }^{86} \mathrm{Sr}_{\mathrm{i}}=0.703588 \pm 0.000010 ; \mathrm{MSWD}=1.34\right)$ using biotite, plagioclase, apatite, and epidote to fit the isochron but excluding the whole rock and hornblende.

The apparent $\mathrm{Rb}-\mathrm{Sr}$ closure age of hornblende calculated relative to plagioclase, apatite, and epidote is $77 \pm 20 \mathrm{Ma}$ $\left({ }^{87} \mathrm{Sr} /{ }^{86} \mathrm{Sr}_{\mathrm{i}}=0.703584 \pm 0.000023 ; \mathrm{MSWD}=2.1\right)$. The lack of precision reflects more the limited range in ${ }^{87} \mathrm{Rb} /{ }^{86} \mathrm{Sr}$ and ${ }^{87} \mathrm{Sr} /{ }^{86} \mathrm{Sr}$ among the minerals than the MSWD. Although this date is not well defined, it is statistically identical to the $82-\mathrm{Ma}{ }^{40} \mathrm{Ar} /{ }^{39} \mathrm{Ar}$ cooling age for this hornblende, suggesting similar closure behavior of both the Rb-Sr and K-Ar systems in hornblende.

Samarium-neodymium data for selected mineral separates for sample 35 are shown in table 4 and figure 12. An unexpected result exhibited by these data is the exceptionally large fractionation of $\mathrm{Sm}$ and $\mathrm{Nd}$ in zircon of this sample displayed in high ${ }^{147} \mathrm{Sm} /{ }^{144} \mathrm{Nd}$ and ${ }^{143} \mathrm{Nd} /{ }^{144} \mathrm{Nd}$ ratios (about 0.72 and 0.51 , respectively). These data, together with those of plagioclase, epidote, and whole rock, yield an apparent age of 111.6+4.0 Ma (fig. 12), with an initial ${ }^{143} \mathrm{Nd} /{ }^{144} \mathrm{Nd}=0.512762 \pm 0.000008\left(\varepsilon_{\mathrm{Nd}}=+5.3, \mathrm{MSWD}=1.3\right)$. This date is similar to the emplacement age determined from $\mathrm{U}-\mathrm{Pb}$ data on zircon for this sample. Data for hornblende and apatite plot below this isochron, thereby indicating younger apparent ages for these minerals. Using our previous assumption that plagioclase and zircon are among the earliest phases to become isotopically closed, then our best estimate for the closure of the Sm-Nd system in zircon is the model date relative to plagioclase of $114.3 \pm 4.6 \mathrm{Ma}\left({ }^{143} \mathrm{Nd} /{ }^{144} \mathrm{Nd}_{\mathrm{i}}=0.512749 \pm 0\right.$ $\left..000013 ; \varepsilon_{\mathrm{Nd}}=+5.1 ; \mathrm{MSWD}=0.4\right)$; this apparent age is identical within analytical uncertainty to the $\mathrm{U}-\mathrm{Pb}$ crystallization age for zircon of $116.8 \pm 0.6 \mathrm{Ma}$.

Samarium-neodymium isochrons that exclude data for zircon also are shown on figure 12. Two isochrons are drawn, one through hornblende, the other through apatite. As with the $\mathrm{Rb}$-Sr system, plagioclase has a slightly lower initial ratio compared to epidote; this reinforces the validity of our assumption that plagioclase is an earlier phase. In addition, the whole-rock data plot above the zircon-plagioclase isochron. From table 4, it is evident that the whole-rock Sm-Nd data are dominated by epidote and both plot near each other on figure 12. The epidote and whole-rock data are consistent with an interpretation that postemplacement interaction with fluids enriched with light rare-earth elements (LREE) (and Rb) produced minor LREE- and Rb-rich secondary phases (chlorite and sericite that are observed in thin section) not included in our analysis of the mineral phases of this sample.

As with the case of the Rb-Sr system for this sample, minerals that became closed with respect to $\mathrm{Sm}$ and $\mathrm{Nd}$ at times younger than $114 \mathrm{Ma}$ will have slightly higher ${ }^{143} \mathrm{Nd} /{ }^{144} \mathrm{Nd}_{\mathrm{i}}$. Our best estimates for the closure ages for hornblende and apatite are the model dates calculated relative to the cluster of points defined by plagioclase, epidote, and whole rock. From this consideration, the hornblende $\mathrm{Sm}-\mathrm{Nd}$ closure date is $80 \pm 10 \mathrm{Ma}$ (fig. $12 ;{ }^{143} \mathrm{Nd} /{ }^{144} \mathrm{Nd}_{\mathrm{i}}=0.512783 \pm .000011$; $\left.\varepsilon_{\mathrm{Nd}}=+4.9 ; \mathrm{MSWD}=1.5\right)$. If plagioclase alone is considered to be collinear with hornblende, the model date is $89 \pm 13 \mathrm{Ma}$; both dates are imprecise but are identical within analytical precision to the $\mathrm{Rb}-\mathrm{Sr}$ and $\mathrm{K}$-Ar closure ages for this separate. Similarly, apatite yields a younger model date of $59 \pm 14$ Ma relative to plagioclase, epidote, and whole rock (fig. 12; $\left.{ }^{143} \mathrm{Nd} /{ }^{144} \mathrm{Nd}_{\mathrm{i}}=0.512779 \pm .000017 ; \varepsilon_{\mathrm{Nd}}=+4.7 ; \mathrm{MSWD}=1.7\right)$, and $66 \pm 10 \mathrm{Ma}$ relative to plagioclase alone. As with the U-Pb and $\mathrm{Rb}-\mathrm{Sr}$ apatite dates, the young $\mathrm{Sm}-\mathrm{Nd}$ apparent age is consistent with open system behavior to about $60 \mathrm{Ma}$. Finally as a test of these model dates, we calculated ${ }^{147} \mathrm{Sm} /{ }^{144} \mathrm{Nd}$ ratios required to produce initial ${ }^{143} \mathrm{Nd} /{ }^{144} \mathrm{Nd}$ values of 0.512783 at $80 \mathrm{Ma}$ and 0.512749 at $114 \mathrm{Ma}$. The calculated ratios fall between 0.10 and 0.14 ; the measured ratios of 0.11 and 0.12 for two whole-rock splits (table 4) establish the internal consistency of our data.

The isotopic data provide additional information on the nature of the source of the magma for sample 35. Correction of the isotopic data for an assumed apparent age of $90 \pm 30$ $\mathrm{Ma}$, which covers the entire range of ${ }^{40} \mathrm{Ar} /{ }^{39} \mathrm{Ar}$ and $\mathrm{Sm}-\mathrm{Nd}$ dates, produces reasonably consistent initial ${ }^{143} \mathrm{Nd} /{ }^{144} \mathrm{Nd}$ values among all phases of 0.51273 to $0.51286\left(\varepsilon \mathrm{Nd}_{\mathrm{I}}=+4\right.$ to +6 ; table 2) and initial ${ }^{87} \mathrm{Sr} /{ }^{86} \mathrm{Sr}$ values of 0.7035 to 0.7036 . The combined initial $\mathrm{Nd}$ and $\mathrm{Sr}$ ratios indicate that the quartz diorite was derived from a depleted-mantle source with a small 
contribution from continental material, similar to those of many island-arc magmas (see, for example, White and Patchett, 1984), and the data plot near the center of the "island arc" field defined by Zartman (1984).

Uranium-thorium-lead data (table 5) are also consistent with an island-arc magma source. The ${ }^{206} \mathrm{~Pb} /{ }^{204} \mathrm{~Pb}$ value for sample 35 (plagioclase) is somewhat higher than is commonly found in midocean-ridge basalts and, when compared at similar ${ }^{206} \mathrm{~Pb} /{ }^{204} \mathrm{~Pb}$ values, the data for sample 35 (plagioclase) exhibit slightly elevated ${ }^{207} \mathrm{~Pb} /{ }^{204} \mathrm{~Pb}$ but similar ${ }^{208} \mathrm{~Pb} /{ }^{204} \mathrm{~Pb}$ values compared to typical oceanic-island basalts. The data plot well within the "island arc" field of Zartman (1984).

Both the U-Pb zircon age and the island-arc isotopic signature of sample 35 suggest that this pluton was formed within the island arc, before or during suturing (see detailed discussion on accretion below). The 116.8-Ma crystallization age is similar to our ${ }^{40} \mathrm{Ar} /{ }^{39} \mathrm{Ar}$ dates for some hornblendes from mafic plutons that we interpret to be emplacement ages. The $\mathrm{U}-\mathrm{Pb}$ zircon date is younger than the 130-Ma metamorphic event documented by us to have affected island-arc rocks to the west. However, as shown for other areas (Sutter and others, 1984; Lund and Snee, 1985; Criss and Fleck, 1987; Lund and Snee, 1988; Manduca, 1988; Selverstone and others, 1992; Manduca and others, 1993; Snee and others, 1995), such as near Riggins to the south, plutonism after a metamorphic pulse is common. This pluton is the oldest of a group of several highly deformed, apparently comagmatic bodies in this area that were emplaced into Orofino Metamorphic Suite metasedimentary rocks early in the deformational history of the area. The narrow elongate outcrop patterns of the orthogneiss units

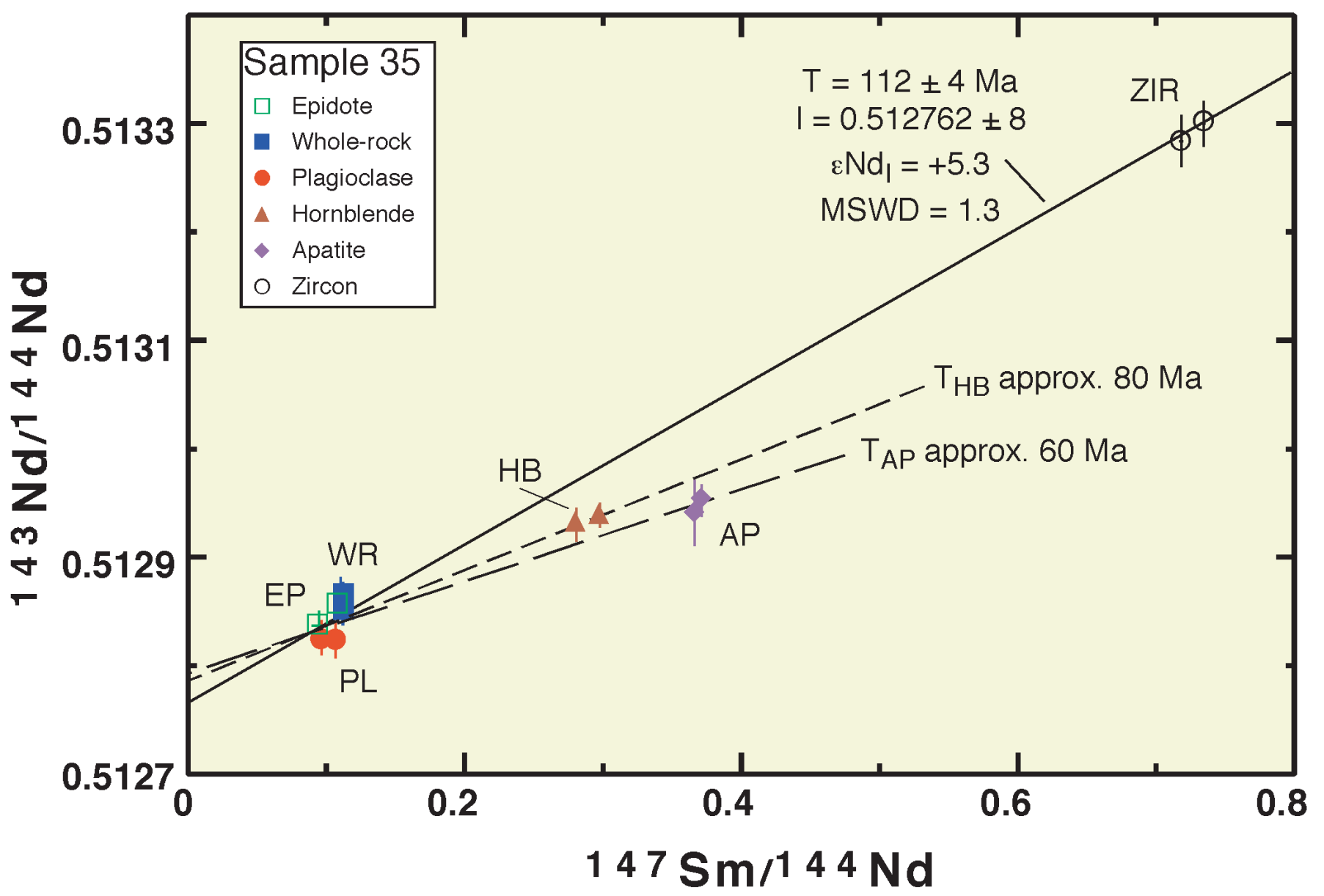

Figure 12. Sm-Nd evolution diagram $\left({ }^{147} \mathrm{Sm} /{ }^{144} \mathrm{Nd}\right.$ versus $\left.{ }^{143} \mathrm{Nd} /{ }^{144} \mathrm{Nd}\right)$ for mineral separates from sample 35 . Uncertainties in ${ }^{143} \mathrm{Nd} /{ }^{144} \mathrm{Nd}$ are indicated by vertical error bars. The isochron defined by the zircon data and the cluster of data to the lower left gives an apparent age of $112 \pm 4 \mathrm{Ma}$ with an initial ${ }^{143} \mathrm{Nd} /{ }^{144} \mathrm{Nd}$ ratio of $0.512762 \pm 0.000008$. This age is in good agreement with the $116-\mathrm{Ma} \mathrm{U}-\mathrm{Pb}$ age, and the relatively high initial ${ }^{143} \mathrm{Nd} /{ }^{144} \mathrm{Nd}$ is consistent with a mantle source such as that exhibited by ocean-island and island-arc basalts. An isochron defined by plagioclase and zircon yields an apparent age of $114 \pm 4 \mathrm{Ma}$. The whole-rock data plot slightly above the plagioclasezircon isochron, which may indicate that the "whole-rock" was not a closed system during later metamorphism. Hornblende and apatite yield model dates of $80 \pm 20$ and $59 \pm 14 \mathrm{Ma}$, respectively, relative to the cluster of points defined by data for plagioclase, epidote, and whole rock. The 80-Ma hornblende apparent age corresponds to recrystallization of the hornblende and may represent the time when the whole-rock system was open and light rare-earth elements were introduced. The 60-Ma apparent age for the apatite is slightly older than the $49-\mathrm{Ma}{ }^{206} \mathrm{~Pb} /{ }^{238} \mathrm{U}$ apparent age of the apatite (table 5) and may represent recrystallization and cooling. 
near Ahsahka are parallel to foliation trends (particularly the smaller tonalite bodies; figs. 3,4 ) and suggest that the plutons may be broadly synkinematic, owing their shape to deformation during emplacement. To the west of sample 35, numerous samples of plutons along the Clearwater River yielded ${ }^{40} \mathrm{Ar} /{ }^{39} \mathrm{Ar}$ hornblende dates of 122 to $115 \mathrm{Ma}$, which are interpreted to be emplacement ages. These plutons along the Clearwater River are apparently chemically related to quartz diorite sample 35. Thus, we conclude that a major period of plutonism occurred within the island-arc terrane when it was either adjacent to or near the Salmon River suture zone.

\section{Summary of Mineral Closure Ages for Quartz Diorite Sample 35}

Our U-Pb, Sm-Nd, Rb-Sr, and ${ }^{40} \mathrm{Ar} /{ }^{39} \mathrm{Ar}$ analyses of quartz diorite sample 35 (fig. 7) provide us with nine closure ages for minerals from this sample. These data are summarized here and used in a subsequent section on the thermal history of the Orofino area.

\begin{tabular}{|c|c|c|c|}
\hline Mineral & $\begin{array}{l}\text { Isotopic } \\
\text { System }\end{array}$ & $\begin{array}{c}\text { Closure } \\
\text { Age (Ma) }\end{array}$ & $\begin{array}{c}\text { Closure } \\
\text { Temperature } \\
\left({ }^{\circ} \mathrm{C}\right)\end{array}$ \\
\hline Zircon & $\mathrm{U}-\mathrm{Pb}$ & $116.8 \pm 0.6(2 \sigma)$ & Crystallization (850) \\
\hline Zircon & Sm-Nd & $114.3 \pm 4.6$ & Unknown \\
\hline Hornblende & ${ }^{40} \mathrm{Ar} /{ }^{39} \mathrm{Ar}$ & $81.2 \pm 0.4$ & $520 \pm 20$ \\
\hline Hornblende & Sm-Nd & $80 \pm 10$ & Unknown \\
\hline Hornblende & $\mathrm{Rb}-\mathrm{Sr}$ & $80 \pm 20$ & Unknown \\
\hline Biotite & ${ }^{40} \mathrm{Ar} /{ }^{39} \mathrm{Ar}$ & $75.3 \pm 0.4$ & $300 \pm 40$ \\
\hline Biotite & $\mathrm{Rb}-\mathrm{Sr}$ & $74.2 \pm 0.6$ & About 300 \\
\hline Zircon & $\begin{array}{l}\text { Fission } \\
\text { Track }^{1}\end{array}$ & $64.4 \pm 7.5$ & About 250 \\
\hline Apatite & $\mathrm{U}-\mathrm{Pb}$ & $47.0 \pm 0.3$ & Unknown \\
\hline Apatite & Sm-Nd & $59+14$ & Unknown \\
\hline
\end{tabular}

${ }^{1}$ Charles Naeser, written commun., 1997

From these data it seems that zircon is equally retentive for the $\mathrm{U}-\mathrm{Pb}$ and $\mathrm{Sm}-\mathrm{Nd}$ systems. Hornblende seems to close to diffusion in the $\mathrm{K}-\mathrm{Ar}, \mathrm{Rb}-\mathrm{Sr}$, and $\mathrm{Sm}-\mathrm{Nd}$ systems at about $500^{\circ} \mathrm{C}$, or these data marked the time of a recrystallization event. Biotite closes to diffusion of argon and rubidium at about the same temperature, as has been long known (see, for example, Jäger, 1979). Finally, the closure temperature for apatite in the U-Pb and $\mathrm{Sm}-\mathrm{Nd}$ systems is lower than zircon fission-track annealing temperature (about 250 ${ }^{\circ} \mathrm{C}$ at a cooling rate of 1 to $10^{\circ} \mathrm{C} / \mathrm{m}$.y.; Sharma and others, 1980 ; Bal and others, 1983) and it is probably similar to that for apatite fission-track annealing, that is, about $80^{\circ} \mathrm{C}$ for similar cooling rates (Naeser, 1979; Sharma and others, 1980).

\section{Tectonic Development of the Salmon River Suture Zone Near Orofino Idaho}

The data that we present in this report provide the foundation for unraveling the tectonic development of the Salmon River suture zone near Orofino, Idaho, from about 145 to $60 \mathrm{Ma}$. These data define the thermal history of the Orofino area, which, when combined with geology, geochemistry, and structure, constrain the timing of island-arc accretion to North America and associated dynamothermal metamorphism. We also infer that a prolonged period of deformation and metamorphism, which occurred after island-arc accretion, is revealed from analysis of the thermal history of this area, and we conclude that this later deformation was responsible for the bend in the ${ }^{87} \mathrm{Sr} /{ }^{86} \mathrm{Sr}$ line.

\section{Thermal History of the Orofino Area}

The U-Pb and ${ }^{40} \mathrm{Ar} /{ }^{39} \mathrm{Ar}$ geochronologic data of this study can be combined into a "thermochronologic profile" for the rocks of the Orofino area. That is, our isotopic dates provide time and temperature information for each dated mineral that, when combined with geologic constraints, allow us to evaluate the thermal history of the area. The combination of geology, structure, and thermochronology leads to a natural subdivision of the rocks of the Orofino area into structurally bound packages of rocks that each underwent separate thermal evolutions. The thermochronologic profiles of each of these packages provide the basis for a model of the tectonic evolution of the Salmon River suture zone near Orofino, described below.

Three main structure- and metamorphism-constrained packages of rocks with unique thermal histories are defined by our data (fig. 13). From west to east these are: (1) quartz diorite and thermally metamorphosed country rocks below the Big Canyon Creek thrust, (2) variably metamorphosed and deformed mafic plutons, amphibolite, and metasedimentary rocks between the Big Canyon Creek thrust and the Ahsahka thrust, and (3) high-grade metasedimentary and plutonic rocks within the boundary zone (above the Ahsahka thrust) and areas to the north and east. The ${ }^{40} \mathrm{Ar}{ }^{\beta 9} \mathrm{Ar}$ data show that these packages experienced distinctly different thermal histories and that the present configuration of the packages is a result of deformation after accretion of the Wallowa terrane to North America. Figures 14 and 15 summarize the spatial distribution of mineral dates in the Peck-Ahsahka-Orofino-Dent-Pierce area and the thermal history of each rock package, respectively, as discussed below.

The oldest event recorded in the study area is the emplacement of biotite-hornblende quartz diorite exposed below the Big Canyon Creek thrust (BCCT) (fig. 14; structural block or rock package 1). Hornblende and biotite from the quartz diorite record cooling, following emplacement and crystallization, from 520 to $300^{\circ} \mathrm{C}$ between 138 and $135 \mathrm{Ma}$. 


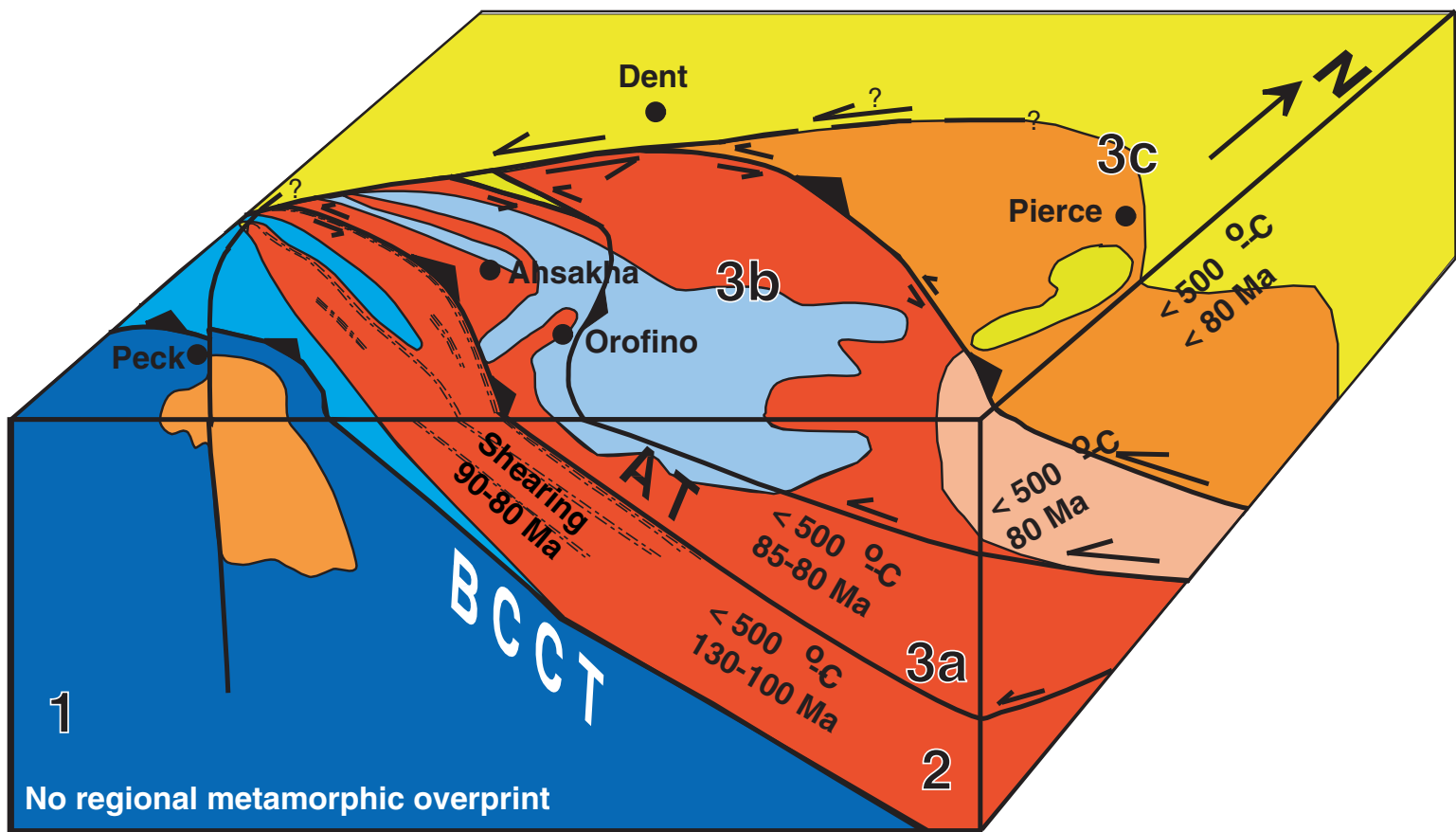

$0 \quad 10$ Kilometers

EXPLANATION

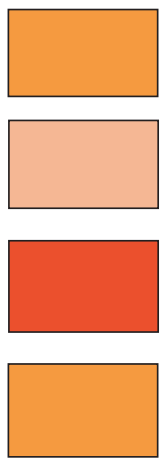

Metaluminous Idaho Batholith plutonic rocks $(<90 \mathrm{Ma})$

Suture-zone plutonic rocks (95-90 Ma)

Island-arc plutonic rocks (122-115 Ma)

Wallowa terrane plutonic rocks (145 Ma)

Wallowa terrane metamorphic rocks $(130 \mathrm{Ma})$

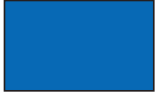

Wallowa terrane rocks (Permian through Triassic)

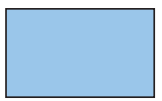

Orofino Metamorphic Suite metamorphic rocks (Permian through Triassic)

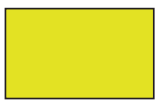

Belt Supergroup metasedimentary rocks (Middle Proterozoic)

\author{
1 Rock packages of differing \\ thermochronologic histories \\ - Towns \\ Faults--Arrows show sense of movement
}

Figure 13. Hypothetical 3-dimensional block diagram of the Ahsahka-Orofino area summarizing geologic history. Discrete packages of rocks record different thermochronologic histories: Rock package 1 consists of island-arc volcanic, sedimentary, and plutonic rocks having no regional metamorphic overprint imparted during suturing of these rocks to North America. Rock package 2 consists of island-arc rocks that were regionally metamorphosed during suturing at 130-100 Ma and were intruded by 122-115-Ma plutons having island-arc affinity. Discrete shear zones within this package record ductile deformation between 90 and 80 Ma. Rock package 3 records prolonged cooling histories. Package $3 a$ consists of highly deformed and regionally metamorphosed Orofino Metamorphic Suite island-arc rocks and plutons that cooled below $500^{\circ} \mathrm{C}$ between 85 and $80 \mathrm{Ma}$. Rock package $3 \mathrm{~b}$ consists of highly deformed and regionally metamorphosed Orofino series island-arc and continental rocks and plutonic rocks having both island-arc and continental affinity that cooled below $500^{\circ} \mathrm{C}$ at about $80 \mathrm{Ma}$. Rock package $3 \mathrm{c}$ consists of Belt Supergroup metasedimentary rocks and plutons of the Idaho Batholith that cooled below $500^{\circ} \mathrm{C}$ after $80 \mathrm{Ma}$. Structures shown on this diagram are all younger than the suturing event (130-100 $\mathrm{Ma}$ ) and include 90-80-Ma thrust faults and associated northeast-over-southwest ductile shear zones, as well as the left-lateral ductile shear zone that formed the west-trending terrrane boundary. The diagram is intended to show partitioning of strain from the northeastover-southwest thrusting of continental rocks over island-arc rocks between 90 and $80 \mathrm{Ma}$ to the contemporaneous left-lateral ductile shear along the west-trending terrane boundary. Abbreviations: AT is Ahsahka thrust and BCCT is Big Canyon creek thrust. 
Based on the argon data, the cooling rate from 138 to $135 \mathrm{Ma}$ was about $73^{\circ} \mathrm{C} / \mathrm{m}$.y. Extrapolation of this cooling rate back to a reasonable emplacement temperature of about 800 to $900^{\circ} \mathrm{C}$ (Naney, 1983) suggests intrusion at about $143 \mathrm{Ma}$, which corresponds to the contact-metamorphic hornblende date of 144 Ma from the amphibolite near the contact. Significantly, the argon data indicate that the rocks below the BCCT were cooler than about $300^{\circ} \mathrm{C}$ (biotite-closure temperature) by $135 \mathrm{Ma}$ and were not affected by the subsequent dynamothermal events that affected rocks that overlie the BCCT (figs. 14, 15).

Rocks between the Big Canyon Creek thrust and the Ahsahka thrust (fig. 14; structural block or rock package 2) record a complex thermal and deformational history. The oldest hornblende dates are from gneiss and amphibolite in the structurally lowest part of the lower amphibolite-facies rockpackage above the BCCT (figs. 14, 15). The argon data indicate that metamorphism of these rocks began by about $129 \mathrm{Ma}$ (oldest metamorphic hornblende-cooling age). The common occurrence of synkinematic (lineated) hornblende as part of the prograde mineral assemblage of the gneiss and amphibolite indicates that metamorphism was accompanied by deformation. The temperature during this event probably was near, but not significantly above, hornblende-closure temperature. ${ }^{40} \mathrm{Ar} /{ }^{39} \mathrm{Ar}$-cooling ages for hornblendes from samples of undeformed plutonic rocks intrusive into the metamorphic rocks are between 122 and $115 \mathrm{Ma}$ and are interpreted to be good approximations of emplacement ages for this suite of maficto intermediate-composition intrusive rocks. A 116.8-Ma $\mathrm{U}-\mathrm{Pb}$ zircon date for a pluton within the boundary zone that is chemically similar to these undeformed plutons between the Big Canyon Creek and the Ahsahka thrusts confirms that this was a period of plutonic activity within the island-arc rocks. Pegmatite intruded these rocks as late as $97 \mathrm{Ma}$; this pegmatite-muscovite date is interpreted to be a minimum estimate of the age of emplacement of the pegmatite and clearly indicates that at least parts of the rock package between the Big Canyon

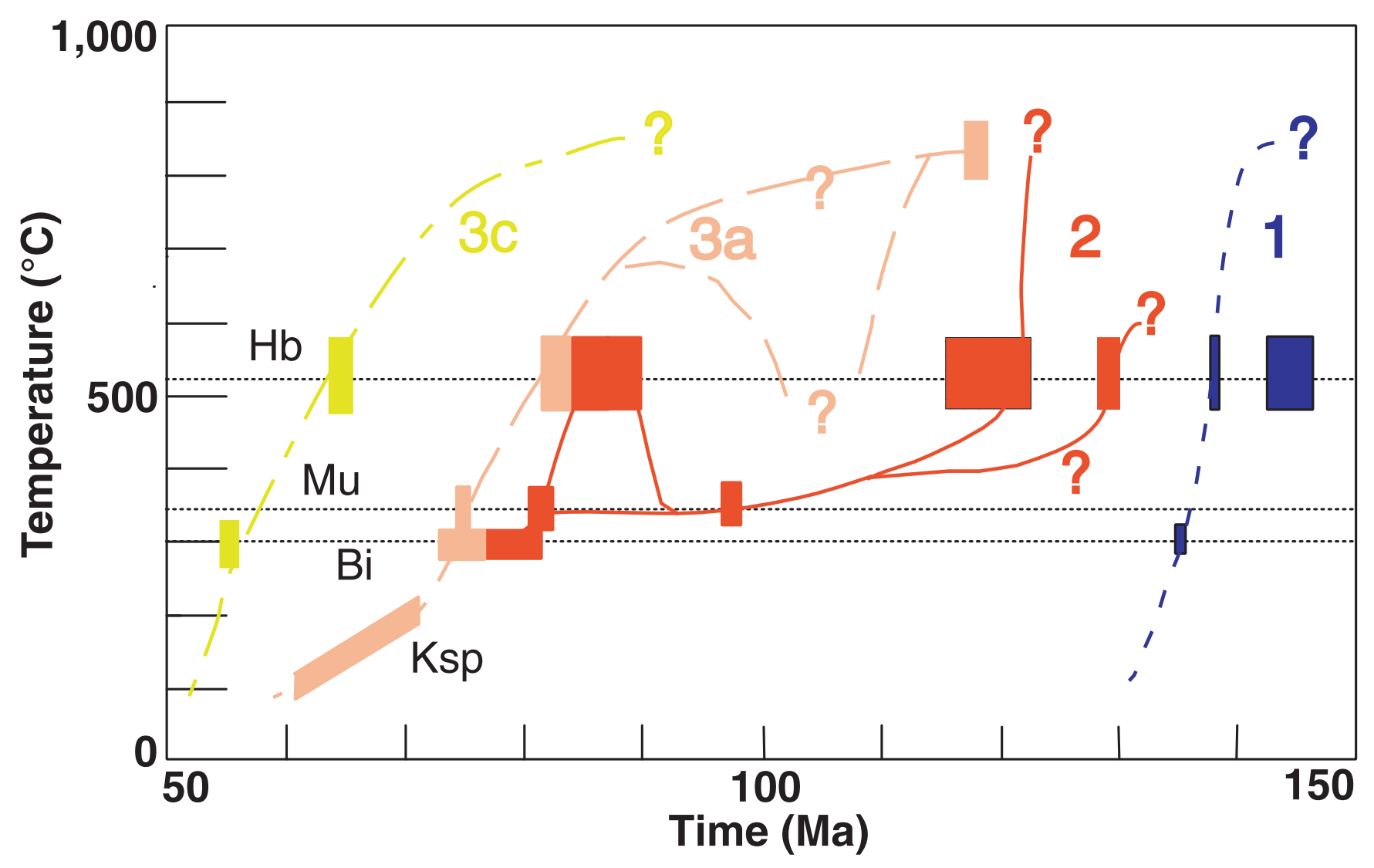

Figure 14. Temperature-versus-time diagram summarizing the interpreted thermal histories of rocks in the study area. Horizontal dotted lines mark mineral-closure temperatures assumed in this study ( $\mathrm{Hb}$, hornblende; Mu, muscovite; Bi, biotite; Ksp, $\mathrm{k}$-feldspar). Horizontal box widths represent either \pm 1 sigma uncertainty brackets (time axis) of a single sample or the lower and upper limits of mineral dates for a group of samples. Vertical box dimensions show range of accepted closure temperatures. Separate cooling curves are shown for each rock package on figure 13: Cooling curve 1 drawn through purple boxes is for rocks below the Big Canyon Creek thrust. Cooling curve 2 drawn through orange boxes is for rocks between the Big Canyon Creek thrust and the Ahsahka thrust. Cooling curve 3a drawn through tan boxes is for rocks above the Ahsahka thrust. Two possible cooling profiles are exhibited to include possibilities of reheating or slow cooling. Cooling curve $3 \mathrm{c}$ drawn through yellow boxes is for slower cooled rocks to the east near Pierce. 


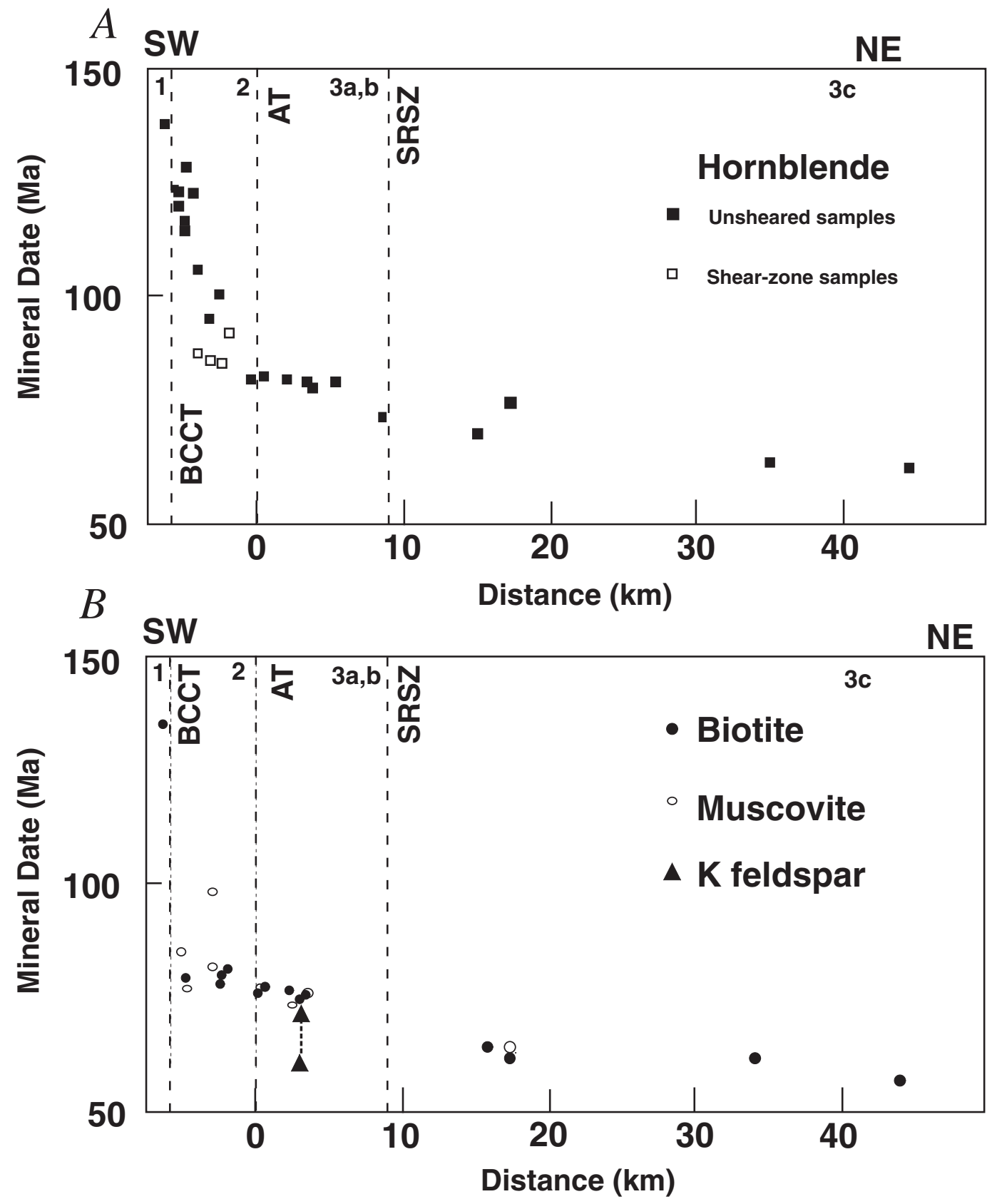

Figure 15. Diagrams of mineral date versus distance summarizing the spatial distribution of mineral dates within the three rock packages discussed in the text (numbers along top of each diagram) and eastward to the vicinity of Pierce and Headquarters, Idaho (fig. 2). Three major structural features indicated by dashed vertical lines are the Big Canyon Creek thrust (BCCT), the Ahsahka thrust (AT), and the Salmon River suture zone (SRSZ). Data are projected onto a west-east profile. Surface trace of the Ahsahka thrust is taken as arbitrary zero-point for distance scale. $A$, Hornblende dates. $B$, Mica and K-feldspar dates; triangles for K-feldspar dates show high and low apparent ages from diffusion profile preserved in the K-feldspar spectrum. 
Creek thrust and the Ahsahka thrust had cooled below $350^{\circ} \mathrm{C}$ (the approximate argon-closure temperature of muscovite) by about $98 \mathrm{Ma} .{ }^{40} \mathrm{Ar} /{ }^{39} \mathrm{Ar}$ dates for hornblende from sheared plutons within this package range between 93 and $85 \mathrm{Ma}$ and probably date northeast-over-southwest-directed ductile thrusting. The formation of new hornblende (rather than actinolite) and the resetting of relict hornblende during shearing suggest that temperatures within shear zones may have been elevated to at least hornblende-closure temperature during shear-zone deformation. Combined, these observations suggest a complex thermal structure following lower amphibolite-facies metamorphism in which the temperature within shear zones may have been locally elevated to near (or above?) $520^{\circ} \mathrm{C}$, but with the ambient temperature not above $350^{\circ} \mathrm{C}$ and not below $300^{\circ} \mathrm{C}$ after about $100 \mathrm{Ma}$. Such a complex thermal structure may have resulted, at least in part, from thermal effects of shear heating or hot fluids passing through the numerous shear zones. Final cooling to below about $300^{\circ} \mathrm{C}$ (biotite-closure temperature) throughout the package occurred by about 80 to $76 \mathrm{Ma}$. The discordance between biotite-cooling ages of $135 \mathrm{Ma}$ in the rock package below the BCCT and $80 \mathrm{Ma}$ in the rock package above the BCCT suggests that the BCCT is younger than $80 \mathrm{Ma}$. The last dated event in the package of rocks above the BCCT is formation of brittle fractures and faults and emplacement of dikes at about $77 \mathrm{Ma}$.

The 35 m.y. discordance between our 116.8-Ma U-Pb zircon date, interpreted to be the age of emplacement of quartz diorite above and east of the Ahsahka thrust (figs. 13, 14, 15; structural block or rock package $3 \mathrm{a}$ ), and the $81-\mathrm{Ma}{ }^{40} \mathrm{Ar} /{ }^{39} \mathrm{Ar}$ cooling age for coexisting hornblende is compatible with two different interpretations (graphically represented by two tracks in curve 3 of fig. 15): (1) The quartz diorite underwent a 35-m.y. period of very slow cooling (about $10^{\circ} \mathrm{C} / \mathrm{m} . \mathrm{y}$., time averaged) from emplacement temperature (about $850^{\circ} \mathrm{C}$; Naney, 1983) to less than $520^{\circ} \mathrm{C}$ (argon-closure temperature of hornblende). (2) Alternatively, after emplacement the pluton cooled below hornblende argon-closure temperature but was reheated above $520^{\circ} \mathrm{C}$ at $81 \mathrm{Ma}$ or before. The presence of embayed kyanite and later well-formed sillimanite in Orofino Metamorphic Suite country-rocks, as discussed above, indicates either (1) a single progressive metamorphism with an early high-pressure stage and a later high-temperature stage, which is consistent with prolonged cooling of the quartz diorite after emplacement, or (2) an earlier high-pressure metamorphic event followed by a later higher temperature metamorphic event, which is consistent with reheating of the quartz diorite after it first cooled below $520^{\circ} \mathrm{C} .{ }^{40} \mathrm{Ar} /{ }^{39} \mathrm{Ar}$ mineral dates from the high-grade rocks within the boundary zone and adjacent areas to the north and east define a fairly simple cooling history following peak metamorphic conditions in the sillimanite zone of the amphibolite facies (figs. 14, 15). Peak temperature during this event (see above) was probably in the range 550 to $650^{\circ} \mathrm{C}$. The occurrence of hornblende and sillimanite lineations indicates that deformation accompanied high-grade recrystallization. This high-temperature deforma- tional and metamorphic event could be the event that reset isotopic systems of sample 35 and rocks in packages $3 \mathrm{a}$ and $3 \mathrm{~b}$.

Cooling rates calculated from mineral pairs provide constraints on the late- to post-thrusting thermal history of rocks above and east of the Ahsahka thrust (fig. 15; structural block or rock package 3a). Initial cooling of the high-grade rocks within the boundary zone is interpreted to have been a function of tectonic uplift during late-stage southwestdirected thrusting and left-lateral translation along the eastwest-trending segment of the terrane boundary (see below). Assuming argon-closure temperatures of 520, 350, and $300^{\circ} \mathrm{C}$, for hornblende, muscovite, and biotite, respectively, calculated cooling rates following cessation of thrust deformation range between 30 and $40^{\circ} \mathrm{C} / \mathrm{m}$.y. and average $35^{\circ} \mathrm{C} / \mathrm{m}$.y. between about 82 and $75 \mathrm{Ma}$. As noted above, depth of emplacement of 116.8-Ma quartz diorite within this package was greater than $25 \mathrm{~km}$ judging from the presence of magmatic epidote (Zen and Hammarstrom, 1984), which provides a minimum pre-uplift depth. Regardless of the postemplacement history of these rocks, an estimate for the rate of uplift after 84 Ma can be calculated by assuming a reasonable paleogeothermal gradient. Using the average cooling rate of $35^{\circ} \mathrm{C} / \mathrm{m}$.y. and assuming reasonable limits for the paleogeothermal gradient of 20 to $30^{\circ} \mathrm{C} / \mathrm{km}$ (compare, Carmichael, 1978; Hyndman and others, 1979, Zen, 1985), calculated uplift rates range from 2.1 to $1.4 \mathrm{~mm} / \mathrm{yr}$ between about 82 and $75 \mathrm{Ma}$. These rates of uplift are similar to the rapid uplift rates of $2 \mathrm{~mm} / \mathrm{yr}$ estimated by Hollister (1982) for rocks east of the Work Channel lineament in British Columbia, a similar geologic environment, and 2 to $3 \mathrm{~mm} / \mathrm{yr}$ estimated by Lund and Snee (1988) for rocks east of the Salmon River suture zone near Riggins. Muscovite-biotite pairs from boundary-zone samples 36 and 38 give similar cooling rates between 75 and $74 \mathrm{Ma}$. Assuming that the age spectrum for K-feldspar sample 37 reflects slow cooling and that the cooling rate between $73.5 \mathrm{Ma}$ (biotite-plateau date) and $70.9 \mathrm{Ma}$ (maximum apparent age for the K-feldspar) was about $20^{\circ} \mathrm{C} / \mathrm{m}$.y., the highest temperature cooling domain in the K-feldspar closed to diffusion of argon at about $250^{\circ} \mathrm{C}$.; assuming a closure temperature of $150^{\circ} \mathrm{C}$ for the lowest temperature cooling domain, the cooling rate between 70.9 and 60.6 Ma (minimum apparent age for the K-feldspar) was probably about $10^{\circ} \mathrm{C} / \mathrm{m}$.y. Using the same assumptions outlined above, the estimated uplift rates for the intervals 73.5 to $70.9 \mathrm{Ma}$ and 70.9 to $60.6 \mathrm{Ma}$ are 0.7 to 1.0 and 0.3 to $0.5 \mathrm{~mm} / \mathrm{yr}$, respectively. Without accurate calculations of the closure temperature for the analyzed K-feldspar, the less-than$300^{\circ} \mathrm{C}$ cooling and uplift history must be viewed cautiously. However, the data show that cooling and uplift certainly were relatively rapid at first and gradually slowed (fig. 15).

The ${ }^{40} \mathrm{Ar} /{ }^{39} \mathrm{Ar}$ data from areas north and east of Orofino (figs. 13, 14, 15; structural blocks or rock packages $3 \mathrm{~b}$ and $3 \mathrm{c}$ ) indicate that cooling in these areas occurred later and apparently at slightly slower rates than observed within the boundary zone near Ahsahka and Orofino. Hornblende and mica dates generally decrease to the north and east, away from the boundary zone, and hornblende-cooling ages are gener- 
ally 10 m.y. older than the cooling ages of coexisting biotites throughout the Ahsahka to Pierce area. Using hornblendemica pairs and assuming the same closure temperatures noted above, calculated average cooling rates are about $35^{\circ} \mathrm{C} / \mathrm{m} . \mathrm{y}$. between 76 and $69 \mathrm{Ma}$ (for rocks along Dworshak Reservoir midway between Ahsahka and Dent), 20 to $25^{\circ} \mathrm{C} / \mathrm{m}$.y. between 75 to $62 \mathrm{Ma}$ (for rocks near Dent), and 35 to $30^{\circ} \mathrm{C} / \mathrm{m}$.y. between about 63 and $55 \mathrm{Ma}$ (for rocks near Pierce). Estimated uplift rates throughout this area range from 0.5 to $2.0 \mathrm{~mm} / \mathrm{yr}$ for paleogeothermal gradients of 30 to $20^{\circ} \mathrm{C} / \mathrm{km}$. The cooling rates are comparable across the entire area from Ahsahka to Pierce, but equivalent cooling near Pierce occurred nearly 10 m.y. later than near Dent; rocks near Dent cooled about 8 m.y. later than rocks at Ahsahka.

The regular decrease in mineral dates away from the boundary zone and the 10-m.y. discordance between hornblende and mica dates, observed in both metamorphic and plutonic rocks, strongly suggest that the dates record cooling that began along the boundary and progressed away from it towards the north and east. The data seem to be most consistent with an interpretation that cooling was related to a regional uplift pattern, in which uplift began along the terrane boundary during Late Cretaceous time and progressed towards the north and east through early Tertiary time. This uplift pattern may have been caused by the buoyancy of less dense Idaho Batholith rocks after emplacement east of the Salmon River suture zone and (or) by isostatic rebound of the underthrust northern margin of the Wallowa terrane following the end of thrusting. In the first alternative, uplift could have been a result of the emplacement of postaccretion plutons that form the northern lobe of the Idaho Batholith. These plutons are known to range in approximate age from about 100 to $57 \mathrm{Ma}$ (Toth, 1987). Granodioritic and similar composition magma is less dense than nearby country rocks because the magma normally crystallizes before rising to a level of equal density. The result is uplift that is driven by the buoyancy of the emplaced magma. In the Orofino area the age of uplift becomes progressively younger to the east. If Toth (1987) is correct that plutons within the central part of the northern lobe of the Idaho Batholith were emplaced primarily at $57 \mathrm{Ma}$, younger uplift toward the east is expected. A similar uplift pattern has been documented by Snee and others (1995) for the southern lobe of the Idaho Batholith.

Alternatively, progressively younger uplift eastward from Orofino could be the result of isostatic rebound after underthrusting of the northern part of the Wallowa terrane under continental rocks of North America. These underthrust rocks would have formed a less dense root extending into the mantle lithosphere that would have favored uplift. As along the Salmon River suture zone to the south, this uplift would begin first along the terrane boundary and progressively proceed eastward. It would not be surprising if both of these mechanisms in part controlled the uplift pattern exhibited by the cooling ages of the rocks in the Orofino area.

Because hornblende and mica ages younger than about 80 Ma decrease gradually from southwest of the terrane-boundary zone towards the north and east, major deformation along the Orofino segment of the boundary probably ended by about 80 $\mathrm{Ma}$; after $80 \mathrm{Ma}$ the two structural plates were coupled.

\section{Timing of Island-Arc Accretion}

The zone that forms the boundary between island-arc terranes accreted to the North American continent in the Mesozoic and the continent itself is well defined throughout western Idaho and has been named the Salmon River suture zone (Salmon River suture zone) by Lund and Snee (1988). This zone marks a sharp discontinuity in the crust that is expressed geochemically and geologically. Data from this study bear directly on the age of accretion along this boundary. A preaccretion age is defined by our 144 - to $135-\mathrm{Ma}{ }^{40} \mathrm{Ar} /{ }^{39} \mathrm{Ar}$ cooling ages for the quartz diorite pluton near Peck and its associated contact metamorphic rocks. This pluton intruded rocks before the oldest regional metamorphism associated with accretionary activity along the Salmon River suture zone. The quartz diorite near Peck is one of a group of plutons, with island-arc chemical affinity, which was emplaced into the Wallowa terrane in several places and which postdates Jurassic and earlier deformation in the Wallowa terrane (see Armstrong and others, 1977; Fleck and Criss, 1985; Walker, 1986; Snee and others, 1995). Plutons of this age and composition are 20 $\mathrm{km}$ or less west of the Salmon River suture zone near Riggins (Sarewitz, 1982; Snee and others, 1995) and within $15 \mathrm{~km}$ of the Salmon River suture zone near Orofino (this study); they have not been recognized on the continent side of the Salmon River suture zone. Postintrusion deformation has moved these plutons closer to the terrane boundary than their original positions (this study; Hamilton, 1963; Onasch, 1977; Myers, 1982; Lund, 1984; Lund and Snee, 1988; Manduca, 1988; Aliberti, 1988), and dynamothermal metamorphism related to accretionary activity on the Salmon River suture zone has affected plutons of this group near the suture zone (Snee and others, 1995). The lack of documented pre-Late Cretaceous ( $>95$ Ma) plutons on the continent side of the Salmon River suture zone suggests that the island-arc terrane was not adjacent to the continent in western Idaho during this magmatic episode and that earlier deformation in the Wallowa terrane preceded accretion to the continent (Lund and Snee, 1985; Fleck and Criss, 1985; Lund and Snee, 1988).

${ }^{40} \mathrm{Ar} /{ }^{39} \mathrm{Ar}$ mineral dates, which record the $130-100-\mathrm{Ma}$ dynamothermal metamorphic event in rocks above the Big Canyon Creek thrust, north of Peck, define the oldest welldocumented metamorphic event in rocks along the Salmon River suture zone. An older 144-Ma Nd-Sm garnet-whole rock "isochron age" from garnet amphibolite west of the Salmon River suture zone and south of Riggins has been reported (Aliberti, 1988; Aliberti and others, 1988). On the basis of the synkinematic character of the garnet and other fabricrelated arguments, $144 \mathrm{Ma}$ was interpreted to be the time of metamorphism and deformation during island arc-continent 
collision. However, the geologic meaning of this date is uncertain because it is based on a two-point isochron from which the basic assumptions of isotopic dating cannot be evaluated (such as initial isotopic equilibrium; see Faure, 1986). Of more interest, Getty and others (1991) reported a preliminary eight-point Sm-Nd mineral-isochron date of $128 \pm 3 \mathrm{Ma}$ for a metamorphic rock in the Pollock Mountain plate south of Riggins, Idaho, which was interpreted by Selverstone and others (1992) to be the age of metamorphism in that plate. If this apparent age proves to be a valid age of metamorphism, it is simlar to the age of our oldest dynamothermal event along the Orofino segment of the Salmon River suture zone. In contrast, the majority of deformational and (or) thermal events recognized west of the Salmon River suture zone in the Riggins area (Lund and Snee, 1988; Snee and others, 1995) are between 118 and 93 Ma. A preliminary U-Pb date of 118 Ma also has been reported for a post-early deformation pluton in the McCall area (fig. 1; Manduca 1988; Manduca and others, 1993), which suggests that deformation along the Salmon River suture zone began before $118 \mathrm{Ma}$. Therefore the oldest accretion-related metamorphism ranges between 130 and 118 Ma, depending on location along the Salmon River suture zone.

Data from the present study indicate that accretionrelated metamorphic events ended by about $100 \mathrm{Ma}$ in the Orofino area. Besides the 130-Ma metamorphic event, our ${ }^{40} \mathrm{Ar} /{ }^{39} \mathrm{Ar}$ dates provide evidence for a period of plutonism within the island-arc terrane between 122 and 115 Ma. Four hornblende-cooling ages for plutons are significantly younger than the hornblende-cooling ages for nearby metamorphic rocks. We interpret the hornblende cooling ages for plutons as minimum emplacement ages with caution, because of the thermal complexity of post-130-Ma effects on the rocks of the Peck area. However, our 116.8-Ma U-Pb zircon date for quartz diorite within the boundary zone of the island-arc terrane near Ahsakha, which is chemically affiliated to these 122-115-Ma plutons, is conclusive evidence that plutons were emplaced into the deformed island arc after 130-Ma metamorphism and gives us additional confidence in the interpretation of the hornblende dates of 122-115 Ma. In the Riggins and McCall areas, emplacement ages of $93 \mathrm{Ma}$ (Lund and Snee, 1988; Snee and others, 1995) and $111 \mathrm{Ma}$ (Manduca, 1988; Manduca and others, 1993) for plutons that intruded both island-arc and continental rocks define a lower limit for the time of the major part of the terrane juxtaposition (Lund and Snee, 1988; Snee and others, 1995). Complex fabrics that were formed in Riggins Group (Paleozoic or Mesozoic) rocks during later uplift-driven ductile deformation (Onasch, 1977; Snee and others, 1995) were likely a result of terrane juxtaposition.

Most of the fabric that developed in rocks of the Orofino area during accretion-related deformation was transposed or overprinted by younger, postaccretion thrust-related uplift. However, the surviving accretion-related structural elements and thermochronologic evidence for rocks in the Orofino area, combined with data from other sections of the Salmon River suture zone, support the conclusions of Lund and Snee (1987) and Snee and others (1995) that at least four dynamothermal metamorphic events affected rocks along the Salmon River suture zone (approximately 130, 118, 109, and $101 \mathrm{Ma}$ ). Two fundamental results of this and other studies (for example, Lund and Snee, 1988; Snee and others, 1995; Selverstone and others, 1992; Davidson and Snee, 1990 are strong evidence that these metamorphic events were caused by Salmon River suture zone activity. These results are (1) multiple regional metamorphic events are localized along the Salmon River suture zone, and (2) plutons were emplaced across the suture zone, as indicated by their isotopic signatures and ages, during the 130to 100-Ma metamorphic activity. Thus, it is likely that there is a causal relationship between 130- to 100-Ma metamorphism and accretionary activity along the Salmon River suture zone.

\section{Postaccretion Deformation and Metamorphism}

The Orofino segment of the Salmon River suture zone was affected by postaccretion deformation, much like the suture zone south of the Orofino area. Along the Orofino segment, however, this later activity more pervasively overprinted evidence for earlier dynamothermal activity than to the south. Our data indicate that the major postaccretion deformation along the entire length of the Salmon River suture zone occurred during the same time period, that is, 93-80 Ma, and was driven by uplift of the continental rocks east of the Salmon River suture zone along a structure or structures virtually coincident with the north-south-trending Salmon River suture zone (see Snee and others, 1995). However, in the Orofino area, the uplifted block includes continental rocks, the Salmon River suture zone, and some island-arc rocks; and this entire package was thrust southwestward over island-arc rocks west of the Salmon River suture zone. (The northern edge of these thrusted rocks defines the east-west-trending segment of the terrane boundary and is discussed below.) This southwestward thrusting overprinted the earlier accretion-related fabrics over a wider area (30 to $50 \mathrm{~km}$ ), whereas south of Orofino, the continental rocks were nearly vertically uplifted relative to the island arc and the overprinting effects of this activity were limited to a much narrower zone (Snee and others, 1995). A summary of events along the Salmon River suture zone is presented below.

\section{Chronology of Events Along the Salmon River Suture Zone}

In the Orofino area, the overlap of hornblende cooling ages from high-grade rocks within the boundary zone (above the Ahsahka thrust) with hornblende ages for shear-zone activity in the lower grade rocks (below the Ahsahka thrust) over the interval of 93 to $80 \mathrm{Ma}$ indicates the thrusting occurred during this time. This deformation erased all earlier fabric 
elements except $F_{1}$ in some locations. The dominant fabric element in Orofino-area rocks is $\mathrm{F}_{2}$, which our structural analysis shows was formed during southwest-directed thrusting after emplacement of 116.2-Ma quartz diorite and related plutons. $\mathrm{F}_{3}$ folds seem to have formed during this high-temperature, high-strain period of deformation but slightly later than $\mathrm{F}_{2}$ and in response to ductile left-lateral shear along the east-westtrending part of the terrane boundary. $\mathrm{F}_{4}$, on the other hand, formed after high-temperature deformation in response to minor postmetamorphic structural adjustments. These events are summarized as follows:

\begin{tabular}{|c|c|c|c|c|}
\hline Age (Ma) & $\begin{array}{l}\text { Fold } \\
\text { event } \\
\left(F_{x}\right)\end{array}$ & Metamorphism & Plutonism & Tectonic Events \\
\hline Post-85 & F4 ? & Contact & $\begin{array}{l}\text { Idaho Batholith } \\
\text { plutonism-peralu- } \\
\text { minous in southern } \\
\text { lobe, metaluminous } \\
\text { in northern; 77-Ma } \\
\text { dike in Orofino area }\end{array}$ & $\begin{array}{l}\text { Slow cooling and } \\
\text { uplift east of Orofino }\end{array}$ \\
\hline $95-85$ & F3 & $\begin{array}{l}\text { Metamor- } \\
\text { phism related } \\
\text { to ductile de- } \\
\text { formation, } \\
\text { thrusting, and } \\
\text { uplft }\end{array}$ & $\begin{array}{l}\text { 1st plutons (meta- } \\
\text { luminous) of the } \\
\text { Idaho Batholith }\end{array}$ & $\begin{array}{l}\text { Southwest-directed } \\
\text { thrusting of conti- } \\
\text { nent and suture zone } \\
\text { over island arc in } \\
\text { Orofino area; "bend" } \\
\text { in } 87 \mathrm{Sr} / 86 \mathrm{Sr} \text { line } \\
\text { is formed; vertical } \\
\text { uplift of continent } \\
\text { along suture zone } \\
\text { south of Orofino }\end{array}$ \\
\hline 95 & F2? & None & None & $\begin{array}{l}\text { Island arc tacked to } \\
\text { continent }\end{array}$ \\
\hline $122-115$ & $\mathrm{~F} 1$ & $\begin{array}{l}\text { Multiple meta- } \\
\text { morphic events } \\
\text { along suture } \\
\text { zone south of } \\
\text { Orofino }\end{array}$ & $\begin{array}{l}\text { Oldest suture-zone } \\
\text { plutons }\end{array}$ & $\begin{array}{l}\text { Continued island-arc } \\
\text { convergence and } \\
\text { transpression }\end{array}$ \\
\hline 130 & Pre-F1 & $\begin{array}{l}1^{\text {st }} \text { suture zone } \\
\text { metamorphism }\end{array}$ & None & $\begin{array}{l}\text { Oblique conver- } \\
\text { gence; right-lateral } \\
\text { transpression }\end{array}$ \\
\hline 145 & None & Contact & Island-arc & $\begin{array}{l}\text { Island arc away } \\
\text { from continent }\end{array}$ \\
\hline
\end{tabular}

Because final metamorphism of rocks within the boundary zone occurred at relatively high temperatures and because all mineral dates for these rocks record cooling, the 116.8-Ma emplacement age of orthogneiss places an upper limit on the age of $\mathrm{F}_{2}$ deformation and fabric development. A lower limit for the age of the fabric comes from 93- to 85-Ma ${ }^{40} \mathrm{Ar} /{ }^{39} \mathrm{Ar}$ dates for shear zones along the Clearwater River; hornblende cooling ages for high-grade gneisses at Ahsakha, which formed synchronously with the shear zones, are $84 \mathrm{Ma}$ or less. The 116.8-Ma gneissic quartz diorite is chemically related to nearby younger tonalitic orthogneiss (Hietanen, 1962; L.W. Snee, unpublished data; fig. 2), which was strongly deformed together with the metasedimentary rocks and quartz diorite that it intrudes, indicating that emplacement of the tonalite also predated $\mathrm{F}_{2}$ deformation and occurred between 116.8 and 93
Ma. Initial ${ }^{87} \mathrm{Sr} /{ }^{86} \mathrm{Sr}$ ratios for the tonalite from samples across the area indicate that it was emplaced across the Salmon River suture zone after accretion of the island arc to the continent; that is, initial ${ }^{87} \mathrm{Sr} /{ }^{86} \mathrm{Sr}$ ratios of the tonalite in the northern exposures are $>0.706$, indicating the involvement of continental crust, but in the Ahsahka/Orofino area, initial ratios of the tonalite and the earlier quartz diorite are $<0.704-0.705$ (Criss and Fleck, 1987; this study), suggesting no involvement of old continental crust (fig. 16). Thus, deformation described by Strayer and others (1989) and in this study that affected both the quartz diorite and tonalitic orthogneiss and preexisting rocks (and produced the dominant foliation, $S_{2}$ ) must postdate juxtaposition of island-arc rocks against continental rocks along the Orofino segment of the Salmon River suture zone.

A consistent northeast-over-southwest sense of shear is defined by both late-stage ductile structures in orthogneiss near Ahsahka (Strayer and others, 1989) and structures within discrete ductile shear zones that cut the mafic plutons below the Ahsahka thrust (AT). Structures within the orthogneiss that provide kinematic information (Strayer and others, 1989) probably formed during latest stages of this deformation when the rocks were below peak metamorphic temperatures and deformation occurred in separated discrete zones. The contrast in metamorphic grade across the AT and the presence of magmatic epidote in upper-plate rocks indicate that vertical displacement along this structure probably was greater than $25 \mathrm{~km}$. Strayer and others (1989) estimated that the strain exhibited in the boundary zone indicated 27 to $84 \mathrm{~km}$ of topto-the-southwest translation of upper plate rocks. Considering the 45-degree dip of the AT and associated shear zones, $35 \mathrm{~km}$ of top-to-the-southwest displacement along the AT is geometrically necessary to account for the $25 \mathrm{~km}$ of uplift. Any translation greater than $35 \mathrm{~km}$ could not have been driven solely by uplift; an additional source of stress was necessary. If the Strayer and others (1989) maximum estimate of $84 \mathrm{~km}$ of top-to-the-southwest translation occurred, the additional 49 $\mathrm{km}$ of top-to-the-southwest movement could have been driven by left-lateral ductile translation as indicated by $\mathrm{F}_{3}$ folds. This left-lateral movement may have been driven by regional stress accommodated by ductile deformation along a structure like the trans-Idaho discontinuity (see below; Yates, 1968; Armstrong and others, 1977). In the Orofino area, left-lateral translation did take place and the movement was accommodated in the zone through which the east-west-trending segment of the terrane boundary passes.

The documented 93-80 Ma time of northeast-over-southwest thrusting along the Orofino segment of the Salmon River suture zone partly coincides with 88- to 79-Ma deformation involving continent-side-up reverse movement along the suture zone near Riggins (Lund and Snee, 1988; Snee and others, 1995). In the Riggins area, this late deformation produced moderately to steeply northeast-dipping foliations and (or) lineations in suture-zone (stitching) tonalites. These late-formed fabrics crosscut earlier fabrics and thrust faults in older rocks. Similar structures have been described near McCall (Manduca, 1988; Manduca and others, 1993; Kuntz, this volume, chapter 
7) and along the South Fork of the Clearwater River (Myers, 1982; Hoover, 1986). Although lineation trends vary along the boundary and structures tend to dip more shallowly near Orofino, from Orofino to McCall the sense of motion is continent-side-up (Lund and others, 1990; Snee and others, 1995; Kuntz, this volume, chapter 7). The deformation was of a significant magnitude along the entire length of the Salmon River suture zone as demonstrated by as much as $25 \mathrm{~km}$ of uplift documented by cooling studies near Riggins (Lund and Snee, 1988; Snee and others, 1995) and the prominent metamorphic breaks across some structures that were active during this event along the length of the Salmon River suture zone.

\section{Origin of the Bend in the ${ }^{87} \mathrm{Sr} /{ }^{86} \mathrm{Sr}$ Line}

As shown in figure 16, strontium isotopic data from granitic rocks suggest that the crustal boundary between island-arc and Precambrian North American continental rocks bends sharply to the west in the vicinity of Orofino (Armstrong and others, 1977; Fleck and Criss, 1985). The origin and tectonic significance of the west-trending segment of the terrane boundary have been the subjects of much speculation. Yates (1968) noted an apparent 320- to 640-km left-lateral offset in major Precambrian to Mesozoic geologic elements along an interpreted northwest-trending structure, the "transIdaho discontinuity," which extends through the Orofino area. Yates suggested that the "trans-Idaho discontinuity" was a major left-lateral transcurrent fault, or fault zone, along which activity began before Permian time and ended by the Late
Cretaceous. Later, Armstrong and others (1977), on the basis of strontium isotopic data, suggested that the "trans-Idaho discontinuity" trends due west from the Orofino area (figure 1). They proposed that this structure may have been a transform fault during initial continental rifting in late Precambrian time (Armstrong and others, 1977) and also acted as a transform (with the opposite sense of motion) during accretion of the Wallowa terrane to the continental margin (Armstrong and others, 1977; Hillhouse and others, 1982).

Because of extensive Tertiary basalt cover to the west, the Orofino area provides essentially the only place to study the pre-Tertiary rocks near the apparently west-trending segment of the Salmon River suture zone. Results of the present study and others provide some limited constraints on the origin and history of this structure. First, mapping for this study and by Hietanen (1962) suggest that structures in the pre-Tertiary rocks are probably continuous around the bend. Second, no evidence for a west-trending brittle strike-slip structure has been observed between island-arc rocks in the Ahsahka-Orofino area and clearly continental quartzite, located several kilometers to the north along Dworshak Reservoir (figure 2). Third, major late-stage deformation along the west-trending Peck-to-Orofino segment of the terrane boundary involved northeast-over-southwest thrusting between about 93 and $80 \mathrm{Ma}$ after emplacement of the late-accretion tonalitic plutons. Fourth, foliations, lithologic contacts, and shear zones in the Peck-Ahsahka-Orofino area and in adjacent areas to the north, east, and southeast (Hietanen, 1962) trend to the northwest or west-northwest and do not coincide directly with the east-west trend of the crustal boundary as defined by the strontium "line" (Armstrong and others, 1977; Fleck and Criss, 1985; figure 16).

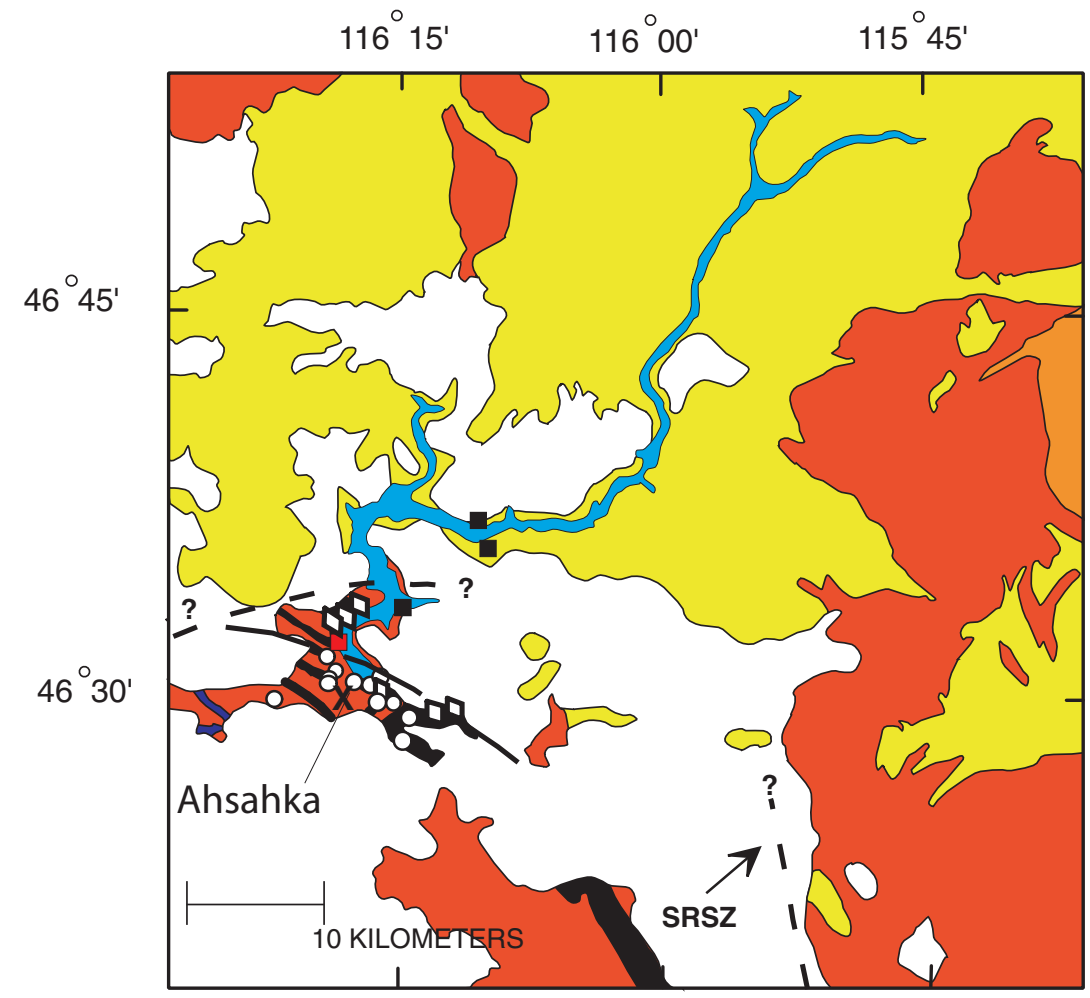

Figure 16. Generalized geologic map of area around Ahsakha and Orofino (explanation as for figure 2) showing strontium isotope geochemical data for plutonic rocks (data from Fleck and Criss, 1985, and this study). Open circles show the locations of samples with initial ${ }^{87} \mathrm{Sr} /{ }^{86} \mathrm{Sr}$ ratios $<0.704$; open diamonds show locations of samples with initial ${ }^{87} \mathrm{Sr} /{ }^{86} \mathrm{Sr}$ ratios between 0.704 and 0.706 ; solid squares show locations of samples with initial ${ }^{87} \mathrm{Sr} /{ }^{86} \mathrm{Sr}$ ratios $>0.706$. Short-dash line shows approximate location of the Salmon River suture zone. Long-dash line shows the southernmost extent in the Ahsahka area of Orofino series rocks with probable continental affinities based on available traceelement data. South of this line, samples have island-arc affinity. 
We propose that the bend in the strontium line is the result of a combination of northeast-over-southwest thrusting of high-grade metamorphic rocks in the boundary zone over island-arc rocks and simultaneous left-lateral ductile translation of continental rocks along a west-trending zone through the Orofino area. Structures interpreted to have formed during the thrust event at 93 to $80 \mathrm{Ma}$ (generally continent-side-up reverse motion along the SRSZ in western Idaho) appear to be continuous around the bend in the terrane boundary, suggesting that the bend formed ductilely during this late deformation event. The

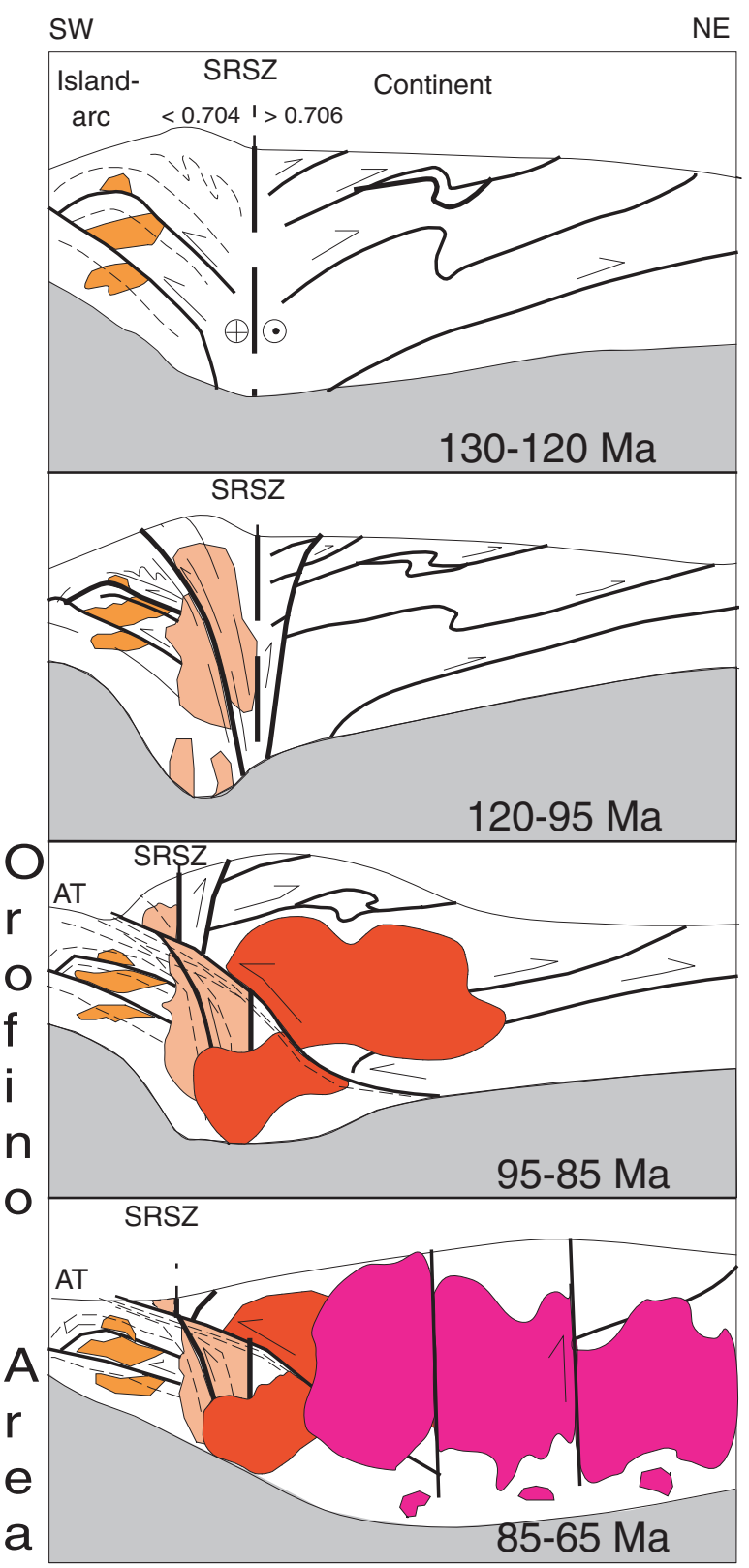

result of this thrusting is the effective southwestward translation of the strontium line and the rotation of the high-grade structures in the boundary zone from vertical to a northeasterly dip.

\section{Summary of the Tectonic Development of the Salmon River Suture Zone}

The Cretaceous tectonic development of the Salmon River suture zone (SRSZ) near Orofino from before130 Ma to 
about $60 \mathrm{Ma}$ is summarized in figure 17-a series of hypothetical cross sections (cartoons) from south of Peck to north of Pierce along a northeasterly trend. These cross sections are intended to generally represent the major tectonic activity along the line of section during each of four periods- 130 to $120 \mathrm{Ma}, 120$ to $95 \mathrm{Ma}, 95$ to $85 \mathrm{Ma}$, and 85 to $65 \mathrm{Ma}$. These cross sections primarily are based on the data of this study, but some conclusions on the tectonic development of the SRSZ near Riggins during this time period that were documented in Snee and others (1995) are also used. Important events summarized on this figure are discussed below.

From 130 to $120 \mathrm{Ma}$, the Salmon River suture zone was the locus of right-slip transpressive movement between islandarc terranes and North America (Lund and Snee, 1988). Dynamothermal metamorphism and deformation accompanied this transpression. To the south of Orofino along the SRSZ, regional thrust faulting verged both to the east and to the west away from the suture zone. In the Orofino area it is difficult to document this thrusting because of the effect of later high-grade metamorphic events. However, near Orofino, as in the south, transpression probably caused thickening of the crust at the suture zone.

During the 120- to 95-Ma period, the thickened crust at and west of the suture zone underwent partial melting at the crust-mantle boundary to form quartz diorite and tonalite magmas. The magmas were emplaced and deformed within ductile structures during continuing right-slip transpression. Rightslip movement was facilitated by emplacement of magma and subsequent fluid flow within the magmas. If dynamothermal metamorphism affected rocks along the Salmon River suture zone in the Orofino area during this time, later events overprinted these effects or they were less pronounced than in other areas to the south.

From 95 to $85 \mathrm{Ma}$ in the Orofino area, thrusting transported North American continental rocks tens of kilometers to the southwest over island-arc rocks. Most strain was developed in the boundary-zone rocks, primarily within the island arc, but some ductile shear zones with an identical sense of shear but unknown amount of displacement formed in the islandarc rocks to the west. Simultaneously, left-lateral translation of continental rocks along a high-grade ductile west-trending zone through the Orofino area transported continental rocks tens of kilometers westward relative to island-arc rocks to the south. Deformation resulting from the left-lateral translation was manifested in $\mathrm{F}_{3}$-related structures. Movement in the high-strain boundary zone brought up rocks at high temperature $\left(>520^{\circ} \mathrm{C}\right)$ that thermally affected footwall rocks. This southwestward thrusting and simultaneous westward strikeslip translation of continental rocks occurred at the same time as more than $25 \mathrm{~km}$ of uplift of continental rocks to the south along the SRSZ, and likely the thrusting and the uplift were linked dynamically. Uplift in the Orofino area, as in the south, was related to bouyancy of voluminous metaluminous magmas of the Idaho Batholith emplaced east of the SRSZ. In the Orofino area, westward translation of continental rocks was possibly related to regional movement along a structure like the "trans-Idaho discontinuity."
From 85 to $65 \mathrm{Ma}$, uplift progressed eastward. Magmatism also progressed eastward (Toth, 1987), and the buoyancy contrast of the plutons compared to their country rocks may have driven this uplift. A similar eastward progression of magmatism and uplift is exhibited from the Riggins area into southwestern Montana (Snee and others, 1995). Alternatively, and perhaps in conjunction, uplift may have been driven by isostatic rebound of the underthrust northern margin of the Wallowa terrane under North American continental rocks. Near Peck, at about $80 \mathrm{Ma}$, the Big Canyon Creek thrust moved plutons and metamorphic rocks over lower grade metamorphic and unmetamorphosed rocks of the Wallowa terrane to the southwest. At about the same time (77 $\mathrm{Ma}$ ), west of the Salmon River suture zone, some high-angle faults and fracture zones formed and volumetrically minor felsic magmas were emplaced as dikes along these fractures and later sheared.

\section{Acknowledgments}

We thank John Sutter, Tracy Vallier, E-an Zen, Mel Kuntz, Jane Hammerstrom, Elaine Aliberti, Jad D'Allura, Mizra Shahid Baig, David Blackwell, David Blake, Allen Kays, Charlie Knowles, Bob Lawrence, Reed Lewis, Karen Lund, Cathy Manduca, Paul Myers, Jane Selverstone, and David White for useful discussions and thoughts about western Idaho geology. Gerry Cebula, Jack Groen, Steve Harlan, and Mick Kunk helped with mineral separation, and Ross Yeoman helped with argon analyses. John Sutter gave access to the Reston argon laboratory for some of our early analyses. John Sutter, Howard Brooks, Jane Hammarstrom, Tony Bryant, Tracy Vallier, and Mel Kuntz provided reviews that helped us clarify our presentation. Thanks also to Mel Kuntz for keeping the publication of this professional paper alive and to Lorna Carter for her editorial skills. Heartfelt thanks go to the late Bob Walker, who conducted the INAA work at the Oregon State University Radiation Center. Part of this work is based on Gary Davidson's master's thesis, which was funded in part by grants from Sigma Xi Honor Society, the Belt Association, the U.S. Geological Survey, and the Department of Geosciences, Oregon State University.

\section{References Cited}

Aliberti, E.A., 1988, A structural, petrographic, and isotopic study of the Rapid River area and selected mafic complexes in the northwestern United States; implications for the evolution of an abrupt island arc-continent boundary: Harvard University, Ph.D. dissertation, 194 p.

Aliberti, E.A., Selverstone, J., Jacobsen, S.B., and Wernicke, B.P., 1988, The Pollack Mountain amphibolite; isotopic and 
petrologic constraints on the evolution of an island arc-continent boundary: Geological Society of America Abstracts with Programs, v. 20, no. 7, p. 403.

Anderson, A.L., 1930, The geology and mineral resources of the region about Orofino, Idaho: Idaho Bureau of Mines and Geology Pamphlet no. 34, 65 p.

Armstrong, R.L., 1975, Precambrian (1500 m.y. old) rocks of central Idaho--the Salmon River arch and its role in Cordilleran sedimentation and tectonics: American Journal of Science, v. 275A, p. 437-467.

Armstrong, R.L., Taubeneck, W.H., and Hales, P.L., 1977, Rb/ $\mathrm{Sr}$ and K/Ar geochronometry of Mesozoic granitic rocks and their Sr isotopic composition, Oregon, Washington, and Idaho: Geological Society of America Bulletin, v. 88, p. 397-411.

Avé Lallemant, H.G., Phelps, D.W., and Sutter, J.F., 1980, ${ }^{40} \mathrm{Ar} /{ }^{39} \mathrm{Ar}$ ages of some pre-Tertiary plutonic and metamorphic rocks of eastern Oregon and their geologic relationships: Geology, v. 8, p. 371-374.

Bal, K.D., Lal, N., and Nagpaul, K.K., 1983, Zircon and sphene as fission-track geochronometer and geothermometer; a reappraisal: Contributions to Mineralogy and Petrology, v. 83, p. 199-203.

Bittner, E., 1987, Migmatite zones in the Bitterroot lobe of the Idaho batholith, in Vallier, T.L., and Brooks, H.C., eds., The Idaho batholith and its border zone: U.S. Geological Survey Professional Paper 1436, p. 73-93.

Brooks, H.C., and Vallier, T.L., 1978, Mesozoic rocks and tectonic evolution of eastern Oregon and western Idaho, in Howell, D.G., and McDougall, K.A., eds., Mesozoic paleogeography of the Western United States: Society of Economic Paleontologists and Mineralogists, Mesozoic Paleogeography Symposium 2, p. 133-146.

Carmichael, D.M., 1978, Metamorphic bathozones and bathograds - a measure of the depth of post-metamorphic uplift and erosion on the regional scale: American Journal of Science, v. 278, p. 769-797.

Criss, R.E., and Fleck, R.J., 1987, Petrogenesis, geochronology, and hydrothermal systems of the northern Idaho batholith and adjacent areas based on ${ }^{18} \mathrm{O} /{ }^{16} \mathrm{O},{ }^{87} \mathrm{Sr} /{ }^{86} \mathrm{Sr}, \mathrm{K}-\mathrm{Ar}$, ${ }^{40} \mathrm{Ar} /{ }^{39} \mathrm{Ar}$ studies, in Vallier, T.L., and Brooks, H.C., eds., The Idaho batholith and its border zone: U.S. Geological Survey Professional Paper 1436, p. 95-137.

Dalrymple, G.B., Alexander, E.C., Jr., Lanphere, M.A., and Kraker, G.P., 1981, Irradiation of samples for ${ }^{40} \mathrm{Ar} /{ }^{39} \mathrm{Ar}$ dating using the U.S Geological Survey TRIGA reactor: U.S. Geological Survey Professional Paper 1176, 56 p.

Davidson, G.F., 1988, Field guide to mylonitic rocks west of
Orofino, Idaho, in Lewis, S.E., and Berg, R.B., eds., Precambrian and Mesozoic plate margins; Montana, Idaho, and Wyoming, with field guides for the $8^{\text {th }}$ International Conference on Basement Tectonics: Montana Bureau of Mines and Geology Special Publication 96, p. 171-174.

Davidson, G.F., 1989, Southwest-vergent thrusting and metamorphism along the northern margin of the Wallowa terrane near Orofino, Idaho: Geological Society of America Abstracts with Programs, v. 21, no. 6, p. A89.

Davidson, G.F., 1991, Cretaceous tectonic history along the Salmon River suture zone near Orofino, Idaho; metamorphic, structural, and ${ }^{40} \mathrm{Ar} /{ }^{39} \mathrm{Ar}$ thermochronologic constraints: Corvallis, Oregon, Oregon State University, Master's thesis, $143 \mathrm{p}$.

Davidson, G.F., and Snee, L.W., 1990, Resetting of the hornblende K-Ar isotopic system during mylonitization-implications for direct dating of ductile shear zones: American Geophysical Union Transactions, v. 71, p. 1662.

Davis, G.A., Monger, J.W.H., and Burchfiel, B.C., 1978, Mesozoic construction of the Cordilleran "collage," central British Columbia to central California, in Howell, D.G., and McDougall, K.A., eds., Mesozoic Paleogeography of the Western United States: Society of Economic Paleontologists and Mineralogists, Mesozoic Paleogeography Symposium 2, p. 1-32.

Dodson, M.H., 1973, Closure temperature in cooling geochronological and petrological systems: Contributions to Mineralogy and Petrology, v. 40, p. 259-274.

Faure, G., 1986, Principles of isotope geology: New York, John Wiley \& Sons, Inc., 589 p.

Fleck, R.J., and Criss, R.E., 1985, Strontium and oxygen isotopic variations in Mesozoic and Tertiary plutons of central Idaho: Contributions to Mineralogy and Petrology, v. 90, p. 281-308.

Flinn, D., 1965, On the symmetry principle and the deformation ellipsoid: Geological Magazine, v. 102, no. 1, p. 36-45.

Getty, S., Selverstone, J., Wernicke, B., and Jacobsen, S., 1991, Sm-Nd dating of multiple garnet growth events and arc-continent collision, Salmon River suture zone, western Idaho: Geological Society of America Abstracts with Programs, v. 23, no. 5, p. A191.

Goldstrand, P.M, 1994, The Mesozoic evolution of the northern Wallowa terrane, northeastern Oregon and western Idaho, in Vallier, T.L., and Brooks, H.C., eds., Stratigraphy, physiography, and mineral resources of the Blue Mountains region: U.S. Geological Survey Professional Paper 1439, p. 29-53.

Hamilton, W., 1963, Metamorphism in the Riggins region, western Idaho: U.S. Geological Survey Professional Paper 436, 95 p. 
Hamilton, W., 1976, Tectonic history of west-central Idaho: Geological Society of America Abstracts with Programs, v. 8, no. 3 , p. $378-379$.

Hames, W.E., and Bowring, S.A., 1994, An empirical evaluation of argon diffusion geometry in muscovite: Earth and Planetary Science Letters, v. 124, p. 161-167.

Harrison, J.E., 1972, Precambrian Belt basin of northwestern United States; its geometry, sedimentation, and copper occurrences: Geological Society of America Bulletin, v. 83, p. $1215-1240$.

Harrison, T.M., 1981, Diffusion of ${ }^{40} \mathrm{Ar}$ in hornblende: Contributions to Mineralogy and Petrology, v. 78, p. 324-331.

Harrison, T.M., and McDougall, I., 1980, Investigations of an intrusive contact, northwest New Zealand -1. Thermal, chronological and isotopic constraints: Geochimica et Cosmochimica Acta, v. 46, p. 1811-1820.

Harrison, T.M., Duncan, I., and McDougall, I., 1985, Diffusion of ${ }^{40} \mathrm{Ar}$ in biotite: temperature, pressure, and compositional effects: Geochimica et Cosmochimica Acta, v. 49, p. 2461-2468.

Hietanen, A., 1962, Metasomatic metamorphism in western Clearwater County, Idaho: U.S. Geological Survey Professional Paper 344-A, 116 p.

Hietanen, A., 1963a, Anorthosite and associated rocks in the Boehls Butte quadrangle and vicinity, Idaho: U.S. Geological Survey Professional Paper 344-B, 78 p.

Hietanen, A., 1963b, Metamorphism of the Belt series in the Elk City-Clarkia area, Idaho: U.S. Geological Survey Professional Paper 344-C, 49 p.

Hietanen, A., 1963c, Idaho batholith near Pierce and Bungalow, Clearwater County, Idaho: U.S. Geological Survey Professional Paper 344-D, 42 p.

Hillhouse, J.W., Gromme, C.S., and Vallier, T.L., 1982, Paleomagnetism and Mesozoic tectonics of the Seven Devils volcanic arc in northeastern Oregon: Journal of Geophysical Research, v. 87, p. 3777-3794.

Holdaway, M.J., 1971, Stability of andalusite and the aluminum silicate phase diagram: American Journal of Science, v. 271 , p. $97-131$.

Hollister, L.S., 1982, Metamorphic evidence for rapid (2 $\mathrm{mm} / \mathrm{yr}$ ) uplift of a portion of the Central Gneiss Complex, Coast Mountains, B.C.: Canadian Mineralogist, v. 20, p. 319-332.

Hoover, A.L., 1986, Transect across the Salmon River suture, South Fork of the Clearwater River, western Idaho; rare earth element geochemical, structural, and metamorphic study: Corvallis, Oregon, Oregon State University, Master's thesis, $138 \mathrm{p}$.
Hoover, A.L., Lund, K., and Snee, L.W., 1985, Tectonic model for the island arc-continent suture zone, west-central Idaho; structural and geochemical constraints: Geological Society of America Abstracts with Programs, v.17, no.7, p. 613.

Hyndman, D.W., 1985, Petrology of igneous and metamorphic rocks: New York, McGraw-Hill Book Company, 786 p.

Hyndman, D.W., and Talbot, J.L., 1976, The Idaho batholith and related subduction complex: Geological Society of America, Cordilleran Section, Field Guide 4, 15 p.

Hyndman, R.D., Jessop, A.M., Judge, A.S., and Rankin, D.S., 1979, Heat flow in the Maritime Provinces of Canada: Canadian Journal of Earth Science, v. 16, p. 1154-1165.

Jäger, E., 1979, Introduction to Geochronology, in Jäger, E., and Hunziker, J.C., eds., Lectures in Isotope Geology: Berlin, Springer-Verlag, p. 1-12.

Johnson, C.H., 1947, Igneous metamorphism in the Orofino region, Idaho: Journal of Geology, v. 55, no. 6, p. 490-501.

Jones, D.L., Silberling, N.J., and Hillhouse, J.W., 1977, Wrangellia-A displaced terrane in northwestern North America: Canadian Journal of Earth Science, v. 14, p. 2565-2577.

Kirschner, D.L., Cosca, M.A., Masson, H., and Hunziker, J.C., 1996, Staircase ${ }^{40} \mathrm{Ar} /{ }^{39} \mathrm{Ar}$ spectra of fine-grained white mica; timing and duration of deformation and empirical constraints on argon diffusion: Geology, v. 24, p. 747-750.

Kopp, R.S., 1959, Petrology and structural analysis of the Orofino metamorphic units: Moscow, Idaho, University of Idaho, Master's thesis, $73 \mathrm{p}$.

Krogh, T.E., 1982, Improved accuracy of U-Pb zircon ages by the creation of more concordant systems using air abrasion technique: Geochimica et Cosmochimica Acta, v. 46, p.637649.

Lang, H.M., and Rice, J.M., 1985, Metamorphism of pelitic rocks in the Snow Peak area, northern Idaho; sequence of events and regional implications: Geological Society of America Bulletin, v. 96, p. 731-736.

Laul, J.C., 1979, Neutron activation analysis of geological materials: Atomic Energy Reviews, v. 17, p. 603-695.

Lund, K., 1984, Tectonic history of a continent-island arc boundary, west-central Idaho: State College, Pennsylvania State University, Ph.D. dissertation, 210 p.

Lund, K., and Snee, L.W., 1985, Structural and metamorphic setting of the central Idaho batholith: Geological Society of America Abstracts with Programs, v. 17, no. 4, p. 253.

Lund, K., and Snee, L.W., 1988, Metamorphism, structural development, and age of the continent-island arc juncture in west-central Idaho, in Ernst, W.G., ed., Metamorphism and Crustal Evolution in the Western Coterminous U.S.: Engle- 
wood Cliffs, New Jersey, Prentice Hall, p. 296-331.

Lund, K., Snee, L.W., and Davidson, G.F., 1990, Comment on Strayer et al., 1989, "Direction and shear sense during suturing of the Seven Devils-Wallowa terrane against North America in western Idaho": Geology, v. 18, p. 1031-1032.

Manduca, C.A., 1988, Geology and geochemistry of the oceanic arc-continent boundary in the western Idaho batholith near McCall: Pasadena, California, California Institute of Technology, Ph.D. dissertation, 272 p.

Manduca, C.A., Kuntz, M.A., and Silver, L.T., 1993, Emplacement and deformation history of the western margin of the Idaho batholith near McCall, Idaho; influence of a major terrane boundary: Geological Society of America Bulletin, v. 105 , p. $749-765$.

McDougall, I., and Harrison, T.M., 1999, Geochronology and thermochronology by the ${ }^{40} \mathrm{Ar} /{ }^{39} \mathrm{Ar}$ method: New York, Oxford University Press, 269p.

Myers, P.E., 1982, Geology of the Harpster area, Idaho County, Idaho: Idaho Bureau of Mines and Geology Bulletin $25,46 \mathrm{p}$.

Naeser, C.W., 1979, Fission-trackdating and geologic annealing of fission tracks, in Jäger, E., and Hunziker, J.C., eds., Lectures in Isotope Geology: Berlin, Springer-Verlag, p. 154-169.

Naney, M.T., 1983, Phase equilibria of rock-forming ferromagnesian silicates in granitic systems: American Journal of Science, v. 283, p. 993-1033.

Onasch, C.M., 1977, Structural evolution of the western margin of the Idaho batholith in the Riggins, Idaho area: State College, Pennsylvania State University, Ph.D. dissertation, $196 \mathrm{p}$.

Rember, W.C., and Bennett, E.H., 1978, Geologic map of the Pullman quadrangle: Idaho Bureau of Mines and Geology, Geologic Map Series.

Samson, S.D., and Alexander, E.C., Jr., 1987, Calibration of the interlaboratory ${ }^{40} \mathrm{Ar} /{ }^{39} \mathrm{Ar}$ dating standard, MMhb-1: Chemical Geology, v. 66, p. 27-34.

Sarewitz, D., 1982, Geology of part of the Heavens Gate quadrangle, Seven Devils Mountains, western Idaho: Corvallis, Oregon, Oregon State University, Master's thesis, 144 p.

Sarewitz, D., 1983, Seven Devils terrane-is it really a piece of Wrangellia?: Geology, v. 11, p. 634-637.

Selverstone, J., Wernicke, B.P., and Aliberti, E.A., 1992, Intracontinental subduction and hinged unroofing along the Salmon River suture zone, west central Idaho: Tectonics, v. 11 , p. 124-144.
Sharma, Y.P., Lal, N., Bal, K.D., Parshad, R., and Nagpaul, K.K., 1980, Closing temperatures of different fission-track clocks: Contributions to Mineralogy and Petrology, v. 72, p. 335-336.

Silberling, N.J., Jones, D.L., Jones, M.C., Jr., and Howell, D.G., 1984, Lithotectonic terrane maps of the western conterminous United States, Part C of Silberling, N.J., and Jones, D.L., Lithotectonic terrane maps of the North American Cordillera: U.S. Geological Survey Open-File Report 84-523, part C, 43 p.

Snee, L.W., 1982, Emplacement and cooling of the Pioneer batholith, southwestern Montana: Columbus, Ohio, The Ohio State University, Ph.D. dissertation, 320 p.

Snee, L.W., 2002, Argon thermochronology of mineral deposits - a review of analytical methods, formulations, and selected applications: U.S. Geological Survey Bulletin 2194, 39 p.

Snee, L.W., Lund, K., and Davidson, G.F., 1987, Ages of metamorphism, deformation, and cooling of juxtaposed oceanic and continental rocks near Orofino, Idaho: Geological Society of America Abstracts with Programs, v. 19, no. 5, p. 335.

Snee, L.W., Sutter, J.F., and Kelly, W.C., 1988, Thermochronology of economic mineral deposits; dating the stages of mineralization at Panasqueira, Portugal, by high-precision ${ }^{40} \mathrm{Ar} /{ }^{39} \mathrm{Ar}$ age spectrum techniques on muscovite: Economic Geology, v. 83, p. 335-354.

Snee, L.W., Foord, E.E., Hill, B., and Carter, S.J., 1989, Regional chemical differences among emeralds and host rocks of Pakistan and Afghanistan; implications for origin of emerald: in Kazmi, A.H., and Snee, L.W., eds., Emeralds of Pakistan--geology, gemology, and genesis: New York, Van Nostrand Reinhold, p. 93-124.

Snee, L.W., Lund, K., Sutter, J.F., Balcer, D.E., and Evans, K.V., 1995, An ${ }^{40} \mathrm{Ar} /{ }^{39} \mathrm{Ar}$ chronicle of the tectonic development of the Salmon River suture zone, western Idaho, in Vallier, T.L., and Brooks, H.C., eds., Petrology and tectonic evolution of pre-Tertiary rocks of the Blue Mountains region: U.S. Geological Survey Professional Paper 1438, p. $359-414$

Steiger, R.H., and Jäger, E., 1977, Subcommission on geochronology: convention on the use of decay constants in geo- and cosmo-chronology: Earth and Planetary Science Letters, v. 26, p. 207-221.

Strayer, L.M., Hyndman, D.W., Sears, J.W., and Myers, P.E., 1989, Direction and shear sense during suturing of the Seven Devils-Wallowa terrane against North America in western Idaho: Geology, v. 17, p. 1025-1028.

Sutter, J.F., Snee, L.W., and Lund, K., 1984, Metamorphic, 
plutonic, and uplift history of a continent-island arc suture zone, west-central Idaho: Geological Society of America Abstracts with Programs, v. 16, no. 6, p. 670.

Toth, M.I., 1987, Petrology and origin of the Bitterroot lobe of the Idaho batholith: in Vallier, T.L., and Brooks, H.C., eds., The Idaho batholith and its border zone: U.S. Geological Survey Professional Paper 1436, p. 9-35.

Turner, G., 1968, The distribution of potassium and argon in chondrites, in Ahrens, L.H., ed., Origin and distribution of the elements: New York, Pergamon Press, p. 387-398.

Turner, F.J., 1981, Metamorphic Petrology: New York, McGraw-Hill International Series in the Earth and Planetary Sciences, $524 \mathrm{p}$.

Vallier, T.L., 1977, The Permian and Triassic Seven Devils Group, western Idaho and northeastern Oregon: U.S. Geological Survey Bulletin 1437, 58 p.

Vallier, T.L., 1995, Petrology of pre-Tertiary igneous rocks in the Blue Mountains region of Oregon, Idaho, and Washington; implications for the geologic evolution of a complex island arc, in Vallier, T.L., and Brooks, H.C., eds., Petrology and tectonic evolution of pre-Tertiary rocks of the Blue Mountains region: U.S. Geological Survey Professional Paper 1438, p. 125-209.

Vallier, T.L., and Batiza, R., 1978, Petrogenesis of spilite and keratophyre from a Permian and Triassic volcanic arc ter- rane, eastern Oregon and western Idaho, U.S.A.: Canadian Journal of Earth Science, v. 15, p. 1356-1369.

Walker, N.W., 1986, U/Pb geochronologic and petrologic studies in the Blue Mountains terrane, northeastern Oregon and westernmost-central Idaho: implications for pre-Tertiary tectonic evolution: Santa Barbara, University of California, Ph.D. dissertation, 214 p.

White, W.M., and Patchett, P.J., 1984, Hf-Nd-Sr isotopes and incompatible element abundances in island arcs; implications for magma origins and crust-mantle evolution: Earth and Planetary Science Letters, v. 67, p.167-185.

Yates, R.G., 1968, The Trans-Idaho discontinuity: Proceedings of the $23^{\text {rd }}$ International Geological Congress, v. 1, p. $117-123$

Zartman, R.E., 1984, Lead, strontium,and neodymium isotopic characterization of mineral deposits relative to their geologic environments: Proceedings of the 27th International Geollogical Congress, v. 12, p. 83-106.

Zen, E-an, 1985, Implications of magmatic epidote-bearing plutons on crustal evolution in the accreted terranes of northwestern North America: Geology, v. 13, p. 266-269.

Zen, E-an, and Hammarstrom, J.M., 1984, Magmatic epidote and its petrologic significance: Geology, v. 12, p. 515-518. 


\title{
4. Ultramafic Rocks of the Western Idaho Cratonic Suture Zone-Composition, Origin, and Emplacement
}

\author{
By Martha M. Godchaux and Bill Bonnichsen
}

\section{Abstract}

The western Idaho ultramafic belt, which extends northward for about $260 \mathrm{~km}$ (160 mi) from Sturgill Peak to the north end of Dworshak Reservoir, consists of small bodies of dunite, serpentinite, metaharzburgite, and clinopyroxenite. Except at the south and north ends of the belt, the ultramafic bodies are exposed in a discontinuous band 16 to $24 \mathrm{~km}$ (10 to $15 \mathrm{mi}$ ) wide along the western side of the suture zone that joins the accreted Mesozoic Blue Mountain island-arc terrane to the west with the older continental crust to the east. All of the ultramafic bodies have been metamorphosed, varying from greenschist to amphibolite facies in metamorphic rank, and most bodies appear to have been emplaced into their present positions by faulting.

Relatively fresh dunites, serpentinites, low-silica and high-silica altered harzburgites, relatively fresh Ca-rich pyroxenites, altered Ca-rich pyroxenites, and chromitites are the main types of ultramafic rocks in western Idaho. Their primary minerals were $\mathrm{Mg}$-rich olivine, bronzitic orthopyroxene, augite, and high-Cr chromite. Metamorphic minerals include anthophyllite, tremolite, talc, chlorite, antigorite, magnesite, and magnetite. Where metamorphosed to the amphibolite facies, some of the ultramafic bodies have gained silica from their surroundings. Blackwall zones adjacent to altered ultramafic bodies include hornblende-garnet-spinel rocks derived from basalt by silica loss and chlorite-rich rocks derived from harzburgite by the addition of alumina.

The five areas containing ultramafic rocks, from south to north, are: (1) the Cuddy Mountain-Sturgill Peak region, where serpentinized harzburgite occurs along the fault zone between two subterranes of the Blue Mountain island-arc accreted terrane; (2) the New Meadows region, where dunite, harzburgite, and chromitite are enclosed within metamorphosed cherts, greywackes, and exhalative rocks of the New Meadows tectonic block; (3) the Riggins region, where serpentinite occurs in the Mesozoic-age metamorphosed volcaniclastic and volcanic rocks of the Riggins Group; (4) the South Fork Clearwater River region, where harzburgite, clinopyroxenite, and extensive blackwall zones occur in schists and gneisses equivalent to the Riggins Group and in Cretaceous-age felsic plutonic rocks; and (5) the Lowell-KamiahDworshak Reservoir region, where dunite and harzburgite that have been largely changed to anthophyllite occur in Proterozoicage metasedimentary rocks and younger felsic plutonic rocks.
The Early Cretaceous docking of the Blue Mountains island-arc terrane against Mesozoic North America and the Late Cretaceous emplacement of the Idaho Batholith have obscured the early history of the western Idaho ultramafic belt. Regardless, the ultramafic bodies probably formed as cumulates when basaltic magma upwelled from the Earth's interior, either at an oceanic ridge or within extending back-arc basins. Convergent tectonic plate motions eventually led to the obduction of the ultramafic bodies, either onto the continental margin of North America or onto the outer margin of the innermost of two or more colliding island arcs. The compressional tectonism that accompanied the subsequent docking of the Blue Mountains island arc remobilized most of the ultramafic bodies into their present locations near major faults and within host rocks of widely varying age, and the emplacement of the Idaho Batholith metamorphosed most of them. The final events in the tectonic history of the Lowell-Kamiah-Dworshak bodies are not well understood. Either the host rocks are much younger than we think they are, or complex sequences of normal and transcurrent faulting must have followed the initial compressive tectonism.

\section{Introduction}

The western Idaho ultramafic belt extends northward about $260 \mathrm{~km}$ (160 mi) from Sturgill Peak, north of Weiser, to the Breakfast Creek area near the north end of Dworshak Reservoir (fig.1). For much of its length, the ultramafic belt lies close to, and just west of, the Mesozoic-age suture zone between the preexisting continental crust and the accreted rocks of the Blue Mountains island-arc terrane (Vallier and Engebretson, 1984; Vallier and Brooks, 1987). This suture zone is characterized by a change in the initial $\mathrm{Sr}$ isotope ratios in plutons, from 0.704 or less to the west to 0.708 or greater to the east (Armstrong and others, 1977; Criss and Fleck, 1987; Fleck and Criss, 1985; Manduca and others, 1993). The ultramafic bodies are concentrated in clusters in the following regions, from south to north (see fig. 1): the Cuddy Mountain-Sturgill Peak region (located southwest of the other regions and somewhat west of the suture zone, so that it is well within the Blue Mountains terrane), the New Meadows region, the Riggins region, the South Fork Clearwater River region, and the Lowell-Kamiah-Dworshak 


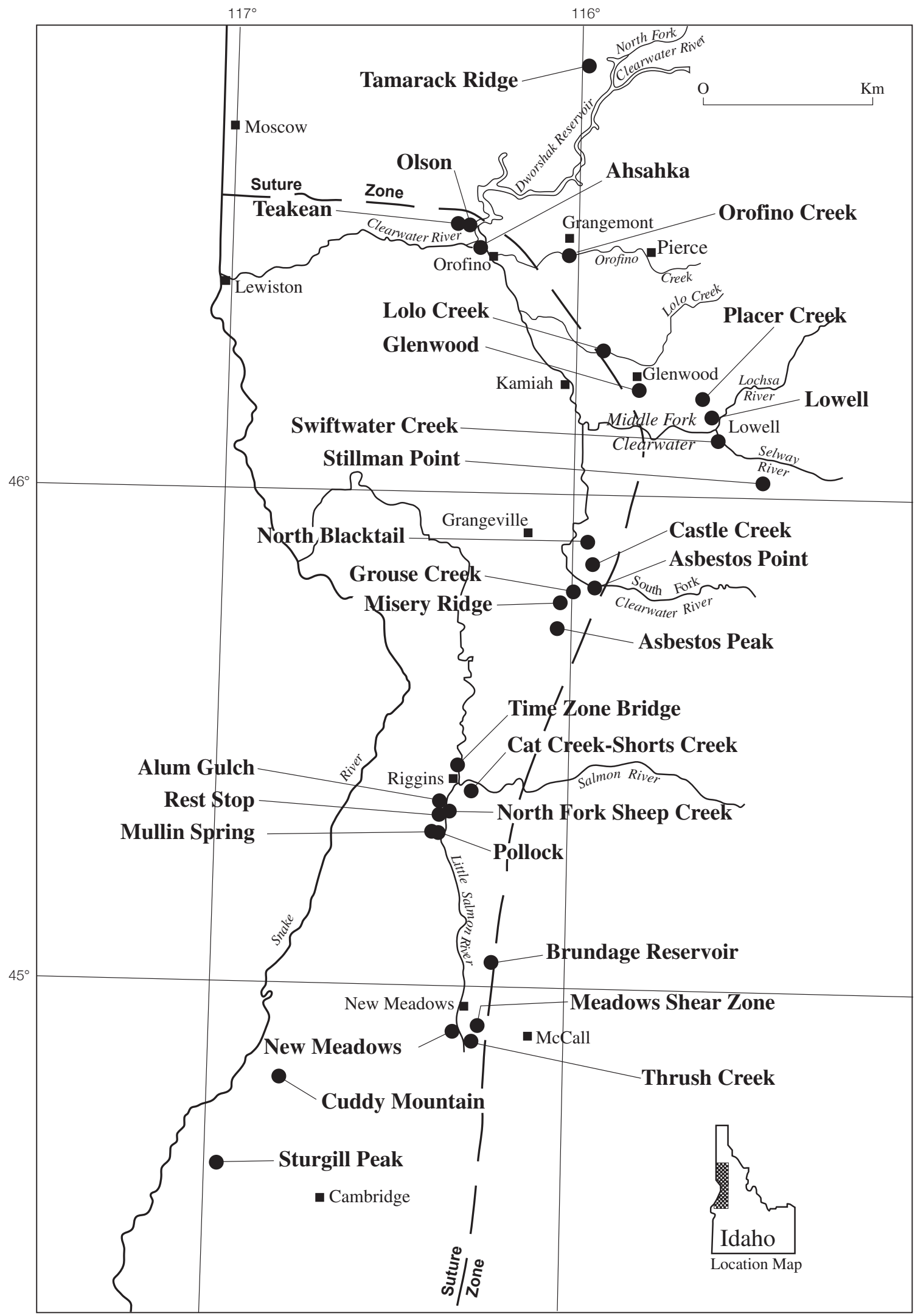

Figure 1. Map of west-central Idaho showing the locations of ultramafic bodies (black dots) in the western Idaho ultramafic belt. The dashed line indicates the approximate location of the suture zone between the continental crust and the accreted-terrane zone. Towns are indicated by small squares 
Reservoir region (located northeast of the other regions and somewhat east of the suture zone, so that it is well within the terrane of cratonic North America).

After they were accreted onto the Mesozoic margin of North America and after the Blue Mountains island-arc terrane had docked against this margin in the Early Cretaceous, the ultramafic bodies and their enclosing rocks were metamorphosed and perhaps further deformed as the various plutons constituting the western part of the Idaho Batholith were emplaced. The ultramafic bodies typically show close spatial relationships to major faults, and it is likely that most, if not all, were moved along faults after they had been emplaced into their general setting between the preexisting craton and the composite Blue Mountains island-arc terrane. The ultramafic bodies in the Cuddy Mountains-Sturgill Peak region are closely associated with a major fault boundary between two adjacent subterranes within the Blue Mountains island-arc terrane.

Geologic mapping and other previous studies that developed significant information on the nature of the ultramafic bodies include the efforts of Skurla (1974) and Mann(1989) in the Cuddy Mountain-Sturgill Peak region, of Bonnichsen (1987) in the New Meadows region, of Hamilton (1963, 1969), Onasch (1977, 1987), Sarewitz (1982) and Aliberti (1988) in the Riggins region, of Myers (1982) and Hoover (1986) in the South Fork Clearwater River region, of Lewis and others (1992) in the Lowell-Kamiah portion of the Lowell-Kamiah-Dworshak region, and of Anderson (1930, 1931), Johnson (1947), and Hietanen (1963) in the northern part of the Lowell-KamiahDworshak region. In addition, Bonnichsen and Godchaux (1994) have reviewed the details of the field occurrences, mineralogy, petrography, chemistry and economic geology of the western Idaho ultramafic belt.

Rocks whose major-element abundances have been changed significantly from their original values are present in parts of the western Idaho ultramafic belt. These include rodingites, originally gabbros or diabases, that have undergone substantial enrichment in calcium and some loss of silica, probably soon after they were formed, and their subsequently metamorphosed equivalents metarodingites. Rocks at the margins of ultramafic bodies that have undergone substantial chemical alteration, becoming enriched in such minerals as chlorite and amphiboles during metamorphism, are referred to as blackwall zones. We use this term for zones developed both in the ultramafic bodies and in the surrounding rocks, because it is commonly impossible to locate precisely the original contact.

\section{Geologic Setting and Petrographic Characteristics of Ultramafic Bodies}

\section{Cuddy Mountain-Sturgill Peak Region}

About $40 \mathrm{~km}$ (25 mi) southwest of New Meadows, in the Sturgill Peak area (fig.1), are bodies of ultramafic rocks asso- ciated with a zone of major faulting (Skurla, 1974). Similar bodies of ultramafic rocks crop out in the Cuddy Mountain area (Mann, 1989). These bodies lie along a major zone of high-angle thrust faulting that extends northeastward from the Conner Creek fault zone in Oregon, passes near Sturgill Peak, and cuts through the Cuddy Mountains as the Cuddy Mountain Fault. In the Cuddy Mountains, discontinuous serpentinite bodies, varying from 15 to $150 \mathrm{~m}$ (50 to $500 \mathrm{ft}$ ) in width, are exposed along the northwest-dipping Cuddy Mountain fault zone for a distance of about $10 \mathrm{~km}(6 \mathrm{mi})$. These serpentinites enclose fragments of the wall rocks of the fault zone and fragments of serpentinite breccia (fig.2). Mann (1989) regards the Cuddy Mountain fault zone to be a high-angle reverse fault that separates rocks of the Paleozoic and Triassic-age Baker Terrane to the northwest (upper plate) from Jurassic-age rocks of the Izee Terrane to the southeast (lower plate). In the Sturgill Peak area (fig.1) (Skurla, 1974), a small body of partly serpentinized harzburgite is located along a northwest-dipping high-angle reverse fault separating Permian(?)-age Grassy Slope phyllites (Baker Terrane) that have been thrust over the Jurassic-age Mann Creek slates (Izee Terrane). The serpentinite near Sturgill Peak occupies an area about $15 \mathrm{~m} \mathrm{(50 \textrm {ft } )}$ wide along the ridge crest and extends down both slopes as float for a few hundred meters. Relict olivine and orthopyroxene are found in some of the least altered samples. Also, minor amounts of a carbonate mineral and traces of graphite are found in some of the serpentinites, but there is no anthophyllite. Some rocks in the ultramafic mass probably have diabasic or gabbroic compositions, inasmuch as plagioclase and augite occur in them.

\section{New Meadows Region}

Bonnichsen (1987) described ultramafic rocks a few kilometers south of New Meadows that occur within the small New Meadows tectonic block, which lies immediately west of the accreted terrane-continental craton suture zone. The New Meadows block contains pre-Tertiary rocks that are mostly peridotite accompanied by metachert and metagraywacke that contain local Mn-enriched beds and various lenses of possible exhalative derivation. The peridotite consists mainly of relatively fresh dunite that locally is severely deformed, exhibiting a flattened fabric. The dunite masses contain harzburgite and local chromitite segregations, and serpentinite and chloriteamphibole schist blackwall zones at their margins.

Mg-rich olivine, bronzitic orthopyroxene, and chromite are the principal minerals in the unaltered peridotite. Olivine is much more abundant than orthopyroxene, so most of the ultramafic rock is dunite. The peridotites vary from possible cumulates with equant olivine grains packed loosely in an interstitial orthopyroxene matrix to severely tectonized rocks in which centimeter-size olivine grains have been strained into sets of subparallel, curved lamellae with distinctive sets of extension cracks perpendicular to the elongation direction. The strong olivine deformation probably occurred during the emplacement of the peridotite masses into their present tec- 
tonic settings; however, we cannot rule out the possibility that it was inherited from an earlier stage of their history.

The deformed olivine and pyroxene grains in the peridotite commonly are cut by undeformed acicular crystals of anthophyllite (which range from a few millimeters up to $30 \mathrm{~cm}$ in length and make a tremendous impression on a first-time visitor) that have largely been replaced by talc. The growth of these hydrous minerals clearly occurred after the deformation of the olivine and pyroxene. In a few places tremolite developed concurrently with anthophyllite and very likely consumed $\mathrm{Ca}$ released by the alteration of sparse original clinopyroxene or $\mathrm{Ca}$ that migrated into the ultramafic bodies from adjacent wall rocks. Following the formation of anthophyllite and tremolite, abundant talc formed veins and masses replacing anthophyllite. The nondeformed character of the anthophyllite and talc suggests that the peridotite bodies were near their present tectonic positions when these minerals formed, allowing them to grow statically. Trondhjemitic and granitic dikes of aplitic to pegmatitic texture locally cut the peridotite. Their injection probably was contemporaneous with the heating event that formed the anthophyllite and talc. Most likely, the injection of these felsic plutonic rocks occurred during the early development of the Idaho Batholith.

Also in the dunite are masses of fine- to medium-grained, nonfoliated metarodingite that consist predominantly of hornblende and epidote, accompanied by accessory amounts of sphene and opaque oxides. Remnants of augite occur sporadically within the cores of the hornblende crystals. These rocks probably originated as diabase or gabbro and subsequently lost silica and gained calcium to become rodingites. Later isochemical metamorphism of the rodingite assemblage (clinopyroxene-garnet-idocrase-epidote) produced the metarodingite assemblage (hornblende-epidote-sphene-oxide).

To the east of the main masses in the New Meadows area, which crop out 1 or $2 \mathrm{~km}$ (0.6-1.2 mi) west of the suture zone between the New Meadows block and the cratonic rocks to the east, small ultramafic bodies crop out immediately adjacent to, and within, the suture zone. In the Thrush Creek area there are detached pyroxene- and hornblende-rich boudins of gabbro and pyroxenite enclosed in gneissic rocks. Altered

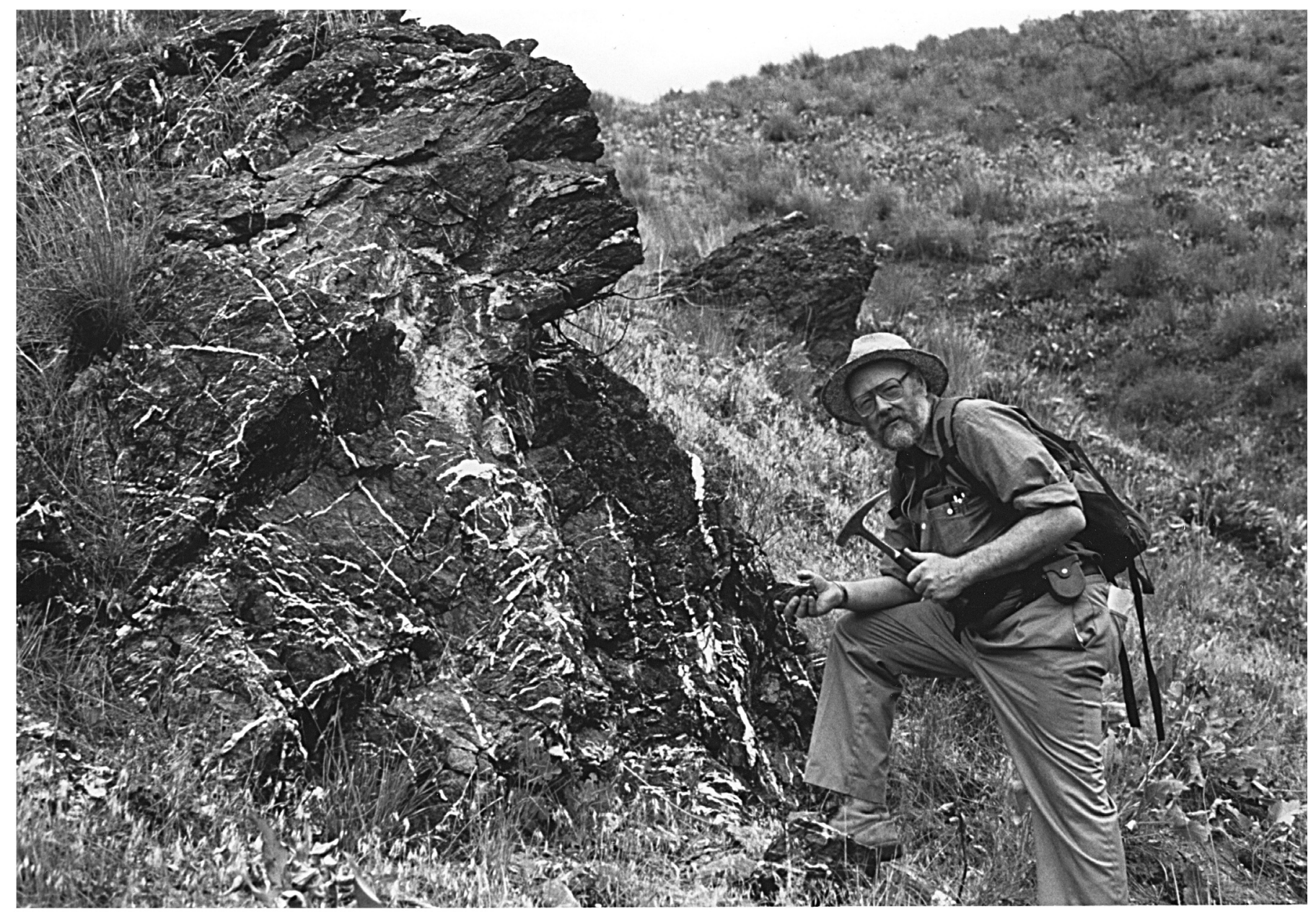

Figure 2. Serpentinite, veined with calcite, in the Cuddy Mountain fault zone. 
equivalents of these rocks are present as tectonic slivers a few meters across; they contain variable proportions of chlorite, serpentine, talc, and $\mathrm{Ca}$ amphibole. A few kilometers south of New Meadows the shear zone along the east side of the New Meadows block is cut by many trondjhemitic pegmatites that contain fragments of nondeformed partly hydrated clinopyroxenite. This relationship suggests that the accretion/obduction event had brought the ultramafic bodies close to their present position before or during the earliest phases of the intrusion of pegmatites related to the Idaho Batholith.

\section{Riggins Region}

The ultramafic bodies in the Riggins region, mapped and described in some detail by Hamilton $(1963,1969)$, were reexamined and remapped by Onasch $(1977,1987)$. They were mapped in the Heavens Gate quadrangle by Sarewitz (1982) and were noted by Aliberti (1988) to extend into the southwestern portion of the region, in the vicinity of Mullin Spring.

Near Riggins, most of the ultramafic bodies are at the base of, or within, the Squaw Creek Schist, which is the uppermost of the three formations that constitute the Riggins Group of probable Early or Middle Mesozoic age. These three formations (the Fiddle Creek, Lightning Creek, and Squaw Creek Schists) are composed primarily of metavolcaniclastic lithologies, with minor amounts of marble, calc-silicate rock, amphibolite, and quartz-rich rocks which vary in texture from quartzite to quartz schist, in the upper part of the Lightning Creek Schist and in the Squaw Creek Schist. Only two ultramafic bodies in the Riggins region, the Time Zone Bridge body and the ultramafic rocks near Pollock and near the Rest Stop on U.S.Highway 95, have been investigated in any detail.

The Time Zone Bridge ultramafic body (fig. 1) is elongate in a northwest-southeast direction and lies between the Lightning Creek Schist to the northeast and the Squaw Creek Schist to the southwest. It consists principally of serpentinite and chlorite-talc-antigorite schist. This Ca-free mineral assemblage suggests these rocks were originally harzburgites. Locally, remnants of original olivine are preserved within the body. Orthopyroxene has not been found; however, granules of opaque minerals outline columnar areas of serpentine, producing ghosts of the original orthopyroxenes. At some of the contacts between serpentinite and the Squaw Creek Schist, chlorite-rich blackwall zones as much as $20 \mathrm{~cm}$ thick have been formed.

The Rest Stop ultramafic body (fig.1) consists principally of serpentinite and talc-chlorite-antigorite schist, with minor anthophyllite, tremolite, magnetite, and magnesite. This ultramafic body probably originated as harzburgite, but no remnants of original pyroxenes or olivine have been found. The enclosing rocks include several lithologies, most notably marble, calc-silicate schist, amphibolite, quartz-rich muscovite schist, and talc schist. The Rest Stop ultramafic body is at the eastern end of an outcrop area of ultramafic rocks that Onasch (1977) mapped as extending 3 to $4 \mathrm{~km}$ (2 to $2.5 \mathrm{mi})$ northwest- ward through an area with numerous landslides, to a body on the west side of White Bird Ridge mapped by Sarewitz (1982) as talc-serpentine, talc-tremolite, and talc-chlorite schist.

Several other bodies have been reported in the Riggins region. Five of these bodies are listed in table 1 and shown in figure 1 (the Pollock, North Fork Sheep Creek, Cat CreekShorts Creek, Alum Gulch, and Mullin Spring areas).

\section{South Fork Clearwater River Region}

A zone of ultramafic bodies extends north-northeastward from Asbestos Peak for about $22.4 \mathrm{~km}$ (14 mi) across the South Fork of the Clearwater River to North Blacktail Butte. These bodies include the Asbestos Peak, Misery Ridge, Grouse Creek, Castle Creek, North Blacktail, and Asbestos Point areas (fig.1, table 1).

The Asbestos Peak body is exposed for a distance of $300 \mathrm{~m}$ along the Asbestos Peak summit ridge and is elongate from southwest to northeast (fig. 3). Widely scattered small outcrops occur to the southwest and northeast of the main body and for about $1.1 \mathrm{~km}$ on the southeast side of the ridge. The main rock type on Asbestos Peak is a coarse-grained, essentially decussate-textured, anthophyllite-rich metaharzburgite containing subordinate amounts of chlorite, talc, and opaque oxides, but little serpentine or Ca amphiboles. Locally, small olivine- and orthopyroxene-bearing remnants of the original harzburgite occur within the anthophyllite body. This rock type hosts irregularly distributed, steeply dipping small lenses of chromite-magnetite-chlorite aggregate (fig. 4). The Asbestos Peak body shows no directional metamorphic fabric. However, it does show what probably is an original, vaguely layered fabric, now steeply dipping (parallel to the aforementioned lenses) and gently folded. Late-stage tabular pegmatite veins intrude the main zone of the body along the northwest and southeast sides of the summit ridge, locally producing a very coarse-grained asbestiform selvage.

Adjacent to the main Asbestos Peak ultramafic body are nearly monomineralic nonschistose chlorite blackwall zones, as much as $5 \mathrm{~m}$ across and $20 \mathrm{~m}$ long; they are most prominently exposed at the northwest margin of the body. Similar but much smaller chlorite-rich zones occur within the main anthophyllite-rich metaharzburgite. The chlorite in the blackwall zone, which has relatively high and distinctly anomalous birefringence, differs systematically from that in the main metaharzburgite, which has lower and nonanomalous birefringence (suggesting that the latter may contain more $\mathrm{Si}$ and $\mathrm{Mg}$ and less $\mathrm{Al}$ and $\mathrm{Fe}$ than the former).

On the southwest side of Asbestos Peak are prominent exposures 6 to $7 \mathrm{~m}$ across and several tens of meters long of an apparently crosscutting body with an unusual and enigmatic composition. It is a black, generally fine-grained, nonfoliated rock consisting principally of green, prismatic to equant hornblende and reddish-brown poikiloblastic and locally cataclasized grossularite-andradite garnets. Additional minerals include clear green spinel, spectacular skeletal ilmenite, 
Table 1. Locations and rock types, western Idaho ultramafic belt.

[See Bonnichsen and Godchaux (1994) for further data.]

\begin{tabular}{ll}
\hline NAME OF ULTRAMAFIC BODY AND LOCATION & MAIN ULTRAMAFIC ROCK TYPES, GEOLOGIC ASSOCIATIONS, AND REFERENCES \\
\hline CUDDY MOUNTAIN-STURGILL PEAK REGION & \\
\hline $\begin{array}{l}\text { Sturgill Peak area, } \\
\text { Sec. 17, T. 15 N., R. } 5 \text { W., Neil Gulch quadrangle. }\end{array}$ & $\begin{array}{c}\text { Partially serpentinized harzburgite along reverse fault zone between Izee and } \\
\text { Baker terranes; Skurla (1974) }\end{array}$ \\
$\begin{array}{l}\text { Cuddy Mountain bodies, secs. 2, 10, 11, 15, 16, } 21 \text { and } \\
\text { 30, T. } 17 \text { N., R. } 4 \text { W., and sec. 25, T. 17 N., R. } 5 \text { W., }\end{array}$ & $\begin{array}{c}\text { Serpentinite along Cuddy Mountain high-angle reverse fault zone between the } \\
\text { Baker and Izee terranes; Mann (1989). }\end{array}$ \\
Cuddy Mountain and Brownlee Dam quadrangles. & \\
\hline
\end{tabular}

\section{NEW MEADOWS REGION}

New Meadows area bodies, secs. 2, 3, 10, and 15,

T. 18 N., R. 1 E., New Meadows quadrangle.

Thrush Creek area, sec. 18 , T. 18 N., R. 2 E.,

New Meadows quadrangle.

Meadows shear zone blocks sec. 5, T. 18 N., R. 2 E. Meadows quadrangle.
Variably metamorphosed dunite, harz-burgite, and chromitite associated with metachert, metagreywacke, and exhalatites in the New Meadows tectonic block; Bonnichsen (1987).

Talc-chlorite-tremolite schist, in felsic to amphibolitic gneisses; Bonnichsen (1987)

Clinopyroxenite partially replaced by hornblende, in trondhjemitic pegmatite along major shear zone; Bonnichsen (1987).

\section{RIGGINS REGION}

Time Zone Bridge body, sec.34, T. 25 N., R. 1 E., and secs. 2 and 3, T. 24 N., R. 1 E. Riggins quadrangle.

Bodies between Pollock Rest Stop and Whitebird Ridge, secs. 7, 8, 16, 17, and 18, T. 23 N., R. 1 E., Pollock and Heavens Gate quadrangles.

Body near Pollock, sec. 20, T. 23 N., R. 1 E., Pollock quadrangle.

North Fork Sheep Creek area, secs. 9, 10, and vicinity, T. 23 N., R. 1 E., Pollock quadrangle.

Bodies in Cat Creek-Shorts Creek area, sec. 24, T. 24 N., R. 1 E.; secs. 19 and 20, T. 24 N., R. 2 E., Riggins and Riggins Hot Springs quadrangles.

Bodies in Alum Gulch Emery Creek area, secs. 29, 32, 33, T. 24 N., R. 1 E., and secs. 4 and 5, T. 23 N., R. 1 E., Riggins and Pollock quadrangles.

Mullin Spring body, sec. 19, T. 23 N., R. 1 E., Heavens Gate quadrangle.
Serpentinite, at the contact between the Squaw Creek and Lightning Creek Schists of the Riggins Group; Hamilton (1963) and Onasch (1977).

Serpentinite and talc-chlorite-tremolite schist, in lower part of Squaw Creek Schist and in Lightning Creek Schist of Riggins Group; Hamilton (1963), Onasch (1977), and Sarewitz (1982).

Serpentinite, in lower part of Squaw Creek Schist of Riggins Group; Onasch (1977).

Serpentinite, in lower part of Squaw Creek Schist of Riggins Group; Hamilton (1963) and Onasch (1977).

Metaperidotite, in lower part of Squaw Creek Schist of Riggins Group; Onasch (1977)

Serpentinite, in lower part of Squaw Creek Schist of Riggins Group, part of ultramafic rocks may be incorporated in large landslide area; Hamilton (1963).

Talc-serpentine, talc-tremolite, and talc-chlorite schists, in Squaw Creek Member of Riggins Group; Sarewitz (1982).

\section{SOUTH FORK CLEARWATER RIVER REGION}

Asbestos Peak area, sec. 26, T. 28 N., R. 3 E., Dairy Mountain quadrangle.

Misery Ridge area, secs. 1 and 12, T. 28 N., R. 3 E., Goodwin Meadows quadrangle
Metaharzburgite and blackwall rocks, in metamorphosed Riggins Group schists and gneisses.

Deformed and altered harzburgite and clinopyroxenite, and blackwall rocks, in schists and gneisses equivalent to the Riggins Group. 
Table 1. Locations and rock types, western Idaho ultramafic belt.-Continued

[See Bonnichsen and Godchaux (1994) for further data.]

\section{NAME OF ULTRAMAFIC BODY AND LOCATION}

Grouse Creek area, secs. 31 and 32, T. 29 N., R. 4 E., Goodwin Meadows and Hungry Ridge quadrangles.

Asbestos Point area, sec. 27, T. 29 N., R. 4 E., Hungry Ridge quadrangle.

Castle Creek area, secs. 10 and 15, T. 29 N., R. 4 E., Hungry Ridge quadrangle.

North Blacktail Butte area, secs. 15, 16, 21, 27, and 28, T. 30 N., R. 4 E., Harpster quadrangle.

Stillman Point area, sec. 16, T. 31 N., R. 8 E., Stillman Point quadrangle.

Swiftwater Creek Bridge, sec. 16, T. 32 N., R. 7 E., Goddard Point quadrangle

\section{MAIN ULTRAMAFIC ROCK TYPES, GEOLOGIC ASSOCIATIONS, AND REFERENCES}

Metaharzburgite and metaclinopyroxenite cut by chlorite-rich veins, in schists and gneisses equivalent to the Riggins Group; Hoover (1986).

Dunite (found only as float) in granodiorite/quartz monzonite orthogneiss unit; Hoover (1986).

Clinopyroxenite and metagabbro, in Castle Creek fault zone, between metamorphosed Riggins Group rocks and trondhjemitic pluton; Myers (1982).

Metaharzburgite, with metagabbro and metapyroxenite, in metamorphosed equivalent of Squaw Creek Schist of the Riggins Group; Myers (1982).

Dunite and pyroxenite, enclosed in Syringa metamorphic sequence; Lewis and others (1992).

Metadunite or harzburgite, enclosed in Syringa metamorphic sequence; Lewis and others (1992).

\section{LOWELL-KAMIAH-DWORSHAK RESERVOIR REGION}

Bodies in Lowell area, secs. 28, 29, 31, and 33, T. 33 N., R. 7 E., Lowell and Syringa quadrangles.

Placer Creek area, sec. 18, T. 33 N., R. 7 E., Syringa quadrangle.

Glenwood area bodies, secs. 9, 10, and vicinity, T. 33 N., R. 5 E., Glenwood quadrangle.

Lolo Creek area, probably Brown Creek Ridge or Weippe South quadrangles.

Orofino Creek area, sec. 1, T. 36 N., R. 3 E., Rudo quadrangle.

Ahsahka area, sec. 1 or 2, T. 36 N., R. 1 E., Orofino West Quadrangle.

Teakean asbestos deposit, sec. 16, T. 37 N., R. 1 E., Ahsahka quadrangle.

Olson asbestos deposit, sec. 15 or 22, T. 37 N., 1 E., Ahsahka quadrangle.

Tamarack Ridge body sec. 29, T. 41 N., R. 4 E., Township Butte quadrangle
Metadunite, metaharzburgite, and talc schist in Cretaceous foliated tonalite and in Syringa metamorphic sequence; Anderson (1930) and Lewis and others (1992).

Ultramafic body enclosed in the Syringa metamorphic sequence; Lewis and others (1992).

Metadunite, metaharzburgite, and anthophyllite deposits, enclosed in Riggins Group or Belt Supergroup; Anderson (1930, 1931).

Anthophyllite occurrences; Anderson (1930).

Metaharzburgite and anthophyllite deposits, in the Belt Supergroup; Anderson (1930) and Johnson (1947).

Ultramafic body in Cretaceous diorite and tonalite, or the Belt Supergroup; Anderson (1930) and Johnson (1947).

Metaharzburgite with Tertiary granite dikes, and the Belt Supergroup; Anderson (1930) and Johnson (1947).

Possible ultramafic occurrence with Cretaceous tonalite or Belt Super-group; Hustedde and others (1981).

Metadunite and chlorite blackwall rocks in Belt Supergroup; Hietanen (1963). 
magnetite, traces of probable cordierite, possible idocrase, and minor amounts of chlorite and clinozoisite. These hornblendegarnet rocks are thought to be a type of blackwall-zone rock that has undergone considerable desilication from original basaltic or andesitic compositions.

Another enigmatic rock type found in the Asbestos Peak area occurs as very small outcrops in a zone about $200 \mathrm{~m}$ wide on the southeast side of the main peak. Pink and granitoidappearing in hand specimen, this rock contains small augen of cordierite granulite (or hornfels?) in a fine-grained matrix of actinolite, chlorite, talc, cordierite, zircon(?) and olivine(?). We tentatively interpret it as either a Mesozoic metavolcanic rock of the host sequence or as a fault slice brought up from midcrustal depths.

The Misery Ridge ultramafic body consists of highly altered ultramafic rocks that are exposed along the crest of Misery Ridge, with prominent outcrops for $300 \mathrm{~m}$ at the north end and low discontinuous outcrops and abundant float for about $5 \mathrm{~km}$ to the southwest (fig. 5). The Misery Ridge body varies little in composition and is strongly deformed, with multiple stages of foliation, lineation, and fold development. No unaltered dunite or harzburgite has been found. The main body is made up of relatively coarse-grained tremolite-chlorite rock with a decussate texture. Locally the extremely elongate tremolite prisms are arranged in a rhombic latticework with fine-grained decussate chlorite in the interstices of the lattice. Ilmenite is an abundant accessory. Shear zones, along which talc is locally abundant, are spaced about $7 \mathrm{~m}$ apart and dip very steeply to the southwest. Subordinate amounts of talc-anthophyllite and talc-tremolite schists occur along the southeast edge of the main exposure and make up much of the float west and south of the main outcrop zone.

Bordering the Misery Ridge body on the north and west is a multiply deformed chlorite-ilmenite-magnetite schist with prominent microfolds and kink bands and abundant (up to 15 percent modal) apatite. Magnetite granules are arranged in short en echelon bands parallel to the principal early schistosity, whereas the tabular ilmenite grains transect it, suggesting that there were two episodes of oxide formation. Apatite grains are preferentially associated with tabular ilmenite. We tentatively interpret this rock type as a blackwall zone, originally developed at the contact between the ultramafic body and its host rocks, a group of very poorly exposed muscovite-rich metapelites. An alternative interpretation is that the chloritic

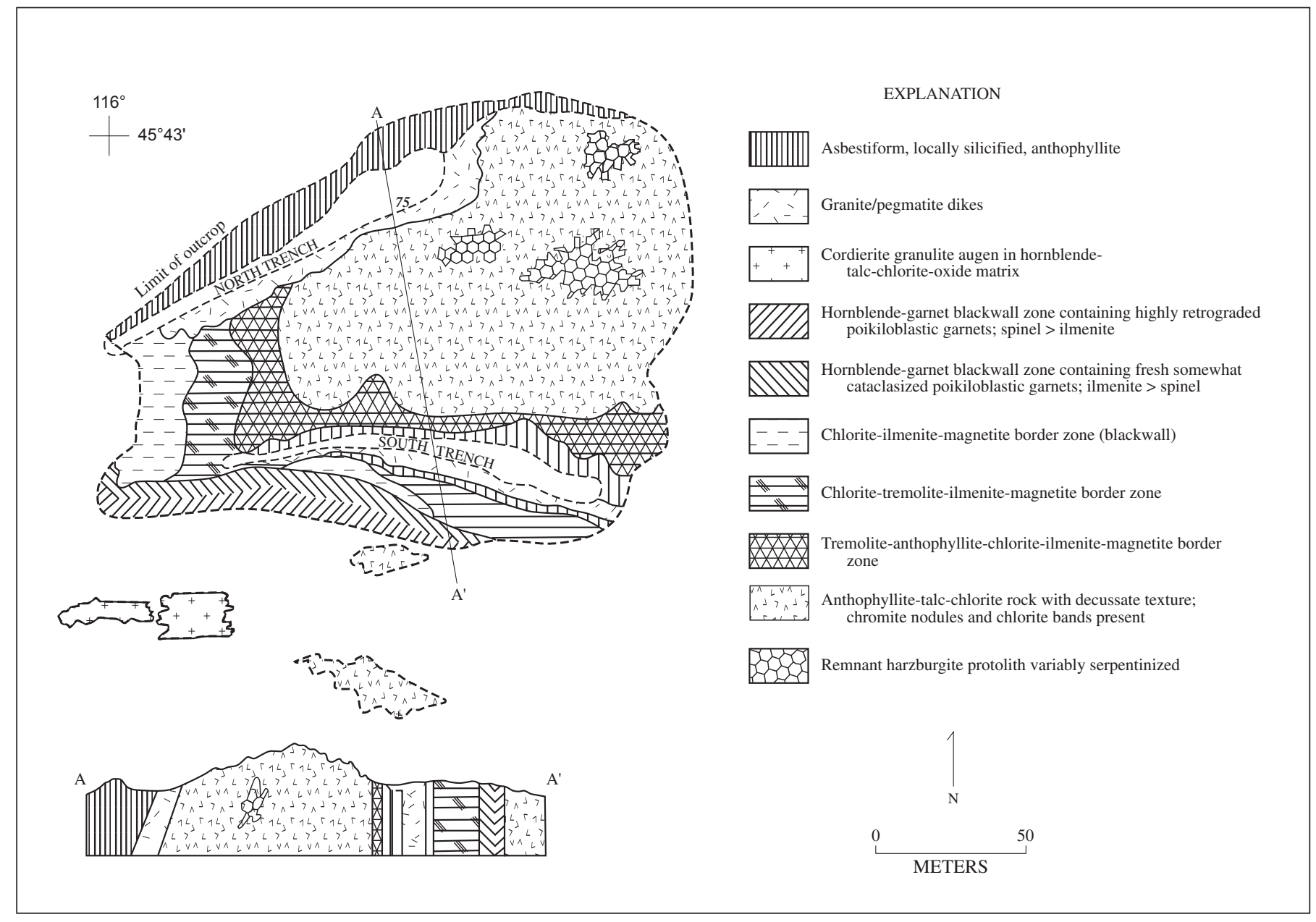

Figure 3. Geologic sketch map and cross section of the Asbestos Peak ultramafic body. 
rock is derived from a metavolcanic lens in the host sequence. Also present at Misery Ridge are anastomosing dikelike bodies of black, fine-grained, nonfoliated hornblende-garnet blackwall-zone rock with skeletal ilmenite and green spinel. This rock type is essentially identical to the hornblende-garnet blackwall-zone rocks at Asbestos Peak, and we interpret them as desilicated basalts or andesites.

The Grouse Creek ultramafic body is within the area mapped by Hoover (1986). She indicates that the ultramafic rocks are a fault slice and now are enclosed in a geologic unit consisting of strongly deformed quartz-mica schist and gneiss and amphibolitic gneiss. The ultramafic rocks at Grouse Creek are undeformed rocks set in a matrix of sheared gneiss and metachert lenses (Hoover, 1986). The predominant ultramafic lithology is a talc-olivine-anthophyllite rock that crops out over most of the eastern two-thirds of the body. Olivine is altered to serpentine along grain margins and in cleavages. The principal original ultramafic rock type in the Grouse Creek body was harzburgite. In addition, Ca-rich pyroxenites crop out in the western third of this body. Chlorite-rich rocks having variable amounts of tremolite-actinolite, garnets, ilmenite, and apatite occur within the Grouse Creek body. The ilmenite crystals range up to $5 \mathrm{~cm}$ across and locally constitute several percent of these rocks. These chlorite-rich rocks appear to be dikelike or veinlike masses cutting the anthophyllite-bearing ultramafic rocks, but their origin is unclear.

The Asbestos Point ultramafic body is located within a porphyritic granodiorite and quartz-monzonite orthogneiss unit, and adjacent to a northeast-trending fault (Hoover, 1986). Rocks in this unit typically have a mylonitic fabric manifested by a weak foliation and a strong lineation. The principal ultramafic rock is fresh dunite that consists primarily of granular, unsheared olivine grains that have produced a recrystallized equilibrium metamorphic fabric. The dunite also includes minor amounts of talc, chrysotile, and brownish opaque oxide grains. Also present at Asbestos Point are rocks that consist mainly of anthophyllite and talc, accompanied by minor chlorite and opaque oxides.

The Castle Creek ultramafic body consists of nonfoliated clinopyroxenites that have high $\mathrm{Cr}$ concentrations. No dunite, harzburgite, or their altered equivalents have been recognized. The clinopyroxenites consist principally of augite, minor orthopyroxene, replacement patches of hornblende, and accessory chlorite, opaque oxides, serpentine, epidote, and possible traces of olivine. Associated with the clinopyroxenite is altered gabbro and chlorite-tremolite phyllite. The zone

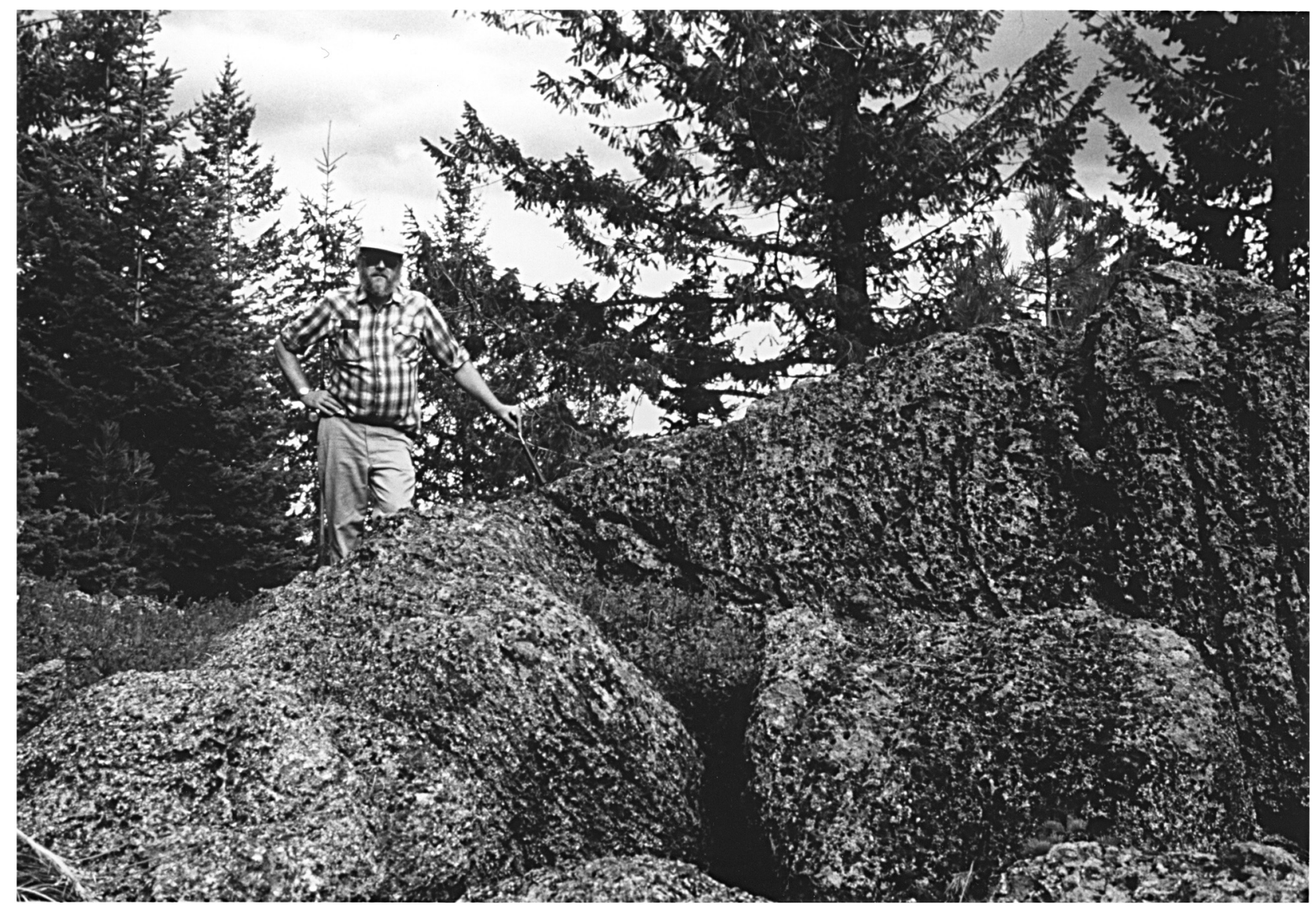

Figure 4. Decussate-textured, anthophyllite-rich metaharzburgite of Asbestos Peak. Prominent cleft in outcrop (upper right) is vertical lens of chromite-magnetite-chlorite aggregate. 
along the Castle Creek Fault where the clinopyroxenites occur lies between an uplifted portion of the Blacktail trondhjemite pluton to the west and biotite-muscovite schists to the east that are equivalent to the Squaw Creek Schist of the Riggins Group (Myers, 1982).

The North Blacktail ultramafic body consists of a crudely stratified, strongly foliated metagabbro and metaperidotite of lenticular form having a maximum thickness of about $260 \mathrm{~m}$ $(850 \mathrm{ft})$. The rocks grade upward from a basal layer of sheared and metamorphosed olivine-pyroxene gabbro, into a core of metaperidotite, and then into a discontinuous uppermost layer of highly altered pyroxenite. Relict olivine and pyroxene have been almost completely altered to antigorite, talc, tremolite, chlorite, zoisite, magnetite, and accessory phlogopite and actinolite. The North Blacktail Butte body is bounded by highangle reverse faults. The enclosing rocks are biotite-muscovite schist interpreted to be the Squaw Creek Schist member of the Riggins Group and minor amounts of phyllonites formed from quartz keratophyres and other lithologies of the Seven Devils volcanics (Myers, 1982).

\section{Lowell-Kamiah-Dworshak Reservoir Region}

Several ultramafic bodies occur in north-central Idaho near the towns of Lowell and Kamiah and near Dworshak Reservoir (fig.1). These include the Stillman Point body, the Swiftwater Creek body, several small bodies near Lowell, the Placer Creek body, several bodies near Glenwood, bodies in

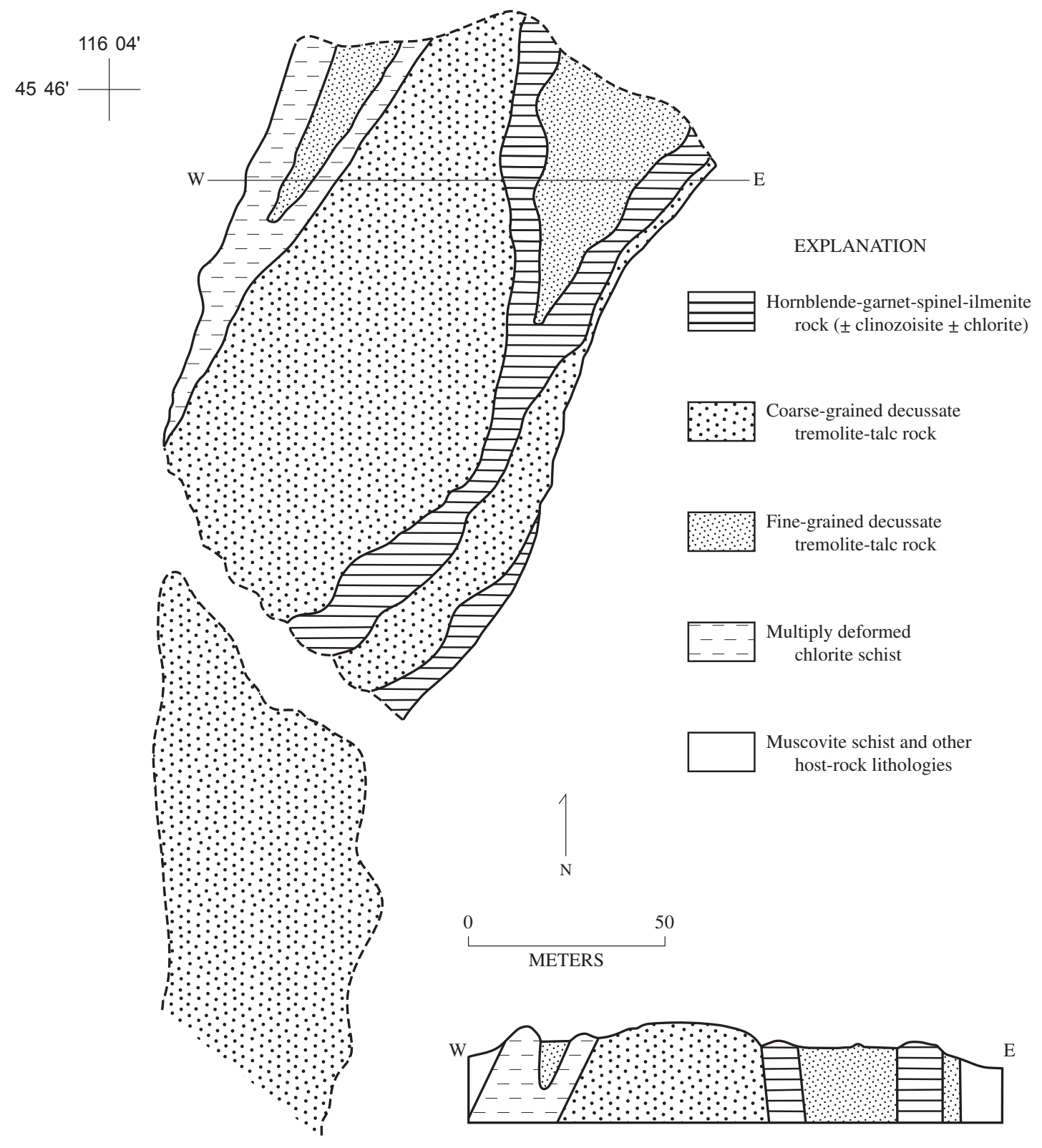

Figure 5. Geologic sketch map and cross section of the Misery Ridge ultramafic body. 
the canyons of Lolo and Orofino Creeks, the Ahsahka body, the Teakean body, the Olson body, and the Tamarack Ridge body. All of these bodies generally occur near the accreted terrane-cratonic margin suture zone, with the important exception of the Tamarack Ridge body, which is $50 \mathrm{~km}$ north of the suture zone.

The Stillman Point body (Lewis and others, 1992) consists of both dunite and pyroxenite enclosed within the quartzite-schist unit of the Syringa metamorphic sequence. This body is $0.4 \mathrm{~km}(0.25 \mathrm{mi})$ wide and is in close proximity to a mass of Cretaceous tonalite.

The Swiftwater Creek Bridge ultramafic body, exposed along the west bank of the Selway River $4.8 \mathrm{~km}$ upstream from Lowell, stands about $30 \mathrm{~m} \mathrm{(100} \mathrm{ft)} \mathrm{high} \mathrm{and} \mathrm{is} \mathrm{about} 60 \mathrm{~m} \mathrm{(200}$ $\mathrm{ft}$ ) thick from east to west. It is a metaharzburgite containing abundant remnants of coarse-grained olivine with a nondeformed texture and hydrous minerals developed along cleavages and fractures. Minerals that have formed at the expense of olivine and possibly from orthopyroxene include talc, actinolite, and chlorite. Abundant anthophyllite, perhaps accompanied by actinolite, occurs as large rosettes. Next to the river at the side of the ultramafic mass and cutting it locally in veinlike or dikelike tabular zones is a green, much finer grained actinolite-rich blackwall zone that probably developed by hydration and alteration of the original peridotite. The Swiftwater Creek Bridge ultramafic body is enclosed in the schist-quartzite unit of the Syringa metamorphic sequence and is adjacent to a mass of Cretaceous-age foliated granodiorite (Lewis and others, 1992). A north-northwest-trending fault adjacent to this ultramafic body is one of several closely spaced faults in the region between the O'Hara Creek Fault on the east and the Yakus Creek Fault on the west (Lewis and others, 1992).

At least four ultramafic bodies have been reported in a small area $3.2 \mathrm{~km} \mathrm{(2} \mathrm{mi)} \mathrm{north-northwest} \mathrm{of} \mathrm{Lowell.} \mathrm{The}$ Icicle Spring metaharzburgite body, located $1.5 \mathrm{~km}$ (about 1 mi) north of Lowell, is essentially identical to the Swiftwater Creek Bridge ultramafic body and contains large anthophyllite rosettes. The Icicle Spring body is enclosed by the strongly foliated Cretaceous tonalite of Coolwater Ridge (Lewis and others, 1992). Near the mouth of Pete King Creek, Anderson (1930) reported a dunite body more than $33 \mathrm{~m}$ long that contains only scattered bundles of amphibole, antigorite, talc, and chlorite. This body is within the schist-quartzite unit of the Syringa metamorphic sequence. About $1.5 \mathrm{~km}$ northwest of the Icicle Spring body is a small body (a few tens of meters long) of talc schist enclosed in plagioclase-biotite schist. The talc-schist body is within the same zone of faults as the Swiftwater Creek Bridge and Icicle Spring ultramafic bodies and also is enclosed by the schist-quartzite unit of the Syringa metamorphic sequence. On the ridge northeast of Big Hill, about $3.2 \mathrm{~km}$ ( $2 \mathrm{mi}$ ) northwest of Lowell, Lewis and others (1992) show another small (a few tens of meters long) ultramafic body that is also enclosed within the schist-quartzite unit of the Syringa metamorphic sequence.

Lewis and others (1992) show another small ultramafic body about $0.4 \mathrm{~km}$ west of Placer Creek. This body is within the schist-quartzite unit of the Syringa metamorphic sequence and generally associated with the northwestward continuation of the series of faults between the Yakus Creek and O'Hara Creek Faults.

Anderson $(1930,1931)$ described the anthophyllite deposits in the Glenwood area that were mined in the early part of the 20th century. Most are in a comparatively small area of 3 or $4 \mathrm{~km}^{2}$; they are mainly lenticular and they range from minor seams a few meters wide to dikes or lenses as much as $28 \mathrm{~m}$ wide and $200 \mathrm{~m}$ long. More than a dozen bodies greater than 10 by $33 \mathrm{~m}$ occur in the area. The anthophyllite fibers are arranged in small bundles that generally lie in all directions, but they have a pronounced tendency to form radial groups as much as $15 \mathrm{~cm}$ in diameter. The principal primary mineral was olivine, some of which remains, accompanied by magnetite, chromite, and picotite spinel. Enstatite probably was initially present; thus the original rocks were dunite and harzburgite. Important secondary minerals reported by Anderson are antigorite, kammererite(?) (a Cr-bearing form of chlorite), anthophyllite, talc, magnesite(?), and pyrite. Talc is much less abundant than anthophyllite and generally replaces both anthophyllite and the earlier antigorite. The Glenwood ultramafic bodies are enclosed in a metamorphic unit considered to be equivalent to the Precambrian-age Prichard Formation of the Belt Supergroup (Rember and Bennett, 1979a). Recent mapping nearby by Lewis and others (1992), however, suggests that the Glenwood ultramafic bodies actually are within a hornblende gneiss unit of probable Mesozoic age, tentatively assigned to the Riggins Group.

Anderson (1930) reported scattered small anthophyllite bodies near, and in, the canyon walls of Lolo Creek. Several metamorphosed dunite and harzburgite bodies, which are a few kilometers from Orofino, are described by Anderson (1930) and Johnson (1947). These include one along Orofino Creek east of the town of Orofino, one in the Ahsahka area, one southeast of Teakean, and the Olson asbestos prospect near Dworshak Reservoir (Hustedde and others, 1981). These bodies now are mainly anthophyllite and contain subordinate amounts of tremolite, talc, chlorite, and magnetite. All these bodies are associated with calc-silicate and plagioclase-quartz-biotite schists of the Wallace Formation of the Proterozoic-age Belt Supergroup and with Cretaceous and Tertiary dioritic, tonalitic, and granitic intrusive rocks (Rember and Bennett, 1979b).

The Tamarack Ridge ultramafic body is located west of Dworshak Reservoir near its northern end, on the south side of Breakfast Creek. Hietanen (1963) reported that it is mostly serpentine that probably originated as dunite. It contains substantial amounts of anthophyllite and some chlorite and talc. The Tamarack Ridge ultramafic body is 0.2 to $0.3 \mathrm{~km}(0.1$ to $0.2 \mathrm{mi}$ ) wide along a road outcrop and is of undetermined length. It is elongate in a northwest-southeast direction and is enclosed in garnet-mica schist of the metamorphosed Prichard Formation of the Belt Supergroup. Chlorite-rich rocks that likely represent blackwall zones formed at the margin of the dunite body. 


\section{Petrology and Chemical Composition}

The mineralogy, petrography, and geochemistry of the ultramafic rocks led us to the following classification: (1) relatively fresh dunites, (2) serpentinites, (3) altered harzburgites or dunites having relatively low silica contents (45-50 percent $\left.\mathrm{SiO}_{2}\right)$, (4) altered harzburgites or dunites having relatively high silica contents (55-60 percent $\mathrm{SiO}_{2}$ ), (5) relatively fresh Carich pyroxenites or peridotites, (6) altered $\mathrm{Ca}$-rich pyroxenites or peridotites, and (7) chromitites. Normalized average values of the major oxides, including $\mathrm{NiO}$ and $\mathrm{Cr}_{2} \mathrm{O}_{3}$ and average values for eight minor elements are presented in table 2 for these seven categories of ultramafic rocks. The full data from which these normalized average values were determined are given in Bonnichsen and Godchaux (1994).

The primary minerals in the dunite-harzburgite suite are olivine, orthopyroxene, and chromite. The primary mineral in the Ca-rich pyroxenite-peridotite suite is diopsidic augite, accompanied in some rocks by orthopyroxene and olivine. Truly primary textures, that is, those produced by igneous processes in a midocean ridge magma chamber and never modified by either brittle deformation or recrystallization, are rare. Where they are present, orthocumulate and adcumulate textures are dominant. Deformed textures, especially microcracking and brittle extension of olivine grains, are very common. Recrystallized textures, particularly equilibrium fabrics in which all olivine-olivine boundaries make 120-degree angles with one another, are common in the New Meadows region and occur sporadically elsewhere. The principal secondary minerals developed in the ultramafic rocks are anthophyllite, tremolite, talc, chlorite, serpentine, carbonates, and magnetite. Most commonly, the secondary minerals are in nondeformed replacement textural relations with the primary minerals. These textures are about evenly divided between successive replacement of less hydrous minerals by lower temperature, more hydrous minerals (retrograde sequences) and the opposite (prograde sequences). When only secondary minerals are present in a rock, however, it is common for foliation and other deformational textures to be present. Photomicrographs of all of the above-mentioned types of ultramafic rocks, showing typical textural relations among the minerals, are shown in figures 6-12.

Rocks associated with the ultramafic bodies are typically metavolcanic, although a few are metasedimentary and a few are extensively altered ultramafics. Most of the metavolcanic rocks show substantial changes from their original compositions. Their mineralogy, petrography, and geochemistry lead us to classify them as: (1) hornblende-garnet blackwall rocks, (2) chlorite-rich blackwall rocks, (3) chlorite-rich blackwall vein rocks, (4) amphibole-rich blackwall rocks, (5) metarodingites, (6) metabasalts, and (7) all other metavolcanics and metasediments. Normalized average compositions of the major oxides and average values for 10 minor elements for the above categories of rocks are presented in table 2. The full data from which these normalized values were derived are given in Bonnichsen and Godchaux (1994).
Hornblende-garnet blackwall rocks typically contain abundant nonpoikiloblastic green hornblende, highly poikiloblastic grossularite-andradite garnet, variable amounts of chlorite, opaque oxides (typically both abundant skeletal ilmenite and granular to euhedral magnetite), and green spinel. Cordierite and idocrase are found in some of these rocks. Chloriterich blackwall rocks are dominated by chlorite, and locally they contain small quantities of amphibole, ilmenite, apatite, and garnet. Amphibole-rich blackwall rocks are composed mainly of tremolite or actinolite, and some have anthophyllite, chlorite, or remnants of primary pyroxenes and olivine. Typically, the various types of blackwall rocks are nonfoliated, but some have been strongly deformed. Some show granoblastic textures indicative of textural equilibrium, whereas other rocks have more complex textural relations indicative of replacement reactions that did not go to completion.

Metarodingites consist principally of hornblende and clinozoisite or epidote, and there are minor chlorite and sphene and remnants of augite in some. Typically, metarodingites display nonfoliated granoblastic textures. Photomicrographs of typical textural relations in several of the types of metamorphic rocks associated with the ultramafic bodies are shown in figures 13-16.

\section{Compositions of Ultramafic Rocks}

The analyses in table 2 show that a number of basic differences exist among the various types of ultramafic rocks. For example, the alteration process, which we suggest happened during regional metamorphism, resulted in minor to significant additions of some constituents to the ultramafic bodies. It is reasonable to assume that each of the altered rock types developed from one of the two initial igneous compositions found in the Idaho ultramafic belt: relatively fresh dunite/harzburgite or Ca-rich pyroxenite. The metamorphic processes of serpentinization and the higher-temperature forms of alteration, in which anthophyllite, tremolite, talc, and chlorite were developed, were accompanied by additions of varying amounts of $\mathrm{H}_{2} \mathrm{O}, \mathrm{CO}_{2}, \mathrm{O}_{2}, \mathrm{SiO}_{2}, \mathrm{TiO}_{2}, \mathrm{Al}_{2} \mathrm{O}_{3}, \mathrm{CaO}$, $\mathrm{Na}_{2} \mathrm{O}, \mathrm{K}_{2} \mathrm{O}, \mathrm{P}_{2} \mathrm{O}_{5}, \mathrm{Zr}, \mathrm{Sr}, \mathrm{V}, \mathrm{Ce}$, and $\mathrm{Ba}$, whereas the original contents of $\mathrm{Fe}_{2} \mathrm{O}_{3}, \mathrm{MnO}, \mathrm{MgO}, \mathrm{Nb}, \mathrm{Zn}$, and La remained essentially unchanged in all but the most extreme cases. In a few rocks it appears that $\mathrm{Ni}, \mathrm{Cr}$, and perhaps even some Fe, were lost during alteration.

The variations in $\mathrm{SiO}_{2}$ and $\mathrm{MgO} /(\mathrm{MgO}+\mathrm{FeO})$ ratios of the various rock types is illustrated in figure 17. This plot shows very little variance in $\mathrm{MgO} /(\mathrm{MgO}+\mathrm{FeO})$ ratios for most of the ultramafic rock types, but considerable variation in the percent of silica. This observation leads to two conclusions. Firstly, the similarity in $\mathrm{MgO} /(\mathrm{MgO}+\mathrm{FeO})$ ratios among the ultramafic rocks argues for a common origin for all of them, and also for the immobility of $\mathrm{MgO}$ and $\mathrm{FeO}$ during metamorphism, so that this "fingerprint" ratio was preserved. Secondly, it may be argued that, at the onset of metamorphism, the ultramafic rocks and their host rocks must have differed dramatically in silica content, leading to steep $\mathrm{SiO}_{2}$ gradients during metamorphism. 
Table 2. Average compositions of ultramafic and associated rocks from the western Idaho ultramafic belt.

[Notes: The individual samples upon which the average values are based were analyzed by Bill Bonnichsen in 1991-93, using x-ray fluorescence spectrometry at the Ronald B. Gilmore Laboratory, Department of Geology and Geography, University of Massachusetts-Amherst. The analyses were performed in duplicate on La-bearing, lithium-tetraborate fused glass discs using modifications of the methods of Norrish and Hutton (1969). Prior to fusion, rock powders were ignited and oxidized in air at $1,000^{\circ} \mathrm{C}$ for 4 hours, or more. Calibrations are based on natural and synthetic standards and total iron was analyzed as Fe203. Where a value of zero ppm is given, the value determined was less than $0.5 \mathrm{ppm}]$

Part A. Normalized average rock compositions.

\begin{tabular}{|c|c|c|c|c|c|}
\hline Column: & 1 & 2 & 3 & 4 & 5 \\
\hline Rock Type: & Dunite & Serpentinite & $\begin{array}{l}\text { Low-silica } \\
\text { altered } \\
\text { harzburgite }\end{array}$ & $\begin{array}{l}\text { High-silica } \\
\text { altered } \\
\text { harzburgite }\end{array}$ & $\begin{array}{c}\text { Fresh } \\
\text { Ca-rich } \\
\text { pyroxenite }\end{array}$ \\
\hline \multicolumn{6}{|l|}{ Weight Percent: } \\
\hline $\mathrm{SiO}_{2}$ & 41.61 & 47.22 & 47.85 & 57.99 & 52.74 \\
\hline $\mathrm{TiO}_{2}$ & 0.00 & 0.03 & 0.02 & 0.02 & 0.09 \\
\hline $\mathrm{A}_{2} \mathrm{O}_{3}$ & 0.27 & 1.88 & 1.31 & 1.32 & 2.14 \\
\hline $\mathrm{Fe}_{2} \mathrm{O}_{3}$ & 9.56 & 8.82 & 9.28 & 6.99 & 4.36 \\
\hline $\mathrm{MnO}$ & 0.17 & 0.09 & 0.13 & 0.09 & 0.12 \\
\hline $\mathrm{MgO}$ & 47.00 & 40.89 & 40.35 & 31.78 & 18.93 \\
\hline $\mathrm{CaO}$ & 0.22 & 0.18 & 0.28 & 1.04 & 20.74 \\
\hline $\mathrm{Na}_{2} \mathrm{O}$ & 0.36 & 0.25 & 0.20 & 0.18 & 0.33 \\
\hline $\mathrm{K}_{2} \mathrm{O}$ & 0.02 & 0.03 & 0.01 & 0.02 & 0.02 \\
\hline $\mathrm{P}_{2} \mathrm{O}_{5}$ & 0.01 & 0.00 & 0.01 & 0.01 & 0.00 \\
\hline $\mathrm{NiO}$ & 0.32 & 0.24 & 0.24 & 0.25 & 0.03 \\
\hline $\mathrm{Cr}_{2} \mathrm{O}_{3}$ & 0.46 & 0.37 & 0.33 & 0.31 & 0.50 \\
\hline Total & 100.00 & 100.00 & 100.00 & 100.00 & 100.00 \\
\hline $\mathrm{MgO} / \mathrm{MgO}+\mathrm{FeO}$ & 0.85 & 0.84 & 0.83 & 0.83 & 0.83 \\
\hline \multicolumn{6}{|l|}{ Parts Per Million: } \\
\hline $\mathrm{Nb}$ & 0 & 0 & 0 & 0 & 0 \\
\hline $\mathrm{Zr}$ & 1 & 1 & 1 & 1 & 2 \\
\hline $\mathrm{Sr}$ & 3 & 4 & 3 & 5 & 8 \\
\hline $\mathrm{Zn}$ & 91 & 54 & 64 & 71 & 20 \\
\hline $\mathrm{Ni}$ & 2543 & 1808 & 1895 & 1931 & 270 \\
\hline $\mathrm{Cr}$ & 3175 & 2482 & 2240 & 2126 & 3397 \\
\hline $\mathrm{V}$ & 20 & 48 & 32 & 31 & 157 \\
\hline $\mathrm{Ce}$ & 2 & 4 & 1 & 5 & 4 \\
\hline $\mathrm{Ba}$ & 2 & 0 & 16 & 4 & 14 \\
\hline $\mathrm{La}$ & 3 & 3 & 0 & 4 & 2 \\
\hline $\begin{array}{l}\text { Number of } \\
\text { Samples }\end{array}$ & 4 & 6 & 4 & 5 & 5 \\
\hline
\end{tabular}


Table 2. Average compositions of ultramafic and associated rocks from the western Idaho ultramafic belt.-Continued

[Notes: The individual samples upon which the average values are based were analyzed by Bill Bonnichsen in 1991-93, using X-ray fluorescence spectrometry at the Ronald B. Gilmore Laboratory, Department of Geology and Geography, University of Massachusetts-Amherst. The analyses were performed in duplicate on La-bearing, lithium-tetraborate fused glass discs using modifications of the methods of Norrish and Hutton (1969). Prior to fusion, rock powders were ignited and oxidized in air at $1,000^{\circ} \mathrm{C}$ for 4 hours, or more. Calibrations are based on natural and synthetic standards and total iron was analyzed as Fe203. Where a value of zero ppm is given, the value determined was less than $0.5 \mathrm{ppm}]$

Part A. Normalized average rock compositions.

\begin{tabular}{lccccc}
\hline \multicolumn{1}{c}{ Column: } & $\mathbf{6}$ & $\mathbf{7}$ & $\mathbf{8}$ & $\mathbf{9}$ & $\mathbf{1 0}$ \\
\hline Rock Type: & $\begin{array}{c}\text { Altered } \\
\text { Ca-rich } \\
\text { pyroxenite }\end{array}$ & Chromitite & Metabasalt & $\begin{array}{c}\text { Hornblende- } \\
\text { garnet } \\
\text { blackwall rock }\end{array}$ & $\begin{array}{c}\text { Chlorite-rich } \\
\text { black-wall rock }\end{array}$ \\
\hline Weight Percent: & & & & & \\
$\mathrm{SiO}_{2}$ & 54.85 & 16.87 & 51.54 & 34.13 & 37.20 \\
$\mathrm{TiO}_{2}$ & 0.23 & 0.10 & 1.40 & 2.76 & 1.34 \\
$\mathrm{Al}_{2} \mathrm{O}_{3}$ & 3.87 & 8.69 & 15.99 & 22.05 & 16.91 \\
$\mathrm{Fe}_{2} \mathrm{O}_{3}$ & 6.38 & 11.17 & 12.68 & 18.49 & 11.97 \\
$\mathrm{MnO}_{\mathrm{MgO}}$ & 0.16 & 0.33 & 0.24 & 0.26 & 0.16 \\
$\mathrm{CaO}_{\mathrm{Na}}$ & 21.12 & 22.43 & 6.73 & 9.95 & 31.97 \\
$\mathrm{Na}_{2} \mathrm{O}$ & 12.61 & 0.01 & 6.56 & 10.49 & 0.24 \\
$\mathrm{~K}_{2} \mathrm{O}$ & 0.30 & 0.29 & 4.61 & 1.28 & 0.13 \\
$\mathrm{P}_{2} \mathrm{O}_{5}$ & 0.10 & 0.02 & 0.16 & 0.37 & 0.01 \\
$\mathrm{NiO}$ & 0.06 & 0.00 & 0.11 & 0.23 & 0.07 \\
$\mathrm{Cr}_{2} \mathrm{O}_{3}$ & 0.12 & 0.20 & & & 100.00 \\
$\mathrm{Total}$ & 0.20 & 39.87 & & & 0.75 \\
$\mathrm{MgO} / \mathrm{MgO}+\mathrm{FeO}$ & 100.00 & 100.00 & 100.00 & 100.00 & \\
& 0.78 & 0.69 & 0.37 & 0.38 &
\end{tabular}

Parts Per Million:

$\begin{array}{lr}\mathrm{Nb} & 1 \\ \mathrm{Zr} & 17 \\ \mathrm{Sr} & 40 \\ \mathrm{Zn} & 63 \\ \mathrm{Ni} & 938 \\ \mathrm{Cr} & 1354 \\ \mathrm{~V} & 132 \\ \mathrm{Ce} & 10 \\ \mathrm{Ba} & 113 \\ \mathrm{La} & 3 \\ & 0\end{array}$

Number of

1
84
117
231
29
6
296
10
22
0
0

$\begin{array}{rr}10 & 5 \\ 112 & 72 \\ 211 & 3 \\ 152 & 87 \\ 211 & 452 \\ 277 & 239 \\ 475 & 190 \\ 18 & 6 \\ 337 & 26 \\ 7 & 4 \\ 0 & 0\end{array}$

Samples 
Table 2. Average compositions of ultramafic and associated rocks from the western Idaho ultramafic belt.-Continued

[Notes: The individual samples upon which the average values are based were analyzed by Bill Bonnichsen in 1991-93, using x-ray fluorescence spectrometry at the Ronald B. Gilmore Laboratory, Department of Geology and Geography, University of Massachusetts-Amherst. The analyses were performed in duplicate on La-bearing, lithium-tetraborate fused glass discs using modifications of the methods of Norrish and Hutton (1969). Prior to fusion, rock powders were ignited and oxidized in air at $1,000^{\circ} \mathrm{C}$ for 4 hours, or more. Calibrations are based on natural and synthetic standards and total iron was analyzed as Fe203. Where a value of zero ppm is given, the value determined was less than $0.5 \mathrm{ppm}]$

Part A. Normalized average rock compositions.

\begin{tabular}{|c|c|c|c|c|c|}
\hline Column: & 11 & 12 & 13 & 14 & 15 \\
\hline Rock Type: & $\begin{array}{l}\text { Chlorite-rich } \\
\text { black-wall } \\
\text { vein rock }\end{array}$ & $\begin{array}{l}\text { Amphibole } \\
\text { rich black- } \\
\text { wall rock }\end{array}$ & Metarodingite & $\begin{array}{c}\text { Adjusted black- } \\
\text { wall } \\
\text { composition }\end{array}$ & $\begin{array}{c}\text { Average } \\
\text { volcanic rocks } \\
\text { of Hamilton } \\
(1963)\end{array}$ \\
\hline \multicolumn{6}{|l|}{ Weight Percent: } \\
\hline $\mathrm{SiO}_{2}$ & 23.80 & 43.65 & 41.65 & 52.50 & 52.55 \\
\hline $\mathrm{TiO}_{2}$ & 4.66 & 1.96 & 2.18 & 2.00 & 1.32 \\
\hline $\mathrm{A}_{2} \mathrm{O}_{3}$ & 21.69 & 9.99 & 15.31 & 16.00 & 16.48 \\
\hline $\mathrm{Fe}_{2} \mathrm{O}_{3}$ & 25.99 & 12.70 & 12.92 & 13.41 & 12.04 \\
\hline $\mathrm{MnO}$ & 0.39 & 0.22 & 0.50 & 0.19 & 0.20 \\
\hline $\mathrm{MgO}$ & 18.20 & 22.26 & 6.94 & 7.22 & 6.40 \\
\hline $\mathrm{CaO}$ & 2.83 & 8.03 & 18.88 & 7.61 & 6.94 \\
\hline $\mathrm{Na}_{2} \mathrm{O}$ & 0.23 & 0.73 & 0.97 & 0.93 & 3.57 \\
\hline $\mathrm{K}_{2} \mathrm{O}$ & 0.03 & 0.07 & 0.36 & 0.27 & 0.32 \\
\hline $\mathrm{P}_{2} \mathrm{O}_{5}$ & 2.18 & 0.40 & 0.29 & 0.16 & 0.18 \\
\hline Total & 100.00 & 100.00 & 100.00 & 100.00 & 100.00 \\
\hline $\mathrm{MgO} / \mathrm{MgO}+\mathrm{FeO}$ & 0.44 & 0.66 & 0.37 & 0.38 & 0.37 \\
\hline \multicolumn{6}{|l|}{ Parts Per Million: } \\
\hline $\mathrm{Nb}$ & 35 & 8 & 7 & & \\
\hline $\mathrm{Zr}$ & 507 & 117 & 174 & & \\
\hline $\mathrm{Sr}$ & 45 & 116 & 446 & & \\
\hline $\mathrm{Zn}$ & 332 & 204 & 312 & & \\
\hline $\mathrm{Ni}$ & 275 & 361 & 132 & & \\
\hline $\mathrm{Cr}$ & 590 & 320 & 188 & & \\
\hline $\mathrm{V}$ & 523 & 216 & 348 & & \\
\hline $\mathrm{Ce}$ & 97 & 19 & 24 & & \\
\hline $\mathrm{Ba}$ & 0 & 9 & 365 & & \\
\hline $\mathrm{La}$ & 41 & 5 & 8 & & \\
\hline Number of & 1 & 1 & 2 & 6 & 5 \\
\hline Samples & & & & & \\
\hline
\end{tabular}


Table 2. Average compositions of ultramafic and associated rocks from the western Idaho ultramafic belt.—Continued

[Notes: The individual samples upon which the average values are based were analyzed by Bill Bonnichsen in 1991-93, using x-ray fluorescence spectrometry at the Ronald B. Gilmore Laboratory, Department of Geology and Geography, University of Massachusetts-Amherst. The analyses were performed in duplicate on La-bearing, lithium-tetraborate fused glass discs using modifications of the methods of Norrish and Hutton (1969). Prior to fusion, rock powders were ignited and oxidized in air at $1,000^{\circ} \mathrm{C}$ for 4 hours, or more. Calibrations are based on natural and synthetic standards and total iron was analyzed as $\mathrm{Fe}_{2} \mathrm{O}_{3}$. Where a value of zero ppm is given, the value determined was less than $0.5 \mathrm{ppm}]$

Part B. Information for normalized average analyses. (The individual analyses from which the averages in columns 1 to 14 were derived are reported in Bonnichsen and Godchaux, 1994.)

1. Relatively fresh dunite. Average of samples W-192, W-193, W194, and C-165.

2. Serpentinite. Average of samples W-6, W-35, TBR-3, and W357A, from Bonnichsen and Godchaux (1994), and samples SR14-1 and SR37-3, from Hamilton (1963). The minor element averages are based only on samples W-6, W-35, TBR-3, and W-357A.

3. Low-silica altered harzburgite or dunite. Average of samples W-68, C-115, C-142, and C-146.

4. High-silica altered harzburgite. Average of samples W-36, AP9, MR-f, C-174, and AP-3.

5. Relatively fresh Ca-rich pyroxenite. Average of samples C136, C-151, C-161, C-169, and BB-1.

6. Altered Ca-rich pyroxenite or peridotite. Average of samples W-107, MR-3, MR-10, and C-131.

7. Chromitite. Average of samples W-220 and W-391.

8. Metabasalt. Average of samples TBR-10 and TBR-11.

9. Hornblende-garnet blackwall rock. Average of samples AP-4,AP-5, C-75, C-91, C-137, and MR-14.

10. Chlorite-rich blackwall rock. Average of samples AP-6, C-89, and C-98.

11. Chlorite-rich blackwall vein rock. Sample C-95.

12. Amphibole-rich blackwall rock. Sample W-63.

13. Metarodingite. Average of samples W-203 and W-205.

14. Adjusted analysis of the six hornblende-garnet blackwall rocks averaged in column 9. Before normalization, 37.81 percent $\mathrm{SiO}_{2}$ was added to the original 34.13 percent, in order to lower the $\mathrm{Al}_{2} \mathrm{O}_{3}$ from 22.05 to 16.00 percent.

15. Average of metamorphosed basalts and basaltic andesites from the Riggins Group. Average of samples SR-114, SR-127C, SR-34, SR-539, and SR-51, from Hamilton (1963). 


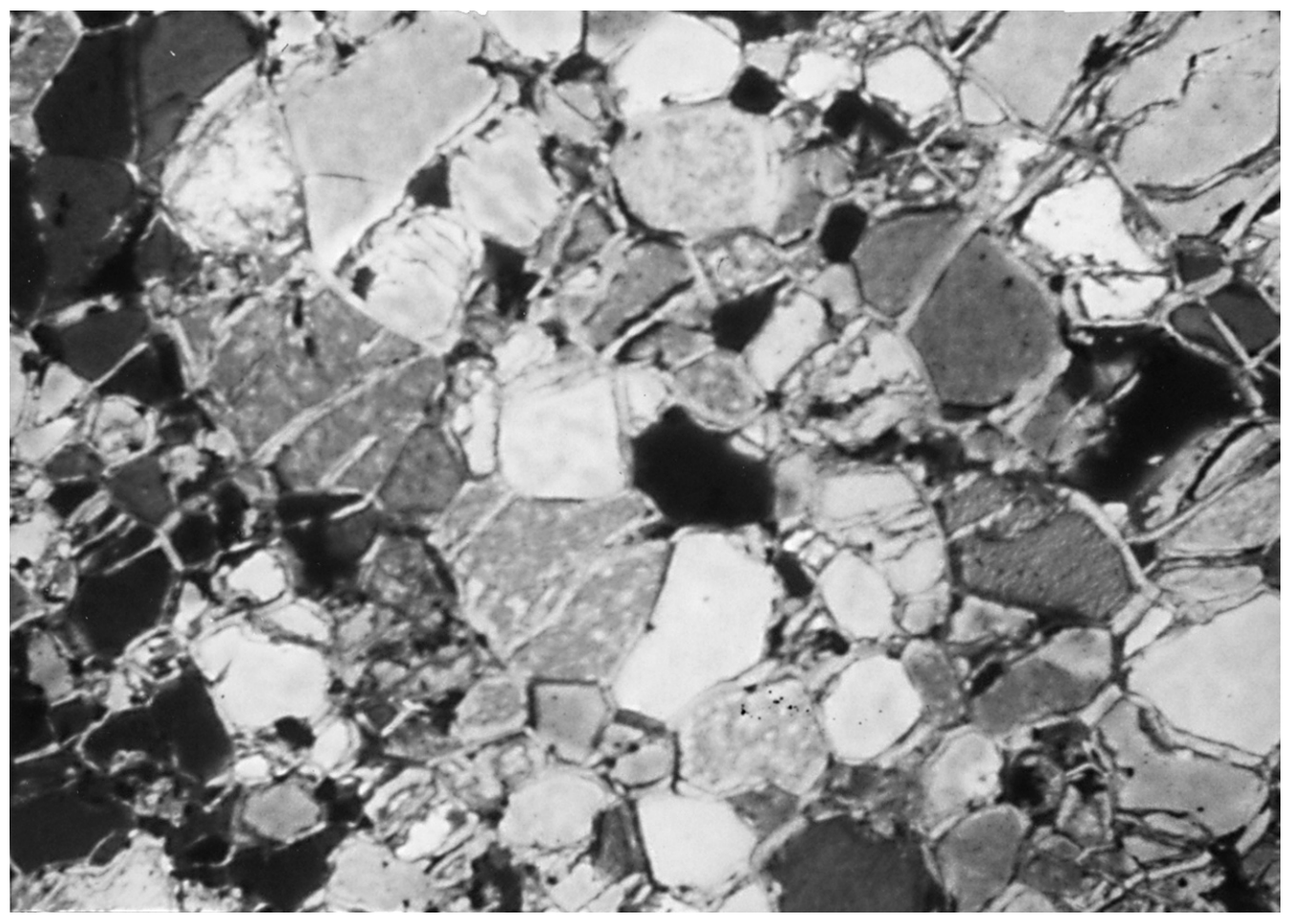

Figure 6. Photomicrograph of fresh dunite from the Asbestos Point ultramafic body. Note the metamorphic equilibrium texture among olivine crystals. Width of photo is $0.5 \mathrm{~cm}$. In this and all photomicrographs, the dimension given is the long dimension of the photograph.

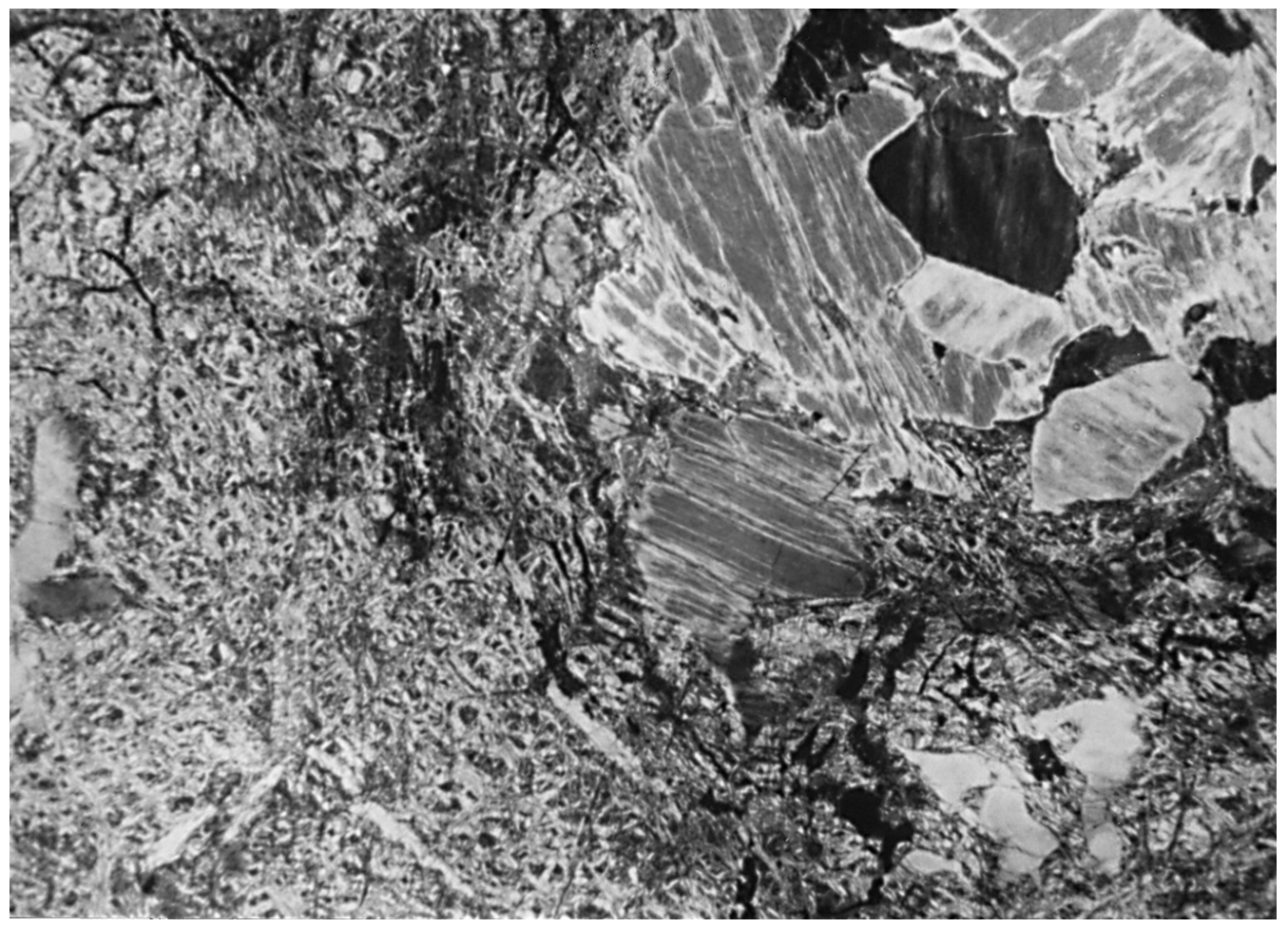

Figure 7. Photomicrograph of serpentinite from the Sturgill Peak ultramafic body. The fine-grained material is serpentine, and the coarse-grained material is orthopyroxene from an unaltered remnant of the original harzburgite. Width of photo is $0.5 \mathrm{~cm}$. 


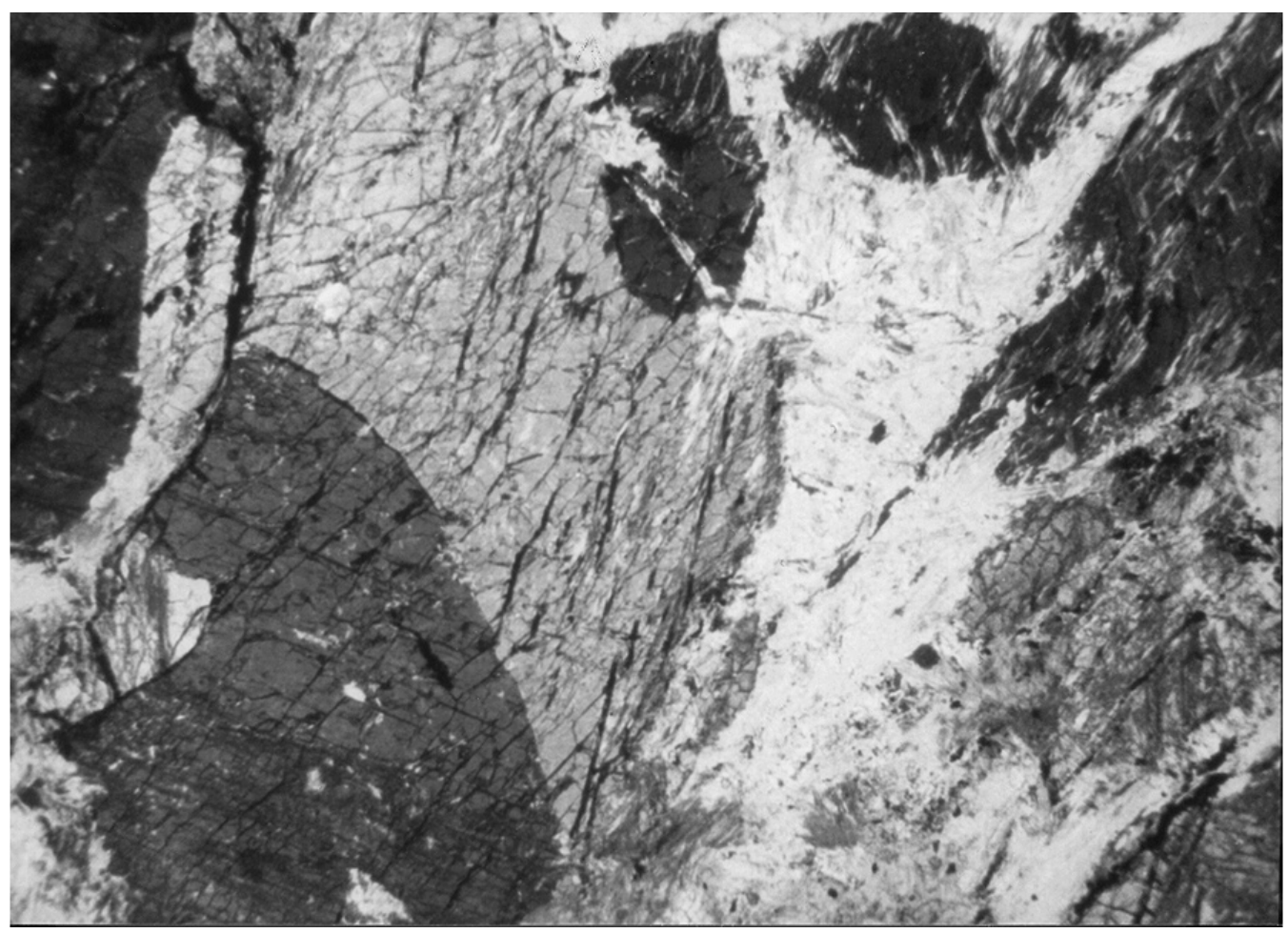

Figure 8. Photomicrograph of low-silica altered harzburgite from the North Blacktail Butte metaperidotite body. The coarse crystals are olivine, and the light-colored, fine-grained material is a mixture of talc and chlorite replacing olivine. Width of photo is $1.2 \mathrm{~cm}$.

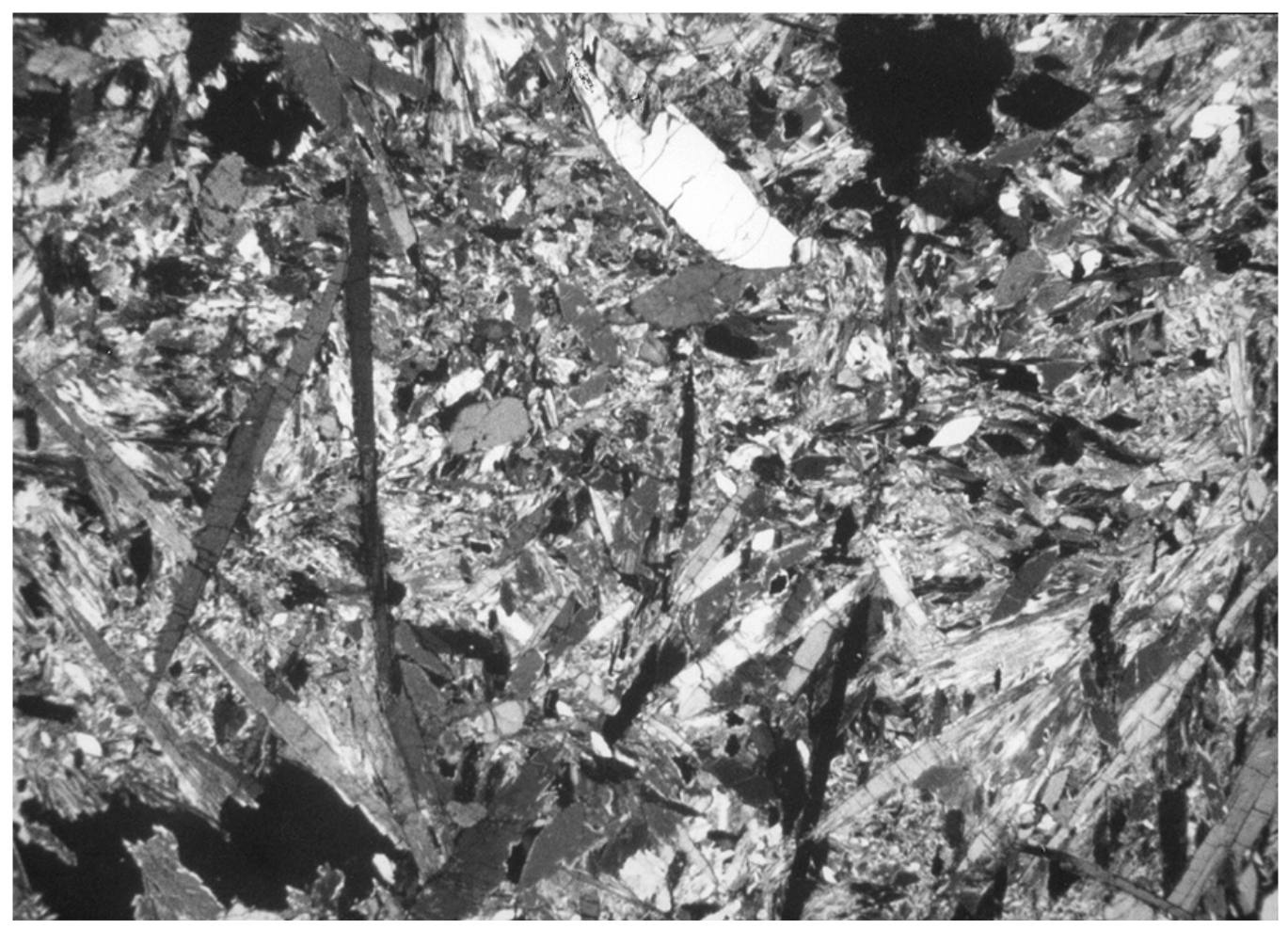

Figure 9. Photomicrograph of high-silica altered harzburgite from the Asbestos Peak ultramafic body. The very elongate crystals are anthophyllite, and the less elongate, relatively large crystals are chlorite. Fine-grained talc also is present; none of the original olivine remains in this view. Width of photo is $1.0 \mathrm{~cm}$. 


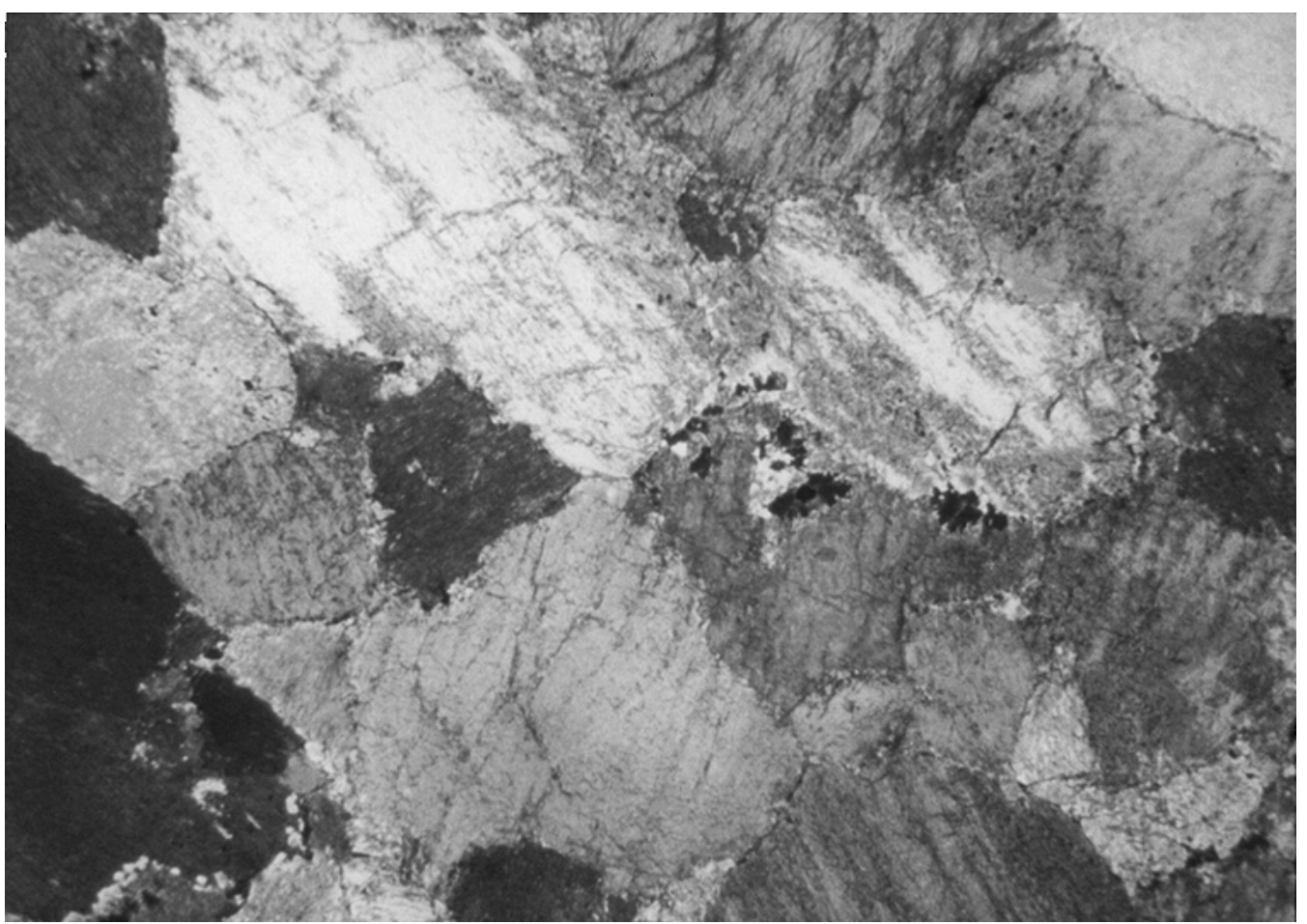

Figure 10. Photomicrograph of fresh, Ca-rich pyroxenite from the Castle Creek ultramafic body. The coarse crystals are diopsidic augite that show traces of alteration along their margins. Width of photo is $1.2 \mathrm{~cm}$.

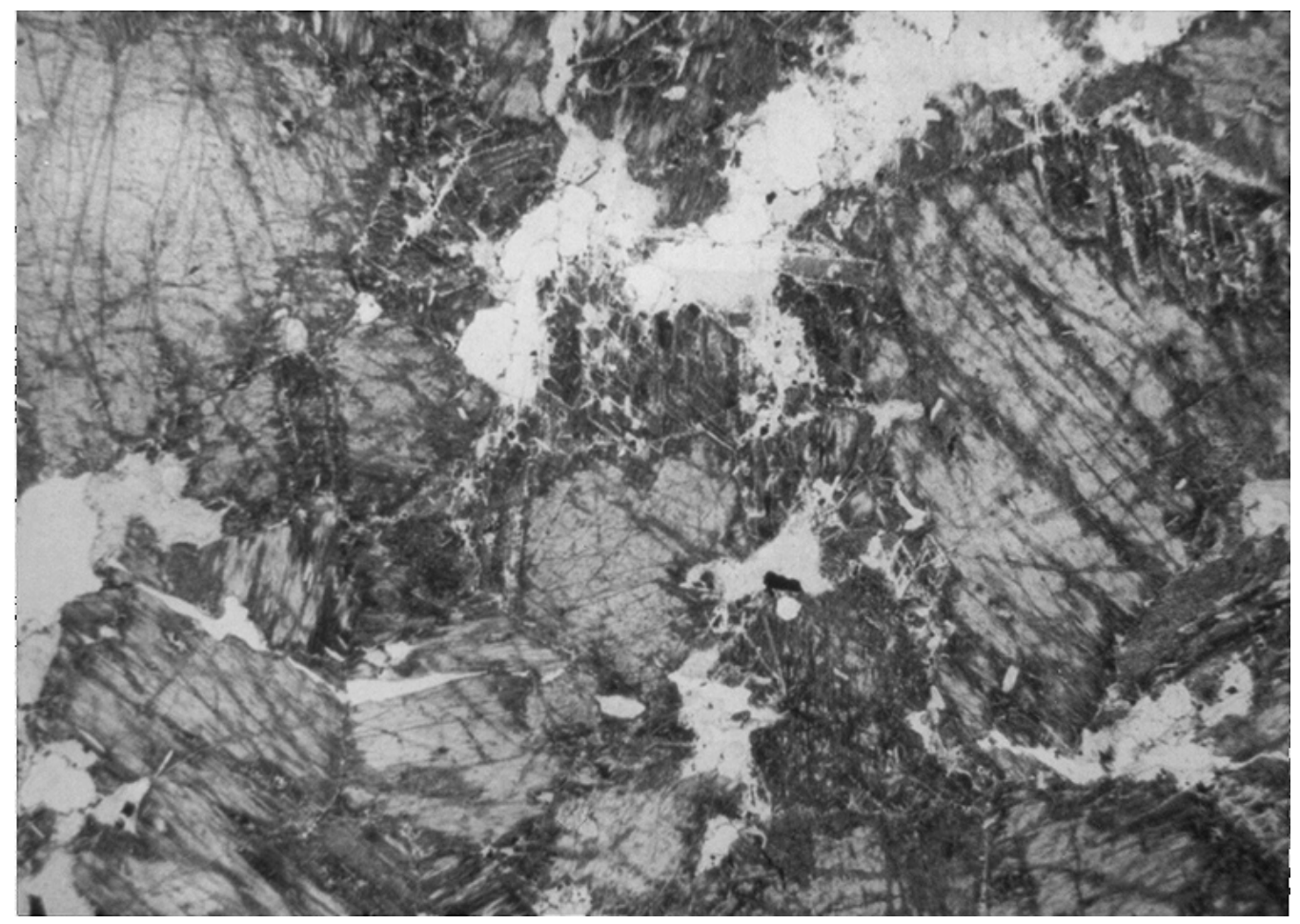

Figure 11. Photomicrograph of altered Ca-rich pyroxenite from the Castle Creek ultramafic body. The coarse crystals are diopsidic augite that have been partly replaced by amphiboles. Width of photo is $1.1 \mathrm{~cm}$. 


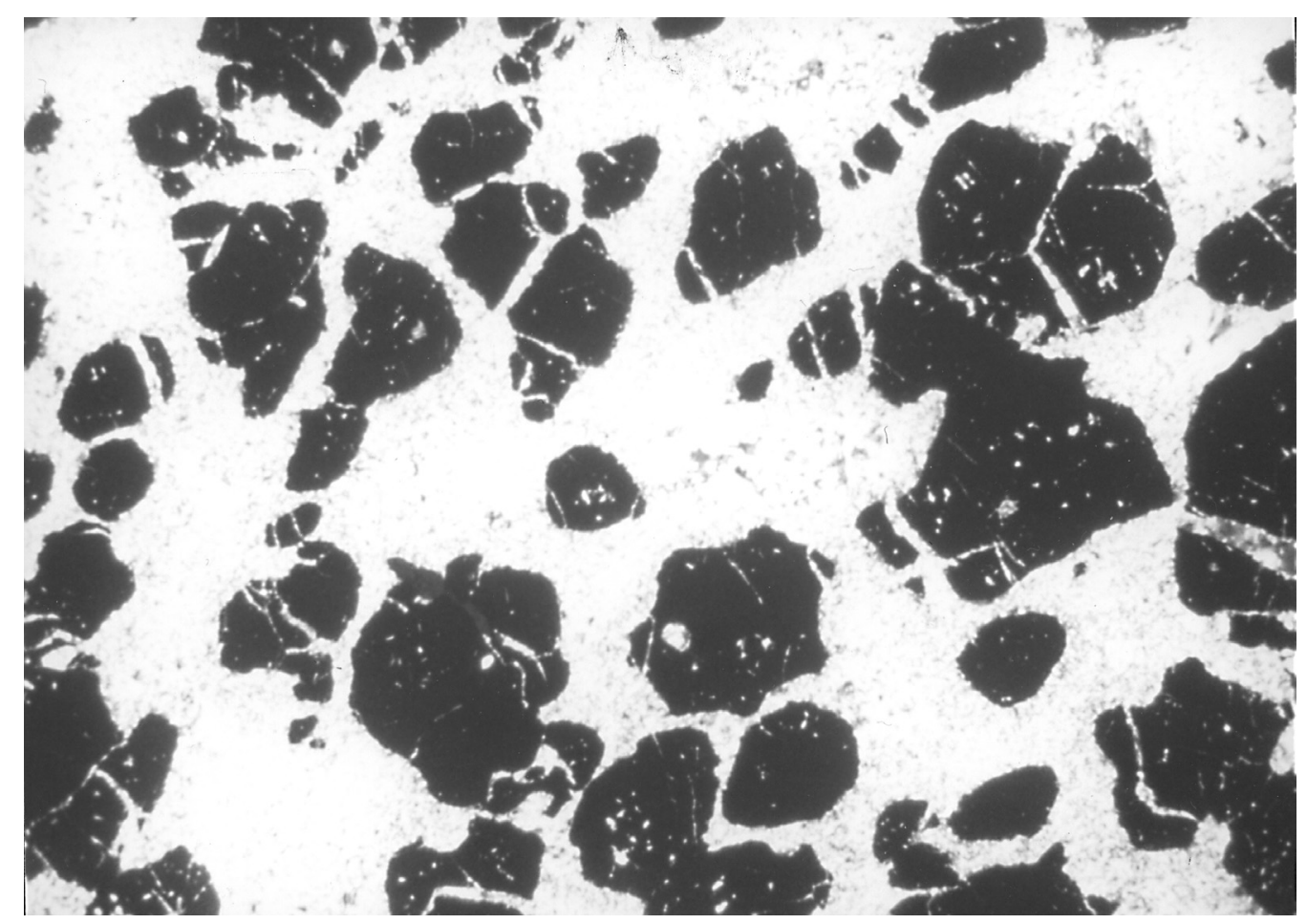

Figure 12. Photomicrograph of chromitite from the New Meadows area. The black crystals are chromite, and the fine-grained matrix is a mixture of serpentine and chlorite. Width of photo is $0.8 \mathrm{~cm}$.

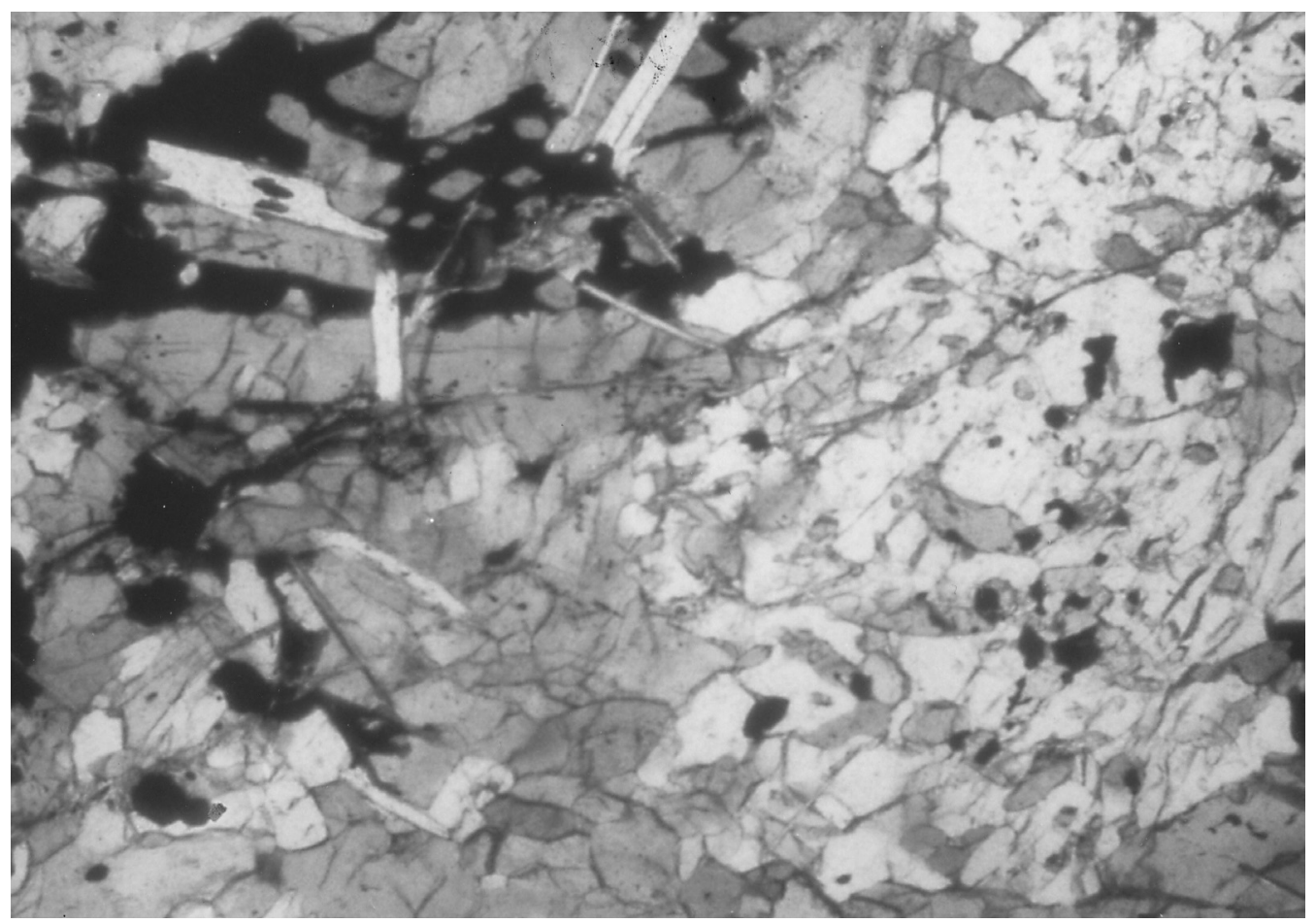

Figure 13. Photomicrograph of a hornblende-garnet blackwall-zone rock from the margin of the Asbestos Peak ultramafic body. The light-colored material is a poikiloblastic garnet crystal; the lightcolored, bladed material is chlorite; the bulk of the grey material is hornblende; the few small, slightly darker grey crystals are spinel; and the black material is ilmenite. Width of photo is $1.0 \mathrm{~cm}$. 


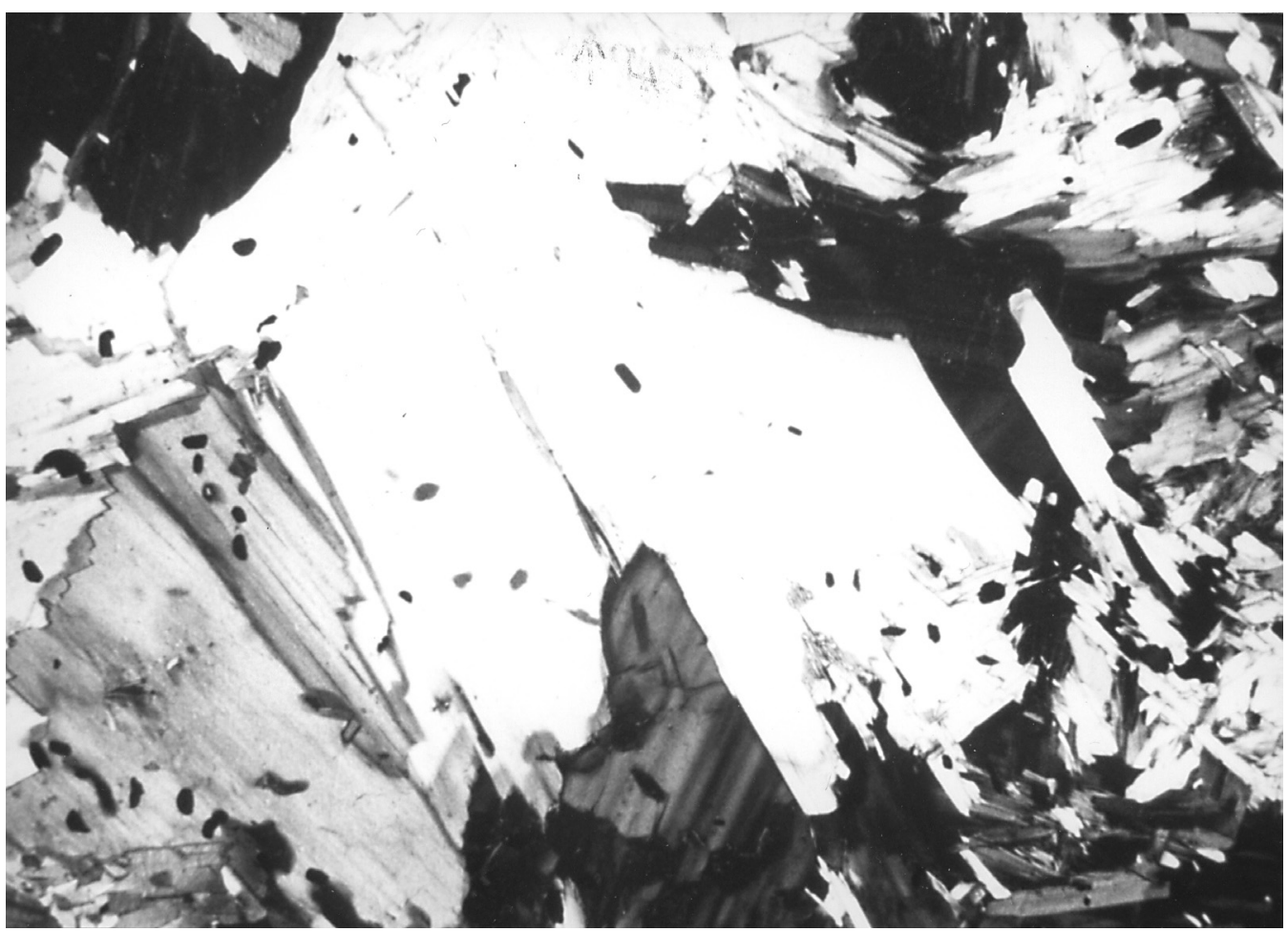

Figure 14. Photomicrograph of a chlorite-rich blackwall-zone rock from the margin of the Asbestos Peak ultramafic body. This rock consists almost entirely of chlorite. Width of photo is $0.8 \mathrm{~cm}$.

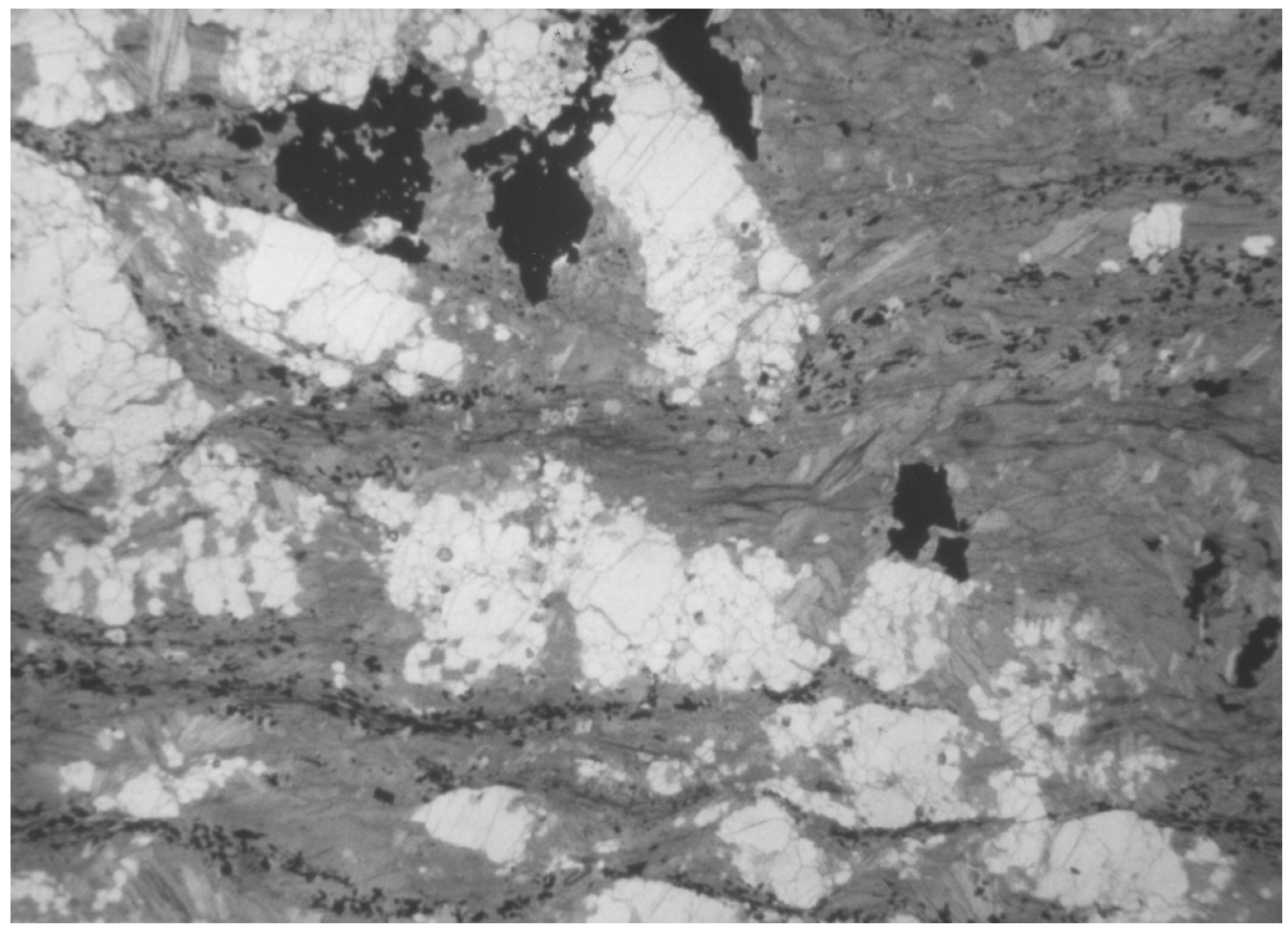

Figure 15. Photomicrograph of an apatite-rich zone within a chlorite-rich blackwall vein rock that cuts the Grouse Creek ultramafic body. The grey material is fine-grained chlorite; the light-colored material is apatite; the black material is ilmenite; and the very fine-grained trains of black material are magnetite. Width of photo is $1.3 \mathrm{~cm}$. 
Serpentinites, when compared to the relatively fresh dunites, contain more $\mathrm{SiO}_{2}$ and less $\mathrm{Fe}_{2} \mathrm{O}_{3}$ and $\mathrm{MgO}$. However, the $\mathrm{MgO}$ / $(\mathrm{MgO}+\mathrm{FeO})$ ratios are essentially the same for the two rock types.

Low-silica altered harzburgites or dunites have compositions that are essentially identical to those of the serpentinites. These low-silica altered harzburgites/dunites differ from the relatively fresh dunites by having higher $\mathrm{Al}_{2} \mathrm{O}_{3}$ and $\mathrm{SiO}_{2}$, and lower $\mathrm{MgO}$, in the same fashion as the serpentinites differ from the fresh dunites.

High-silica altered harzburgites differ from the relatively fresh dunites, serpentinites, and low-silica altered harzburgites by containing more $\mathrm{SiO}_{2}$, but less $\mathrm{MgO}$ and $\mathrm{Fe}_{2} \mathrm{O}_{3}$. We suggest that substantial $\mathrm{SiO}_{2}$ was added to the original harzburgite to form the high-silica altered harzburgites. This is consistent with the presence in some of these rocks of relict olivine or relict textures that suggest original olivine. Also, wall rocks proximal to some of the high-silica altered harzburgites seem to have lost substantial amounts of $\mathrm{SiO}_{2}$. Like the serpentinites and low-silica altered harzburgites, the high-silica altered harzburgites have more $\mathrm{Al}_{2} \mathrm{O}_{3}$ than the relatively fresh dunites, and some appear to have gained $\mathrm{CaO}$ and $\mathrm{Na}_{2} \mathrm{O}$.

When relatively fresh Ca-rich pyroxenites are compared to dunites, harzburgites, and their serpentinized or otherwise altered equivalents, both groups have similar $\mathrm{MgO} /$
$(\mathrm{MgO}+\mathrm{FeO})$ ratios and $\mathrm{Cr}$ contents. The $\mathrm{Ca}$-rich pyroxenites, however, contain more $\mathrm{Al}_{2} \mathrm{O}_{3}$ than the relatively fresh dunites. This probably reflects the presence of significant amounts of $\mathrm{Al}_{2} \mathrm{O}_{3}$ in diopsidic augite. The Ca-rich pyroxenites, unlike the dunites and harzburgites, contain only meager amounts of $\mathrm{Ni}$ and less $\mathrm{Zn}$ than the dunite-harzburgite group. Most likely this reflects the paucity of olivine and orthopyroxene in $\mathrm{Ca}$-rich pyroxenites.

Altered Ca-rich pyroxenites and peridotites, when compared to relatively fresh equivalents, display more chemical diversity. This reflects the introduction of $\mathrm{Al}_{2} \mathrm{O}_{3}, \mathrm{TiO}_{2}, \mathrm{Zr}, \mathrm{Sr}$, $\mathrm{Ba}, \mathrm{Ce}$, and other constituents, and perhaps the loss of some $\mathrm{Cr}$ and $\mathrm{Fe}$, as amphibole, epidote, and chlorite were formed.

The chromitite composition (table 2) reflects the mineral chromite, as well as serpentine and other fine-grained hydrous silicates, that these rocks contain. The average chromitite contains around 40 percent $\mathrm{Cr}_{2} \mathrm{O}_{3}$, suggesting that the chromite within the rock probably is of the high-Cr type, which is typical of podiform chromite deposits (Thayer, 1973). If the silica and an approximately equivalent molecular percentage of iron plus magnesium oxides were subtracted from the analysis of chromitite, to account for the 40 percent or so of serpentine and chlorite minerals, then the $\mathrm{Cr}_{2} \mathrm{O}_{3}$ content would be in the 55-60 percent range for the remaining chromite.

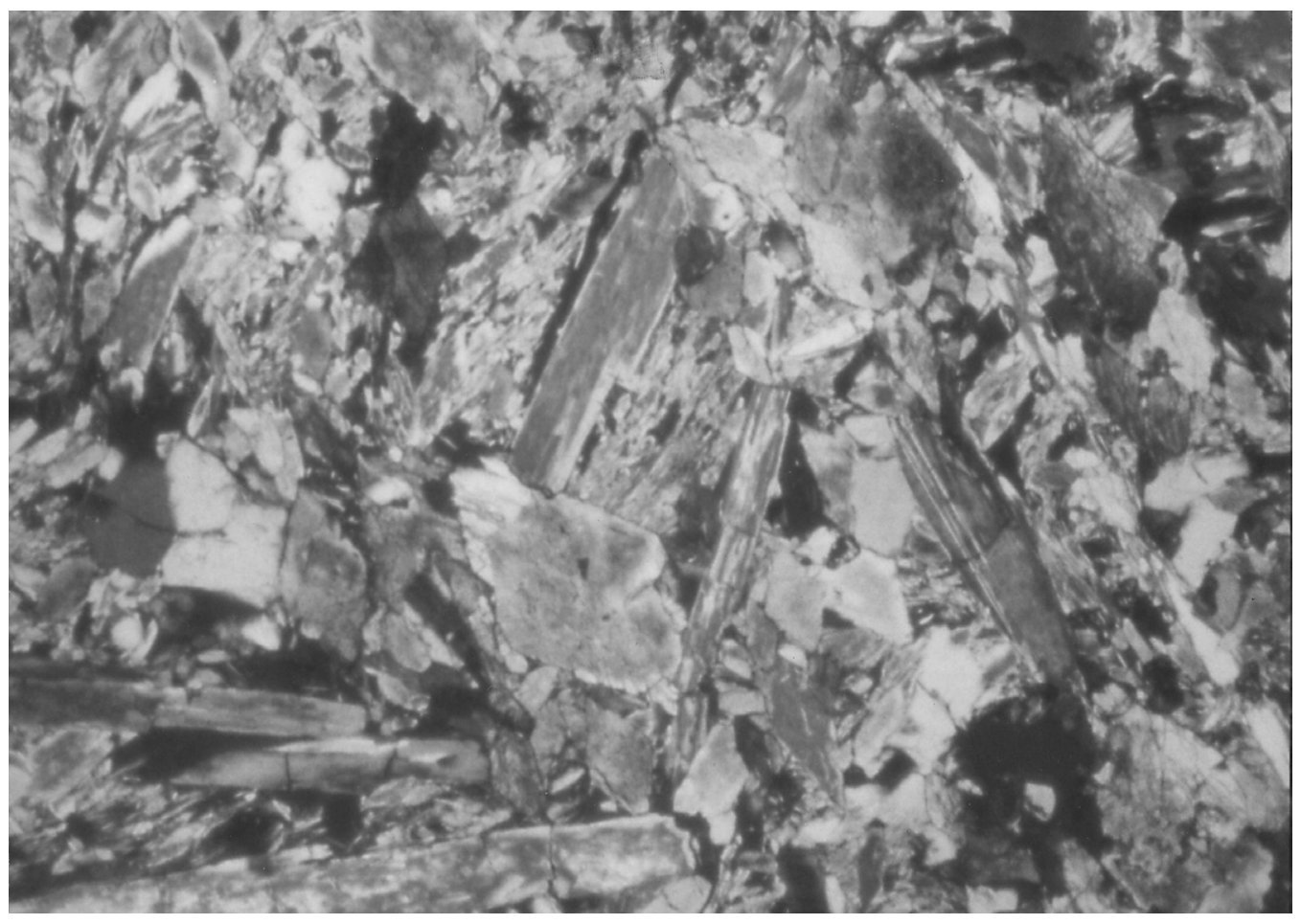

Figure 16. Photomicrograph of an amphibole-rich blackwall-zone rock from the Misery Ridge ultramafic body. This rock is composed almost entirely of tremolite. Width of photo is $0.5 \mathrm{~cm}$. 


\section{Compositions of Metamorphic Rocks Associated with Ultramafic Rocks}

The analyses in table 2 show that the compositions of rocks associated with the ultramafic bodies vary widely. They typically are characterized by $\mathrm{SiO}_{2}$ contents that are comparable to the ultramafic rocks and lower than most volcanic rocks; however, they have higher concentrations of $\mathrm{Al}$ and $\mathrm{Fe}$ than do the ultramafic rocks. The associated rocks have much less $\mathrm{Cr}$ and $\mathrm{Ni}$ and have much lower $\mathrm{MgO} /(\mathrm{MgO}+\mathrm{FeO})$ ratios than do the ultramafic rocks. Also, these associated rocks have much greater abundances of many elements, including $\mathrm{Ti}, \mathrm{Na}, \mathrm{K}, \mathrm{P}$, $\mathrm{Nb}, \mathrm{Zr}, \mathrm{Sr}, \mathrm{V}, \mathrm{Ce}$, and $\mathrm{Ba}$, than do the ultramafic rocks.

The average analyses of some metabasalts from dikelike bodies near the Time Zone Bridge serpentinite body are included in table 2 . These rocks are essentially spilites that have abnormally high $\mathrm{Na}$ and abnormally low $\mathrm{Ca}$ and $\mathrm{K}$ contents. The compositions of the spilites are similar to the average basalt and andesite analyses from the Riggins Group reported by Hamilton (1963) that are listed in table 2.

The major-element compositions of the hornblendegarnet blackwall-zone rocks are peculiar. These rocks do not particularly resemble normal types of ultramafic or mafic plutonic rocks. Even though their $\mathrm{SiO}_{2}$ contents are low enough for them to resemble ultramafic rocks, their $\mathrm{Fe}, \mathrm{Mg}$, $\mathrm{Ti}, \mathrm{Al}, \mathrm{Ca}, \mathrm{Cr}$, and $\mathrm{Ni}$ contents suggest that they are not ultramafic or mafic plutonic rocks. The fairly specific association of the hornblende-garnet blackwall rocks with the margins of ultramafic bodies that have gained silica suggests that transfer of silica from the former to the latter was an important allochemical metamorphic process. In terms of mineral reactions, the $\mathrm{SiO}_{2}$ needed to convert olivine to anthophyllite and talc in the ultramafic rocks may have been derived from simultaneous conversion of pyroxene and plagioclase to amphibole and garnet in basaltic wall rocks immediately adjacent to the ultramafic bodies, and the hornblende-garnet blackwall rocks might thus have lost $\mathrm{SiO}_{2}$. We suggest that

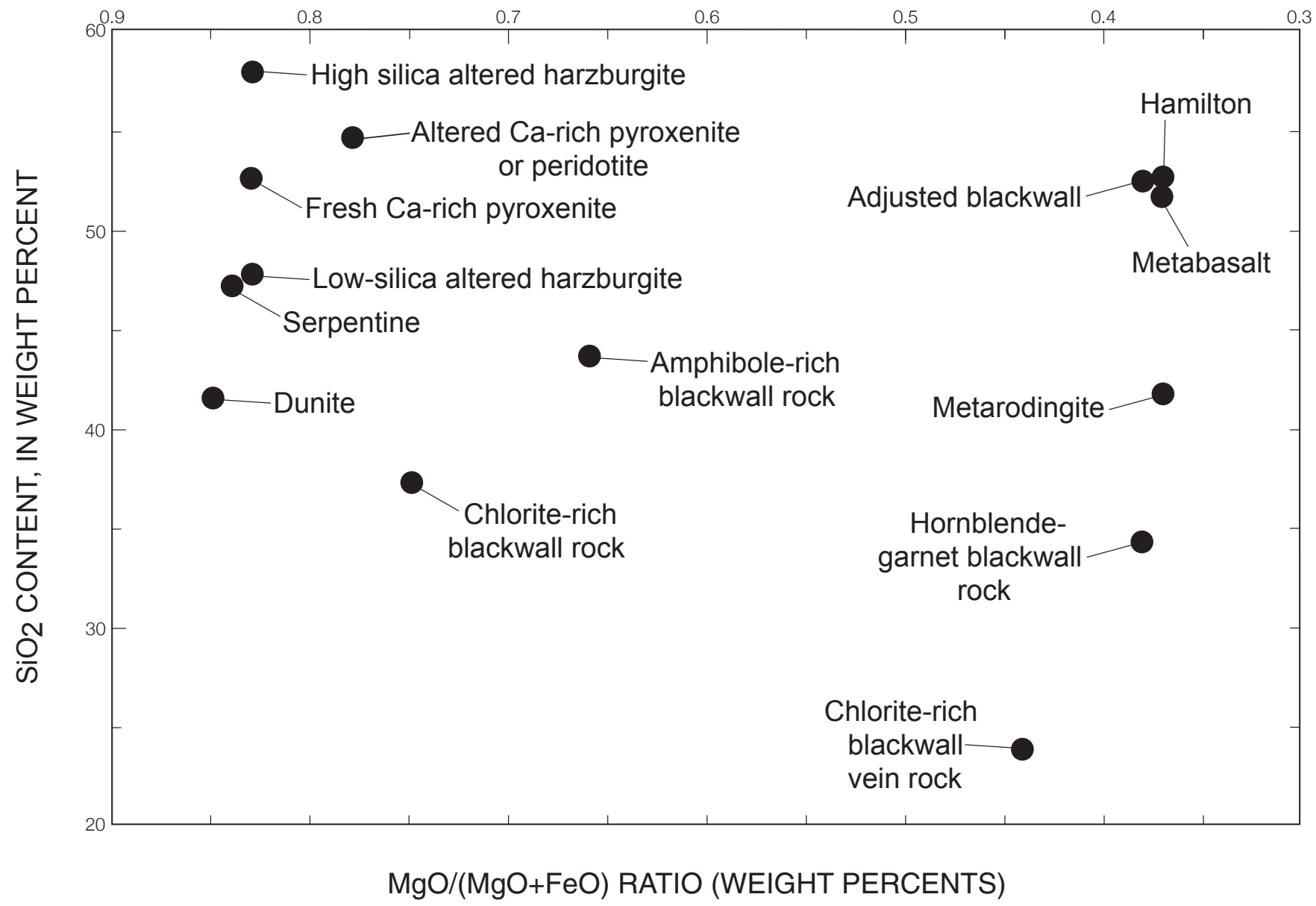

Figure 17. Plot of average silica contents versus $\mathrm{MgO} /(\mathrm{MgO}+\mathrm{Fe} 0)$ ratios for the various types of ultramafic and associated rocks in the western Idaho ultramafic belt. See table 2 for the data. "Adjusted blackwall" represents adjusted values for average hornblende-garnet blackwall rock; "Hamilton" represents average of metamorphosed basalts and basaltic andesites reported by Hamilton (1963). 
the hornblende-garnet blackwall rocks might originally have been volcanic or tuffaceous rocks of generally basaltic or andesitic compositions. An alternative possibility is that the hornblende-garnet blackwall rocks originated as basaltic dikes derived from the ultramafic rocks during a partial melting episode prior to or concurrent with obduction. Postemplacement shearing and weathering and erosion have obscured the structural relations between the hornblendegarnet blackwall rocks and the ultramafics to such an extent that it is not possible to rule out either mode of origin.

To investigate if the hornblende-garnet blackwall rocks might be desilicated basalts or andesites we have added $\mathrm{SiO}_{2}$ to their average analysis (table 2; see Bonnichsen and Godchaux, 1994, for more details). Except for the low $\mathrm{Na}_{2} \mathrm{O}$ value, the adjusted analysis matches a basalt or basaltic andesite analysis very well. To develop this adjusted analysis, enough $\mathrm{SiO}_{2}$ was added to the original analysis to decrease the $\mathrm{Al}_{2} \mathrm{O}_{3}$ to a value that would be reasonable for basalt and andesite, about 16 percent. For comparison, the average of five metamorphosed basalts and basaltic andesites from the Riggins Group (Hamilton, 1963) is given in table 2 and is shown in figure 17.

The average compositions of chlorite-rich blackwall rocks (table 2) from the Asbestos Peak and Grouse Creek ultramafic bodies show that these rocks have $\mathrm{MgO}$ / $(\mathrm{MgO}+\mathrm{FeO})$ ratios that are nearly as high as those in the ultramafic bodies. Aside from their higher $\mathrm{MgO} /(\mathrm{MgO}+\mathrm{FeO})$ ratios, the chlorite-rich blackwall rocks are somewhat like the hornblende-garnet blackwall rocks in their contents of $\mathrm{SiO}_{2}, \mathrm{TiO}_{2}$, and $\mathrm{Al}_{2} \mathrm{O}_{3}$, but they are considerably higher than the hornblende-garnet blackwall rocks in their total of $\mathrm{MgO}$ and $\mathrm{Fe}_{2} \mathrm{O}_{3}$ and much lower in $\mathrm{CaO}$ and several of the minor elements. These characteristics suggest that the chlorite-rich rocks initially were ultramafic, but underwent extensive alteration during metamorphism.

The chlorite-rich blackwall vein analysis (table 2), from the Grouse Creek ultramafic body, has a lower $\mathrm{MgO}$ / $(\mathrm{MgO}+\mathrm{FeO})$ ratio than the other chlorite-rich rocks and has a very high $\mathrm{TiO}_{2}$ content. Furthermore, the chlorite-rich blackwall vein has very high contents of $\mathrm{P}_{2} \mathrm{O}_{5}$ and several of the minor elements, in comparison to the enclosing ultramafic body or to the other blackwall rocks. In view of its composition, we doubt that this rock type was originally ultramafic, but we find it difficult to identify its protolith. Its composition has probably been modified substantially.

The analysis of an amphibole-rich blackwall rock (table 2), from the margin of one of the New Meadows ultramafic masses, shows a relatively high $\mathrm{MgO} /(\mathrm{MgO}+\mathrm{FeO})$ ratio, along with a relatively low content of many elements (such as $\mathrm{Nb}, \mathrm{Ce}, \mathrm{Ba}, \mathrm{La}$ ) that also are typically low in the ultramafic rocks, suggesting an ultramafic protolith. If amphibolerich blackwall rocks were originally ultramafic, then relatively large amounts of $\mathrm{Al}_{2} \mathrm{O}_{3}, \mathrm{CaO}$, and rare-earth elements have been added during alteration.

The average analysis of metarodingite (table 2) is derived from rocks in the New Meadows area. These rocks prob- ably were originally diabasic dikes, but they show the typical alteration pattern of rodingites, loss of $\mathrm{SiO}_{2}$ and alkalis and gain of $\mathrm{CaO}$ and $\mathrm{MnO}$.

\section{Discussion}

\section{Summary of Geologic History}

The overall geologic setting and geochemical nature suggest that the ultramafic bodies in western Idaho initially formed in an oceanic environment, either accumulating at an oceanic ridge crest as new basaltic material upwelled from the interior of the earth, or forming in an extending back-arc basin environment between the continent and an island arc.

The facts that the Blue Mountains island-arc terrane (Vallier and Brooks, 1987) lies immediately west of the Precambrian-cored continental crust and that the ultramafic rocks are in the zone of greatest structural deformation between these terranes (the remnants of the back-arc basin), or belong to the dismembered eastern part of the Blue Mountains terrane, indicate that plate motion during the Mesozoic played a large role in bringing the ultramafic rocks to their present position. Whether the ultramafic rocks were obducted onto the continental margin at a convergent plate margin or were brought into the continental margin environment by a more complex series of plate motions has yet to be resolved. All the ultramafic bodies near the suture zone were regionally metamorphosed to the greenschist or amphibolite facies, implying their initial subduction to moderate depths before they were returned to the surface along reverse faults and obducted, and all were deformed. For some bodies, only the margins were disturbed, but for others, the interiors were completely tectonized.

Both the Early Cretaceous docking of the Blue Mountains island arc terrane and the Late Cretaceous emplacement of the Idaho Batholith have obscured the earlier history of the western Idaho ultramafic belt. The docking process, which nestled the Blue Mountains island-arc terrane against the preexisting continental crust, was accompanied by considerable east-west compression, and perhaps by north-south translation, so that flattening and shearing were concentrated where the accreted terrane-continental crust suture zone developed. Then the intrusion, during the Late Cretaceous, of plutons of the Idaho Batholith adjacent to and within the suture zone continued the metamorphism and deformation of the ultramafic rocks. East-west compressive forces probably were still acting on the suture zone when emplacement of the early phases of the Idaho Batholith contributed to development of the steeply plunging lineations and steeply dipping foliations that penetrate many rocks along the suture zone. These steep lineations, in conjunction with the concordant attitudes of granitoid dikes and veins in the region, suggest that the area east of the suture zone was uplifted and perhaps thrust westward over the edge of the accreted terrane. 


\section{Some Unanswered Questions and Possible Answers}

Our systematic inventory and description of the western Idaho ultramafic belt highlights the unusual diversity of protoliths, of metamorphic assemblages, and of host rocks in this utterly charming and chronically underappreciated belt of alpine ultramafic bodies, but the new knowledge also raises additional questions. Some of these unanswered questions that emerge regarding the origin and evolution of the ultramafic rocks are discussed below.

(1) Why Are There Two Apparently Different Kinds of Ultramafic Rocks, a Dominant Dunite-Harzburgite Suite and a Less Common Suite Composed Essentially of Ca-Rich Pyroxene?

The dunite-harzburgite suite that includes the serpentinites are ultramafic rocks normally expected in a continental margin environment. These are the common ultramafic rock types that form in oceanic environments and that eventually may be obducted onto continental margins by plate convergence. Ca-pyroxene-rich pyroxenites, however, are not common rock types of this environment. We do not know if they were a small part of an otherwise normal dunite-harzburgite sequence, or if they were formed independently in some other type of upper mantle or lower crust environment and were later tectonically emplaced into the same structural zone as the dunites and harzburgites. The high $\mathrm{MgO} /(\mathrm{MgO}+\mathrm{FeO})$ ratios and high $\mathrm{Cr}$ contents of the Ca-pyroxene-rich rocks is consistent with their origin in an environment similar to that of the dunites and harzburgites. On these grounds, we suggest that the Ca-pyroxene-rich rocks were not formed in their own special environment, but simply represent minor variants of the dunite-harzburgite suite.

\section{(2) Are the Ultramafic Bodies Fragments of Ophiolite Com- plexes?}

Direct, conclusive, evidence that the western Idaho ultramafic rocks are fragments of ophiolite complexes is scant. However, a few observations suggest that this interpretation is reasonable for at least some of the bodies. These observations include the association of metachert and other metasediments (including biotite-barite rocks probably derived from exhalatites) and metarodingite dikes, in association with the ultramafic bodies in the New Meadows region. Bonnichsen (1987) postulated that the peridotite and associated metasedimentary rocks there might be a melange assemblage that was deformed in an oceanic trench environment. Lenses of metachert in the Grouse Creek area (Hoover, 1986) and the gradational upwards transition from olivine-pyroxene metagabbro to metaperidotite to highly altered pyroxenite in the North Blacktail Butte ultramafic body (Myers, 1982) also suggest this interpretation. Apart from these observations we conclude that, if the ultramafic bodies were once parts of ophiolite complexes, they have been thoroughly changed from ophiolite rock- sequence configurations by subsequent tectonic events. Even if some of the ultramafic bodies are from ophiolite sequences, it is not necessary that all are; some may have originated via extreme crystal fractionation in calcalkaline magmas in islandarc environments.

(3) Why Do Different Host Rocks Enclose the Ultramafic Bodies?

There are major variations in the host rocks that enclose the ultramafic bodies. For example, the Mesozoic-age Riggins Group in the south, the Proterozoic(?)Syringa metamorphic sequence in the Lowell region, and the Proterozoic-age Belt Supergroup at the northern end of the ultramafic belt all enclose ultramafic bodies. These variable rock types and ages present a dilemma for interpreting how and when the ultramafic rocks were formed. If only Mesozoic or late Paleozoic ultramafic rocks exist, and if the Proterozoic ages assigned to the Syringa and Belt rocks are correct, then the ultramafic bodies enclosed within Syringa metamorphic rocks (Lewis and others, 1992) and Belt Supergroup metasediments (Hietanen, 1963) cannot be stratabound fragments enclosed within those formations (as in a melange), because the ultramafic rocks are much younger. This view (young ultramafic rocks hosted by much older rocks) requires that the ultramafic bodies were structurally emplaced into the Syringa and Belt host rocks. The ultramafic rocks could be stratabound if the map units labeled as the Syringa metamorphic sequence and as the Belt Supergroup by Lewis and others (1992), Hietanen (1963), and Rember and Bennett (1979a, b) are actually northward extensions of the Mesozoic terrane and the Riggins Group. We prefer the alternative that the ultramafic rocks within the Syringa and Belt map units were structurally emplaced into their host units along major faults. It is possible, however, that there may be two or more ages of ultramafic rocks, another scenario which would permit all the ultramafic bodies to be stratabound. One group would be Mesozoic and enclosed within the Riggins Group. The other would be Proterozoic and stratabound within Syringa and Belt enclosing formations. Although we do not favor this explanation, it is a plausible interpretation and should not be discounted. Since the metamorphism of the ultramafic bodies occurred after they were emplaced, most of them would have become very similar mineralogically simply because they started with similar chemical compositions. The hornblende-garnet blackwall rocks, however, are so unusual that their association with ultramafic bodies enclosed in host rocks of all three groups (Riggins Group, Syringa Sequence, and Belt Supergroup) may lend some support to the idea that all the host rocks are Mesozoic.

(4) When Did the Chemical Alteration Take Place, Relative to the Other Events?

We have made two assumptions regarding the alteration of the ultramafic rocks and associated wall rocks. First, we assume that the rodingitization process which reduced the abundances of silica and alkalis, and increased the abundance 
of $\mathrm{CaO}$ - probably initially as carbonate minerals - in basaltic or gabbroic rocks associated with the ultramafic bodies occurred very early in the geologic history, while the rocks were still part of an oceanic lithosphere. Sea-floor hot-spring activity and subsea-floor circulation of hydrothermal fluids and rock alteration are important processes that accompany the upwelling of basaltic magma and the formation of ultramafic cumulates at midoceanic ridges and in rift environments. We suggest that the metarodingites found in the New Meadows area obtained their chemical characteristics at this early preobduction and premetamorphism time in their geologic history, rather than later, during the regional metamorphism.

Secondly, we assume that silica-depletion, which we contend formed the hornblende-garnet blackwall rocks from protoliths that initially were generally basaltic, occurred after the ultramafic rocks had been emplaced into their present host rocks. We also assume that the excess silica that invaded the ultramafic bodies to form the high-silica altered harzburgites entered the ultramafic rocks during regional metamorphism, rather than before it. Although it seems logical to view these two processes (silica losses from the wall rocks and silica gains in the adjacent ultramafic rocks) as coupled complementary processes, we have not offered any evidence that events happened this way, or that the alteration was driven by the movement of fluids during the regional metamorphism.

We have yet to rule out the possibility that the silicapoor hornblende-garnet rocks actually underwent alteration processes at a very early time in their geologic history, perhaps in a sea-floor environment, and that their origin is similar to the rocks that we have called rodingites. It also is possible that the high-silica altered harzburgites started as rocks composed almost entirely of orthopyroxene (for example, bronzitites), rather than as harzburgites, consisting of both olivine and orthopyroxene. If this were so, then little or no silica would be required to have been added to them in order to give them their present bulk compositions; only $\mathrm{H}_{2} \mathrm{O}$ would be needed to convert the orthopyroxene to anthophyllite and talc. These alternate possibilities suggest that further investigations to resolve the timing of events would be useful.

\section{Concluding Comments}

We believe that all the ultramafic bodies are of the same general Mesozoic age even though they are enclosed within formations of varying age, and that the northern bodies (Tamarack Ridge, Teakean, Olson, Ahsahka, Orofino Creek, Lolo Creek, Glenwood, Placer Creek, Lowell, Swiftwater Creek, and Stillman Point) were moved into these older rocks along major faults. We can ask whether some or all of the ultramafic bodies that are enclosed in the Riggins Group were faulted into their host rocks, or if they are stratabound bodies that were deformed along with their host rocks before or during the time when the Blue Mountains island arc docked against North America. Hamilton (1963) and Onasch (1977,
1987) favor the model that the ultramafic bodies in the Riggins region were faulted into their final resting places within the Riggins Group after the ultramafic rocks had been emplaced within the continental margin, before or during the docking of the Blue Mountains island arc. Later, some of these faults may have been deformed and partially or completely obliterated as deformation and metamorphism continued within the suture zone. We believe this interpretation to be quite reasonable, and to be applicable elsewhere along the suture zone, especially in the case of the northern ultramafic bodies.

The ultramafic bodies in the New Meadows region are associated with rocks that might be considered as part of an oceanic, inner-trench-wall assemblage; thus they might be interpreted as being stratabound within their host rocks. For that reason, major, postdocking faults are not needed to account for their locations. This view is consistent with the generally less altered and less deformed nature of the ultramafic rocks in the New Meadows region, as compared to other parts of the suture zone.

Farther to the southwest, in the Cuddy Mountain-Sturgill Peak region, the highly deformed but only incipiently metamorphosed ultramafic rocks occur along a high-angle reverse fault (Skurla, 1974; Mann, 1989) that marks the boundary between major subterranes within the Blue Mountain island arc. This suggests that these ultramafic rocks were deformed by tectonic processes that are independent of, or at least earlier than, the development of the accreted terrane-continental crust suture zone.

Important questions regarding the origin and evolution of the ultramafic rocks in western Idaho remain unanswered. These are general questions that apply not only to the ultramafic rocks themselves, but also to the evolution of the suture zone and to the nature of the processes involved in juxtaposing the Blue Mountains island arc against the Mesozoic margin of North America, and to the evolution of the Idaho Batholith. In this regard, the western Idaho ultramafic rocks may hold some of the answers as to how the western margin of North America has evolved. We encourage others to conduct further studies on these interesting rocks and to address these and other questions.

\section{Acknowledgments}

Many individuals and organizations have helped us with the research leading to this paper. We would especially like to thank Paul Myers, Mel Kuntz, David Blake, Elaine Aliberti, Cathryn Allen-Manduca, Amy Hoover, James LeAnderson, Howard Brooks, Tracy Vallier, James Zarubica, and others working in the problem areas of western Idaho with whom we have had interesting and stimulating field trips and discussions over the past several years. From the Idaho Geological Survey, we particularly thank Reed Lewis, Earl Bennett, and Charles Knowles for various discussions, and we thank Timothy Funderburg and Loudon Stanford of the Digital Mapping and Information Lab for preparing the illustrations. From the 
University of Massachusetts at Amherst, where we analyzed our rocks, we thank J. Michael Rhodes, Pete Dawson, and Marshall Chapman of the Ronald B. Gilmore X-Ray Fluorescence Laboratory for their consideration and help. From Mount Holyoke College, which provided the financial backing for important technical laboratory assistance, we thank Steven Roof and Jennifer Thompson for their magnificent efforts. Finally, we thank the Idaho Geological Survey for its longterm backing for this work, and the University of Idaho College of Mines' Idaho Mines and Mineral Resources Research Institute for the financial assistance provided in 1988-89, which significantly facilitated our investigations. We thank Richard Berg, Mark Ferns, and Mel Kuntz for helpful and insightful reviews. Lastly we thank Ruth S. Miller for ongoing financial, intellectual, and moral support and helpful critical discussions in all phases of the work.

\section{References Cited}

Aliberti, E.A., 1988, A structural, petrographic, and isotopic study of the Rapid River area and selected mafic complexes in the northwestern United States; implications for the evolution of an abrupt island arc-continental boundary: Cambridge, Massachusetts, Harvard University, Ph.D. dissertation, $194 \mathrm{p}$.

Anderson, A.L., 1930, The geology and mineral resources of the region about Orofino, Idaho: Idaho Bureau of Mines and Geology Pamphlet 34, 63 p.

Anderson, A.L., 1931, Genesis of anthophyllite deposits near Kamiah, Idaho: Journal of Geology, v. 39, no. 1, p. 68-81.

Armstrong, R.L., Taubeneck, W.H., and Hales, P.O., 1977, $\mathrm{Rb}-\mathrm{Sr}$ and $\mathrm{K}-\mathrm{Ar}$ geochronomtry of Mesozoic granitic rocks and their $\mathrm{Sr}$ isotopic composition, Oregon, Washington, and Idaho: Geological Society of America Bulletin, v. 88, p. 397-411.

Bonnichsen, Bill, 1987, Pre-Cenozoic geology of the West Mountain-Council Mountain-New Meadows area, westcentral Idaho, in Vallier, T.L., and Brooks, H.C., eds., Geology of the Blue Mountains region of Oregon, Idaho, and Washington; the Idaho batholith and its border zone: U.S. Geological Survey Professional Paper 1436, p. 151-170.

Bonnichsen, Bill, and Godchaux, M.M., 1994, Geology of the western Idaho ultramafic belt: Idaho Geological Survey Staff Report 94-3, p. 1-75.

Criss, R.E., and Fleck, R.J., 1987, Petrogenesis, geochronology, and hydrothermal systems of the northern Idaho batholith and adjacent areas based on ${ }^{18} \mathrm{O} /{ }^{16} \mathrm{O},{ }^{87} \mathrm{Sr} /{ }^{86} \mathrm{Sr}, \mathrm{K}-\mathrm{Ar}$, and ${ }^{40} \mathrm{Ar} /{ }^{39} \mathrm{Ar}$ studies, in Vallier, T.L., and Brooks, H.C., eds., Geology of the Blue Mountains region of Oregon, Idaho, and Washington; The Idaho batholith and its border zone:
U.S. Geological Survey Professional Paper 1436, p. 95-137.

Fleck, R.J., and Criss, R.E., 1985, Strontium and oxygen isotopic variations in Mesozoic and Tertiary plutons of central Idaho: Contributions to Mineralogy and Petrology, v. 90, p. 291-308.

Hamilton, Warren, 1963, Metamorphism in the Riggins region, western Idaho: U.S. Geological Survey Professional Paper 436, 95 p.

Hamilton, Warren, 1969, Reconnaissance geologic map of the Riggins quadrangle, west-central Idaho: U.S. Geological Survey Miscellaneous Geologic Investigations Map I-579, scale 1:125,000.

Hietanen, Anna, 1963, Anorthosite and associated rocks in the Boehls Butte quadrangle and vicinity, Idaho: U.S. Geological Survey Professional Paper 344-B, 78 p.

Hoover, A.L., 1986, Transect across the Salmon River structure, South Fork of the Clearwater River, western Idaho; rare earth element geochemical, structural, and metamorphic study: Corvallis, Oregon, Oregon State University, Masters thesis, $138 \mathrm{p}$.

Hustedde, G.S., Strowd, W.B., Mitchell, V.E. and Bennett, E.H., 1981, Mines and prospects of the Pullman quadrangle, Idaho: Idaho Bureau of Mines and Geology Mines and Prospects Map Series, 8 p., scale 1:250,000.

Johnson, C.H., 1947, Igneous metamorphism in the Orofino region, Idaho: Journal of Geology, v. 55, no. 6, p. 490-507.

Lewis, R.S., Burmester, R.F., Reynolds, R.W., Bennett, E.H., Myers, P.E., and Reid, R.R., 1992, Geologic map of the Lochsa River area, northern Idaho: Idaho Geologic Survey Geologic Map Series, scale 1:100,000.

Manduca, C.A., Kuntz, M.A., and Silver, L.T., 1993, Emplacement and deformation history of the western margin of the Idaho batholith near McCall, Idaho; influence of a major terrane boundary: Geological Society of America Bulletin, v. 105, p. $749-765$.

Mann, G.M., 1989, Seismicity and Late Cenozoic faulting in the Brownlee Dam area, Idaho-Oregon; a preliminary report: U.S. Geological Survey Open File Report 89-429, 46 p., map scale 1:24,000.

Myers, P.E., 1982, Geology of the Harpster area, Idaho County, Idaho: Idaho Bureau of Mines and Geology Bulletin 25, $46 \mathrm{p}$.

Norrish, K., and Hutton, J.T., 1969, An accurate X-ray spectrographic method for the analysis of a wide range of geological samples: Geochimica et Cosmochimica Acta, v. 33, p. 431-454.

Onasch, C.M., 1977, Structural evolution of the western 
margin of the Idaho batholith in the Riggins, Idaho area: University Park, Pennsylvania, Pennsylvania State University, Ph.D. dissertation, 296 p.

Onasch, C,M., 1987, Temporal and spatial relations between folding, intrusion, metamorphism, and thrust faulting in the Riggins area, west-central Idaho, in Vallier, T.C. and Brooks, H.C., eds., Geology of the Blue Mountains region of Oregon, Idaho, and Washington; the Idaho batholith and its border zone: U.S. Geological Survey Professional Paper 1436, p. 139-149.

Rember, W.C., and Bennett, E.H., 1979a, Geologic map of the Hamilton quadrangle, Idaho: Idaho Bureau of Mines and Geology Geologic Map Series, Hamilton Two-Degree Map, scale 1:250,000.

Rember, W.C., and Bennett, E.H., 1979b, Geologic map of the Pullman quadrangle, Idaho: Idaho Bureau of Mines and Geology Geologic Map Series, Pullman Two-Degree Map, scale 1:250,000.

Sarewitz, D.R., 1982, Geology of a part of the Heavens Gate quadrangle, Seven Devils Mountains, western Idaho: Corvallis, Oregon, Oregon State University, Masters thesis, 144 p.

Skurla, S.J., 1974, Geology of the Sturgill Peak area, Washington County, Idaho: Corvallis, Oregon, Oregon State University, Masters thesis, $98 \mathrm{p}$.

Thayer, T.P., 1973, Chromium, in Brobst, D.A., and Pratt, W.P., eds., United States Mineral Resources: U.S. Geological Survey Professional Paper 820, p. 111-121.

Vallier, T.L., and Brooks, H.C., 1987, The Idaho batholith and its border zone; a regional perspective, in Vallier, T.L., and Brooks, H.C., eds., Geology of the Blue Mountains region of Oregon, Idaho, and Washington; the Idaho batholith and its border zone: U.S. Geological Survey Professional Paper 1436, p. 1-7.

Vallier, T.L., and Engebretson, D.C., 1984, The Blue Mountains island arc of Oregon, Idaho, and Washington; an allocthonous terrane from the ancestral Pacific Ocean?, in Howell, D.G., and others, eds., Proceedings of the CircumPacific Terrane Conference: Stanford University Publications in the Geological Sciences, v. 18, p. 197-199. 


\title{
5. The Idaho Batholith near McCall, Idaho-Field Relations, Petrology, Major-Element Chemistry, Emplacement History, and Magma Genesis
}

\author{
By Mel A. Kuntz
}

\section{Abstract}

Regional mapping along the western margin of the Idaho Batholith near McCall, Idaho, has identified Late Cretaceous tonalite, granodiorite, and monzogranite plutonic units east of the Salmon River suture zone. The leucogranodiorite of Jumbo Creek forms a pinwheel shape pluton about $5 \mathrm{~km}$ diameter that suggests that it was emplaced within a zone of local, transpressive (left lateral) deformation. The tonalite of Payette River and the granodiorite of Box Lake form narrow, north-trending plutons, $3-12 \mathrm{~km}$ wide, that are continuous for distances of more than $50 \mathrm{~km}$ within the study area. Textural variants of the monzogranite of Lick Creek form map units that are approximately equant in plan and lack the pronounced north-south elongation of the tonalite and granodiorite plutons. ${ }^{40} \mathrm{Ar} /{ }^{39} \mathrm{Ar}$ and $\mathrm{U}-\mathrm{Pb}$ ages indicate that the four plutonic units were formed in the same thermal pulse of magmatism, uplift, and cooling. The oldest plutonic unit (leucogranodiorite of Jumbo Creek) formed about $94 \mathrm{Ma}$, followed by the tonalite of Payette River at about $90 \mathrm{Ma}$, and the youngest unit (monzogranite of Lick Creek) formed about $83 \mathrm{Ma}$.

Metasedimentary rocks of continental provenance form screens within the tonalite and granodiorite plutonic units in the study area, but are not found within monzogranite units. The metasedimentary rocks have textures and mineral assemblages that suggest metamorphism in the sillimanite-muscovite and sillimanite-orthoclase zones of the amphibolite facies and hornblende-hornfels and pyroxene-hornfels facies at temperatures of approximately $700^{\circ} \mathrm{C}$ and pressures of about $5.8 \mathrm{kbar}$, which equate to a geothermal gradient of about $35^{\circ} \mathrm{C} / \mathrm{km}$.

The transition from older leucogranodiorite of Jumbo Creek and tonalite of Payette River to the younger monzogranite of Lick Creek represents a transition in the melt source from dominantly I-type, igneous source rocks, perhaps with a mantle component, to continental-crust source rocks that probably had a significant metasedimentary component. The transition also represents a spatial change in source rocks, from subducted tonalite and trondhjemite of the Blue Mountains island-arc terrane on the west that were source rocks for tonalite; to a mixture of arc-volcanic and continental rocks, at the arc-continent boundary in a syncollision environment, that partially melted to produce granodiorite magma, to Proterozoic gneisses and/or metasediments of the North American continent, east of the arc-continent boundary, that partially melted to form anatectic monzogranite.

Models for the formation of magmas are related to subduction and suturing of the Blue Mountains island-arc terrane to the western margin of North America in Late Cretaceous time. Tectonic compression resulting from the plate interaction was the driving mechanism for horizontal shortening, vertical thickening of the crust by A-type subduction, metamorphism, and magmatism. Tonalite magma formed by dehydration melting of tonalitic and amphibolitic source rocks in a crust 45 to $60 \mathrm{~km}$ thick under a high geothermal gradient $\left(35^{\circ} \mathrm{C} / \mathrm{km}\right)$. The partial melting of fertile Proterozoic gneisses containing large volumes of muscovite and biotite was an extremely efficient process, yielding a small volume of leucogranodiorite magma initially (Jumbo Creek pluton) and huge volumes of monzogranite magma later (monzogranite of Lick Creek) that may have formed largely in place.

\section{Introduction}

In west-central Idaho, in what is traditionally known as the "western border zone" of the Idaho Batholith (Hamilton, 1963), the batholith consists of two major parts. The eastern, main part consists chiefly of tonalite, granodiorite, and monzogranite plutons that contain screens and isolated inclusions of metasedimentary rocks of continental origin. The western part consists of quartz diorite, tonalite, and trondhjemite plutons, some of which are separated by screens of metamorphosed plutonic and volcanic rocks that formed in oceanic-arc environments. These two parts are separated by the Salmon River suture zone (Kuntz and Snee, this volume, chapter 1) between preplutonic metasedimentary rocks of continental origin on the east and preplutonic, accreted, island-arc rocks on the west (fig.1).

The Hazard Creek Complex lies west of the suture zone (figs. 1, 2). It consists of variably deformed and metamorphosed quartz diorite and trondhjemite plutons that were emplaced in Jurassic(?) and Cretaceous time. The Little Goose Creek Complex lies along the Salmon River suture zone (figs. 

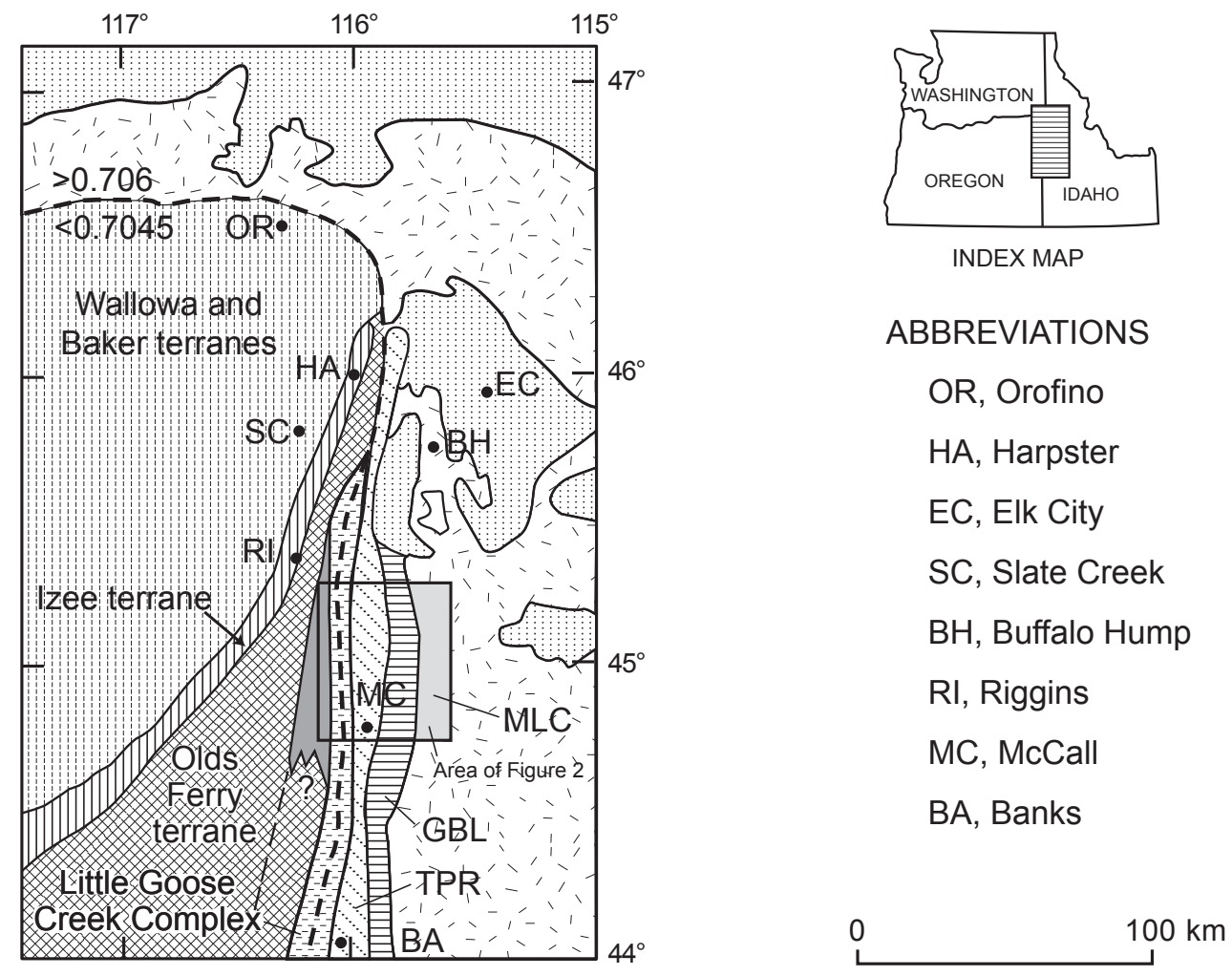

\section{EXPLANATION}

\section{WEST}

Blue Mountains islandarc terrane (Paleozoic and Mesozoic)

Wallowa and Baker terranes

Izee terrane

Olds Ferry terrane

\section{Plutonic rocks of Idaho Batholith}

Little Goose Creek Complex

(Cretaceous) and correlative units

Hazard Creek Complex (Cretaceous and Jurrassic?)

\section{EAST}

Plutonic rocks of Idaho Batholith (Late Cretaceous)

I'- Plutonic units (undivided) of the Idaho Batholith

Monzogranite of Lick Creek (MLC)

Granodiorite of Box Lake (GBL)

Tonalite of Payette River (TPR)

Continental rocks

Metasedimentary rocks (Paleozoic(?), Proterozoic, and pre-Middle Proterozoic gneissic basement rocks)

- - - - ${ }^{87} \mathrm{Sr} /{ }^{86} \mathrm{Sr}$ isotope boundary

Figure 1. Generalized geologic map of eastern Oregon and western Idaho showing region of Blue Mountains island arc and western margin of Idaho Batholith. Box shows area of figure 2. 
1,2). It consists chiefly of porphyritic granodiorite and lesser tonalite that were emplaced in the Cretaceous Period between accreted oceanic-arc terranes and the continental margin. Field, petrologic, geochemical, and structural characteristics of the Hazard Creek and Little Goose Creek Complexes are described by Manduca and others (1993).

Rocks in each of the complexes were affected by deformation during and after their emplacement in response to east-west contraction and transpressive (right lateral) deformation along the Salmon River suture zone (Manduca and others, 1993; McClelland and others, 2000). The last episode of deformation along the suture zone was the formation of protomylonitic fabrics. The mylonitization was most intense along the boundary between the accreted terranes and the continental margin but also affected rocks farther west in the Hazard Creek Complex and for several kilometers east into tonalite of Payette River. The tonalite of Payette River contains a pronounced, steep planar foliation and downdip mineral lineation (Kuntz, this volume, chapter 7). The ductile mylonitic deformation took place under conditions of the upper amphibolite facies, and the penetrative mylonitic fabric was superimposed on the foliation and lineation in the tonalite of Payette River.

Several lines of evidence show the chemical contrast between plutonic rocks of oceanic and continental affinities on either side of the Salmon River suture zone. Plutons west of the suture zone have ${ }^{87 / 86} \mathrm{Sr}_{\mathrm{ri}}$ of $0.7030-0.7045$, and plutons east of the suture zone have ${ }^{87 / 86} \mathrm{Sr}_{\mathrm{ri}}>0.7060$ (Fleck and Criss, this volume, chapter 2; Armstrong and others, 1977; Fleck and Criss, 1985; Criss and Fleck, 1987; Manduca and others, 1992). Measured strontium ratios of the tonalite of Payette River are 0.7082 to 0.71108 (R. J. Fleck, USGS, oral commun., 2002). The $\mathrm{Sr}_{\mathrm{i}}$ 0.7045-0.7060 line coincides with the 1.5-km-thick mylonite in the Salmon River suture zone in the Orofino, Idaho area (Strayer and others, 1989; Fleck and Criss, this volume, chapter 2). In the McCall area, the 0.7045-0.7060 line is roughly coincident with the contact between the Hazard Creek Complex and the Little Goose Creek Complex (figs. 1, 2 ) and with the western margin of the mylonite zone (Fleck and Criss, this volume, chapter 2).

Oxygen isotopes (Criss and Fleck, 1987; Manduca and others, 1992) also show a rather abrupt change along the western margin of the batholith: plutons west of the suture zone have $\delta^{18} \mathrm{O}$ of +5.5 to +10.5 per mil, and plutons east of the suture zone have $\delta^{18} \mathrm{O}$ of +8.0 to +12.4 per mil. Criss and Fleck (1987) noted that the $\mathrm{Rb} / \mathrm{Sr}$ values for plutons west of the suture zone are $<0.08$ and for plutons east of the suture are 0.04-0.25. These chemical characteristics suggest, in a general way, that plutons west of the suture zone crystallized from magmas derived from mantle sources and that plutons east of the suture zone crystallized from magmas derived partly or wholly from continental rocks (Criss and Fleck, 1987; Manduca and others, 1992).

Bouguer gravity anomalies (Bankey, 1992) are less diagnostic of the oceanic-continental rock transition because they reflect dense basaltic rocks of the Columbia River Basalt Group that are present west of the Salmon River suture zone and less dense, granitic rocks of the Idaho Batholith east of the suture zone. Magnetic anomalies (McCafferty, 1992) also are not particularly diagnostic of the oceaniccontinental rock transition because small, high-frequency anomalies to the west reflect basalt flows of the Columbia River Basalt Group that have highly variable thicknesses and contrasting magnetic polarity and because large, low-frequency anomalies to the east reflect broad tracts of plutonic rocks of the Idaho Batholith that have very low magnetic intensities (Criss and Champion, 1984).

The timing of assemblage and accretion of various oceanic terranes to the western edge of the continent and emplacement of the granitic plutons into the oceanic and continental terranes is reasonably well known for west-central Idaho and eastern Oregon (see, for example, Criss and Fleck, 1987; Vallier and Brooks, 1987; Lund and Snee, 1988; Manduca and others, 1993; Vallier, 1995; and papers in this volume). Briefly, accretion of the Blue Mountains island arc took place between 120 and $90 \mathrm{Ma}$, and plutonism west of the suture zone was contemporaneous with accretion ( 120-95 Ma); some of the western plutons are allochthonous, and some were emplaced into accreted rocks. The main phase of plutonism in the Idaho Batholith east of the suture zone occurred during the period 95-70 Ma.

\section{Purpose of This Report}

This report is a result of a regional geologic study of the Idaho Batholith near McCall, Idaho. The study included field mapping and petrological, geochemical, and isotopic studies of the plutonic rocks in the main part of the batholith and in rocks of the western part of the batholith west of the Salmon River suture zone. This paper describes and interprets field, petrologic, and major-element chemical characteristics, and ages for plutonic units that lie east of the Salmon River suture zone near McCall. The field and petrologic data are based on field mapping in fourteen 7.5-minute quadrangles (most of fig.2). Preliminary ${ }^{40} \mathrm{Ar} /{ }^{39} \mathrm{Ar}$ mineral ages are reported for some plutonic units. These ages, plus several U-Pb zircon ages, are used to establish the sequence and approximate times of emplacement of the plutonic units.

\section{Previous Studies}

Parts of the study area were mapped by Larsen and Schmidt (1956), Schmidt (1964), and Hamilton (1963, 1969). Plutonic units west of the suture zone were mapped and described by Manduca and others (1993). Regional perspectives of the Salmon River suture zone have been provided by Lund and Snee (1988), Snee and others (1995), Strayer and others (1989), Selverstone and others (1992), Manduca and others $(1992,1993)$, and papers in this volume. There are many perspectives of the island-arc terrane west of the suture zone, but the most complete summary is that of Vallier (1995, and references therein). Regional perspectives of parts of 


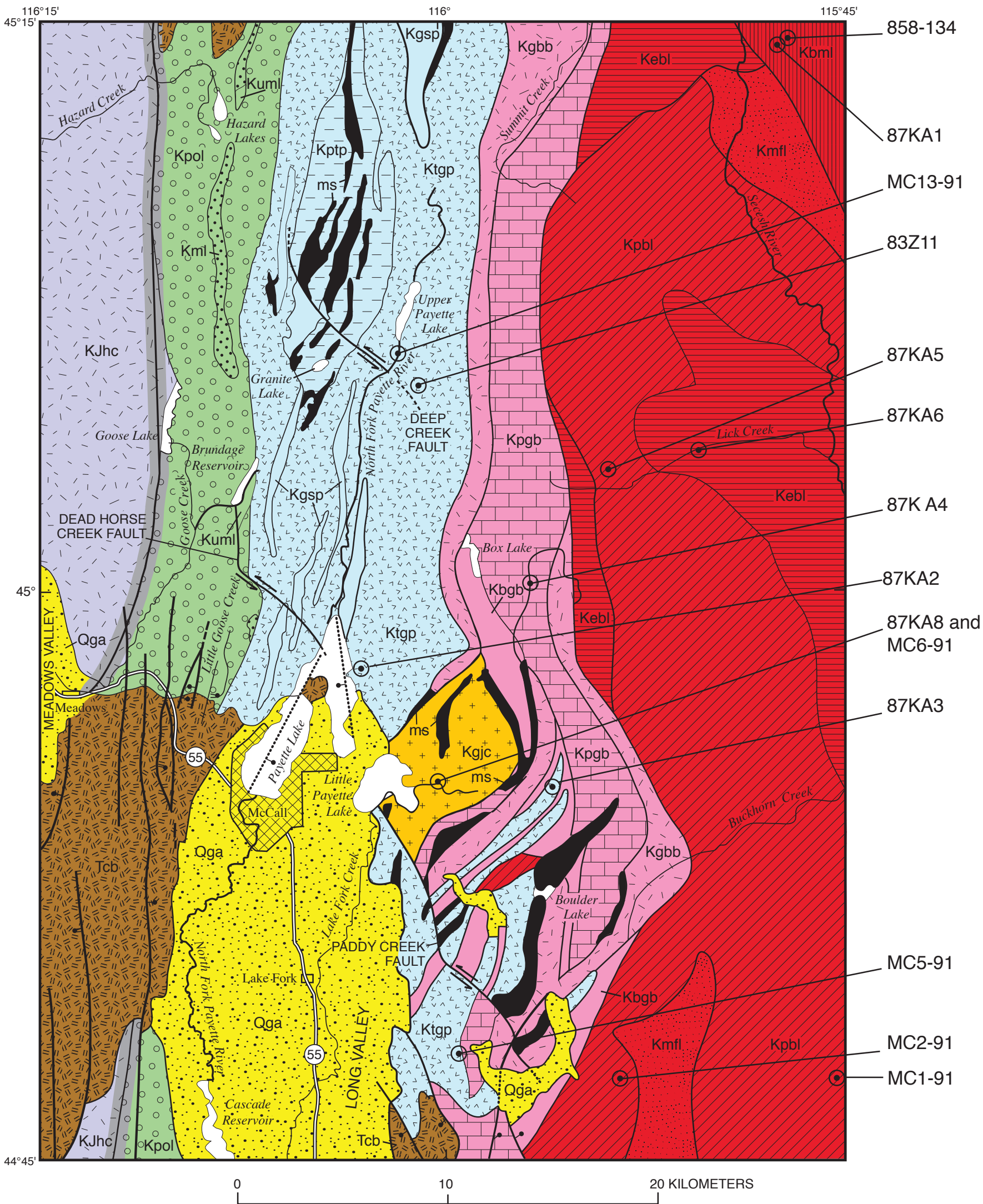

Figure 2. Generalized geologic map of the Idaho Batholith near McCall, Idaho. Sample numbers along margins of map refer to samples listed in table 3. 


\section{EXPLANATION}

Surficial deposits (Quaternary)

$\because$ Qga: Glacial and alluvial deposits

\section{Columbia River Basalt Group (Miocene)}

Basalt flows and interbedded sedimentary deposits

Monzogranite of Lick Creek (Cretaceous)

Porphyritic muscovite-feldspar monzogranite

Equigranular biotite-muscovite monzogranite

Porphyritic biotite monzogranite

Equigranular biotite monzogranite

\section{Granodiorite of Box Lake (Cretaceous)}

Kbgb Porphyritic biotite granodiorite

Porphyritic granodiorite

Ḱǵb̄: Granodiorite of border zone

Leucogranodiorite of Jumbo Creek (Cretaceous)

$+{ }_{+}^{\mathrm{Kgjc}}+{ }_{+}^{+} \quad$ Biotite leucogranodiorite

Tonalite of Payette River (Cretaceous)

Kgsp Granodiorite sills, dikes, and small plutons

- $\overline{\text { K }} \overline{\mathrm{p}} \mathrm{p} \mathrm{p}-$ Porphyritic tonalite

Ktgp Tonalite, granodiorite, and quartz diorite

Little Goose Creek Complex (Cretaceous)

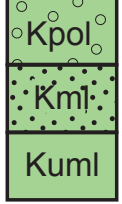

Porphyritic orthogneiss

Mafic rocks, mostly tonalite gneiss

Ultramafic and mafic rocks

Hazard Creek Complex (Jurassic (?) and Cretaceous)

-Kjhç- Chiefly tonalite, trondhjemite, and K-feldspar-bearing plutonic rocks (undivided)

ms

Paleozoic(?) and Proterozoic

Metasedimentary rocks

Contact - Dashed where approximately located

$\rightleftharpoons \quad$ Fault — Dashed where approximately located; dotted where concealed. Bar and ball on downthrown side; arrows show direction of movement

Initial strontium isotope ratio isopleth; the Salmon River suture zone

- Sample site - sample number given in margin

Figure 2.-Continued. 
the Idaho batholith have been provided by Hyndman (1983, 1984), Fleck and Criss (1985), Schuster and Bickford (1985), Lewis and others (1987), Toth (1987), Criss and Fleck (1987), Fleck (1990), Foster and Hyndman (1990), and Foster and others (2001). Mapping presented in this study was generalized as part of a larger area (Lund and others, 1997).

\section{General Field Relations of Plutonic Units}

Mapping of the Idaho Batholith east of the Salmon River suture zone has defined tonalite, leucogranodiorite, granodiorite, and monzogranite plutonic units, from west to east (fig. 2). Tonalite and granodiorite form narrow, north-trending plutons, 3-12 km wide and $50 \mathrm{~km}$ or more long (fig. 2). Whether these map units can be traced for any great distances to the north or south is not known, but a narrow belt of tonalite is known to extend, perhaps continuously, for at least $200 \mathrm{~km}$ north and 100 $\mathrm{km}$ south of the McCall area (Lund and Snee, 1988; Myers, 1982; Strayer and others, 1989; Russell, 1988; Snee and others, this volume, chapter 3 ). Tonalite and granodiorite of the narrow plutons in the McCall area possess a pronounced, nearly vertical foliation that is roughly parallel to contacts and down-dip mineral lineation (Kuntz, this volume, chapter 7).

Tonalite of Payette River (fig. 2) forms a belt $9-11 \mathrm{~km}$ wide immediately east of the Little Goose Creek Complex and 3-5 km east of the Salmon River suture zone. The tonalite is lithologically inhomogeneous; it is made up chiefly of biotitehornblende tonalite but locally includes quartz gabbro, quartz diorite, biotite tonalite, and biotite granodiorite. Metasedimentary rocks, mainly metapelitic schist, calc-silicate hornfels, and metaquartzite, form screens between plutons; the same rock types also form inclusions within tonalite and granodiorite plutons. Only the largest screens are shown in figure 2.

The leucogranodiorite of Jumbo Creek forms a pinwheelshaped pluton, which suggests emplacement during left-lateral shearing along a strike-slip fault(s). The leucogranodiorite of Jumbo Creek is surrounded by a sheath consisting of calcsilicate gneisses, calcareous metaquartzite, and metapelitic schists. Layering in the metasedimentary rocks is steep and parallel to the contacts of Jumbo Creek pluton, suggesting that the pluton was emplaced within and shouldered aside a screen of metasedimentary rocks (see figures 3 and 4 of Kuntz, this volume, chapter 7). The screen was located between the accreted terranes and the western margin of the North American continent at the time of emplacement of the leucogranodiorite of Jumbo Creek.

The lithologically heterogeneous granodiorite of Box Lake forms a narrow band 3-10 km wide east of the tonalite of Payette River. The width and trend of this band are uniform north of Box Lake. The band widens and trends southeast and then southwest between Box Lake and Boulder Lake, where the granodiorite intrudes many screens and inclusions of metasedimentary rocks and tonalite of Payette River.

The monzogranite of Lick Creek forms map units that are more equant in plan and lack the pronounced north-south elon- gation of the tonalite and granodiorite plutons. In addition, the monzogranite typically lacks the nearly vertical foliation and downdip mineral lineation that is characteristic of tonalite and granodiorite plutons. Several textural and lithologic variants of the monzogranite of Lick Creek have been mapped (fig. 2). These variants have broadly gradational boundaries; thus, they are considered to reflect local differences in magma composition or regions of magma that were emplaced or crystallized under slightly variable temperature-pressure conditions.

Screens and inclusions of metasedimentary rocks are rare in monzogranite plutons.

The granodiorite of Box Lake occupies an intermediate geographic position between the tonalite of Payette River and the monzogranite of Lick Creek. The granodiorite is clearly intrusive into the tonalite and grades into monzogranite, suggesting it formed slightly before the monzogranite. These field relations suggest that the emplacement sequence was leucogranodiorite of Jumbo Creek (oldest), tonalite of Payette River, granodiorite of Box Lake, and monzogranite of Lick Creek (youngest). The emplacement sequence based on field relationships is supported by uranium-lead zircon ages and ${ }^{40} \mathrm{Ar} /{ }^{39} \mathrm{Ar}$ ages, as discussed farther on.

\section{Metasedimentary Rocks}

\section{Field Relations, Petrology, and General Correlations}

Metasedimentary rocks occur mainly as screens within the tonalite of Payette River in the area west of Upper Payette Lake, as a sheath surrounding the leucogranodiorite of Jumbo Creek, and as isolated masses in the tonalite of Payette River and the granodiorite of Box Lake near Boulder Lake (fig. 2).

In the tonalite of Payette River near and north of Granite Lake (fig. 2), the metasedimentary rocks are chiefly long, narrow, mostly continuous belts that range from less than a meter wide and a few meters long to masses about $0.5 \mathrm{~km}$ across and as long as several kilometers. Intrusions by irregular bodies of tonalite divide and separate layers, imparting a septate character to the distribution of metasedimentary rocks near Granite Lake. The aggregate thickness of these metasedimentary rocks is approximately $1-1.5 \mathrm{~km}$ at that locality.

The calc-silicate gneiss, calcareous metaquartzite, and metapelitic schist that form the discontinuous sheath around the margins of the bulbous leucogranodiorite pluton of Jumbo Creek are as much as $0.5 \mathrm{~km}$ wide and several kilometers long (fig. 2).

Metaquartzite in screens between plutons of tonalite of Payette River and granodiorite of Box Lake near Boulder Lake typically contains planar relict bedding, and there is little indication of folding of layers. The large screen north and south of Boulder Lake consists of vertical to near-vertical, massive, 
tan to gray metaquartzite and minor metapelitic rocks that are $1-1.5 \mathrm{~km}$ thick.

The general geographic distribution of the metasedimentary rocks is (1) metapelite, minor calc-silicate, and minor amphibolite in the western one-third of the study area; (2) calc-silicate, metaquartzite, and minor metapelitic rocks in the central one-third; and (3) metaquartzite, minor calc-silicate, and minor metapelitic rocks in the eastern one-third of the study area. The metasedimentary rocks were derived from pelitic, fine- to medium-grained sands and silts, calcareoussiliceous sands, and quartz-rich sands. These rocks are now, respectively, pelitic schists and gneisses, calc-silicate hornfelses, and metaquartzites. This suite of rocks is believed to represent sediments deposited in a miogeoclinal prism at the western edge of the North American continent during Middle Proterozoic and Paleozoic (?) time.

Metasedimentary rocks of the McCall area are isolated from the nearest well-studied stratigraphic sections of sedimentary and metasedimentary rocks in west-central Idaho; thus, correlation to other units is tenuous. Lund and others (1997) mapped all metasedimentary rocks in the area of figure 2 as "metasedimentary rocks, undivided" of Middle Proterozoic(?) to Paleozoic(?) age.

\section{Mineral Assemblages and Metamorphic Grade}

The mineral assemblages in McCall metamorphic rocks (table 1 and fig. 3) are equivocal with respect to precise definition of metamorphic facies. The sillimanite-muscovite and sillimanite-orthoclase zones of the amphibolite facies and both hornblende-hornfels and pyroxene-hornfels facies are suggested. Fibrolitic sillimanite is present in metapelitic rocks and calcareous metaquartzites (table 1), but kyanite was not observed, suggesting that the sillimanite-bearing rocks were subjected to temperatures of greater than about $630^{\circ} \mathrm{C}$ (Richardson and others, 1969).

Interestingly, certain mineral phases and mineral assemblages suggest the hornblende-hornfels facies, such as hornblende in basic rocks, and biotite-muscovite (rare)-wollastonite-diopside and wollastonite-diopside-quartz in calc-silicate rocks. However, andalusite, anthophyllite, and muscovite, typical of the hornblende hornfels facies, are rare or absent. Other assemblages, such as fibrolitic sillimanite and Ksparcordierite-quartz in metapelitic rocks, diopside-wollastonitecalcite-grossular-scapolite $\left(\mathrm{Me}_{50-60}\right)$ in calc-silicate rocks, and poikiloblastic hypersthene and hypersthene+cordierite in basic rocks suggest the pyroxene hornfels facies (fig. 4; Hyndman, 1985; Winkler, 1979, Turner, 1968).

Regardless of precise definition of metamorphic facies, the mineral assemblages listed in table 1 suggest that the metamorphic rocks in the McCall area were subjected to approximately 3-6 kbar and temperatures of $600-775^{\circ} \mathrm{C}$., based on current petrogenetic grids (see, for example, summaries in Hyndman, 1985; Winkler, 1979). For comparison, Weston and others (1993) suggest that pelitic migmatites (metapelites) in the tonalite of Payette River were subjected to temperatures of about $700^{\circ} \mathrm{C}$ and pressures of $5.8 \mathrm{kbar}(\sim 19 \mathrm{~km}$ depth) before or at the time of emplacement of the tonalite of Payette River, which equates to conditions in the amphibolite facies and a geothermal gradient of about $35^{\circ} \mathrm{C} / \mathrm{km}$.

\section{Field Relations, Petrology, and Petrog- raphy of Plutonic Units}

\section{Leucogranodiorite of Jumbo Creek}

Leucogranodiorite forms a $40-\mathrm{km}^{2}$, pinwheel shaped pluton about $8 \mathrm{~km}$ east of McCall (fig. 2). The pluton is informally named for exposures along the north side of Lake Fork Creek near Jumbo Creek. The leucogranodiorite contains plagioclase, quartz, and potassium feldspar; biotite is the main mafic mineral. The rock is tan, coarse-grained (most crystals 4-8 mm), typically allotriomorphic-hypidiomorphic granular. Distinctive clots of shredded biotite define a steep foliation that is pronounced near the margins of the pluton but less distinct toward its center.

Large compositional variation in leucogranodiorite of Jumbo Creek is caused by significant variation in the modal amount of potassium feldspar (table 2, fig. 4A). Rocks plot mainly in the granodiorite and monzogranite fields; the average composition is granodiorite. The average color index $(\mathrm{CI}=4.4)$ is lower than all other plutonic units in the McCall area.

Quartz crystals in leucogranodiorite of Jumbo Creek are typically anhedral, rounded, 4-8 $\mathrm{mm}$ in maximum dimension, and weakly strained. Subgrains in quartz have straight boundaries and differ from one another by $\leq 8^{\circ}$ in extinction position. Plagioclase crystals are anhedralsubhedral, 3-8 mm long, and possess weak to moderate, normal, discontinuous zones. The maximum compositional range of zones is about 10 mol-percent An. Plagioclase is characterized by complex twins, some of which appear to be due to abundant clots of plagioclase crystals that are epitaxially joined to one another. Poikilitic, rounded inclusions of quartz and potassium feldspar $<0.05 \mathrm{~mm}$ diameter are common in plagioclase. Minor alteration of plagioclase to muscovite and clay minerals has occurred mainly in crystal cores. Potassium feldspar crystals are anhedral-subhedral and 4-7 mm long. Most contain simple twins, but others contain both tartan and simple twins, suggesting initial crystallization as orthoclase and later partial inversion to microcline. Most potassium feldspar crystals contain rounded, poikilitic inclusions of quartz, plagioclase, and biotite near margins, and some have been weakly altered to muscovite. A few crystals have small patches of string perthite.

Dark brown to dark reddish-brown, anhedral to subhedral flakes of biotite, $0.5-1.5 \mathrm{~mm}$ wide, are typically arranged in 
Table 1. Mineral assemblages in metasedimentary rocks of pendants and screens and in mafic inclusions of plutonic units of the Idaho Batholith near McCall, Idaho.

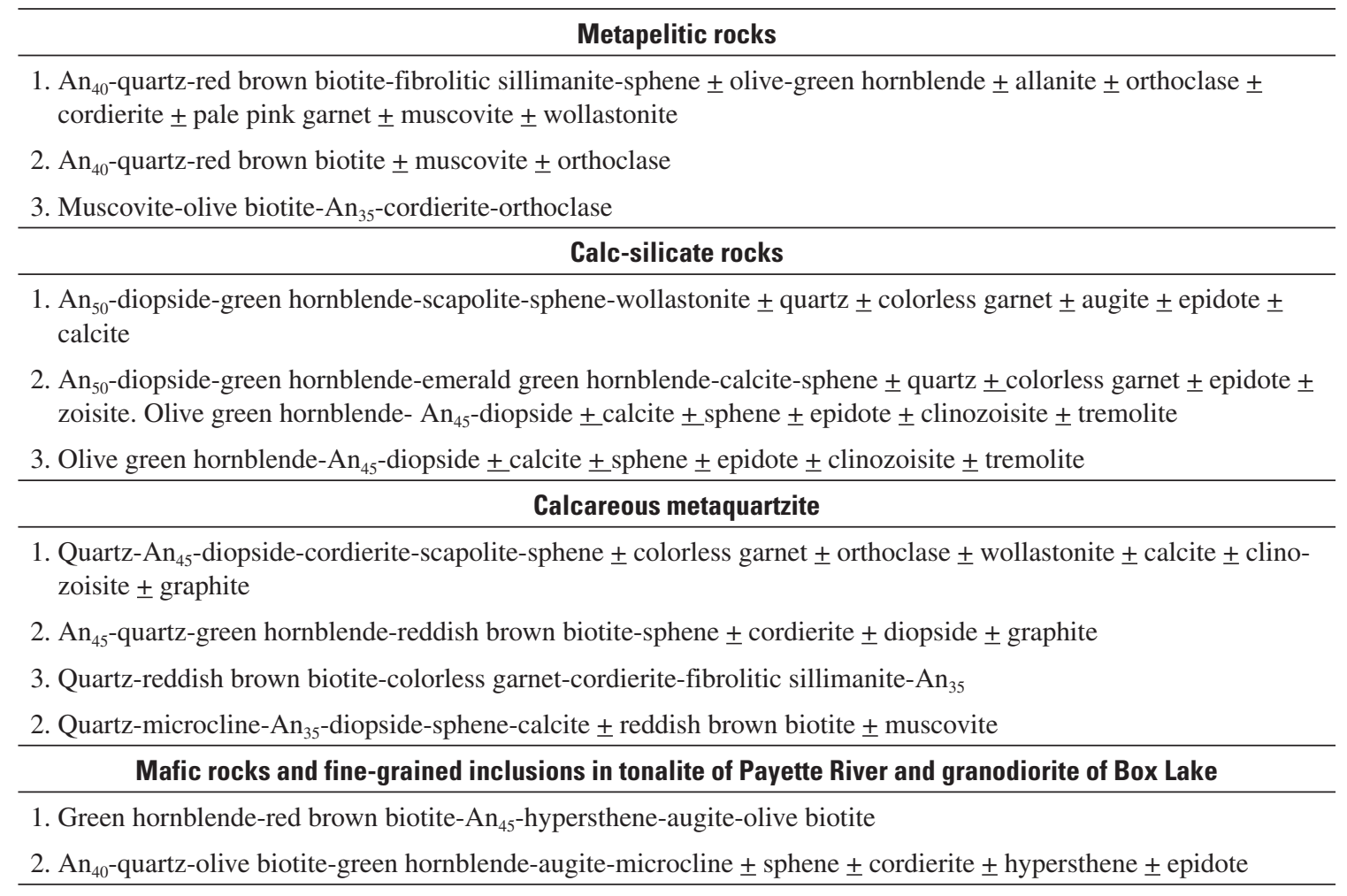

clots of 3 to 10 crystals. Biotite in the clots has altered to limegreen chlorite and, rarely, muscovite. Small crystals $(<1 \mathrm{~mm})$ of olive-green to emerald-green hornblende, typically altered to biotite and chlorite, are rare. Dark brown to deep red allanite crystals $<1 \mathrm{~mm}$ long, some of which are strongly zoned, and granules of titanite and epidote $<0.2 \mathrm{~mm}$ across are found in some samples. Pale pink, sieve crystals of garnet $<1 \mathrm{~mm}$ in diameter contain rounded inclusions of quartz, biotite, feldspar, and clinozoisite and occur near the margins of the pluton. The distribution of garnets suggests that they represent either xenocrysts that remained after partial digestion of inclusions of metasedimentary rocks or direct crystallization from magma enriched in aluminum by partial melting of metasedimentary rocks.

Opaque minerals are very rare; equant crystals $\leq 0.4 \mathrm{~mm}$ in diameter are associated with biotite flakes in some samples, but other samples contain no opaque minerals. In most samples, the only opaque minerals are those that formed by alteration of biotite.

\section{Tonalite of Payette River}

Tonalitic rocks form a band 9-11 km wide along the western edge of the study area, immediately east of the Salmon River suture zone. Good exposures of the tonalite are in road cuts along the highway north of McCall that parallels the
North Fork of the Payette River. This plutonic unit is given the informal name based on that locality.

Modal compositions of samples from the tonalite of Payette River are variable; the unit consists of biotite tonalite, hornblende-rich tonalite, biotite granodiorite, quartz diorite, and quartz gabbro in approximate decreasing order of abundance (table 2, fig. 4). Outcrops of these variants are small $\left(<0.5 \mathrm{~km}^{2}\right)$, and contacts between them are typically gradational; thus these variants were not mapped separately and are not considered separate plutons. The term "tonalite of Payette River" as used in this paper includes all of these rock types.

Tonalite is typically dark gray and coarse-grained (crystal size 2-8 $\mathrm{mm}$ ). The rock consists of about 50 percent plagioclase, and the remainder is roughly equal parts of quartz, biotite, and hornblende (table 2, fig.4). Biotite exceeds hornblende in most tonalite. The color index range is 11-40 and averages about 25 . The tonalite is spotted where biotite and hornblende occur as larger compound crystals. One variant of tonalite mapped separately is porphyritic tonalite: it contains large phenocrysts of potassium feldspar (table 2; map unit Kptp in fig. 2). This variant occupies several square kilometers surrounding large screens of metasedimentary rocks in the northern part of the map area (fig. 2). This spatial arrangement suggests that the porphyritic rocks may be a result of contamination by metasedimentary rocks of the screens.

Granodiorite in tonalite of Payette River appears much like the tonalite in hand specimen; it is coarse grained, has 


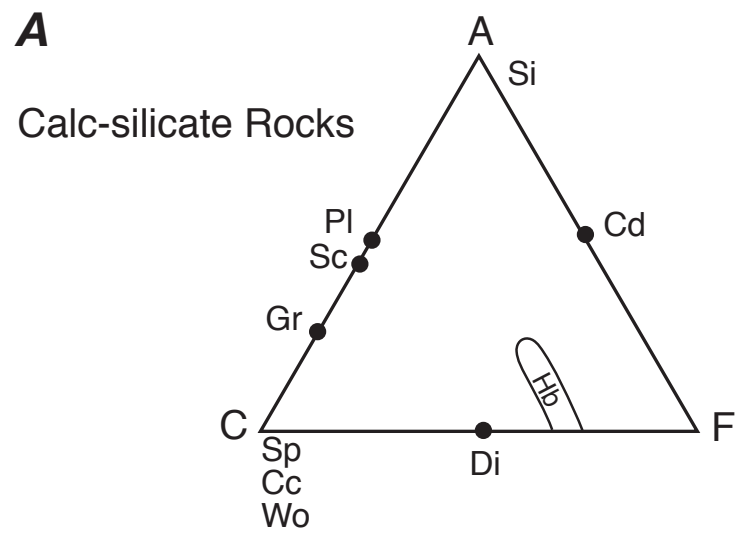

D
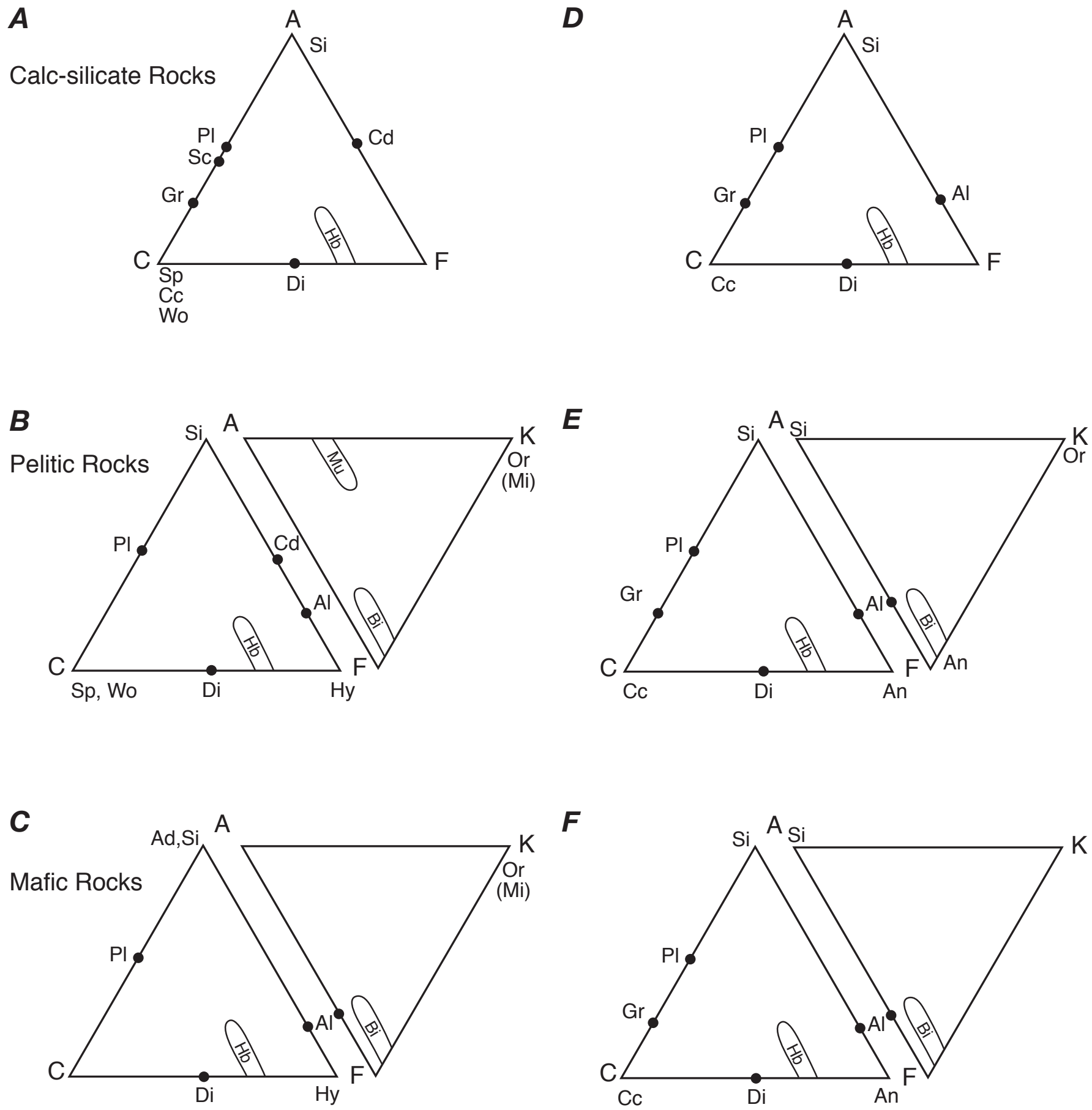

Figure 3. ACF and AKF diagrams showing mineral assemblages in metasedimentary screens and inclusions in plutonic rocks of the McCall area. Diagrams are shown for calc-silicate, metapelitic, and mafic rocks for the pyroxene-hornfels facies $(A, B$, and $C)$ and the sillimanite-orthoclase zone of the amphibolite facies (D, E and F). Figure compiled from data in Hyndman (1985), Turner (1968), and Winkler (1979). Abbreviations: Si, sillimanite; Cd, cordierite; PI, plagioclase; Sc, scapolite; Gr, grossular; Sp, titanite, Cc, calcite; Wo, wollastonite; $\mathrm{Di}$, diopside; $\mathrm{Hb}$, hornblende; Al, almandine; Bi, biotite; Or, orthoclase; Mi, microcline; Hy, hypersthene; Ad, andalusite; Hy, hypersthene; Mu, muscovite: An, anorthite. 


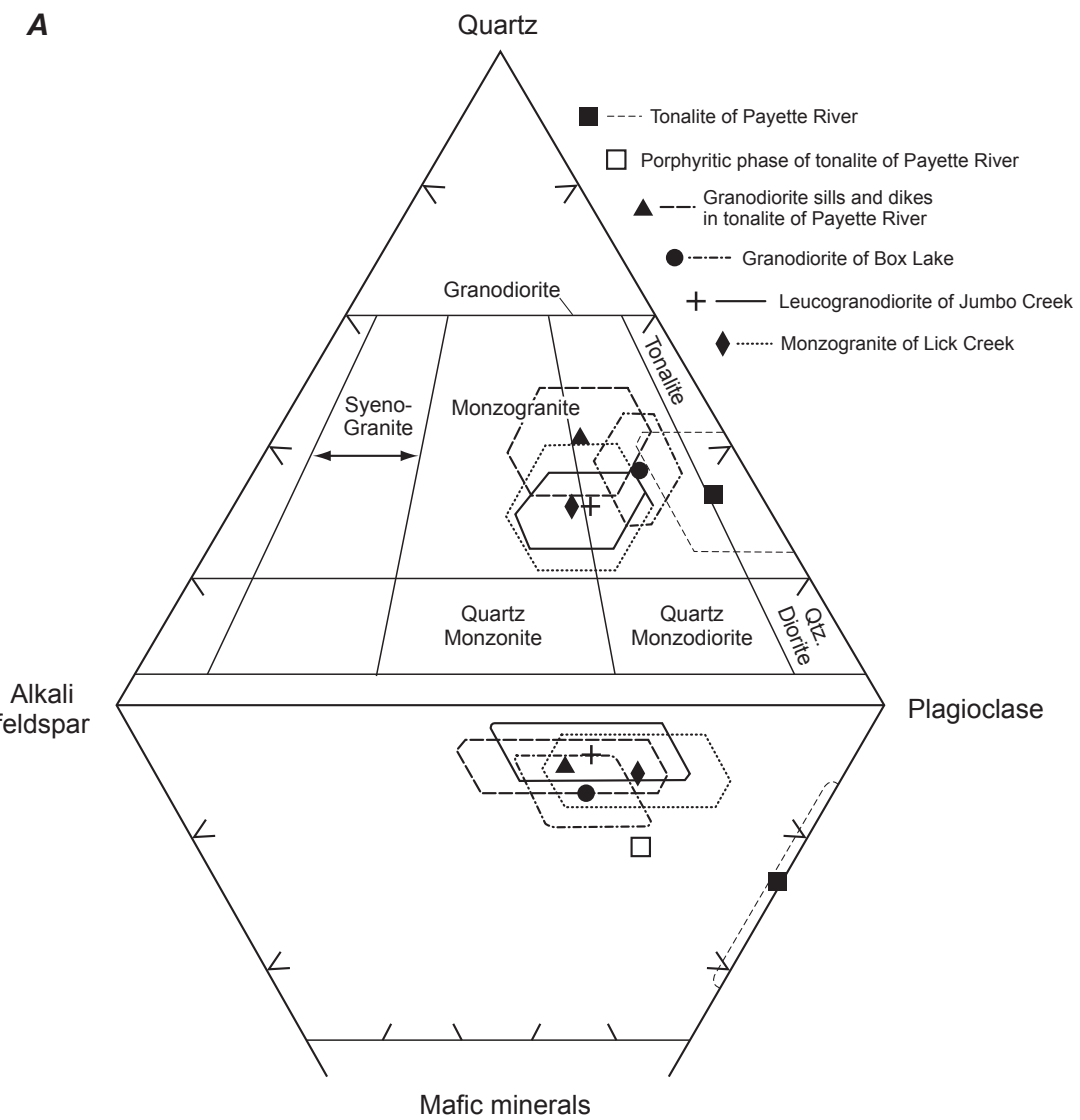

(pyroxene, hornblende, biotite, opaque minerals)

\section{B}

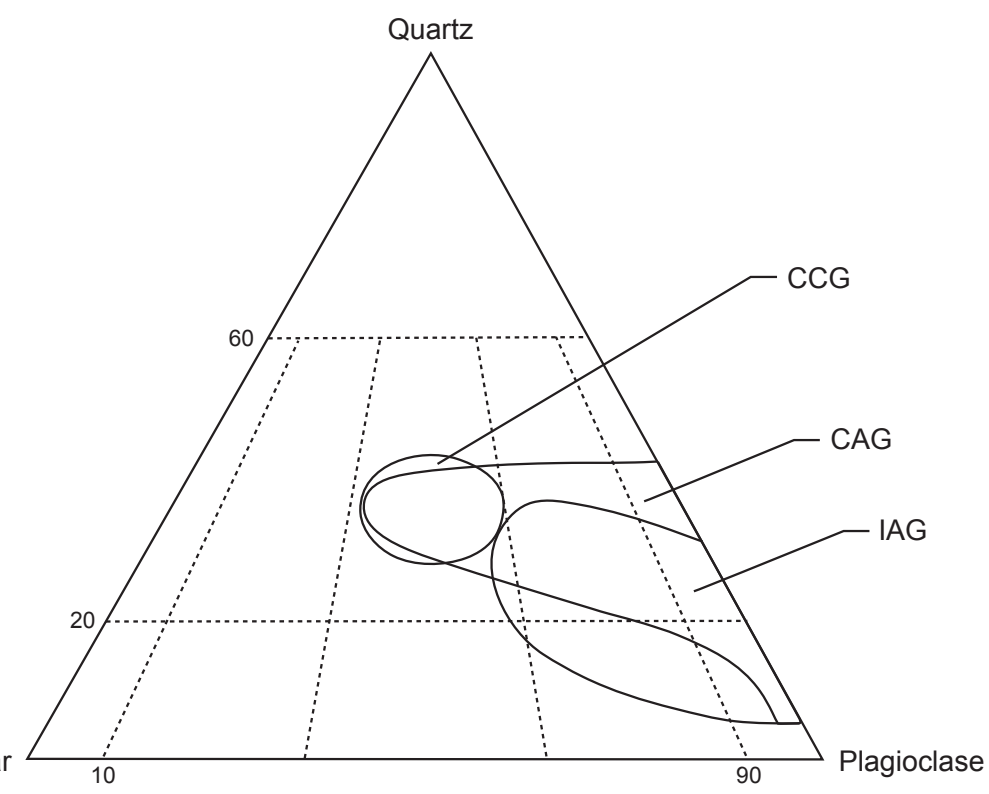

Figure 4. Triangular mineral-composition diagrams for plutonic rocks. $A$, Quartz-alkali feldspar-plagioclase-mafic minerals diagram of modal analyses of plutonic rocks of the Idaho Batholith near McCall, Idaho. Polygons show mean and one standard deviation of the modal amounts of the three minerals at the apices of each triangle. $B$, Tectonic discrimination diagram for granitoid rocks after Maniar and Piccoli (1989). Abbreviations: IAG, islandarc granitoids; CAG, continental-arc granitoids; CCG, continental-collision granitoids. 
a slightly lower color index, and has significant amounts of interstitial potassium feldspar (table 2). Granodiorite exhibits gradational contacts and resembles the tonalite in mineralogy, fabric, and structure. These relations suggest that the granodiorite is a synplutonic, textural-mineralogical variant of tonalite of Payette River.

Plagioclase crystals are mostly subhedral, equant, and 2-5 $\mathrm{mm}$ in longest dimension, but euhedral, tabular crystals are also common. Typical rocks have weak normal and oscillatory zoned plagioclase. The total compositional range of plagioclase determined by optical methods is $\mathrm{An}_{26}-\mathrm{An}_{55}$; most crystals are $\mathrm{An}_{34^{-}}$ $\mathrm{An}_{40}$. A few rocks contain clots of epitaxial plagioclase crystals. Some plagioclase crystals in nearly all thin sections display poikilitic borders that contain inclusions of hornblende, biotite, apatite, epidote, and, rarely, potassium feldspar. Irregular crystals of potassium feldspar, typically $\leq 0.5 \mathrm{~mm}$ diameter, occupy interstices between plagioclase, quartz, and mafic minerals in some samples of tonalite. Potassium feldspar is microcline, but it lacks gridiron twinning and is not perthitic.

Stubby, anhedral to subhedral, deep olive-brown to reddish-olive-brown crystals of biotite, typically 1-3 mm in longest dimension, are ubiquitous in tonalite. The biotite commonly occurs in clots of several crystals together with hornblende, titanite, allanite, epidote, and apatite. Green hornblende crystals are anhedral to subhedral, 2-4 mm long, and typically contain poikilitic inclusions of quartz, biotite, and plagioclase. Hornblende is typically interlayered with biotite and associated with titanite and epidote. Augite and enstatite are rare in tonalite but fairly common in quartz diorite and quartz gabbro. Where present, both pyroxenes are partly altered to green hornblende and hematite.

Quartz is roughly equant, 2-4 mm, anhedral, and has sutured or embayed contacts with other minerals. Most quartz is interstitial to other minerals, but it occurs rarely as larger, rounded crystals as long $8 \mathrm{~mm}$. In most thin sections, quartz is strained and consists of as many as 10 to 20 subgrains, each of which has straight boundaries and differs in extinction from neighbor subgrains by 1-3 degrees of extinction position.

Subhedral to euhedral, $0.2-1.5-\mathrm{mm}$ allanite is a common accessory mineral. Many allanite crystals are zoned; cores are deep tan, brown, and orange-brown in thin section. Rims of allanite crystals have paler colors. Pale yellow to pale yellowish-green epidote crystals and granules, typically $\leq 0.3 \mathrm{~mm}$ long, adhere to the surfaces of many allanite crystals. Epidote also occurs as discrete crystals. These factors suggest that the epidote is magmatic, as suggested by Zen (1988). Titanite ranges from nearly absent to about 1 modal percent in tonalite. It occurs mostly as granules $\leq 0.5 \mathrm{~mm}$ but also as euhedral, wedge-shaped crystals as long as $5 \mathrm{~mm}$. Some titanite is skeletal. Allanite, epidote, and titanite are typically associated with biotite and/ or hornblende. Opaque minerals are sparse in tonalite of Payette River. Equant crystals of magnetite $<1 \mathrm{~mm}$ across are scattered throughout the rock and also attached to biotite, hornblende, and accessory minerals.
Biotite and hornblende, and to a lesser extent plagioclase laths, are preferentially oriented in nearly vertical planes, producing a characteristic foliation in most variants of tonalite of Payette River. Most exposures also display a pronounced lineation formed by alignment of magmatic minerals including prismatic hornblende, feldspar laths, and trains of biotite flakes and quartz crystals (Kuntz, this volume, chapter 7). Evidence for early protoclastic or later mylonitic deformation occurs near the western border of the tonalite (Manduca and others, 1993; McClelland and others, 2000).

The texture of tonalite is typically hypidiomorphicgranular, and most crystals are 2-6 mm long. Allotriomorphic and seriate textures are present locally. A texture in which anhedral crystals of quartz, plagioclase, and biotite occupy the interstices between larger, euhedral to subhedral crystals of plagioclase is common. Inequigranular rocks containing crystals of plagioclase, quartz, and hornblende as long as 10 $\mathrm{mm}$ and set in a matrix of the same minerals that are typically $\leq 5 \mathrm{~mm}$ also occur locally.

Fine-grained mafic enclaves that consist mainly of plagioclase, quartz, hornblende, and biotite are common in tonalite of Payette River. The inclusions range from microscopic to blocks and lenses a few tens of meters in longest dimension; most are disc shaped. The inclusions are elongated parallel to the rock fabric of the enclosing tonalite. The minerals are typically $0.5-2 \mathrm{~mm}$ in longest dimension, and the inclusions have a typical granular texture. Some inclusions are layered because of segregation of light and dark minerals; layers are typically $\leq 5$ $\mathrm{mm}$ thick. The inclusions are considered to be cognate because they contain the same minerals and the minerals appear to have the same compositions as those in the enclosing tonalitic rocks. Sample 83K5 (table 2) is such an inclusion; note that its mineralogical and chemical compositions are similar to those of other samples of tonalite of Payette River. Foliation and lineation in tonalite are continuous through and not deflected by the mafic inclusions, suggesting that the inclusions had viscosities identical or similar to that of the enclosing tonalite at the time of fabric development (John and Blundy, 1993). These features reinforce the conclusion that the inclusions are cognate.

The tonalite of Payette River is bounded on the west by rocks of the Little Goose Creek Complex described by Manduca and others (1993). The contact between these two units is an abrupt structural, rather than intrusive, contact. Where the contact is well exposed, particularly about 1 mi east of Brundage Reservoir, rocks of the Little Goose Creek Complex and tonalite of Payette River are tectonically interleaved over a distance of about $50 \mathrm{~m}$. Nearly all rocks of the Little Goose Creek Complex and the interleaved tonalite are intensely mylonitized where they lie within the contact zone. This deformation also extends for several hundred meters to $1 \mathrm{~km}$ eastward into the tonalite, suggesting a fault contact. In contrast, the eastern contact of the tonalite of Payette River with the granodiorite of Box Lake is gradational over a distance of several tens of meters to as much as $0.5 \mathrm{~km}$. 
Table 2. Major-element analyses, mesonorms, and modal analyses of selected plutonic rocks of the Idaho Batholith near McCall, Idaho.

[Analysts: A.J. Bartel, E.L. Brandt, J.H. Christie, L.L. Jackson, C.S.E. Papp, D.F. Siems, K.C. Stewart, and J.E. Taggart; -- not detected, tr., trace, that is, less than 1\% modal volume]

\begin{tabular}{|c|c|c|c|c|c|c|c|c|c|c|c|c|c|c|c|c|c|c|}
\hline & \multicolumn{4}{|c|}{ Tonalite of Payette River } & \multirow{2}{*}{$\begin{array}{c}\begin{array}{c}\text { Tonalite inclusion in } \\
\text { tonalite of Payette } \\
\text { River }\end{array} \\
83 \mathrm{~K} 5 \\
\end{array}$} & \multirow{2}{*}{$\begin{array}{c}\begin{array}{c}\text { Porphyritic phase of } \\
\text { tonalite } \\
\text { of Payette River }\end{array} \\
85 C 16 \\
\end{array}$} & \multicolumn{3}{|c|}{$\begin{array}{l}\text { Granodiorite sills and } \\
\text { dikes in tonalite of } \\
\text { Payette River }\end{array}$} & \multicolumn{4}{|c|}{ Granodiorite of Box Lake } & \multirow{2}{*}{$\begin{array}{c}\begin{array}{c}\text { Leucogranodiorite } \\
\text { pluton of } \\
\text { Jumbo Creek }\end{array} \\
84 K 20 \\
\end{array}$} & \multicolumn{4}{|c|}{ Monzogranite of Lick Creek } \\
\hline & $81 \mathrm{~K} 51$ & $83 Z 11$ & $86 K 53$ & $86 \mathrm{~K} 68$ & & & $85 C 1$ & $81 K 15$ & $81 K 58$ & $86 \mathrm{~K} 6$ & $87 K 26$ & $87 K 27$ & $86 K 18$ & & $83 C 74$ & 86К3 & $87 / K 23$ & 87K18 \\
\hline $\mathrm{SiO}_{2}$ & 52.80 & 59.60 & 65.50 & 63.00 & 57.20 & 69.50 & 72.40 & 73.60 & 76.70 & 67.40 & 73.30 & 73.30 & 69.80 & 71.90 & 73.70 & 74.90 & 75.20 & 73.90 \\
\hline $\mathrm{TiO}_{2}$ & 1.26 & 0.91 & 0.56 & 0.83 & 1.00 & 0.40 & 0.36 & 0.17 & 0.03 & 0.53 & 0.22 & 0.23 & 0.44 & 0.43 & 0.13 & 0.07 & 0.05 & 0.06 \\
\hline $\mathrm{Al}_{2} \mathrm{O}_{3}$ & 19.20 & 17.50 & 16.70 & 16.50 & 17.70 & 15.00 & 14.20 & 14.20 & 13.40 & 16.90 & 14.80 & 14.50 & 15.10 & 14.20 & 14.60 & 14.30 & 14.10 & 15.20 \\
\hline $\mathrm{Fe}_{2} \mathrm{O}_{3}$ & 1.13 & 1.90 & 0.62 & 1.16 & 1.61 & 0.41 & 8.66 & 0.24 & 0.06 & 2.13 & 0.18 & 0.24 & 0.74 & 0.86 & 0.40 & 0.28 & 0.25 & 0.06 \\
\hline $\mathrm{FeO}$ & 5.86 & 3.87 & 2.97 & 4.07 & 5.43 & 2.68 & 1.50 & 0.66 & 0.26 & 0.84 & 1.12 & 1.38 & 2.15 & 2.75 & 0.91 & 0.44 & 0.47 & 0.52 \\
\hline MnO & 0.12 & 0.09 & 0.07 & 0.08 & 0.12 & 0.05 & 0.04 & 0.02 & 0.02 & 0.04 & 0.03 & 0.02 & 0.06 & 0.08 & 0.03 & 0.02 & 0.02 & 0.02 \\
\hline $\mathrm{MgO}$ & 4.81 & 3.18 & 1.77 & 2.75 & 3.29 & 0.95 & 0.62 & 0.39 & 0.12 & 1.08 & 0.41 & 0.56 & 0.95 & 0.80 & 0.40 & 0.19 & 0.18 & 0.21 \\
\hline $\mathrm{CaO}$ & 8.65 & 6.76 & 5.22 & 5.07 & 7.69 & 3.26 & 2.27 & 1.87 & 1.09 & 4.62 & 2.15 & 2.50 & 3.16 & 1.97 & 1.64 & 1.55 & 1.51 & 2.34 \\
\hline $\mathrm{Na}_{2} \mathrm{O}$ & 3.84 & 3.08 & 3.57 & 2.99 & 3.13 & 2.98 & 3.37 & 2.51 & 3.24 & 3.72 & 3.71 & 3.51 & 3.34 & 3.75 & 3.64 & 3.54 & 3.43 & 4.18 \\
\hline $\mathrm{K}_{2} \mathrm{O}$ & 0.81 & 1.90 & 1.54 & 2.13 & 1.57 & 3.85 & 3.27 & 5.16 & 4.86 & 1.70 & 3.15 & 2.91 & 3.44 & 2.39 & 3.63 & 3.76 & 3.83 & 2.41 \\
\hline $\mathrm{H}_{2} \mathrm{O}+$ & 0.85 & 0.73 & 0.55 & 0.66 & 0.83 & 0.50 & 0.39 & 0.65 & 0.11 & 0.57 & 0.45 & 0.38 & 0.39 & 0.30 & 0.56 & 0.60 & 0.58 & 0.38 \\
\hline $\mathbf{P}_{2} \mathbf{O}_{5}$ & 0.34 & 0.29 & 0.22 & 0.19 & 0.26 & 0.13 & 0.11 & 0.05 & 0.05 & 0.22 & 0.06 & 0.05 & 0.15 & 0.06 & 0.05 & 0.05 & 0.05 & 0.05 \\
\hline $\mathrm{CO}_{2}$ & $\underline{0.20}$ & $\underline{0.05}$ & - & $=$ & $\leq 0.01$ & $\leq 0.01$ & $\leq 0.01$ & $\leq 0.01$ & $\leq 0.01$ & $\leq 0.01$ & $\underline{0.01}$ & $\leq 0.09$ & $\leq 0.0$ & $\leq 0.0$ & $\leq 0.01$ & $\leq 0.01$ & $\leq 0.01$ & $\leq 0.01$ \\
\hline Total & 99.87 & 99.86 & 99.29 & 99.43 & 99.83 & 99.71 & 99.19 & 99.52 & 99.94 & 99.75 & 99.58 & 99.67 & 99.72 & 99.49 & 99.69 & 99.70 & 99.67 & 99.33 \\
\hline \multicolumn{19}{|c|}{ Mesonorms } \\
\hline q & 3.2 & 19.0 & 28.0 & 27.0 & 12.8 & 30.8 & 35.9 & 35.5 & 37.0 & 30.0 & 35.3 & 36.9 & 30.8 & 36.9 & 35.3 & 36.7 & 37.6 & 35.6 \\
\hline c & 1.4 & 0.0 & 0.3 & 0.5 & 0.0 & 0.3 & 1.2 & 1.2 & 0.9 & 1.0 & 1.5 & 1.3 & 0.5 & 2.0 & 1.8 & 1.7 & 1.7 & 1.6 \\
\hline or & 0.0 & 3.4 & 0.0 & 1.1 & 4.1 & 15.9 & 14.7 & 29.0 & 28.2 & 31.6 & 31.6 & 29.9 & 28.1 & 31.8 & 31.0 & 30.1 & 29.2 & 35.6 \\
\hline ab & 31.8 & 26.3 & 30.2 & 25.3 & 26.5 & 25.3 & 28.8 & 21.4 & 27.4 & 31.6 & 31.6 & 29.9 & 28.1 & 31.8 & 31.0 & 30.1 & 29.2 & 35.6 \\
\hline an & 17.9 & 25.5 & 23.8 & 23.9 & 22.7 & 15.3 & 10.6 & 8.9 & 5.1 & 21.6 & 10.4 & 11.6 & 14.7 & 9.4 & 7.8 & 7.4 & 7.2 & 11.4 \\
\hline bi & 11.2 & 12.4 & 6.4 & 18.6 & 8.1 & 11.7 & 8.1 & 2.8 & 1.0 & 6.2 & 4.1 & 5.1 & 8.0 & 12.5 & 3.3 & 1.5 & 1.5 & 2.0 \\
\hline hb & 30.4 & 8.9 & 0.6 & 0.0 & 21.8 & 0.0 & 0.0 & 0.0 & 0.0 & 0.0 & 0.0 & 0.0 & 0.0 & 0.1 & 0.0 & 0.0 & 0.0 & 0.0 \\
\hline ap & 0.8 & 0.7 & 0.5 & 0.4 & 0.6 & 0.3 & 0.3 & 0.1 & 0.1 & 0.5 & 0.1 & 0.1 & 0.4 & & 0.1 & 0.1 & 0.1 & 0.1 \\
\hline $\mathrm{mt}$ & 1.6 & 2.8 & 0.0 & 1.7 & 2.3 & 0.0 & 0.0 & 0.3 & 0.1 & 0.0 & 0.3 & 0.3 & 1.1 & 0.0 & 0.6 & 0.4 & 0.4 & 0.1 \\
\hline hm & 0.0 & 0.0 & 0.0 & 0.0 & 0.0 & 0.0 & 0.0 & 0.0 & 0.0 & 2.1 & 0.0 & 0.0 & 0.0 & 0.0 & 0.0 & 0.0 & 0.0 & 0.0 \\
\hline il & 1.2 & 0.9 & 0.5 & 0.8 & 0.9 & 0.4 & 0.3 & 0.2 & 0.0 & 0.5 & 0.2 & 0.2 & 0.4 & 0.4 & 0.1 & 0.1 & 0.0 & 0.1 \\
\hline cc & 0.5 & 0.1 & 0.0 & 0.0 & 0.0 & 0.0 & 0.0 & 0.0 & 0.0 & 0.0 & 0.0 & 0.2 & 0.0 & 0.0 & 0.0 & 0.0 & 0.0 & 0.0 \\
\hline $\mathbf{r}$ & 0.1 & 0.0 & 0.3 & -0.1 & 0.1 & 0.0 & 0.1 & 0.5 & 0.2 & 0.3 & 0.3 & 0.2 & 0.1 & 0.0 & 0.4 & 0.5 & 0.5 & 0.3 \\
\hline \multicolumn{19}{|l|}{ Normative } \\
\hline $\mathrm{An} / \mathrm{Ab}+\mathbf{A n}(\%)$ & 36 & 49 & 44 & 49 & 46 & 38 & 27 & 29 & 16 & 14 & 25 & 28 & 34 & 23 & 20 & 20 & 20 & 24 \\
\hline \multicolumn{19}{|c|}{ Modal Analyses } \\
\hline Quartz & 14.1 & 13.5 & 30.8 & 21.5 & 25.5 & 31.3 & 29.1 & 37.8 & 41.3 & 31.5 & 26.8 & 36.3 & 32.7 & 31.4 & 35.8 & 29.5 & 40.0 & 31.5 \\
\hline Plagioclase & 45.4 & 54.5 & 53.3 & 54.1 & 41.0 & 33.7 & 48.1 & 26.1 & 26.5 & 46.1 & 46.4 & 37.5 & 51.5 & 46.4 & 37.8 & 29.7 & 35.5 & 45.3 \\
\hline Alk. Feldspar & -- & -- & 0.6 & tr. & -- & 20.2 & 13.3 & 29.2 & 29.8 & 12.1 & 20.6 & 18.1 & 5.2 & 11.7 & 17.3 & 34.2 & 20.6 & 16.8 \\
\hline Biotite & 5.4 & 16.6 & 3.6 & 21.9 & 12.9 & 8.2 & 9.3 & 6.7 & 2.1 & 9.4 & 5.5 & 6.0 & 9.5 & 8.2 & 5.5 & 4.5 & tr. & 4.7 \\
\hline Hornblende & 31.3 & 14.9 & -- & tr. & 19.2 & 6.6 & -. & -- & -- & tr. & -- & -- & 1.0 & -- & -- & -- & -- & -- \\
\hline
\end{tabular}


Table 2. Major-element analyses, mesonorms, and modal analyses of selected plutonic rocks of the Idaho Batholith near McCall, Idaho.—Continued

[Analysts: A.J. Bartel, E.L. Brandt, J.H. Christie, L.L. Jackson, C.S.E. Papp, D.F. Siems, K.C. Stewart, and J.E. Taggart; -- not detected, tr., trace, that is, less than 1\% modal volume.]

\begin{tabular}{|c|c|c|c|c|c|c|c|c|c|c|c|c|c|c|c|c|c|c|}
\hline & \multicolumn{4}{|c|}{ Tonalite of Payette River } & \multirow{2}{*}{$\begin{array}{c}\begin{array}{c}\text { Tonalite inclusion in } \\
\text { tonalite of Payette River }\end{array} \\
83 K 5 \\
\end{array}$} & \multirow{2}{*}{$\begin{array}{c}\begin{array}{c}\text { Porphyritic phase of } \\
\text { tonalite } \\
\text { of Payette River }\end{array} \\
85 C 16\end{array}$} & \multicolumn{3}{|c|}{$\begin{array}{l}\text { Granodiorite sills and dikes } \\
\text { in tonalite of Payette River }\end{array}$} & \multicolumn{4}{|c|}{ Granodiorite of Box Lake } & \multirow{2}{*}{$\begin{array}{c}\text { Leucogranodiorite pluton of } \\
\text { Jumbo Creek } \\
84 K 20 \\
\end{array}$} & \multicolumn{4}{|c|}{ Monzogranite of Lick Creek } \\
\hline & $81 \mathrm{k1}$ & $83 Z 11$ & $86 \mathrm{~K} 53$ & $86 \mathrm{~K} 68$ & & & $85 C 1$ & $81 K 15$ & $81 \mathrm{k1K8}$ & $86 \mathrm{~K} 6$ & $87 \mathrm{~K} 26$ & $87 \mathrm{~K} 27$ & $86 \mathrm{~K} 18$ & & $83 \mathrm{C} 74$ & $86 \mathrm{~K} 3$ & $87 \mathrm{~K} 23$ & 87К18 \\
\hline Pyroxene & -- & -- & tr. & 1.1 & -- & -- & -- & -- & -- & -- & -- & -- & -- & -- & -- & -- & -- & -- \\
\hline Chlorite & 2.2 & tr. & -- & tr. & tr. & -- & tr. & tr. & -- & tr. & tr. & tr. & tr. & tr. & tr. & tr. & tr. & tr. \\
\hline Muscovite & -- & -- & -- & -- & -- & -- & tr. & -- & tr. & tr. & tr. & 1.4 & -- & tr. & 3.0 & 1.9 & 2.6 & 1.7 \\
\hline Epidote & tr. & tr. & tr. & -- & -- & -- & tr. & tr. & -- & -- & -- & -- & tr. & tr. & -- & -- & -- & -- \\
\hline Sphene & tr. & tr. & tr. & -- & 1.0 & -- & tr. & -- & -- & tr. & -- & -- & tr. & -- & -- & -- & -- & -- \\
\hline Opaques & 1.6 & tr. & tr. & tr. & -- & tr. & tr. & tr. & tr. & tr. & tr. & tr. & tr. & tr. & tr. & -- & -- & -- \\
\hline Accessory & tr. & tr. & tr. & tr. & tr. & tr. & tr. & tr. & tr. & tr. & tr. & tr. & tr. & tr. & tr. & tr. & tr. & tr. \\
\hline Garnet & & & & & & & -- & -- & -- & & & & & 1.9 & & & & \\
\hline $\begin{array}{l}A n / \\
A b+A n(\%)\end{array}$ & $31-39$ & $30-40$ & $32-40$ & $32-39$ & $33-41$ & $28-36$ & $23-26$ & $21-28$ & $17-28$ & $16-42$ & $18-25$ & $18-28$ & $23-27$ & $18-24$ & $15-23$ & $15-24$ & $12-23$ & $10-25$ \\
\hline
\end{tabular}




\section{Leucogranodiorite Sills and Dikes in Tonalite of Payette River}

Leucogranodiorite forms long $(\sim 10 \mathrm{~km})$, narrow $(\sim 0.5$ $\mathrm{km}$ ), sill-like plutons (map unit Kgsp, fig. 2) in a zone about $5 \mathrm{~km}$ wide that is roughly centered on the North Fork Payette River. The largest pluton is about $1.5 \mathrm{~km}$ wide and extends for at least $12 \mathrm{~km}$ north-northeast beginning from a point about 10 $\mathrm{km}$ north of Upper Payette Lake. A weak foliation in leucogranodiorite sills and dikes is produced by alignment of biotite flakes and by parallel alignment of quartz crystals. Contacts of leucogranodiorite sills with tonalite are sharp and mostly parallel to the prominent primary mineral foliation of the tonalite, but locally the leucogranodiorite forms dikes that cut sharply across that foliation. Modal compositions of leucogranodiorite sills and dikes are highly variable compared to other plutonic units of the Idaho Batholith in the McCall area (table 2, fig. 4A); leucogranodiorite spans the range from monzogranite through granodiorite to tonalite. There is considerable variation in the amount of potassium feldspar, plagioclase, and quartz, but the color index of these rocks is fairly uniform and averages 6.3.

Leucogranodiorite in the sills and dikes is allotriomorphic-hypidiomorphic granular and most crystals are 1-5 $\mathrm{mm}$ long. Some leucogranodiorite is porphyritic, containing relatively large crystals of quartz and feldspar 3-7 mm long in a finer grained matrix. Feldspars and biotite in the leucogranodiorite are altered compared to the same minerals in tonalite of Payette River. At many localities, the leucogranodiorite is cut by numerous quartz veins and contains secondary crystals of potassium feldspar as long as $10 \mathrm{~mm}$.

Quartz in leucogranodiorite sills and dikes is invariably anhedral and weakly strained; subgrains have straight boundaries. Plagioclase $\left(\mathrm{An}_{15-36}\right)$ crystals are anhedral to subhedral and range from 0.5 to $4 \mathrm{~mm}$ long. Discontinuous, normalzoned plagioclases have a compositional range of as much as 20 mol-percent An in some samples, but plagioclases in other samples possess only weak normal zoning and a compositional range of less than 10 mol-percent An. Many of the larger plagioclase crystals are poikilitic, having quartz, biotite, and potassium feldspar inclusions. Myrmekite is common in most samples. Plagioclase is commonly altered to muscovite, potassium feldspar, and dusty clay minerals. Anhedral crystals of potassium feldspar are typically $\leq 1 \mathrm{~mm}$ in longest dimension and interstitial to other minerals. Some samples contain subhedral crystals of potassium feldspar as large as $5 \mathrm{~mm}$. These large crystals are poikilitic near their margins and contain rounded inclusions of quartz and biotite. Most crystals have tartan twins but some larger crystals contain simple twins. String or bleb perthite is common. Some crystals have cores that are more strongly altered than rims. Muscovite and dusty clay minerals are alteration products of potassium feldspar.

Olive-brown to reddish-brown biotite is the only mafic mineral in most samples of leucogranodiorite sills and dikes. Biotite is typically anhedral to subhedral and 1-8 mm wide. Alteration to green chlorite and muscovite along cleavages and the edges of biotite flakes is common. Olive-green hornblende is rare. Rare euhedra of muscovite that are contiguous to biotite may be primary. Brown to tan, euhedral crystals of allanite $\leq 2 \mathrm{~mm}$ long and granules of titanite $\leq 1 \mathrm{~mm}$ are common. Apatite and zircon are rare in leucogranodiorite.

Primary opaque minerals are rare in leucogranodiorite sills and dikes. Most opaque minerals are small $(\leq 0.5 \mathrm{~mm})$, equant, and with chlorite and rutile are chiefly alteration products of biotite. Pyrite was identified in several samples.

\section{Granodiorite of Box Lake}

Granodiorite of Box Lake forms a narrow, 3-6 km wide, north-trending composite intrusion along the eastern margin of the tonalite of Payette River. This unit is informally named for exposures along the shores of Box Lake, about $15 \mathrm{~km}$ northeast of McCall (fig. 2). The trend of granodiorite of Box Lake is southeast and southwest around the pinwheel shape leucogranodiorite pluton of Jumbo Creek east of Little Payette Lake. At that locality, the granodiorite of Box Lake is $\sim 10$ $\mathrm{km}$ wide and contains screens of metasedimentary rocks and tonalite of Payette River that are as much as $1 \mathrm{~km}$ wide and 5 km long (fig. 2).

Granodiorite of Box Lake is a highly variable lithologic unit; three lithologic-textural varieties have been mapped within it. In most places along its east and west margins, it is a variable mixture of equigranular granodiorite and inclusions of metasedimentary rocks and tonalite, forming the equigranular granodiorite of the border zone (map unit Kgbb, fig. 2). Inclusions make up more than 50 percent of the rock in many areas of the border zone. The inclusions range in size from fragments a few centimeters across to blocks that are as much as several hundred meters in longest dimension. The two longest dimensions of large inequidimensional metasediment and tonalite inclusions lie within the plane of regional foliation, suggesting that they represent a dismembered set of screens. Along its eastern border, the granodiorite of Box Lake typically contains phenocrysts of potassium feldspar as long as $20 \mathrm{~mm}$, thus forming the porphyritic granodiorite map unit (map unit Kpgb, fig. 2). The porphyritic granodiorite typically contains few inclusions of metasedimentary rocks or tonalite. Granodiorite containing relatively large $(2-3 \mathrm{~mm})$ crystals of biotite is also found near Boulder Lake among large screens of tonalite of Payette River, thus forming porphyritic biotite granodiorite (map unit Kbgb, fig. 2).

In spite of the significant textural variation in granodiorite of Box Lake, the color index of modally analyzed specimens is fairly uniform and averages 6.8 (table 2, fig. 4A).

The contrast in amount of inclusions from east to west within the granodiorite of Box Lake suggests that the granodiorite was intruded into metasedimentary rocks and previously solidified tonalite of Payette River chiefly by stoping. This relationship argues that there was a significant time gap between solidification of tonalite of Payette River and subsequent emplacement of the granodiorite of Box Lake.

Inclusion-free granodiorite of Box Lake is characterized by a distinctive tannish-gray color and medium-grained 
crystalline texture. It is finer grained than any other plutonic unit in the McCall area. Granodiorite consists of plagioclase, quartz, potassium feldspar, biotite, and minor muscovite and hornblende. The average crystal size is $2-4 \mathrm{~mm}$, but some quartz crystals are as long as $7 \mathrm{~mm}$. Porphyritic granodiorite contains phenocrysts of potassium feldspar as long as $10 \mathrm{~mm}$. The typical texture of granodiorite of Box Lake is allotriomorphic-hypidiomorphic granular. In hiatal samples, quartz, plagioclase, and potassium feldspar crystals are intergranular with respect to larger crystals of the same minerals plus biotite. A steep, weak foliation is defined by preferred alignment of biotite flakes and, rarely, hornblende prisms. Locally, foliation is also indicated by preferentially oriented, inequidimensional inclusions (Kuntz, this volume, chapter 7).

Modal variation in the granodiorite of Box Lake (fig. $4 A$ ) is caused by high variation in the amount of quartz and relatively constant proportions of potassium feldspar and plagioclase. Most samples of granodiorite of Box Lake are granodiorite in the modal classification.

Quartz crystals in granodiorite of Box Lake are typically anhedral, strained, and roughly equant. Patches of quartz consist of several subgrains that may differ from one another by $10-18^{\circ}$ in extinction position. Subgrains typically have straight boundaries, but sutured boundaries are also observed.

Plagioclase is typically anhedral-subhedral and discontinuously normally zoned. Zoned crystals have an An mol-percent range of 7 or less. Most crystals are equant, 1-4 mm long, and bordered by rinds of myrmekite $<0.3 \mathrm{~mm}$ thick. Clots of plagioclase consist of several crystals, each of which has patchy compositional zones. Poikilitic inclusions of quartz, biotite, glass, and potassium feldspar are common in plagioclase. Minor alteration to muscovite, particularly in cores, is found in plagioclase crystals in some samples. Potassium feldspar crystals are typically anhedral-subhedral, 1-4 mm long, and contain small patches of string or blebby perthite. Crystal twinning in most thin sections is simple. Local areas of tartan twinning are concentrated near mineral inclusions, suggesting initial crystallization as orthoclase and later partial inversion to microcline. Zoning in some crystals is marked by perthitic cores and nonperthitic rims.

Reddish-brown to brownish-olive, anhedral to euhedral flakes of biotite, $0.5-3 \mathrm{~mm}$ wide, are the main mafic mineral in granodiorite of Box Lake. In thin section, biotite is locally altered to lime-green or emerald-green chlorite and to muscovite. Muscovite is typically interlayered with biotite but some crystals of primary(?) muscovite occur as large $(\sim 2 \mathrm{~mm})$ euhedra between crystals of feldspars and quartz. Small ( $<0.5 \mathrm{~mm})$, euhedral, equant crystals of green to blue-green hornblende occur in roughly half of the samples examined. All hornblende crystals are contiguous to or interleaved with biotite.

Most samples of granodiorite of Box Lake contain small crystals of allanite and/or epidote $\leq 0.4 \mathrm{~mm}$ long. Two types of titanite occur in granodiorite of Box Lake: small granules $(\leq 0.2 \mathrm{~mm})$ and $\operatorname{logs}$ of granules (roughly 0.3 by $1.0 \mathrm{~mm}$ ), both located between biotite flakes. Rare, euhe- dral, wedge-shaped titanite crystals are $\leq 6 \mathrm{~mm}$ long. Equant crystals of opaque minerals are rare in granodiorite of Box Lake. Most opaque minerals are 0.2-0.4 mm wide and occur with chlorite and muscovite as alteration products of biotite. Some opaque minerals $\leq 0.2 \mathrm{~mm}$ wide are associated with apatite, titanite, and biotite. Apatite and zircon crystals, both $\leq 0.5 \mathrm{~mm}$, are rare.

The contact of granodiorite of Box Lake with tonalite of Payette River is typically gradational over distances of several hundred meters. The contact is mapped where the color index of the rock drops below about 10, where crystal size is typically less than about $4 \mathrm{~mm}$, and where inclusions of tonalite and metasedimentary rocks are enclosed by granodiorite that has a typical tannish-gray color.

\section{Monzogranite of Lick Creek}

The monzogranite of Lick Creek is informally named for exposures at the headwaters and along the margins of Lick Creek, about 20-25 km northeast of McCall (Figure 2). Four textural-mineralogical variants constitute the monzogranite of Lick Creek (fig. 2). The most common variant is porphyritic biotite monzogranite (map unit Kpbl, fig. $2)$, which has a low color index $(\leq 5)$, contains conspicuous biotite, and has a distinctive pink color owing to large (10-30 mm long), rare to abundant crystals of potassium feldspar. Equigranular biotite monzogranite (map unit Kebl, fig. 2) contains few or no potassium feldspar phenocrysts. Where muscovite forms megascopic crystals in equigranular, two-mica monzogranite, the rock is mapped as equigranular biotite-muscovite monzogranite (map unit Kbml, fig. 2). In the northeast and southeast parts of the map area, porphyritic muscovite-potassium feldspar monzogranite (map unit Kmfl, fig. 2) contains muscovite and potassium feldspar phenocrysts, both as large as $10 \mathrm{~mm}$. Contacts between these textural-mineralogical variants are gradational over distances of hundreds of meters; thus the variants are considered to be volumes of a single monzogranite magma that crystallized under slightly different P-T-X conditions.

Monzogranite of Lick Creek has modal compositions that overlap those of the granodiorite of Box Lake (table 2, fig. 4A), but rocks of the two units appear distinctly different in hand specimen. Most of the monzogranite of Lick Creek is medium to coarse grained and pink as opposed to the typically granular, tannish-gray character of all units of the granodiorite of Box Lake. The contact between the two map units is gradational over distances of as much as $500 \mathrm{~m}$ in some areas but in other areas is relatively sharp, occurring within distances of only a few meters. In many localities, the contact is easy to recognize because the granodiorite of Box Lake contains numerous inclusions of metasedimentary rocks and the monzogranite of Lick Creek is essentially free of inclusions. In addition, pegmatite, aplite, and granitic dikes are less common in the monzogranite of Lick Creek and more common in the granodiorite of Box Lake. 
In some localities, orientation of tabular to blocky crystals of potassium feldspar and/or flakes of biotite defines a weak foliation; but in most localities, foliation is absent (Kuntz, this volume, chapter 7). Monzogranite weathers to grus in many nonglaciated high areas.

Quartz in the monzogranite of Lick Creek occurs as rounded, mostly equant, anhedral crystals that are typically 4-6 mm long. In some rocks, quartz crystals are smaller $(\leq 1$ $\mathrm{mm})$ and interstitial to feldspars and biotite. Some of the larger crystals are composite; they consist of 2-5 smaller crystals that have sutured boundaries with one another, suggesting subsolidus recrystallization. The composite crystals of quartz typically form a mosaic of strained subgrains that display undulose extinction and differ from one another in extinction position by as much as $15^{\circ}$.

There are typically two sizes of potassium feldspar crystals: small $(\leq 1.5 \mathrm{~mm})$, anhedral to subhedral crystals that are interstitial to crystals of quartz and plagioclase, and subhedral to euhedral phenocrysts $10-30 \mathrm{~mm}$ long. Both large and small crystals of potassium feldspar are typically poikilitic, containing rounded inclusions of quartz, plagioclase, and biotite. Most crystals are untwined, but some contain simple twins, indicating that the potassium feldspar is orthoclase. Tartan twins are rare, occurring mainly at intersections of cleavage. Most crystals contain string, rod, or patch perthite, and some show evidence of zoning. Plagioclase crystals are typically subhedral to euhedral, 1-4 mm long, and contain pronounced concentric, discontinuous, normal, and oscillatory zones. The composition averages about 15 mol-percent An. Some crystals are as long as $7 \mathrm{~mm}$, and many contain poikilitic inclusions of biotite and have bulbous projections of myrmekite. Cores are altered to muscovite in many crystals.

Both biotite and muscovite are present in nearly all samples. Biotite is reddish-brown and occurs as anhedral, subhedral flakes $0.5-1.5 \mathrm{~mm}$ in diameter. Much biotite has altered either to mint-green chlorite and opaque minerals or to muscovite, but rarely to both sets of minerals in the same thin section. Muscovite is clearly a secondary mineral in most samples and occurs as anhedral, skeletal, or shredded-looking crystals as an alteration product of biotite, plagioclase, and potassium feldspar. In about half of the thin sections examined, large euhedral crystals of muscovite as much as $3 \mathrm{~mm}$ in diameter are in various textural relationships that suggest primary crystallization (Zen, 1985). For example, muscovite occurs between plagioclase crystals and attached to outer surfaces of biotite crystals, but not within biotite crystals along cleavage surfaces. Mint-green chlorite is an alteration product of biotite in many samples. Green hornblende is a trace accessory mineral.

The accessory minerals allanite, epidote, titanite, and opaque minerals, so common in other plutonic units, are nearly absent in monzogranite of Lick Creek. Small granules of clear epidote and titanite are rarely associated with biotite, and very rare, small ( $\leq 0.3 \mathrm{~mm}$ diameter), equant crystals of opaque minerals are an alteration product of biotite flakes in some samples, but most samples are essentially free of opaques. Zircon and apatite are rare.

\section{Dikes and Veins}

Granitic pegmatite and aplite dikes, clearly of magmatic origin, and quartz veins and quartz-feldspar veins of probable hydrothermal origin are common in tonalite of Payette River and granodiorite of Box Lake. For the most part, the dikes are undeformed and planar in all areas studied. Locally they are offset a few centimeters to (rarely) a few meters by small faults. Most dikes are either pegmatitic or aplitic in texture, but locally pegmatite dikes having aplitic centers and aplite dikes having pegmatitic cores or edges are present. Most dikes are $0.1-0.3 \mathrm{~m}$ in width; rarely do widths exceed $1 \mathrm{~m}$. Veins are typically $\leq 0.1 \mathrm{~m}$ wide.

Dikes are abundant in the granodiorite of Box Lake and gradually decrease in abundance to the west into tonalite of Payette River. Dikes are also abundant along the western margin of the monzogranite of Lick Creek but decrease markedly in abundance to the east. The composition of the dikes and veins and their concentration at the margin suggest that they were generated by the monzogranite of Lick Creek.

\section{Age, Uplift, and Cooling of Plutonic Units}

Preliminary U-Pb dates for zircon and ${ }^{40} \mathrm{Ar} /{ }^{39} \mathrm{Ar}$ age-spectrum dates for hornblende, biotite, muscovite, and potassium feldspar are tabulated for several plutonic units in table 3.

$\mathrm{U}-\mathrm{Pb}$ ages give the best estimate of the time of magma formation, and ${ }^{40} \mathrm{Ar}{ }^{39} \mathrm{Ar}$ ages of hornblende, biotite, muscovite, and potassium feldspar can be used to infer the cooling and uplift history of plutons. Because Ar-bearing minerals remain open to argon diffusion during post-crystallization cooling and deformation and because argon-closure temperatures vary for each argon-bearing mineral (table 3), the listed Ar-age-spectrum dates give minimum ages for emplacement.

Where U-Pb ages for zircon and ${ }^{40} \mathrm{Ar} /^{39} \mathrm{Ar}$ ages for hornblende are available for a single plutonic unit, $\mathrm{U}-\mathrm{Pb}$ zircon ages are about 8-10 m.y. older than the ${ }^{40} \mathrm{Ar} /{ }^{39} \mathrm{Ar}$ ages for hornblende. Similarly, the ${ }^{40} \mathrm{Ar}^{39} \mathrm{Ar}$ ages for hornblende are about 2-3 m.y. older than the ${ }^{40} \mathrm{Ar} /{ }^{39} \mathrm{Ar}$ biotite ages. Biotite and muscovite ${ }^{40} \mathrm{Ar} r^{39} \mathrm{Ar}$ ages for another unit are $\sim 10-13 \mathrm{~m}$.y. younger than its $\mathrm{U}-\mathrm{Pb}$ zircon age, and a ${ }^{40} \mathrm{Ar} /{ }^{39} \mathrm{Ar}$ potassium feldspar age is a few million years younger than the ${ }^{40} \mathrm{Ar} /{ }^{39} \mathrm{Ar}$ muscovite age. These age variations likely reflect progressive cooling of the rock, probably through uplift (Snee, 2002). Because there are few zircon ages and hornblende ages, emplacement ages of plutonic rocks in the McCall area must be considered only as preliminary estimates.

A single $\mathrm{U}-\mathrm{Pb}$ zircon age for leucogranodiorite of Jumbo Creek is $94 \pm 4 \mathrm{Ma}$ (table 3 ). Three U-Pb zircon ages for the tonalite of Payette River average about $90 \mathrm{Ma}$ (table 3). ${ }^{40} \mathrm{Ar} /{ }^{39} \mathrm{Ar}$ ages of hornblende and biotite for the tonalite of Payette River are about $80 \mathrm{Ma}$ and $77 \mathrm{Ma}$, respectively, suggesting a period of at least 10 m.y. for cooling from an initial 
Table 3. U-Pb and ${ }^{40} \mathrm{Ar} /{ }^{39} \mathrm{Ar}$ ages (in Ma) of plutonic units of the Idaho Batholith east of the Salmon River suture zone near McCall, Idaho.

[Sample numbers refer to samples taken in the greater McCall, Idaho region. U-Pb zircon ages by D.M. Unruh, U.S. Geological Survey, Denver, CO are preliminary, uninterpreted ages. ${ }^{40} \mathrm{Ar} /{ }^{39} \mathrm{Ar}$ hornblende, biotite, muscovite and potassium feldspar ages by L.W. Snee, U.S. Geological Survey, Denver, Colorado, are preliminary and not interpreted. Biotite ages in brackets are disturbed and thus not plotted in figure 5.]

\begin{tabular}{|c|c|c|c|c|c|c|}
\hline & Sample no. & Zircon & Hornblende & Biotite & Muscovite & $\begin{array}{l}\text { Potassium } \\
\text { feldspar }\end{array}$ \\
\hline Ar-closure temp. range ${ }^{(+)}$ & & & $480^{\circ}-580^{\circ} \mathrm{C}$ & $240^{\circ}-320^{\circ} \mathrm{C}$ & $270^{\circ}-325^{\circ} \mathrm{C}$ & $270^{\circ}-325^{\circ} \mathrm{C}$ \\
\hline Accepted closure temp..$^{(+)}$ & & & $580^{\circ} \mathrm{C}$ & $280^{\circ} \mathrm{C}$ & $300^{\circ} \mathrm{C}$ & $130^{\circ} \mathrm{C}$ \\
\hline \multirow{2}{*}{ Leucogranodiorite of Jumbo Creek } & MC6-91 & $94.4 \pm 1.1$ & & & & \\
\hline & 87KA8 & & & $79.0 \pm 0.2$ & & \\
\hline \multirow[t]{5}{*}{ Tonalite of Payette River } & $83 \mathrm{Z} 11^{(*)}$ & $90 \pm 5^{*}$ & $81.3 \pm 0.4$ & & & \\
\hline & MC13-91) & $88.9 \pm 1.3$ & & & & \\
\hline & MC5-91 & $91.2 \pm 1.0$ & & & & \\
\hline & $87 \mathrm{KA} 2$ & & $81.5 \pm 0.3$ & $79.5 \pm 1.0$ & & \\
\hline & 87KA3 & & $79.2 \pm 0.3$ & $76.6 \pm 0.2$ & & \\
\hline Granodiorite of Box Lake & 87KA4 & & & {$[76.5 \pm 1.0]$} & $73.9 \pm 0.2$ & \\
\hline \multirow{6}{*}{ Monzogranite of Lick Creek } & MC1-91 & $82.2 \pm 1.1$ & & & & \\
\hline & $\operatorname{MC} 2-91^{(\mathrm{x})}$ & $82.9 \pm 5.2$ & & & & \\
\hline & $87 \mathrm{KA} 1$ & & & {$[75.1 \pm 1.0]$} & $74.9 \pm 0.3$ & \\
\hline & 87KA5 & & & {$[75.5 \pm 1.0]$} & $74.4 \pm 0.2$ & \\
\hline & 87KA6 & & & {$[75.0 \pm 1.0]$} & $73.2 \pm 0.2$ & \\
\hline & $858-134 \mathrm{E}$ & & & $74.6 \pm 0.4$ & $71.9 \pm 0.4$ & $68.7 \pm 0.4$ \\
\hline
\end{tabular}

(*)Zircon age from Manduca and others (1993). All other zircon ages from D.M Unruh, U.S. Geological Survey, Denver, Colorado

(+)Argon closure temperatures from Snee (2002)

tonalite igneous crystallization temperature of approximately $1,000^{\circ} \mathrm{C}$. (Wyllie and Rutter, 1988) to a temperature of argon retention in hornblende, about $530^{\circ} \mathrm{C}$ (fig. 5). The zircon ages correspond well to similar ages for tonalite plutons east of the Salmon River suture zone elsewhere in western Idaho (Lund and Snee, 1988; Snee and others, 1995; Snee and others, this volume, chapter 3).

The U-Pb zircon age of $83 \pm 5 \mathrm{Ma}$ for monzogranite of Lick Creek (table 3) suggests that emplacement of the monzogranite of Lick Creek followed emplacement of the tonalite of Payette River by approximately 6 m.y. A U-Pb zircon age is not available for the granodiorite of Box Lake, but field relations discussed earlier indicate that this plutonic unit was emplaced after the tonalite of Payette River and before the monzogranite of Lick Creek. The ${ }^{40} \mathrm{Ar} /{ }^{39} \mathrm{Ar}$ ages from biotite and muscovite are nearly identical for the granodiorite of Box Lake and the monzogranite of Lick Creek, suggesting that they cooled together through about $300^{\circ} \mathrm{C}$., the approximate temperature for argon retention in biotite and muscovite. The ${ }^{40} \mathrm{Ar} /{ }^{39} \mathrm{Ar}$ biotite ages for tonalite of Payette River are approximately $4 \mathrm{~m}$.y. older than the ${ }^{40} \mathrm{Ar}{ }^{30} \mathrm{Ar}$ biotite age for the grano- diorite of Box Lake, which supports conclusions described earlier that several million years may have elapsed between emplacement of the tonalite of Payette River and subsequent emplacement of the granodiorite of Box Lake. The similarity in ${ }^{40} \mathrm{Ar}{ }^{39} \mathrm{Ar}$ ages for biotite and muscovite for granodiorite of Box Lake and monzogranite of Lick Creek accords with the evidence of the gradational contact that these two plutonic units were emplaced nearly simultaneously, with the granodiorite preceding the monzogranite. The radiometric age data suggest that $85 \mathrm{Ma}$ is a reasonable age for the granodiorite of Box Lake.

The aggregate $\mathrm{U}-\mathrm{Pb}$ zircon and ${ }^{40} \mathrm{Ar} /{ }^{39} \mathrm{Ar}$ dates shown in table 3 suggest that the plutonic units east of the Salmon River suture zone were formed during the same thermal regime but at different depths. The data indicate that the magma-forming thermal event began at about 94 Ma with the formation of the leucogranodiorite of Jumbo Creek, followed by the tonalite of Payette River at $90 \mathrm{Ma}$, followed approximately $5 \mathrm{~m}$.y. later by the formation of the granodiorite of Box Lake, and ended with the emplacement of the monzogranite of Lick Creek at approximately $83 \mathrm{Ma}$. 


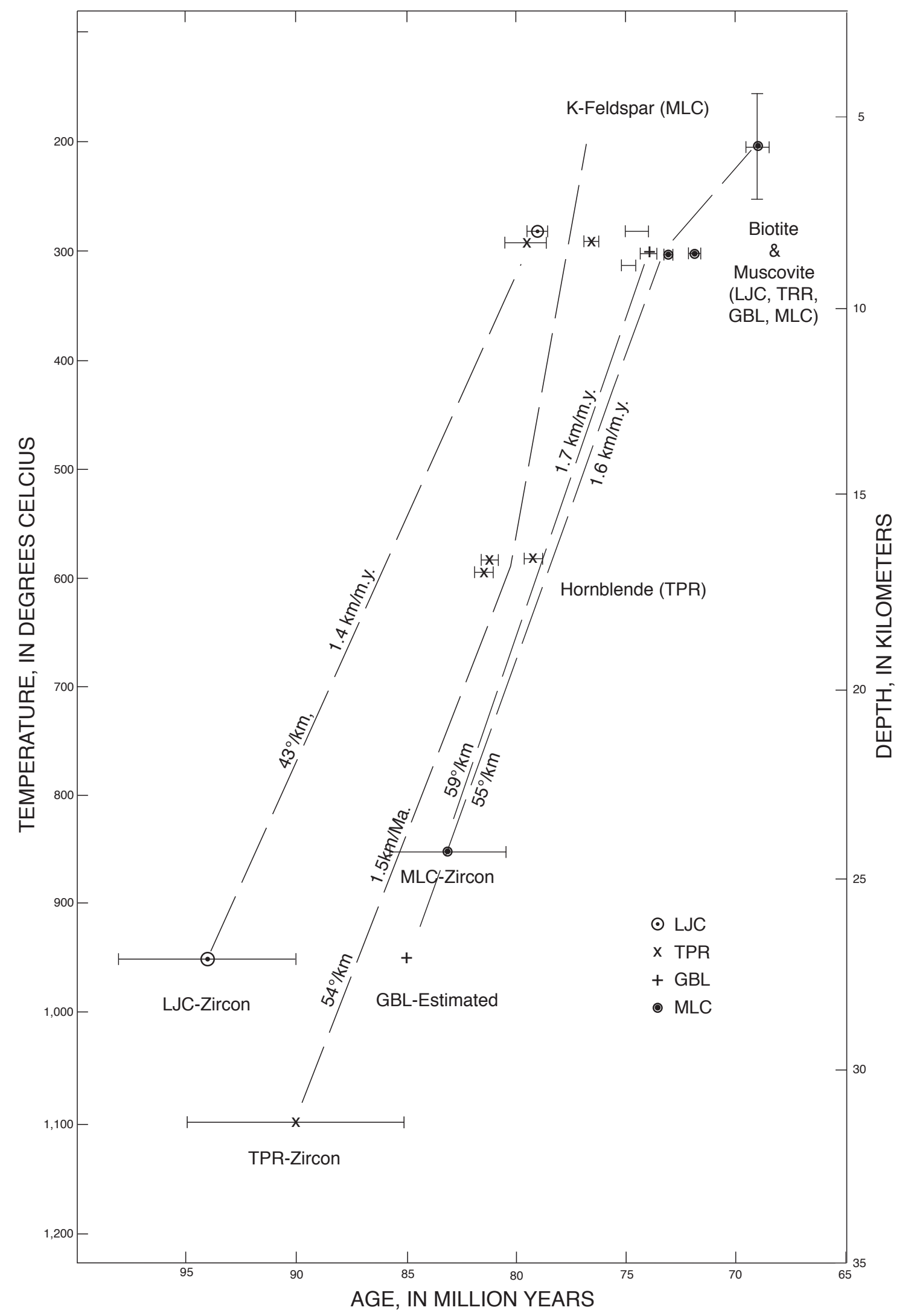

Figure 5. Age and interpreted uplift and cooling histories of plutonic units of the Idaho Batholith near McCall, Idaho. Abbreviations: LJC, leucogranodiorite of Jumbo Creek; TPR, tonalite of Payette River; GBL, granodiorite of Box Lake; MLC, monzogranite of Lick Creek. Age and temperature ranges from table 3. 
An interpreted emplacement-cooling-uplift history of the plutonic units, based on an assumed geothermal gradient of $30^{\circ} \mathrm{C} / \mathrm{km}$, is shown in figure 5 . The formation of magma of the leucogranodiorite of Jumbo Creek at a depth of about 30 $\mathrm{km}$ and temperatures of about $900^{\circ} \mathrm{C}$ is based on experimental data provided by Robertson and Wyllie (1971). Formation of magma for the tonalite of Box Lake at a depth of about 35-40 $\mathrm{km}$ and at a temperature of about $1100^{\circ} \mathrm{C}$ is based on ideas presented by Zen (1988), Wyllie and others (1977), and Wyllie and Rutter (1988). The formation of magma for monzogranite of Lick Creek is shown at a temperature of about $850^{\circ} \mathrm{C}$ (Hyndman, 1981; Clemens and Vielzeuf, 1987) at about 84 Ma, which yields a depth of about $28 \mathrm{~km}$. This depth may be greater than that predicted from experimental data for magma generation by about $10 \mathrm{~km}$, as discussed farther on in this paper. The genesis of magmas for plutonic rocks of the McCall area is discussed in greater detail farther on. The ages and closure-temperature data for muscovite and biotite indicate that the plutonic units cooled to approximately $300^{\circ} \mathrm{C}$ at various times, with the leucogranodiorite of Jumbo Creek reaching approximately that temperature at about $80 \mathrm{Ma}$ and the monzogranite of Lick Creek reaching that temperature at about 73 Ma.

Figure 5 shows the temperature-depth-age relations for magma generation, uplift, and cooling history of the plutonic units. In spite of the imprecision in the ages of the plutonic units and uncertainties in the depths of magma formation, the data in figure 5 suggests uplift rates for the western border zone of the Idaho Batholith of about $1.5 \mathrm{~km} / \mathrm{m}$.y. to 2.1 $\mathrm{km} / \mathrm{m}$.y. and cooling rates of approximately $50^{\circ} \mathrm{C} / \mathrm{m}$.y.

\section{Modal Analyses and Classification of Plutonic Rocks}

Modal analyses for a number of granitoid rocks of the Idaho Batholith east of the Salmon River suture zone are shown in fig. $4 A$ and some of the analyses are listed in table 2.

Maniar and Piccoli (1989) portrayed modal fields of granitoids that are representative of various tectonic environments on the quartz-alkali feldspar-plagioclase diagram (fig. $4 B$ ). The tonalite of Payette River plots in the modal field of island-arc granitoids on the tonalite-trondhjemite trend. The more felsic McCall rocks plot in the continental-arc and continental-collision granitoid fields.

The near absence of opaque minerals in monzogranite of Lick Creek, leucogranodiorite of Jumbo Creek and granodiorite of Box Lake accords with observations reached by Criss and Champion (1984) that granitic rocks of the interior of the Idaho Batholith have very low magnetic susceptibilities. Criss and Champion indicate that the low magnetic susceptibilities $\left(<\sim 5 \times 10^{-5} \mathrm{cgs}\right)$ of these rocks are related to rarity of magnetite and relatively high abundance of ilmenite. The tonalite of Payette River coincides geographically with the western part of the Idaho batholith that has higher magnetic susceptibilities ( $>25 \times 10^{-5} \mathrm{cgs}$ ), suggesting that some of the opaque minerals in tonalite of Payette River is magnetite. On this basis, the tonalite of Payette River appears to be a pluton of the magnetite series, and the granodiorite of Box Lake, leucogranodiorite of Jumbo Creek and monzogranite of Lick Creek appear to be plutons of the ilmenite series of Ishihara $(1977,1981)$. Criss and Champion (1984) noted that Idaho Batholith plutons of the magnetite series are clearly I-type granitoids and that Idaho Batholith plutons of the ilmenite series typically have S-type characteristics.

\section{Major-Element Characteristics of Granitoids in the McCall Area}

\section{Major-Element Analyses and Mesonorms}

Major-element analyses were obtained for 50 plutonic rocks in the McCall area. Table 2 lists representative analyses and mesonorms for the various plutonic units.

Mesonormative minerals (Barth, 1962) provide a closer approximation to the modal mineral compositions of plutonic rocks of the McCall area than do CIPW norms, because hornblende and biotite are calculated in the mesonorm in contrast to the anhydrous phases diopside and hypersthene as calculated in the CIPW norm. In addition, aluminum and potassium are apportioned to biotite as well as orthoclase, thus giving a better approximation of relative alumninum saturation. The presence of "c" or corundum, as calculated in the mesonorm, indicates that there is an excess of $\mathrm{Al}_{2} \mathrm{O}_{3}$ over that required for feldspars and biotite, and thus the "c" content suggests the presence of another Al-bearing modal phase, typically muscovite. In table 1 , it can be seen that "c" contents in excess of 1.0 percent equate with presence of modal muscovite.

\section{Chemical Characteristics}

The more felsic McCall-area plutonic rocks plot mostly as calc-alkaline, but most groups of samples straddle the division between calc-alkaline granite and tholeiitic granite (fig. $6 A$ ). These trends are typical of granodiorite-monzogranite plutons of orogenic belts (Cobbing, 2000). Figure $6 B$ shows that $\mathrm{McCa}$ ll rocks have a fairly narrow range of $\mathrm{Na}_{2} \mathrm{O}$ contents but vary broadly in $\mathrm{K}_{2} \mathrm{O}$ contents. The tonalite of Payette River has the most restricted range of $\mathrm{K}_{2} \mathrm{O}$, and the granodiorite sills and dikes in tonalite of Payette River have a broad range of $\mathrm{K}_{2} \mathrm{O}$ content, which suggests the possibility of several modes of origin for rocks of the latter group. In the classification of Chappell and Stephens (1988), most McCall rocks are I-type granites, although the tonalite of Payette River has M-type granitoid affinities and the granodiorite sills and dikes have some S-type affinities (fig. 6B). In the terminology of Pecarillo and Taylor (1976), McCall plutonic rocks are typically 

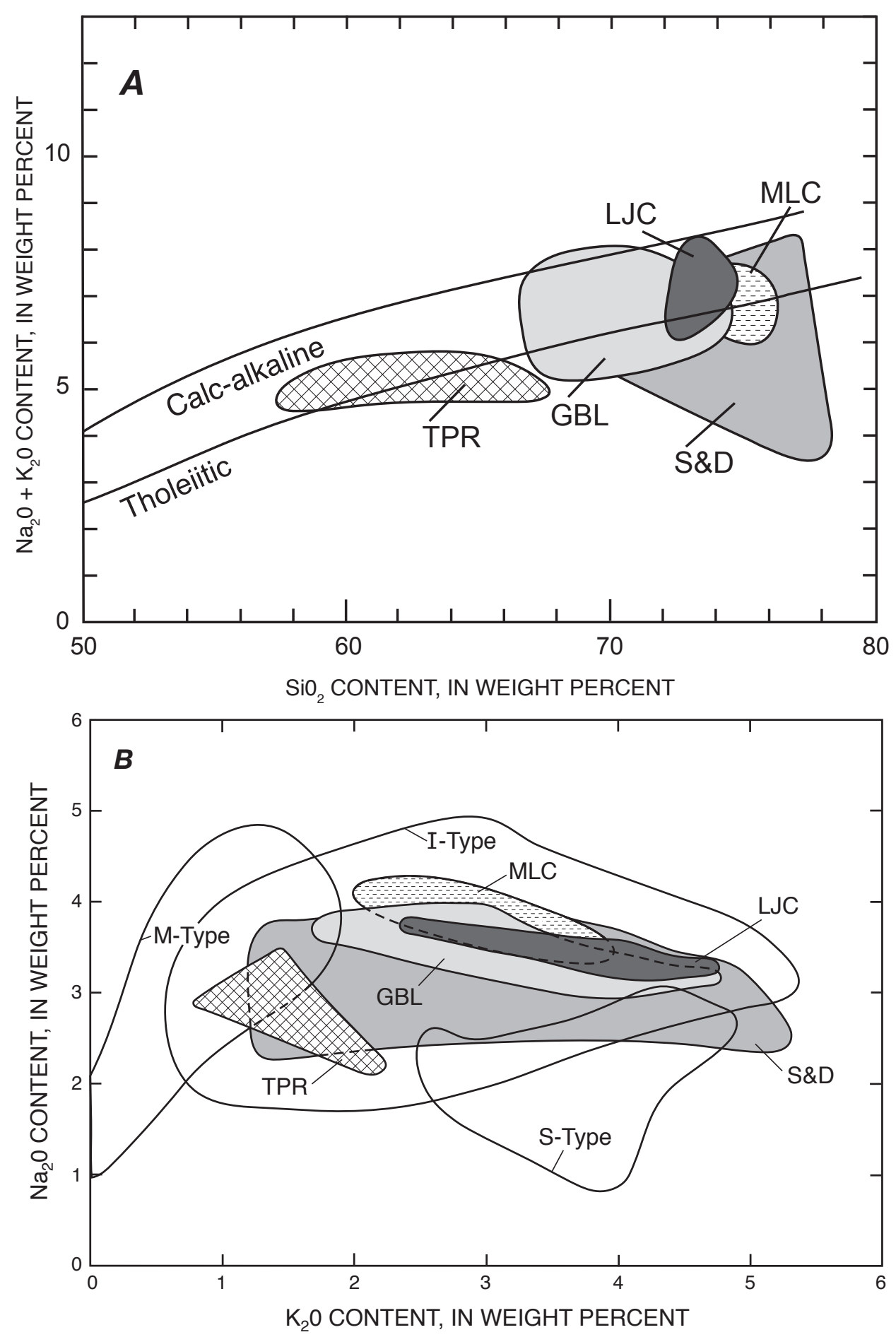

Figure 6. Comparison plots of some major oxides and ratios for plutonic units of the Idaho Batholith near McCall, Idaho. In all diagrams, the number of major-element analyses plotted are: tonalite of Payette River (TPR), 11; granodiorite of Box Lake (GBL), 12; leucogranodiorite of Jumbo Creek (LJC), 4; granodiorite sills and dikes intruded into TPR (S\&D), 12; monzogranite of Lick Creek (MLC), 12. A, Alkali vs. silica plot showing fields for tholeiitic and calc-alkaline rock series, after Irvine and Baragar (1971). $B, \mathrm{Na}_{2} \mathrm{O}$ vs. $\mathrm{K}_{2} \mathrm{O}$ plot; I-type, S-type, and M-type granitoid fields from Chappell and Stephens (1988). C, $\mathrm{K}_{2} \mathrm{O}$ vs. $\mathrm{SiO}_{2}$ plot; potassium terminology from Pecarillo and Taylor (1976). D, Alumina saturation diagram after Shand (1947); I-type and S-type discrimination line from Chappell and White (1974) and tectonic discrimination fields from Maniar and Piccoli (1989). Additional abbreviations: IAG, island-arc granitoids; CAG, continental-arc granitoids; CCG, continental-collision granitoids. 

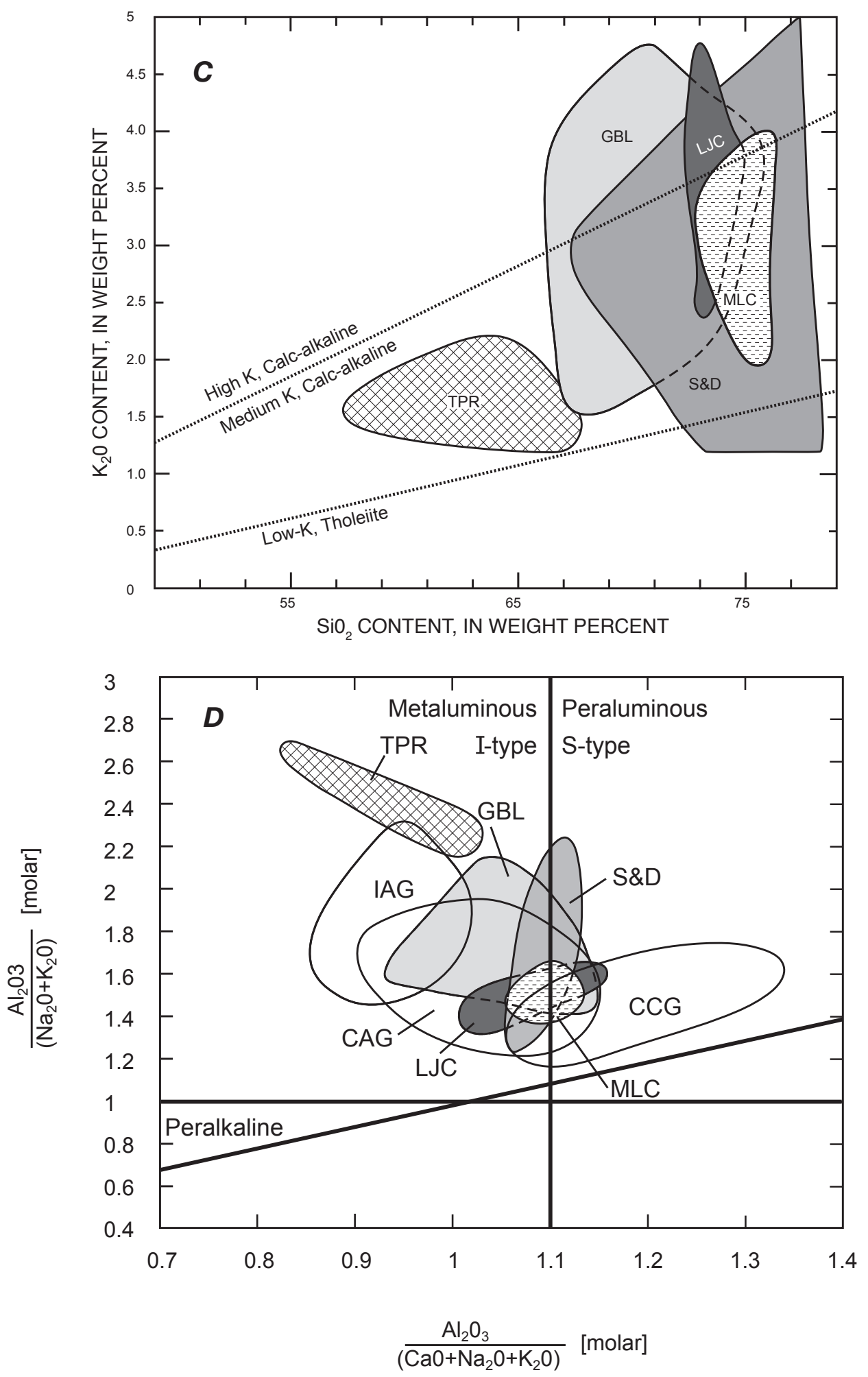

Figure 6.-Continued 
"medium-K, calc-alkaline" rocks, but a few samples of the granodiorite of Box Lake, leucogranodiorite of Jumbo Creek, and sills and dikes in the tonalite of Payette River plot in the "high-K, calc-alkaline" field (fig. 6C).

The alumina balance of McCall plutonic rocks is shown in figure $6 D$. If alumina exceeds the amount necessary to combine with the soda, potash, and lime to form feldspars (peraluminous rocks), the excess alumina appears in distinctive aluminous minerals such as biotite, muscovite, corundum, topaz, and garnet. For rocks in which alumina is less than the sum of the alkalis (metaluminous rocks), the alumina is apportioned into minerals such as hornblende, epidote, biotite, and pyroxenes. These relationships are found in the mineralogy of the McCall plutonic rocks, where the tonalite of Payette River is mostly metaluminous (hornblende, pyroxene, biotite) and the other groups of plutonic rocks are mostly or completely peraluminous (biotite, muscovite, mesonormative "c"; see table 2).

The tonalite of Payette River is an "M/wP" type (metaluminous to weakly peraluminous granites), and McCall-area granodiorites and monzogranites and the leucogranodiorite of Jumbo Creek are "sP" types (strongly peraluminous monzogranites and granodiorites) in the terminology of Miller and Barton (1990).

\section{Granite-Source Classifications and Further Discrimination of Tectonic Environments for McCall Granitoids}

Chappel and White (1974) formulated a classification of granitoids with respect to their mode of origin based on geological, geochemical, and isotopic characteristics and defined I- and S-type granites. They defined S-type granitoids as formed from crustal sedimentary source regions and I-type granitoids as derived from crustal igneous source regions. Subsequently, A-type (anorogenic) and M-type (mantle-derived) granitoids have been identified.

The relationships between these granite types, the source regions for granitic magmas, and their tectonic settings have now been widely discussed and debated (see, for example, summaries in Barbarin, 1990; Clarke, 1992; and Cobbing, 2000). Barbarin (1990) concluded that there is a broad spectrum from wholly mantle to wholly crustal source regions and that there is a broad correlation between granite chemical types and their tectonic settings. Atherton (1993, p. 1017) concluded that "the chemistry of the source region is often the result of a long history of mantle and crust enrichment/depletion, which may have no relation to the tectonic setting prevailing on magma genesis." Cobbing (2000) concluded that "the typological system provides no more than a framework within which a great variety of granitoids can be loosely accommodated" and "its' virtue is that different aspects of granite geology can be more readily understood if they can be shown to reflect or characterize different aspects of global tectonics."

M-type granitoids fall into two classes: (1) ocean-floor plagiogranites and (2) quartz diorites and tonalites of oceanic island arcs. The latter type is considered to have formed from subduction of oceanic crust beneath island arcs. Cordilleran I-type granitoids are considered to be subduction related at the borders of major continents. The I-type granitoids, principally tonalite, granodiorite, and monzogranite, are slightly more evolved than M-types, suggesting that magmas for these rocks were derived from both mantle and crustal-igneous protolith source regions. The chemical characteristics of the various alphabet-granite types are shown in figures $6 B, C, D$. These diagrams indicate that tonalite of Payette River has both Mand I-type affinities.

S-type granitoids were defined originally by Chappell and White (1974) for granite plutons in southeast Australia, where they were interpreted as resulting from the melting of a metasedimentary protolith. In other parts of the world, some granites that contain metasedimentary enclaves and are clearly of anatectic origin do not conform to the geochemical criteria for S-type granites established by Chappell and White (1974). Rather, these granites have I-type chemical and mineralogical affinities. Cobbing (2000) noted that S-type granitoids are more variable than I-type granitoids because crustal sedimentary sources are inherently more variable than the mantle or basaltic lower crust. S-type granites occur in both collisional and postcollisional, postorogenic tectonic settings.

Note in figure $6 B$ that all McCall granitoids, except some of the sills and dikes in tonalite of Payette River, plot in the I-type field and outside the S-type field; thus igneous oceanic and continental protoliths are suggested as source rocks for McCall granitoids. However, in light of the above discussion, the more felsic McCall granitoids could have been derived by anatexis of metasedimentary source regions.

Figures $4 B$ and $6 D$ suggest that the tonalite of Payette River is best categorized as belonging to the island-arc granitoid (IAG) group and the other McCall-area granitoid plutonic groups correspond to continental-arc granitoids (CAG). According to Maniar and Piccoli (1989), island-arc granitoids are rocks of magmatic arcs formed by subduction of one oceanic plate beneath another oceanic plate; they contain hornblende, biotite, and pyroxene, have a silica range of 60-68 percent, and are predominantly metaluminous. These authors gave granitic rocks of Papua, New Guinea, as a modern example. Continental-arc granitoids are rocks of magmatic arcs formed on a continent owing to subduction of an oceanic plate beneath the continent. These granitoids contain biotite, hornblende, and epidote, have a silica range of 62-76 percent, and are metaluminous and peraluminous. The granitic rocks of the Sierra Nevada and Idaho Batholiths are given as modern examples (Maniar and Piccoli, 1989).

The tectonic discrimination diagram (fig. 7) is after Batchelor and Bowden (1985), based on the multicationic diagram of de la Roche and others (1980) and the tectonomag- 
matic divisions for granitoid rocks proposed by Pitcher (1982). In the multicationic approach, all major cations in the rock ( $\mathrm{Si}, \mathrm{Na}, \mathrm{K}, \mathrm{Fe}, \mathrm{Ti}, \mathrm{Ca}, \mathrm{Mg}, \mathrm{Al}$ ) are employed in establishing the petrogenetic-tectonic discrimination for granitoids. The distribution of the compositional fields for McCall granitoids in figure 7 indicates a sequential progression in tectonic conditions from precollision granitoids formed at about $90 \mathrm{Ma}$ (tonalite of Payette River) to syncollision granitoids that represent anatectic melts formed about $85 \mathrm{Ma}$ (granodiorite of Box Lake) and at about $83 \mathrm{Ma}$ (monzogranite of Lick Creek).

In summary, it appears that the transition from older tonalite of Payette River through leucogranodiorite of Jumbo Creek and granodiorite of Box Lake to the younger monzogranite of Lick Creek represents a transition from dominantly I-type, igneous source rocks, perhaps with a mantle component, to purely igneous source rocks, and finally to crustal source rocks that may have a significant metasedimentary component. As noted by Cobbing (2000), the M-, I- and S-type categories of granitoids reflect a progressive increase in the proportion of more ancient crustal materials in their generation.

\section{Genesis of Magmas}

\section{Magma Genesis and Plate Tectonics}

Granitoid magmas may be formed by differentiation of mantle-derived basalts, by partial fusion of deep crustal rocks,

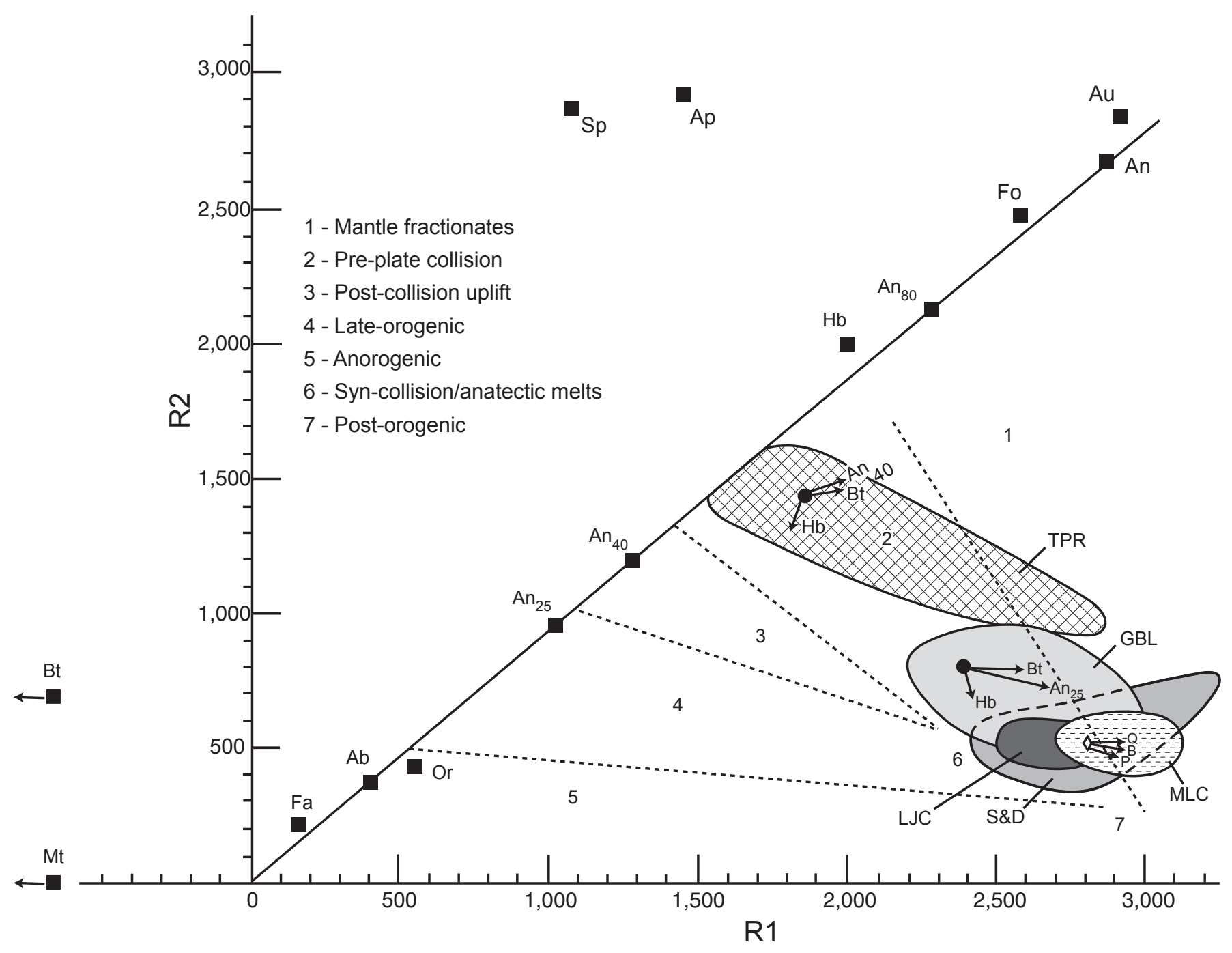

Figure 7. Compositions of granitoid rocks of the McCall area plotted on the R1-R2 multicationic diagram of Batchelor and Bowden (1985). This tectonic discrimination diagram shows fields for tonalite of Payette River (TPR), granodiorite of Box Lake (GBL), leucogranodiorite sills and dikes in tonalite of Payette River (S\&D), leucogranodiorite of Jumbo Creek (LJC), and monzogranite of Lick Creek (MLC). Fractional crystallization vectors are discussed in the text. Mineral abbreviations: Au, augite; An, anorthite; Fo, forsterite, Sp, sphene, $\mathrm{Ap}$, apatite, $\mathrm{Hb}$, hornblende; $\mathrm{Ab}$, albite, Or, orthoclase, Fa, fayalite; $\mathrm{Mt}$, magnetite; $\mathrm{Bt}$, biotite. 
or by interaction of melts from mantle and crustal sources (Wyllie and Rutter, 1988). The potential sites of the generation of calc-alkaline granitoid magmas are in the deep crust, in subducted oceanic crust, in the mantle wedge above a subducted lithospheric slab, or by complex processes involving material from all three environments. The relationships between these magma-generating processes and plate tectonics have been widely discussed. Wyllie (1988) stated that plate tectonics provides the framework for generation of different suites of rocks and for moving rock masses into the pressuretemperature conditions necessary for magma genesis. He demonstrated these relationships by constructing petrological cross sections for various tectonic environments by transferring experimentally derived phase boundaries for source rocks onto assumed thermal structures for locales for magma genesis in the upper mantle and lower crust (fig. 8). The following discussion, based in part on the Wyllie (1988) and Wyllie and Rutter (1988) models, centers on the generation of tonalite, granodiorite, and monzogranite magmas for the McCall area in a tectonic setting.

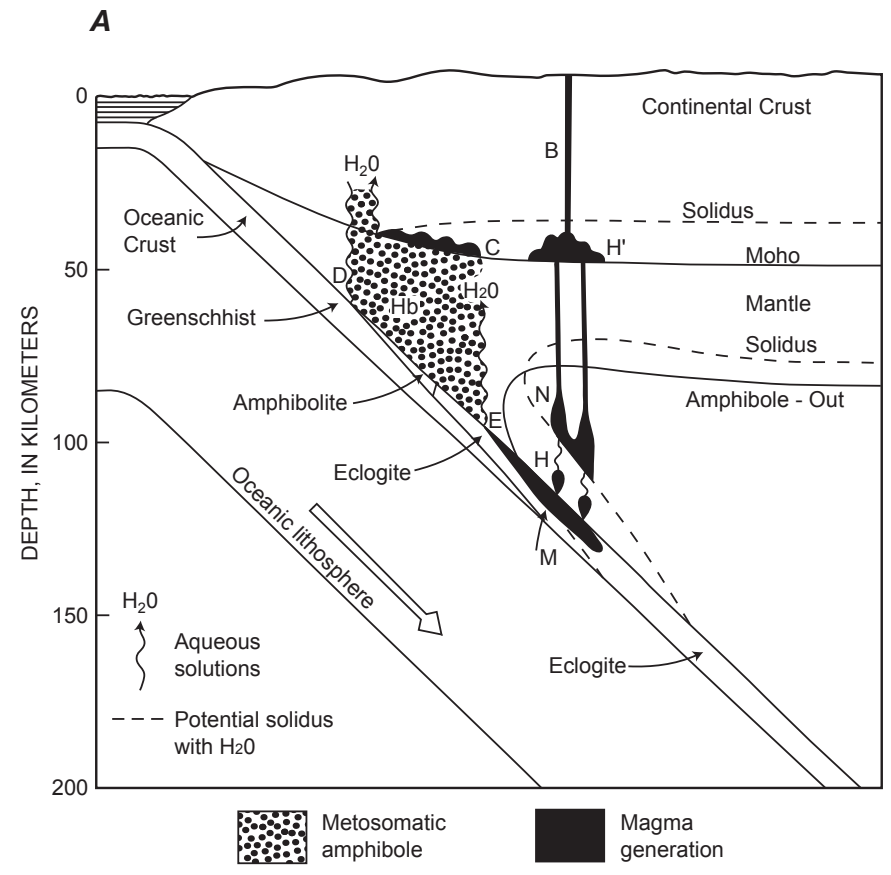

The application of plate tectonic-magma genesis relationships to the Idaho Batholith has been dealt with in only a cursory way. Foster and others (2001) stated that the Bitterroot lobe of the Idaho Batholith formed during crustal thickening and subsequent extension of the hinterland of the Cordilleran orogen. The accretion and subduction event and the generation and emplacement of plutonic units of the Idaho Batholith that are east of the Salmon River suture zone in the McCall area are temporally and spatially related; thus the genesis of tonalite, granodiorite, and monzogranite magmas can be set in a plate-tectonic framework.

\section{Plate-Tectonic Regime of the McCall Area, 150-50 Ma}

The subduction of the various oceanic plates (Farallon, Kula, and Vancouver) and the Blue Mountains island arc beneath the overriding North American plate along the western margin of pre-Cretaceous North America has been

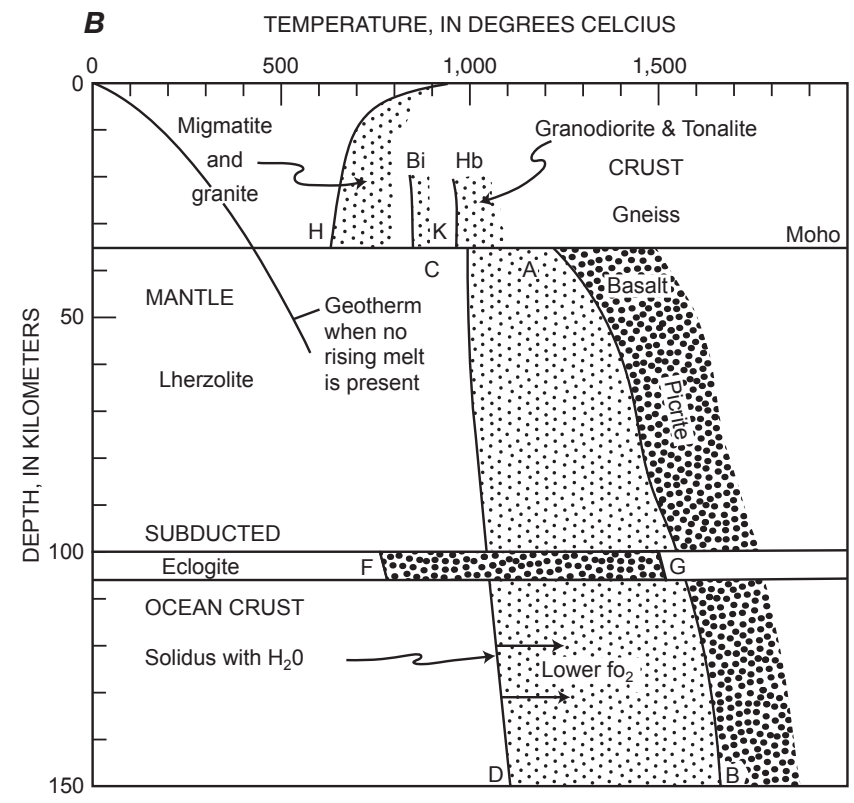

Figure 8. Diagrams showing conditions for magma generation in the crust and upper mantle. A, Petrologic structure for convergent plate boundary region with relatively warm crust and warm mantle wedge (after Wyllie and Rutter, 1988). B, The major sites of magma generation (stippled) in continental crust, mantle and subducted oceanic crust (after Wyllie and Rutter, 1988). In A, dashed lines are solidus curves for various rock types; magma is generated where vapor occurs within these boundaries. Vapor rising from oceanic crust undergoing dehydration reactions in the conversion from greenschist-facies to amphibolite and eclogite causes amphibolitization of the region $\mathrm{D}-\mathrm{E}$ of the mantle wedge and melting of continental crust at $\mathrm{C}$, which is equivalent to curve $\mathrm{H}$ in $\mathrm{B}$, the vapor-saturated solidus for granitic gneiss of the continental crust. In the absence of aqueous vapor, continental rocks begin to melt in dehydration reactions where hydrous minerals release $\mathrm{H}_{2} \mathrm{O}$ for formation of water-undersaturated melts. Reactions involving biotite and hornblende are located near $\mathrm{K}$ in $\mathrm{B}$. Melt $\mathrm{M}$ in A represents melted oceanic crust, which forms in the temperature interval $\mathrm{F}-\mathrm{G}$ in $\mathrm{B}$. Melt $\mathrm{M}$ reacts with overlying mantle wedge at $\mathrm{H}$ and releases aqueous vapor that causes melting as the vapor crosses the mantle solidus at $\mathrm{N}$ and $\mathrm{C}-\mathrm{D}$ in $\mathrm{B}$. Magma rising from $\mathrm{N}$ may provide sufficient heat to cause melting of the lower crust at $\mathrm{H}^{\prime}$. Line $\mathrm{A}-\mathrm{B}$ in $B$ is the solidus for vapor-free mantle peridotite at much higher temperatures. 
described by Engebretson and others (1984) and, for the latitude of McCall, by Vallier (1995). Variations in the modes, geometry, and rates of this subduction were the major tectonic controls for the evolution of the Sevier orogeny (Livaccari, 1991). The early stages of that orogeny (120-80 Ma) were characterized by the development of a magmatic arc in the thickened hinterland and fold-and-thrust belts in the foreland to the east. The later stages (80-45 Ma) involved migration of the locus of deformation and magmatism into the Laramide Rocky Mountain foreland (Hamilton, 1988a; Allmendinger, 1992; Livaccari, 1991).

Before about $150 \mathrm{Ma}$, the Blue Mountains island arc was completely assembled of its five subterranes. The arc was intruded by calc-alkaline plutons in the period 155$115 \mathrm{Ma}$, apparently emplaced into "thickened" crust (Vallier, 1995). The Blue Mountains island arc lay parallel to North America and continued to migrate northward with the continent during this period, according to Vallier (1995). The accretion of the arc to North America probably began in Late Jurassic or Early Cretaceous time, but the major part of the accretion occurred during the period 120-115 Ma (Vallier, 1995). The arc was amalgamated to North America by $115 \mathrm{Ma}$, and subduction was then located outboard of the newly accreted terrane (Vallier, 1995). Arc magmatism and fold-thrust deformation began about $120 \mathrm{Ma}$ and intensified in the period 105-100 Ma because of moderate increase in the convergence rate of the Farallon and North American plates (Livaccari, 1991; Engebretson and others, 1984). The major pulse of tonalite plutonism, including emplacement of the tonalite of Payette River, occurred during the period 120-80 Ma (Livaccari, 1991; Foster and others, 2001); ages of these tonalite plutons become progressively younger from west to east (Fleck and Criss, 1985; Criss and Fleck, 1987). Tonalite plutons older than $95 \mathrm{Ma}$ were intruded into the newly accreted oceanic crust $\left(\mathrm{Sr}_{\mathrm{i}}<0.7045\right)$ west of the Salmon River suture zone; tonalite plutons younger than 95 $\mathrm{Ma}$, having isotopic signatures indicative of derivation from or interaction with ancient crust $\left(\mathrm{Sr}_{\mathrm{i}}>0.7060\right)$, were intruded east of the Salmon River suture zone (Farmer and DePaolo, 1983; Fleck and Criss, 1985; Criss and Fleck, 1987; Miller and Barton, 1990).

As a result of the intensification of magmatism and deformation in the period 105-100 Ma, there was an eastward shift and increase in the vigor of arc magmatism and an increase in subduction-induced heating of the hinterland crust (Livaccari, 1991; Miller and Barton, 1990). Compressive plate-convergence reduced lithosphere strength, allowing more effective thickening of the hinterland crust (Patino-Douce and others, 1990; Foster and others, 2001) and topographic uplift by telescoping of the thermally weakened zone, all of which characterize the process of A-type subduction (Howell, 1989). Allmendinger (1992) emphasized that the tectonic compression resulting from the plate interaction was the driving mechanism for horizontal shortening and vertical thickening of the crust and the consequent isostatically driven uplift of the hinterland and gravity-induced, cratonward propagation of the Cordilleran thrust belt. As the uplifted region continued to grow laterally by overthrusting, the culmination of the deformation produced a peak of hinterland metamorphism at 90-70 Ma (Livaccari, 1991). Peraluminous granites, indicative of a rising geothermal gradient, crustal thickening, and anatexis, were intruded into the magmatic arc during the period 90-70 Ma (Hamilton, 1988a; Livaccari, 1991; Allmendinger, 1992).

\section{Granodiorite Magmas}

The leucogranodiorite of Jumbo Creek and the granodiorite of Box Lake have chemical characteristics gradational with the monzogranite of Lick Creek (table 2; fig. 6 ), which suggests that the granodiorites were formed by partial melting processes similar to those that formed the monzogranite of Lick Creek. The compositional distinction between the three rock types is likely the result of chemical and mineralogical differences in the source regions of the pre-Cretaceous continental margin from which the magmas were derived by partial melting. The clear age distinction between the leucogranodiorite of Jumbo Creek (94 Ma) and granodiorite of Box Lake ( $85 \mathrm{Ma})$ indicates that granodiorite magma was produced in two separate events, but from similar source materials.

The contact relations between the granodiorite of Box Lake and monzogranite of Lick Creek suggest that granodiorite and monzogranite magmas were produced in the same thermal cycle of magma genesis. The lack of interlayering and crosscutting field relationships between the granodiorite and monzogranite implies that there was no lateral intermingling of the two magma types.

On the basis of experimental studies, Piwinskii and Wyllie (1968) and Robertson and Wyllie (1971) showed that production of granodiorite magmas for reasonable crustal models regarding water content of crustal source materials (water undersaturated magma) requires temperatures of $1,000-1,100^{\circ} \mathrm{C}$. They considered that such high temperatures make it improbable that granodiorite magmas can be generated by partial melting in the crust. However, several factors not considered in the experimental studies that favor generation of granodiorite magmas under reasonable crustal conditions are: (1) the possibility that source materials contain enough water and/or hydrous minerals to saturate the magma, yielding temperatures of about $900-950^{\circ} \mathrm{C}$; (2) relatively high crustal temperatures may have existed in the crust in the region of magma formation in the period 94-85 Ma because of unique tectonic conditions that fostered overthrusting, horizontal shortening, vertical thickening, and subduction-induced heating of the crust - temperatures of about $1,000^{\circ} \mathrm{C}$ existed in the crust at the time of formation of tonalite magmas, as discussed below; and (3) optimal source-rock fertility (Thompson, 1996) and the presence of significant amounts of biotite, which favors biotite dehydration melting and rapid production of magma (Clemens and Vielzeuf, 1987) in source rocks. These factors 
are discussed in greater detail farther on in the discussion of the origin of tonalite and monzogranite magmas.

In summary, the conditions for generation of the leucogranodiorite magma are partial melting of water-saturated or near-saturated, biotite-rich, pre-Cretaceous metasedimentary rocks of the western edge of the North America Plate, in or slightly to the east of the Salmon River suture zone at $94 \mathrm{Ma}$. The partial melting occurred at temperatures of about $950^{\circ} \mathrm{C}$ and pressures of about 6-8 kbar, equivalent to depths of about $25-30 \mathrm{~km}$. The physical conditions for the formation of the granodiorite of Box Lake and for the monzogranite of Lick Creek are believed to be roughly similar. The two nearly contemporaneous magmas probably sampled source regions that were separated from one another in a horizontal sense, that is, the source regions were distributed in a mafic to felsic arrangement from west to east. Similar reasoning was used by Silver and Chappel (1988) to account for the compositional systematics of the plutonic units of the Peninsular Ranges Batholith.

\section{Tonalite Magmas}

\section{General Statement}

Wyllie (1988) and Clarke (1992) suggested four possible alternatives for the origin of tonalities: (1) they are products of fractional crystallization of andesitic magmas, the characteristic volcanic rock of convergent plate margins (B in fig. $8 B$ ); (2) they originate from underplating and melting of crustal rocks by mafic magmas ( $\mathrm{H}^{\prime}$ in fig. $8 A$ ), (3) they do not represent magmas at all, but rather are liquid-crystal mushes in which the liquid is granitic and the crystals are dioritic and represent restite material; or (4) they are the refractory residuum of partial melting of quartzo-feldspathic rock.

The widespread distribution of tonalite in the Cordilleran batholiths (for example, Idaho, Peninsular Ranges) suggests that a single, major process yielding primary tonalite magma, tied to plate-tectonic processes, is responsible for tonalite magmatism. On the other hand, the broad variability in the lithologic character and chemistry of tonalities, the fact that they undergo polybaric and polythermal fractional crystallization en route to their site of intrusion, and the fact that they must interact with country rocks on their slow ascent suggested to Clarke (1992) that "no amount of investigation of their phase relations is going to help determine the nature of their source." In spite of Clarke's caution, data about potential source rocks, their phase relations, and the thermal structure of convergent plate margins may provide information about the conditions that produced the tonalite of Payette River.

\section{Source Materials}

Wyllie (1977) and Clarke (1992) pointed out that the high liquidus temperatures for tonalite magmas, $950-1,000^{\circ} \mathrm{C}$ with excess $\mathrm{H}_{2} \mathrm{O}$ and about $1,100^{\circ} \mathrm{C}$ for 2 percent water, preclude their formation by melting of crustal rocks of normal thickness ( 30-40 km) under normal regional metamorphic conditions. However, tonalite magmas could be formed by partial melting of appropriate source rocks in a thickened crust ( $45-60 \mathrm{~km})$ under normal regional metamorphic conditions, as advocated by Zen (1988).

Information about the nature of the crust of the accreted and subducted Blue Mountains island-arc terrane (Vallier, 1995) can be used to constrain the composition of oceanic crust subducted west of the Idaho Batholith in Late Cretaceous time. Briefly, the Blue Mountains region constitutes a complex, multigenerational, intraoceanic volcanic arc consisting partly of igneous rocks, mostly tonalite and trondhjemite, amphibolite, volcanic-arc sediments, and marine sedimentary rocks. Additional igneous components of the island-arc complex are gabbro, quartz diorite, and diorite intrusive rocks, diabase dikes, and both mafic and silicic flows. The early (late Paleozoic through Triassic) intrusive and volcanic rocks are mainly tholeiitic, and the later (Jurassic through Cretaceous rocks) are calc-alkaline (Vallier, 1995). All of these volcanic and intrusive rocks have initial $\mathrm{Sr}$ isotopic ratios of $<0.7045$ (Robert Fleck, oral commun., 2002). These rocks were subducted beneath the North American continent in the period 120-100 Ma and, because of density considerations (Howell, 1989), much of this material may have been underplated to the continent. Ellis and others (1999) have shown that accretion of small terranes can cause crustal-scale fold nappes and shear zones, with accompanying underplating and/or frontal accretion. The subducted tonalitic-trondhjemitic rocks of the Blue Mountains island-arc terrane are likely source rocks for the formation of the tonalite of Payette River.

\section{Tonalite Magma Formation}

In the thermal-melting model illustrated in figure $8 \mathrm{~A}$, various rock masses are shown to a depth of about $150 \mathrm{~km}$ and a steep $\left(45^{\circ}\right)$ inclination of the downgoing slab is assumed. Hamilton (1988a) and Livaccari and Perry (1993) suggest that subduction was steep during slow convergence in the period 120-80 Ma and that convergence then accelerated, causing shallowing or possibly flattening of the subducted slab, in the period 80-60 Ma because the slab could not sink out of the way of the advancing continent or perhaps because of subduction and underplating of buoyant oceanic plateaus (that is, the Blue Mountains island arc).

Zen (1988) gave petrographic evidence for the magmatic origin of epidote in Late Cretaceous tonalite plutons in the western Cordillera. In the McCall area, Zen studied the Round Valley pluton (110 Ma), which is located about $15 \mathrm{~km}$ west of the Salmon River suture zone. From experimental data on the stability of epidote and quartz in tonalite magma, he concluded that magmatic epidote in tonalite indicates a pressure of consolidation of not less than $6 \mathrm{kbar}$, which equates to emplacement depths for the tonalite plutons of 20 to $30 \mathrm{~km}$. He also estimated crustal 
thickness $(45-60 \mathrm{~km})$ and geothermal gradients $\left(20-30^{\circ} \mathrm{C} /\right.$ $\mathrm{km})$ at the time of emplacement of the tonalite plutons, and he concluded that the tonalite magma could have formed by partial melting of the lower crust. This model suggests that the composition of most of the lower crust of the Blue Mountains island-arc terrane west of the Salmon River suture zone was tonalite because tonalite is the predominant rock type of plutons that intruded the Blue Mountains terrane. More siliceous granitoids, which would have required more siliceous source rocks to have formed by partial melting at the temperatures required for formation of tonalite magma, are extremely rare or absent.

The generation of tonalite magma by partial melting of tonalitic and amphibolitic source rocks is shown in figure $9 \mathrm{~A}$, where $20^{\circ} \mathrm{C} / \mathrm{km}, 25^{\circ} \mathrm{C} / \mathrm{km}$, and $30^{\circ} \mathrm{C} / \mathrm{km}$ geothermal gradients are superimposed on the phase diagram for tonalite. Dehy- dration melting experiments on tonalite and amphibolite (Wyllie and others, 1997; and Wyllie and Rutter, 1988) show that biotite and amphibole contribute to the melting in successive steps and that melt volumes approaching 50 percent are produced when rocks are heated from about $800^{\circ} \mathrm{C}$ to about $950-975^{\circ} \mathrm{C}$. The partial melting of tonalite and amphibolite source rocks, as depicted in figure $9 \mathrm{~A}$, was likely responsible for the generation of the voluminous tonalite plutons and amphibolite units of the Blue Mountains islandarc terrane and the tonalite of Payette River.

The partial melting of tonalite and amphibolite source rocks in a thickened crust by normal metamorphic heating is probably an oversimplified melting model for the origin of the tonalite of Payette River. Measured strontium ratios of the tonalite of Payette River (Fleck and Criss, this volume, chapter 2) suggest that hybridization involving significant amounts of
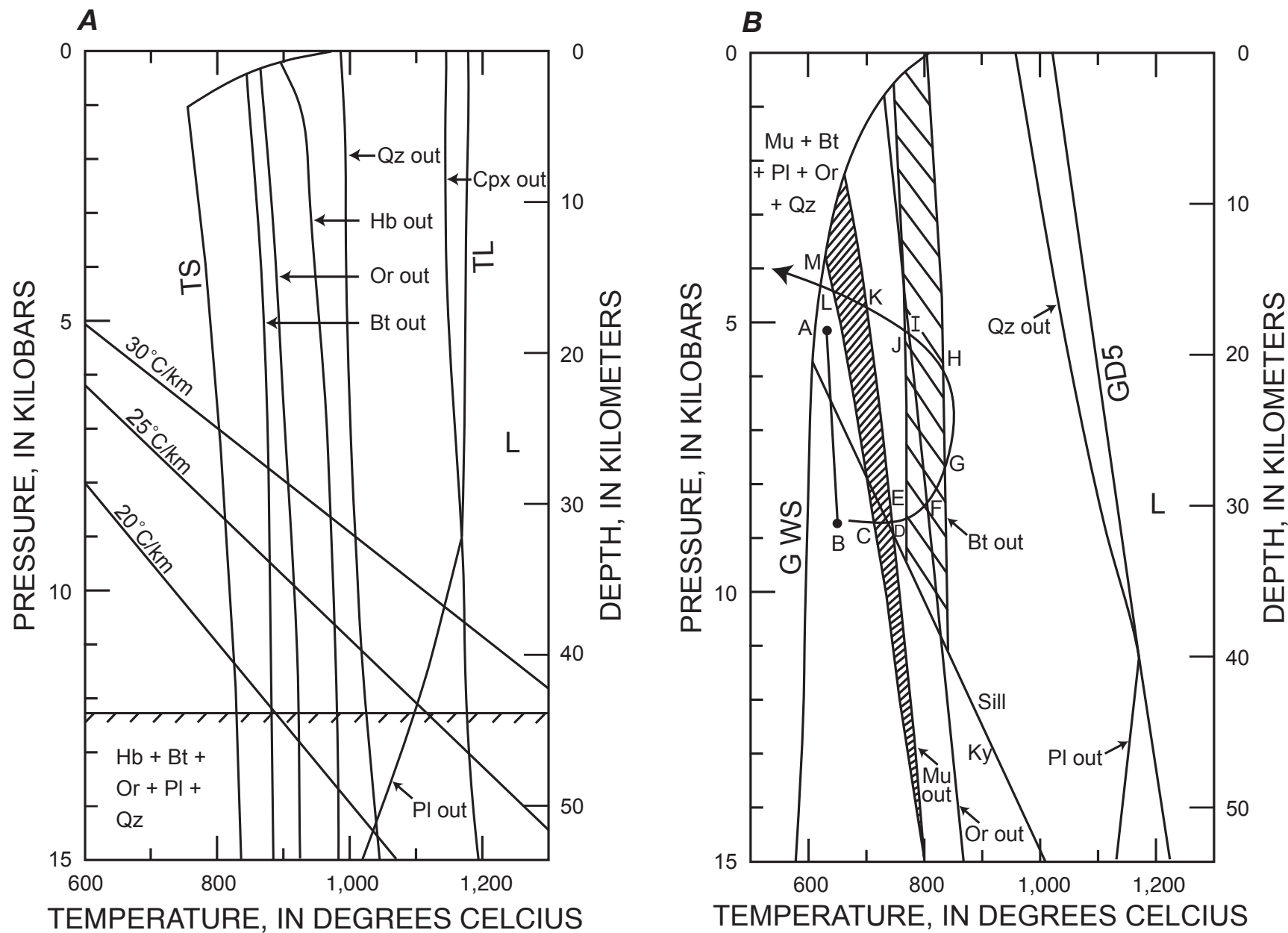

Figure 9. Phase diagrams applicable to plutonic units of the Idaho Batholith near McCall, Idaho. Abbreviations: Hb, hornblende; Bt, biotite; Or, orthoclase; PI, plagioclase; 0z, quartz; Cpx, clinopyroxene; Sill, sillimanite; Ky, kyanite; GDS, granite dry solidus; GWS, granite wet solidus; TS, tonalite solidus; TL, tonalite liquidus; $L$, liquid. $A$, Phase diagram for tonalite without excess vapor, but with sufficient water to hydrate rock with formation of biotite and hornblende, after Wyllie and Rutter (1988). Cross-hatched horizontal line represents top of crustal section believed to have been partially melted to produce tonalite magmas, after Zen (1988). B, Phase diagram for $\mathrm{H} 20$-saturated and dehydration melting for muscovite-biotite granite, after Thompson (1996). Fine ruling shows P-T conditions for dehydration melting of muscovite (Mu); coarse ruling shows $\mathrm{P}-\mathrm{T}$ conditions for dehydration melting of biotite (Bt). The crustal thickening (A-B)-melting (C-G)crystallization (H-M) path follows Brown (1994). 
continental crust appears to be appropriate for the origin of McCall tonalite magmas.

Such a process, a modification of the partial melting of thickened tonalite-amphibolite crust due to regional metamorphic heating, can be visualized in figure $8 A$ at points $\mathrm{C}$ and H'. Wyllie (1988) noted that the deep continental crust, having an average composition close to andesite, provides a unique magmatic hearth for generation of tonalite magma. At point $\mathrm{C}$, tonalitic and amphibolitic source rocks at the base of the continental crust are partially melted by regional metamorphic crustal heating, rising basalt magmas, and perhaps by volatile flux rising from the downgoing slab. In addition, vapor-absent dehydration melting of gneisses at the base of the crust (H') by magmas formed in the downgoing oceanic crust $(\mathrm{M})$ or in the mantle $(\mathrm{N})$ may also yield tonalite magmas. Constraints on the latter process include the appropriate potential crustal source rocks, such as tonalites and amphibolites, as well as temperatures that reach at least $1,100^{\circ} \mathrm{C}$ with a small amount of water.

Miller and Barton (1990) state that the tonalite "M/wP" plutons of the Idaho Batholith require a major continental crustal component to produce their major-element chemistry and mineralogy, which is consistent with an interpretation involving basalt magmas entering the continental crust and hybridizing to form tonalite plutons. Hyndman and Foster (1988) described mafic dikes in tonalite at the northern margin of the Bitteroot lobe of the Idaho Batholith and ascribed the dikes to basalt magmas that were emplaced into the base of the crust, where they were instrumental in the formation of tonalite magmas. Similar dikes have not been found in the McCall area, but the fine-grained, gneissic mafic inclusions in the tonalite of Payette River may represent clots of subcrustal magma or they may be remnants of the deep crustal rocks that were partially melted to yield tonalite magma.

Whereas the above discussion offers no hard models for the formation of tonalite magma in the McCall region, it summarizes possible source regions and mechanisms of magma formation within a plate-tectonic framework. Zen's (1988) model for the formation of tonalite magma west of the Salmon River suture zone by dehydration melting may be ascribed to "thickening" of the accreted crust by accretion (A-type subduction) processes. The accretion added appropriate source rocks, such as those in the Blue Mountains island-arc terrane, to the edge of the North American Plate. After accretion, the tonalite and amphibolite rocks of the Blue Mountains island-arc terrane constituted part of the downgoing slab and they were subducted, and perhaps underplated, beneath the North American continent in the period 120-100 Ma. As shown in figure $9 \mathrm{~A}$, partial melting of a tonalite or amphibolite source region in a crust 45 to $60 \mathrm{~km}$ thick could well have taken place under normal geothermal gradients. Such a model requires no additional heat source, such as introduction of basalt magmas from mantle source regions. Patino-Douce and others (1990) noted that mafic rocks associated with the Sevier granitoid intrusions are virtually unknown, except for the Idaho Batholith case. They concluded that influx of mantle-derived magmas into the Cordilleran crust was neither a major factor nor a requisite for large-scale ana- texis of the crust. The relatively high ${ }^{87} \mathrm{Sr} /{ }^{86} \mathrm{Sr}$ ratios of the tonalite of Payette River indicate that the tonalite magmas interacted with rocks of the continental crust; these may have been interleaved with the tonalitic rocks of the source region during thickening and A-type subduction, or they may have been part of the roof above the subducted and underplated tonalitic/amphibolitic source rocks.

\section{Monzogranite Magmas}

\section{General Statement}

Felsic granitoid plutons are major components of batholiths formed in continental-arc and continental-collision plate-tectonic settings. There is widespread agreement that the more felsic granitoid magmas, including peraluminous types, form from partial melting of continental crust. Two simple explanations for genesis of felsic granitoids are (1) that partial melting of the lower continental crust is driven by heat generated by mafic magmas derived from a subduction zone and/or (2) that tectonic thickening of the crust provides a unique thermal structure that promotes partial melting of the lower or middle continental crust. Just as a similar argument was made for tonalite magmas, the widespread distribution of peraluminous granites suggests that a single major process, tied to plate-tectonic processes, was responsible for generating the huge volumes of peraluminous granites in the Idaho Batholith.

Important factors that bear on the genesis of monzogranite plutons in the Idaho Batholith are (1) the tectonic conditions at the time of magma generation, particularly the role and implications of thickening of the continental crust; (2) the petrologic character of the lower crust (potential source rocks) in the area of the Idaho Batholith at the time of monzogranite emplacement, that is, what was the fertility of these rocks with respect to generation of monzogranite magma?; and (3) the phase relations of two important mineral phases in the monzogranites, muscovite and biotite, and their bearing on the origin of magmas. In addition, important questions that bear on the origin of the monzogranite magmas are (4) why is there so little textural and mineralogical variation and zoning in the monzogranite of Lick Creek as compared to granitoid plutons in other Cordilleran batholiths such as the Sierra Nevada Batholith?; and (5) what is the significance of the lack of enclaves (xenoliths of country rocks, restite refractory residues, and mafic enclaves) in the monzogranite of Lick Creek?

\section{Crustal Thickening and Thermal Implications for Formation of Monzogranite Magma}

Due to moderate increase in the convergence rate of the Farallon and North American Plates (Engebretson and others, 1984) and increase in the rate of subduction (Miller and oth- 
ers, 1992), which probably reached its peak in the period 105$100 \mathrm{Ma}$ (Patino-Douce and others, 1990; Foster and others, 2001), thickening of the continental crust was concentrated in the hinterland of the Sevier orogenic belt by processes of A-type subduction. Crustal thickness may have reached a maximum of $60 \mathrm{~km}$, was accompanied by ultrametamorphism and anatexis, and was followed by denudation faulting, extension, and uplift (Patino-Douce and others, 1990).

Several studies have calculated geotherms and the pressure-temperature-time paths followed by rocks during episodes of continental thickening, in which hot deeper rocks are thrust over colder rocks (for example, England and Thompson, 1986; Thompson, 1999; DeYoreo and others, 1989; Patino-Douce and others, 1990). These studies conclude that extensive melting of the lower crust is a likely result of large-scale continental thickening, even in the absence of anomalous, advective heat transfer from the mantle. The volume of melt generated is a function of mantle heat flux, the temperatures achieved, and the thickness of the thrust sheet. England and Thompson (1986) stated that the highest geotherms are produced after thickening, when the subcrustal heat flux is high, and/or when there is a sizeable interval between thickening and the onset of crustal thinning. In addition to altering geotherms, crustal thickening can bury more water-rich rocks, originally at shallow crustal levels, to depths up to $35 \mathrm{~km}$, and the consequent dehydration reactions can liberate significant amounts of water. In addition to the thermal consequences of crustal thickening, other sources of crustal heat that can contribute to crustal melting are radiogenic heat, injected hot granite, heating of a thickened continental root by adjacent hot mantle, and intrusion of mantle-derived basalt magma (Thompson, 1999). Ponded basalt magma at the base of the crust can induce widespread melting in fertile rock types (Huppert and Sparks, 1988; Thompson, 1999). Clemens and Vielzeuf (1987) stated that unless the tectonic conditions of thickening allow for the introduction of relatively large amounts of pore (free) water into the lower crust, significant melting will not take place without additional heat input from subcrustal sources. This condition would be maximized if thickening occurred by thrusting and the lower plate contained low-grade metamorphic or sedimentary rocks, which would provide $\mathrm{H}_{2} \mathrm{O}$ for partial melting by dehydration reactions involving hydrous minerals. However, Clemens and Vielzeuf (1987) concluded that significant quantities of crustal melt would be produced only where there is extra heat input from mantle sources. In contrast, Patino-Douce and others (1990) suggested that regional anatexis is an end product of classical Barrovian metamorphism that results from crustal thickening, but mobile granitoid magmas are produced only if the thickening ratio (maximum crustal thickness attained/original crustal thickness) exceeds 1.5 , even in the absence of a free $\mathrm{H}_{2} \mathrm{O}$-rich phase.

\section{Source Rocks and Fertility}

The rocks of the middle and deep crust beneath the future site of the Idaho Batholith at 100 Ma can only be surmised from available field data on rocks found within and beneath the Idaho Batholith. About $50 \mathrm{~km}$ northeast of McCall, Proterozoic quartz-feldspar-muscovite-biotite migmatitic gneisses and coarse-grained schists consisting largely of biotite, muscovite, plagioclase, and quartz form sub-Belt crystalline rocks. In the same area, metamorphosed argillite, siltite, sandy carbonate, and quartzite of the Middle Proterozoic Yellowjacket Formation and vitreous white quartzite of the Hoodoo Quartzite form roof rocks of the batholith (Hamilton, 1988a; Cater and others, 1973). Along its northeastern margin, the Idaho Batholith was emplaced into pre-Belt basement gneisses and into sillimanite-zone pelitic schists of the Middle Proterozoic Prichard Formation. The batholith was emplaced below most or all of the Belt Supergroup, approximately 17-21 km thick (Hyndman, 1981).

The exceptionally large volumes of monzogranite in the Idaho Batholith indicate that optimum conditions for generation of crustal melt were met. Factors that govern optimum melt production are (1) source fertility (that is, how close the crustal source rock composition approaches eutectic and minimum melt composition in the haplogranite system, (2) the amount of $\mathrm{H}_{2} \mathrm{O}$ at the melting site in the form of pore water and/or hydrous minerals in the source rock, and (3) the intensity, temperature and location of the heat supply (Thompson, 1999). Optimum fertility depends on micas and feldspars in eutectic proportions in the source rock that will produce the maximum amount of melt at or just above the solidus for the nearest eutectic (Thompson, 1996). The Proterozoic quartz- feldspar-, muscovite- and biotite-bearing migmatitic gneisses and coarse-grained schists consisting largely of biotite, muscovite, plagioclase, and quartz that form sub-Belt crystalline rocks have the necessary mineralogical composition to qualify as source rocks of optimum fertility.

\section{Implications of Muscovite and Biotite Content in Source Rocks}

Wyllie (1977, 1983), Thompson (1996) and PatinoDouce and Johnston (1991) demonstrated the dominance of feldspar-quartz assemblages in source rocks and the important role of hydrous minerals such as muscovite and biotite in crustal melting processes. Primary granite melts with moderate $\mathrm{H}_{2} \mathrm{O}$ content can be generated from crustal rocks that have plagioclase and quartz, and water-saturated granitic liquids can exist through only a few degrees above the solidus. Thus, any increase in temperature produces a $\mathrm{H}_{2} \mathrm{O}$-undersaturated, vapor-absent granite liquid, and the $\mathrm{H}_{2} \mathrm{O}$ content of the melt is governed by the dehydration melting of hydrous minerals such as muscovite and biotite. The water liberated from the dehydration reactions of the micas is dissolved in the melt, and a separate vapor phase is not formed.

Recent experimental studies on the melting of pelitic and other quartzofeldspathic rocks has shown the importance of muscovite and biotite in forming granitic magmas and 
the mechanisms by which such magmas separate from their high-grade residue and migrate to higher crustal levels. PatinoDouce and others (1990) stressed that the entire crust cannot serve as a granitoid source rock. The fertile layer exists within a certain crustal thickness, generally within the middle crust (15-25 km for the Sevier orogenic belt, equivalent to $\mathrm{P}_{\text {total }}$ of $\sim 5 \mathrm{kbar}$ ); rocks at deeper crustal levels are not considered viable protoliths because they are probably refractory granulites. Patino-Douce and others (1990) stressed that widespread dehydration melting requires protoliths rich in hydrous minerals (micas and/or amphiboles) and can thus take place only at crustal levels that were not previously subjected to granulitefacies pressure and temperature conditions. In addition, they stated that dehydration melting corresponds to the pressuretemperature conditions of the amphibolite-to-granulite facies transition; thus granulite may represent restitic assemblages resulting from anatectic events. They concluded that granitoid intrusive complexes composed almost exclusively of peraluminous and K-rich rocks are derived by partial melting of aluminum-rich metamorphic rocks such as muscovite-biotite schists and gneisses.

Clemens and Vielzeuf (1987), Vielzeuf and Holloway (1988), and Patino-Douce and others (1990) noted that muscovite breakdown in the melting of pelites begins at about $650^{\circ} \mathrm{C}$, is complete below $800^{\circ} \mathrm{C}$, and yields only small amounts (no more than 10-15 percent) of melt, which results in the formation of migmatites. In contrast, breakdown of biotite occurs at temperatures of $850-900^{\circ} \mathrm{C}$ and is marked by a dramatic increase in the volume of melt, as much as 40-60 percent melt by volume. Because most pelites at metamorphic grades below granulite grade are biotite rich, pelites and other biotite-rich, quartzofeldspathic rocks are the most fertile and favored source rocks. Clemens and Vielzeuf (1987) described the ideal situation for the formation of peraluminous magmas: under certain conditions of continental collision and crustal thickening, water-rich fluids are introduced into the site of partial melting and significant amounts of melt are produced if temperatures reach about $850^{\circ} \mathrm{C}$. These cool, relatively wet magmas would be relatively immobile, and if melting occurred at a pressure greater than $\sim 3.5 \mathrm{kbar}$ ( $\geq 12 \mathrm{~km}$ depth), muscovite-bearing, syntectonic granite would be formed. In contrast, PatinoDouce and others (1990) concluded that granitoid magmas formed by biotite-induced dehydration melting (water undersaturated) can produce a melt fraction of at least 30 percent, the critical melt fraction necessary for magma mobilization, and there is no need to appeal to introduced water-rich fluids.

\section{Water Content of Monzogranite Magmas and Its Implications}

In an application of experimental data, Hyndman (1981) suggested that muscovite-bearing granites can form only at pressures of $\geq 5 \mathrm{kbar}$ ( $>15 \mathrm{~km}$ ); thus he concluded that if a magma derives all of its water by dehydration melting of muscovite, the melt is undersaturated and will rise no farther than the depth represented by the watersaturated granite solidus. If granite magma formed in rocks containing sillimanite, the depth of formation would be less than $\sim 25 \mathrm{~km}$ (more than $\sim 25 \mathrm{~km}$ if the rocks contained kyanite) and emplacement depth would be about $17 \mathrm{~km}$. He thus reasoned that muscovite-bearing granites probably did not move or intrude upward far from their source rocks. He stated that the felsic granitic rocks of the Idaho Batholith were generated under relatively wet conditions because their bulk composition lies on the minimum melting curve for water-saturated granite at a depth of about $17 \mathrm{~km}(\sim 5$ kbar), and so the magmas apparently formed by partial melting of basement or metasedimentary rocks of the Belt Supergroup that overly the basement.

Although written before the experimental work on partial melting of pelitic rocks, Hyndman's conclusions were prescient regarding the depth of generation and emplacement of muscovite-bearing granitoids of the Idaho Batholith. In light of the roles of muscovite and biotite in experimental partial melting of pelites, perhaps the only modification of his conclusions would be that generation of the monzogranites of the Idaho Batholith probably involved melting of biotite in addition to muscovite. This would imply that monzogranites formed at higher temperatures, presumably at greater depths, and were emplaced to shallower crustal levels than advocated by Hyndman. Hyndmans' conclusions about wet magmas being immobile would be little modified if water-rich fluids were introduced into the site of partial melting, as advocated by Clemens and Vielzeuf (1987).

\section{Monzogranite Magma Formation}

Several factors appear to be critical in evaluating the petrogenesis of monzogranite magma. First, the huge volumes of monzogranite that make up much of the Idaho Batholith suggest the presence of large tracts of fertile source rocks before $100 \mathrm{Ma}$. These probably included muscovite and biotite-bearing pre-Belt basement gneiss and schist that are now exposed locally within and on the margins of the batholith. Pelitic varieties of the Belt Supergroup may also qualify as candidates for source rocks. Second, it seems clear that regional temperatures reached at least $850^{\circ} \mathrm{C}$ and that dehydration melting of biotite was a major and necessary factor. Third, on the basis of arguments for origin of peraluminous granite magmas (Clemens and Vielzeuf, 1987), I conclude that monzogranite magmas were "wet" and that they migrated only a short distance from their source rocks.

Figure $9 B$ shows experimental data for muscovitebiotite granite and a hypothetical pressure-temperaturedepth path for the formation of monzogranite magma in the McCall area. The depth and temperature of the fertile muscovite- and biotite-bearing source rocks of the crust before magma formation were at about $20 \mathrm{~km}$ and a temperature 
of about $625^{\circ} \mathrm{C}$, consistent with the sillimanite-muscovite zone of the amphibolite facies (point A on fig. 9B). The source rocks are assumed to be water undersaturated, thus they are below their solidus. Crustal thickening increases the depth of the source rocks to about $30 \mathrm{~km}$, corresponding to a pressure increase to about 8-9 kbar (point B on fig. 9B). Heating of the crust occurs by thermal relaxation, longer incubation periods, slow erosion rates, low crustal thermal conductivity, and high crustal radiogenic heat production in collision belts (Zen 1988; De Yoreo and others, 1989); Thompson and Connolly 1995). Melting of the source rock begins at point $C$ in figure $9 B$ at about $720^{\circ} \mathrm{C}$ with the initiation of dehydration melting of muscovite; all of the muscovite is consumed at point $\mathrm{D}$. Biotite dehydration melting begins at point $\mathrm{E}$, all of the orthoclase is consumed in the melt as the temperature reaches point $\mathrm{F}$, and the biotite is completely consumed at point $\mathrm{G}$ at a temperature of about $850^{\circ} \mathrm{C}$. At the maximum temperature, the magma consists largely of melted muscovite, biotite, orthoclase, minor plagioclase, and quartz. Upon cooling related to isostatically driven uplift and erosion of the zone of magma in the hinterland, biotite crystallizes in the melt through the temperature range of points $\mathrm{H}-\mathrm{J}$, orthoclase begins to crystallize at point I, and muscovite crystallizes through the temperature interval K-L. A separate vapor phase may be generated between $\mathrm{L}$ and $\mathrm{M}$, and the magma crystallizes at $\mathrm{M}$ at an emplacement depth of about $17 \mathrm{~km}$.

While the anatexis-crystallization scheme described here is hypothetical, it is constrained to some extent by the mineralogy of the monzogranite of Lick Creek and by experimental data for muscovite-biotite granite. The anatexis-crystallization scheme portrayed follows a "counterclockwise" path, where pressure increases, which is typical of orogenic belts in which crustal thickening is followed by erosional exhumation and/or extensional thinning and/ or orogenic collapse (Brown, 1994). The crystallization and decreasing pressure-depth path followed by the experimental monzogranite magma could represent either the effects of uplift and cooling resulting from crustal thickening and denudation of magma generated in place or separation of the magma from source rocks and upward emplacement to shallower levels in the crust.

Partial melting of fertile Proterozoic gneisses was an efficient process; it yielded huge volumes of monzogranite of Lick Creek. The previous discussion also indicates that there was little mineralogical and chemical contrast between source rocks and partial melts. If emplacement of granitic magma to higher crustal levels is largely as a result of the density contrast between melt and restite, then the lack of mineralogical (density) contrast between melt and restite suggests that emplacement of monzogranite magma to higher crustal levels may not have occurred. The near lack of internal structures formed by magma movement, such as lineation and flow foliation (see Kuntz, this volume, chapter 7), suggests that the monzogranite of Lick Creek may have formed largely in place at the site of fertile source rocks.

\section{Further Application of Experimental Data to the Formation of McCall Granitoids}

\section{The System 0-Or-Ab-An- $\mathrm{H}_{2} \mathrm{O}$ and Crystallization Sequence in McCall Granitoids}

Mesonormative compositions of tonalite of Payette River, granodiorite of Box Lake, and monzogranite of Lick Creek are plotted on the fold-out haplogranite (simple, ideal granite) system Q-Or-Ab-An at $\mathrm{P}_{\mathrm{H}_{2} \mathrm{O}}=5 \mathrm{kbar}$ in figure $10 \mathrm{~A}$. For reasons described above, the mesonormative compositions of McCall granitoids offer the best proxy for the components of this phase diagram. The Q-Or-Ab-An- $\mathrm{H}_{2} \mathrm{O}$ system is the best approximation for granitoid rocks having greater than 80 modal and mesonormative percentages of quartz plus plagioclase plus alkali feldspar; thus the system can be applied to most McCall-area granitoids (see table 2), except perhaps the most mafic of the tonalites.

The Q-Or-Ab-An- $\mathrm{H}_{2} \mathrm{O}$ system is not ideal for assessing crystallization of the tonalite of Payette River because the system lacks mafic minerals (pyroxene, hornblende, biotite), and the system may only suggest the crystallization sequence for plagioclase and quartz. The tonalite compositional field plots within the $\mathrm{Pl}+\mathrm{L}$ (plagioclase plus liquid) field in three of the four ternary systems, suggesting that plagioclase was the first mineral to crystallize from tonalite magmas, followed by quartz. This conclusion is in accord with crystal shape and rock textures for tonalite of Payette River.

The compositional field for the granodiorite of Box Lake falls on the $\mathrm{Q}+\mathrm{L}$ and $\mathrm{Pl}+\mathrm{L}$ cotectic lines in the $\mathrm{Q}-\mathrm{Ab}-\mathrm{An}$ and Or-An-Q ternary systems, suggesting that quartz and plagioclase crystallized simultaneously and were followed later by alkali feldspar. The fact that the granodiorite field lies on the plagioclase-quartz cotectic suggests that the bulk composition of granodiorite of Box Lake was controlled by plagioclasequartz-melt equilibria.

The compositional field for monzogranite of Box Lake lies within or mostly within the $\mathrm{Q}+\mathrm{L}$ field in three of the four ternary systems. In terms of liquid paths, this relationship suggests that quartz was the first phase to crystallize from monzogranite magma, followed by plagioclase and/or alkali feldspar.

The compositional fields for the monozgranite of Lick Creek and the granodiorite of Box Lake lie near but to the quartz-rich side of the trend of the ternary minima and eutectics in the Q-Ab-Or system at water pressures of about 1-2 kbar (fig.10A). These compositions can be interpreted in light of experimental data on the partial melting of crustal quartzofeldspathic and pelitic rocks. An example is that provided by Winkler (1979) for the anatexis of a paragneiss, that contained 34 percent $\mathrm{An}_{28}$ and roughly equal proportions ( 20 percent) of alkali feldspar, quartz and biotite, at $\mathrm{P}_{\mathrm{H}_{2} \mathrm{O}}=5 \mathrm{kbar}$ (fig. $10 B$ ). The initial melt has a composition at "a" on figure $10 \mathrm{~B}$ at a temperature of $655^{\circ} \mathrm{C}$. With an increase to $665^{\circ} \mathrm{C}$, 

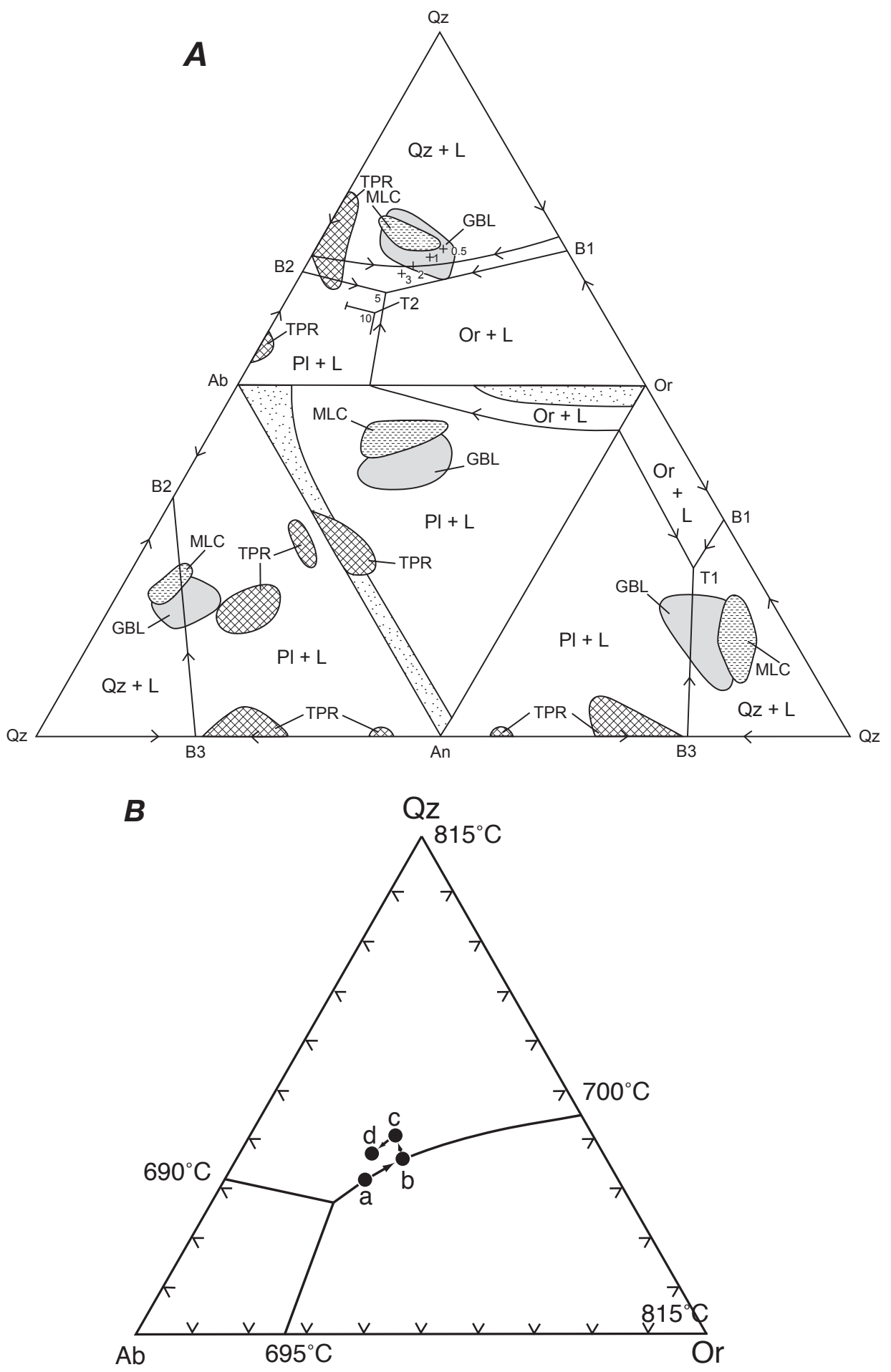

Figure 10. Quartz-plagioclase-orthoclase diagram for plutonic rocks of the Idaho Batholith near McCall, Idaho, and experimental studies. Abbreviations: $0 z$, quartz; Or, orthoclase; $\mathrm{Pl}$, plagioclase; $\mathrm{Ab}$-albite, $\mathrm{An}$, anorthite; $\mathrm{L}$, liquid. $A$, The haplogranite $\left(\mathrm{Oz}-\mathrm{Or}-\mathrm{Ab}-\mathrm{An}_{\mathrm{H}} \mathrm{H} \mathrm{O}\right)$ system at 5 $\mathrm{kbar}$ (data from Ragland, 1989). Mesonormative-minerals composition fields for various plutonic units are shown; number of samples plotted is: tonalite of Payette River (TPR), 11; granodiorite of Box Lake (GBL), 12; monzogranite of Lick Creek (MLC), 12. B, Results of melting experiments at $\mathrm{P}_{\mathrm{H}_{2} \mathrm{O}}=5 \mathrm{Bar}$ on paragneiss after Winkler (1979). Paragneiss shown has composition of 34 percent plagioclase (An28), 20 percent alkali feldspar $\left(A b_{17}\right), 26$ percent quartz, and 20 percent biotite. Letters (a-b-c-d) representing the melting sequence is referred to in the text. 
all of the alkali feldspar is consumed and equal amounts of plagioclase and quartz form the melt on the cotectic at "b". At this point, only $10^{\circ} \mathrm{C}$ above the solidus, melt constitutes about 60 percent of the original rock. With an additional increase of $10^{\circ} \mathrm{C}$, the remaining amount of quartz joins the melt, which moves to composition " $\mathrm{c}$ ", which lies on the $\mathrm{Q}+\mathrm{Pl}+\mathrm{L}+\mathrm{V}$ surface. An additional increase of $40^{\circ} \mathrm{C}$, from $675^{\circ} \mathrm{C}$ to $715^{\circ} \mathrm{C}$, produces complete melting of the plagioclase and the final composition of the melt " $d$ ", which lies within the $\mathrm{Pl}+\mathrm{L}+\mathrm{V}$ space. Winkler stated that incomplete melting of biotite may have been a result of the high $\mathrm{Mg}$ content of the biotite. Use of the example given by Winkler is not meant to imply that magmas for the granodiorite of Box Lake and the monzogranite of Lick Creek formed by partial melting of source rocks having compositions similar to the paragneiss cited, but analysis of the experimental data implies that the monzogranite magma, if formed by anatexis, was derived from materials that were relatively poor in alkali feldspar and relatively rich in plagioclase and quartz.

\section{Assessment of Fractional Crystallization and Magma Mixing for Compositional Variation in McCall-Area Granitoids}

The R1-R2 diagram (fig.7) is useful for assessing fractional crystallization and magma mixing because the change in bulk-rock composition, magma-mixing paths, and fractionation paths can be easily visualized (Batchelor and Bowden, (1985). The R1-R2 composition fields of various McCall-area granitoids form a nearly straight path perpendicular to the $\mathrm{R} 1=\mathrm{R} 2$ line in figure 7 , suggesting possible magma mixing between mafic (tonalite) and felsic (monzogranite) components. However, this relationship requires that the two magma types coexisted in both time and space in order to generate intermediate (granodiorite) magma compositions. The age data discussed above suggests that there was a time interval of 4 to 7 m.y. between the emplacement of the tonalite and monzogranite plutons in the $\mathrm{McC}$ all area, and arguments presented above suggest that the source regions (and the magmas derived from them) were distributed in a mafic to felsic arrangement from west to east. These two factors suggest that magmamixing processes were unlikely in creating the compositional variation in McCall-area granitoids.

The R1-R2 positions of various rock-forming minerals are also shown in figure 7. A fractionation path can be shown by a vector drawn from an R1-R2 bulk-rock composition directly away from the R1-R2 composition of the fractionating phase. If a number of phases fractionate together, then the fractionation vector is the sum of the vectors for each fractionated phase. If crystal fractionation is a significant process, the composition fields of various rock groups should have a shape elongated in a direction away from the main fractionated phase(s).

Significant amounts of hornblende, biotite, and plagioclase $\left(\sim \mathrm{An}_{40}\right)$, in combination, may have been fractionated to form the orientation and elongation of the composition field for the tonalite of Payette River in figure 7. Because these three minerals are major modal phases in the tonalite, fractionation of these phases may have played a major role in creating the broad compositional field for tonalite of Payette River. Biotite, hornblende, and plagioclase $\left(\mathrm{An}_{25}\right)$ may have been important fractionated phases to account for the shape of the composition field for granodiorite of Box Lake. Similarly, the compositional variation for the monzogranite of Lick Creek can be accounted for by limited amounts of fractionation of orthoclase, biotite, and oligoclase.

In summary, crystal fractionation may have played a major role in causing the broad compositional variation in the tonalite of Payette River and a lesser or minor role in causing the limited compositional variation in the monzogranite of Lick Creek.

\section{Some Remaining Questions and Pos- sible Answers}

As noted previously in the discussion of the petrology and field relations, there appears to be a lack of pluton-scale compositional zoning in the monzogranite of Lick Creek when compared, for example, to some of the strongly zoned plutons of the Sierra Nevada Batholith (see, for example, Bateman and others, 1963). Pitcher (1997) noted that compositional zoning is common in I-type granites but rare or weak in S-type granites. He also stated that processes that lead to zoning are sidewall accretion, recharge by magmas of varying composition, and multipulse injection of melts fractionated elsewhere. These processes are much more likely in the I-type granites, where there is a dual input of mantle and crustal sources and the magmas are highly fluidal. S-type granites derived by partial melting of crustal rocks are typically mushy magmas, and their intrusion histories are simple, representing a single or a few draughts from a non-evolving magma source. Thus strong composition-zoned plutons are not expected in this type of granitoid (Pitcher, 1997).

Textural zoning is easily distinguished in the monzogranite of Lick Creek and mapped in the field (fig. 2). Contacts between the textural variants are gradational over distances of hundreds of meters; thus the textural variants are considered to be volumes of a single monzogranite magma that crystallized under slightly different $\mathrm{P}_{\text {tot }}-\mathrm{T}-\mathrm{X}-\mathrm{P}_{\mathrm{H}_{2} \mathrm{O}}$ conditions. An intriguing question concerns the roughly north-south elongation and broadly elongated distribution patterns of the textural variants (fig.2); if the monzogranite magmas were mushy and traveled only short distances (if at all) from their source rocks, could these map patterns reflect original compositional variations or stratigraphy in the source rocks? Another possible factor affecting formation of the varied rock textures, not easily evaluated, could be the water content of fluids rising into the site of magma generation.

The lack of enclaves in the monzogranite of Lick Creek prompts several questions related to the origin 
of monzogranite magma. If the monzogranites formed by dehydration or even "wet" partial melting of pre-Belt metamorphic rocks, and if magmas moved only very short distances from their source rocks, why do we not see at least some evidence of these source rocks as enclaves? Were the source rocks so fertile that they were completely melted? I suggest that these questions can be interpreted in light of the type of source rocks. If there was little mineralogical and chemical contrast between the monzogranite magmas and the extremely fertile source rocks, almost complete melting of source rocks is implied. The absence of enclaves enriched in quartz, cordierite, garnet and aluminum-silicate phases in the monzogranite of Lick Creek is evidence of nearly complete melting of source rocks.

\section{A Conjectural Plate-Tectonic Sce- nario for the Development of the Idaho Batholith Near McCall, Idaho}

The field and age relations of the plutonic units of the Idaho Batholith east of the Salmon River suture zone indicate that magma formation, intrusion, and regional deformation were closely linked in time and space and that they are related to the plate-tectonic development of the western margin of North America in Late Cretaceous time. The variation in the composition and structure of the plutonic units, from older, relatively low ${ }^{87} \mathrm{Sr} /{ }^{86} \mathrm{Sr}$ tonalite plutons that are strongly foliated and lineated in the west, to younger, more felsic, relatively high ${ }^{87} \mathrm{Sr} /{ }^{86} \mathrm{Sr}$ monzogranite plutons that mostly lack internal structures in the east, reflects the waning stages of the Late Cretaceous deformation at the arc-continent boundary. The age information summarized in table 3 suggests that the generation and emplacement of tonalite, granodiorite, and monzogranite plutons took place within a time span of approximately $10 \mathrm{~m}$.y.

Possible tectonic relations between plutonic-rock units and source rocks at the western margin of North America in Late Cretaceous time are illustrated in diagrammatic cross sections in figure 11. At about 115-110 Ma (fig.11A), the North American Plate consisted of Proterozoic basement gneisses (NA) and probably also Proterozoic and younger continental sedimentary rocks (CS). Following the island-arc model by Hamilton (1988b), a fore-arc basin and an accretionary prism probably lay between the accreting Blue Mountains island-arc terrane and the continent. The fore-arc basin and accretionary prism consisted of sediments derived from both the continent and from the Blue Mountains island arc, which was outboard or newly accreted to the continent by $110 \mathrm{Ma}$. There was a moderate increase in the rate of convergence of the Farallon and North American Plates at 105-100 Ma, and the Blue Mountains island-arc terrane was part of the descending Pacific Plate. In addition, there was an increase in subductioninduced conductive heating of the hinterland crust, which reduced lithospheric strength and fostered A-type subduction and crustal thickening (Livaccari (1991).

In the period 100-90 Ma (fig. 11B), the western margin of North America near and east of the Salmon River suture zone was intensely deformed and affected by the modes, geometry, and rates of subduction between the North American plate and various subducted Pacific plates (Engebretson and others, 1984; Livaccari, 1991; Miller and others, 1992). In figure $11 B$, deformation of the accretionary prism, fore-arc basin, and continental sedimentary sequence is shown to take place by A-type subduction, causing thickening of the hinterland. The deformation and thickening of the hinterland eventually caused elevated geotherms at the base of the crust and created the environment for partial melting of various source rocks. The tonalite magmas were derived from partial melting of older igneous rocks, probably tonalites of the subducted Blue Mountains island-arc terrain. The measured strontium-isotope ratios $(0.7082$ to 0.71108$)$ indicate that the tonalite magmas had significant interaction with continentally derived sedimentary and metamorphic rocks. This interaction may have been with rocks in the accretionary prism or perhaps with Proterozoic basement gneisses. The tonalite plutons were emplaced along the Salmon River suture zone in a transpressional tectonic regime (Kuntz, this volume, chapter 7).

In the period 90-85 $\mathrm{Ma}$ (fig. $11 \mathrm{C}$ ), the deformation, thickening, and heating of the hinterland migrated eastward toward the foreland, causing the raising of geotherms in Proterozoic gneissic basement rocks. The granodiorite of Box Lake is believed to represent the partial melting of a mixture of arc-volcanic and continental rocks of the forearc basin. Farther east, partial but nearly complete melting of the gneissic basement rocks formed the monzogranite of Lick Creek.

The age sequence from older, more mafic plutonic rocks eastward to younger, more felsic plutonic rocks reflects the eastward shift in arc magmatism that was characteristic of Cordilleran magmatism throughout the western part of North America in the Late Cretaceous. The mafic to felsic series, as it applies to the McCall granitoids, also represents an eastward spatial transition in source rocks, from subducted tonalite of the Blue Mountains island-arc, to a mixture of arc-volcanic and continental rocks at the arc-continent boundary, to Proterozoic basement gneisses of the North American continent.

\section{Acknowledgments}

I greatly appreciate helicopter and logistical support for field work provided by the Payette National Forest, U.S. Forest Service. Cathryn Allen Manduca, James R. La Fortune, and Catherine Gockley provided able field assistance for this project. This paper benefited from the superb reviews of Keith Howard, Ren Thompson, and Karen Lund. Mary Berger patiently and carefully prepared the figures. 

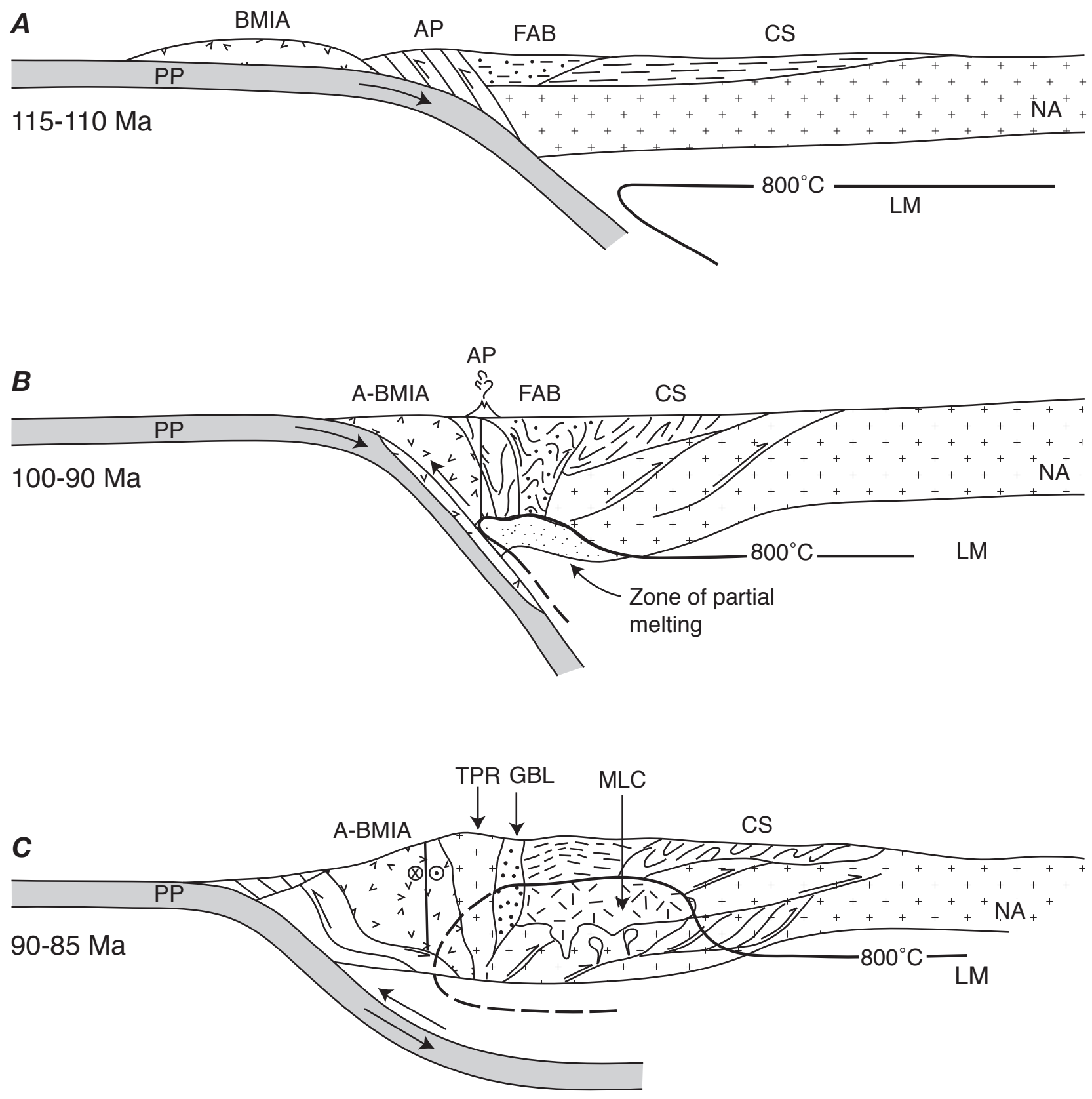

Figure 11. Diagrams showing inferred plate-tectonic conditions, positions of source rocks, and magmatic conditions along the western margin of North America during various time periods: $A, 115-110 \mathrm{Ma} ; B, 100-90 \mathrm{Ma}$, and $C, 90-85 \mathrm{Ma}$. Abbreviations: BMIA, Blue Mountains island-arc terrane; A-BMIA, accreted Blue Mountains island-arc terrane; AP, accretionary prism; FAB, fore-arc basin; CS, continental sedimentary rocks (mainly Middle Proterozoic and lower Paleozoic); PP, oceanic crust of Pacific Plate; NA, basement rocks of the North America Plate; LM, lithospheric mantle; TPR, tonalite of Payette River; GBL, granodiorite of Box Lake; MLC, monzogranite of Lick Creek. Arrows show relative movement between plates and between different parts of the crust in $A, B$, and $C$. Not to scale. 


\section{References Cited}

Allmendinger, R.W., 1992, Fold and thrust tectonics of the western United States exclusive of the accreted terranes, in Burchfiel, B.C., Lipman, P.W., and Hogback, M.L., eds., The Cordilleran orogen; conterminous U.S.: Boulder, Colorado, Geological Society of America, The Geology of North America, v. G-3, p. 583-607.

Armstrong, R.L., Taubeneck, W.H., and Hales, P.O., 1977, $\mathrm{Rb}-\mathrm{Sr}$ and $\mathrm{K}$-Ar geochronometry of Mesozoic granitic rocks and their Sr isotopic composition, Oregon, Washington, and Idaho: Geological Society of America Bulletin, v. 88, p. 397-411.

Atherton, M.P., 1993, Granite magmatism: Journal of the Geological Society of London, v. 150, p. 1009-1023.

Bankey, Vicki, 1992, Complete Bouguer gravity, isostatic residual gravity, and related geophysical maps centered on the Idaho batholith and Challis volcanic field, northwestern United States: U.S. Geological Survey Geophysical Investigations Map GP-995, scale 1:1,000,000.

Barbarin, B., 1990, Granitoids; main petrogenetic classifications in relation to origin and tectonic setting: Geological Journal, v. 25, p. 227-238.

Barth, T.F.W., 1962, Theoretical petrology ( $2^{\text {nd }}$ ed.): New York, John Wiley and Sons, 416 p.

Batchelor, R.A., and Bowden, P., 1985, Petrogenetic interpretation of granitoid rock series using multicationic parameters: Chemical Geology, v. 48, p. 43-55.

Bateman, P.C., Clarke, L.D., Huber, L.K., Moore, J.G., and Rinehart, C.D., 1963, The Sierra Nevada batholith; a synthesis of recent work across the central part: U.S. Geological Survey Professional Paper 414D, 45p.

Brown, M., 1994, The generation, segregation, ascent and emplacement of granite magma; the migmatite to crustally derived granite connection in thickened orogens: Earth Science Reviews, v. 36, p. 83-130.

Cater, F.W., Pinckney, D.M., Hamilton, W.B., Parker, R.L., Weldin, R.D., Close, T.J., and Zilka, N.T., 1973, Mineral resources or the Idaho Primitive Area and vicinity, Idaho: U. S. Geological Survey Bulletin 1304, 431 p.

Chappell, B.W., and Stephens, W.E., 1988, Origin of infracrustal I-type granite magmas: Transactions of the Royal Society of Edinburgh, Earth Sciences, v. 79, p. 71-86.

Chappell, B.W., and White, A.J.R., 1974, Two contrasting granite types: Pacific Geology, v. 8, p. 173-174.

Clarke, D.B., 1992, Granitoid rocks: New York, , Chapman and Hall, Topics in Earth Sciences no. 7, 296 p.
Clemens, J.D., and Vielzeuf, D., 1987, Constraints on melting and magma production in the crust: Earth and Planetary Science Letters, v. 86, p. 287-306.

Cobbing, J., 2000, The geology and mapping of granite batholiths: Berlin, Springer, Lecture Notes in Earth Sciences no. 96, 141 p.

Criss, R.E., and Champion, D.E., 1984, Magnetic properties of granitic rocks from the southern half of the Idaho batholith; influences of hydrothermal alteration and implications for aeromagnetic interpretation: Journal of Geophysical Research, v. 89, p. 1277-1296.

Criss, R.E., and Fleck, R.J., 1987, Petrogenesis, geochronology, and hydrothermal systems of the northern Idaho batholith and adjacent areas based on ${ }^{18} \mathrm{O} /{ }^{16} \mathrm{O}, \mathrm{D} / \mathrm{H},{ }^{87} \mathrm{Sr} /{ }^{86} \mathrm{Sr}, \mathrm{K}-\mathrm{Ar}$ and 40Ar/39Ar studies, in Vallier, T.L., and Brooks, H C., eds., Geology of the Blue Mountains region of Oregon, Idaho, and Washington; the Idaho batholith and its border zone: U.S. Geological Survey Professional Paper 1436, p. 95-138.

de la Roche, H., Leterrier, J., Grand Claude, P., and Marchal, M., 1980, A classification of volcanic and plutonic rocks using R1-R2 diagrams and major-element analyses-its relationships with current nomenclature: Chemical Geology, v. 29, 183-210.

DeYoreo, J.J., Lux, D.R., and Guidotti, C.V., 1989, The role of crustal anatexis and magma migration in the thermal evolution of regions of thickened continental crust, in Daly, J.S., Cliff, R.A., and Yardley, B.W.D., eds., Evolution of metamorphic belts: Geological Society of London Special Publication 43, p. 187-202.

Ellis, S., Beaumont, C., and Pfiffner, O.A., 1999, Geodynamic models of crustal-scale episodic tectonic accretion and underplating in subduction zones: Journal of Geophysical Research, v. 104, p. 15,169-15,190.

Engebretson D.C., Cox, A., and Gordon, R G., 1984, Relative motions between oceanic plates of the Pacific basin: Journal of Geophysical Research, v. 89, p. 10,219-10,310.

England, P.C., and Thompson, A., 1986, Some thermal and tectonic models for crustal melting in continental collision zones, in Coward, M.P., and Ries, A.C., eds., Collision tectonics: Geological Society Special Publication 19, p. 83-94.

Farmer, G.L., and DePaolo, D.J., 1983, Origin of Mesozoic and Tertiary granite in the western United States and implications for pre-Mesozoic crustal structure; $1, \mathrm{Nd}$ and $\mathrm{Sr}$ isotopic studies in the geocline of the northern Great Basin: Journal of Geophysical Research, v. 88, p. 10141-10161.

Fleck, R.J., 1990, Neodymium, strontium, and trace-element evidence of crustal anatexis and magma mixing in the Idaho batholith, in Anderson, J.L., ed., The nature and origin of Cordilleran magmatism: Geological Society of America Memoir 174, p. 359-374. 
Fleck, R.J., and Criss, R.E., 1985, Strontium and oxygen isotopic variations in Mesozoic and Tertiary plutons of central Idaho: Contributions to Mineralogy and Petrology, v. 90, p. 291-308.

Foster, D.A., and Hyndman, D.W., 1990, Magma mixing and mingling between synplutonic mafic dikes and granite in the Idaho-Bitterroot batholith, in Anderson, J.L., ed., The nature and origin of Cordilleran magmatism: Geological Society of America Memoir 174, p. 347-358.

Foster, D.A., Schaefer, C., Fanning, C.M., and Hyndman, D.W., 2001, Relationships between crustal partial melting, plutonism, orogeny, and exhumation; Idaho-Bitterroot batholith: Tectonophysics, v. 342, p. 313-350.

Hamilton, W.B., 1963, Metamorphism in the Riggins region, western Idaho: U. S. Geological Survey Professional Paper 436, $95 \mathrm{p}$.

Hamilton, W.B., 1969, Reconnaissance geologic map of the Riggins quadrangle, west-central Idaho: U. S. Geological Survey Miscellaneous Investigations Series Map I-579, scale 1:125,000.

Hamilton, W.B., 1988a, Tectonic setting and variations with depth of some Cretaceous and Cenozoic structural and magmatic systems of the western United States, in Ernst, W.G., ed., Metamorphism and crustal evolution of the western United States: Englewood Cliffs, New Jersey, Prentice-Hall, p. 1-40.

Hamilton, W.B., 1988b, Plate tectonics and island arcs: Geological Society of America Bulletin, v. 100, p. 1503-1527.

Howell, D.G., 1989, Tectonics of suspect terranes: London, Chapman and Hall, Topics in Earth Sciences, no. 3, 232 p.

Huppert, H.E., and Sparks, R.S.J., 1988, The generation of granitic magmas by intrusion of basalt into continental crust: Journal of Petrology, v. 29, p. 599-624.

Hyndman, D.W., 1981, Controls on source and depth of emplacement of granitic magma: Geology, v. 9, p. 244-249.

Hyndman, D.W., 1983, The Idaho batholith and associated plutons, Idaho and western Montana, in Roddick, J. A., ed., Circum-Pacific plutonic terranes: Geological Society of America Memoir 159, p. 213-240.

Hyndman, D.W., 1984, A chemical and petrographic section through the northern Idaho batholith: Journal of Geology, v. 92, p. 83-102.

Hyndman, D.W., 1985, Petrology of igneous and metamorphic rocks (2nd ed.): New York, McGraw Hill Book Company, $786 \mathrm{p}$.

Hyndman, D.W., and Foster, D.A., 1988, The role of tonalites and mafic dikes in the generation of the Idaho batholith: Journal of Geology, v. 96, p. 31-46.
Irvine, T.N., and Baragar, W.R.A., 1971, A guide to the chemical classification of the common igneous rocks: Canadian Journal of Earth Sciences, v. 8, p. 523-548.

Ishihara, S., 1977, The magnetite-series and the ilmenite series granitic rocks: Min. Geol., v. 27, p. 293-305.

Ishihara, S., 1981, The granitoid series and mineralization: Economic Geology, 75th Anniversary Volume, p. 458-484.

John, B.E., and Blundy, J.D., 1993, Emplacement-related deformation of granitoid magmas, southern Adamello massif, Italy: Geological Society of America Bulletin, v. 105, p. 1517-1541.

Larsen, E.S., Jr., and Schmidt, R.G., 1956, A reconnaissance of the Idaho batholith and comparison with the southern California batholith: U. S. Geological Survey Bulletin 1070-A, 33 p.

Lewis, R.S., Kilsgaard, T.H., Bennett, E.H., and Hall, W.E., 1987, Lithologic and chemical characteristics of the central and southeastern part of the southern lobe of the Idaho batholith, in Vallier, T.L., and Brooks, H.C., eds., Geology of the Blue Mountains region of Oregon, Idaho, and Washington; the Idaho batholith and its border zone: U.S. Geological Survey Professional Paper 1436, p.171-196.

Livaccari, R.F., 1991, Role of crustal thickening and extensional collapse in the tectonic evolution of the SevierLaramide orogeny, western United States: Geology, v. 19, p. 1104-1107.

Livaccari, R.F., and Perry, F.V., 1993, Isotopic evidence for preservation of Cordilleran lithospheric mantle during Sevier-Laramide orogeny, western United States: Geology, v. 21, p. 719-722.

Lund, K., and Snee, L.W., 1988, Metamorphism, structural development, and age of the continent-island arc juncture in west-central Idaho, in Ernst, W. G., ed., Metamorphism and crustal evolution, western conterminous United States: Englewood Cliffs, New Jersey, Prentice-Hall, Rubey Volume VII, p. 296-331.

Lund, K., Kuntz, M.A., Manduca, C.A., Gammons, C.H., Evans, K.V., Tysdal, R.G., Winkler, G.R., and Conner, J.J., 1997, Geologic map of the western Salmon River Mountains, Valley and Idaho Counties, west-central Idaho: U. S. Geological Survey, Miscellaneous Investigations Map I2599, scale 1:100,000.

Manduca, C.A., Silver, L.T., and Taylor, H.P., $1992,{ }^{87} \mathrm{Sr} /{ }^{86} \mathrm{Sr}$ and ${ }^{18} \mathrm{O} /{ }^{16} \mathrm{O}$ isotopic systematics and geochemistry of granitoid plutons across a steeply dipping boundary between contrasting lithospheric blocks in western Idaho: Contributions to Mineralogy and Petrology, v. 109, 355-372.

Manduca, C.A., Kuntz, M.A., and Silver, L.T., 1993, Emplacement and deformation history of the western margin of the 
Idaho batholith near McCall, Idaho; influence of a major terrane boundary: Geological Society of America Bulletin, v. 105, p. $749-765$.

Maniar, P.D., and Piccoli, P.M., 1989, Tectonic discrimination of granitoids: Geological Society of America Bulletin, v. 101, p. 635-643.

McCafferty, A.E., 1992, Aeromagnetic and terrace-magnetization maps centered on the Idaho batholith and Challis volcanic field, northwestern United States: U.S. Geological Survey Geophysical Investigations Map GP-994, scale $1: 1,000,000$.

McClelland, W.C., Tikoff, B., and Manduca, C.A., 2000, Twophase evolution of accretionary margins; examples from the North American Cordillera: Tectonophysics, v. 326, p. 37-55.

Miller, C.F., and Barton, M.D., 1990, Phanerozoic plutonism in the Cordilleran interior, U.S.A., in Kay, S.M., and Rapela, C.W., eds., Plutonism from Antarctica to Alaska: Geological Society of America Special Paper 241, p. 213-231.

Miller, D.M., Nilsen, T.H., and Bilodeau, W.L., 1992, Late Cretaceous to early Eocene geologic evolution of the U. S. Cordillera, in Burchfield, B.C., Lipman, P.W., and Zoback, M.L., eds., The Cordilleran orogen; conterminous U. S.: Boulder, Colorado, Geological Society of America, The Geology of North America, v. G-3, p. 205-259.

Myers, P.E., 1982, Geology of the Harpster area, Idaho County, Idaho: Idaho Bureau of Mines and Geology Bulletin 25, $46 \mathrm{p}$.

Patino-Douce, A.E., and Johnston, A.D., 1991, Phase equilibria and melt productivity in the pelitic system; implications for the origin of peraluminous granitoids and aluminous granulites: Contributions to Mineralogy and Petrology, v. 107, p. 202-218.

Patino-Douce, A.E., Humphreys, E.D., and Johnston, A.D., 1990, Anatexis and metamorphism in tectonically thickened continental crust exemplified by the Sevier hinterland, western North America: Earth and Planetary Science Letters, v. 97, p. 290-315.

Pecarillo, A., and Taylor, S R., 1976, Geochemistry of Eocene calc-alkaline volcanic rocks from the Kastamonu area, northern Turkey: Contributions to Mineralogy and Petrology, v. 58, p. 63-81.

Pitcher, W.S., 1982, Granite type and tectonic environment, in Hsu, K.J., ed., Mountain building processes: London, Academic Press, p. 19-40.

Pitcher, W.S., 1997, The nature and origin of granite (2nd ed.): London, Chapman and Hall, 387 p.

Piwinskii, A.J., and Wyllie, P.J., 1968, Experimental studies of igneous rock series; a zone pluton in the Wallowa Batholith,
Oregon: Journal of Geology, v. 76, p. 205-234.

Ragland, P.C., 1989, Basic analytical petrology: New York, Oxford University Press, 369 p.

Richardson, S.W., Gilbert, M.C., and Bell, P.M., 1969, Experimental determination of kyanite-andalusite-sillimanite equilibria; the aluminum silicate triple point: American Journal of Science, v. 267, p. 259-257.

Robertson, J.K., and Wyllie, P.J., 1971, Rock-water systems, with special reference to the water-deficient region: American Journal of Science, v. 271, p. 252-277.

Russell, C.W., 1988, Crystallization of the Banks complex; implication for middle crustal evolution in Cordilleran batholithic terranes: Seattle, University of Washington, Ph.D. dissertation, 228 p.

Schmidt, D.L., 1964, Reconnaissance petrographic cross section of the Idaho batholith in Adams and Valley counties, Idaho: U.S. Geological Survey Bulletin 1181-G, 50 p.

Schuster, R.D., and Bickford, M.E., 1985, Chemical and isotopic evidence for the petrogenesis of the northeastern Idaho batholith: Journal of Geology, v. 93, p. 727-742.

Selverstone, J., Aliberti, E., and Wernicke, B.P., 1992, Intracontinental subduction and hinged unroofing along the Salmon River suture zone, west central Idaho: Tectonics, v. 11, p. 124-144.

Shand, S.J., 1947, Eruptive rocks: London, T. Murby and Co., 444 p.

Silver, L.T., and Chappel, B.W., 1988, The Peninsular Ranges batholith; an insight into the evolution of Cordilleran batholiths of southwestern North America: Transactions of the Royal Society of Edinburgh, Earth Sciences, v. 79, p. $105-121$.

Snee, L.W., 2002, Argon thermochronology of mineral deposits-a review of analytical methods, formulations, and selected applications: U. S. Geological Survey Bulletin 2194, 39 p.

Snee, L.W., Lund, K., Sutter, J.F., Balcer, D.E., and Evans, K.V., 1995, An ${ }^{40} \mathrm{Ar} /{ }^{39}$ Ar chronicle of the tectonic development of the Salmon River suture zone, western Idaho, in Vallier, T.L., and Brooks, H.C., eds., Geology of the Blue Mountains region of Oregon, Idaho, and Washington; petrology and tectonic evolution of pre-Tertiary rocks: U. S. Geological Survey Professional Paper 1438, p. 359-414.

Strayer, L.M., IV, Hyndman, D.W., Sears, J.W., and Myers, P.E., 1989, Direction and shear sense during suturing of Seven Devils-Wallowa terrane against North America in western Idaho: Geology, v. 17, p. 1025-1028.

Thompson, A.B., 1996, Fertility of crustal rocks during ana- 
texis: Transactions of the Royal Society of Edinburgh, Earth Sciences, v. 87, p. 1-10.

Thompson, A.B., 1999, Some space-time relationships for crustal melting and granitic intrusion at various depths, in Castro, A., Fernandez, C., and Vigneresse, J.L., eds., Understanding granites; integrating new and classical techniques: Geological Society of London Special Publication 168, p. 7-25.

Thompson, A.B., and Connolly, J.A.D., 1995, Melting of the continental crust; some thermal and petrological constraints on anatexis in continental collision zones and other tectonic settings: Journal of Geophysical Research, v. 100, p. $15565-15579$.

Toth, M.I., 1987, Petrology and origin of the Bitterroot lobe of the Idaho batholith, in Vallier, T.L., and Brooks, H.C., eds., Geology of the Blue Mountains region of Oregon, Idaho, and Washington; petrology and tectonic evolution of preTertiary rocks: U. S. Geological Survey Professional Paper 1438, p. 9-35.

Turner, F.J., 1968, Metamorphic petrology: New York, McGraw-Hill Book Company, 403 p.

Vallier, T.L., 1995, Petrology of pre-Tertiary igneous rocks in the Blue Mountains region of Oregon, Idaho, and Washington; implications for the geologic evolution of a complex island arc, in Vallier, T.L., and Brooks, H.C., eds., Geology of the Blue Mountains region of Oregon, Idaho, and Washington; petrology and tectonic evolution of pre-Tertiary rocks of the blue Mountains region: U. S. Geological Survey Professional Paper 1438, p. 125-210.

Vallier, T.L., and Brooks, H.C., 1987, The Idaho batholith and its border zone; a regional perspective, in Vallier, T.L., and Brooks, H.C., eds., Geology of the Blue Mountains region of Oregon, Idaho, and Washington; the Idaho batholith and its border zone: U.S. Geological Survey Professional Paper 1436, p.1-7.

Vielzeuf, D., and Holloway, J.R., 1988, Experimental determination of the fluid-absent melting relations in the pelitic system, consequences for crustal differentiation: Contributions to Mineralogy and Petrology, v. 98, p. 257-276.

Weston, P., Manduca, C.A., and Selverstone, J., 1993, Depth of emplacement of the Payette River tonalite and tectonic implications for the arc-continent boundary in west-central Idaho [abs.]: Geological Society of America Abstracts with Programs, v. 25, no. 5, p. 163.

Winkler, H.G.F., 1979, Petrogenesis of metamorphic rocks (5th ed.): New York, Springer-Verlag, 348 p.

Wyllie, P.J., 1977, Crustal anatexis; an experimental review: Tectonophysics, vol. 43, p. 41-71.

Wyllie, P.J., 1983, Experimental studies on biotite- and muscovite-granites and some crustal magmatic sources, in Atherton, M.P., and Gribble, C.D., eds., Migmatites, melting and metamorphism: Mineralogical Society of the University of Glasgow, p. 37-51.

Wyllie, P.J., 1988, Magma genesis, plate tectonics, and chemical differentiation of the Earth: Reviews of Geophysics, v. 26, p. 370-404.

Wyllie, P.J., and Rutter, M.J., 1988, Melting sites at convergent plate boundaries with experimental data on vapor-absent tonalite gneiss: Rendiconti Della Societa Italiana di Mineralogia E Petrologia, v. 43, p. 1291-1306.

Wyllie, P.J., Wolf, M.B., and van der Laan, S.R., 1997, Conditions for the formation of tonalites and trondhjemites; magmatic sources and products, in DeWit, M.J. and Ashwal, L.D., eds., Greenstone belts: Oxford Monographs on Geology and Geophysics, no. 35, p. 256-266.

Zen, E-An, 1985, Muscovite: McGraw-Hill Yearbook of Science and Technology, p. 283-287.

Zen, E-an, 1988, Tectonic significance of high-pressure plutonic rocks in the western Cordillera of North America, in Ernst, W.G., ed., Metamorphism and crustal evolution of the western United States: Englewood Cliffs, New Jersey, Prentice-Hall, p. 41-67. 



\title{
6. Mesozoic Telescoping of Island-Arc Terranes and Geologic Evolution of the Cuddy Mountains Region, Western Idaho
}

\author{
By Gary M. Mann and Tracy L. Vallier
}

\section{Abstract}

Three discrete fault-bounded tectonic belts of pre-Cenozoic rocks are juxtaposed in an 8-km-wide area in the Cuddy Mountains of western Idaho. These belts are correlated with the Wallowa, Baker, and Olds Ferry terranes of the accreted Blue Mountains island arc. Structural and lithologic evidence suggests that these terranes are kindred and that they formed in adjacent parts of a single, complex island arc over a long interval of time.

In eastern Oregon the terranes form wide, approximately east-west-trending structural belts. Major Mesozoic shear zones and structural trends in eastern Oregon bend to the northeast and the terranes narrow rapidly as they approach the Idaho border. In the Cuddy Mountains of western Idaho the terranes trend approximately N. $35^{\circ}$ E. and bend even further to the north as they approach the Salmon River suture zone, where at least two of the terranes reappear from beneath late Cenozoic volcanic rocks as highly metamorphosed and tectonized rocks. Narrow and well-exposed belts in the Cuddy Mountains contain the most easterly exposures of rocks that are characteristic of the three major terranes in the Blue Mountains. The terrane-narrowing phenomenon is most likely the result of thrust faulting during late Mesozoic accretion of the Blue Mountains island arc to North America, when leftoblique transpression was coupled with the partial preservation of original arc morphology.

Some of the thrust faults have been reactivated during late Cenozoic deformation. For example, the bounding fault between the Baker and Olds Ferry belts in the western Cuddy Mountains, the Cuddy Mountain Fault, was reactivated and provides continuity to the Connor Creek Fault in eastern Oregon and possibly to the Rapid River Thrust of western Idaho. Clockwise rotation of the Cuddy Mountains uplift is inferred from sinistral offset of the Cuddy Mountain Fault by the Brownlee Fault, as well as sinistral offset of drainages along the Cuddy Mountain Fault.

\section{Introduction}

The pre-Cenozoic rocks of eastern Oregon and western Idaho were part of a complex island arc, the Blue Mountain island arc (BMIA), that is composed of rocks ranging in age from Devonian through the Early Cretaceous. The pre-Cenozoic rocks of the BMIA were assigned to tectonostratigraphic terranes (fig. 1) in a series of papers by Vallier and others (1977), Brooks and Vallier (1978), and Dickinson and Thayer (1978). Names applied to the terranes by Silberling and others (1984) are used in this paper. Vallier (1995), however, pointed out the similarities between rocks of the Izee terrane and the Jurassic Weatherby Formation (Brooks and others, 1976) that crops out in the Cuddy Mountains and speculated that the Izee terrane and equivalent rocks extend eastward from east-central Oregon into the Cuddy Mountains region and from there to the border zone of the Idaho Batholith near Riggins, Idaho. For purposes of this paper, however, we retain the terrane assignments of Silberling and others (1984) and include the Weatherby Formation within the Olds Ferry terrane.

This paper is written to discuss the geologic evolution of the Cuddy Mountains region and relate it to the tectonic evolution of the Blue Mountains island arc, particularly with regard to the late Mesozoic telescoping of terranes along thrust faults and the arc's accretion to North America. First, we review the geology of late Paleozoic and Mesozoic tectonostratigraphic terranes in the Blue Mountains. Then, we describe the stratigraphy and structure of three tectonic belts in the Cuddy Mountains region and correlate them with terranes in other parts of the Blue Mountains. Late Triassic to Early Cretaceous evolutionary stages of the island arc are subsequently discussed in light of other investigations. We conclude by showing that late Cenozoic tectonics and the resultant structures have been influenced by the pre-Cenozoic faults.

\section{Terranes Of The Blue Mountains Island Arc}

Important to understanding the geologic framework of the Blue Mountains region are the tenets that (1) the pre-Cenozoic rocks formed in an intra-oceanic volcanic arc (Hamilton, 1963; Vallier, 1977) and (2) kindred tectonostratigraphic terranes compose the arc (Vallier, 1995). The occurrence of overthrust faults and extensive tectonic shortening on a regional basis was recognized by Brooks and others (1976) and more thor- 


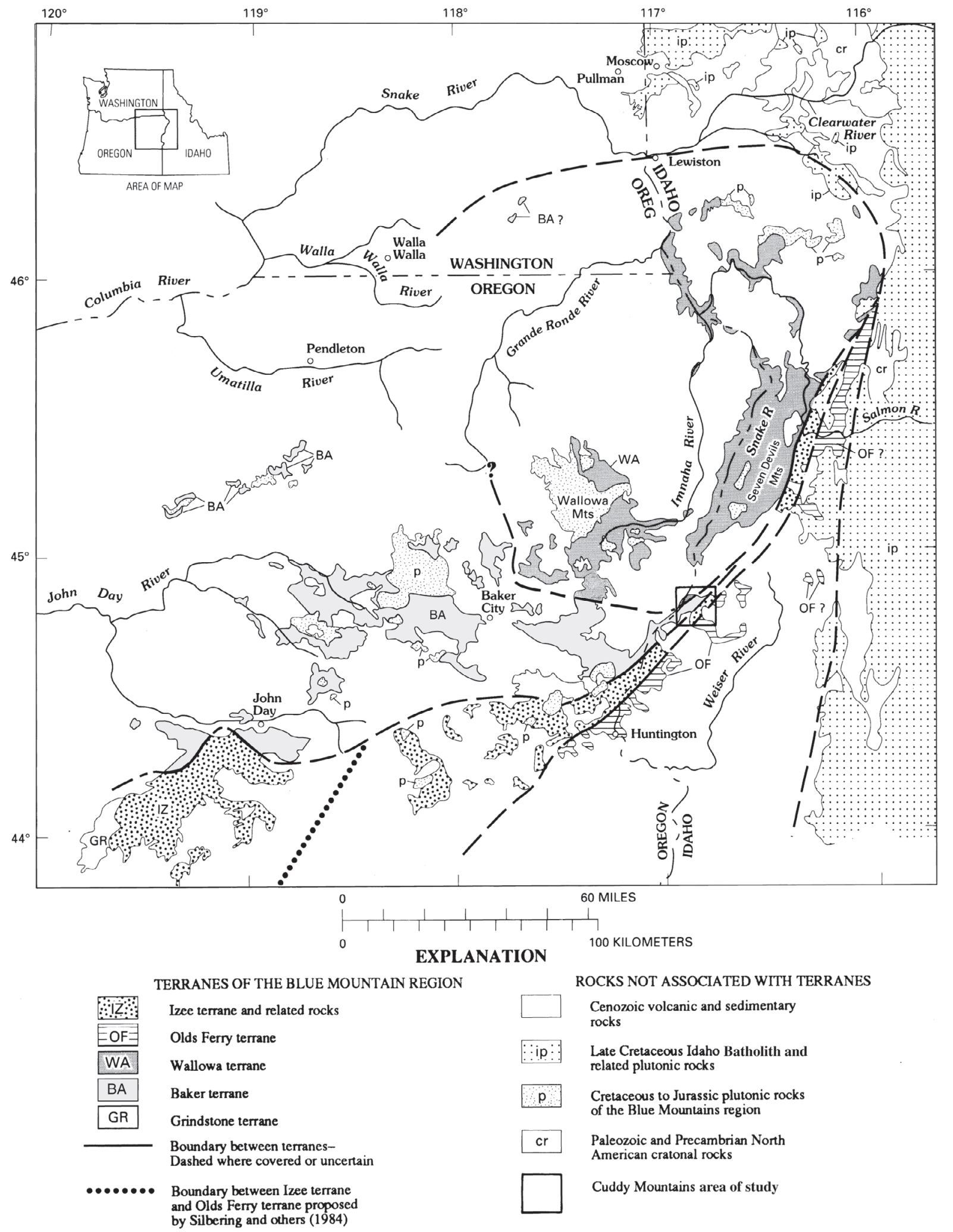

Figure 1. Tectonostratigraphic terranes of the Blue Mountains island arc (modified from Vallier, 1995). Note that the Olds Ferry terrane is mapped northward to form part of the western border of the Idaho Batholith and that rocks correlative with the Izee terrane, including the Weatherby Formation of Brooks (1979b) and the Squaw Creek Schist of Hamilton (1963), also are continued through eastern Oregon and into western Idaho. In this paper we use the terrane assignments of Silberling and others (1984). 
oughly described by Roure (1982). The tectonostratigraphic terrane concept, used to explain complex geologic relations in large parts of western North America (Jones and others, 1977; Davis and others, 1978; Coney and others, 1980; Saleeby, 1983; Silberling and others, 1984; Howell and others, 1985; Wilson and others, 1991), has been particularly helpful in understanding the evolution of the Blue Mountains island arc and its relationship to other accreted terranes of Mesozoic North America. The four principal BMIA terranes, Baker, Wallowa, Olds Ferry, and Izee, are described from previous studies in eastern Oregon. The Grindstone terrane, a small fragment of the BMIA that is exposed near the western edge of the pre-Cenozoic inliers, is not discussed in this paper; a summary of that terrane is given by Blome and Nestell (1991).

\section{Baker Terrane}

The Baker terrane, structurally the most complex of the four principal terranes in the Blue Mountains region, is by far the most extensive (fig. 1). Early work in the Baker terrane by Gilluly (1937) recognized a large variety of igneous and metamorphic rocks and two major formations, the Elkhorn Ridge Argillite and Burnt River Schist. The Baker terrane was referred to as the oceanic crust terrane (Vallier and others, 1977), the dismembered oceanic crust terrane (Brooks and Vallier, 1978; Brooks, 1979a), and the central mélange terrane (Dickinson, 1979), before being named the Baker terrane by Silberling and others (1984). In much of northeastern Oregon the Baker terrane is a chaotic assemblage of Devonian through Late Triassic igneous and sedimentary rocks that have undergone varying degrees of metamorphism and deformation. Metamorphosed lavas have seamount, mid-ocean ridge, and island arc chemical affinities (Mullen, 1985; Vallier, 1995). Serpentinite-matrix mélange occurs in some parts of the terrane (Brooks and others, 1976). The foliated and metamorphosed rock assemblages are dominated by phyllite and quartz phyllite with common to abundant ribbon chert and carbonate. Gabbro, quartz diorite, and volcanic rocks occur discontinuously throughout the terrane. Most of the Baker terrane apparently formed in the BMIA fore-arc region(s), and many of the rocks were probably scraped off an oceanic plate or plates during the subduction process (Dickinson and Thayer, 1978; Mullen, 1985; Vallier, 1995), thereby forming an accretionary wedge. Ferns and Brooks (1995) divided the Baker terrane west of Baker City, Oregon, into the Bournes and Greenhorn subterranes. They concluded that the Bournes subterrane represents part of an accretionary complex and the Greenhorn subterrane is the remnant of a disrupted fore-arc region.

Upper Triassic to Middle Jurassic sedimentary rocks of the Izee terrane and the Weatherby Formation overlap parts of the Baker terrane; exposures of the Baker terrane occur where these younger rocks were stripped off by erosion and where Baker terrane rocks have been shoved through the overlying sedimentary rocks along thrust faults (Roure, 1982; Ferns and Brooks, 1995). Jurassic and Cretaceous plutons (mostly 150 to
$135 \mathrm{Ma}$ ) intruded all of the terranes, except the exposed parts of the Grindstone, and stitched some of them together after most intra-arc amalgamation had occurred, but before final accretion of the arc to the continent.

\section{Wallowa Terrane}

The Wallowa terrane (Silberling and others, 1984) was previously called the volcanic arc terrane (Vallier and others, 1977), the Wallowa Mountains-Seven Devils Mountains volcanic arc terrane (Brooks and Vallier, 1978), and the Seven Devils terrane (Dickinson and Thayer, 1978). The terrane includes pre-Cenozoic rocks in the Wallowa and Seven Devils Mountains and in the intervening Snake River canyon (Vallier, 1995). Rocks are Pennsylvanian(?) through Early Cretaceous in age and most have been metamorphosed to the greenschist facies. A Lower Permian stratified sequence of mostly andesitic and rhyolitic volcaniclastic rocks and subordinate volcanic flow rocks are in part coeval with, and in part overlie, Pennsylvanian(?) and Early Permian dike units. Early Permian to Middle Triassic plutonic rock bodies of gabbro, trondhjemite, and tonalite are common. The Permian rocks are notably enriched in sodium and depleted in potassium; some rhyolite (quartz keratophyre) samples contain as much as 7 weight percent $\mathrm{Na}_{2} \mathrm{O}$ and less than 0.1 weight percent $\mathrm{K}_{2} \mathrm{O}$ (Vallier, 1995). Middle and Upper Triassic (Ladinian and Karnian) basaltic to andesitic volcanic flow and volcaniclastic rocks make up the dominant stratified sequence in the Wallowa terrane. These volcanic rocks are low-potassium island arc tholeiites, similar to many of the lavas in the Tonga island arc (Vallier, 1995). Massive (and reefal) carbonate units and sandstone-mudstone flysch units of Late Triassic (late Karnian and early Norian) and Early to Middle Jurassic ages unconformably overlie the older stratified and plutonic rocks. Late Jurassic and Early Cretaceous batholiths and stocks cut the older rock sequences as they do in the Baker and Olds Ferry terranes.

Jones and others (1977) proposed that the Wallowa terrane is a fragment of the Wrangellia superterrane on the basis of paleomagnetic, stratigraphic, and faunal evidence. Triassic paleolatitudes of the Wallowa terrane are comparable to those of several Wrangellia fragments (from Vancouver and Queen Charlotte Islands, British Columbia, and the Wrangell Mountains of Alaska), all of which have undergone large south to north lateral translation since their formation (Hillhouse and others, 1982). The chemical data from the Triassic Wallowa terrane lavas (Sarewitz, 1983; Vallier, 1995) indicate different mantle sources and settings for lava eruptions (for example, oceanic plateau or back-arc setting for the northern fragments of Wrangellia and volcanic-arc setting in the Wallowa terrane). We assume that the entire BMIA and the Wrangellian terrane, and many of the other oceanic terrane fragments in Canada and southeastern Alaska, were part of a large complex of island arcs and oceanic plateaus such as those found today in the southwestern Pacific Ocean (for example, the Solomon Islands). A model such as this can explain the present close 
proximity of igneous rocks that were derived from different mantle sources and subsequently emplaced tectonically. However, we don't know how close these fragments were to the late Paleozoic and Mesozoic continental margin of North America during their formation and transport.

\section{Olds Ferry Terrane}

The Olds Ferry terrane includes part of the volcanic arc terrane of Vallier and others (1977) and the Juniper MountainCuddy Mountain volcanic arc terrane and flysch terrane of Brooks and Vallier (1978). Silberling and others (1984) included the Weatherby Formation (Brooks, 1979b) in the Olds Ferry terrane.

The Olds Ferry terrane is lithologically similar to, but chronologically distinct from, the Wallowa terrane. Like the Permian and Triassic igneous rocks in the Wallowa terrane, the Triassic and Early Jurassic igneous rocks in the Olds Ferry terrane evolved along the magmatic axis of an island arc (Vallier, 1995, 1998). The lavas have distinctly higher weight percentages of incompatible elements than those from the Wallowa terrane. The Olds Ferry terrane volcanic rocks (named the Huntington Formation by Brooks and others, 1976) are mostly Late Triassic (late Karnian and Norian) in age, and the intrusive rocks, exclusive of the Jurassic to Cretaceous plutons, range in age from Middle Triassic to Early Jurassic. In contrast, volcanic rocks of the Wallowa terrane range in age from Early Permian to Late Triassic (early Karnian), and intrusive rocks, exclusive of the Jurassic to Cretaceous plutons, are late Paleozoic (mostly Early Permian) to Late Triassic in age (Vallier, 1995). These age ranges may change as additional geochronological data, specifically from single-grain zircon $\mathrm{U}-\mathrm{Pb}$ studies, are available.

The differences in age and petrology led Vallier (1995) to suggest that the Olds Ferry terrane formed on the inboard edge of the much larger Blue Mountains island arc and nearer the North American continent beginning in the Late Triassic (late Karnian and early Norian) after a significant Late Triassic change in convergence vectors, possibly involving a near reversal similar to the middle Miocene reversal in the Solomon island arc. The Olds Ferry magmatic axis continued to evolve through the Early Jurassic, while the Wallowa terrane became mostly passive, lying then within the outer fore-arc region of the Olds Ferry terrane. Furthermore, the Olds Ferry stratified rocks may have had parts of the Baker terrane as basement (Vallier, 1998).

\section{Izee Terrane}

The Izee terrane in eastern Oregon contains a thick coherent sequence of clastic sedimentary rocks, with subordinate limestone and volcanic rocks, of Late Triassic to Middle Jurassic age (Dickinson, 1979; Blome and others, 1986). It is part of the flysch terrane of Brooks and Vallier (1978). Rocks of the Izee terrane along the western boundary, as defined by Silberling and others (1984), overlie an unconformity that was cut across rocks of the
Grindstone and Baker terranes. Rocks of the Izee terrane along the eastern boundary (as defined by Silberling and others 1984), however, are covered by Tertiary volcanic rocks (fig. 1). Rocks lithologically similar to those of the Izee terrane crop out a short distance east of that eastern boundary and form a wide but coherent belt that can be traced eastward in Oregon and thence northeastward across the Snake River into Idaho. These rocks in eastern Oregon, the Weatherby Formation (Brooks, 1979b), are Jurassic in age (Brooks, 1979b; Imlay, 1986), and in part equivalent to rocks in the Izee terrane of Silberling and others (1984). Brooks and Vallier (1978) and Vallier (1995, 1998) suggested that the Weatherby Formation, and probably the Squaw Creek Schist (Hamilton, 1963 ) in the Riggins, Idaho region, are eastward extensions of rocks in the Izee terrane.

The Izee terrane rocks, including the correlative rocks that crop out further east, overlap the Grindstone and Baker terranes on the west. The Izee terrane and probable correlative rocks formed in the fore-arc region of the Olds Ferry magmatic axis (Dickinson, 1979), and possibly as an intra-arc basin between parts of the Wallowa and Baker terranes and the Olds Ferry magmatic axis (Vallier, 1995). The Baker terrane not only underlies parts of the Izee terrane and its correlative rocks, but also contributed detritus to the sedimentary sequences as islands of the outer fore-arc region of the Olds Ferry volcanic arc were eroded.

\section{Tectonic Belts of the Cuddy Mountains Region}

Two tectonic belts in the Cuddy Mountains area, the Baker and Olds Ferry, are continuous with the Baker and Olds Ferry tectonostratigraphic terranes that merge from the southwest. A third belt, herein referred to informally as the Wildhorse belt, is tentatively correlated with the Wallowa terrane. In this section we describe the tectonic belts and their structural boundaries in the Cuddy Mountains region and correlate them with BMIA tectonostratigraphic terranes. We use the terms "belts" and "terranes" somewhat interchangeably, but in general we refer to "belts" when discussing the Cuddy Mountains area and to "terranes" when discussing regional aspects. The term "belts" seems more appropriate in the local area because they are fragments of the BMIA terranes and are not completely representative of the terranes as described from outcrops elsewhere. For example, the Baker belt in the Cuddy Mountains area is mostly stratified and lithologically similar to the Elkhorn Ridge Argillite (Gilluly, 1937) rather than to the Baker terrane as a whole, which has large outcrop areas of gabbro, serpentinite, and mélange.

\section{Wildhorse Belt and Wildhorse Formation}

The Wildhorse belt includes the Wildhorse formation (informal name) of Mann (1989) and its underlying plutonic 
basement. The Wildhorse formation is well exposed in the Wildhorse River canyon, the type area of the formation (fig. 2). The formation and the underlying plutonic rocks also crop out in the Snake River canyon north of Brownlee Dam. In Wildhorse River canyon the formation consists of a basal, buff colored, volcanic sandstone with minor limestone and conglomerate interbeds ( $\mathrm{kvs}$; symbols are those used on figures showing maps and cross sections), gradationally overlain by approximately $300 \mathrm{~m}$ of massive limestone and carbonate flysch rocks (kl). The carbonate rocks are depositionally overlain by a thick sequence of volcaniclastic breccia and conglomerate (Kvb). These sedimentary rocks form a transgressive sequence that records the uplift of probable slope to mid-shelf rocks and subsequent burial by coarse volcaniclastic debris ( $\mathrm{kvb}$ ). The rocks strike northeast, similar to rocks in the adjacent Olds Ferry and Baker tectonic belts; however, the Wildhorse formation rocks dip steeply southeast as much as $80^{\circ}$. We suspect that some are overturned. Strata in the other tectonic belts of the Cuddy Mountains dip mostly to the northwest.

The basal unit of the Wildhorse formation ( Kvs), composed of buff-colored volcanic sandstone with limestone interbeds, unconformably (?) overlies a basement complex of quartz diorite, diabase, and trondhjemite (Pkqd). Younger and more massive carbonate units ( $\mathrm{kl}$ ) are chaotically mixed with volcanic breccia ( $\mathrm{kvb}$ ) in outcrops along the Snake River canyon inlier (fig. 2). These chaotic stratigraphic relationships indicate an olistostromal or submarine-landslide origin for the deformation.

In Wildhorse River canyon the stratigraphy of the formation is preserved and basal unit Kvs is gradationally overlain by a 300-m-thick sequence of bluish-colored recrystallized limestone ( Kl) (fig. 2). Kl consists of two subunits. The basal 100 -m-thick subunit is composed of a repetitive succession of flyschlike interbeds of limestone and calcareous shaley siltstone. The upper 200-m-thick subunit is composed of massive bioclastic limestone. Thin sections of rocks from the upper bioclastic limestone subunit reveal a wide assortment of bioclastic detritus with an abundance of pellotoids and shell hash. The megafossil bivalve Halobia sp. collected from the limestone indicates a Late Triassic (Norian) age (N.J. Silberling, written commun., 1986) which is coeval with parts of the Martin Bridge Limestone of the Wallowa terrane and with the Huntington Formation of the Olds Ferry terrane. We doubt that it is part of the Olds Ferry terrane, however, because of the stratigraphy and structural relationships discussed below.

The Martin Bridge Limestone of Hells Canyon, located approximately $35 \mathrm{~km}$ north of the study area, was deposited in a shelf environment as a carbonate platform (Vallier, 1977), whereas in the southern Wallowa Mountains, about $40 \mathrm{~km}$ northwest of the Cuddy Mountains, a reef is well exposed in the Martin Bridge Limestone. The bioclastic texture of the Wildhorse formation limestone ( $\mathrm{kl}$ ) and its flyschlike lower unit suggest transport of biogenic materials from areas of high energy (nearshore) to a lowenergy, upper slope to outer shelf, environment.

The limestone unit is depositionally overlain in Wildhorse River Canyon by a thick sequence of poorly sorted, maroon-colored, volcanic breccia and conglomerate ( $\mathrm{kvb}$ ).
Although the top of the unit is not identified, its minimum thickness is approximately $65 \mathrm{~m}$. The clast compositions in unit $\mathrm{kvb}$ are predominantly andesite, basalt, and volcaniclastic rocks, although rare clasts of trondhjemite and quartz diorite occur, most likely derived from nearby plutonic bodies.

The Permian and Triassic stratified rocks of the Seven Devils Group, as described by Vallier (1977) in the Wallowa terrane, are either absent or very rare within the Wildhorse belt of the Cuddy Mountains region. Most rocks in the Seven Devils Group of the Wallowa terrane, particularly the Early Permian Hunsaker Creek Formation and the Middle to Late Triassic (Ladinian and Karnian) rocks of the Wild Sheep Creek Formation, are older than those in the Wildhorse formation. There are, however, some lithologic similarities between the oldest ( $\mathrm{kvs}$ ) unit of the Wildhorse formation and some of the volcaniclastic rocks in the youngest formation of the Seven Devils Group, the Doyle Creek Formation. The limestone unit ( $\mathrm{k} 1)$ in the Wildhorse formation is correlative with the Martin Bridge Limestone, on the basis of age and similar appearance. Younger rocks in the Wildhorse formation, specifically those that overlie the limestone unit, are not correlated with any rocks of the Seven Devils Group.

Quartz diorite and trondhjemite rocks (unit Pkqd) unconformably underlie, and are in fault contact with, rocks of the Wildhorse formation in the Snake River inlier and Wildhorse River canyons (fig. 2). Because of these relations, and the occurrence of plutonic clasts with similar compositions in unit $\mathrm{kvb}$, unit Pkqd is clearly plutonic igneous basement to the Wildhorse formation. This unit is highly cataclastic and locally mylonitic and is intruded by numerous fine-grained quartz diorite dikes, both in the Snake River canyon inlier and in Wildhorse River canyon. Major-element-oxide and trace-element compositions of the cataclastic quartz diorite and fine-grained dikes are essentially identical (Mann, 1991). Some of the quartz-rich rocks are chemically and petrographically similar to albite granite (soda-rich trondhjemite) in the Sparta area (Gilluly, 1933; Prostka, 1962) and to some plutons in the Wallowa terrane (Vallier, 1995). On the basis of present-day geographic proximity to rocks of the Wallowa terrane to the north, lithologic and age similarities to some of the Late Triassic stratified rocks of the Wallowa terrane, and similar compositions of plutonic rocks, we conclude that rocks of the Wildhorse Formation and its plutonic basement (Pkqd) which together make up the Wildhorse belt, are part of the Wallowa terrane.

\section{Wildhorse Shear Zone}

The Wildhorse shear zone (WSZ) is a major structure in the area, and we believe that it marks a thrust fault duplex that was active during the telescoping of terranes and (or) accretion of the island arc to the North American continent. There is no stratigraphic contact between rocks of the Wildhorse formation (Wildhorse belt) and the Baker belt. Instead, Wildhorse belt rocks are separated from the Baker belt by several fault-bounded slices of metamorphosed sedimentary, volcanic, and plutonic rocks within a wide zone that Mann (1989) 
informally referred to as the Wildhorse shear zone (WSZ). All rocks within the WSZ are highly sheared, cataclastic, or mylonitic. Some of the fault-bounded slices contain rocks that are unique in the western Cuddy Mountains. The rock units (fig. 2) include a stratified volcaniclastic rock sequence (PKvs), a chert conglomerate $(\mathrm{P} k \mathrm{c})$, a silicic tuff $(\mathrm{P} k \mathrm{v})$, and a long slice of dismembered quartz diorite (PKqd). A small isolated outcrop of garnet mylonite (PzMzm) in lower Dukes Creek (fig. 2 ) is directly on strike with the WSZ, but is separated from it by flows of the overlying Columbia River Basalt Group. It was mapped as part of the WSZ.
A belt of dismembered quartz diorite (Pkqd), which we correlated above with the Wallowa terrane, is the most coherent structural slice in the WSZ, and in most places it separates the wide variety of rocks in Wildhorse River canyon into two major groups: the Wildhorse belt on the northwest and Baker belt to the southeast. Although most rocks on the northwest side of the dismembered quartz diorite slice belong to the Wildhorse formation (Wallowa terrane), unit PKvs is lithologically similar to rocks of the Baker belt (and terrane). It is predominantly composed of volcaniclastic sandstone and siltstone, silicic tuff, ribbon chert, and

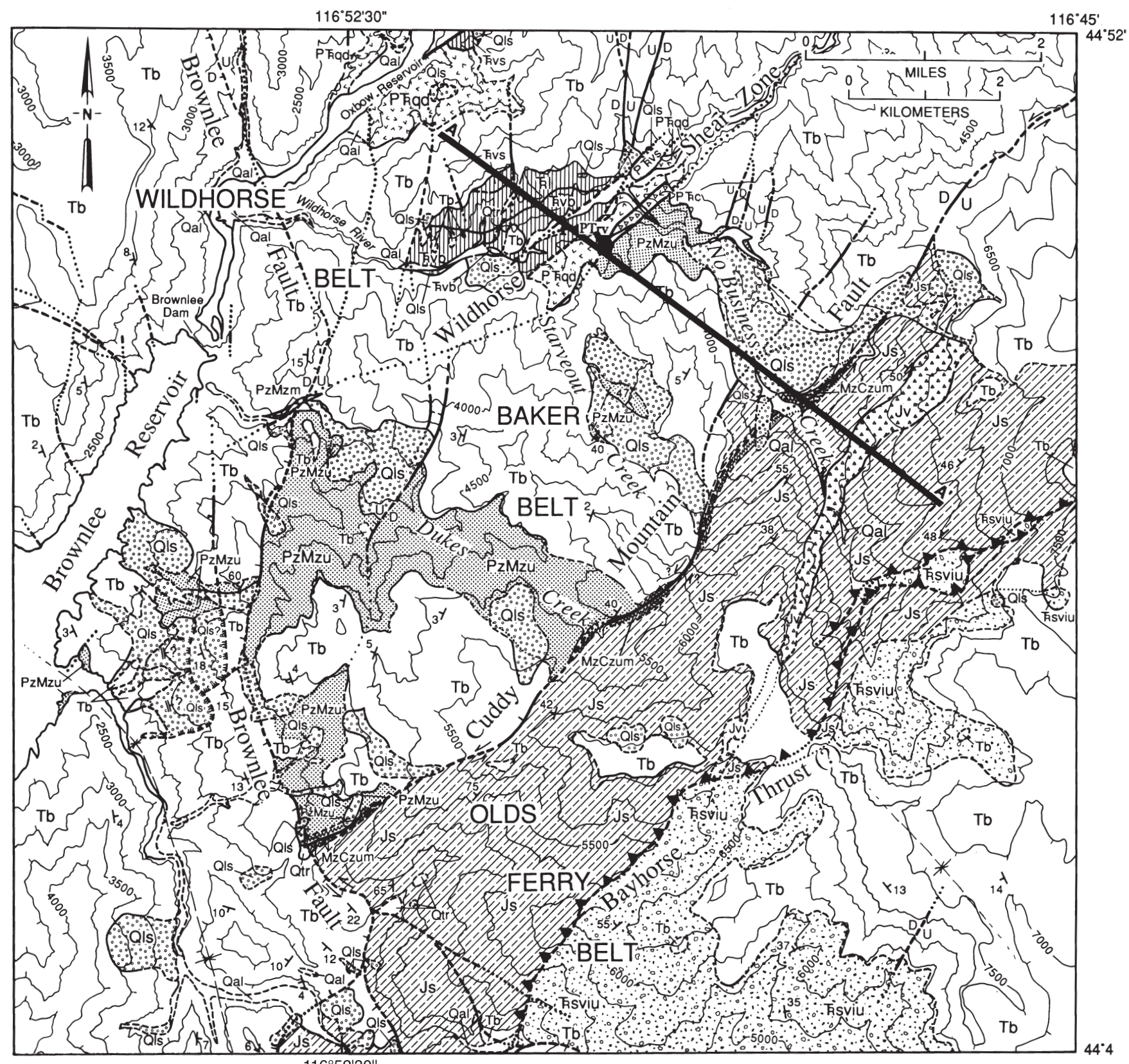

$116^{\circ} 52^{\prime} 30^{\prime \prime}$

Figure 2. Geologic Map of the western Cuddy Mountains region (modified from Mann, 1989). Line A-A' marks cross section shown in figure 3 . Contour interval is 500 feet. 
thin beds of limestone. Thin sections of laminated, cherty interbeds reveal organic-rich laminae with abundant, poorly preserved Radiolaria. A solitary fusulinid identified in a thin section of calcareous siltstone indicates a Paleozoic age. The tectonic juxtaposition of this unit with rocks of the Wildhorse Formation would seem to suggest that PKvs belongs to the Wildhorse belt of the Wallowa terrane. However, no fusulinids or ribbon cherts have ever been identified in rocks of the Wallowa terrane. Because of these facts and its lithologic similarity and proximity to rocks of the Baker belt, $\mathrm{P}$ kvs is interpreted to be a fault-emplaced sliver of the Baker belt (or terrane).

Chert conglomerate $(\mathrm{P} F \mathrm{c})$ in the southeast part of the WSZ is in fault contact with the dismembered igneous rock (Pkqd) and rocks of the Baker belt (PzMzu) (fig. 2). This conglomerate contains well-rounded chert clasts that were clearly derived from the Baker belt (or terrane) along with some boulders of recrystallized limestone. A silicic tuff unit (PKv), a fault sliver, also is in tectonic contact with rocks of the Baker belt and the chert conglomerate. This small sliver is probably part of the Baker belt as indicated by its structural position.
The curved outcrop pattern and varying width of the dismembered and fault-bounded plutonic rock slice (Pkqd) is similar to structural styles that are associated with thrust faults. At one point near unit $\mathrm{P} k \mathrm{~V}$ this plutonic rock slice is only about $100 \mathrm{~m}$ wide, whereas $1 \mathrm{~km}$ southwest it is nearly $800 \mathrm{~m}$ wide (fig. 2). The southern boundary, concealed by Columbia River Basalt, must intersect the Baker belt-garnet mylonite (PzMzm) tectonic contact in lower Dukes Creek (fig. 2), which is on structural trend with the WSZ. The undulose and scoopshaped outcrop geometry of this belt probably is the result of upper and lower plate irregularities within a thrust duplex, rather than the result of strike-slip fragmentation. Baker belt rocks immediately adjacent to, and in tectonic contact with this dismembered quartz diorite (Pkqd), exhibit linear outcrop patterns in steeply dipping chert and carbonate interbeds. This relation constrains deformation geometry of the undulose plutonic rock belt faults to being originally curvilinear, and not subsequently folded, because adjacent Baker belt rocks in tectonic contact along these faults are not noticeably folded. This also supports a thrust or oblique-compressional origin for the faults rather than a purely strike-slip origin. Boyer and

\section{EXPLANATION}

\begin{tabular}{|c|c|c|}
\hline & Qal & Alluvium \\
\hline & Qls & Landslide debris \\
\hline & Qtr & Travertine \\
\hline & $\mathrm{Tb}$ & Basalt, predominantly \\
\hline 11111 & Js & $\begin{array}{l}\text { Sedimentary rocks, } \\
\text { Jurassic }\end{array}$ \\
\hline & JV & Andesite tuff, Jurassic \\
\hline$\stackrel{8}{8}$ & Rsviu & $\begin{array}{l}\text { Undifferentiated sedimentary, } \\
\text { volcanic, and intrusive rocks, } \\
\text { Triassic }\end{array}$ \\
\hline & $\overline{\mathrm{k} v b}$ & Volcanic breccia, Triassic \\
\hline & ki & Limestone, Triassic \\
\hline & kVS & $\begin{array}{l}\text { Tuffaceous sedimentary rocks, } \\
\text { Triassic }\end{array}$ \\
\hline wWWW/ & zzGum & Ultramafic rocks \\
\hline & PkVs & $\begin{array}{l}\text { Volcaniclastic sedimentary rocks, } \\
\text { Permian or Triassic }\end{array}$ \\
\hline$\left.\nabla^{\nabla} \nabla_{\nabla}^{\nabla} \nabla \nabla\right\rangle$ & $\mathrm{P}_{\mathrm{KC}}$ & Conglomerate, Permo-Triassic (?) \\
\hline 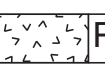 & Rqd & Intrusive rocks, Permo-Triassic (?) \\
\hline
\end{tabular}

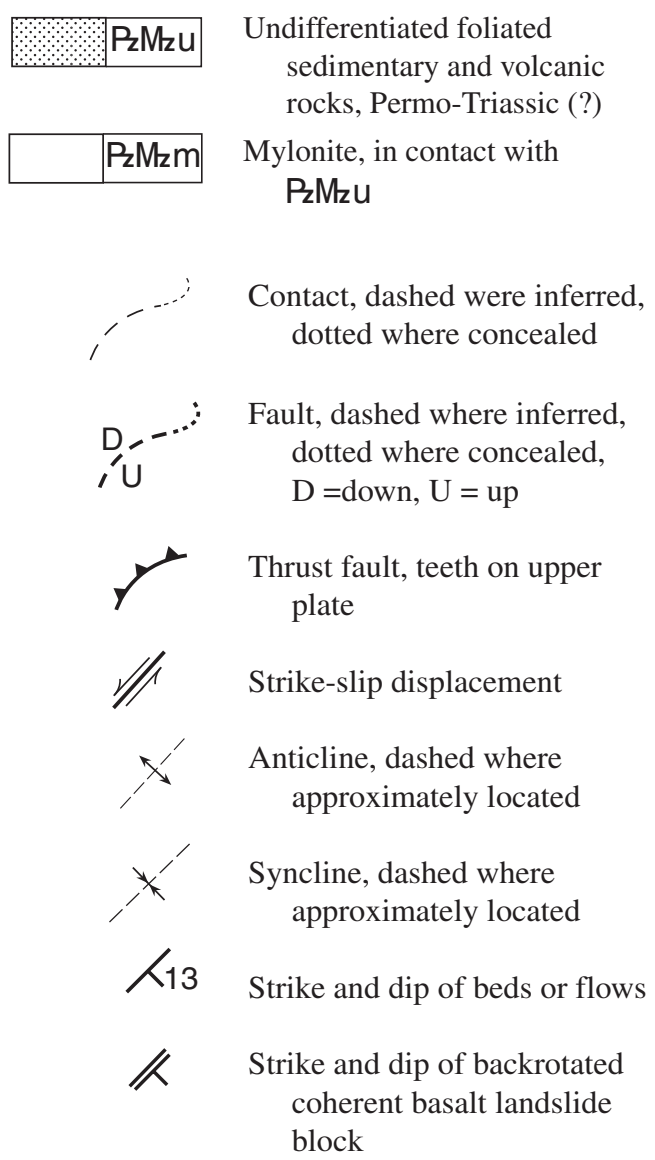

Figure 2.-Continued. 
Elliot (1982) emphasized the importance of lateral changes in the geometry of horses (elongate fault-bounded rock bodies) in thrust duplex systems, stating that "the distinctive scoop shape of roof, subsidiary, or floor thrusts is the result of oblique and lateral ramping."

The hanging wall of the roof thrust along the west side of the WSZ is represented by the fault contacts between rocks of the Wildhorse formation with Pkqd to the southwest and with Pkvs to the northeast. The floor thrust surface along the east side of the WSZ is represented by the fault contacts between $\mathrm{P}$ kqd and Baker belt rocks to the southwest, and P Kv and P Kc from Baker belt rocks to the northeast. Rock units unique to the WSZ, such as Pkc, PKvs, and PKv, appear to be of Baker belt affinity, and likely were emplaced as fault-bounded horses stripped from the Baker belt by progressive collapse of the footwall ramp during oblique-thrust duplexing. The dismembered belt of igneous rock ( $\mathrm{P}$ kqd) is probably a hanging-wall fragment plucked from the Wallowa terrane basement during thrusting. Slickenside striae within the WSZ generally occur on steeply dipping fault planes and have moderate to steep southeast plunges, although a variety of oblique orientations were observed which probably record only the last movement along the faults.

Other major belt-bounding faults in the area, such as the Cuddy Mountain Fault and the unnamed fault (Bayhorse Thrust on fig. 2) that separates the Triassic part of the Olds Ferry terrane (Huntington Formation) from the overlying Jurassic Weatherby Formation, dip to the northwest at between $40^{\circ}$ and $60^{\circ}$. However, the faults that make up the WSZ have such short areal exposure and complex interactions that a consistent dip direction could not be established. It is probable that faults within the WSZ are nearly vertical near the surface and dip more northwesterly at depth (see cross-section, fig. $3)$. Because of the geometry of nearby parallel reverse faults, and the style of deformation within the WSZ, we interpret the present-day WSZ to be a high-angle reverse fault zone with an oblique component.

An isolated outcrop of garnet mylonite (PzMzm) in lower Dukes Creek, on strike with the WSZ to the northeast (fig. 2), is an exception to the structural style in the WSZ. The protolith was a clinopyroxene-rich gabbro that now contains euhedral, post-mylonitic, almandine crystals interspersed in the mylonitic fabric. Mylonite folia trend $\mathrm{N} 20^{\circ} \mathrm{E}$. The outcrop is in tectonic contact with, and contains fragments of, Baker belt rocks. This structural position places the outcrop on strike with the cataclastic quartz diorite basement ( $\mathrm{P} \mathrm{kqd}$ ) in Wildhorse River canyon. However, the plunge of mineral lineations is nearly horizontal in oriented samples collected at the outcrop. This orientation is representative for most of the outcrop, although a wide range of orientations do occur near the fault contact with rocks of the Baker belt. It is possible that the mylonitic fabric formed during Late Triassic deformation documented by Avé Lallemant and others (1985) as mostly strike-slip in the Wallowa terrane. If so, then the WSZ may have been subsequently reactivated as an oblique reverse (thrust) fault during the accretion processes.

\section{Baker Belt}

The Baker belt (or terrane) rocks in the western Cuddy Mountains region are confined to an elongate area between the Cuddy Mountain Fault on the southeast and the WSZ on the northwest (fig. 2). The outcrop width of the belt in the Dukes Creek area is about $5 \mathrm{~km}$, and at a distance of only $5 \mathrm{~km}$ farther northeast, in lower elevations of No Business Creek canyon, the belt narrows to a width of little more than $2 \mathrm{~km}$, after which the Baker terrane rocks disappear beneath flows of Columbia River Basalt (fig. 2). About 50-60 km northeast along the Salmon River suture zone south of Riggins, Idaho, rocks of the Baker terrane apparently are absent and Wallowa and Olds Ferry ter-

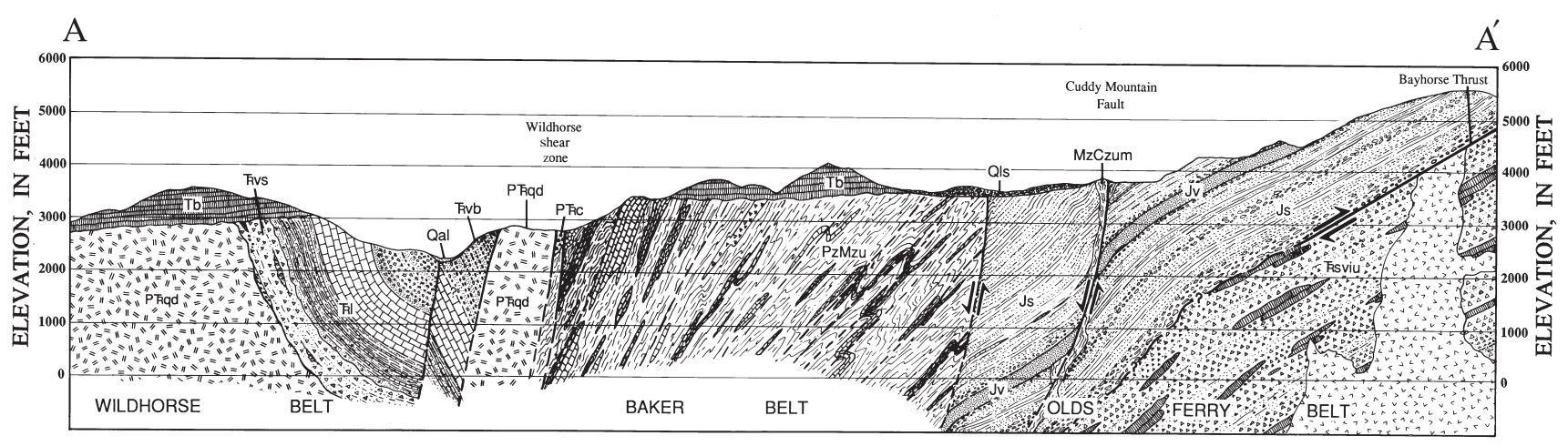

Figure 3. Cross section A-A' from figure 2. The unconformity between the Weatherby Formation (Js) and the Huntington Formation ( Rsviu) is also faulted, as shown by arrows along the dashed unconformity. This fault is the Bayhorse Thrust of Livingston (1932). For explanation of unit symbols, see figure 2. 
rane (?) rocks are in fault contact with cratonic rocks. Therefore, Baker terrane rocks in lower No Business Creek canyon are probably the easternmost known exposures of that terrane. Some outcrops near New Meadows, Idaho, are possible exceptions, where Bonnichsen (1987) mapped highly metamorphosed rocks that may be correlative with the Baker terrane.

The absence of dismembered igneous bodies and serpentinite-matrix mélange in Baker belt rocks of the western Cuddy Mountains suggests that the sediments in this part of the Baker terrane formed in a relatively stable tectonic setting. Some chert beds can be followed for nearly $2 \mathrm{~km}$ in the Wildhorse River canyon and Dukes Creek areas. Numerous small shear zones coincident with, and at acute angles to bedding, indicate tectonic shortening by thrusting. Most of this deformation occurs along bedding planes within phyllite and is probably related to an early phase of island-arc deformation, most likely in the fore-arc region during the Permian and Triassic periods rather than to late Mesozoic accretion processes.

Rocks of the Baker belt in our study area generally dip steeply northwest and have a pervasive N. $30^{\circ}-40^{\circ}$ E. strike. Chert is abundant and occurs in massive, brecciated, and ribbon beds, many of which can be traced for considerable distances. Phyllite and cherty phyllite are abundant. Limestone and marble occur as laterally discontinuous lenses. All gradations between chert, phyllite, and limestone are present, similar to parts of the Elkhorn Ridge Argillite (Gilluly, 1937) and to rocks in the Bournes subterrane (Ferns and Brooks, 1995).

\section{Olds Ferry Belt (Weatherby and Huntington Formations)}

Silberling and others (1984) did not recognize the Izee terrane in western Idaho, and elsewhere they show the Olds Ferry terrane in tectonic contact with the Baker terrane. Brooks and Vallier (1978) suggested that rocks correlative with the Izee terrane (Weatherby Formation and Squaw Creek Schist) extend across eastern Oregon and into western Idaho. Structural and depositional contacts in the western Cuddy Mountains region indicate, however, that the Weatherby Formation lies unconformably on the Huntington Formation, and is derived in large part from it. This unconformity was then subjected to thrust or reverse faulting (fig. 3). Because of the original unconformable nature of the contact between the two formations and their lithologic similarities, we retain the usage of Silberling and others (1984) and include them both within the Olds Ferry terrane. We recognize the formations as separate mappable units in this study (fig. 2).

The Olds Ferry belt (or terrane) in the western Cuddy Mountains area includes the Huntington and Weatherby Formations and a suite of plutonic bodies that range from gabbro to quartz diorite in composition. Included within the Weatherby Formation are a distinctive red and green conglomerate and a rhyodacite tuff unit. The Late Triassic (mostly Norian) Huntington Formation, as described by Brooks (1979b) from exposures in eastern Oregon south of the Cuddy Moun- tains along the Snake River canyon, is included in the Olds Ferry terrane and is the oldest stratified unit in that terrane. Volcanic conglomerate and sandstone are the most abundant rocks in the Huntington Formation of the western Cuddy Mountains (fig. 2, southeastern corner), and limestone, tuff, and volcanic flow rocks are subordinate. The volcanic rocks consist of flow breccia, spilite, andesite, keratophyre, and dacite porphyry (Fankhauser, 1969; Slater, 1969; Bruce, 1971; King, 1971; Skurla, 1974; Hendrickson, 1975; and Cyrus Field, written commun., 1988). The stratified rocks are in places intruded by quartz diorite, diorite, and gabbro plutons of Late Triassic and Early Jurassic ages. Chemical analyses indicate that the igneous rocks (both volcanic flow rocks and plutonic rocks) are a suite of potassium-rich arc tholeiites, and their differentiates (Vallier, 1995).

The Weatherby Formation in the western Cuddy Mountains crops out in a narrow 3-km-wide belt that trends N. $40^{\circ}$ E. Most beds dip northwest between $45^{\circ}$ and $60^{\circ}$, significantly less than the average dip of strata in the adjacent Baker belt. A distinctive red and green conglomerate (Brooks, 1967; Slater, 1969; Bruce, 1971) marks the boundary between the Jurassic Weatherby Formation and Triassic Huntington Formation and was mapped as part of the Weatherby Formation. The boundary, where mapped in eastern Oregon and western Idaho, is faulted, and the conglomerate in many places is highly tectonized. The conglomerate is correlative with the Jett Creek Member of the Weatherby Formation as described near Lime, Oregon (Brooks, 1979b). The clast assemblage in the red and green conglomerate is essentially identical to that of underlying metavolcanic conglomerates in the Huntington Formation, and the two are very difficult to distinguish in outcrop. A porphyritic rhyodacite tuff overlies the red and green conglomerate unconformably. The tuff is regionally extensive and was isotopically dated at about 200 Ma (Cyrus Field, written commun., 1988).

The upper part of the Weatherby Formation is dominated by a flyschlike assemblage of sandstone, siltstone, and shales. Flute and groove casts, graded beds, and shale rip-up clast beds typical of turbidity current deposition are common in outcrops. Many sandstones are composed of silicic volcanic rock and crystal fragments, with minor chert, calcite, serpentinite and opaque minerals. These dominant sandstones are interbedded with a few sandstone beds composed almost entirely of chert grains and recrystallized radiolarian tests that apparently were derived from erosion of the Baker terrane. Interbedded finer-grained beds have high contents of phyllitic material. Downsection, the clastic component of the Weatherby Formation becomes increasingly dominated by silicic and intermediate volcanic detritus that was derived from erosion of the Huntington Formation. Grain size also increases dramatically downsection, and coarse-grained volcaniclastic sandstones and conglomerate beds replace the flyschoid facies. Conglomerate clasts are mainly of andesite and dacite with subordinate limestone, sandstone, quartz, chert, and plutonic components. A Jurassic age for the Weatherby Formation is based on regional and local fossil identifications, especially ammonite fauna (Brooks, 1979b; Imlay, 1986). Dickinson and Thayer (1978) and Dickin- 
son (1979) suggested that most Izee terrane (Weatherby Formation) sediments were deposited in interarc basins that developed after formation of the Olds Ferry (or Huntington) volcanic arc in the Late Triassic to Early Jurassic. This is supported by our observations that Weatherby Formation sedimentary rocks in the western Cuddy Mountains had source rocks in the underlying Upper Triassic Huntington Formation and in the Baker terrane. Vallier (1995) used the Solomon Islands arc as a modern analogy, where a Miocene change in convergence direction led to the formation of a deep intra-arc basin.

Deposition of the basal red and green conglomerate of Brooks (1967) occurred in a marine environment in the Early Jurassic, as indicated by the presence of the marine bivalve Entolium sp. (Bruce, 1971). It is a basal conglomerate of the Weatherby Formation and marks a marine transgression during extensive erosion of the Huntington Formation and associated plutonic rocks. The rhyodacite crystal tuff was then deposited unconformably on this conglomerate. Conglomerate beds become less common upsection, and flyschoid sequences of interbedded sandstone and shale dominate. Flute and groove casts, graded bedding, and rip-up clasts of shale indicate deposition by turbidity currents. The overall upward-fining sedimentary sequence in the Weatherby Formation suggests either that the Jurassic intra-arc basin was subsiding rapidly or that the source area relief had decreased. Conglomerate from the lower part of the Weatherby Formation is clearly derived from erosion of the underlying Huntington Formation, whereas sandstone in the upper part of the formation also contains clasts derived from the Baker terrane.

In upper No Business Creek canyon, the reverse fault contact between the Weatherby and Huntington Formations passes upward into the Weatherby Formation (fig. 2). Lenticular fault-bounded inliers of Huntington Formation rocks in places are tectonically incorporated into the Weatherby Formation. According to Slater (1969) and Bruce (1971), parts of the originally unconformable contact between the two formations may still be intact. However, no completely untectonized contact between the two formations was observed in the western Cuddy Mountains area. The tuffaceous matrix of the Weatherby Formation's basal red and green conglomerate contains abundant sericite and chlorite and is highly sheared, thereby suggesting pervasive low-angle or bedding-plane faulting along this contact. It is likely that low-angle and bedding-plane faults within the conglomerate accommodated significant shortening and may have been another of the thrust faults that was active during the arc's accretion to North America.

The Baker belt was thrust over the Weatherby Formation along the Cuddy Mountain Fault probably during late Mesozoic (Late Jurassic and Early Cretaceous) accretion processes. Postaccretion tectonism may have steepened the angle of the fault to the present dip of approximately $65^{\circ} \mathrm{NW}$. Sometime after extrusion of the last flows of the Miocene Columbia River Basalt Group, the Cuddy Mountain Fault was reactivated as a normal fault with as much as $700 \mathrm{~m}$ of retrograde dip-slip displacement (Mann, 1989) and a significant left-lateral component of motion (Mann, 1991).

\section{Geologic Evolution of Blue Mountains Island Arc and Its Accretion to North America}

A speculative plate-tectonic model for the evolution of the Blue Mountains island arc from the late Paleozoic to the Late Cretaceous in seven stages was presented by Vallier $(1995,1998)$. Three of the major stages, beginning in the Late Triassic, are modified and reviewed here (fig. 4). These three stages focus on Late Triassic through Early Cretaceous evolution during east-northeastward transport of the arc and its accretion to North America.

The late Middle and early Late Triassic time interval (235-225 Ma) was one of voluminous magmatic activity in the Wallowa terrane and of minor, probably related, activity in what is now the Baker terrane (Vallier, 1995). Sinistral movement along major fault zones in the Wallowa terrane (Avé Lallemant and others, 1985) suggests extensive internal deformation of the arc and may account for some of its lateral movement during that time. Formation of a fore-arc basin and irregular basins along the inner wall of the trench, olistostromal sliding of large blocks, intrusion of serpentinite diapirs, and accretion of materials from the oceanic plate probably all occurred in the fore-arc region of the Wallowa terrane, exemplified by parts of what is now the Baker terrane.

The Olds Ferry terrane evolved mostly during the Late Triassic to Middle Jurassic (225-175 Ma) interval (fig. 4A) after a suspected change in plate convergence vectors. It grew first as an arc magmatic axis on older island-arc crust that was probably composed mostly of the Baker terrane. The consequent growth of the Olds Ferry terrane would make the Wallowa and Baker terranes parts of the Olds Ferry fore-arc region (Vallier, 1995, 1998). An arc-reversal model like that proposed for the Solomon island arc (Kroenke, 1984) could explain these relationships. Thus, igneous activity decreased in the Wallowa terrane when the Olds Ferry terrane magmatic axis was initiated. Carbonate banks (Martin Bridge Limestone and correlative strata) were deposited on subsiding parts of the new fore-arc region. A large intra-arc basin (between and on the Olds Ferry and the composite Baker and Wallowa terranes) formed, and the sediments deposited in the basin ultimately became the Izee terrane and correlative rocks to the east.

According to Vallier $(1995,1998)$, the Olds Ferry terrane was the oceanic part of an extensive volcanic arc that bordered North America in the Late Triassic and the Early Jurassic. It is possible that some of the arc developed as a continental volcanic arc (Mortimore, 1986). Northward movement of the Blue Mountains island arc along with the North American craton (Irving and Irving, 1982) probably began by at least the latest Triassic or earliest Jurassic. Close proximity to North America, by at least $180 \mathrm{Ma}$, is suggested by an early Bajocian marine fauna in the Wallowa terrane that has North American 
affinities (Stanley and Beauvais, 1990). However, most of the Blue Mountains arc was probably close enough to the North American craton and miogeocline during the Late Permian through Jurassic interval to have received faunal and sedimentary influences from it.

The Blue Mountains island arc continued to migrate northward with North America during the Middle and Late Jurassic, about 175 to $150 \mathrm{Ma}$ (fig. $4 B$ ). During the collision of the Blue Mountains island arc with North America, terranes of the BMIA were telescoped against North America along major oblique (?) overthrust faults that created the distinct tectonic belts that are so well exposed in the western Cuddy Mountains region (fig. 2). The Wallowa terrane was thrust over the Baker terrane along the Wildhorse shear zone, and the Baker terrane was thrust over the Weatherby Formation (continuation of the Izee terrane) along the Connor Creek-Cuddy Mountains fault system (Brooks and others, 1976; Mann, 1989). Much of the Weatherby Formation was thrust over the Huntington Formation along the Bayhorse thrust fault of Livingston (1932), which appears to have some expression in the southeast corner of the study area (fig. 2).

Structural relations between the tectonic belts and within the fault zones themselves show that latest deformation was related to appreciable shortening by thrust faulting accompanied by an oblique component of motion. The terrane-thinning geometry is most likely the result of left-oblique transpression coupled with partial preservation of original arc terrane morphology. For example, fore-arc deposits represented by the Baker Terrane would only have formed seaward (west or southwest) of the Wallowa arc axis and would necessarily be thin and terminate in the Cuddy Mountains area. Most shortening and thinning probably

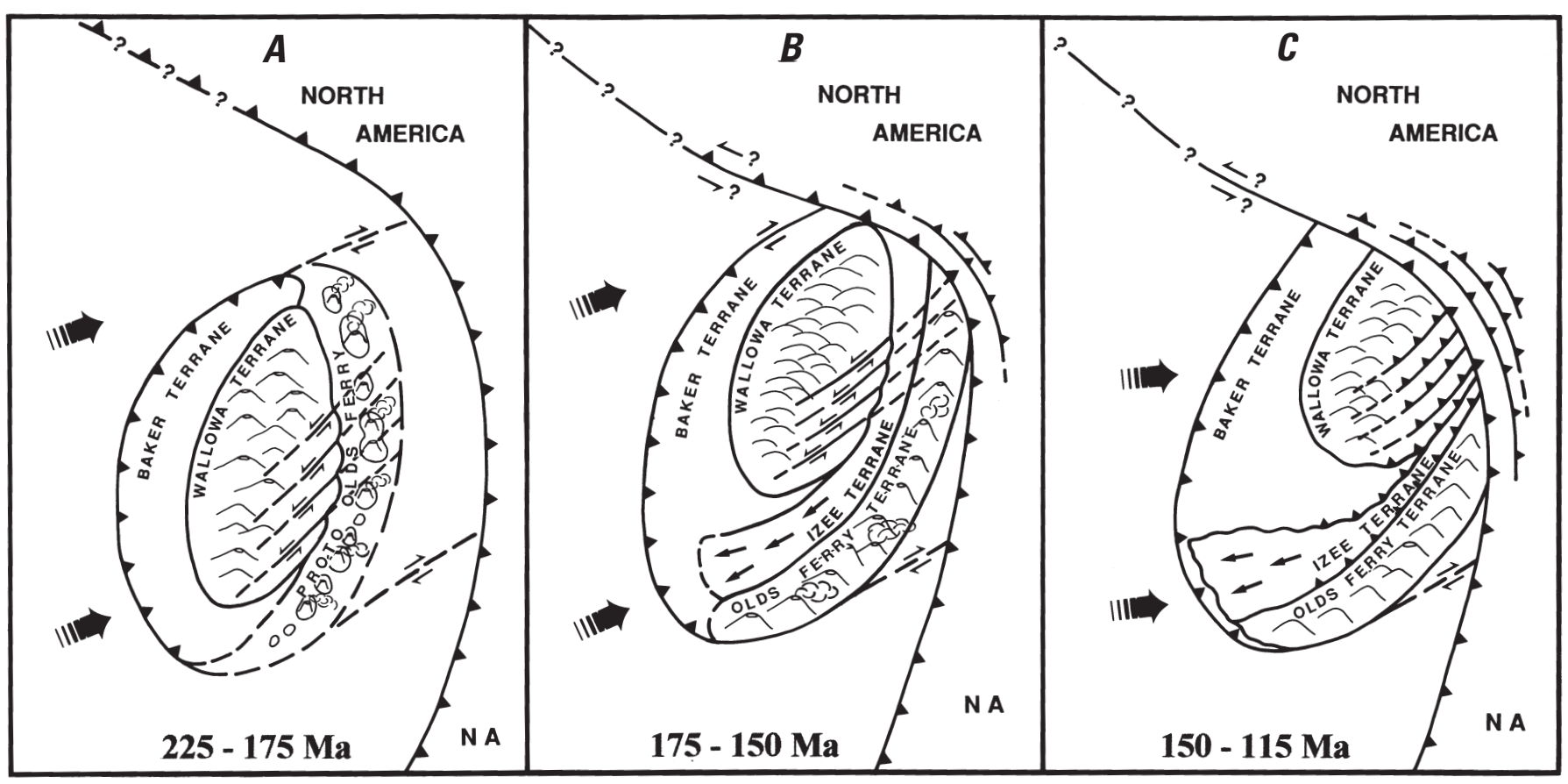

Figure 4. Schematic diagrams for three stages in the evolution of the BMIA (Blue Mountains island arc) beginning in the late Triassic. These diagrams are based, in part, on the seven-stage model of Vallier (1995), but focus on different time intervals to better reflect the western Cuddy Mountains region and accretionary tectonics of the island arc. Width of area covered is approximately 300 mi. Stage 1 $(A)$, Late Triassic to Middle Jurassic (Norian to Bajocian; 225-175 Ma), when the Olds Ferry magmatic axis was active. During that time interval and after a suspected change in plate vectors in the Late Triassic, the Wallowa terrane and parts of the Baker terrane became the fore-arc region to the Olds Ferry magmatic axis. The Izee terrane (and Weatherby Formation) sediments were deposited in a wide basin that formed between the Olds Ferry arc and the combined Wallowa terrane and Baker terrane fore-arc region. Arrows within the Izee terrane show suspected sediment transport directions. Most northward transport of the BMIA occurred during this time interval. Stage $2(B)$, Middle and Late Jurassic (Bajocian to Tithonian; 175-150 Ma), when volcanic activity greatly decreased in the BMIA and early stages of accretion to the North American craton occurred. Most of the suspected oblique thrust faulting occurred during this time interval and formed the narrowed tectonic belts now exposed in the western Cuddy Mountains region. Stage $3(C)$, Late Jurassic and Early Cretaceous (Tithonian to Aptian; 150-115 Ma), when Jurassic to Cretaceous plutonic rocks, some of batholith size, were intruded into the terranes; some of these plutons stitched the terranes together. Final stages of accretion occurred in the interval 120 to $115 \mathrm{Ma}$. Clockwise rotation of the BMIA after accretion (Wilson and Cox, 1980) and westward displacement of other parts of the island arc (Wernicke and Klepacki, 1988) are not shown. 
occurred during early accretion processes in the Late Jurassic (160-145 Ma), because elsewhere in the BMIA latest Jurassic and Early Cretaceous plutons cut faulted terrane boundaries and thereby stitch the terranes together (fig. $4 C$ ). In the Cuddy Mountains region, however, we do not know how much deformation occurred during the last phases of accretion in the Early Cretaceous (120-115 Ma; Lund and Snee, 1988; Vallier, 1995); the tectonic belts are not stitched by those Early Cretaceous plutonic bodies. Right-lateral strikeslip faulting may have been instrumental in the final accretion process (Wernicke and Klepacki, 1988), when fragments of the complex island arc (and adjacent parts of the Wrangellia terrane) were broken away to be subsequently transported northward along the cratonic margin.

\section{Late Cenozoic Reactivation of Meso- zoic Structures and Regional Structural Correlations}

Some faulted boundaries between tectonic belts in the western Cuddy Mountains were reactivated in the late Cenozoic, during post-middle Miocene deformation. Furthermore, some of these late Cenozoic fault displacements are superimposed on Mesozoic faults and form structural ties to the terrane boundaries of Silberling and others (1984) in eastern Oregon that otherwise would be concealed beneath middle Miocene basalt flows of the Columbia River Basalt Group.

The Cuddy Mountain Fault borders the northwest side of the Cuddy Mountains uplift (fig. 5) and separates the Baker and Olds Ferry belts (terranes). This same terranebounding fault zone is referred to as the Connor Creek Fault in eastern Oregon (Brooks and others, 1976) and as the Lick Creek Fault northeast of the Cuddy Mountains uplift (Fitzgerald, 1983). Mann (1989) suggested that the Cuddy Mountains uplift is a rhombic horst, and that the uplift is driven by a restraining bend along the Rush Peak Fault, which bounds the southeast side of the Cuddy Mountains. The Cuddy Mountain Fault was reactivated in the late Cenozoic as a normal fault with as much as $700 \mathrm{~m}$ of retrograde dip-slip offset (fig. 3), and a significant component of leftlateral motion. Unlike the complex Wildhorse shear zone, the Cuddy Mountain Fault consists of a simple $70^{\circ}$ northwestdipping fault plane that was already intruded by serpentinite (PzMzu, fig. 2) during the Mesozoic. The low shear strength of the serpentinite intrusive plane may have allowed this fault to preferentially reactivate.

Clockwise rotation of the Cuddy Mountains uplift is inferred from a 1.3-km sinistral offset of the Cuddy Mountain Fault by the Brownlee Fault (figs. 2, 6), and a similar offset of the northwest part of the Hornet Creek Fault by the Cuddy Mountain Fault (fig. 5) (Mann and Meyer, 1993). The offset segment of the Cuddy Mountain Fault lies along the lower
Grade Creek drainage and passes to the southwest into the middle fork of Brownlee Creek. Two inliers of Baker belt rocks are tectonically juxtaposed against Weatherby Formation rocks in the middle fork of Brownlee Creek, and the fault has up-to-the-east displacement of approximately $150 \mathrm{~m}$. The Cuddy Mountain Fault is also offset in an apparent rightlateral sense by the Sturgill Peak Fault approximately one km from the previously recognized Connor Creek Fault of Brooks and others (1976).

The northern extension of the Cuddy Mountain Fault is coincident with the Lick Creek Fault of Fitzgerald (1983). Several kilometers northeast of No Business Creek Canyon at Emery Creek, an excellent exposure of the fault zone yields a strike of $\mathrm{N} .35^{\circ} \mathrm{E}$., dipping from $80^{\circ} \mathrm{SE}$. to vertical with slickenside striae plunging $35^{\circ} \mathrm{SW}$. The rake of the striae implies a dominant strike-slip component. Mann (1991) noted systematic left-lateral offset of Quaternary drainages in the No Business Creek Canyon area, which is consistent with these fault-plane striae measurements. The linear trend of the fault in the Lick Creek area and the measurements at the Emery Creek site suggest that the fault becomes more vertical to the northeast. The absence of Mesozoic BMIA inliers in the Lick Creek drainage does not allow for direct correlation to Mesozoic structure; however, the uninterrupted continuity of the fault zone strongly implies a correlation. On the basis of our regional studies, the Lick Creek Fault appears to pass northeast through a drainage divide into the Rapid River area, suggesting continuity with the Rapid River Thrust (Hamilton, 1963; Aliberti, 1988). The structural continuities mapped in the western Cuddy Mountains thereby provide links between the Connor Creek Fault in eastern Oregon and the Rapid River Thrust of western Idaho via the Cuddy Mountain and Lick Creek Faults.

The Brownlee Fault is a basin-bounding hinge fault bordering the east side of the Pine Valley graben, which is interpreted to be a pull-apart basin (Mann, 1989; Mann and Meyer, 1993). Dip-slip displacements of approximately $500 \mathrm{~m}$ near its intersection with the Cuddy Mountain Fault, accompanied by erosional unroofing of the Miocene volcanic carapace, are responsible for the extensive footwall exposures of Baker belt, Weatherby Formation, and Huntington Formation rocks in this area. Mann (1989) suggested that the intersection of the Brownlee Fault and Cuddy Mountain Fault was a site of seismic strain accumulation, and that at least one magnitude 3.4 earthquake in 1983, and possibly three other larger events, occurred near or at this intersection.

\section{Conclusions}

Detailed geologic mapping at the 7.5-minute-quadrangle scale in the western Cuddy Mountains of western Idaho revealed three, separate, fault-bounded tectonic belts of pre-Cenozoic rocks that provide an important structural link with other parts of the Blue Mountains in eastern Oregon and western Idaho. These tectonic belts evolved in separate parts 


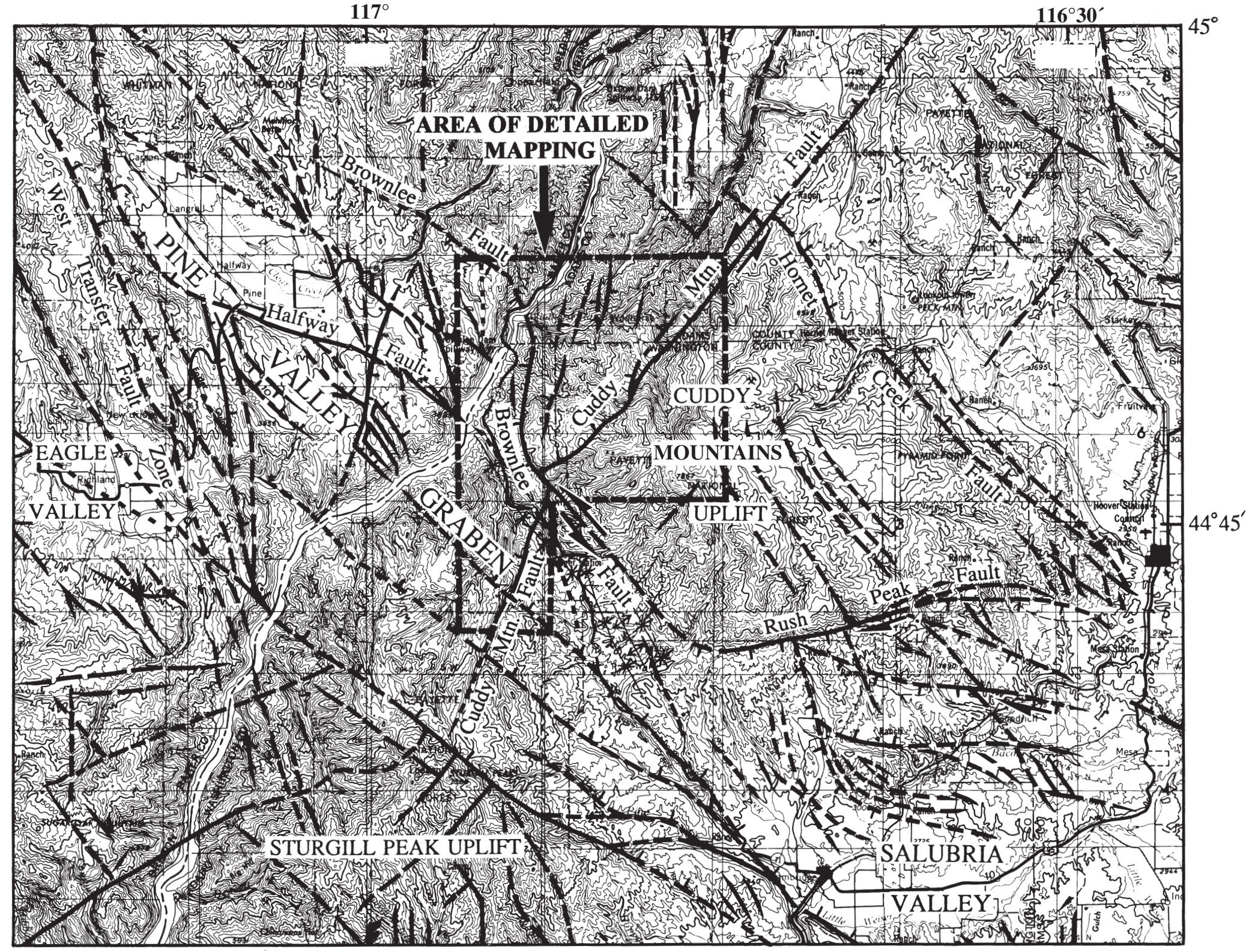

Figure 5. Map showing the Late Cenozoic structures in the Cuddy Mountains region of western Idaho regime (after Mann and Meyer, 1993). Note the distinct rhombic pattern of the Cuddy Mountains uplift. Pine Valley is a probable pull-apart basin that formed as a consequence of a regional strike-slip stress. Heavy outline marks approximate local study area in western Cuddy Mountains. 


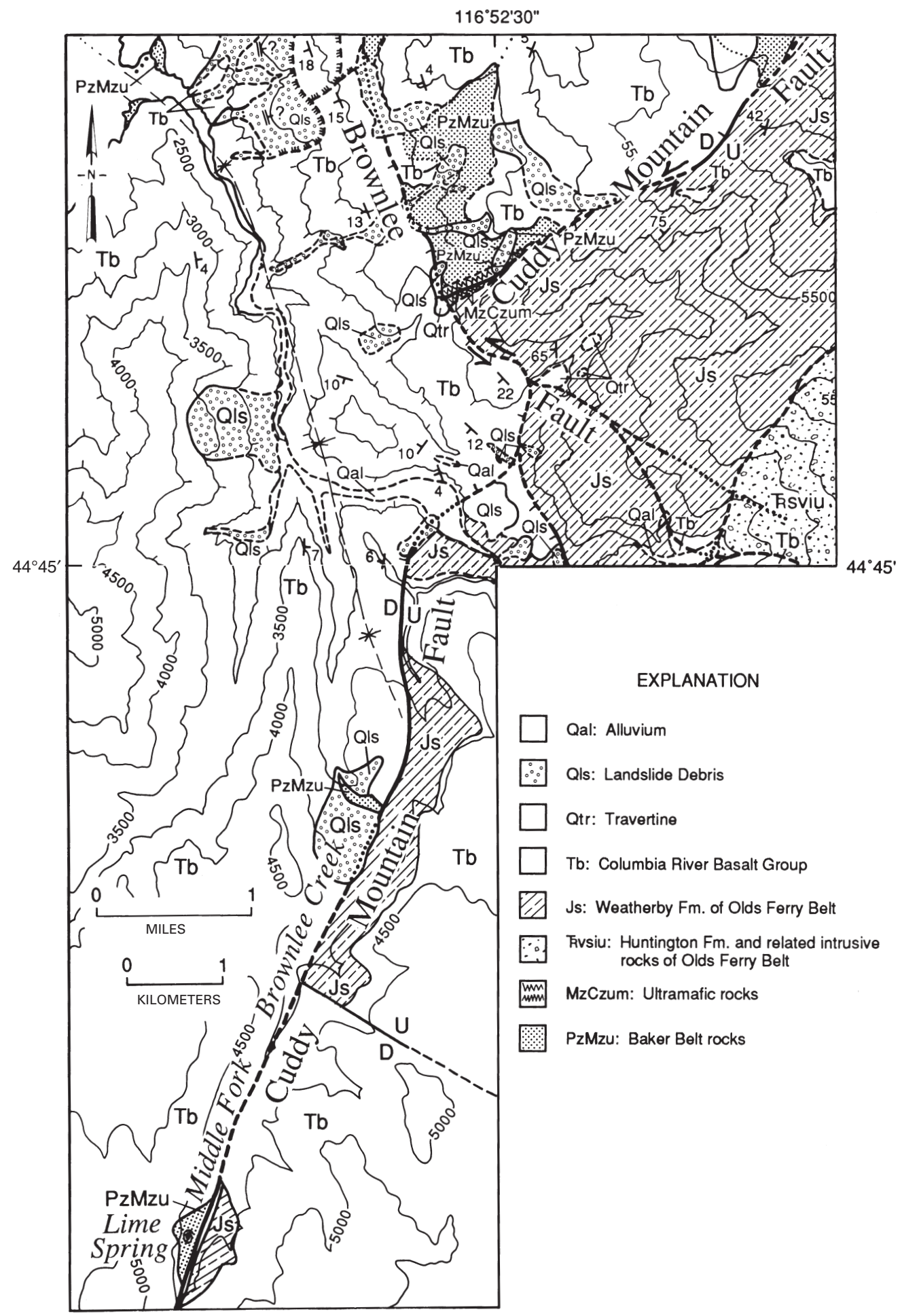

Figure 6. Map showing the 1.3-km offset of the Cuddy Mountain by the Brownlee Fault in the southwestern part of the Cuddy Mountains region. See figure 2 for more complete explanation of units and symbols. Double strike lines signify rotated blocks of Columbia River Basalt (Tb) that apparently are part of the adjacent landslide unit. Trsviu and Js mark rocks of the Olds Ferry belt. PzMzu marks rocks of the Baker belt. Notice the abundance of landslides in the mapped area. The Cuddy Mountain Fault is the linking fault between the Lick Creek Fault to the north and the Connor Creek Fault to the south. 
of what is believed to have been a single, but very complex, pre-Cenozoic island arc. This complex island arc apparently collided with the North American margin in the late Mesozoic, with final events occurring in the Early Cretaceous. During early stages of the collision, these tectonic belts, which are correlative with the terranes of Silberling and others (1984), were telescoped against the North American craton along several major fault zones that are best exposed in the western Cuddy Mountains of Idaho. The tectonic belts described here offer the last good exposures of rocks that are representative of the terranes of Silberling and others (1984); at least two of the terranes probably reappear as greatly tectonized and metamorphosed rock units along the Salmon River suture zone to the northeast.

The mostly Permian and Triassic Wallowa terrane, which we believe has rocks that are correlative to the Wildhorse belt and Wildhorse formation of Mann (1989), was obliquely thrust over the Baker belt along the Wildhorse shear zone (figs. 2, 3). The Wildhorse formation is composed of bioclastic limestone, flyschlike calcareous siltstone, volcanic breccia and sandstone. In the Snake River canyon below Brownlee Dam (fig. 2), rocks of the Wildhorse formation rest unconformably on, or are in fault contact with, a quartz diorite-trondhjemite basement complex that is very similar to many of the late Paleozoic and Early Triassic plutonic rocks described by Vallier (1995), the oldest of which may be igneous basement to the Wallowa terrane. Very similar plutonic rocks in Wildhorse River canyon occur in a narrow fault-bounded slice between the Baker belt and the Wildhorse formation. Several other rock units unique to the area, and of probable Baker terrane affinity, occur in fault-bounded slices between rocks of the Baker belt and Wildhorse Formation. This highly cataclastic and tectonized juxtaposition, which constitutes the Wildhorse shear zone, probably evolved in a thrust duplex. The predominance of tectonic bodies of Baker terrane affinity in the shear zone may then be explained as the result of progressive footwall ramp collapse during thrust duplexing. The quartz diorite "basement" in the Wildhorse shear zone probably represents a hanging wall fragment of Wallowa terrane plutonic rocks.

The complex assemblage of dominantly metasedimentary rocks making up the Baker belt (or terrane) occurs in a 6- to $2.5-\mathrm{km}$-wide, northeastward tapering, fault-bounded wedge in the center of the study area. The Baker terrane is believed to have formed in the fore-arc region of the Blue Mountains island arc (Mullen, 1985; Avé Lallemant, 1995). The Baker belt rocks in the Cuddy Mountains region generally dip steeply to the northwest and follow a pervasive $\mathrm{N}$. $30^{\circ}-40^{\circ}$ E. strike. Although cataclastic gabbro, recrystallized limestone, and argillite occur, most rocks are ribbon and massive chert, phyllite, and cherty phyllite. Baker terrane rocks in this region lack the chaotic mélange and large tectonized igneous bodies that are more characteristic of eastern Oregon outcrops. It is probable that this local occurrence of Baker terrane rocks formed in a more stable fore-arc setting than many parts of the terrane in eastern Oregon. The belt narrows rapidly towards the northeast and is projected to tectonically pinch out a few kilometers northeast of the study area under flows of the Columbia River Basalt Group. Rocks correlative to the Baker terrane are either absent or unrecognized along and near the Salmon River suture zone.

During late Mesozoic accretionary processes the Baker belt was thrust over the Jurassic Weatherby Formation (Olds Ferry terrane) along the Cuddy Mountain Fault (fig. 2). Rocks in the lower part of the Weatherby Formation are clearly derived from those of the underlying Huntington Formation. Parts of the originally unconformable contact between the rocks of the Weatherby and Huntington Formations are apparently preserved in places (Slater, 1969; Bruce, 1971); however, they are in tectonic contact farther south along the Bayhorse Thrust of Livingston (1932), and the intensely sheared basal red and green conglomerate of Brooks (1967), which separates the two formations, indicates significant tectonic transport. The upper part of the Weatherby Formation is composed of a flyschoid sequence of siliceous sandstone, siltstone, and shale. These clastic rocks have flute and groove casts, graded beds, and shale rip-up beds that indicate transport by turbidity currents. Some of these sandstones have abundant fragments of radiolarianbearing chert and phyllite, which strongly suggests erosion from and proximity to the Baker terrane. The lower part of the formation is increasingly conglomeratic, and clast compositions are essentially identical to the volcaniclastic suite of the underlying Huntington Formation. The clastic and subordinate volcanic rocks of the Weatherby Formation are believed to have been deposited either in a fore-arc basin or in an inter-arc basin between the Wallowa and Olds Ferry volcanic arcs.

Terranes of the BMIA and the tectonic belts in western Idaho were tectonically telescoped during impingement and accretion of the arc to North America. Most of the faulting in eastern Oregon was completed by the latest Jurassic, as shown by the stitching of terranes by Late Jurassic and Early Cretaceous plutons. We do not know, however, when thrusting and reverse faulting ended in the western Cuddy Mountains region and suspect that it may have continued until final phases of accretion of the arc to North America in the Early Cretaceous. Thrusting and reverse faulting were apparently very extensive, and the east-directed overriding of tectonic packages greatly narrowed the original terranes. Furthermore, original island-arc morphology, most notably for the Baker terrane, may also have contributed to terrane thinning.

Late Cenozoic deformation is influenced by some of the Mesozoic terrane-bounding faults in the western Cuddy Mountains region. Clockwise rotation of the Cuddy Mountains uplift is inferred from the sinistral offset of the Cuddy Mountain Fault by the Brownlee Fault and a similar offset of the Hornet Creek Fault by the Cuddy Mountain Fault. The Brownlee Fault is a basin-bounding hinge fault along the eastern side of a seismically active pull-apart basin, the Pine Valley graben. 


\section{Acknowledgments}

We thank Howard Brooks and Norm Silberling, who reviewed an early draft of this manuscript. Howard also provided encouragement and regional advice during all phases of this study. We thank the kindness of many residents in the Cuddy Mountains region, particularly Helen Schmidt, Ralph and Dottie Brown, and Mike and Peg Hillman, all of whom treated us as neighbors and friends. In addition, we appreciate the advice and enthusiasm of Elwood (Woody) Brooks, who provided many thoughtful suggestions during the course of this study. We thank Susan Vath for assistance with illustrations.

\section{References Cited}

Aliberti, E.A., 1988, A structural, petrographic, and isotopic study of the Rapid River area and selected mafic complexes in the northwestern United States-implications for the evolution of an abrupt island-arc-continent boundary: Cambridge, Mass., Harvard University, Ph.D. dissertation, 194 p.

Avé Lallemant, H.G., 1995, Pre-Cretaceous tectonic evolution of the Blue Mountains province, northeastern Oregon, in Vallier, T.L., and Brooks, H.C., eds., Geology of the Blue Mountains region of Oregon, Idaho, and Washington; Petrology and tectonic evolution of pre-Tertiary rocks of the Blue Mountains region: U.S. Geological Survey Professional Paper 1438, p. 271-304.

Avé Lallemant, H.G., Schmidt, W.J., and Kraft, J.L., 1985, Major Late-Triassic strike-slip displacement in the Seven Devils terrane, Oregon and Idaho-a result of left-oblique plate convergence?: Tectonophysics, v. 119, p. 299-328.

Blome, C.D., and Nestell, M.K., 1991, Evolution of a PermoTriassic sedimentary mélange, Grindstone terrane, eastcentral Oregon: Geological Society of America Bulletin, v. 103, p. 1280-1296.

Blome, C.D., Jones, D.L., Murchey, B.L., and Liniecki, Margaret, 1986, Geologic implications of radiolarian-bearing Paleozoic and Mesozoic rocks from the Blue Mountains province, eastern Oregon, in Vallier, T.L., and Brooks, H.C., eds., Geology of the Blue Mountains region of Oregon, Idaho, and Washington; Geologic implications of Paleozoic and Mesozoic paleontology and biostratigraphy, Blue Mountains province, Oregon and Idaho: U.S. Geological Survey Professional Paper 1435, p. 79-93.

Bonnichsen, Bill, 1987, Pre-Cenozoic geology of the West Mountain-Council Mountain-New Meadows area, westcentral Idaho, in Vallier, T.L., and Brooks, H.C., eds., Geology of the Blue Mountains region of Oregon, Idaho, and Washington; the Idaho Batholith and its border zone: U.S. Geological Survey Professional Paper 1436, p. 151-170.
Boyer, S., and Elliot, D., 1982, Thrust systems: American Association of Petroleum Geologists Bulletin, v. 66, p. 1196-1230.

Brooks, H.C., 1967, Distinctive conglomerate layer near Lime, Baker County, Oregon: The Ore Bin, v. 29, p. 113-119.

Brooks, H.C., 1979a, Plate tectonics and the geologic history of the Blue Mountains: Oregon Geology, v. 41, no. 5, p.71-80.

Brooks, H.C., 1979b, Geologic map of the Huntington and part of the Olds Ferry quadrangles, Baker and Malheur Counties, Oregon: Oregon Department of Geology and Mineral Industries Geological Map Series GMS-13, scale $1: 62,500$.

Brooks, H.C., and Vallier, T.L., 1978, Mesozoic rocks and tectonic evolution of eastern Oregon and western Idaho, in Howell, D.G., and McDougall, K.A., eds., Mesozoic paleogeography of the Western United States: Los Angeles, Society of Economic Paleontologists and Mineralogists, Pacific Section, Pacific Coast Paleogeography Symposium 2, p. 133-145.

Brooks, H.C., McIntyre, J.R., and Walker, G.W., 1976, Geology of the Oregon part of the Baker $1^{\circ}$ by $2^{\circ}$ quadrangle: Oregon Department of Geology and Mineral Industries Geological Map Series GMS-7, 29 p. of text, scale 1:250,000.

Bruce, W.R., 1971, Geology, mineral deposits, and alteration of parts of the Cuddy Mountains district, western Idaho: Corvallis, Oregon State University, Ph.D. dissertation, 165 p.

Coney, P.J., Jones, D.L., and Monger, J.W.H., 1980, Cordilleran suspect terranes: Nature, v. 288, p. 329-333.

Davis, G.A., Monger, J.W.H., and Burchfiel, B.C., 1978, Mesozoic construction of the Cordilleran "collage," central British Columbia to central California, in Howell, D.G., and McDougall, K.A., eds., Mesozoic paleogeography of the Western United States: Los Angeles, Society of Economic Paleontologists and Mineralogists, Pacific Section, Pacific Coast Paleogeography Symposium 2: p. 1-32.

Dickinson, W.R., 1979, Mesozoic fore-arc basin in central Oregon: Geology, v. 7, p. 166-170.

Dickinson, W.R., 2004, Evolution of the North America Cordillera: Annual Review of Earth and Planetary Sciences, v. 32, p. 13-45.

Dickinson, W.R., and Thayer, T.P., 1978, Paleogeographic and paleotectonic implications of Mesozoic stratigraphy and structure in the John Day inlier of central Oregon, in Howell, D.G., and McDougall, K.A., eds., Mesozoic paleogeography of the Western United States: Los Angeles, Society of Economic Paleontologists and Mineralogists, 
Pacific Section, Pacific Coast Paleogeography Symposium 2, p. 147-161.

Fankhauser, R.E., 1969, Geology and mineralization of the southern Cuddy Mountains, Washington County, Idaho: Corvallis, Oregon State University, Master's thesis, 126 p.

Ferns, M.L., and Brooks, H.C., 1995, The Bourne and Greenhorn subterranes of the Baker terrane, northeastern Oregon; implications for the evolution of the Blue Mountains islandarc sysem, in Vallier, T.L., and Brooks, H.C., eds., Geology of the Blue Mountains region of Oregon, Idaho, and Washington; petrology and tectonic evolution of pre-Tertiary rocks of the Blue Mountains region: U.S. Geological Survey Professional Paper 1438, p. 331-358.

Fitzgerald, J.F., 1983, Geology and basalt stratigraphy of the Weiser embayment, west-central Idaho, in Bonnichsen, B., and Breckenridge, R.M., eds., Cenozoic geology of Idaho: Idaho Bureau of Mines and Geology Bulletin. 26, p. 103-128.

Gilluly, James, 1933, Replacement origin of the albite granite near Sparta, Oregon: U.S. Geological Survey Professional Paper 175-C, 16 p.

Gilluly, James, 1937, Geology and mineral resources of the Baker quadrangle, Oregon: U.S. Geological Survey Bulletin 879, 119 p.

Hamilton, Warren, 1963, Metamorphism in the Riggins region, western Idaho: U.S. Geological Survey Professional Paper 436, 95 p.

Hendricksen, T.A., 1975, Geology and mineral deposits of the Mineral-Iron Mountain district, Washington County, Idaho, and of a metallized zone in western Idaho and eastern Oregon: Corvallis, Oregon State University, Ph.D. dissertation, $205 \mathrm{p}$.

Hillhouse, J., Grommé, S., and Vallier, T., 1982, Paleomagnetism and Mesozoic tectonics of the Seven Devils Arc in northeastern Oregon: Journal of Geophysical Research, v. 87, p. 3777-3794.

Howell, D.G., Jones, D.L., and Schermer, E.R., 1985, Tectonostratigraphic terranes of the circum-Pacific region, in Howell, D.G., ed., Tectonostratigraphic terranes of the circum-Pacific region: Houston, Circum-Pacific Council for Energy and Mineral Resources Earth Science Series, v. 1, p. 3-30.

Imlay, R.W., 1986, Jurassic ammonites and biostratigraphy of eastern Oregon and western Idaho, in Vallier, T.L., and Brooks, H.C., eds., Geology of the Blue Mountains region of Oregon, Idaho, and Washington; geologic implications of Paleozoic and Mesozoic paleontology and biostratigraphy, Blue Mountains province, Oregon and Idaho: U.S. geological Survey Professional Paper 1435, p. 53-57.
Irving, E.E., and Irving, G.A., 1982, Apparent polar wander paths, Carboniferous through Cenozoic and the assembly of Gondwana: Geophysical Surveys, v. 4, p. 141-188.

Jones, D.L., Silberling, N.J., and Hillhouse, J.W., 1977, Wrangellia - a displaced terrane in northwestern North America: Canadian Journal of Earth Sciences, v. 14, p. 2565-2577.

King, J.R., 1971, The geology of the southeastern Cuddy Mountain district, western Idaho: Corvallis, Oregon State University, Master's thesis, $78 \mathrm{p}$.

Kroenke, L.W., 1984, Cenozoic development of the southwest Pacific: Suva, Fiji, U.N. ESCAP, Committee for Co-ordination of Joint Prospecting for Mineral Resources in South Pacific Offshore Areas (CCOP/SOPAC), Technical Bulletin $6,122 \mathrm{p}$.

Livingston, D.C., 1932, A major overthrust in western Idaho and northeastern Oregon: Northwest Science, v. 6, p. 31-36.

Lund, Karen, and Snee, L.W., 1988, Metamorphism, structural development, and age of the continent-island arc juncture in west-central Idaho, in Ernst, W.G., ed., Metamorphism and crustal evolution, western conterminous United States: Geological Society of America, Rubey Volume VII, p. 296-337.

Mann, G.M., 1988, Geologic maps of the Brownlee Dam and Cuddy Mountain 7.5-minute quadrangles: U.S. Geological Survey Open-File Report 88-657, 2 map sheets, scale $1: 24,000$.

Mann, G.M., 1989, Seismicity and Late Cenozoic faulting in the Brownlee Dam area-Oregon and Idaho, a preliminary report: U.S. Geological Survey Open-File Report 89-429, 46 p.

Mann, G.M., 1991, Geology and seismicity of the Pine Valley and Cuddy Mountains region, Idaho-Oregon: Hayward, California State University, Master's thesis, 220 p.

Mann, G.M., and Meyer, C.E., 1993, Late Cenozoic structure and correlations to seismicity along the "Olympic-Wallowa Lineament," northwest United States: Geological Society of America Bulletin, v. 105, no. 7, p. 853-876.

Mortimore, Nicholas, 1986, Late Triassic, arc-related, potassic igneous rocks in the North American Cordillera: Geology, v. 14 , p. 1035-1038.

Mullen, E.M., 1985, Petrologic character of Permian and Triassic greenstones from the melange terrane of eastern Oregon and their implications for terrane origin: Geology, v. 13, p. 131-134.

Prostka, H.J., 1962, Geology of the Sparta quadrangle, Oregon: Oregon Department of Geology and Mineral Industries, Geologic Map Series GMS-1, 1 map sheet, scale 1:62,000.

Roure, F., 1982, Mise en evidence d'une tectonique majeur de Juassique Superior dans le nord-est de l'Oregon (sect- 
eur de Huntington): Comptes Rendues Habdomadaires des Seances de l'Academie des Sciences de Paris, Ser. 2, v. 294, p. 921-925.

Saleeby, J.B., 1983, Accretionary tectonics of the North American Cordillera: Annual Review of Earth and Planetary Sciences, v. 11, p. 45-73.

Sarewitz, D., 1983, Seven Devils terrane-is it really a piece of Wrangellia?: Geology, v. 11, p. 634-637.

Silberling, N.J., Jones, D.L., Blake, M.C., Jr., and Howell, D.G., 1984, Lithotectonic terrane map of the western conterminous United States, Part C of Silberling, N.J., and Jones, D.L., eds., Lithotectonic terrane maps of the North American Cordillera: U.S.Geological Survey Open-File Report 84-523, 44 p. of text, 1 map sheet, scale 1:2,500,000.

Skurla, S.J., 1974, The geology of the Sturgill Peak area, Washington County, Idaho: Corvallis, Oregon State University, Master's thesis, $98 \mathrm{p}$.

Slater, M.N., 1969, The geology and mineral deposits of the western Cuddy Mountain district, western Idaho: Corvallis, Oregon State University, Master's thesis, 82 p.

Stanley, G.D., Jr., and Beauvais, L., 1990, Middle Jurassic corals from the Wallowa terrane, west-central Idaho: Journal of Paleontology, v. 64, p. 352-362.

Vallier, T.L., 1977, The Permian and Triassic Seven Devils Group, western Idaho and northeastern Oregon: U.S. Geo- logical Survey Bulletin 1437, 58 p.

Vallier, T.L., 1995, Petrology of pre-Tertiary igneous rocks in the Blue Mountains region of Oregon, Idaho, and Washington; implications for the geologic evolution of a complex island arc, in Vallier, T.L., and Brooks, H.C., eds., Geology of the Blue Mountains region of Oregon, Idaho, and Washington; petrology and tectonic evolution of pre-Tertiary rocks of the Blue Mountains region: U.S. Geological Survey Professional Paper 1438, p. 125-209.

Vallier, Tracy, 1998, Islands and rapids, a geologic story of Hells Canyon: Lewiston, Idaho, Confluence Press, 162 p.

Vallier, T.L., Brooks, H.C., and Thayer, T.P., 1977, Paleozoic rocks of eastern Oregon and western Idaho, in Stewart, J.H., Stevens, C.H., and Fritsche, A.E., eds., Paleozoic paleogeography of the Western United States: Los Angeles, Society of Economic Paleontologists and Mineralogists, Pacific Section, Pacific Coast Paleogeography Symposium 1, p. 455-466.

Wernicke, Brian, and Klepacki, D.W., 1988, Escape hypothesis for the Stikine block: Geology, v. 16, p. 461-464.

Wilson, Douglas, and Cox, Allan, 1980, Paleomagnetic evidence for the tectonic rotation of Jurassic plutons in the Blue Mountains, eastern Oregon: Journal of Geophysical Research, v. 85, no. B7, p. 3681-3689.

Wilson, K.M., Hay, W.W., and Wold, C.N., 1991, Mesozoic evolution of exotic terranes and marginal seas, western North America: Marine Geology, v. 102, p. 311-361. 


\section{Structure and Tectonic Evolution of Plutonic Units of the Idaho Batholith Near McCall, Idaho}

By Mel A. Kuntz

\section{Abstract}

The map patterns and structures of plutonic units of the Idaho Batholith near McCall, Idaho, east of the Salmon River suture, are indicative of the tectonic environments at the time of pluton emplacement. The pinwheel character of the leucogranodiorite of Jumbo Creek in map view suggests that it was emplaced and rotated clockwise within a screen of metasedimentary rocks that were being deformed by local left-lateral strike-slip faulting at approximately $94 \mathrm{Ma}$. A pronounced foliation and a stretching mineral lineation in the long, narrow tonalite of Payette River and granodiorite of Box Lake plutonic units were formed by vertical flow of magma in a transpression-dominated, contractional setting. The tonalite of Payette River formed at approximately $90 \mathrm{Ma}$ and the granodiorite of Box Lake formed at approximately $85 \mathrm{Ma}$. Emplacement of these two plutonic units occurred mainly by diking. The equant outcrop shape and the weak development of foliation and lineation suggest that the plutons of the monzogranite of Lick Creek formed by partial melting of fertile pelitic rocks in the middle crust and that the magma migrated only short distances and ponded to form extensive laccoliths during a period of extension at approximately $83 \mathrm{Ma}$. The emplacement of plutons of the monzogranite of Lick Creek was probably localized along flat ramps and nappes on lowangle, hinterland-dipping faults during ductile extension.

The orientation of foliation, lineation, dikes, and joints in the plutonic units record a tectonic history in which paleostrains changed in intensity and direction during the sequential emplacement of the plutonic units. Specifically, a contractional regime, with the axis of shortening oriented northwest-southeast, existed between 90 and $85 \mathrm{Ma}$ during emplacement of the tonalite and granodiorite plutons. An extensional regime, with the axis of extension oriented southwest-northeast, existed at $82 \mathrm{Ma}$ during the emplacement of monzogranite plutons and certainly existed after about $80 \mathrm{Ma}$ during formation of joints and emplacement of dikes and veins. The motion trajectory of the North America plate with respect to the Salmon River suture zone is homoaxial and approximately synchronous with the orientation of the paleostrain axes.

\section{Introduction}

\section{Regional Tectonic Relations and Nomenclature}

Regional mapping of the border zone of the Idaho Batholith near McCall, Idaho (fig. 1) has led to the identification of plutonic units of Late Cretaceous tonalite, granodiorite, and monzogranite. These plutonic units contain inclusions and pendants of continentally derived quartzite, gneiss, and schist (Kuntz, this volume, chapter 5; Manduca and others, 1993). Lying to the west of these Late Cretaceous plutons are Early Cretaceous, moderately to highly deformed tonalite, quartz diorite, and trondhjemite plutons, some of which are separated by screens and pendants of metamorphosed plutonic and volcanic rocks of oceanic-arc affinity. These plutonic and metavolcanic rocks are allochthonous and constitute part of the Blue Mountains island-arc terrane that was accreted to the western edge of North America during the Mesozoic (Manduca and others, 1993; Vallier, 1995).

The Hazard Creek Complex (fig. 1) consists of variably deformed and metamorphosed quartz diorite and trondhjemite plutons that were emplaced in Jurassic(?) and Cretaceous time west of the continent-oceanic arc boundary. The Little Goose Creek Complex (fig. 1) consists chiefly of porphyritic granodiorite and lesser tonalite that were emplaced in the Early Cretaceous along the boundary between accreted oceanic-arc terranes and the continental margin. Available U-Pb zircon ages of the plutons in both complexes range from $118 \pm 5 \mathrm{Ma}$ to $110 \pm 5 \mathrm{Ma}$ (D. Unruh, unpublished data). McClelland and others (2000) stated that the syndeformational tonalitic plutons west of the Salmon River suture zone are concordant with shear-zone fabrics that locally preserve dextral strike-slip kinematic indicators. These plutons also contain pervasive downdip mineral and elongation lineations. On the basis of these factors, McClelland and others (2000) infer that the tonalitic plutons were emplaced and deformed in an intra-arc transpressional setting. They also state that western Idaho and eastern Oregon were affected by a two-stage process involving underthrusting of accreted crustal fragments followed by development of subvertical, intra-arc transpressional shear zones, one of which is the Salmon River suture zone. Large amounts of 


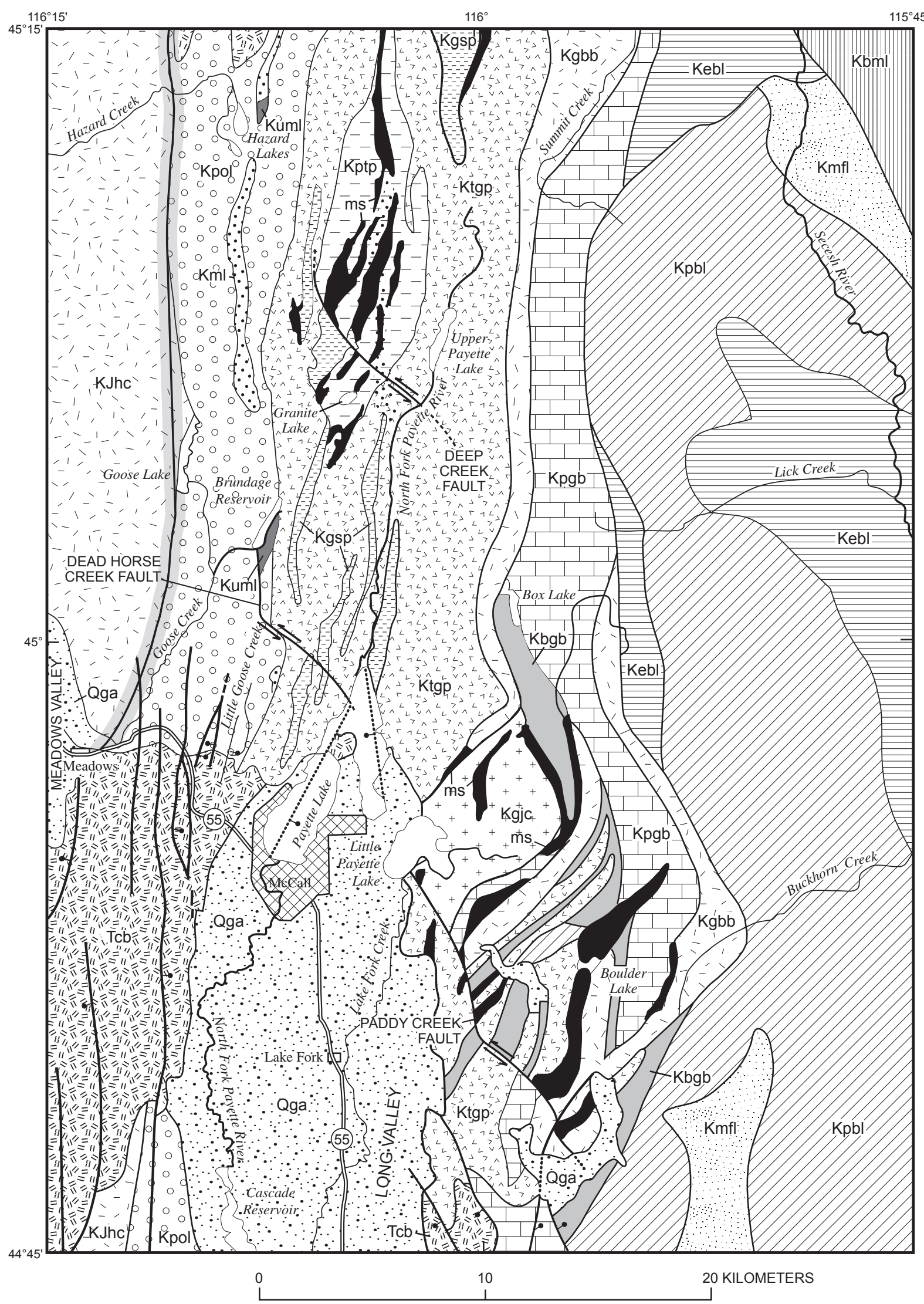

Figure 1. Generalized geologic map of the McCall, Idaho, area. 


\section{EXPLANATION}

$\therefore$ Qga

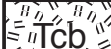

$=1, \mathrm{Cb}_{11}$

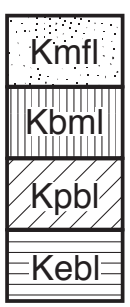

Kbgb

Kpgb

-Kǵb̄'

+ Kgjc +

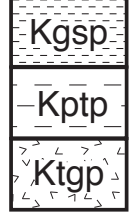

$\mathrm{Kpol}^{\circ}$

$\because \dot{\mathrm{k}} \mathrm{i}: \mathrm{O}$ $\because \ldots$

Kuml

$-1$

\section{Surficial deposits (Quaternary)}

Glacial and alluvial deposits

Columbia River Basalt Group (Miocene)

Basalt flows and interbedded sedimentary deposits

Monzogranite of Lick Creek (Cretaceous)

Porphyritic muscovite-feldspar monzogranite

Equigranular biotite-muscovite monzogranite

Porphyritic biotite monzogranite

Equigranular biotite monzogranite

Granodiorite of Box Lake (Cretaceous)

Porphyritic biotite granodiorite

Porphyritic granodiorite

Granodiorite of border zone

Leucogranodiorite of Jumbo Creek (Cretaceous)

Biotite leucogranodiorite

Tonalite of Payette River (Cretaceous)

Granodiorite sills, dikes, and small plutons

Porphyritic tonalite

Tonalite, granodiorite and quartz diorite

\section{Little Goose Creek Complex (Cretaceous)}

Porphyritic orthogneiss

Mafic rocks, mostly tonalite gneiss

Ultramafic and mafic rocks

Hazard Creek Complex (Jurassic (?) and Cretaceous)

- Kjhç ${ }^{-}$Chiefly tonalite, trondhjemite and K-feldspar bearing plutonic rocks (undivided)

ms Paleozoic(?) and Proterozoic Metasedimentary rocks

Contact - Dashed where approximately located

$\rightleftharpoons$ Fault - Dashed where approximately located; dotted where concealed. Bar and ball on downthrown side; arrows show direction of movement

Initial strontium isotope ratio isopleth. See text for discussion.

Figure 1.-Continued. 
uplift and rapid exhumation occurred along the suture zone, which acted like a transpressional flower structure (Lund, 1984; Lund and Snee 1988; Selverstone and others, 1992).

The boundary that separates the Late Cretaceous plutonic rocks and the accreted, allochthonous rocks is the Salmon River suture (Lund and Snee, 1988). The Salmon River suture is best defined by steeply dipping, tabular, tonalitic plutons (see Snee and others, this volume, chapter 3; Lund and Snee, 1988 ) and by an abrupt change in ${ }^{87} \mathrm{Sr} /{ }^{86} \mathrm{Sr}$ ratio (Fleck and Criss, this volume, chapter 2; and fig. 1 of this paper).

McClelland and others (2000) defined the Salmon River suture zone as an approximately $50-\mathrm{km}$-wide belt (in the area between McCall and Riggins, Idaho; see fig. 1 of Kuntz and Snee, this volume, chapter 1) that includes a Cretaceous thrust belt on the west, the Late Cretaceous western Idaho shear zone, and deformed plutons of the western part of the Idaho Batholith. They use the term western Idaho shear zone for a $\sim 10$-km-wide belt of mid- to Late Cretaceous, steeply dipping to vertical, ductile fabrics and anastomosing shear zones that is roughly coincident with and superimposed on the accretionary feature termed the Salmon River suture zone. The western Idaho shear zone is essentially equivalent to the Salmon River suture, as defined by Lund and Snee (1988), in terms of geographic location. The formation of the ductile fabrics and shear zones occurred during the later stages of the accretion of the Blue Mountains island-arc terrane to the western edge of North America (McClelland and others, 2000).

This paper discusses the structure of plutonic units that lie east of the Salmon River suture, the petrology and geochemical evolution of which are described in greater detail in Kuntz (this volume, chapter 5). Reconnaissance and detailed field mapping of these plutonic units was made in an area of twelve $71 / 2$-minute quadrangles north and east of McCall, Idaho (fig. 1).

\section{Plutonic Units of the Idaho Batholith East of the Salmon River Suture}

Field relations and available $\mathrm{U}-\mathrm{Pb}$ zircon ages suggest that the leucogranodiorite pluton of Jumbo creek formed about 94 $\mathrm{Ma}$, the tonalite of Payette River formed about $90 \mathrm{Ma}$, and the monzogranite of Lick Creek formed $82 \mathrm{Ma}$ (Kuntz, this volume, chapter 5). A U-Pb zircon age is not available for the granodiorite of Box Lake, but field relations indicate that it was emplaced after the tonalite of Payette River and prior to emplacement of the monzogranite of Lick Creek, thus an age of approximately $85 \mathrm{Ma}$ seems reasonable for the granodiorite of Box Lake.

Each of the plutonic units in this region has a unique three-dimensional shape. The oldest unit, the leucogranodiorite of Jumbo Creek, forms a pinwheel-shaped pluton in plan view (fig. 1), which suggests emplacement during left-lateral shearing along bounding strike-slip faults. A sheath consisting of calc-silicate gneisses, calcareous metaquartzite, and metapelitic schists partly surrounds the leucogranodiorite of Jumbo Creek. Layering in the metasedimentary rocks is steep and parallel to the contacts of Jumbo Creek pluton, suggesting that the pluton was emplaced within and shouldered aside a screen of metasedimentary rocks, producing an antiform (see fig. 3). The tonalite of Payette River, occurs as a narrow (9-11 $\mathrm{km}$ wide), strongly foliated and lineated, composite pluton that consists of a series of north-trending, dikelike bodies that range in thickness from 200 to $10,000 \mathrm{~m}$. The composite pluton is more than $50 \mathrm{~km}$ long within the study area. The granodiorite of Box Lake also forms a narrow (3-6 km wide) pluton east of the tonalite of Payette River. This plutonic unit contains foliations and lineations that are more diffuse than those in the tonalite of Payette River. The plutons of the monzogranite of Lick Creek are more equant in plan, and foliation and lineation in these plutons are less easily discerned, more diffuse, or simply absent. The tonalite and granodiorite plutons have sharp contacts with their wall rocks and with each other, suggesting separate intrusive pulses separated by a significant time interval. Contacts between the monzogranite plutonic units are typically diffuse, suggesting that they originated by partial melting of broadly homogeneous source rocks and were emplaced within a short time span or, perhaps, simultaneously.

\section{Previous Field-Based Studies}

Previous studies of tectonic relationships of plutonic rocks with respect to the Salmon River suture zone have been conducted near McCall and north of McCall near Riggins, Harpster, and Orofino, Idaho. Other papers (and references therein) in this volume deal with this general subject; specific mention is given here about tectonic relationships of Late Cretaceous plutonic rocks that lie east of the Salmon River suture zone.

Manduca and others (1993) described a series of metamorphic and compressional deformational events that occurred along the Salmon River suture zone near McCall in response to east-west compression related to the accretion of oceanic, island-arc terranes to the western margin of the North American craton during Early and Late Cretaceous. They demonstrated that the latest period of deformation, in which rocks were deformed by subsolidus, ductile deformation, produced a penetrative strained fabric and strong foliation and lineation in plutonic rocks that lie both west and east of the Salmon River suture, including the tonalite of Payette River.

Hamilton (1963a, 1963b), Lund (1984), Onasch (1987), and Lund and Snee (1988) all concluded that emplacement of the tonalite and granodiorite plutonic units of the Idaho Batholith in the Riggins, Idaho, area were broadly syntectonic with deformation and metamorphism along the Salmon River suture zone. Lund (1984) and Lund and Snee (1988) placed the deformation, metamorphism, and emplacement of plutons in the Riggins area into a plate-tectonic setting. They stated that these processes were related to the accretion of allochthonous islandarc rocks against continental rocks of North America along a right-lateral, transcurrent fault, the Salmon River suture. Lund and Snee (1988) stated that after about $93 \mathrm{Ma}$, ductile deformation and metamorphic processes relaxed along the suture, giving 
way to melting processes, emplacement of voluminous magmas of the Idaho Batholith, and consanguineous uplift.

Myers (1982) described plutonic units of the Idaho Batholith near Harpster, about $60 \mathrm{~km}$ north of Riggins. He stated that plutonic units east of the Salmon River suture zone formed by partial melting of Precambrian metasedimentary rocks and were emplaced by diapiric upwelling that was synkinematic with Late Cretaceous cataclasis, thrust faulting, folding, and metamorphism.

In the Orofino area, Snee and others (this volume, chapter 3) document the emplacement of plutonic rocks east of the Salmon River suture zone at approximately $90 \mathrm{Ma}$. These rocks resulted from partial melting of underthrust, accreted terranes. Emplacement of these relatively low-density postaccretion plutons, and/or isostatic rebound of the underthrust rocks, caused rapid and pronounced uplift of the Idaho Batholith east of the Salmon River suture zone.

McClelland and others (2000) state that the parallelism of magmatic and solid-state deformational fabrics of plutons within and near the Salmon River suture zone indicates that emplacement of the intrusives was "broadly syntectonic and controlled by the Salmon River shear zone."

\section{Plan of This Paper}

This paper explores the development of structures in the plutonic units of the Idaho Batholith that lie east of the Salmon River suture and examines whether the emplacement of the plutons and development of the structures within them was also "broadly syntectonic and controlled by the Salmon River shear zone." The paper also investigates the relations of those structures to plate convergence, strain partitioning, and the waning stages of the Late Cretaceous deformation in the Salmon River suture zone. Also discussed is the role of transpression and its effect on the formation of structures in rocks involved in plate convergence.

A very brief background summary of the plate-tectonic schemes for the western edge of North America in the area of western Idaho and eastern Oregon in the Late Cretaceous is presented. A visual model of tectonic relations between the accreted terranes and the North America Plate, the development of the Salmon River suture zone, and the formation and emplacement of plutonic units of the Idaho Batholith that lie east of the Salmon River suture is shown diagrammatically in figure 5. That figure is based chiefly on the background summary.

\section{Structures in the Plutonic Rocks}

\section{Methods of Analysis}

Routine measurements of the orientation of foliations, lineations, joints, and dikes were made in all plutonic units in the McCall area. Most of these measurements are shown in the Geologic Map of the Secesh Summit-Lick Creek Summit-Whangdoodle Creek area by Kuntz (unpublished mapping). These structural data are summarized and analyzed by lower-hemisphere projections (fig. 2) that are separated into a northern and southern domain for each plutonic unit.

The north and south domains of the tonalite of Payette River are separated by the leucogranodiorite pluton of Jumbo Creek. Tonalite in the northern domain is not greatly disturbed by faulting or intrusion of younger plutons, whereas tonalite in the southern domain consists chiefly of three main blocks within the granodiorite of Box Lake (fig. 2). The granodiorite of Box Lake is divided into two domains at $45^{\circ} \mathrm{N}$. latitude. Granodiorite in the northern domain forms a narrow, north-trending pluton of fairly uniform structural trend. Granodiorite in the southern domain intrudes and is separated by pendants of metasedimentary rock and large screens of tonalite of Payette River. Granodiorite in the southern domain also wraps around the eastern margin of the leucogranodiorite pluton of Jumbo Creek. The boundary between the two domains for monzogranite of Lick Creek, also drawn at $45^{\circ} \mathrm{N}$. latitude (fig. 2), separates rocks to the north that appear to be unaffected by the leucogranodiorite pluton of Jumbo Creek and rocks to the south that wrap around the Jumbo Creek pluton.

Detailed structural studies of plutonic rocks, such as those by Brun and Pons (1981), Paterson and others (1991, 1998), and John and Blundy (1993), with the intent of determining stress and strain history, were not conducted for the plutonic units of the McCall area. Rather, the intent of this study was to characterize the general structural features of the plutonic units in order to determine the general strain regime(s) that existed east of the Salmon River suture in the period 94-80 Ma and to make inferences regarding the orientation of stresses and their tectonic significance. This procedure follows similar studies of plutonic rocks in the Riggins area by Lund and Snee (1988), who related pluton emplacement to various stages of suturing of the allochthonous rocks of the Blue Mountains island-arc terrane to North American continental rocks in the Late Cretaceous, and studies by Oldow and others (1984), who related structures in Mesozoic rocks of the Sierran arc to the kinematics of Pacific Plate motions relative to North America. Briefly, Oldow and others (1984) stated that development of homoaxial structures in arc rocks is probably analogous to shortening in presentday arc systems undergoing oblique convergence in which the shortening axis is parallel to the normal component of convergence. They speculated that the preponderance of northwest to north-northwest trending contractional features in the Sierran arc, mainly folds, was related to right oblique convergence along the western edge of North America during the Mesozoic. They also speculated that the structures in the Sierran arc may be a reflection of the orientation of the trench and may not constrain the sense or amount of obliquity of convergence. 


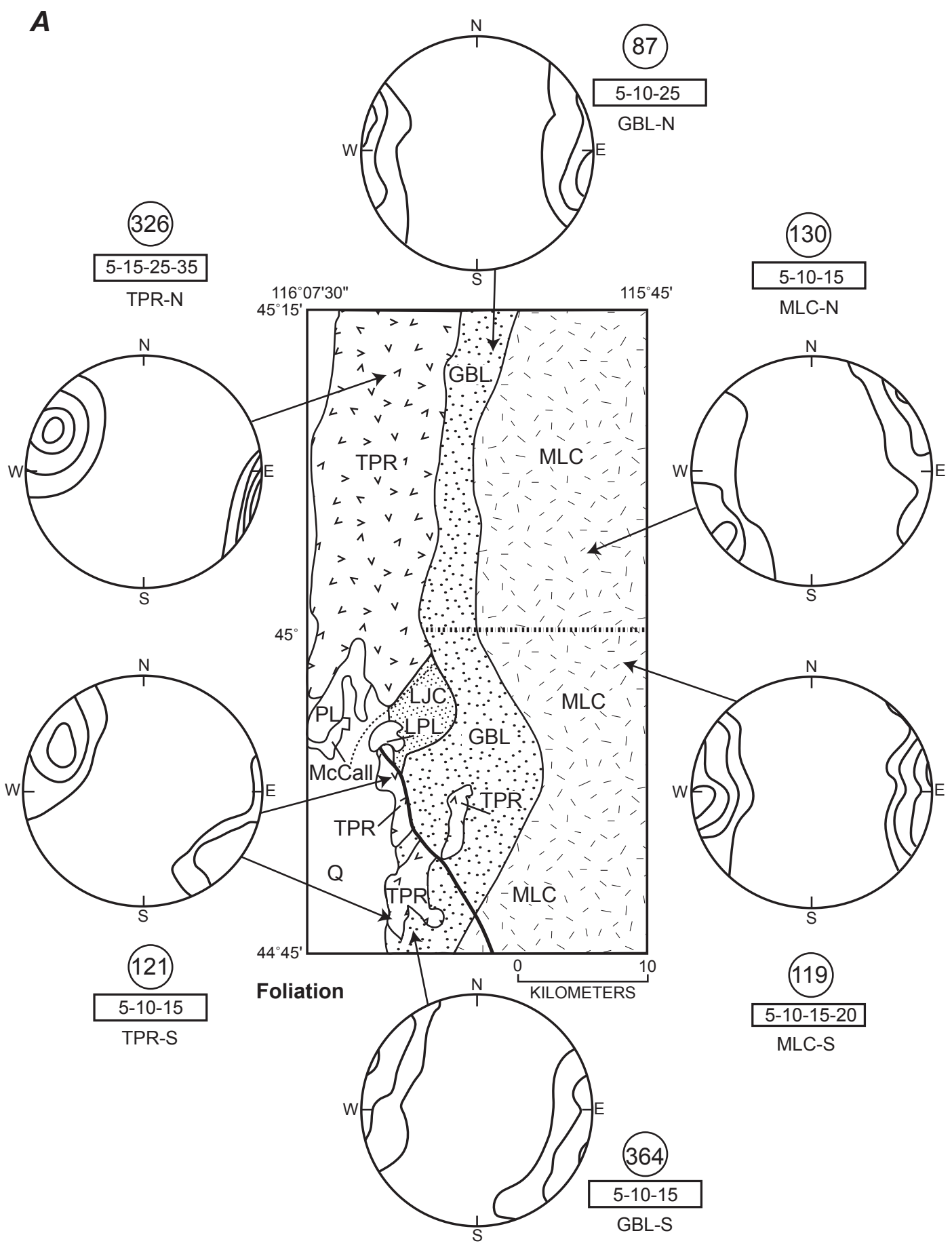

Figure 2. Equal-area, lower-hemisphere diagrams showing the orientations of foliation, lineations, joints, and dikes in plutonic units of the Idaho Batholith near McCall, Idaho. For each equal-area diagram, number in circle is total number of measurements and numbers in rectangle are contours in percent per 2 percent of total area of stereogram. Abbreviations: LJC, leucogranodiorite of Jumbo Creek 4; TPR, tonalite of Payette River; GBL, granodiorite of Box Lake; MLC, monzogranite of Lick Creek; PL, Payette Lake; LPL, Little Payette Lake; $\mathrm{Q}$, Quaternary surficial deposits of Long Valley; $\mathrm{N}$, northern domain; $\mathrm{S}$, southern domain. $A$, Poles to foliation. $B$, Lineations. $C$, Poles to dikes. $D$, Poles to joints. 


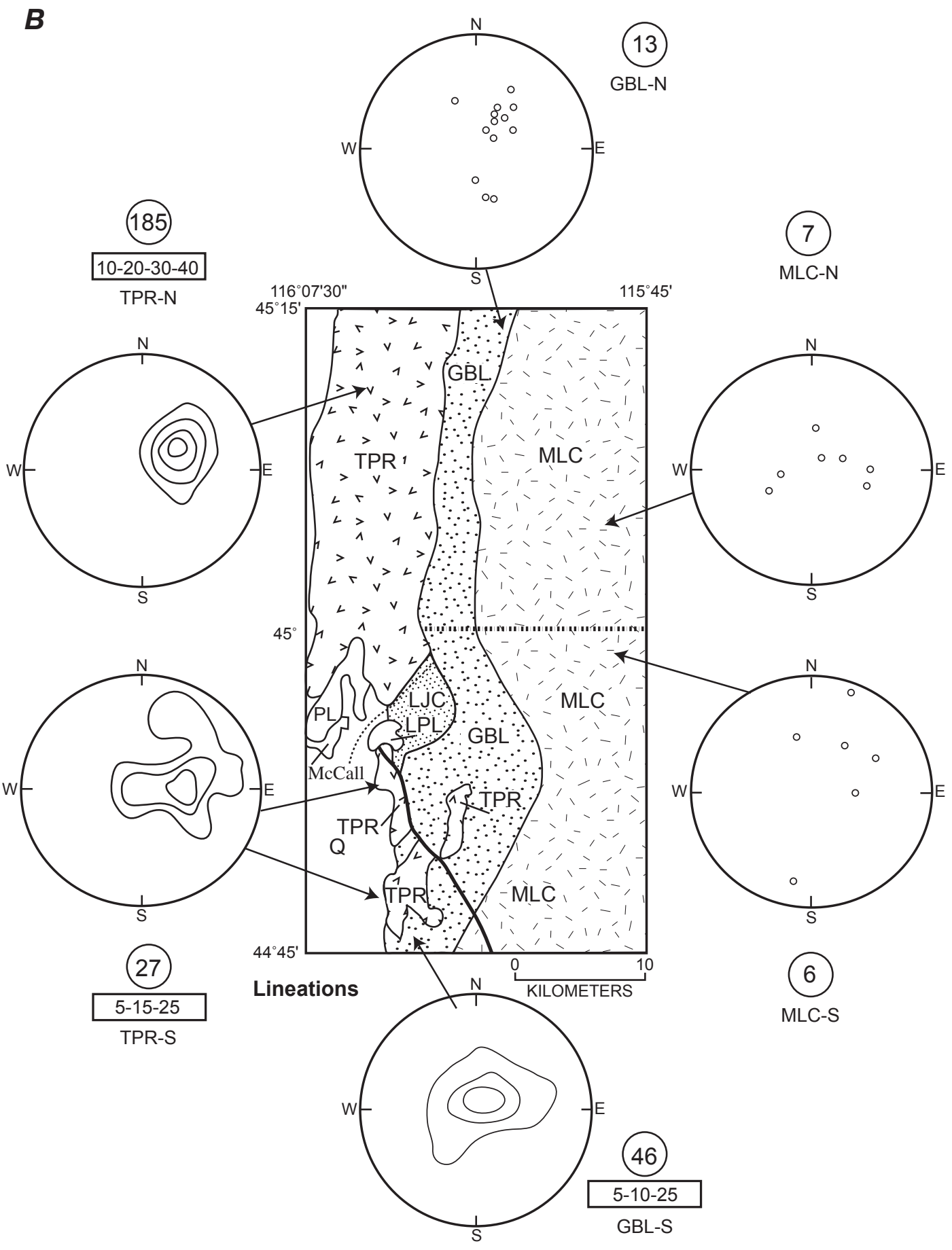

Figure 2-Continued. 


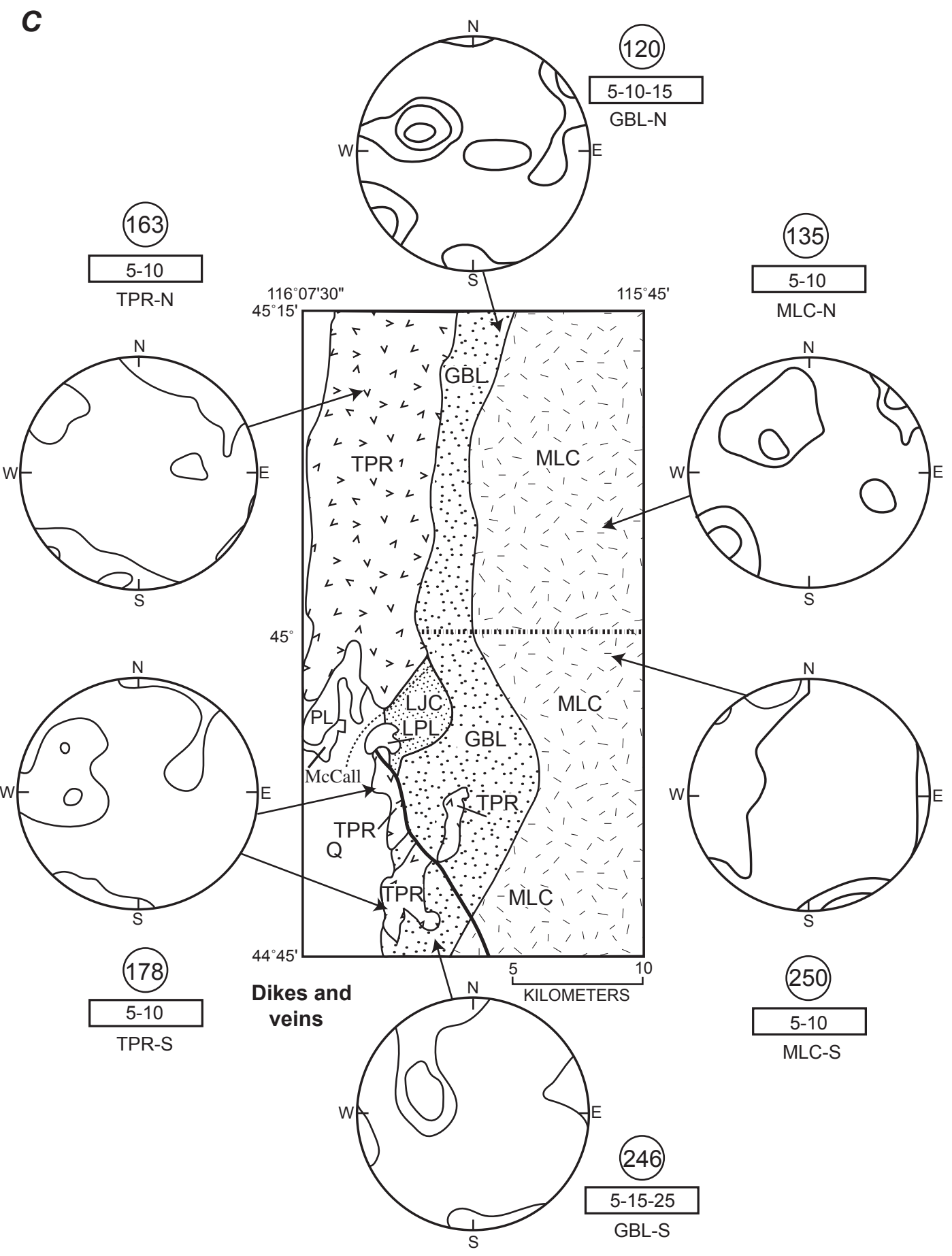

Figure 2.-Continued. 


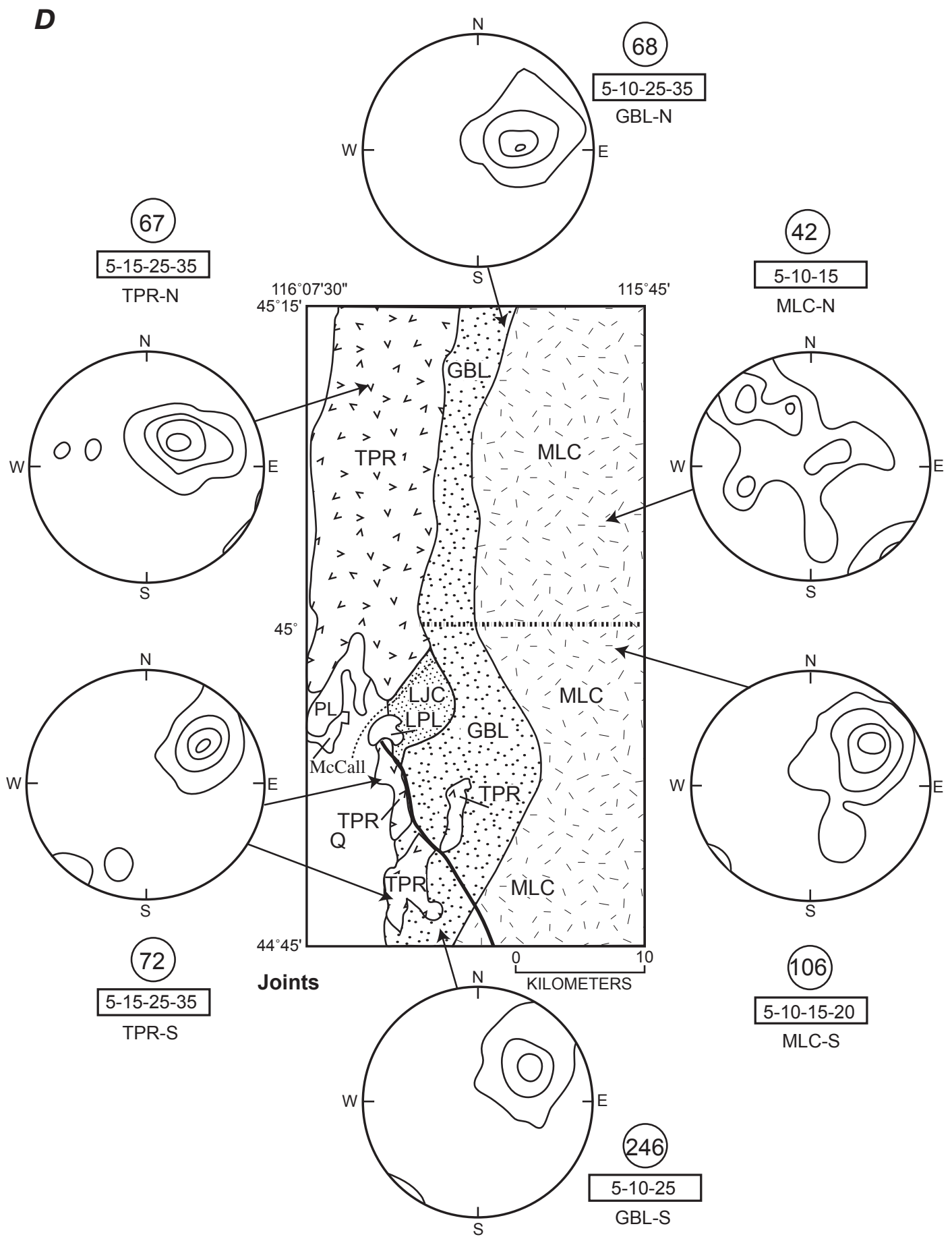

Figure 2.-Continued. 


\section{Foliation}

The most prominent structural feature of plutonic units of the Idaho Batholith east of the Salmon River suture is a primary foliation that is typically accompanied by mineral lineation. Foliation is very well developed in the tonalite of Payette River, less well developed in the granodiorite of Box Lake, and weak to absent in the monzogranite of Lick Creek. The aligned crystals that form the foliation and lineations are mostly undeformed, thus the foliation and lineation in plutonic rocks of the McCall area is a "syncrystallization fabric" in the terminology of Tikoff and Green (1997) and a "pre-crystallization fabric" in the terminology of Hutton (1988).

The Jumbo Creek pluton is partly surrounded by a sheath of metasedimentary rocks that ranges in width from $150 \mathrm{~m}$ to about $500 \mathrm{~m}$. The distribution of the metasedimentary rocks suggests that the pluton was emplaced within and distended a large roof pendant of metasedimentary rocks, producing an antiform. By employing this interpretation and projecting the metasedimentary rock units upward on either side of the pluton, it appears that a minimum of 5,000-6,000 feet of the Jumbo Creek pluton has been eroded away. Foliation in the leucogranodiorite of Jumbo Creek is formed by alignment of biotite flakes and inclusions of metasedimentary rocks. In hand specimen and thin section, the biotite has a distinctive "shredded" appearance, suggesting significant amounts of subsolidus deformation after pluton emplacement. Foliation in the Jumbo Creek pluton is typically parallel to the outer contact of the pluton and has outward dips of $50-85^{\circ}$. The dips are generally steepest near the contact and shallower near the center of the pluton (fig. 3). Too few orientations of the foliation were made in the leucogranodiorite of Jumbo Creek to make statistical estimates of the strength of that fabric, thus only general, qualitative statements can be made.

In the tonalite of Payette River, foliation is formed by alignment of biotite flakes, tabular feldspar crystals, elongated hornblende crystals, and discoidal inclusions of mafic and metasedimentary rock. The foliation is locally enhanced by segregation of minerals into light- and dark-colored layers that give the tonalite a pronounced gneissic structure. Biotite flakes and discoidal inclusions form the foliation in the granodiorite of Box Lake. In the monzogranite of Lick Creek, the foliation is produced mainly by preferentially aligned tabular feldspars and less commonly by aligned biotite and muscovite flakes.

Foliation in the tonalite of Payette River strikes N. 20-30 E. and dips about $70^{\circ}$ to the southeast. The orientation of foliation in the northern domain is uniform (maximum of 35 percent per 2 percent area, that is, a maximum of 35 percent of poles to the plane of foliation fall within 2 percent of the area of the lower hemisphere; fig. $2 A$ ), reflecting the relative lack of disturbance of tonalite of Payette River by faulting and intrusion by younger plutonic units. This relationship contrasts with a less uniform foliation in tonalite in the southern domain (maximum 25 percent per 2 percent area, fig. $2 A$ ), perhaps reflecting that the tonalite bodies in the south have been locally reoriented by complex faults and by intrusion of the younger granodiorite of Box Lake.

Foliation in the granodiorite of Box Lake has a strongly preferred orientation, especially in the northern domain where the foliation strikes nearly north-south and is vertical (fig.2A). In the southern domain, the foliation has a N.20$25^{\circ} \mathrm{E}$. strike and also dips nearly vertically. The uniform orientation in the northern domain (maximum 25 percent per 2 percent area, fig. $2 A$ ) reflects the long, narrow outcrop pattern and nearly parallel contacts. The less uniform orientation in the southern domain results partly from emplacement of the granodiorite of Box Lake around the leucogranodiorite of Jumbo Creek. The less uniform orientation may reflect the broken and divided nature of the granodiorite of Box Lake caused by large inclusions of tonalite and pendants of metasedimentary rocks (fig.1). The narrow outcrop width and the abundance of tonalite and metasedimentary inclusions suggests emplacement of the granodiorite of Box Lake as thin sheets into the region between the older plutonic units of tonalite of Payette River and leucogranodiorite of Jumbo Creek and the metasedimentary rocks that represented the former western edge of the continent.

Foliation in monzogranite of Lick Creek is difficult to identify, but aligned blocky feldspars can be recognized in some outcrops and biotite schlieren are found locally. Foliation in the monzogranite of Lick Creek dips steeply and strikes northwest through north to northeast in the northern part of the study area (fig. $2 A$ ). The northwest through north to northeast strikes may be interpreted as reflecting foliation formed parallel to pluton contacts. In addition, the orientation of the foliation tends to become weaker and more diffuse several kilometers east of the pluton's western contact, where many of the attitudes were measured. The more strongly oriented, north-south-striking, steeply dipping foliation in the monzogranite of Lick Creek in the southern domain may reflect the indistinct contacts between textural phases that strike nearly north-south (figs.1, 2A).

\section{Lineations}

Lineations that plunge down dip in the plane of foliation are a common and prominent feature in the tonalite of Payette River and only slightly less prominent in the granodiorite of Box Lake. The most common type of lineation in tonalite and granodiorite is a mineral lineation formed by the preferred orientation of elongate minerals such as hornblende. Aligned prolate inclusions of mafic and metasedimentary rocks also form lineations in tonalite and granodiorite. Streaks and trains of more equant minerals such as quartz and biotite locally define a lineation in tonalite, granodiorite, and, very locally, monzogranite. The preferred orientation of tabular feldspars forms a lineation in the monzogranite of Lick Creek that is weakly developed and extremely hard to recognize in the field.

Lineations in the northern domain of the tonalite of Payette River have a very strong preferred orientation (fig. $2 B$ ); they typically plunge $45-80^{\circ}$ and have a bearing of about $\mathrm{N}$. 
$50^{\circ} \mathrm{E}$. The orientation of lineations in the southern domain of the tonalite of Payette River plunge $30-90^{\circ}$, averaging about $60^{\circ}$, and have a bearing of about N. $45^{\circ} \mathrm{E}$. The variable angle of plunge may reflect the partial reorientation of large blocks of tonalite by intrusions of granodiorite of Box Lake (figs.1, 2B).

Northeast plunges are well represented in the limited sample $(\mathrm{N}=13)$ of lineations in the northern domain of the granodiorite of Box Lake (fig. $2 B$ ). In the southern domain, lineations are steep and plunge mostly east to northeast. Similarly, the few lineations identified in both the northern and southern domains of the monzogranite of Lick Creek also plunge generally northeast to east.

Similar well-foliated and well-lineated tonalitic plutons are common along the Salmon River suture zone in western Idaho. Lund and Snee (1988) have described them in the
Riggins-Slate Creek area 50-80 km north of McCall, Myers (1982) has described them in the Harpster area $100 \mathrm{~km}$ north of McCall, Strayer and others (1989) and Snee and others (this volume, chapter 3 ) have described them from the Orofino area about $175 \mathrm{~km}$ north of McCall, and Russell (1988) has described them from the Banks area about $80 \mathrm{~km}$ south of McCall (see Kuntz and Snee, this volume, chapter 1, fig. 1).

\section{Dikes and Veins}

Dikes and veins have a very strong preferred orientation in the tonalite of Payette River and granodiorite of Box Lake, where stereogram maxima reach 35 percent per 2 percent area in three of four domains and 25 percent per 2 percent area in the other domain (fig. $2 C$ ). In these four domains, dikes typi-

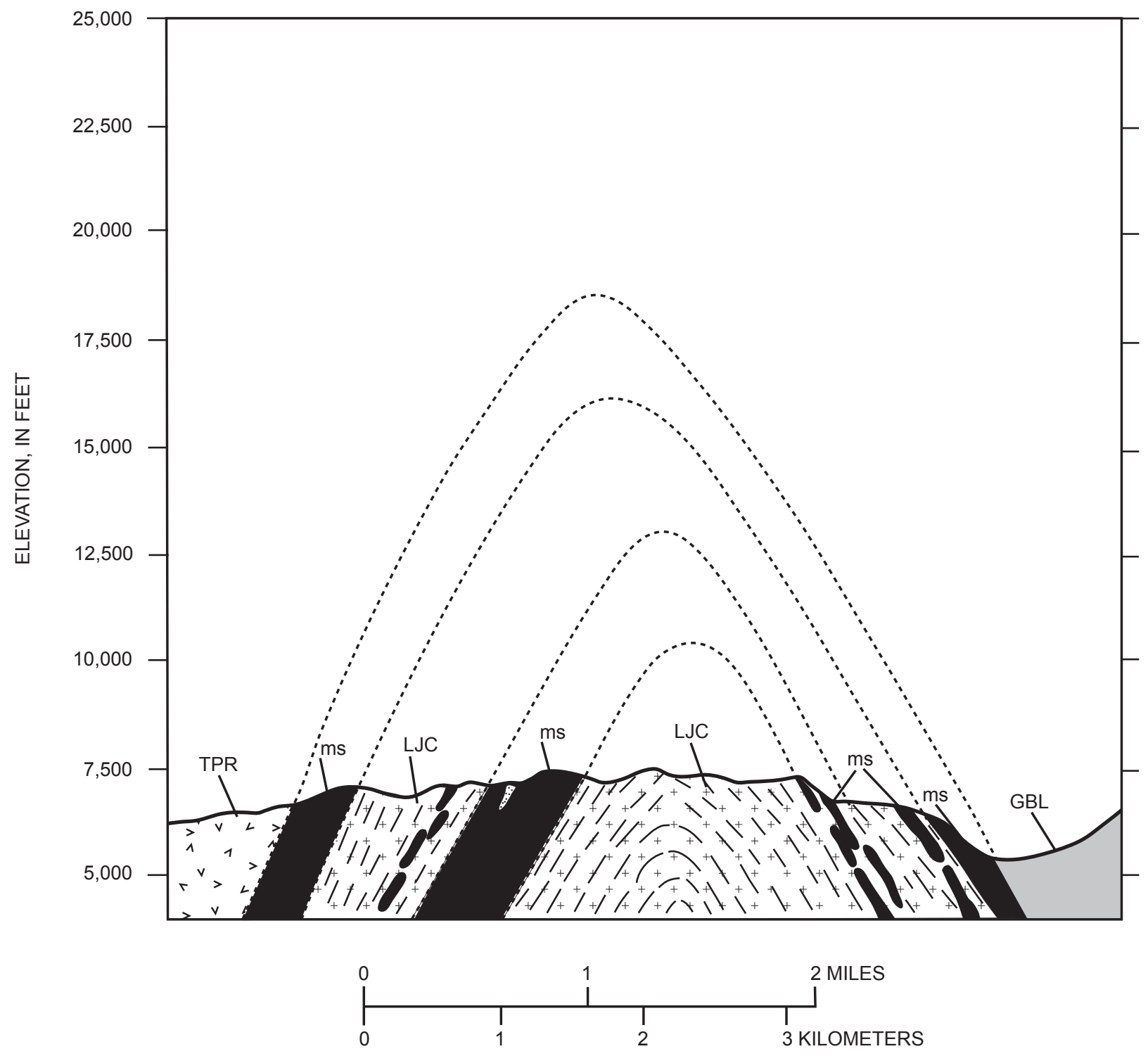

Figure 3. Cross section of the leucogranodiorite pluton of Jumbo Creek at its widest part, showing orientation of foliation, enclosing rocks, and upward projection of eroded rocks. Abbreviations: LJC, leucogranodiorite of Jumbo Creek; TPR, tonalite of Payette River; ms, metasedimentary rocks; GBL, granodiorite of Box Lake. 
cally strike N. $35-45^{\circ} \mathrm{W}$. and dip about $30-50^{\circ}$ southwest. The dikes and veins do not correspond to an observed joint orientation in these four domains (compare figs $2 C, D$ ). The clear implication of this relationship is that the dikes and veins did not fill joints parallel to the observed and measured joints.

In the southern domain of the monzogranite of Lick Creek, dikes and veins strike northwest and dip moderately to the southwest, similar to the orientation of dikes and veins in granodiorite and tonalite (fig. 2C). Dikes and veins have a different orientation in the northern domain for the monzogranite of Lick Creek, where they generally strike northeast and dip moderately to steeply to the southeast. In the northern domain, there are only a few northwest-striking, southwestdipping dikes and veins, which are so prominent elsewhere in the study area. The unique orientation of dikes and veins in the northern domain of the monzogranite of Lick Creek may represent different conditions of regional stress from the stress conditions that affected older tonalite, granodiorite, and monzogranite units. This relation may indicate that plutonic units in the northern domain are younger than plutonic units of the monzogranite of Lick Creek in the southern domain.

\section{Joints}

Joints are conspicuous and common features of outcrops in all plutonic units of the Idaho Batholith near McCall. The joints are smooth-surfaced, continuous, and planar; they are $\mathrm{J} 1$ joints in the terminology of Heidrick and Titley (1982). Very few of the joints contain mineral fillings or coatings. There is no field evidence of any movement across the joints and they are considered to be purely extensional. Of the four categories of structures analyzed by statistical methods, joints have the weakest preferred orientation (fig. 2D), having a maximum of only 10 percent per 2 percent area in five of the six domains and a maximum of 15 percent per 2 percent area in one domain (GBL-N of fig. 2D). In the granodiorite of Box Lake and the monzogranite of Lick Creek, predominant joints strike N. $30-75^{\circ} \mathrm{E}$. and dip $30-75^{\circ}$ southeast. Another joint set, striking about N. $40^{\circ} \mathrm{W}$. and dipping about $85^{\circ}$ northeast, is also common.

\section{Axes of Shortening and Extension}

Before discussing the origin of the structures in the McCall area in the next section, the following assumptions are made: (1) Foliation and lineation formed in compressional shear and poles to foliation planes are roughly parallel to axes of shortening, (2) lineations are stretching lineations that are nearly parallel to axes of extension, and (3) poles to dikes and joints are also nearly parallel to axes of extension. It is also assumed that foliations and lineations formed by flow during emplacement, although such an assumption is controversial because magmatic fabrics may reflect only the last increment of strain of comparatively weak materials (Paterson and others, 1998). However, as Paterson and others (1998) point out, magmatic fabrics may provide a relatively direct record of paleostresses in orogenic belts.

\section{Poles to Foliation and Axes of Shortening at Approximately 90-82 Ma}

Foliation in tonalite of Payette River strikes N. $10-30^{\circ}$ E. and dips about $80^{\circ}$ to the east-southeast (figs. $2 A, 4 A$ ), slightly oblique to the contact between the tonalite and the Little Goose Creek Complex. Foliation in granodiorite of Box Lake is essentially parallel in trend to that in tonalite of Payette River, except that the dip of foliation is vertical in the granodiorite (figs. $2 A, 4 A$ ). The orientation of the foliation in both plutons suggests that the axis of shortening was nearly horizontal and had west-northwest to east-southeast trend during the interval 90-85 Ma during emplacement of tonalite of Payette River and granodiorite of Box Lake.

Foliation planes in the monzogranite of Lick Creek strike N. $10-40^{\circ} \mathrm{W}$. and dip about $80^{\circ}$ east, oblique to the nearly north-south orientation of the contact between granodiorite of Box Lake and monzogranite of Lick Creek. The poles to the foliation planes in monzogranite of Lick Creek yield shortening axes that have west-southwest to southwest trends, which are not homoaxial with northwest- to west-trending shortening axes of the older tonalite of Payette River and granodiorite of Box Lake (fig. 4A). These divergent orientations suggest that shortening axes rotated counterclockwise from northwest to southwest between about $85 \mathrm{Ma}$ and about $82 \mathrm{Ma}$.

\section{Lineations and Axes of Extension at Approxi- mately 90-82 Ma.}

Because foliation and lineation in plutonic rocks of the McCall area formed during the same emplacement process, lineation is also a syncrystallization fabric (Tikoff and Green, 1997). The mineral lineations are interpreted as stretching lineations that reflect shear in the plane of magma transport.

Mineral lineations plunge $50-75^{\circ}$ to the northeast and have a bearing of N. $40-80^{\circ}$ E. in tonalite of Payette River and granodiorite of Box Lake (figs. 2A, $4 B$ ). Lineations are rare in monzogranite of Lick Creek, hence they are not plotted in figure $4 B$-but most of them have orientations similar to lineations in the tonalite of Payette River and the granodiorite of Box Lake, that is, in the northeast quadrant. Sufficient lineation-orientation data have not been obtained to determine if lineations in the monzogranite of Lick Creek are oriented in a counterclockwise direction with respect to lineations in tonalite of Payette River and granodiorite of Box Lake, similar to the rotation inferred from foliation data.

\section{Dikes, Veins, and Axes of Extension at Approxi- mately 80 Ma.}

Dikes and veins in plutonic rocks of the McCall area are remarkably planar, indicating that they formed after the plu- 
tonic rocks had solidified. The dikes and veins are spatially and temporally related to the monzogranite of Lick Creek; thus it seems reasonable to infer that the dikes and veins formed soon after emplacement of the monzogranite, probably about $80 \mathrm{Ma}$ or shortly thereafter (Kuntz, this volume, chapter 5).

Poles to planar dikes and veins in five of the domains plot in the northeast quadrant with moderate dip (figs. $2 C, 4 C$ ).

The extension axes represented by poles to dikes and veins are similar in trend to the extension axes represented by lineations (compare figs. $2 \mathrm{~B}, 4 \mathrm{C}$ ), except that extension axes represented by the lineations generally have greater plunge.

It is inferred that most dikes and veins in the McCall area formed their own conduits by hydraulic fracture, as described by Delaney and others (1986). This suggests that a distinct fluid phase separated at or near the end of crystallization of the monzogranite of Lick Creek and that fluid pressures increased sufficiently to cause fracture of the surrounding rocks. The stress field at the time was markedly anisotropic, which explains the strong preferred orientation of the dikes and veins.

Dikes and veins in plutons of the porphyry copper belt of Arizona may be good analogs of dikes and veins in the McCall area. Heidrick and Titley (1982) demonstrated that dikes and veins are very strongly oriented along the Laramide compression direction in every one of the porphyry-copper plutons they studied. The orientation of dikes and veins in tectonically active regions such as the Idaho Batholith and the Arizona porphyry-copper plutons contrasts markedly with dike and vein orientations in tectonically quiescent regions such as
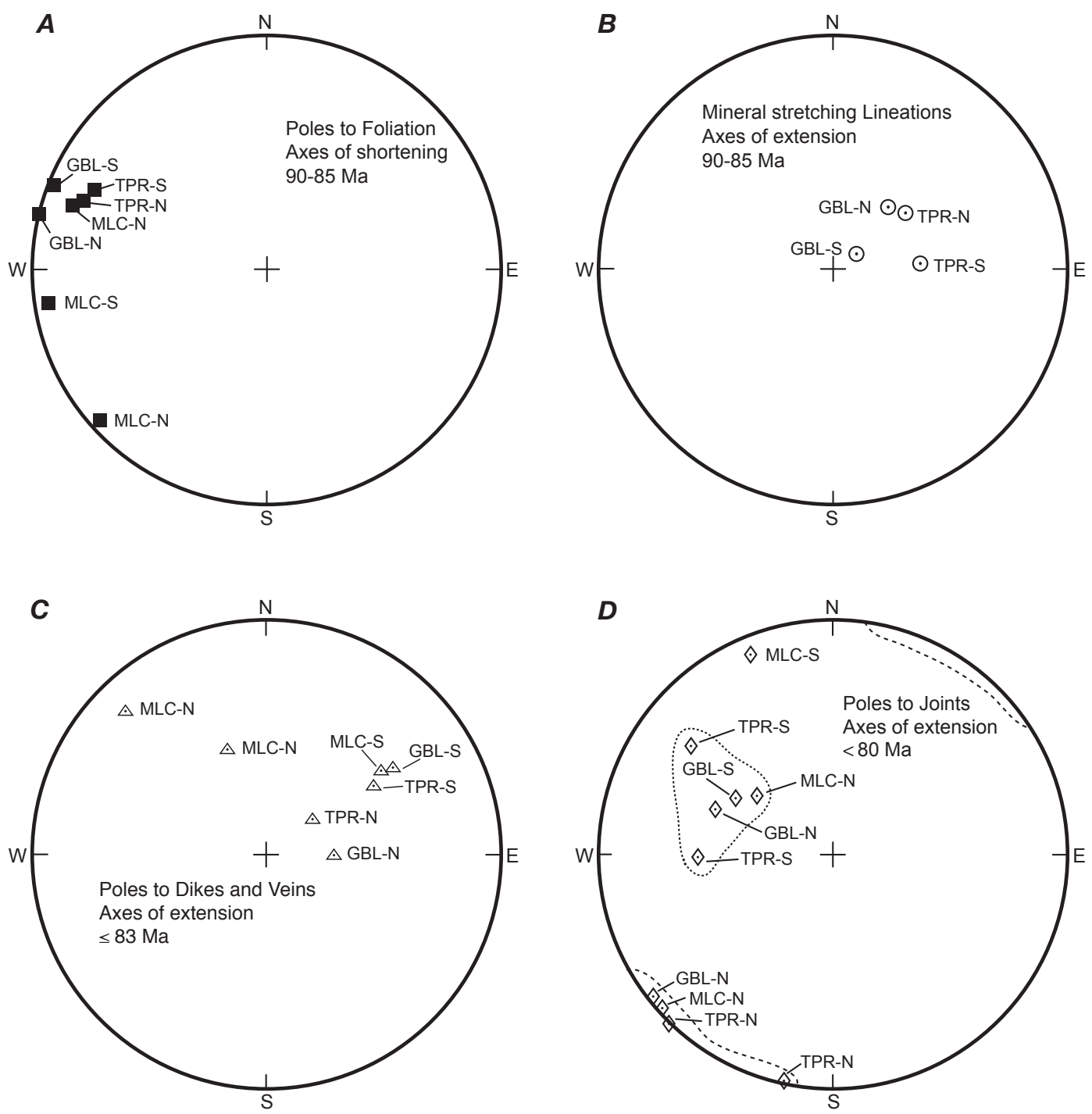

Figure 4. Lower-hemisphere projections of axes of shortening and axes of extension in the McCall area in the period 90-80 Ma. Data shown in this figure are a summary of data shown in figure 2. Abbreviations: TPR, tonalite of Payette River; GBL, granodiorite of Box Lake; MLC, monzogranite of Lick Creek; N, northern domain; $\mathrm{S}$, southern domain. $A$, Poles to foliation; axes of shortening at 90-80 Ma. $B$, Mineral-stretching lineations; axes of extension at 90-80 Ma. C, Poles to dikes and veins; axes of extension at $\sim 80 \mathrm{Ma}$. $D$, Poles to joints; axes of extension at $\sim 80 \mathrm{Ma}$. 
the Henderson-Urad molybdenum mine in Colorado, where dikes and veins are arranged in a radial and concentric pattern around the Henderson stocks (Carten and others, 1988; Coe, 1995).

It is inferred that most dikes and veins in the McCall, Idaho, area formed in a strain system that had an orientation nearly identical to that at the time of formation of monzogranite of Lick Creek. That is, axes of compression trended northeast (fig. 2A). Because the axes of extension lie perpendicular to the plane that includes the axis of compression and the intermediate axis, the axis of compression at the time of dike and vein formation was not horizontal but probably plunged about $30-60^{\circ}$ to the southwest. Dikes and veins in the northern domain of monzogranite of Lick Creek filled fractures having northeast strike and moderate dip to the southeast. This fracture set formed after the earlier period of dike and vein filling in the southern domain of the monzogranite of Lick Creek. Comparison of the orientation of poles to dikes and veins for the two domains of the monzogranite of Lick Creek suggests that the extension axis rotated counterclockwise from a bearing of about N. $50^{\circ}$ E. to a bearing of about N. $40^{\circ} \mathrm{W}$ (fig. $4 C$ ).

\section{Joints and Axes of Extension at Approximately $80 \mathrm{Ma}$}

Joints chiefly form perpendicular to the direction of least principal compressive stress (Delaney and others, 1986). Segal and Pollard (1983), and Verbeek and Grout (1992) have shown that dikes and joints may be related in terms of regional stress fields. For example, magmas that form dikes may advance by filling self-generated fractures if older, suitably oriented joints are absent. For most of the McCall area, there is a general lack of correlation between the orientation of dikes and joints and, moreover, most of the dikes and joints are roughly perpendicular to one another.

There are two main preferred orientations of joints in the McCall area. Joints of one set have a northeast strike and moderate dip to the southeast, yielding an extension axis that plunges moderately about N. $60^{\circ} \mathrm{W}$. (fig. $4 D$ ). Joints of the second set, present only in the northern half of the study area, strike about N. $40^{\circ} \mathrm{W}$. and are vertical, yielding a subhorizontal extension axis having a trend of approximately S. $50^{\circ} \mathrm{W}$.

Dikes and veins are parallel to regional joints in only one of the six domains in the McCall area, the northern domain of the monzogranite of Lick Creek (figs. $2 C, 4 D$ ). The general lack of correlation between the orientation of dikes and joints suggests that dikes generated their own conduits by hydraulic fracture throughout most of the McCall area and that jointparallel dikes may have filled preexisting joints only in the northern domain of the monzogranite of Lick Creek. This, in turn, suggests that most joints in the McCall area largely postdate the emplacement of dikes. The time of formation of the joints is not known, but they must be younger than about
$80 \mathrm{Ma}$ because joints postdate emplacement of all plutonic units and dikes.

\section{Reorientation of the Stress System in the McCall Area in the Period 90-80 Ma}

The variable strain directions shown in figure 4 suggest that the stress system was reoriented during the period 90-80 Ma. The axis of shortening trended west-northwest and was nearly horizontal at 90-85 Ma (foliation in tonalite of Payette River and granodiorite of Box Lake) and trended southwestnortheast and was nearly horizontal about $82 \mathrm{Ma}$ (foliation in monzogranite of Lick Creek). The axis of extension had a plunge of $70^{\circ}$ northeast and a bearing of about N. $50^{\circ} \mathrm{E}$. between $90 \mathrm{Ma}$ and about $85 \mathrm{Ma}$ (stretching lineations in tonalite of Payette River and granodiorite of Box Lake). The axis of extension had a plunge of about $50^{\circ}$ northeast and a bearing of about N. $50^{\circ} \mathrm{E}$. at about $80 \mathrm{Ma}$ (dikes), zero plunge and a bearing of about N. $50^{\circ}$ E. at approximately $80 \mathrm{Ma}$ or younger (one joint set), and a plunge of about $80^{\circ}$ northwest and a bearing of N. $60^{\circ} \mathrm{W}$. also at approximately $80 \mathrm{Ma}$ or younger (other joint set).

These relations suggest that the shortening axes rotated counterclockwise about $60^{\circ}$ from northwest to southwest between $90 \mathrm{Ma}$ and $82 \mathrm{Ma}$. The extension axes also appear to have rotated about $80^{\circ}$ in a counterclockwise direction and became increasingly shallow between $90 \mathrm{Ma}$ and $80 \mathrm{Ma}$. The nearly orthogonal orientation of the axes of extension for the two joint sets (fig. 4D) at about 80 Ma suggests that the $\mathrm{McC}$ all region may have experienced a transition from a dominantly shortening strain system (crustal contraction due to transpression) to a dominantly extensional strain system (crustal extension due to transtension), whereby the axis of shortening at the time of emplacement of the monzogranite of Lick Creek became an axis of extension at the time of formation of northwest-trending joints.

\section{Background for Tectonic Interpretations of Paleostrains}

\section{The Role of Transpression in the Development of Foliation and Lineation}

Ave'Lallement and Oldow (1988) state that two main sets of tectonic features are related to oblique plate convergence. They are (1) faulting, folding, and the development of foliation (and lineation, though not so stated) in the fore-arc and back-arc regions (processes related to the transpression component of plate motion that is perpendicular to the plate margin), and (2) 
strike-slip movement in the fore-arc region (processes related to the transpression component parallel to the plate margin).

Fossen and Tikoff (1998) have described a spectrum of transpressional and transtensional deformation that can result from oblique plate interactions. They note that there is a common notion that major transcurrent motion only occurs on vertical faults or shear zones and produces horizontal lineations. However, they conclude that for terrane boundaries that involve components of both contraction and strike-slip motion (transpression), vertical foliation will result with either vertical (the case for the McCall area) or horizontal lineation. Fossen and Tikoff (1998) note that the lineation direction in transpressional shear zones does not necessarily reflect the tectonic movement direction of the simple shear components of deformation. They also note that vertical lineations can also result from high-angle reverse faulting, perhaps because narrow transpressional zones between colliding blocks have very high uplift rates, much of which may be accomplished by high-angle reverse faulting. In addition, Fossen and Tikoff (1998) note that the existence of steeply oriented, dowdip lineations does not rule out the possibility of major (hundreds to thousands of kilometers) strike-slip motion on shear zones.

Teyssier and Tikoff (1999) note that the tendency to produce and to enhance the stability of vertical foliation and vertical lineation is favored by the following factors: (1) transpression dominated by pure shear occurs with the angle of convergence $>20^{\circ}$; (2) there is a small coaxial component of extension in the horizontal direction that allows for minimal lateral extrusion in the zone of deformation and promotes maximum extrusion in the vertical direction; and (3) with increasing finite strain, original horizontal lineation switches to vertical lineation in transpression.

\section{Possible Relations Among Transpression, Plate Movements, and Structures in Plutonic Rocks}

McClelland and others (2000) postulate that underthrusting of the oceanic plate(s) and subsequent development of the Salmon River suture zone occurred in western Idaho from 130 to $80 \mathrm{Ma}$, that the accretionary thrust dipped to the east, that the continental margin overrode the accreted fragments, and that there was postaccretion exhumation of the accretionary orogen within an intra-arc transpressional setting. They agree with Lund and Snee (1988) that the suture zone acted as a transpressional flower structure, which, through a combination of buoyancy and tectonic forces, resulted in both rapid exhumation and preservation of metamorphic fabrics. In addition, McClelland and others (2000) agree that in transpressional deformation, the long axis of the finite strain ellipsoid is generally vertical and high strain zones favor vertical foliation and lineation.

These models suggest that the vertical foliation and lineation in plutonic rocks of the Idaho Batholith along the east side of the Salmon River suture zone probably formed during emplacement of the rocks within the suture zone under conditions of pure-shear-dominated transpression, a small coaxial component of extension in the horizontal direction, a high component of extension in the vertical direction, and high finite strain.

\section{Relative Movement of the North America Plate and the Orientation of Axes of Shortening in the Period 90-82 Ma}

The change in motion trajectories for the North America Plate in the period 90-80 Ma may explain the shifting orientation of the paleostrain system that affected the plutonic units of the Idaho Batholith near McCall. The North America Plate moved from southeast to northwest from 120 to $90 \mathrm{Ma}$, then moved from east to west from about 90 to $75 \mathrm{Ma}$, and then from east-northeast to westsouthwest from 70 to $50 \mathrm{Ma}$ (Engebretson and others, 1984). The relative southeast to northwest movement of the North America Plate (Engebretson and others, 1984) is homoaxial with inferred greatest shortening directions for the period 90-82 Ma (fig. 4A). The change in motion trajectory for the North America Plate, from northwest to west, generally coincides with the inferred timing of the change in the orientation of the shortening axes in the McCall area at about $80 \mathrm{Ma}$. After $80 \mathrm{Ma}$, shortening axes were reoriented northeast-southwest, which generally coincides with the west-southwest movement of the North America plate from 70 to $50 \mathrm{Ma}$, and extension axes were reoriented northwest-southeast.

The approximate temporal parallelism of the motion trajectories for the North America Plate and the shortening axes derived for the observed structures in the plutonic rocks in the McCall area suggests that the orientation of the structures may be related to the direction of movement of the North America Plate with respect to the suture zone rather than to the relative movement of Pacific oceanic plates with respect to North America.

\section{Pluton Emplacement in a Zone of Con- traction and Strike-Slip Faulting}

The concept that emplacement of magmas is governed by gravity-driven diapiric rise and ballooning in areas of extension or little if any compression dominated studies of plutonism until about 1990. The recognition that trondhjemite and tonalite plutons were emplaced in orogenic belts that had experienced severe contraction required modification of these concepts. The emplacement of plutons in convergent tectonic settings has been elucidated clearly only in the last decade. 
Tikoff and Greene (1997) and De St. Blanquat and others (1998) noted that the combination of strike-slip faulting and arc-normal contractional tectonism is a common setting for magmatic arcs. In addition, they also stated that transpressional kinematics may create crustal thickening that leads to granite generation and exhumation during magmatism. Transpressional deformation causes vertical movement from the pure-shear component of deformation, which is a consequence of a fixed lower boundary and a free upper boundary. As a result, the vertical growth required by transpressional kinematics is provided by the segregation and upward movement of magma. The fabrics exhibited by wall rocks and plutons (vertical foliations and vertical lineations) are also consistent with transpression. De St. Blanquat and others (1998) describe the relation between transpression and magma emplacement as follows: "In a transpressional magmatic arc, the kinematics and transpression appear to be intricately linked. As more magma is transferred and emplaced within the magmatic arc, localization of the transcurrent component of plate motion occurs in strikeslip fault zones within the arc. This strike-slip tectonism, in turn, provides room for ascending magma."

The relation of magma overpressuring and tectonism is an important factor in magma emplacement. De St. Blanquat and others (1998) note that in magmatic arcs, tectonic overpressuring may contribute directly to magmatic overpressuring because, as the wall rocks are pushed together, they exert a force on the magma, which significantly increases its pressure, and the horizontal component of the tectonic load is partly transferred into a vertical driving force. Robin and Cruden (1994) showed that transpression-induced overpressuring increases with the square of depth; thus a pronounced vertical pressure gradient is created in the crust. This effect, combined with the vertical lithostatic load and magma buoyancy, acts to effectively move granitic magma upward in the crust. De St. Blanquat and others (1988) state that "overpressured magma will move toward the lowest-pressure region by opening its own conduits, either by diking or intruding pre-existing pathways, such as shear zones. This idea of magma overpressuring also explains the common observation of plutons emplaced in contractional settings."

De St. Blanquat and others (1998) also apply the concept of magma overpressuring to pluton emplacement. They note that upward or lateral movement of pluton-size bodies of magma may be very rare. They envision that dikelike pulses of magma aggregate into plutonic bodies in a stepwise fashion, and they state that rather than magmas rising to a level of neutral buoyancy, they rise until they are incapable of deforming or moving wall rocks. While plutons are assembled, the magmas may simply push rocks out of the way vertically (using the free-boundary condition at the Earth's surface) or horizontally by lateral ballooning. Granitic bodies assist regional tectonism by creating space, pushing away their margins, and moving to lower pressure regions. In short, De
St. Blanquat and others (1998) state that the effects of tectonically controlled magmatism and magma-controlled deformation are not only indistinguishable, but are ultimately the same phenomenon, creating a feedback loop between transpression and magma generation and ascent.

With these concepts as a background, the structural development and emplacement of the plutonic units of the Idaho Batholith can be reasonably interpreted.

\section{Structural Development and Emplace- ment of Plutonic Units}

\section{A Brief Discussion of the Later Stages of the Tectonic Evolution of the Salmon River Suture Zone Near Mccall, Idaho}

Vallier and Brooks (1987), Vallier (1995), and Snee and others (1995) have given details for the assembly and amalgamation of the Blue Mountains island arc to North America and the tectonic evolution of the Salmon River suture zone. Vallier (1995) presented a seven-stage history for the Blue Mountains island arc and its amalgamation to North America, the latter parts of which are here summarized graphically in figure 5. Vallier and Brooks (1987) state that the accretion of the Blue Mountains island arc to North America was completed by 85 Ma. Lund and Snee (1988) and Snee and others (1995) state that the island-arc terrane had been completely amalgamated to North America and stitched to it by emplacement of tonalitic plutons by $93 \mathrm{Ma}$. Figure $5 \mathrm{~A}$ shows the emplacement of the leucogranodiorite pluton of Jumbo Creek in a strikeslip dominated Salmon River shear zone at the boundary of the accreted island-arc terrane and the pre-Cretaceous, highly deformed metasedimentary rocks at the western edge of the North America Plate. This representation is based largely on Vallier's (1995) seventh stage.

Figure $5 B$ shows inferred plate and tectonic configurations at approximately $90 \mathrm{Ma}$, also based largely on Vallier's (1995) seventh stage. In that stage, the Blue Mountains island-arc terrane is amalgamated to North America, rightlateral movement takes place on the Salmon River suture zone, emplacement of the tonalite of Payette River and granodiorite of Box Lake occurs within and east of the Salmon River suture zone, uplift of the igneous terrane occurs east of the Salmon river suture zone, and subduction of the Pacific plate(s) occurs outboard of the accreted Blue Mountains island-arc terrane (fig. 5B). An eighth stage may be added to Vallier's scheme for $\sim 82 \mathrm{Ma}$, in which plutons of the monzogranite of Lick Creek were emplaced during the later stages of the development of the Sevier orogenic belt along hinterland-dipping, flat-ramp faults and nappes (fig. $5 C$ ). 
$\boldsymbol{A}$

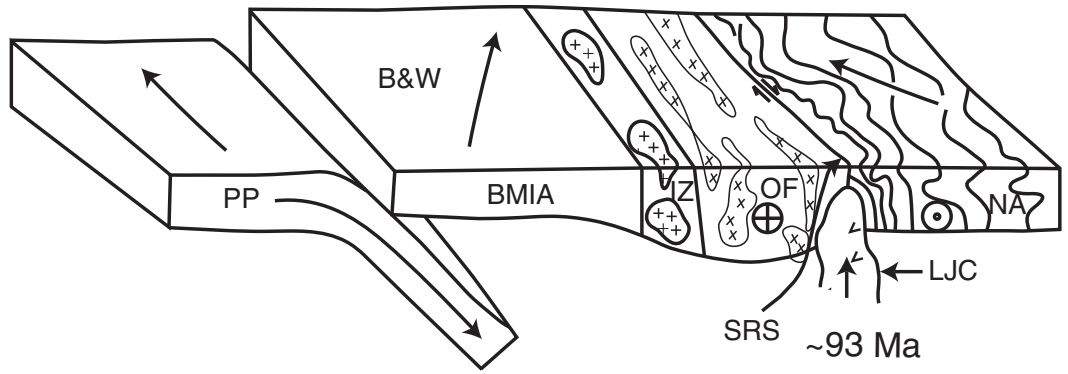

B

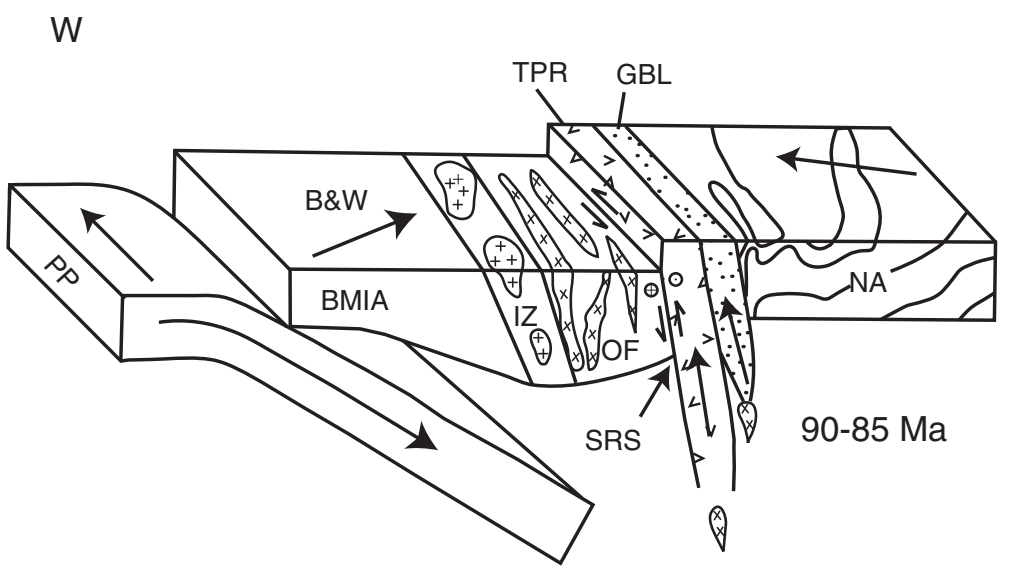

$E$

C

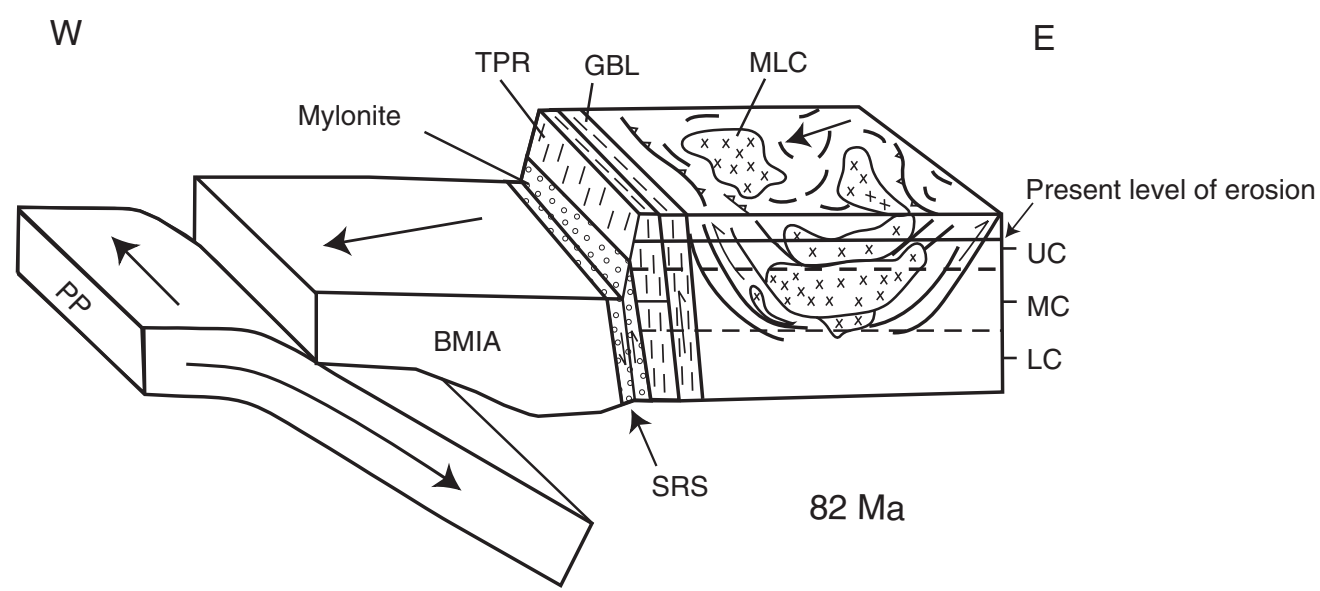

Figure 5. Schematic representation (cartoon) of plate-tectonic evolution of the west coast of North America at approximate present-day latitude of $45^{\circ} \mathrm{N}$ for the period $93-80 \mathrm{Ma}$. Abbreviations: $\mathrm{PP}, \mathrm{Pacific}$ plates; BMIA, Blue Mountains island arc; B\&W, Baker and Wallowa terranes; OF, Olds Ferry terrane; NA, North America; IZ, Izee terrane; LJC, leucogranodiorite of Jumbo Creek; TPR, tonalite of Payette River; GBL, granodiorite of Box Lake; MLC, monzogranite of Lick Creek; SRS, Salmon River suture; UC, upper crust; MC, middle crust; LC, lower crust. Arrows show motion trajectories of various terranes and North America, based primarily on Engebretson (1985) and Vallier (1995). Diagrams are not to scale. A, At $93 \mathrm{Ma}$, during emplacement of the leucogranodiorite pluton of Jumbo Creek. Squiggly lines in North America block diagrammatically represent folded, Pre-Cretaceous metasedimentary rocks. $B$, Approximately $90-85$ $\mathrm{Ma}$, during emplacement of the tonalite of Payette River and granodiorite of Box Lake. C, At $82 \mathrm{Ma}$, during emplacement of the monzogranite plutons of Lick Creek. 


\section{Leucogranodiorite of Jumbo Creek}

The leucogranodiorite pluton of Jumbo Creek was emplaced at approximately $94 \mathrm{Ma}$ (Kuntz, this volume, chapter 5). The structure, outcrop pattern, and distribution of metasedimentary rocks in a sheath around the Jumbo Creek pluton suggest that the pluton was emplaced into and distended a large screen of metasedimentary rocks that occupied the zone between accreted terranes and metasedimentary rocks of the North America plate to the east, producing an antiformal structure in cross section (fig. 3). The outcrop pattern of the Jumbo Creek pluton has a clockwise-rotated, "pin-wheel" aspect (fig. 1), suggesting left slip on bounding faults that were located within the screen of metasedimentary rocks that now form the sheath around the Jumbo Creek pluton.

The seeming inconsistency between the regional dextral slip indicators along the Salmon River suture at about $94 \mathrm{Ma}$ (McClelland, 2000) and the left-slip suggested by the pinwheel outcrop pattern may be reconciled by the studies of McKenzie and Jackson (1986), who showed that in broad zones of distributed fault deformation, rotation of faultbounded blocks within the zone are in the opposite sense (left slip) of the strike-slip component (right slip) across the zone as a whole (fig. 6). The pinwheel outcrop pattern suggests a genetic link between the Paddy Creek, Dead Horse Creek, and Deep Creek left-slip, strike-slip faults in and near the screen of metasedimentary rocks (fig. 1) and the emplacement of the leucogranodiorite pluton of Jumbo Creek. Tikoff and Teyssier
(1992) have shown that plutons having similar, rotated map patterns are emplaced in releasing-bend and dilational-jog regions between arc-parallel, strike-slip faults. These models imply that there was a broad zone of transpressional, right-slip movement along and to the east of the present-day Salmon River suture zone and that left-slip faults within the zone of distributed deformation provided the locus for emplacement and rotation of the Jumbo Creek pluton (fig. 6). The left-slip faults were localized within the screen of metasedimentary rocks that now form the sheath of the Jumbo Creek pluton. Thus, the eastern boundary of the broad zone of right-slip, distributed faulting was located east of the leucogranodiorite pluton of Jumbo Creek, as shown in figure 6.

The leucogranodiorite pluton of Jumbo Creek was probably emplaced in a dilational jog produced as a result of leftlateral faulting concentrated within metasedimentary rocks. The filling and expansion of the walls of the metasedimentary rocks by leucogranodiorite magma was aided by widening of the jog as right-lateral faulting continued, as shown diagrammatically in figure $5 \mathrm{~A}$.

\section{Tonalite of Payette River}

The tectonic regime of the McCall region in the area of the Salmon River suture zone was one of strong contraction and transpressional deformation about 90 Ma during emplacement of the tonalite of Payette River (fig. 5A). Kuntz (this volume, chapter 5) has described a model for the origin of

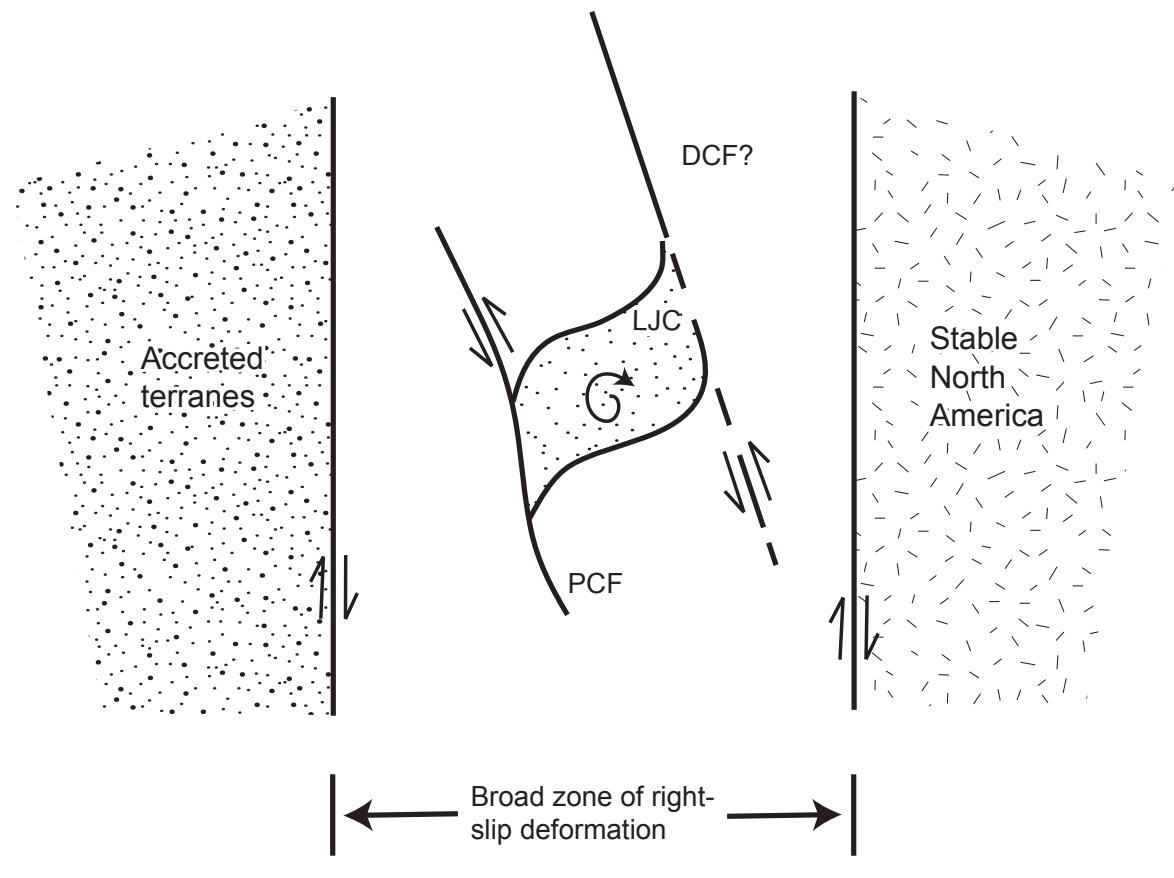

Figure 6. Diagrammatic representation of the rotation of the leucogranodiorite pluton of Jumbo Creek as a fault-bounded block within a broad zone of right-slip deformation. Based on ideas presented in McKenzie and Jackson (1986). Abbreviations: LJC, leucogranodiorite pluton of Jumbo Creek; PCF, Paddy Creek Fault; DCF?, hypothesized southward continuation of the Deep Creek Fault (see fig. 1). 
tonalite magma involving partial melting of subducted tonalite and amphibolite of the accreted terranes in a thickened crust at depths of 45-60 km under temperatures of a normal geothermal gradient. The studies of De St. Blanquat and others (1998) show that transpressional deformation causes crustal thickening that leads to magma generation and exhumation during magmatism. Thus, regional tectonics and genesis of granitic magma are linked processes; granitic melts influence crustal behavior during ascent within actively deforming shear zones, and shear zones provide loci for not only the generation but also the ascent of granitic magma.

Tonalite magma was emplaced as dikelike bodies mainly along the eastern margin of the active Salmon River suture zone (fig. 5B). Transpressional deformation in the suture zone caused vertical movement from the pure-shear component of deformation. The upward movement of magma produced vertical foliations and vertical lineations in both wall rocks and plutons. The continued, upward movement of magma and concomitant formation of vertical foliations and lineations indicate that intrusion was synchronous with dip-slip, shear deformation related to uplift of the interior of the Idaho Batholith during the Sevier orogeny (Lund and Snee, 1988; Snee and others, this volume, chapter 3). The upward movement of magma was probably facilitated by pure-shear dominated transpression that occurred with the angle of convergence $>20^{\circ}$, and there was a small coaxial component of extension in the horizontal direction that promoted maximum extrusion in the vertical direction, as advocated by Teyssier and Tikoff (1999).

Magma overpressuring (De St. Blanquat and others, 1998), combined with the vertical lithostatic load and magma buoyancy, acted to effectively move tonalite magma upward in the crust. The tonalite of Payette River was probably emplaced as dikelike pulses of magma that rose and deformed wall rocks by moving to lower pressure regions. The development of the strong fabrics was facilitated by conditions of pure-sheardominated transpression, a high component of extension in the vertical direction, and high finite strain.

The paleostrains represented by vertical foliations and lineations in the tonalite of Payette River may be related to the direction of movement of the North America Plate with respect to the Salmon River suture zone, that is, the relative southeast to northwest movement of the North America Plate is homoaxial with inferred greatest shortening directions at 90 Ma (fig. $5 B$ ). It is thus inferred that the shear-strain system that produced the vertical foliations and lineations in the tonalite of Payette River may have been influenced more by the direction of motion of the North American Plate with respect to the Salmon River suture zone than by direction of movement of the Pacific oceanic plate(s).

\section{Granodiorite of Box Lake}

Field relations and age dates (Kuntz, this volume, chapter 5 ) indicate that emplacement of the granodiorite of Box Lake followed emplacement of the tonalite of Payette River at 90
Ma and preceded emplacement of the monzogranite of Lick Creek at $82 \mathrm{Ma}$. The long, narrow outcrop pattern (fig. 1) and the well-formed foliation and downdip mineral lineation (fig. $2 B$ ) in granodiorite of Box Lake suggest that it too formed by dike-emplacement processes similar to those for the tonalite of Payette River. The nearly vertical foliation and lineation indicate that boundary between tonalite of Payette River and the craton was also a ductile shear zone having mainly vertical movement. The many inclusions of metasedimentary rocks and tonalite within the granodiorite of Box Lake indicate that stoping played a significant role during emplacement.

The relatively weaker strength of foliation and lineation fabrics in the granodiorite of Box Lake, vis-à-vis similar fabrics in the tonalite of Payette River, suggests that there was a moderate component of extension in the vertical direction and that the rate of finite strain was probably less than the strain rate that operated during emplacement of the tonalite of Payette River. This may be viewed in a geographic sense to indicate that strain rate decreased or weakened from the Salmon River suture zone eastward during the period 90-85 Ma. Alternatively, the stress system had weakened slightly over a period of a few million years from the time of emplacement of the tonalite of Payette River to the time of emplacement of the granodiorite of Box Lake.

\section{Monzogranite of Lick Creek}

The genesis of granitic magma in magmatic arcs appears to be spatially and temporally related to crustal thickening, a natural consequence of transpression (for example, Hutton and Reavy, 1992; D'Lemos and others, 1992, De Saint Blanquat and others, 1998). Kuntz (this volume, chapter 5) has described a model in which large volumes of peraluminous monzogranite melt were generated by almost complete melting of optimally fertile Proterozoic source rocks, which was fostered by thickening of the continental crust in the hinterland of the Sevier orogenic belt by A-type subduction. Models for the Sevier orogeny invoke compressive plate convergence as the driving mechanism for horizontal shortening and vertical thickening of the crust and reduced lithosphere strength, which allow for topographic uplift by telescoping of the thermally weakened zone (Livaccari, 1991; Patino-Douce and others, 1990; Foster and others, 2001). The isostatic uplift of the hinterland caused gravity-induced, cratonward propagation of the Cordilleran thrust belt along flat-ramp thrusts and nappes during the Sevier orogeny (Allmendinger, 1992). A peak of hinterland metamorphism and peraluminous granite-magma generation occurred at 90-70 Ma (Lund and Snee, 1988; Snee and others, this volume, chapter 3; Fleck and Criss, this volume, chapter 2 ), which are indicative of a rising geothermal gradient, crustal thickening, and anatexis (Livaccari, 1991; Allmendinger, 1992). Kuntz (this volume, chapter 5) also speculates that the plutons of the monzogranite of Lick Creek may represent magmas that were essentially "formed in place" or moved only very short distances from 
their site of generation, and were not emplaced to significantly higher crustal levels.

At present, there are few models that account for the generation and transport of granitoid magma that might bear upon the development of broad areas of granitoid rocks, such as the granitic core of the Idaho Batholith near McCall. However, one relatively older study and several recent studies offer general principles that are applicable to the origin of the monzogranite of Lick Creek.

Hyndman and Foster (1988) advocated that strong heating of Proterozoic pre-Belt and lower Belt sedimentary rocks in Late Jurassic and Cretaceous time at the western margin of North America above the subducted, sinking Pacific Plate caused partial melting to form the Bitterroot and Atlanta lobes of the Idaho Batholith. They suggested that the granitic magmas rose 5 to $10 \mathrm{~km}$ from their site of generation to crystallize at depths of 10-15 km and that emplacement of granitoid plutons was associated with deformation and primary, highgrade metamorphism. These ideas are in general accord with the mode of formation of monzogranite magma advocated by Kuntz (this volume, chapter 5) and summarized above.

Studies of a well-exposed granitoid magmatic arc in New Zealand by Klepeis and others (2003) showed that diking and melt-enhanced fracturing were important mechanisms for the segregation and ascent of melt out of the lower and middle crust. A combination of fracture networks and deformation in shear zones enhanced the movement of partial melt both horizontally and vertically through the crust. Another important conclusion reached by Klepeis and others (2003) was that the shift in structural style, from contraction and crustal thickening to crustal thinning and decompression, corresponded to the end of subduction and a reorganization of plate boundaries outboard of the subduction zone that lay to the east of the New Zealand study area. The conclusions of Klepeis and others (2003) suggest that diking and melt-enhanced fracturing were important mechanisms for formation and segregation of melt for monzogranite magma in the $\mathrm{McC}$ all region. As discussed previously, the contractional regime in the McCall area probably weakened by $80 \mathrm{Ma}$ and may have been replaced by an extensional regime. This conclusion is supported by the change in structural style from contraction and crustal thickening to crustal thinning and decompression noted by Klepeis and others (2003) for the New Zealand area. The end of subduction and reorganization of plate boundaries identified by Klepeis and others (2003) for the New Zealand area may have implications for the McCall region, that is, the emplacement of the monzogranite of Lick Creek at 82 Ma may mark the time at which subduction in the area fully ceased and was replaced by subduction outboard (west) of the terranes that had been added to the North America Plate (fig. 5C).

A study of the Shuswap Range in the Canadian Cordillera by Vanderhaeghe and Teyssier (2001) showed that late Mesozoic crustal melting and magma intrusion, which followed crustal thickening, caused a decrease in crustal viscosity by several orders of magnitude in various crustal layers. They stated that during the early stages of crustal thickening, shortening was accommodated by formation of nappes and large-scale thrusting, which caused decoupling along a basement-cover decollement. This deformation caused a modification of rheological layering in the crust, which, in turn, enhanced major mechanical decoupling at the brittle-ductile transition and also across the top of a zone of partial melting deeper in the crust. They speculated that magma bodies, most likely derived from high fractions of partial melting of thick and fertile pelitic rocks in the middle crust, migrated to the base of the brittle, upper crust and "ponded to make laccoliths traceable over tens of miles." In addition, they state that after magma formation, the modified rheological behavior caused the upper crust to be affected by normal faulting and the lower crust to be affected by ductile thinning. The implications of the Vanderhaehge and Teyssier (2001) study for the McCall area are significant. Their findings suggest that formation of nappes and large-scale thrusts produced a significant decrease in crustal viscosity, which localized magma formation, and that large tracts of monzogranite magma formed by ponding at the brittle-ductile transition at the base of the upper crust. The Shuswap study by Vanderhaeghe and Teyssier (2001) provides a model for the transition from a contraction-dominated structural regime to an extensional regime in the McCall area at $\sim 82 \mathrm{Ma}$.

Grocott and others (1994), in a study of Mesozoic granitic plutons in the Andean magmatic arc of northern Chile, showed that large granitic plutons were fed by dikes and localized along flat ramps on low-angle, hinterland-dipping, normal-slip faults during ductile extension of a thickened crust. In their model, dikes transfer magma from the site of partial melting to the fault system, and extensional movement on the faults at flat ramps created dilational jogs for the accumulation of magma by lateral ballooning. It is interesting to note that the dilational-jog concept so strongly favored by many for localization of granitic plutons on transcurrent faults is also favored by Grocott and others (1994) for localization of plutons on extensional faults and, in combination with the "ponding" mechanism of Vanderhaeghe and Teyssier (2001), is suggested as the mechanism that best accounts for the emplacement of the monzogranite of Lick Creek (fig. 5C).

\section{Acknowledgments}

Cathryn Allen Manduca, James R. LaFortune, and Catherine Gockley served as able field assistants. The fieldwork was greatly aided by helicopter and communication support provided by the U.S. Department of Agriculture, Payette National Forest. Karl Kellogg and Ren Thompson reviewed an early version of this paper, and Karen Lund and J. Michael O'Neill provided trenchant and thorough reviews of the latest version. I also appreciate the skill and patience of Mary Berger, who prepared the computer-drafted figures for this paper. 


\section{References Cited}

Allmendinger, R.W., 1992, Fold and thrust tectonics of the western United States exclusive of the accreted terranes, in Burchfiel, B.C., Lipman, P.W., and Hogback, M.L., eds., The Cordilleran orogen; conterminous U.S.: Boulder, Colorado, Geological Society of America, The Geology of North America, v. G-3, p. 583-607.

Ave' Lallement, H.G., and Oldow, J.S., 1988, Early Mesozoic southward migration of Cordilleran transpressional terranes: Tectonics, v. 7, p. 1057-1075.

Brun, J.P., and Pons, J., 1981, Strain patterns of pluton emplacement in crust undergoing non-coaxial deformation, Sierra Morena, southern Spain: Journal of Structural Geology, v. 3, p. 219-229.

Carten, R.B., Geraghty, E.P., Walker, B.M., and Shannon, J.R., 1988, Cyclic development of igneous features and their relationship to high-temperature hydrothermal features in the Henderson porphyry molybdenum deposit, Colorado: Economic Geology, v. 83, p. 266-296.

Coe, J.A., 1995, Close-range photogrammetric geologic mapping and structural analysis, Henderson mine, Empire, Colorado: Golden, Colorado, Colorado School of Mines, Master's thesis, $192 \mathrm{p}$.

Delaney, P.T., Pollard, D.D., Ziony, J.T., and McKee, E.H., 1986, Field relations between dikes and joints; emplacement processes and paleostress analysis: Journal of Geophysical Research, v. 91, p. 4920-4938.

De St. Blanquat, M., Tikoff, B., Teyssier, C., and Vigneresse, J.L., 1998, Transpressional kinematics and magmatic arcs, in Holdsworth, R.E., Strachan, R.A., and Dewey, J.F., eds., Continental transpression and transtensional tectonics: Geological Society of London Special Publication 135, p. 327-340.

D’Lemos, R.S., Brown, M., and Strachan, R.A., 1992, Granite magma generation, ascent and emplacement within a transpressional orogen: Journal of the Geological Society of London, v. 149, p. 487-490.

Engebretson, D.C., 1985, Relative motions between oceanic and continental plates in the Pacific Basin: Geological Society of America Special Paper 206, 59 p.

Engebretson, D.C., Cox, A., and Gordon, R.G., 1984, Relative motions between oceanic plates of the Pacific Basin: Journal of Geophysical Research, v. 89, p. 10219-10310.

Fossen, H., and Tikoff, B., 1998, Extended models of transpression and transtension and application to tectonic settings, in Holdsworth, R.E., Strachan, R.A., and Dewey, J.F., eds., Continental transpression and transtensional tectonics, Geological Society of London Special Publication 135, p. 15-33.
Foster, D.A., Schaefer, C., Fanning, C.M., and Hyndman, D.W., 2001, Relationships between crustal partial melting, plutonism, orogeny, and exhumation; Idaho-Bitterroot batholith: Tectonophysics, v. 342, p. 313-350.

Grocott, J., Brown, M., Dallmeyer, R.D., Taylor, G.K., and Treloar, P.J., 1994, Mechanisms of continental growth in extensional arcs; an example from the Andean plate-boundary zone: Geology, v. 22, p. 391-394.

Hamilton, W., 1963a, Overlapping of late Mesozoic orogens in western Idaho: Geological Society of America Bulletin, v. 96, p. 779-799.

Hamilton, W.B., 1963b, Metamorphism in the Riggins region, western Idaho: U.S. Geological Survey Professional Paper 436, $95 \mathrm{p}$.

Heidrick, T.L, and Titley, S.R., 1982, Fracture and dike patterns in Laramide plutons and their structural and tectonic implications, in Titley, S.R., ed., Advances in geology of the porphyry copper deposits, southwestern North America: Tucson, The University of Arizona Press, p. 73-91.

Hutton, D.H.W., 1988, Granite emplacement mechanisms and tectonic controls; inferences from deformation studies: Transactions of the Royal Society of Edinburgh, Earth Sciences, v. 79, p. 245-255.

Hutton, D.H.W., and Reavy, R.J., 1992, Strike-slip tectonics and granite petrogenesis: Tectonics, v. 11, p. 960-967.

Hyndman, D.W., and Foster, D.A., 1988, The role of tonalites and mafic dikes in the generation of the Idaho Batholith: Journal of Geology, v. 96, p. 31-46.

John, B.E., and Blundy, J.D., 1993, Emplacement-related deformation of granitoid magmas, southern Adamello massif, Italy: Geological Society of America Bulletin, v. 105, p. 1517-1541.

Klepeis, K.A., Clark, G.L., and Rushmer, T., 2003, Magma transport and coupling between deformation and magmatism in the continental lithosphere: GSA Today, v. 13, p. 4-11.

Livaccari, R.F., 1991, Role of crustal thickening and extensional collapse in the tectonic evolution of the SevierLaramide orogeny, western United States: Geology, v. 19, p. 1104-1107.

Lund, Karen, 1984, Tectonic history of a continent-island arc boundary, west-central Idaho: University Park, Pennsylvania, Pennsylvania State University, Ph.D. dissertation, 210 p.

Lund, Karen, and Snee, L.W., 1988, Metamorphism, structural development, and age of the continent-island arc juncture in west-central Idaho, in Ernst, W.G., ed., Metamorphism and crustal evolution, western conterminous United States; Rubey Volume VII: Englewood Cliffs, New Jersey, Prentice-Hall, p. 296-331. 
McClelland, W.C., Tikoff, B., and Manduca, C.A., 2000, Twophase evolution of accretionary margins; examples from the North American Cordillera: Tectonophysics, v. 326, p. 37-55.

McKenzie, D., and Jackson, J., 1986, A block model of distributed deformation by faulting: Journal of the Geological Society of London, v. 143, p. 349-353.

Manduca, C.A., Kuntz, M.A., and Silver, L.T., 1993, Emplacement and deformation history of the western margin of the Idaho batholith near McCall, Idaho; influence of a major terrane boundary: Geological Society of America Bulletin, v. 105 , p. $749-765$.

Myers, P.E., 1982, Geology of the Harpster area, Idaho County, Idaho: Idaho Bureau of Mines and Geology Bulletin $25,46 \mathrm{p}$.

Oldow, J.S., Ave' Lallement, H.G., and Schmidt, W.J., 1984, Kinematics of plate convergence deduced from Mesozoic structures in the western Cordillera: Tectonics, v. 3, p. 201-227.

Onasch, C.M., 1987, Temporal and spatial relations between folding, intrusion, metamorphism and thrust faulting in the Riggins area, west-central Idaho, in Vallier, T.L., and Brooks, H.C., eds., Geology of the Blue Mountains region of Oregon, Idaho, and Washington; the Idaho batholith and its border zone: U. S. Geological Survey Professional Paper 1436, p. 139-149.

Paterson, S.R., Tobisch, O.T., and Vernon, R.H., 1991, Emplacement and deformation of granitoids during volcanic arc construction in the Foothills terrane, central Sierra Nevada, California: Tectonophysics, v. 191, p. 89-110.

Paterson, S.R., Fowler, T.K., Jr., Schmidt, K.L., Yoshinobu, A.S., Yuan, E.S., and Miller, R.B., 1998, Interpreting magmatic fabric patterns in plutons: Lithos, v. 44, p. 53-82.

Patino-Douce, A.E., Humphreys, E.D., and Johnston, A.D., 1990, Anatexis and metamorphism in tectonically thickened continental crust exemplified by the Sevier hinterland, western North America: Earth and Planetary Science Letters, v. 97, p. 290-315.

Robin, P.-Y.F., and Cruden, A.R., 1994, Strain and vorticity patterns in ideally ductile transpression zones: Journal of Structural Geology, v. 16, p. 447-466.

Russell, C.W., 1988, Crystallization of the Banks complex; implication for middle crustal evolution in Cordilleran batholithic terranes: Seattle, University of Washington, Ph.D. dissertation, 228 p.

Segal, P., and Pollard, D.D., 1983, Joint formation in granitic rock of the Sierra Nevada: Geological Society of America Bulletin, V. 94, p. 563-575.
Selverstone, J., Aliberti, E., and Wernicke, B.P., 1992, Intracontinental subduction and hinged unroofing along the Salmon River suture zone, west central Idaho: Tectonics, v. 11, p. 124-144.

Snee, L.W., Lund, K., Sutter, J.F., Balcer, D.E., and Evans, K.V., 1995, An ${ }^{40} \mathrm{Ar} /{ }^{39} \mathrm{Ar}$ chronicle of the tectonic development of the Salmon River suture zone, western Idaho, in Vallier, T.L., and Brooks, H.C., eds., Geology of the Blue Mountains region of Oregon, Idaho, and Washington; petrology and tectonic evolution of pre-Tertiary rocks of the Blue Mountains region: U. S. Geological Survey Professional Paper 1438, p. 359-414.

Strayer, L.M., IV, Hyndman, D.W., Sears, J.W., and Myers, P.E., 1989, Direction and shear sense during suturing of Seven Devils-Wallowa terrane against North America in western Idaho: Geology, v. 17, p. 1025-1028.

Teyssier, C., and Tikoff, B., 1999, Fabric stability in oblique convergence and divergence: Journal of Structural Geology, v. 21, p. 969-974.

Tikoff, B., and Greene, D., 1997, Stretching lineations in transpressional shear zones: Journal of Structural Geology, v. 19 , p. $29-40$.

Tikoff, B., and Teyssier, C., 1992, Crustal-scale, en-echelon "P-shear" tensional bridges; a possible solution to the batholithic room problem: Geology, v. 20, p. 927-930.

Vallier, T.L., 1995, Petrology of pre-Tertiary igneous rocks in the Blue Mountains region of Oregon, Idaho, and Washington; implications for the geologic evolution of a complex island arc; in Vallier, T.L., and Brooks, H.C., eds., Geology of the Blue Mountains region of Oregon, Idaho, and Washington; petrology and tectonic evolution of pre-Tertiary rocks of the Blue Mountains region: U. S. Geological Survey Professional Paper 1438, p. 125-209.

Vallier, T.L., and Brooks, H.C., 1987, The Idaho batholith and its border zone; a regional perspective, in Vallier, T.L., and Brooks, H.C., eds., Geology of the Blue Mountains region of Oregon, Idaho, and Washington; the Idaho batholith and its border zone: U.S. Geological Survey Professional Paper 1436, p.1-7.

Vanderhaeghe, O., and Teyssier, C., 2001, Partial melting and flow of orogens, in Teyssier, C., and Vanderhaeghe, O., eds., Partial melting of crust and flow of orogens: Tectonophysics, v. 342, p. 451-472.

Verbeeck, E.R., and Grout, M.M., 1992, Geometry and structural evolution of gilsonite dikes in the eastern Uinta basin, Utah: U.S. Geological Survey Bulletin 1787, 44 p. 
Other than this note, this page intentionally left blank. 
原

产

$\underset{\infty}{\infty}$

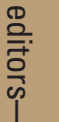

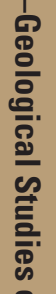

$\stackrel{\circ}{\stackrel{7}{\vec{D}}}$

禹

졸 